\title{
REVISTA
}

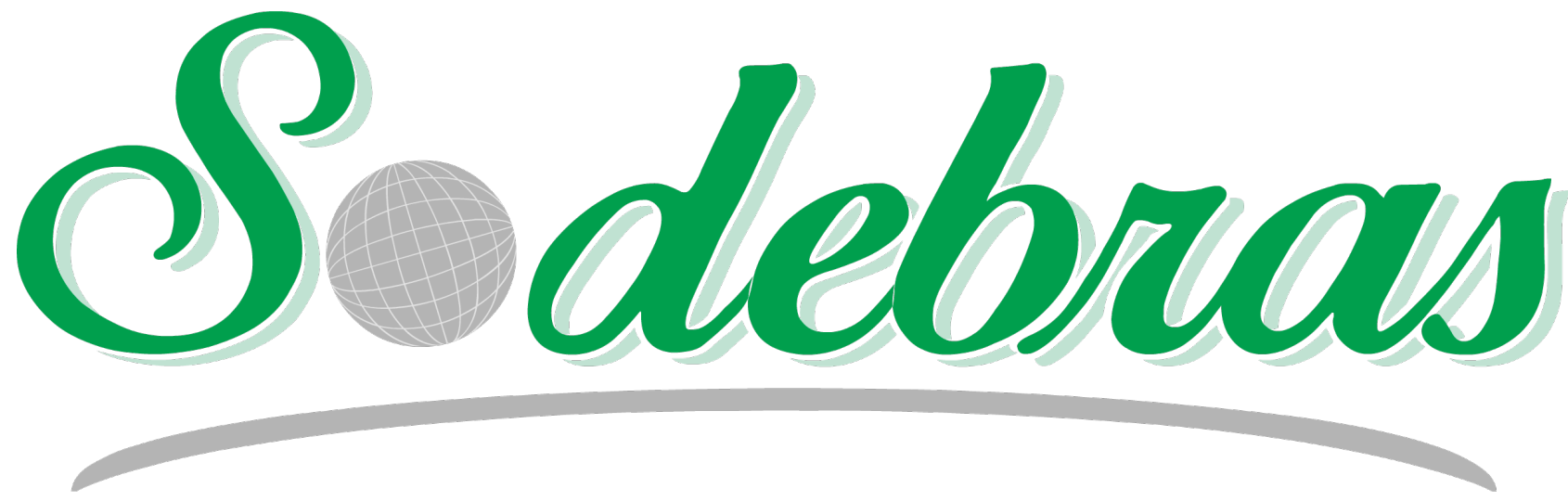

SOLUÇÕES PARA O DESENVOLVIMENTO DO PAIÍS 


\title{
ARTIGOS PUBLICADOS
}

\author{
PUBLICAÇÃO MENSAL
}

Nesta edição

LINGUAGEM NÃO VERBAL NO PROCESSO DE RECRUTAMENTO E SELEÇÃO - Petrus Coltre Nogueira; Sandra Maria Coltre; Paulo Roberto Chavarria Nogueira

A IMUNIDADE TRIBUTÁRIA DAS ENTIDADES RELIGIOSAS - Hélio Silvio Ourém Campos; Thiago Paraíso Vilela Santana

O CONCEITO DO DIREITO À SAÚDE NO BRASIL DE 2005 A 2015 - Nélio Fernandes Borrozzino; Maria

Elisa Gonzalez Manso

ESPORTISMO - COMPETÊNCIAS ADQUIRIDAS NO ESPORTE QUE AUXILIAM O ATINGIMENTO DA ALTA PERFORMANCE PROFISSIONAL - Rodrigo Guimarães Motta; Wagner Castropil; Neusa Santos

UMA ALTERNATIVA PARA SE INTERNACIONALIZAR: ESTUDO DE CASO DE EMPRESA DE MÉDIO PORTE DO AGRONEGÓCIO BRASILEIRO - Vânia Margarida Ferreira; Helder Antônio Da Silva; Nicássia Feliciana Novôa; Cláudia Maria Miranda De Araújo Pereira

BIOCOMBUSTÍVEIS NO BRASIL: PROSPECÇÃO TECNOLÓGICA SOB O ENFOQUE DE PEDIDOS DE PATENTES - Maria Gabriela Beilfuss Rocha Jorge; David Calhau Jorge; Lúcia Marina Scatena; Mônica Hitomi Okura

LEVANTAMENTO DO USO DE BUSINESS INTELLIGENCE COMO FERRAMENTA DE TOMADA DE DECISÃO NOS INSTITUTOS FEDERAIS DE EDUCAÇÃO - Jefferson Steidel Dos Santos; Denise Fukumi Tsunoda

ABORDANDO UM DOS MAIORES ACIDENTES NUCLEARES DA HISTÓRIA ATRAVÉS DA INTERDISCIPLINARIDADE - Rosana Petinatti Da Cruz; Maria Lúcia Teixeira Guerra De Mendonça; Adriana Ramos Pinheiro; Aramis David Correa; José Carlos Fernandes Costa; Raimundo Nonato Da Silveira Júnior ...

O USO DA TECNOLOGIA NO ENSINO SUPERIOR: UM OLHAR PARA AS MEDIAÇÕES EXISTENTES NAS AULAS DE UM CURSO DE PEDAGOGIA - Adriana Recla; Andrés Barrios Rocha; Félix Forero García

A IMPORTÂNCIA DA INTERAÇÃO ESCOLA-FAMÍLIA PARA O DESENVOLVIMENTO DE CRIANÇAS SUPERDOTADAS - Márcia Stefanello Fischborn; Désirée Gonçalves Raggi

ESTRATÉGIAS PEDAGÓGICAS OBSERVADA NA SALA DE RECURSOS: ESTUDANTE COM TRANSTORNO GLOBAL DO DESENVOLVIMENTO - Adriana De Souza Carreira; Gabriely Cabestré Amorim; Vera Lúcia Messias Fialho Capellini

ESTUDO DAS POSSIBILIDADES DE CONEXÃO DA SUSTENTABILIDADE, COM O ENSINO DE QUÍMICA, AS PRÁTICAS EDUCATIVAS E O DESENVOLVIMENTO LOCAL - Edward Aredes Silva Júnior; Adilene Gonçalves Quaresma

O ENSINO-APRENDIZAGEM DE CIÊNCIAS DE UM ALUNO COM SÍNDROME DE DOWN - Giancarlo Silva Costa; Nilson Santos Trindade

FORMAÇÃO CONTINUADA DE EDUCADORES DO CAMPO: PROBLEMATIZANDO A RELAÇÃO ENTRE FORMAÇÃO E DESENVOLVIMENTO PROFISSIONAL - Maria Jucilene Lima Ferreira

PROJETOS DE LETRAMENTO: ESTRATÉGIAS INTEGRADORAS DE APRENDIZAGEM - Elza R. Barbosa Peixoto; Maria José De Pinho 
ALIMENTAÇÃO SAUDÁVEL COMO METODOLOGIA DE ENSINO DE BIOLOGIA - Josiane Da Silva Brito; Carolina Lomando Cañete

AVALIAÇÃO DE CRIANÇAS POR DOENÇAS RESPIRATÓRIAS EM UMA UNIDADE DE PRONTO ATENDIMENTO EM MARINGÁ- PR - Viviane Fonseca Bungart'; José Paulo Garcia Cortez; Eraldo Schunk Silva; Ana Lúcia Da Silva; Lucia Elaine Ranieri Cortez

PERFIL EPIDEMIOLÓGICO DA INFECÇÃO PELO VÍRUS DA HEPATITE B NO MUNICÍPIO DE PARAGOMINAS-PA - Eliete Soares Moreira; Nilcinete Pereira Da Silva; Rogério Valois Laurentino; Nilson Santos Trindade

USUÁRIOS DOS SISTEMAS DE SAÚDE: A PERCEPÇÃO E AVALIAÇÃO DOS SERVIÇOS RECEBIDOS Izabelle Cristina Garcia Rodrigues; Ivana França; Vera Lucia Pereira Dos Santos; Daniel De Christo; João Luiz Coelho Ribas

PARÂMETROS PREDITIVOS DO USO DE NARGUILÉ E SUAS CONSEQUÊNCIAS - Eliane Gouveia De Morais Sanchez; Nayara De Paula Guerreiro; Beatriz Ribeiro Farinha; Katiuscia Pereira De Resende; Hugo Machado Sanchez

TRATAMENTOS PRÉ-GERMINATIVOS DE SEMENTES DE COENTRO CULTIVADAS NO SUBMÉDIO SÃO FRANCISCO - Gilmario Noberto De Souza; Isa Gabriela Vieira De Andrade; Sâmela Deise De Pinho Gonçalves; Glória Caroline Santos Barbosa Da Silva; Antônio Bruno Nunes Oliveira; Willian Costa Bezerra; Carlos Alberto Aragão

CARACTERIZAÇÃO DE PÃES ELABORADOS COM SUBSTITUIÇÃO PARCIAL DE FARINHA DE TRIGO POR FARINHA FUNCIONAL DE CENOURA (Daucus carota) - Ana Lúcia Becker Rohlfes; Nádia De Monte Baccar; Liliane Marquardt; Valeriano Antonio Corbellini; Raquel Cassel Tassinari; Bruno Engel; Júlia Muller Trevisan...

MÉTODO DE AVALIAÇÃO APROXIMADA PARA A PROBABILIDADE DA UNIÃO DE EVENTOS INDEPENDENTES - Edson Luiz Ursini, Paulo S. Martins

FORMAÇÃO DO ALN POR ASSOCIAÇÃO RADIATIVA - Carmen M. Andreazza; Amaury A. De Almeida; Demétrio T. Ceccatto

ESTUDO DA ESTABILIDADE DO ARCO ELÉTRICO GERADO PELA SOLDAGEM DE REVESTIMENTO (FCAW) DEVIDO À VARIAÇÃO DA TENSÃO/CORRENTE E VELOCIDADE DE SOLDAGEM - Celso Alves Correa; João Roberto Sartori Moreno; Luiz Guilherme Marin

COMPARAÇÃO DOS MÉTODOS DE GERAÇÃO DA SPWM VIA PONTO A PONTO E MODULOS PWM DO MICROCONTROLADOR NO CONTROLE DE UM MIT - Luiz Carlos Gomes; Marcio Abud Marcelino

CONCENTRAÇÃO DE TENSÕES EM PEÇAS E COMPONENTES ESTRUTURAIS ATRAVÉS DO MÉTODO DOS ELEMENTOS FINITOS - Erick Siqueira Guidi; Fernando De Azevedo Silva; Caio Cavagioni; Carlos Alberto Chaves

GESTÃO DE PROCESSOS INDUSTRIAIS - APLICAÇÃO DO COMISSIONAMENTO INTEGRADO NO PROCESSO DE GASEIFICAÇÃO - Gloria Maria Alves Ney; Marcio Zamboti Fortes; Gilson Lima Alves Brito ..

ALTERNATIVAS PARA REDUÇÃO DOS RESÍDUOS FINAIS DA UNIDADE DE VALORIZAÇÃO DE RECICLÁVEIS DE CURITIBA/PR ALTERNATIVES FOR THE REDUCTION OF FINAL WASTE OF THE CURITIBA /PR RECYCLABLE RECOVERY UNIT - Robson Seleme; Adriana De Paula Lacerda Santos; Eduardo Palmeira; Wiliam De Assis Silva; Izabel Cristina Zattar; Alessandra De Paula

CONCEPÇÕES DOS DISCENTES EM RELAÇÃO À FORMAÇÃO DE PROFESSORES DE BIOLOGIA NA MODALIDADE A DISTANCIA NO PERÍODO DE 2013-2016 EM PARAUAPEBAS - PA - Maiely Glenda Guimaraes Da Silva; Nilson Santos Trindade 


\section{Área: Interdisciplinar}

\begin{tabular}{|l|l|}
$9-8$ & LINGUAGEM NÃO VERBAL NO PROCESSO DE RECRUTAMENTO E SELEÇÃO \\
& $\begin{array}{l}\text { NON-VERBAL LANGUAGE IN THE RECRUITMENT AND SELECTION PROCESS } \\
\text { Petrus Coltre Nogueira; Sandra Maria Coltre; Paulo Roberto Chavarria Nogueira }\end{array}$ \\
\hline
\end{tabular}




\title{
LINGUAGEM NÃO VERBAL NO PROCESSO DE RECRUTAMENTO E SELEÇÃO
}

\author{
NON-VERBAL LANGUAGE IN THE RECRUITMENT AND SELECTION \\ PROCESS
}

\author{
PETRUS COLTRE NOGUEIRA ${ }^{1}$; SANDRA MARIA COLTRE ${ }^{2}$; PAULO ROBERTO CHAVARRIA \\ NOGUEIRA $^{3}$ \\ 1 - FASUL; $2 ; 3$ - UNIOESTE \\ p.coltre@hotmail.com; sandracutul@gmail.com; paulo.nogueira@unioeste.br
}

\begin{abstract}
Resumo - $O$ estudo foi de cunho bibliográfico exploratório e investigou a linguagem não verbal, no processo de recrutamento $e$ seleção. No mundo globalizado é nas organizações onde os indivíduos buscam seu sustento, formas de realização $e$ prosperidade. Apesar das organizações serem um fenômeno complexo, sua existência contribui para a sustentabilidade da sociedade. Para que possa ter sustentabilidade se faz necessário recrutar pessoas que contribuam para esta prosperidade. Por isso o empenho atual é a busca de talentos, e é por meio do subsistema de recrutamento e seleção, que isto acontece. As pesquisas demonstram que a comunicação não verbal é a parte mais importante para todos os processos de interação entre as pessoas. No processo de recrutamento e seleção, no momento da entrevista, é o momento mais importante na avaliação da coerência entre o que o se expressa e o que o corpo fala.
\end{abstract}

Palavras-chave: Comunicação. Integração. Seleção.

Abstract - The study was of an exploratory bibliographic nature and investigated the nonverbal language, in the process of recruitment and selection. In the globalized world it is in organizations where individuals seek their livelihoods, forms of achievement and prosperity. Although organizations are a complex phenomenon, their existence contributes to the sustainability of society. In order to be sustainable, it is necessary to recruit people who contribute to this prosperity. That is why the current effort is the search for talent, and it is through the recruitment and selection subsystem that this happens. Research shows that nonverbal communication is the most important part of all processes of interaction between people. In the recruitment and selection process, at the time of the interview, it is the most important moment in assessing the coherence between what is expressed and what the body speaks.

Keywords - Communication. Integration. Selection.

\section{INTRODUÇÃO}

A comunicação é fundamental tanto nas relações pessoais como nas organizacionais e educacionais. Ela é realizada de várias maneiras, todavia para haver entendimento entre as pessoas é necessário que a mensagem seja recebida com o mesmo sentido com o qual foi transmitida. A comunicação é tanto verbal como não verbal. Estudos indicam que todo o processo comunicacional é realizado em grande parte pela comunicação não-verbal.

Para Alcure (1996), a comunicação verbal corresponde muito pouco em relação ao processo comunicacional. A maior parte da comunicação se embasa na comunicação não verbal. Em países de idiomas diferentes e diversidade cultural, há uma compreensão da mensagem pela expressão não verbal, ou seja: um sorriso é sempre um sorriso, o choro é sempre choro, a arrogância é sempre arrogância, o medo ou angústia são expressados pelos mesmos gestos de suor nas mãos, expressões faciais tensas, fala tensa e atitudes de pouco acessibilidade.

Não importa o lugar, a comunicação não verbal é muito poderosa. Todavia, a comunicação somente é poderosa, se for assertiva e se houver coerência entre a fala da boca e a fala do corpo, o receptor da mensagem vai perceber que algo não está adequado e a comunicação é afetada e o entendimento torna-se impossível.

No processo comunicacional existe a subjetividade e nos processos de recrutamento e seleção, cabe ao selecionador, ter competência e preparo para lidar com as mais variadas situações, para realizar a escolha adequada do perfil do candidato ao cargo. Neste processo, entender outros sinais é de fundamental importância. Recrutar e selecionar são processos que envolvem investimentos e qualificação dos profissionais que o realizam. E, quando ele não atinge seu principal objetivo que é trazer talentos à organização, os custos crescem e todos perdem.

A comunicação envolve tanto a via verbal como não verbal. Estes dois níveis de comunicação são concomitantes nas interações comunicacionais entre os indivíduos, onde um complementa o outro no momento da comunicação.

A linguagem não verbal nem sempre é consciente para o seu usuário. Gaiarsa (1982) alerta que é necessário exercitar ver o outro através da atenta observação de seus movimentos corporais, forma de falar, expressar, postura corporal, olhar, movimento da boca, para que a se possa ver o outro além de suas dissimulações.

Em uma sociedade de organizações, este conhecimento para o processo de recrutamento e seleção de novos colaboradores é muito útil, pois tal observação torna o diálogo muito mais interativo e assertivo. Neste contexto, este estudo explorou a seguinte problemática: Qual a importância da linguagem não verbal no processo de recrutamento e seleção?

Neste sentido, não se sabe ao certo quando o ser humano começou a se comunicar, mas a comunicação não verbal surgiu antes da comunicação verbal, por meio de 
gestos e grunhidos tendo com o tempo evoluído para uma linguagem verbal compreensível (LYONS, 1981).

Para Mesquita (1997), os leigos se fascinam pela comunicação não verbal, todavia ela data de tempos imemoriais. Muitos séculos antes, os chineses acreditavam que era possível analisar a personalidade das pessoas por meio de suas características pessoais.

Entre 1014 e 1940, os cientistas demonstraram interesses pela comunicação não verbal. Davis, 1979 e Silva (187 apud MESQUITA (1997), pressupunham que a influência se originou do livro de Charles Darwin: The expression of emotion in the man and animal", publicado em 1872.

Para Perles (2007) o motivo de viver em grupos e por questões se sobrevivência houve a criação dos primeiros signos linguísticos, por meio de gestos que possuíam um aglomerado de significados. Com o passar do tempo esses gestos foram aperfeiçoados evoluindo para símbolos que representavam uma comunicação mais sistematizada. A necessidade de organizar e sistematizar esses símbolos para que fossem melhor compreendidos deu-se origem a linguagem, que nada mais é do que um complexo aglomerado sistema de comunicação por meios de gestos, ou seja, linguagem não verbal.

Pesquisadores de diferentes áreas se debruçaram sobre este tema. Birdwhistell (1970) muito contribuiu com seus estudos sobre o tema e chegou a conclusão que comunicar extrapola a mecânica de codificar e decodificar sinais. É antes de tudo, um ato criativo, uma negociação que promove significado de existência entre os envolvidos. Por isso, ela nunca pode se analisada ou interpretada fora do contexto social dos envolvidos.

Segundo Gois, Nogueira e Vieira (2011), no mundo contemporâneo foi com Reich que a linguagem corporal ganhou força. A partir daí o tema se tornou importante nos processos de psicoterapia. Constataram os estudos que, os comportamentos não verbais, como o tom de voz, a movimentação da pessoa, as posturas a expressões do olhar, do movimento da boca, olhos enfim, toda mímica corporal tinha significados que nem sempre estão alinhados a comunicação verbal.

Alcure (1996) indicava década anterior, que vários sinais de comunicação podem reforçar ou substituir ou contrariar a comunicação verbal. A fala é composta da expressabilidade individual (movimentos dos olhos, da boca, bochechas, sombrancelhas em suas diversas combinações e variações), junto com a postura (inclinação corporal, gestos, proximidade distância, toques e energia emanada, que muitos percebem ou sentem. Estes sinais são denominados de paralínguisticos e possuem significados diversos em relação a cada cultura. Neste contexto, a semiologia, para Peirce (1977), consiste em classificar e inferir sobre a existência dos objetos no mundo. Para Barthes (1971), por meio dela é possivel analisar os fenômenos culturais da comunicação, tanto a linguagem verbal como a não verbal. Explica que isso é possível pois, o fenômeno da comunicação envolve escrita, desenhos, línguas nativas ou formalizadas, códigos e signos, inclusive a comunicação paralinguística.

Concorda Wolton (2010) com Pierce (1977) e Barthes (1971), que os objetos do mundo em forma de signos são aquilo que os indivíduos reconhecem como seu mundo, pela interpretação da nossa mente em relação ao que já conhecemos. Este processo ocorre pela mente que reconhece e interpreta os signos que organizam a linguagem, tanto a verbal como a não verbal.

Neste contexto, a comunicação não verbal para Corraze (1982), ocorre no corpo devido a predisposição física, fisiológica e de movimento, aos adornos, roupas, tatuagens e cicatrizes e o território, entendido como o espaço físico que cerca o corpo, que cada pessoa determina a distância entre os demais.

Mesquita (1997) indicava o aumento do número de pesquisas científicas sobre a importância da comunicação não verbal nas organizações devido o seu impacto na gestão dos processos organizacionais. Knapp e Hall, 1990 apud (ANTÉRIO, 2014) classificaram a conduta não verbal divididas em sete áreas como:
“a) movimento corporal ou cinésica (emblemas, ilustradores, expressões de afeto, reguladores e adaptadores); b) características físicas; c) comportamentos táteis; d) paralinguagem (qualidades vocais e vocalização); e) proxêmica; f) artefatos; e g) o meio ambiente (KNAPP e HALL, 1990 apud (ANTÉRIO, p. 237, 2014)”.

Para eles, a expressabilidade pela via não verbal é poderosa e busca estabelecer um sentido comunicacional e emocional, bem como, dar significado aos relacionamentos e a resposta do outro nas relações diárias.

Concordavam Feyerisen e De Lannoy (1996), que os sinais corporais que se transmite no processo de comunicação seja em que contexto for, exerce efeito sobre as demais pessoas. Este efeito é importante nas relações entre as pessoas frente ao contexto onde se encontram ou as atividades que praticam em seu trabalho.

Observaram também, que os componentes verbais e não verbais na comunicabilidade das pessoas interagem de forma simultânea e o contexto pode ressaltar mais a comunicação verbal do que a não verbal e vice e versa. Esta diferenciação se vincula ao como cada pessoa interpreta sua vivência. Todavia, este processo é inconsciente.

Davis (1979) indicava que a comunicação não verbal é uma interação de informações que são geradas abaixo do nível de consciência, pois são transmitidas pelos canais não verbais.

Para Argyle, 1978 apud (MESQUITA, 1997), a comunicação não verbal envolve a expressão facial, gestos e movimentos corporal, e envolve um comportamento espacial e de aparência. Knapp, 1982 apud (MESQUITA, 1997) corroboram, que a linguagem não verbal corresponde a da mais metade do que realmente se quer dizer. A forma como movimentamos o corpo como um todo, olhos mãos, pés, etc. Quando essa linguagem não condiz com a linguagem verbal, as outras pessoas percebem que algo não está certo, isso ocorre geralmente quando mentimos ou expressarmos algo diferente do que se pensa, pelo fato de não conseguirmos controlar complemente a comunicação não verbal (WOLTON, 2010).

Continua que, muitos dos gestos que são realizados quando se fala demonstram a sua real intenção. Por exemplo, a pessoa pode se expressar de forma calma e tranquila, mas demonstrar ser uma pessoa ansiosa ou nervosa, pelo fato do corpo não conseguir mentir nos movimentos das mãos, ou olhos ou respiração. Indicam também os autores, que se pode treinar para aprender a disfarçar alguns gestos se a outra pessoa sabe ler os sinais corporais saberá que algo não está certo. 
Neste contexto, a comunicação nas organizações é fundamental para seu sucesso e sustentabilidade. Em todos os seus subsistemas: recursos humanos, financeira, marketing, logística enfim, todos estes subsistemas devem se comunicar adequadamente para o sucesso da organização. E, a qualidade das pessoas que dela fazem parte é um fator chave de sucesso, indicam BOWDITCH; BUONO (2004); (RIBEIRO, 2005).

Corroboram Bowditch; Buono (2004); Ribeiro (2005), que o processo de recrutamento e seleção é o subsistema de recursos humanos pelo qual as organizações selecionam os seus talentos. Por isso, compreender os aspectos da comunicação não verbal é fundamental para evitar transtornos comportamentais posteriores a contratação.

O recrutamento e seleção visa colocar esse colaborador no melhor setor dentro da empresa para que possa desempenhar o melhor papel possível de acordo o perfil do colaborador, se faz necessário que $\mathrm{o}$ processo de recrutamento e seleção seja eficaz.

Para Bowditch; Buono (2004) e Ribeiro (2005) de todas as técnicas de recrutamento seleção e na gestão de pessoas, a entrevista é a considerada o método mais eficaz. Por meio dela pode-se identificar uma série de fatores de forneceram sinais para compreender para além do currículo a coerências entre o que se fala e o que se faz. A forma como as pessoas se movimentam, falam, olham e respiram, pode indicar dados importantes sobre sua personalidade e pensamentos não expressos.

Seguindo esse entendimento, Mattos (1992) via o processo de recrutamento e seleção o melhor lugar para conhecer o candidato e suas verdadeiras intenções, pois é onde se tem contato com o futuro colaborador cara a cara. Um discurso previamente preparado pode gerar maior possibilidade de ser contratado, porém fazer o corpo ser coerente com isso é uma tarefa impossível porque não se consegue controlar todos os movimentos do corpo, fala, gestos o que leva a gerar sinais de incoerência entre o que o corpo fala em relação a oralidade. Para que o entrevistador possa perceber esses sinais não verbais, além de saber os seus significados e lê-los como um conjunto deve estar atendo a coerência entre o movimento do corpo e o conteúdo da fala. $\mathrm{O}$ entrevistado pode expressa-los a qualquer momento de forma condizente ou não, a sua real intenção e o entrevistador pode constatar se há coerência ou não. Caso esteja falando algo que não condiz com a verdade, pode deixar isso transparecer por meio da linguagem não verbal.

Corroboram Gois, Nogueira e Vieira (2011), que devese estar atento as expressões corporais, olhos, braços, posturas enfim, no conjunto verbal e não verbal da comunicação. Para eles em um processo de recrutamento e seleção a linguagem não verbal é fundamental para avaliar a coerência entre do que se diz e se faz. Com isso pode-se perceber informações que estão subjacentes ao processo comunicacional.

Todavia alertavam Feyerisen e De Lannoy (1996), que existem muitas variações, já que certos movimentos ou expressões corporais de significado universal, podem ser interpretados de forma diferente em relação a cultura do grupo. Por exemplo, no Brasil ficar olhando fixamente nos olhos enquanto se conversa é interpretado como sinal de firmeza, segurança ou caráter. Já em países europeus e nos Estado Unidos, isso é interpretado como afronta ou invasão de privacidade, como se constou nestes estudos. Uma atitude aberta é avaliada como positiva nos Estados Unidos, porém considerada imoral pelos japoneses. Os japoneses por sua vez valorizam o status social, enquanto os americanos avaliam em termos de simpatia (FEYERISEN E DE LANNOY, 1996). Continuam que, para os italianos gesticular faz parte inerente de sua comunicação. Movimentos de cabeça para cima e para baixo significam afirmação e da esquerda para a direita, negação. Entretanto, em certas regiões do sudeste europeu o entendimento é invertido. Movimentos com a cabeça de cima para baixo é negação e esquerda e direita é aceitação.

Gaiarsa (1984), alertava que as emoções promovem movimentos musculares visíveis, seja de raiva, medo, amor. A raiva altera a respiração, o corpo se prepara para luta e a musculatura se contraí de forma ampla. As sobrancelhas mudam, o olhar, os cantos da boca enfim, as emoções que se sente, mesmo que se faça um esforço para não demonstrá-las, são visíveis na comunicação não verbal. E, Gaiarsa, (2002) confirma que a expressão não verbal ainda é muito estudada pela psicologia, pois tudo o que não é dito por palavras são expressos no tom de voz, na expressão do rosto, no gesto e movimento do corpo e na atitude.

Portanto, na entrevista de seleção é onde este componente se juntam. Cabe ao recrutador estar preparado para observar, segundo Guirand (2001), a cinésia dos gestos, a proxêmica que é a posição do corpo no território e distância posicionada entre os interlocutores e a prosódica, como as entonações, suspiros e variações de voz são articuladas.

\section{RESULTADOS}

O estudo é de cunho exploratório bibliográfico. Os dados utilizados são dados registrados sobre o tema em material de caráter científico.

Destacamos que resultados discutidos a seguir, se referem a estudos publicados que inferem sobre o tema abordado. Argtle e Dean, 1965 apud (CHANLAT, (1933), relacionaram a distância física e o contato visual que separa as pessoas em seu processo de interação. Tocar o próprio rosto ou se inclinar para trás indica que a pessoa quer distancia do outro. Adotar intencionalmente postura de espelho do outro é um sinal de interação de na maioria das vezes é positiva. Todavia, há indivíduos muitos observadores que não se sentem confortáveis com a postura de espelho.

Dion, Berscheid e Walster, 1972 apud (SANTOS et. $a l$, 1992) demonstram em sua pesquisa que pessoas atraentes são consideradas mais felizes e com maior capacidade profissional do que as menos atraentes. Isso pode interferir no processo de recrutamento e seleção, caso o recrutador seja despreparado para tal tarefa. Em outro estudo, eles constataram que adultos aplica punições mais severas as crianças menos atraentes, o que pode afetar seu comportamento futuro.

Souza-Poza e Rohrberg, 1977 apud (FEYREISEN; LANNOY, (1993), observaram que os gestos diminuem de frequência quando em uma entrevista, se fala em temas íntimos ou de cunho pessoal. E, Ricci-Bitti et al. 1979 apud (FEYREISEN; LANNOY, (1993), constaram que a frequência dos gestos aumenta as perguntas que agradam o entrevistado.

Grusec e Abramovitch, 1978 apud (FEYREISEN; LANNOY (1993), constataram que imitar o comportamento de outras pessoas, na maioria das vezes provoca uma interação positiva. Imitar o comportamento de outra pessoa (brincadeiras, sorrisos etc.) também estabelece mais interação positiva do que negativa. Mostrar a ponta da 
língua para uma pessoa, aumenta o tempo em que a outra pessoa irá estabelecer conversa.

Zuckerman, 1981 apud (FEYREISEN; LANNOY, (1993), estudaram sinais verbais que permitiam detectar mentiras e constataram que os mentirosos se mexem menos que do que os que contam a verdade. Pessoas que mentem aumentam os movimentos de auto contato, mudam o tom da voz, realizam movimentos contraditórios com a fala e mudam sua expressão facial.

De Paulo e Rosenthal, 1982 apud (FEYREISEN; LANNOY, (1993), verificou que mulheres são mais sensíveis que homens e adolescentes, quanto a sinais corporais faciais indiscretos emitidos pelos seus interlocutores. Pessoas que se parecem com alguém que gostamos ou não gostamos afetam a forma como a comunicação verbal e não verbal se processa.

De acordo com Rector e Trinta, 1985 apud (MESQUITA,1997) corroborado por Silva (2012), os estudos de Mehrabian e colaboradores demonstraram que $55 \%$ de nossa comunicação é por meio da não verbal envolvendo face a face se dá pelo movimento do corpo, gestos e expressões faciais. $38 \%$ se referem a tonalidade e intensidade da voz e $7 \%$ é realizada pela fala. Ou seja, a comunicação em qualquer processo de trabalho, extrapola apenas a fala. Ressaltam os autores ainda, que a comunicação não verbal, quando ao controle consciente dos envolvidos, oferece uma comunicação mais assertiva e informações mais fidedignas.

O estudo desenvolvido por Francis e Evans, 1987 apud SANTOS et al, 1992), recrutadores avaliaram fotos de uma mesma modelo vestida de forma diferente. As melhores avaliações de emprego foram indicadas para as fotos da modelo com vestimentas caras.

Serra, 1990 apud (MESQUITA, 1997), em sua tese de doutoramento intitulado Empatia: um estudo da comunicação não-verbal terapeuta-cliente propõe um instrumento de análise da comunicação não-verbal na relação interpessoal. A conclusão que chegou foi a importância dos profissionais entenderem o mundo silencioso do corpo e ficar atento as mensagens que ele envia no processo de comunicação. Além disso, acredita que todo profissional estará melhor preparado quando tiver consciência de sua habilidade profissional, possuir formas de analisar o discurso não verbal do outro e como a linguagem não verbal afeta as relações interpessoais.

Silva e Caramaschi, 1991 apud (MESQUITA, 1997, realizaram uma pesquisa que mensurou diferentes habilidades para falar dos sinais de expressão faciais e julgar estas expressões de uma forma holística e concluiram que:

[...] as pessoas julgam razoavelmente bem as expressões globais das sete emoções básicas (alegria, medo, surpresa, tristeza, raiva, desprezo e nojo), mas não conseguem descrever satisfatoriamente os componentes de cada uma destas expressões. Este estudo pontua que perceber não significa compreender, ter consciência ou deter conhecimentos sobre os processos de percepção da comunicação não-verbal (Silva e Caramaschi, 1991 apud (MESQUITA, p.161, 1997).”

Wolton (2010) reflete sobre o papel da comunicação em um mundo onde a tecnologia diminui a comunicação cara a cara. Informações são bombardeadas diariamente o que complica a comunicação e o seu entendimento, por alerta que a comunicação é mais complexa que a informação. A comunicação relacional é importante para a compreensão real do outro, se preocupa com a onipresença das tecnologias, que inibe a tanto a capacidade crítica como a real intenção ou significado o outro. Constatou que no processo de recrutamento e seleção, a análise do currículo não é suficiente para concluir de forma efetiva sobre os novos candidatos. Por isso, a entrevista é uma fase fundamental para a compreensão de realizar uma avaliação mais assertiva nos processos de recrutamento e seleção.

Ramos e Bortagarai (2012) em sua pesquisa com estudantes de Medicina constataram sobre a importância em se melhorar a comunicação não verbal para ampliar a compreender o paciente, todavia indicaram que não dominam tais conceitos e se focam mais na comunicação verbal. Já a pesquisa realizada por Santos; Tanaka; Carmagnani (2015), sobre o significado da comunicação para as entrevistadoras na seleção de profissionais de enfermagem, concluíram que os envolvidos não usam de forma consciente os sinais não verbais, e os cumprimentos e demais movimentos corporais, não são percebidos ou não há a preocupação em decifrar tais sinais. A vestimenta também afeta o sistema de comunicação. Pessoas com roupas extravagantes são consideradas inapropriadas, tanto para homens como para mulheres. Ou seja, ao participar de um processo de recrutamento e seleção a vestimenta deve ser séria.

$\mathrm{O}$ estudo constatou que as enfermeiras participantes concordam de sua importância, entretanto indicam que isso é uma competência a ser desenvolvida no âmbito social e profissional. Essa competência se desenvolve por meio do relacionamento interpessoal e estudos sobre o tema.

No processo de recrutamento e seleção todas estas descobertas são utilizadas e o profissional que realiza esta função na empresa deve desenvolver competências necessárias para poder, na entrevista, constatar o que realmente esta para além da fala e das aparências.

Os estudos apresentados demonstram que gestos e posturas corporais transmitem uma gama enorme de informações diversas no processo de comunicação. Estas informações se vinculam a idade, sexo, status e a cultura onde a comunicação ocorre. Estes dados experimentais apontam que tanto os sinais verbais e não verbais interagem e possuem significados que ficam difíceis de serem isolados, já que ocorrem simultaneamente.

Portanto, a comunicação não verbal é poderosa e no processo de recrutamento e seleção e quando o recrutador é habilidoso em interpretá-la torna-se um recurso útil, já que, como foi dito, a entrevista é parte importante neste processo. É quando se pode avaliar a pessoa em sua expressabilidade por meio da coerência ou não entre a fala e o movimento do corpo.

\section{CONCLUSÃO}

Os estudos demonstraram que a comunicação não verbal é importante para todo o processo de gestão das organizações. Quando bem elaborada leva a resolução de conflitos com a diminuição de comunicações contraditórias. Interpretar a comunicação não verbal é saber o que a pessoal de fato diz e quais são suas reais intenções durante uma conversa. Para o entrevistador decifrar esses sinais deve saber lê-los em conjunto e nunca isoladamente.

A comunicação não verbal é uma forma complexa de interação interpessoal, onde os significados nem sempre são 
decodificados de maneira correta. Estes erros são devidos a pouca consciência que se tem dele. Todavia é habilidade que pode ser aprendida para que fique sob controle do entrevistador a maior parte do tempo e promova a percepção mais efetiva dos comportamentos referentes aos novos talentos a serem contratados.

Além disso, deve-se considerar as emoções envolvidas ao se transmitir mensagens e lembrar que, a comunicação não verbal é fortemente influenciada pelo contexto e diferentes culturas e nos processos organizacionais.

$\mathrm{E}$, sua utilidade no processo de recrutamento e seleção é inovação crucial, na maioria das vezes, para a escolha assertiva na seleção de novos talentos. Ou seja, adequar o candidato ao perfil da vaga e conseguir maior retenção destes talentos e diminuir a rotatividade nas organizações.

\section{REFERÊNCIAS BIBLIOGRÁFICAS}

ALCURE, L. F. Comunicação verbal e não verbal. 2.ed. Rio de Janeiro: Senac, 1996.

ANTÉRIO, D. A importância do olhar na relação comunicativa entre professor e aluno. Revista Temas em Educação, João Pessoa, v.23, n.2, p. 234-248 , jul.-dez. 2014. p. 234-248. Disponível: http://periodicos.ufpb.br/ojs/index.php/rteo/article/view/182 56/12571. Acesso em, 06/09/2016.

FEYERISEN, P. DE LANNOY, J.D. Linguagem do corpo, gestualidade e comunicação. IN: CHANLAT, J. F. O indivíduo na organização: dimensões esquecidas. v. 2, São Paulo: Atlas, 1993, p. 17-37.

BARTHES, R. Elementos de semiologia. São Paulo, Cultrix, 1971.

BIRDWHISTELL, R. El lenguage de la expression corporal. Barcelona, Gustavo Gill, 1970.

BOWDITCH, L. J.; BUONO, F. A. Elementos de comportamento organizacional. São Paulo: ThomsonPioneira, 2004.

COELHO, B. J. Comunicação Verbal. 2 ed. Goiânia: Cultura, 2005.

CORRAZE, J. As comunicações não-verbais. Rio de Janeiro, Zahar, 1982.

DAVIS, F. A comunicação não-verbal. São Paulo, Summus, 1979.

GAIARSA, J. A. Trabalho corporal em psicoterapia, fundamentos e técnicas: couraça muscular do caráter - W Reich. São Paulo: Ágora, 1984.

O corpo fala? Motriz, Rio Claro, v.8, n.3, p.85-90, set/dez.,2002. Disponivel em: http://www.rc.unesp.br/ib/efisica/motriz/08n3/Gaiarsa.pdf.A cesso em: 17 nov. 2016.

GOIS, A. K.; NOGUEIRA, M. F. M.; VIEIRA, N. V. A Linguagem do corpo e a comunicação nas organizações . Revista Anagrama: Revista Científica Interdisciplinar da Graduação. Ano 4 - Ed. 4. Junho-Agosto de 2011. Acesso em 08/08/2016 http://www.revistas.univerciencia.org/index.php/anagrama/a rticle/viewFile/7608/7004

FEYREISEN, P.; LANNOY, J.D. Linguagem do corpo, gestualidade e comunicação. In: CHANLAT, J.F (org). O individuo na organização: dimensões esquecidas. V.II, São Paulo: Altas, 1993, p. 18-37.

MATTOS, R. De recursos a seres humanos na empresa. Editora Livre, 1992

MESQUITA, R. M. Comunicação não-verbal: relevância na atuação profissional. In: Rev. Paulista. Educ. Fís., São Paulo, 11(2):155-63, jul./dez. 1997. http://citrus.uspnet.usp.br/eef/uploads/arquivo/v11\%20n2\% 20artigo7.pdf. Acesso em 20/08/2016.

PEIRCE, C. S. Semiótica. São Paulo: Editora Perspectiva, 1977.

RAMOS, A. P. A; BORTAGARAI, F.M. comunicação nãoverbal na área da saúde. Rev. CEFAC. 2012 Jan-Fev; 14(1):164-170. Disponível em http://www.scielo.br/pdf/rcefac/v14n1/186_10.pdf, acesso em 21/08/2016.

RIBEIRO, A. L. Gestão de Pessoas. 7. ed. São Paulo: Editora Saraiva, 2005.

SANTOS, A.B.S; TANAKA,L.H.; CARMAGNANI, M.I. Significados da comunicação não verbal para as entrevistadoras na seleção de profissionais de enfermagem. Revista mineira de enfermagem. 2015. Disponível em http://www.reme.org.br/artigo/detalhes/1048, acesso 21/08/2016.

SANTOS, A. A.; CONCEIÇÃO, L.H.P; ROSA, S.S; LEMOS, C.G.; MAZZIO, S.A.; ABREU, A.C.; OTTAL, W. A influência do tipo de vestimenta na formação de primeiras impressões e na reação à aproximação de um estranho. Revista Psic. Teor. e Pesq, Brasília, 1992. Vol. 8, N. 1, p. 78-88. Disponível em: https://revistaptp.unb.br/index.php/ptp/article/viewFile/1437 1424. Acesso em 20/08/2016.

SILVA, M.J.P. Comunicação tem remédio: a comunicação interpessoais na área de saude. 10. ed. São Paulo: Loyola, 2012.

WEIL, P.; TOMPAKOW, R.. O corpo fala: a linguagem silenciosa da comunicação não-verbal. Rio de Janeiro: Vozes, 1986.

WOLTON, D.. Informar não é comunicar. Porto Alegre: Sulina, 2010.

\section{COPYRIGHT}

Direitos autorais: Os autores são os únicos responsáveis pelo material incluído no artigo. 


\section{Área: Ciências Humanas e Sociais}

\begin{tabular}{|c|c|}
\hline 6-1 & $\begin{array}{l}\text { A IMUNIDADE TRIBUTÁRIA DAS ENTIDADES RELIGIOSAS } \\
\text { THE IMMUNITY TAX OF RELIGIOUS ENTITIES } \\
\text { Hélio Silvio Ourém Campos; Thiago Paraíso Vilela Santana }\end{array}$ \\
\hline $6-1$ & $\begin{array}{l}\text { O CONCEITO DO DIREITO À SAÚDE NO BRASIL DE } 2005 \text { A } 2015 \\
\text { HEALTH LAW CONCEPT IN BRAZIL } 2005 \text { TO } 2015 \\
\text { Nélio Fernandes Borrozzino; Maria Elisa Gonzalez Manso }\end{array}$ \\
\hline $6-2$ & $\begin{array}{l}\text { ESPORTISMO - COMPETÊNCIAS ADQUIRIDAS NO ESPORTE QUE AUXILIAM O } \\
\text { ATINGIMENTO DA ALTA PERFORMANCE PROFISSIONAL } \\
\text { ESPORTISMO - COMPETENCIES ACQUIRED IN SPORTS PRACTICE THAT ARE } \\
\text { HELPFUL TO ACHIEVE HIGH PROFESSIONAL PERFORMANCE } \\
\text { Rodrigo Guimarães Motta; Wagner Castropil; Neusa Santos }\end{array}$ \\
\hline $6-2$ & $\begin{array}{l}\text { UMA ALTERNATIVA PARA SE INTERNACIONALIZAR: ESTUDO DE CASO DE } \\
\text { EMPRESA DE MÉDIO PORTE DO AGRONEGÓCIO BRASILEIRO } \\
\text { AN ALTERNATIVE TO INTERNATIONALIZE: CASE STUDY OF MID-SIZED } \\
\text { COMPANY OF BRAZILIAN AGRIBUSINESS } \\
\text { Vânia Margarida Ferreira; Helder Antônio Da Silva; Nicássia Feliciana Novôa; Cláudia } \\
\text { Maria Miranda De Araújo Pereira }\end{array}$ \\
\hline $6-7$ & $\begin{array}{l}\text { BIOCOMBUSTÍVEIS NO BRASIL: PROSPECÇÃO TECNOLÓGICA SOB O } \\
\text { ENFOQUE DE PEDIDOS DE PATENTES } \\
\text { BIOFUELS IN BRAZIL: TECHNOLOGICAL PROSPECTING UNDER THE } \\
\text { PATENT APPLICATIONS APPROACH } \\
\text { Maria Gabriela Beilfuss Rocha Jorge; David Calhau Jorge; Lúcia Marina Scatena; } \\
\text { Mônica Hitomi Okura }\end{array}$ \\
\hline $6-7$ & $\begin{array}{l}\text { LEVANTAMENTO DO USO DE BUSINESS INTELLIGENCE COMO FERRAMENTA } \\
\text { DE TOMADA DE DECISÃO NOS INSTITUTOS FEDERAIS DE EDUCAÇÃO } \\
\text { LIFTING THE USE OF BUSINESS INTELLIGENCE AS A DECISION-MAKING } \\
\text { TOOL IN THE FEDERAL INSTITUTES OF EDUCATION } \\
\text { Jefferson Steidel Dos Santos; Denise Fukumi Tsunoda }\end{array}$ \\
\hline $7-1$ & $\begin{array}{l}\text { ABORDANDO UM DOS MAIORES ACIDENTES NUCLEARES DA HISTÓRIA } \\
\text { ATRAVÉS DA INTERDISCIPLINARIDADE } \\
\text { DISCUSSING ONE OF THE BIGGEST NUCLEAR ACCIDENTS OF HISTORY } \\
\text { USING INTERDISCIPLINARITY } \\
\text { Rosana Petinatti Da CruZ; Maria Lúcia Teixeira Guerra De Mendonça; Adriana } \\
\text { Ramos Pinheiro; Aramis David Correa; José Carlos Fernandes Costa; Raimundo } \\
\text { Nonato Da Silveira Júnior }\end{array}$ \\
\hline
\end{tabular}




\begin{tabular}{|c|c|}
\hline 7-8 & $\begin{array}{l}\text { O USO DA TECNOLOGIA NO ENSINO SUPERIOR: UM OLHAR PARA AS } \\
\text { MEDIAÇÕES EXISTENTES NAS AULAS DE UM CURSO DE PEDAGOGIA } \\
\text { USE OF TECHNOLOGY IN HIGHER EDUCATION: A LOOK AT EXISTING } \\
\text { MEDIATIONS IN THE CLASSROOMS OF A PEDAGOGY COURSE } \\
\text { Adriana Recla; Andrés Barrios Rocha; Félix Forero García }\end{array}$ \\
\hline $7-8$ & $\begin{array}{llll}\text { A IMPORTÂNCIA DA INTERAÇÃO } & \text { ESCOLA-FAMÍLIA } & \text { PARA } & \text { O } \\
\text { DESENVOLVIMENTO DE CRIANÇAS SUPERDOTADAS } & & \\
\text { THE IMPORTANCE OF SCHOOL-FAMILY INTERVENTION } & \text { FOR } & \text { THE } \\
\text { DEVELOPMENT OF SUPERDOTED CHILDREN } & & \\
\text { Márcia Stefanello Fischborn; Désirée Gonçalves Raggi } & & \end{array}$ \\
\hline $7-8$ & $\begin{array}{l}\text { ESTRATÉGIAS PEDAGÓGICAS OBSERVADA NA SALA DE RECURSOS: } \\
\text { ESTUDANTE COM TRANSTORNO GLOBAL DO DESENVOLVIMENTO } \\
\text { EDUCATIONAL STRATEGIES OBSERVED IN ROOM FEATURES: STUDENT } \\
\text { WITH GLOBAL DEVELOPMENT DISORDER } \\
\text { Adriana De Souza Carreira; Gabriely Cabestré Amorim; Vera Lúcia Messias Fialho } \\
\text { Capellini }\end{array}$ \\
\hline $7-8$ & $\begin{array}{l}\text { ESTUDO DAS POSSIBILIDADES DE CONEXÃO DA SUSTENTABILIDADE, COM } \\
\text { O ENSINO DE QUIIMICA, AS PRÁTICAS EDUCATIVAS E O DESENVOLVIMENTO } \\
\text { LOCAL } \\
\text { STUDY OF THE POSSIBILITIES OF CONNECTING SUSTAINABILITY, WITH } \\
\text { CHEMISTRY EDUCATION, EDUCATIONAL PRACTICES AND LOCAL } \\
\text { DEVELOPMENT } \\
\text { Edward Aredes Silva Júnior; Adilene Gonçalves Quaresma }\end{array}$ \\
\hline $7-8$ & $\begin{array}{l}\text { O ENSINO-APRENDIZAGEM DE CIÊNCIAS DE UM ALUNO COM SÍNDROME DE } \\
\text { DOWN } \\
\text { THE TEACHING-LEARNING SCIENCE OF A STUDENT WITH DOWN SYNDROME } \\
\text { Giancarlo Silva Costa; Nilson Santos Trindade }\end{array}$ \\
\hline $7-8$ & 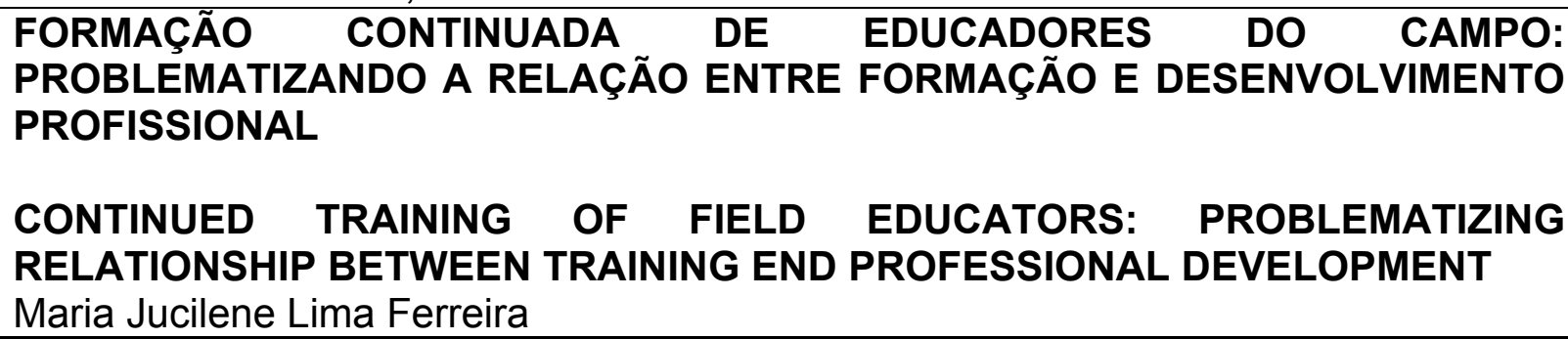 \\
\hline 8-1 & $\begin{array}{lllll}\text { PROJETOS DE } & \text { LETRAMENTO: } & \text { ESTRATÉGIAS } & \text { INTEGRADORAS } & \text { DE } \\
\text { APRENDIZAGEM } & & & & \end{array}$ \\
\hline
\end{tabular}




\title{
A IMUNIDADE TRIBUTÁRIA DAS ENTIDADES RELIGIOSAS THE IMMUNITY TAX OF RELIGIOUS ENTITIES
}

\author{
HÉLIO SILVIO OURÉM CAMPOS ${ }^{1}$; THIAGO PARAÍSO VILELA SANTANA ${ }^{2}$ \\ 1; 2 - UNIVERSIDADE CATÓLICA DE PERNAMBUCO \\ vania.souza@jfpe.jus.br; grupo6vf@gmail.com
}

\begin{abstract}
Resumo - O Brasil é um Estado laico, desde o período Republicano, tendo início no ano de 1891. A imunidade religiosa só para os templos de qualquer culto a partir do ano de 1946, o que fez das entidades religiosas imunes aos impostos incidentes sobre renda, patrimônio e serviço quando vinculados a suas atividades essenciais. A extensão da imunidade tributária, advinda da interpretação da doutrina e da jurisprudência traz certas dúvidas de até onde essa extensão advém de poder político, ou do costume, além de não haver um consenso na definição da finalidade essencial, componente que reforça a necessidade da imunidade. Diante disso, esse trabalho monográfico discute problemas relativos à imunidade e à finalidade essencial das atividades desses entes, motivo pelo qual este tem imunidade além da proteção a liberdade de culto.
\end{abstract}

Palavras-chave: Imunidade. Constituição. Finalidade Essencial.

Abstract - Brazil is a secular state since the Republican period, beginning in the year 1891. The religious immunity only to the temples of any cult from 1946, which made the immune religious entities to taxes on income, equity and service when linked to their core activities. The extent of tax immunity, arising from the interpretation of the doctrine and jurisprudence has certain doubts as far as this extension comes from political power, or custom, and there is no consensus in defining the essential purpose component that reinforces the need for immunity. Therefore, this monograph discusses problems related to immunity and the essential purpose of the activities of these entities, which is why they have immunity and protecting the freedom of worship.

Keywords: Immunity. Constitution. Essential Purpose.

\section{INTRODUÇÃO}

O presente trabalho tem como tema a imunidade tributária das entidades religiosas, partindo de todo um debate acerca do instituto. Como metodologia, usamos a bibliográfica como também nos baseamos no texto Constitucional e na legislação pátria.

O Brasil é um Estado laico, contudo não tem esse caráter desde sua formação enquanto nação. Com a vinda dos portugueses, a corte não trouxe somente sua cultura, vestimenta, nem conhecimento, com os colonizadores estava presente a Igreja Católica como parte fundamental das decisões estatais e do cotidiano do povo português.

Nos debruçamos na evolução histórica da liberdade religiosa, do ponto onde só o culto a Igreja de Roma era permitido até o momento em que estamos, onde existe a liberdade de culto, não interessando o seguimento religioso. Através da legislação pátria, da primeira Constituição até a presente, bem como com o Código Tributário Nacional-
CTN, portarias da Receita Federal, pareceres da Procuradoria Geral da Fazenda Nacional-PGFN, jurisprudência dos Tribunais Superiores e doutrina buscamos elucidar certas dúvidas acerca da matéria, buscando trabalhar com as diferenças entre a imunidade e isenção e trabalhar toda a problemática sobre a finalidade essencial dessas entidades.

Lembramos aos líderes das entidades e seus praticantes a importância do registro de suas comunidades de fé, junto ao cartório e a Receita Federal obtendo o Cadastro Nacional de Pessoa Jurídica-CNPJ.

Por se tratar de uma imunidade, o que a fasta a condição de contribuinte sobre os impostos sobre patrimônio, renda e serviço, tem esse trabalho o intuito de mostrar a importância da permanência deste instituto como também relembrar que essa é uma forma do Estado garantir aos brasileiros segurança na realização de seus cultos e na prática de sua fé.

Com esse trabalho objetivamos elucidar certas dúvidas acerca deste tema, bem como tentar estabelecer uma forma de se enxergar a finalidade essencial.

\section{DO ESTADO LAICO E DA LIBERDADE RELIGIOSA NO BRASIL}

\section{Da Laicidade e da Liberdade Religiosa}

É importante estabelecer o que de fato significa laicidade. Existem correntes que usam desse conceito quando se é conveniente, ocultando às vezes o real sentido do Estado laico. Nossa Carta Magna não define o que seria laicidade, o que falhou de certa forma alguns pactos e convenções internacionais, até que surgiu a Declaração Universal da Laicidade no Século $\mathrm{XXI}^{1}$ traz referências importantes para definir laicidade entre seus arts. $4^{\circ}$ e $7^{\circ}$ :

Artigo 4. Definimos a laicidade como a harmonização, em diversas conjunturas sócio-históricas e geopolíticas, dos três princípios já indicados: respeito à liberdade de consciência e à sua prática individual e coletiva; autonomia da política e da sociedade civil com relação às normas religiosas e filosóficas particulares; nenhuma discriminação direta ou indireta contra os seres humanos.

(...)

Artigo 6. A laicidade, assim concebida, constitui um elemento chave da vida democrática. Impregna, inevitavelmente, o político e o jurídico, acompanhando

1 Declaração apresentada no Senado francês em 9 de dezembro de 2005, por ocasião das comemorações do centenário da separação entre Estado e Igreja na França. 
assim os avanços da democracia, o reconhecimento dos direitos fundamentais e a aceitação social e política do pluralismo.

Artigo 7. A laicidade não é patrimônio exclusivo de uma cultura, de uma nação ou de um continente (...). ${ }^{2}$

Essa declaração possui caráter informal, contudo é o documento que tem como objetivo definir esse conceito, tendo em vista que as maiorias dos documentos internacionais abordam a liberdade religiosa, sendo esta parte do que se entende sobre a laicidade. Isso pode ser observado no art.18 da Declaração Universal dos Direitos Humanos $^{3}$, no art.18 do Pacto Internacional de Direitos Civis e Políticos ${ }^{4}$, no art.12 da Convenção Americana de Direitos Humanos- Pacto de San Jose da Costa Rica ${ }^{5}$ ou no art. $1^{\circ}$ da Declaração sobre a Eliminação de Todas as Formas de Intolerância de Discriminação Baseadas em Religião ou Crença ${ }^{6}$.

Dos pontos elencados pela Declaração, resta claro que a laicidade consiste na garantia da liberdade religiosa e por isso uma não submissão pública a normas de caráter religioso, bem com a rejeição a discriminação religiosa. Aqui o que traz legitimação ao Estado é a democracia e não o sagrado, a legitimação é advinda de um Estado constitucional que garante direitos fundamentais.

\section{Liberdade Religiosa Incluída na cláusula Pétrea da Constituição Federal de 1988.}

A Carta Magna vigente foi um marco fundamental para o povo brasileiro. A Constituição Cidadão foi um alento após um governo ditatorial que em muito oprimiu seu povo, e que não dava ambiente estável para o exercício de certos direitos, o que mudou após ser promulgada a Constituição vigente.

Algo que revigorou a sociedade, algo que trouxe segurança aos brasileiros foi o fato de ser reconhecida como cláusula pétrea a liberdade religiosa. Afirmar-se em sem

\footnotetext{
${ }^{2}$ Encontrado no: http://jurisway.jusbrasil.com.br/noticias/34742/tjrs-magistrado-participa-de-convencao-iberoamericana-pelasliberdades-laicas . Acesso em 14/05/2015

${ }^{3}$ Declaração Universal dos Direitos Humanos, art.18: Toda pessoa tem direito à liberdade de pensamento, de consciência e de religião; este direito implica a liberdade de mudar de religião ou de conviçção, assim como a liberdade de manifestar a religião ou convicção, sozinho ou em comum, tanto em público como em privado, pelo ensino, pela prática, pelo culto e pelos ritos.

${ }^{4}$ Pacto Internacional de Direitos Civis e Políticos (1966). Art.18. 1. Toda pessoa terá direito a liberdade de pensamento, de consciência e de religião. Esse direito implicará a liberdade de ter ou adotar uma religião ou uma crença de sua escolha e a liberdade de professar sua religião ou crença, individual ou coletivamente, tanto pública como privadamente, por meio do culto, da celebração de ritos, de práticas e do ensino. (...)

${ }^{5}$ Convenção Americana de Direitos Humanos- Pacto de San Jose da Costa Rica. Art.12. 1. Toda pessoa tem direito à liberdade de consciência e de religião. (...)2. Ninguém pode ser submetido a medidas restritivas que possam limitar sua liberdade de conservar sua religião ou suas crenças (...)4. Os pais e, quando for o caso, os tutores, têm direito a que seus filhos e pupilos recebam a educação religiosa e moral que esteja de acordo com suas próprias convicções.

${ }^{6}$ Art. $1^{\circ}$. $§ 1$. Toda pessoa tem o direito de liberdade de pensamento, de consciência e de religião. Este direito inclui a liberdade de ter uma religião ou qualquer convicção a sua escolha, assim como a liberdade de manifestar sua religião ou suas convicções individuais ou coletivamente, tanto em público como em privado, mediante o culto, a observância, a prática e o ensino.
}

medo de represálias é sim algo que deve ser louvado, bem como o art.60, parágrafo $4^{\circ}$, inciso $\mathrm{V}$ :

Art. 60. A Constituição poderá ser emendada mediante proposta:

$\S 4^{\circ}$ Não será objeto de deliberação a proposta de emenda tendente a abolir:

IV - os direitos e garantias individuais.

Essa consagração como direito fundamental, fez da proteção a liberdade de consciência um pilar da Constituição Federal de 1988 . O art. $5^{\circ}$ é muito forte, pois em seu caput fica definido que:

Art. $5^{\circ}$ Todos são iguais perante a lei, sem distinção de qualquer natureza, garantindo-se aos brasileiros e aos estrangeiros residentes no País a inviolabilidade do direito à vida, à liberdade, à igualdade, à segurança e à propriedade, nos termos seguintes: (grifos nossos) ${ }^{7}$

O inciso VI regula especificamente a proteção da liberdade de crença, seja ela de crer ou de não crer em fé alguma: "é inviolável a liberdade de consciência e de crença, sendo assegurado o livre exercício dos cultos religiosos e garantida, na forma da lei, a proteção aos locais de culto e a suas liturgias".

Da forma que a Carta Magna vigente foi redigida, essas garantias só podem ser perdidas através de uma nova constituição. Caso essas garantias não fossem abraçadas por uma nova constituição seria um retrocesso social homérico. As proteções a liberdade de crença aparecem também no inciso VIII, onde ninguém será privado de direitos por crença religiosa, filosófica ou política, contudo podendo invocar para se eximir de obrigação legal.

É comum homens jovens se declararem cristãos para não servirem as Forças Armadas, por exemplo, pois não querem usar armamento ou por qualquer motivo. Foi muito feliz a constituinte ao redigir o inciso anterior, o VII que é a prestação de assistência religiosa nas entidades civis, militares ou de internação coletiva, algo que supre as necessidades de uma obrigação imposta somente aos homens, contudo respeitando a crença de cada um.

\section{DA IMUNIDADE TRIBUTÁRIA DOS TEMPLOS DE CULTO}

$\mathrm{O}$ art. 150, VI, $b$, da Constituição vigente estabelece a imunidade tributária aos templos de qualquer culto. Essa imunidade i mpede que os Entes Federativos exerçam seu poder de tributar todos os que contém o artigo constitucional.

Ao se compreender a imunidade de forma ampla, vemos que tudo o que pertence a entidade religiosa é protegido da incidência do tributo, não só IPTU, mas todos os tributos tendo quem defenda a imunidade em relação aos Imposto de Importação, se houver compra de produtos para exercer a atividade e estes não forem comprados dentro do país, tendo em vista que o contribuinte é o comerciante. Na solução de consulta $n^{\circ} 109-C O S I T$ de 22 de abril, de 2014 veio uma situação interessante a respeito da imunidade referente ao Imposto de Importação (II) e o Imposto Sobre os Produtos Industrializados (IPI), sendo, portanto, um caso envolvendo Igreja Protestante que pleiteava reconhecimento

\footnotetext{
${ }^{7}$ Constituição Federal de 1988.

http://www.planalto.gov.br/ccivil_03/Constituicao/ConstituicaoCompilado. htm. Acesso em 21/08/2015.

${ }^{8}$ Idem.
} 
de sua imunidade, ao importar equipamento de audiovisual com a finalidade de transmitir o culto via internet.

Os doutrinadores têm posicionamentos diferentes a respeito deste ponto. A Constituição Federal em seu art.150 dispõe sobre a limitação do poder de tributar e toca nesta questão da finalidade essencial no par. $4^{\circ}$, sendo este relacionado também as entidades religiosas:

Art. 150. Sem prejuízo de outras garantias asseguradas ao contribuinte, é vedado à União, aos Estados, ao Distrito Federal e aos Municípios:

(...)

VI - instituir impostos sobre

(...)

$\S 4^{\circ}$ - As vedações expressas no inciso VI, alíneas "b" e "c", compreendem somente o patrimônio, a renda e os serviços, relacionados com as finalidades essenciais das entidades nelas mencionadas. (grifos nosso)

Em dissertação de mestrado escreveu Luiz Mesquita sobre o seguinte:

Partindo dessa ponderação, pressupomos que, se a última Carta Magna tivesse aperfeiçoado o texto, seguindo da expressão "e dela decorrente", o alargamento da imunidade religiosa dos templos de culto seria justificado, mas parece que este não foi o pensamento do constituinte. ${ }^{9}$

Como a Carta Magna não usa essa expressão deixa livre a interpretação, o que resulta em posicionamentos restritivos como de Aliomar Baleeiro, Sérgio Pinto Martins, onde o posicionamento no que se relaciona a finalidade essencial é altamente restritivo. Para Aliomar, por exemplo, as casas "... de aluguel, terrenos, bens e rendas do Bispado ou da paróquia."

Cabe às entidades religiosas em seus estatutos declararem sua missão, estabelecer a finalidade de sua existência. Ao operador do direito cabe enxergar a finalidade essencial como um sistema, onde existem funções fundamentais e funções acessórias. Se enxergarmos a finalidade essencial como um conjunto de funções que atestem o mister da entidade, pode facilitar a identificação do que de fato está alinhado a entidade e o que não participa de sua função primordial.

As constituições começaram conferindo irrestrito poder e privilégios à Igreja de Roma, imunizando-a de tributos e fazendo desta participante de decisões estatais. Da Constituição de 1824 até a Carta Magna vigente tivemos enquanto povo muitos avanços sobre a liberdade religiosa, primeiro permitindo outras religiões atuarem de forma livre, contudo com pequenas restrições, depois com o Decreto $\mathrm{n}^{\circ}$ 119-A de 1890 que vetou que houvesse por parte do Estado discriminação religiosa até chegarmos num momento que ainda não perfeito, mas um momento em que a tolerância tem sido tema bastante debatido com o objetivo de diminuir o preconceito.

A legislação pátria imuniza o terceiro setor da cobrança de impostos, imuniza as finalidades essenciais das entidades religiosas e no momento em que se constatar que há um desvirtuamento que venha a lesar não só os membros da comunidade de fé, como também lesar a sociedade é importante que medidas sejam tomadas como, por exemplo, o fim da imunidade.

${ }^{9}$ Mesquita, Luiz. Da Imunidade Religiosa no Brasil Perspectiva no Direito Tributário. Recife.2014.pag.37.

\section{AS FORMALIDADES LEGAIS DAS ENTIDADES RELIGIOSAS NO BRASIL}

As entidades religiosas precisam ser regularizadas para exercer sua função, para adquirir patrimônio, para assinar contratos. O Código Civil vigente em seu art.44 elenca as pessoas jurídicas de direito privado:

(...)

Art. 44. São pessoas jurídicas de direito privado:

IV - as organizações religiosas ${ }^{10}$;

Ao elencar as entidades religiosas como organizações dotadas de personalidade o legislador trouxe um direito e um dever para essas instituições. O dever é de obter cadastro junto ao Ministério da Fazenda, de se organizar através de um estatuto e com isso vem o direito de poder ser visto como ente dotado de personalidade e capacidade para atos da vida civil. A criação e o reconhecimento desta organização como pessoa jurídica de direito privado vieram com a lei $\mathrm{n}^{\circ} 10.825$, de 22 de dezembro, de 2003 que acrescentou ao art.44 do código civil o inc.IV e o par.1.

$\S$ 1 São livres a criação, a organização, a estruturação interna e o funcionamento das organizações religiosas, sendo vedado ao poder público negar-lhes reconhecimento ou registro dos atos constitutivos e necessários ao seu funcionamento ${ }^{11}$.

O registro deve ser feito em cartório, onde será registrado o estatuto da entidade onde, deve constar os requisitos elencados nos arts. 46 e 54 do Código Civil vigente. Deve-se lembrar que não basta existir civilmente, mas cabe a entidade obter registro junto a Fazenda pelo simples fato de que a imunidade não recai sobre taxas, bem como se faz necessário para qualquer transação negocial com essas organizações a existência do Cadastro Nacional de Pessoa Jurídica-CNPJ.

O Brasil mesmo sendo o país com o maior número de católicos no mundo, com cerca de 123,2 milhões de sua população- de um pouco mais de 200 milhões hojedeclarando-se seguidores da Igreja de Roma, no entanto se observarmos os números do último censo vamos constatar uma grande queda dos católicos romanos que respondem por $64,6 \%$ da população contra os $92 \%$ em $1970^{12}$.

É visível o crescimento indiscriminado de igrejas, sendo a maioria no meio neopentecostal e pentecostal, contudo se deve tomar muito cuidado se as mesmas estão regularizadas e se estão exercendo as atividades com as quais se comprometeu se envolver na fundação da organização. Sobre esse assunto dispõe o Código Civil vigente em seu art.50 da seguinte forma:

Art. 50. Em caso de abuso da personalidade jurídica, caracterizado pelo desvio de finalidade, ou pela confusão patrimonial, pode o juiz decidir, a requerimento da parte, ou do Ministério Público quando lhe couber intervir no processo, que os efeitos de certas e determinadas relações de obrigações sejam estendidos aos bens particulares dos administradores ou sócios da pessoa jurídica.

\footnotetext{
${ }^{10}$ Brasil.Lei $\mathrm{n}^{\mathrm{0}} 10.406$, de 10 de janeiro de 2002.

http://www.planalto.gov.br/ccivil_03/leis/2002/L10406.htm. Acesso em:01/10/2015

${ }^{11}$ Lei ${ }^{\circ} 10.825 / 03$

http://www.planalto.gov.br/ccivil_03/leis/2003/L10.825.htm\#art44. Acesso em:01/10/2015

${ }^{12}$ ANTUNES, Anderson. The richest pastors in Brazil. Forbes.

Disponível em:

<http://www.forbes.com/sites/andersonantunes/2013/01/17/the-richestpastors-inbrazil/>.Acesso em: 04/10/2015.
} 
Após o registro a personalidade jurídica da entidade está atrelada a sua finalidade essencial. O momento do protestantismo no Brasil, tendo em vista que as demais religiões não têm enfrentado problemas dessa envergadura, é muito complicado por ter se tornado uma fonte "inesgotável" de recursos financeiros. As "igrejas" onde a teologia da prosperidade é pregada além de sugar de seus membros os recursos, acabam por se afastar dos princípios da ética cristã, fazendo do dinheiro ou da prosperidade os deuses cultuados no local. Todo o discurso é baseado no ganho, onde quem dá mais ganha mais. Se olharmos de forma objetiva podemos lembrar das pirâmides financeiras, onde os ganhos são obtidos com o dinheiro investido e com as pessoas que abastecem os que estão a cima na estrutura.

Com tudo que é noticiado e com a matéria da Forbes, fica muito a mostra que a finalidade é obter ganhos. Tem quem defenda que a Lei $\mathrm{n}^{\mathrm{o}} 12.850$, de 2 de agosto de 2013 pode ser aplicada nas igrejas, pois existe um sistema bem organizado, formado por mais de quatro pessoas e que objetivam auferir vantagem que no caso é financeira. Não se pode negar que a imunidade que é conferida as entidades religiosas ainda geram desconfianças, porque da mesma forma que serve para proteger a liberdade religiosa, a liberdade de opinião, também serve como um muro que é usado por criminosos que fazem das entidades uma fonte de renda não baseado no trabalho duro, no cuidado das pessoas, e sim no lucro pelo abuso da fé.

Por mais que esses problemas sejam reais, nunca se deve esquecer que a proteção constitucional tem um intuito de proteger todas as religiões e que isso faz parte do Estado Democrático de Direito. A imunidade é dada aos "templos de qualquer culto", todas as religiões estão abarcadas e pela liberdade de crença até os que não creem tem seu direito resguardado.

\section{As peculiaridades da legislação tributária sobre as entidades religiosas.}

A norma tributária veta os Entes federativos (União, Estados, Distrito Federal e Municípios) cobrem imposto as entidades religiosas e das demais instituições elencadas no art.150, inc.VI, $b$, da Constituição Federal, contudo a imunidade não atinge as outras espécies tributárias como, por exemplo, as taxas.

A obrigação tributária é principal ou acessória, é assim que o CTN estabelece em seu art.113. Seguindo o uso do CTN, devemos olhar o conceito da obrigação tributária pelo que dispõe o código em seu art. $3^{\circ}$, que diz:

Art. $3^{\circ}$ Tributo é toda prestação pecuniária compulsória, em moeda ou cujo valor nela se possa exprimir, que não constitua sanção de ato ilícito, instituída em lei e cobrada mediante atividade administrativa plenamente vinculada (grifos nossos).

Existem obrigações acessórias às quais os templos estão subordinados, tais como manter em dia o alvará de funcionamento, prestar informações de empregados junto ao Ministério do Trabalho, oferecer a declaração anual junto à Receita Federal, preencher a GFIP para recolhimento da quota previdenciária. Sobre esse último, vale lembrar que não recai sobre valores de subsistência, ou seja, as prebendas pagas aos ministros de confissão religiosa, como se encontra no art. 22, inciso IV, parágrafo 13 da Lei no 8.212, de 24 de julho de 1991.

Uma das obrigações que atingem as entidades religiosas consta a não distribuição de parcela de seu patrimônio, renda a qualquer título ${ }^{13}$. Interessante que esse requisito, caso não obedecido pode impedir o gozo da imunidade pelas entidades religiosas, bem como pelas outras instituições sem fins lucrativos. Nas entidades religiosas pode-se aplicar de forma que ninguém pode utilizar desse patrimônio para benefício próprio, seja membro ou nãomembro.

Vale ressaltar que não cabe aí a remuneração dos líderes das entidades religiosas. Nem todos os ministros recebem um salário, os padres fazem voto de pobreza, por exemplo, não possuindo bem algum sendo o seu sustento advindo da própria ordem. A maioria dos ministros recebem um valor pelos seus serviços, contudo a figura do pastor, por exemplo, é bem peculiar por não ser ele empregado da instituição o que não dá o caráter de assalariado, bem como não é um prestador de serviço somente. Para todos os efeitos, os ganhos dos líderes das entidades religiosas são regulados pela lei de seguridade social.

Nos trabalhos de missionários, onde algumas denominações, especialmente aquelas consideradas tradicionais, desenvolvem em suas estratégias missionárias de evangelização o envio de missionários ao exterior, sustentando os vocacionados, por exemplo. Neste sentido, os valores destinados ao exterior são parte das atividades essenciais da organização religiosa, sendo protegido, portanto, da cobrança de impostos, como já pacificado administrativamente nas Decisões números 039/98 e 202/2004, respectivamente procedentes da SRRF/1 ${ }^{\text {a }}$ RF e SRRF/9 ${ }^{\mathrm{a}}$ RF, Publicadas no DOU: 29.10.1998 e 10.08.2004.

O registro das entidades religiosas é essencial. A carga de princípios exercitada pela religião não deve atuar na escuridão, a margem da legalidade, afastada da sociedade. Cabe as entidades, aos seus líderes dar exemplo de conduta obedecendo a legislação pátria no registro enquanto sociedade simples, obter o número no cadastro de pessoa jurídica, possuir alvará de funcionamento, autorização para construções ou reforma.

\section{CONCLUSÃO}

Concluímos esse trabalho assegurando que a laicidade estatal é muito importante, que permitir que o povo possa se sentir livre para expressar sua fé, para es expressar enquanto indivíduo fundamental para a manutenção do Estado Democrático de Direito. Ao se respeitar o direito de culto, ao permitir o exercício da individualidade vemos o compromisso do Estado com os Direitos Humanos. O Brasil passou por uma série de ida e vindas até abandonar o caráter confessional até chegar a laicidade, caminho não muito fácil de ser trilhado mas mostra que enquanto País evoluiu bem até os dias de hoje.

A imunidade das entidades é uma forma saudável do Estado proteger a liberdade de crença, sem se envolver de forma íntima com nenhuma religião, o que afetaria o seu caráter laico. Sobre a imunidade, acompanhamos o entendimento do STF que é ampliativo, dando essa condição de imune ao ente e não ao templo. A finalidade essencial é da entidade e não do espaço de culto, o que seria um contrassenso afirmar que cabe ao lugar e não a quem faz dele propício a imunidade. A imunidade dada as entidades religiosas é característica de Estado laico, pois as pessoas Brasil, Lei Complementar $\quad \mathrm{n}^{\circ} 104,10$ de janeiro de 2001.
http://www.planalto.gov.br/ccivil_03/leis/LCP/Lcp104.htm. em:06/01/2015. 
necessitam crer, se envolver e se desenvolver buscando serem melhores na busca espiritual que tem como consequência um cidadão melhor.

Alertamos os líderes religiosos que realizem suas atividades de forma regularizada, pra que não passem por situações constrangedoras. Registro civil, CNPJ, alvará de funcionamento, alvará pra reforma de imóveis para construção ou reforma de templo, tudo isso é importante para manter a lisura da entidade intacta. Caso a entidade não obedeça às formalidades legais, bem como não esteja quite com as obrigações tributárias acessórias corre o risco de passar por procedimento administrativo e de ter como sanção a suspensão da imunidade.

Por fim, cremos que é importante que os cidadãos tenham o conhecimento da importância da imunidade, que se tenham clareza de que ela não existe para favorecer determinados grupos ou classes sociais, bem como não é razão para que haja impunidade quando usarem de ma-fé.

\section{REFERÊNCIAS}

\section{ALEMANHA. Lei Fundamental da República Federal da Alemanha. Dispõe}

sobre a Constituição alemã. Disponível em:<http://www.brasil.diplo.de/contentblob/3254212/Daten/ 1330556/ConstituicaoPortugues_PDF.pdf >. Acesso em: 15 out. 2015.

ANTUNES, Anderson. The richest pastors in Brazil. Forbes.Disponível

<http://www.forbes.com/sites/andersonantunes/2013/01/17/t herichest-pastors-in-brazil/>. Acesso em: 04 outubro. 2015.

Constituição da República Federativa do Brasil, de 1988. Disponível em: <http://www.planalto.gov.br/ccivil_03/Constituicao/Constit ui\%C3\%A7ao.htm>.Acesso em: 21 set. 2015.

Lei $n^{0}$ 3.193, 4 de jul. 1957. Dispõe sobre a aplicação do art. 31, V, letra b, da Constituição Federal. Disponível <http://www.planalto.gov.br/ccivil_03/leis/1950-

1969/L3193.htm>. Acesso em: 18 ago. 2015

Lei $n^{0}$ 4.117, 27 de ago. 1962. Institui o Código Brasileiro de Telecomunicações. Disponível em: <http://www.planalto.gov.br/ccivil_03/leis/14117.htm>. Acesso em: 28 nov. 2014.

. Lei n. 5.172, 25 out. 1966. Dispõe sobre o Sistema Tributário Nacional e institui normas gerais de direito tributário aplicáveis à União, Estados e Municípios. Disponível <http://www.planalto.gov.br/ccivil_03/leis/15172.htm>. Acesso em: 31 ago. 2015.

. Lei no 6.404, de 15 de dezembro de 1976. Dispõe sobre as Sociedades por Ações. Disponível em: <http://www.planalto.gov.br/ccivil_03/leis/16404consol>.ht m. Acesso em 26.ago. 2015.

Lei n. 8.137, de 27 de dezembro de 1990. Define crimes contra a ordem tributária, econômica e contra as relações de consumo, e dá outras providências. Disponível em: <http://www.planalto.gov.br/ccivil_03/leis/18137.htm>. Acesso em 17 set. 2015.
Lei n. 8.981, de 20 de janeiro de 1995. Altera a

legislação tributária federal e dá outras providências.

Disponível em:

<http://www.planalto.gov.br/ccivil_03/leis/L8981.htm>.

Acesso em 01 out. 2015.

Lei n. 9.532, de 10 de dezembro de 1997. Altera a legislação tributária federal e dá outras providências. Disponível em:

<http://www.planalto.gov.br/ccivil_03/leis/19532.htm>. Acesso em 10 out. 2014.

Lei n. 9.718, de 27 de novembro de 1998. Altera a Legislação Tributária Federal. Disponível em: <http://www.planalto.gov.br/ccivil_03/leis/19718.htm>.

Acesso em 03 out. 2015.

Lei n. 12.328, de 15 de setembro de 2010. Institui o Dia Nacional do Evangélico a ser comemorado no dia 30 de novembro de cada ano. Disponível em: <http://www.planalto.gov.br/ccivil_03/_Ato2007-

2010/2010/Lei/L12328.htm>. Acesso em: 13.set. 2015.

Decreto n. 7.107, de 11 de fevereiro de 2010. Promulga o Acordo entre o Governo da República Federativa do Brasil e a Santa Sé relativo ao Estatuto Jurídico da Igreja Católica no Brasil, firmado na Cidade do Vaticano, em 13 de novembro de 2008. Disponível em: <http://www.planalto.gov.br/ccivil_03/_Ato2007-

2010/2010/Decreto/D7107.htm>. Acesso em: 10.ago. 2015.

Lei n. 8.212, de 24 de julho de 1991. Dispõe sobre a organização da Seguridade Social, institui Plano de Custeio, e dá outras providências. Disponível em: <http://www.planalto.gov.br/ccivil_03/leis/18212cons.htm>. Acesso em: 10 ago. 2015.

Lei n. 9.430, de 27 de dezembro de 1996. Dispõe sobre a legislação tributária federal, as contribuições para a seguridade social, o processo administrativo de consulta e dá outras providências. Disponível em: <http://www.planalto.gov.br/ccivil_03/leis/19430.htm>.

Acesso em: 07 ago. 2015.

Lei n. 9.472, de 16 de julho de 1997. Dispõe sobre a organização dos serviços de telecomunicações, a criação e funcionamento de um órgão regulador e outros aspectos institucionais, nos termos da Emenda Constitucional $\mathrm{n}^{\circ}$ 8, de 1995. Disponível em:

<http://www.planalto.gov.br/ccivil_03/Leis/L9472.htm>. Acesso em: 27 nov. 2014.

Lei n. 9.532, de 10 de dezembro de 1997. Altera a legislação tributária federal e dá outras providências.

Disponível em:

<http://www.receita.fazenda.gov.br/Legislacao/leis/Ant2001 /lei953297.htm>. Acesso em: 07 ago. 2015.

Procuradoria Geral da Fazenda NacionalPGFN/CAT n ${ }^{\circ} 1.483$, de 2001, objeto do Parecer Cosit $n^{\circ}$ 18, de 4 de julho de 2002. Podendo ser encontrado: http://www.receita.fazenda.gov.br/publico/Legislacao/Soluc oesConsultaCosit/2014/SCCosit1092014.pdf

PGFN/CAT n ${ }^{\circ}$ 2.137, de 30 de setembro de 2010.Podendo ser encontrado:

http://www.receita.fazenda.gov.br/publico/Legislacao/Soluc oesConsultaCosit/2014/SCCosit1092014.pdf 
Supremo Tribunal Federal. STF - RE. Ag. 734.339. IMUNIDADE TRIBUTÁRIA. IPTU. TEMPLO RELIGIOSO. DEBATE SOBRE A DESTINAÇÃO DO IMÓVEL. Disponível em:

http://webcache.googleusercontent.com/search?q=cache:1_w kmh_n4vkJ:www.stf.jus.br/portal/processo/verProcessoPeca .asp\%3Fid\%3D128662158\%26tipoApp\%3D.pdf+\&cd=1\&h l=pt-BR\&ct=clnk\&gl=br. Acesso em: 04 set. 2015.

BRASÍLIA. Tribunal de Justiça. TJ-DF AC: 20010110875766 DF. Disponível em: http://tjdf.jusbrasil.com.br/jurisprudencia/3132137/apelacao-civelac-20010110875766-df. Acesso em: 24/08/2015

Lei n 893, 28 jul. 1995. Institui no Distrito Federal o "Dia do Evangélico" e dá outras providências. Disponível em:

<http://www.sinj.df.gov.br/sinj/Arquivo.ashx?id_norma_co nsolidado=48852>. Acesso em: 13 ago. 2014.

BRUGGER, Winfried. Da hostilidade passando pelo reconhecimento até a identificação: Modelos de Estado e Igreja e sua relação com a liberdade Religiosa. Direitos fundamentais \& justiça: $n^{\circ} 10$ - jan./mar. 2010. Disponível em:<http://www.dfj.inf.br/Arquivos/PDF_Livre/10_Dout_E strangeira_1.pdf $>$ Acesso em: 08 mai. 2015.

CONVENÇÃO AMERICANA DE DIREITOS HUMANOS. Pacto de San Jose da Costa Rica, 22 nov. 1969.

Disponível

em:<http://www.pge.sp.gov.br/centrodeestudos/bibliotecavi rtual/instrumentos/sanjose.

htm>. Acesso em 14 jun. 2015.

HOBSBAWM, Eric J. A Era das revoluções 1789 - 1848. São Paulo: Paz e Terra, 2009.

INSTITUTO BRASILEIRO DE GEOGRAFIA E ESTATÍSTICA. Séries históricas e estatísticas. Disponível em:<seriesestatisticas.ibge.gov.br/lista_tema.aspx?op $=2 \&$ no $=10>$. Acesso em: Acesso em 11 de junho de 2015 .

JOÃO PESSOA. Lei Complementar $\mathbf{n}^{\mathbf{0}}$ 053, de 23 de dezembro 2008. Institui o Código Tributário Municipal e dá outras providências. Disponível em:http://www.joaopessoa.pb.gov.br/portal/wp-

content/uploads/2012/04/Lei_Organica_de_Joao_Pessoa.pdf . Acesso em:26/09/2015

MACHADO SEGUNDO, Hugo de Brito. Processo Tributário. 8. ed. São Paulo: Atlas, 2014.

ORGANIZAÇÃO DAS NAÇÕES UNIDAS, Carta das nações unidas e estatuto da Corte Internacional de Justiça, 26 jun. 1945. Disponível em: <http://www.brasil.gov.br/cidadania-ejustica/2009/11/declaracao-universal-dosdireitos-humanosgarante-igualdade-social>. Acesso em: 15 out. 2014.

Declaração Universal dos direitos humanos, 10 dez. 1948. Disponível em:

<http://portal.mj.gov.br/sedh/ct/legis_intern/ddh_bib_inter_ universal.htm>. Acesso em: 14 .jul. $201 \overline{5}$.

\section{COPYRIGHT}

Direitos autorais: Os autores são os únicos responsáveis pelo material incluído no artigo.
${ }^{1}$ Juiz Federal; Líder de Grupo de Pesquisa - CNPq: "Política e Tributação: aspectos materiais e processuais"; Professor da Escola Superior da Magistratura de Pernambuco; Professor Titular e Membro do Conselho Superior da Universidade Católica de Pernambuco (Graduação e Mestrado); Doutor em Direito pela Universidade Federal de Pernambuco e Doutorado pela Faculdade Clássica de Direito de Lisboa; Mestre em Direito pela Universidade Federal de Pernambuco e pela Faculdade Clássica de Direito de Lisboa - (Equivalência); Ex-Procurador do Estado de Pernambuco; Ex-Procurador do Município do Recife; ExProcurador Federal; Pós-doutorado pela Universidade Clássica de Lisboa.

E-mail: http://www.ourem.web44.net; http://lattes.cnpq.br/1508584545879443

${ }^{2}$ Bacharel em Direito pela Universidade Católica de Pernambuco. E-mail: grupo6v@gmail.com 


\title{
Revista SODEBRAS - Volume 12 \\ $\mathrm{N}^{\circ} 134$ - FEVEREIRO/ 2017
}

\section{O CONCEITO DO DIREITO À SAÚDE NO BRASIL DE 2005 A 2015}

\author{
HEALTH LAW CONCEPT IN BRAZIL 2005 TO 2015
}

\author{
NÉLIO FERNANDES BORROZZINO ${ }^{1}$; MARIA ELISA GONZALEZ MANSO ${ }^{1}$ \\ 1 - PONTIFÍCIA UNIVERSIDADE CATÓLICA DE SÃO PAULO - SP \\ neliofb@gmail.com; mansomeg@hotmail.com
}

\begin{abstract}
Resumo - O direito à saúde foi uma conquista social no mundo $e$, no Brasil, teve seu desdobramento positivo com a criação do Sistema Único de Saúde (SUS) em 1990. Utilizando uma metodologia restritiva, o presente estudo buscou publicações sobre o assunto entre os anos de 2005 e 2015, encontrando as seguintes temáticas: Saúde como um direito social; Acesso à saúde; Acesso à medicamentos; Judicialização do Direito à Saúde e Outros temas pertinentes. Como suposto, há uma importante lacuna entre a lei $e$ a realidade brasileira, convergindo sobre o uso do judiciário para acesso à saúde, muito embora ainda tratado como um direito social.
\end{abstract}

Palavras-chave: Direito à Saúde. Legislação Sanitária. Revisão.

\begin{abstract}
The right to health was a social achievement in the world and, in Brazil, had its positive development with the creation of the Sistema Unico de Saúde (SUS) in 1990. Using a restrictive methodology, this study sought to publications on the subject between the years 2005 and 2015, meeting the following themes: Health as a social right; Access to health care; Access to medicines; Legalization of the right to health and other relevant topics. As supposed, there is a significant gap between the law and the Brazilian reality, converging on the use of the judiciary to access to health, although still treated as a social right.
\end{abstract}

Keywords: Health Rights. Legislation Health. Review

\section{INTRODUÇÃO}

Nos dias que seguem, a saúde é um direito de todos e um dever do estado no Brasil, entretanto um assunto que é considerado ainda novo para o país. (BRASIL, 1988) De fato, a preocupação com a saúde surgiu de forma positivada com a Constituição Federal de 1988, que trouxe consigo um aspecto mais humanitário, pautado nos direitos fundamentais e na dignidade da pessoa humana, abrangendo esse direito à saúde como uma temática crucial ao desenvolvimento da sociedade brasileira, porém essa mesma preocupação insurge gradativamente aparecendo por intermédio dos direitos humanos, intrinsicamente e timidamente, nos séculos XIX e XX antes de nossa carta constitucional mais recente. Dallari (1988), registrando os fatos de um momento constituinte, escreve ao final da década de 80 um artigo explicando as nuances do direito à saúde como uma garantia mesmo antes da promulgação da atual constituição, o citando no artigo 25 da Declaração Universal dos Direitos do Homem, da Organização das Nações Unidas, como uma das condições necessárias para uma vida com dignidade.

Percorrendo o caminho histórico dos direitos humanos encontraremos a reação de grupos oprimidos clamando por direitos básicos (como a liberdade e a dignidade) frente aos grupos opressores de cada época. Essa viagem inicia-se com as autoridades governamentais da antiguidade e seguem com a carta magna da Inglaterra, as declarações de direito do século XVIII, chegando à industrialização e às revoluções socialistas do século XX (Russa em 1917 e Alemã em 1919), onde o direito ao trabalho é colocado como algo fundamental às sociedades. Inicialmente, a preocupação com a saúde antes da industrialização visava apenas o afastamento do doente para evitar o contagio aos demais trabalhadores, entretanto com a urbanização e a indústria, os próprios funcionários e empresários passaram a se preocupar com o quesito saúde. Os primeiros viam a necessidade de aumentar o seu padrão de vida residindo em cidades urbanizadas e os segundos perceberam que precisavam manter seus funcionários saudáveis para não interferir em sua produção e em sua própria saúde, devido ao ambiente de trabalho compartilhado. Logo, o processo para responsabilizar o estado ao invés dos empresários foi natural, pois a necessidade de garantir saúde ao povo não se limitava apenas aos trabalhadores, passando a se tornar uma garantia a todos e um direito garantido pelo governo (DALLARI, 1988).

Nesse contexto, a criação do Sistema Único de Saúde (SUS) após a promulgação da Constituição Federal de 88 pela lei 8080/90 viabiliza a universalização e o acesso à saúde no Brasil, garantindo de forma infraconstitucional especificar como o estado garantirá o direito à saúde para todos (BRASIL, 1990).

O presente artigo objetiva entender como as publicações desse direito são relatadas no Brasil na última década, supondo que a sociedade acadêmica o entende como uma forma de acesso do povo aos serviços de saúde brasileiros e uma maneira de promover uma vida com, no mínimo, garantia de necessidades básicas.

\section{METODO}

Trata-se de uma revisão sistemática da literatura de caráter qualitativo. Para a análise dos artigos encontrados foram utilizados os seguintes critérios de inclusão: Idiomas em Português, Espanhol ou Inglês; Artigos Completos; e Ano de publicação de 2005 a 2015.

Um importante critério de exclusão foi o texto do artigo não abordar a temática principal do presente estudo, ou seja, não abordar o direito à saúde no Brasil como eixo de pesquisa. 
Como conduta inicial, foi realizada uma busca por descritores de assuntos em três bases eletrônicas em saúde através de dois resultados cadastrados no Descritores em Ciências da Saúde (DECS): Saúde e Direito à Saúde. Nesse passo, foram encontrados vinte (20) artigos na Lilacs e nenhum artigo na Scielo e Medline. De forma complementar, houve uma nova busca utilizando apenas o segundo descritor na base de dados Scielo e Medline, com o resultado de setenta e cinco artigos (75). Concluindo a análise inicial, foram utilizados noventa e cinco (95) exemplares.

Dos artigos selecionados, realizamos as seguintes exclusões: Vinte e oito artigos (28) apresentavam ano de publicação inferior à 2005; dez (10) não tratavam da temática pretendida; Dois (2) não possuíam o texto completo. Resultando em cinquenta e cinco (55) artigos dentro dos critérios de inclusão.

Mediante a leitura dos resumos os artigos remanescentes foram classificados em sub-grupos temáticos para melhor compreensão do assunto tratado.

\section{RESULTADOS}

\section{1 - Saúde como Direito Social}

De fato, em um contexto histórico, o direito à saúde inicia-se por um movimento social, principalmente ligado aos direitos do trabalho e humanos, para chegar na forma positiva de direito fundamental encontrado na constituição brasileira. Dos artigos analisados, quinze (15) relacionam esse direito a um aspecto social.

Machado (2009), realiza uma contextualização histórica dos direitos sociais no mundo para analisar o direito à saúde em nosso país. Em seu texto, nota-se a relevância de mostrar várias facetas desse direito social, e não apenas enquadra-lo como o simples acesso à saúde, mas também descrevendo-o como algo amplo e complexo, como disposto na lei 8080/90 em seu artigo $3^{\circ}$, que determina as seguintes condições determinantes à saúde: "alimentação, a moradia, o saneamento básico, o meio ambiente, o trabalho, a renda, a educação, o transporte, o lazer e o acesso aos bens e serviços essenciais". O autor cita Bobbio, inclusive, para tratar a saúde como um direito social em constante desenvolvimento ligado à política em uma sociedade. Após alguns anos, em 2012, Machado e Dain trazem um estudo analítico sobre uma audiência pública realizada pelo Supremo Tribunal Federal (STF) a fim de refletir sobre as ações de saúde que chegam nessa instancia do poder judiciário. Seu principal objetivo é entender como a judicialização é expressada pelos participantes, abrangendo as diretrizes do SUS como argumentos contrários e favoráveis a intervenção estatal no assunto. Como a temática Judicialização à saúde foi um assunto de expressão nesse presente artigo, será tratada com maiores detalhes posteriormente.

Em outro contexto, voltado ao controle social à saúde, Soratto, Witt e Faria (2010) abordam a temática como um desafio e posteriormente, em 2013, trazem a percepção dos profissionais da Estratégia de Saúde na Família (ESF) sobre o assunto. No que tange os objetivos dessa revisão, ambos estudos tratam de algo extremamente relevante, a participação do povo à saúde. É através dessa participação cidadã que a democracia é realizada na área da saúde, promovendo de forma descentralizada e regionalizada a adequação de estratégias para diferentes regiões do Brasil, tal como previsto na lei que deu origem SUS. Consoante aos citados, a relação entre saúde e cidadania é abordada por Silva et al (2010) sobre a ótica das representações sociais na constituição de 88 , também chamada de constituição cidadã. Com base na lei maior, os autores focam sua dissertação no conceito de saúde como um direito de todos e um dever do estado. Tipicamente, a responsabilização do estado para promover a saúde aos cidadãos é, segundo os autores, um problema crucial para garantir a plena cidadania à população.

Em contrapartida, Vargas et al. (2007) ensejam que para se alcançar a cidadania plena, incluindo os direitos de saúde, deve-se superar um enorme obstáculo: A exclusão social. Trata-se do abismo criado na sociedade frente toda a pobreza e situação de desigualdade, onde essa experiência popular de não valorização de direitos fundamentais (algo histórico que caminha há muito tempo ao lado dos brasileiros) acarretam um sério déficit para a compreensão de democracia e cidadania. Embora conquistar tais direitos fundamentais na carta magna brasileira seja motivo de comemoração, trata-se de um direito em desenvolvimento que pode utilizar a enfermagem e as demais profissões da saúde como instrumentos nessa evolução. Ao se tratar de problemáticas, Asensi (2013) fundamenta-se que não obstante o estado deve ser o responsabilizado pela saúde integral dos indivíduos, sendo a própria população carente na forma correta para reivindicar seus direitos.

Destoante dos demais autores, encontramos os estudos de Ventura et al (2012) e Lima et al (2009). Estes, tratam o direito à saúde sob a ótica dos direitos humanos na observância dos cuidados de enfermagem em cidadãos que utilizam o SUS. Trata-se de um estudo com enfoque no enfermeiro como mediador para garantir o direito à saúde aos pacientes e, como algo inerente a profissão, garantir a cidadania aos cidadãos que utilizam esse serviço de saúde. Já aqueles, realizaram um estudo comparativo relacionando as políticas de saúde brasileiras com as italianas a fim de, em uma análise histórica, encontrar como o processo para materializar o direito à saúde ocorreu em ambos estados. Como resultado, os autores apontam que existe uma convergência histórica desse direito vinculado a forças operarias e a consagração de saúde vinculada ao direito trabalhista.

Embora legitimado na lei o direito a saúde como um direito social e um dever estatal, abrangendo o território nacional, parece provocar uma enorme lacuna entre o ser e dever ser jurídico. Trata-se de um assunto recente ao estado brasileiro e, como algo ligado a cidadania e inerente às políticas sociais, apresenta déficits relacionados aos grandes problemas de desigualdade social país. Entende-se que certamente há um conceito de direito à saúde que é compreendido pelos autores que abordam essa temática como um direito frágil (que não deixa de ser uma conquista) e em constante desenvolvimento (ASENSI, 2010; GARBOIS et al, 2008; BAPTISTA et al, 2009; FLEURY, 2009; VELEZ ARANGO, 2011; GIZARDI et al, 2008).

\section{2 - Acesso a Saúde}

Claramente, quando disposto que saúde é um direito de todos na Constituição Federal não houve limitação por parte do legislador para o acesso à saúde no Brasil, em encontro que, segundo a mesma constituição, não se pode haver descriminação conforme o caput do artigo $5^{\circ}$ "Todos são iguais perante a lei, sem distinção de qualquer natureza, 
garantindo-se aos brasileiros e aos estrangeiros residentes no País a inviolabilidade do direito à vida, à liberdade, à igualdade, à segurança e à propriedade, nos termos seguintes" que são tradados nos incisos posteriores ao texto. Concorda-se então, que o acesso à saúde é também um direito de todos, algo que foi abordado nos seis (6) artigos elencados, não necessariamente em um aspecto positivo.

Petean et al (2013), em um excelente estudo de caso, traz toda a problemática da trajetória de uma vítima de trauma por acidente de motocicleta e o seu dificultoso acesso à saúde do início ao fim de seu tratamento. Como tratado no tópico anterior, as dificuldades e a baixa resolutividade dos serviços de saúde promovem uma lacuna importante entre o ser [o que de fato ocorre] e o dever ser [a saúde como direito de todos] que, ao serem expostos em estudos como esse, mostram a necessidade de desenvolver melhorias urgentes à políticas públicas de saúde.

Essa deficiência também é apontada nos estudos de Kelber et al (2010) ao tratar sobre como o assunto é visto internamente em um serviço de atendimento domiciliar em saúde, em concordância com Silva (2010), que aborda um contexto semelhante, porém com os usuários de uma unidade básica de saúde e Puccini (2008) que realiza uma análise sobre a demanda não agendada utilizando o serviço público de saúde e a criação das chamadas assistência médicas ambulatorial (AMA) com o objetivo de aliviar a demanda das unidades básicas para esse tipo de atendimento. Não destoante dos demais, o autor expõe que esse tipo de serviço é ineficaz, inclusive não compreendendo as próprias diretrizes do SUS.

Para finalizar essa linha de raciocínio pautada na ineficácia do serviço de saúde, encontramos um terno denominado Contradireito à saúde, exposto por Fleury (2011). Trata-se da fundamentação dessa lacuna abordada entre a lei e como realmente encontra-se os serviços de saúde públicos no pais: Precariedade de serviços e equipamentos, desigualdade social na atenção hospitalar, negação da cidadania e insegurança dos usuários desse serviço.

Em contrapartida, o artigo de Vieira et al. (2014) realiza um comparativo ao acesso à saúde de pessoas com HIV/AIDS frente a ações estatais, comparando Brasil, África do Sul e Moçambique. Sobre essa temática, os autores confirmam que há a concretização desse acesso mediado pelas políticas públicas, colocando o Brasil a frente dessa universalização de cuidados aos demais países comparados.

Esperamos com o amadurecimento do estado brasileiro a conquista no âmbito real dos direitos sociais, mais especificamente o da saúde, multiplicando os casos de sucesso, como o exposto no parágrafo anterior, para os demais assuntos que carecem de atenção.

\section{3 - Acesso a Medicamentos}

Além do acesso à saúde e, especificamente, o cuidado a pessoas portadoras de HIV/AIDS, o acesso a medicamentos e insumos foi uma de grande relevância nos estudos encontrados. Partindo do pressuposto que existem patologias e condições de saúdes incontroláveis sem medicações e do próprio conceito de saúde como algo integral, o acesso a essas medicações se tornam intriscicamente ligadas ao próprio direito à saúde, sendo o assunto abordado em quinze (15) artigos elencados.
O assunto é tão complexo que, mesmo se tratando de direito à saúde, possui uma política própria a nível nacional. Hunt e Khosla (2008), traçam as responsabilidades dos estados e das indústrias farmacêuticas para garantir os medicamentos ditos como essenciais à população. Eles abordam a garantia das diretrizes do SUS pautadas em medicamentos, atingindo uma população que carece dessa atenção e vinculando a evolução dos estados para que essa distribuição igualitária ocorra. Paula et al (2011), em concordância aos primeiros autores, abordam a percepção dos usuários desses medicamentos essenciais sobre o direito à saúde e conclui que os próprios usuários consideram um grande déficit nas políticas de saúde pública, principalmente pelas medicações que lhe são necessárias nem sempre estarem disponíveis para aquisição pelo SUS.

Os demais estudos, treze (13), que tratam a temática de acesso a medicamentos expõe o assunto relacionado à jurisdição do direito à saúde, ou seja, pesquisas que englobam as decisões judiciais acerca ao acesso às medicações, assuntos que serão tratados a seguir.

\section{4 - Judicialização do Direito à Saúde}

A saúde como direito universal no estado brasileiro traz um grande salto aos direitos humanos e sociais, porém cria uma nova tendência de utilização ao poder judiciário para reclamar bens e direitos relacionados à saúde. Nos estudos elencados, cinco (5) tratam sobre essa utilização jurisdicional e, mais especificamente, treze (13) tratam sobre essa utilização voltada ao acesso a medicamentos, como exposto anteriormente.

Diniz et al (2014) descrevem as tendências do poder judiciário no Distrito Federal e dispõe os bens de saúde mais demandados nos processos jurídicos, os classificando como: Vagas em UTI na rede privada - representando 66\% -, seguido por Acesso a Medicamentos (15\%) e Assistência Médica (13\%). A grande demanda de processos relacionados ao acesso a medicações alerta sobre como o assunto é relevante à pesquisa, porém também demonstra como as bases carecem de artigos relacionados à judicialização com enfoque a reclamações por vagas em redes de saúde, pois não observamos artigos relacionados considerando a sua importância. Em uma análise semelhante, porém sem tratar de forma discriminada o direito à saúde, Travassos et al (2013), discorre sobre características e resultados de acórdãos comparando três tribunais brasileiros sobre processos em saúde. Como resultado impactante, dentre outros, o estudo mostrou que $97,8 \%$ das decisões foram favoráveis aos usuários. As decisões judiciárias remontam um aspecto social e, consequentemente, uma evolução oportuna sobre a resolução de conflitos da sociedade, logo, o número expressivo em aprovações a favor do usuário mostram que o déficit do sistema de saúde colocado nos outros tópicos desse estudo pode buscar a sua resolução mediante as decisões judiciais (BELLATO et al, 2012). Entretanto, as políticas públicas devem satisfazer a demanda da população, reservando o uso do poder judiciário apenas em casos excepcionais, mesmo quando o assunto for saúde (GOMES et al, 2014).

Outro defict analisado por Vieira e Zucchi (2009) é a falta de cobertura pelas políticas públicas para determinadas patologias. Como o direito tratado não discrimina e determina que a própria saúde é um direito à todos, a gama 
de patologias a serem tratadas se tornam incontáveis e, dificilmente, acolhidas por toda política de saúde no pais.

Especificamente sobre o acesso a medicações, de forma geral, a grande abrangência do direito à saúde embarga a utilização do sistema judiciário para a aquisição de produtos que fogem das políticas públicas vigentes (MACEDO et al, 2011; MACHADO et al, 2011). Embora o SUS tenha como preocupação a criação de listas para medicações de distribuição comum, sabemos que nem todas as patologias e medicamentos estão ali disponíveis e discriminados, dando ensejo a reclamação ao sistema judiciário em busca de seu direito à saúde. De forma generalista, os estudos apontam para o déficit no mundo normativo e a crescente utilização de liminares judiciais para a aquisição desse direito (VIEIRA, 2008; VENTURA et al, 2010; DALLARI, 2010; PEPE et al, 2010; LEITE e MAFRA, 2010), entretanto também trazem um aspecto positivo, pois teoricamente as políticas públicas de saúde se adequam sobre as decisões judiciais condizentes e favoráveis ao usuário, pois como dito, tratam-se de um respiro sobre as necessidades da sociedade e a sua própria evolução no âmbito jurídico (GOMES e AMADOR, 2015; FIGUEIREDO et al, 2013). Embora, como apontado por Chieffi et al (2013), Provone, Leite e Amaral (2013), a equidade e as demais diretrizes do SUS como alvos de violação pelo mesmo sistema, sabendo que o acesso à justiça em saúde encontra-se com certa limitação às pessoas com maior poder aquisitivo e conhecimento sobre seus direitos, fixando e comprovando as desigualdades sociais existentes no pais.

\section{5 - Demais Assuntos}

Aprofundando os estudos em temáticas que são menos frequentes na literatura, o direito à saúde aparece de forma especializada em vários assuntos. Em geral, tais temas mostram que essa área de pesquisa necessita de maior atenção para estudos aprofundados. Foram classificados quatorze (14) artigos nessa etapa, que são distribuídos como: Infecção Hospitalar - abrangendo o direito aos pacientes na prevenção dessa manifestação (SOUSA, 2007 e 2008; PUCCINI, 2011); Direito ao Acesso à Informação Estudos analisando a perspectivas dos agentes envolvidos em relação às informações e conhecimento sobre saúde (XAVIER et al, 2013; VASCONCELOS et al, 2014; LEITE et al, 2014); Direito à Saúde em Sistema Prisionais Abordando a temática sobre o acesso à saúde para pessoas com privação de liberdade, inclusive em casos psiquiátricos (MARTINS et al, 2014; CORREIA et al, 2007); Direito à Saúde como Princípio da Integralidade - tratando de um aspecto histórico e vinculando o princípio da integralidade com as diretrizes do SUS (BRITO-SILVA, 2012); Saúde nas Escolas - Uma revisão sobre a temática, analisando as políticas públicas ligadas a saúde escolar (CASEMIRO et al, 2014); Programas de Distribuição de Renda Analisando os programas de distribuição de renda com a finalidade de melhorar os indicadores de saúde na américa latina (FONSECA et al, 2007); Direito à Saúde para Pacientes Psiquiátricos - Analisando dois perfis de instituições psiquiátricas diferenciados (GASTAL e GUTFREIND, 2007); Direito à Saúde no Mercosul Analisando o acesso à saúde para os países vizinhos do Brasil, mediante a política de saúde nacional (DAL PRA, 2007); Direito à Saúde Infantil - Estudo voltado para o direito das crianças visando, de forma resumida, a sua proteção integral (ANDRADE, 2013).

\section{CONCLUSÃO}

O direito à saúde evoluiu historicamente com os direitos sociais e trabalhistas, sendo efetivado no final do sec. XX com a constituição federal de 1988. Inicialmente, com interesses produtivos, os empregadores classificavam a saúde dos trabalhadores como essencial para o bom funcionamento das empresas e, paulatinamente o estado passa a se responsabilizar pela saúde de todo o povo como um interesse coletivo.

Além do direito social citado, os estudos apontam esse direito como inerente a dignidade da pessoa humana, acesso à própria saúde, aquisição de insumos e materiais necessários para tal e, quando não disponíveis, a utilização do judiciário para reclamação desses direitos, dentre outros assuntos, tratando de forma integral o acesso $\mathrm{e} a$ disponibilidade da saúde à população brasileira.

Embora o direito à saúde seja um grande avanço ao Brasil, a responsabilização estatal onde a saúde é um direito de todos torna a legislação abrangente e distante de como as coisas realmente ocorrem, eclodindo uma importante lacuna entre a lei e as ações de políticas públicas de saúde nacionais. Trata-se de um pais com diferenças culturais importantes, desigualdades sociais gritantes, serviços e equipamentos precários e uma vasta extensão territorial.

Por fim, a amplitude da temática engaja que o assunto em pauta merece uma atenção aprofundada, pois ela apresenta várias facetas que não necessariamente foram tratadas nesse estudo.

\section{REFERÊNCIAS BIBLIOGRÁFICAS}

ANDRADE, Raquel Dully et al. Integralidade das ações entre profissionais e serviços: prerrogativa ao direito à saúde da criança. Esc. Anna Nery, Rio de Janeiro , v. 17, n. 4, p. 772 780, Dec. 2013. disponível em $<$ http://www.scielo.br/scielo.php?script=sci_arttext\&pid=S141 4-81452013000400772\&lng=en\&nrm=iso>. Acesso em 05 de maio de 2015 .

ASENSI, Felipe Dutra. Saúde, Poder Judiciário e sociedade: uma análise de Brasil e Portugal. Physis, Rio de Janeiro, v. 23, n. 3, p. 801-820, Sept. 2013. disponível em $<$ http://www.scielo.br/scielo.php?script=sci_arttext\&pid=S010 3-73312013000300008\&lng=en\&nrm=iso>. Acesso $30 \mathrm{abr}$ 2015.

ASENSI, Felipe Dutra. Judicialização ou juridicização? As instituições jurídicas e suas estratégias na saúde. Physis, Rio de Janeiro, v. 20, n. 1, p. 33-55, 2010. Disponível em $<$ http://www.scielo.br/scielo.php?script=sci_arttext\&pid=S010 3-73312010000100004\&lng=en\&nrm=iso>. accesso 30 Apr. 2015.

BAPTISTA, Tatiana Wargas de Faria; MACHADO, Cristiani Vieira; LIMA, Luciana Dias de. Responsabilidade do Estado e direito à saúde no Brasil: um balanço da atuação dos Poderes. Ciênc. Saúde coletiva, Rio de Janeiro, v. 14, n. 3, p. 829-839, June $2009 . \quad$ Available from <http://www.scielo.br/scielo.php?script=sci_arttext\&pid=S141 3-81232009000300018\&lng=en\&nrm=iso > . access on 30 Apr. 2015 . 
BELLATO, Roseney et al. Mediação do direito à saúde pelo tribunal de justiça: análise da demanda. Texto contexto enferm., Florianópolis, v. 21, n. 2, p. 356-362, June 2012. Available

from <http://www.scielo.br/scielo.php?script=sci_arttext\&pid=S010 4-07072012000200013\&lng=en\&nrm=iso>. access on 05 May 2015.

BRASIL. Constituição (1988). Constituição da República Federativa do Brasil. Brasília, DF: Senado; 1988.

BRITO-SILVA, Keila; BEZERRA, Adriana Falangola Benjamin; TANAKA, Oswaldo Yoshimi. Direito à saúde e integralidade: uma discussão sobre os desafios e caminhos para sua efetivação. Interface (Botucatu), Botucatu, v. 16, n. 40, p. 249-260, Mar. 2012. Available from <http://www.scielo.br/scielo.php?script=sci_arttext\&pid=S141 4-32832012000100019\&lng=en\&nrm=iso>. access on 05 May 2015. Epub Apr 19, 2012.

CASEMIRO, Juliana Pereira; FONSECA, Alexandre Brasil Carvalho da; SECCO, Fabio Vellozo Martins. Promover saúde na escola: reflexões a partir de uma revisãosobre saúde escolar na América Latina. Ciênc. Saúde coletiva, Rio de Janeiro, v. 19, n. 3, p. 829-840, Mar. 2014. Available from <http://www.scielo.br/scielo.php?script=sci_arttext\&pid=S141 3-81232014000300829\&lng=en\&nrm=iso > . access on 05 May 2015.

CHIEFFI, Ana Luiza; BARATA, Rita Barradas. Judicialização da política pública de assistência farmacêutica e equiidade. Cad. Saúde Pública, Rio de Janeiro, v. 25, n. 8, p. 1839-1849, Aug. $2009 . \quad$ Available from <http://www.scielo.br/scielo.php?script=sci_arttext\&pid=S010 $2-311 X 2009000800020 \& \operatorname{lng}=\mathrm{en} \& \mathrm{nrm}=\mathrm{iso}>$. access on 05 May 2015.

CORREIA, Ludmila Cerqueira; LIMA, Isabel Maria Sampaio Oliveira; ALVES, Vânia Sampaio. Direitos das pessoas com transtorno mental autoras de delitos. Cad. Saúde Pública, Rio de Janeiro, v. 23, n. 9, p. 1995-2002, Sept. 2007. Available from

$<$ http://www.scielo.br/scielo.php?script=sci_arttext\&pid=S010 $2-311 X 2007000900002 \& \operatorname{lng}=$ en\&nrm=iso $>$. access on 05 May 2015.

DALLARI, Sueli Gandolfi. Uma nova disciplina: o direito sanitário. Rev. Saúde Pública, São Paulo, v. 22, n. 4, p. 327334, ago. 1988. Disponível em $<$ http://www.scielo.br/scielo.php?script=sci_arttext\&pid=S003 4-89101988000400008\&lng=pt\&nrm=iso>. Acessos em 29 abr. 2015.

DALLARI, Sueli Gandolfi. O direito à saúde. Rev. Saúde Pública, São Paulo, v. 22, n. 1, p. 57-63, fev. 1988. Disponível em

<http://www.scielo.br/scielo.php?script=sci_arttext\&pid=S003 4-89101988000100008\&lng=pt\&nrm=iso>. Acessos em 29 abr. 2015.

DALLARI, Sueli Gandolfi. Controle judicial da política de assistência farmacêutica: direito, ciência e técnica. Physis, Rio de Janeiro, v. 20, n. 1, p. 57-75 2010. Available from $<$ http://www.scielo.br/scielo.php?script=sci_arttext\&pid=S010 3-73312010000100005\&lng=en\&nrm=iso >. access on 05 May 2015.

DAL PRA, Keli Regina; MENDES, Jussara Maria Rosa; MIOTO, Regina Célia Tamaso. O desafio da integração social no MERCOSUL: uma discussão sobre a cidadania e o direito à saúde. Cad. Saúde Pública, io de Janeiro,v. 23, supl. 2, p. S164S173, $2007 . \quad$ Available from $<$ http://www.scielo.br/scielo.php?script=sci_arttext\&pid=S010 $2-311 X 2007001400006 \& \operatorname{lng}=\mathrm{en} \& n r m=\mathrm{iso}>$. access on 05 May 2015.

DINIZ, Debora; MACHADO, Teresa Robichez de Carvalho; PENALVA, Janaina. A judicialização da saúde no Distrito Federal, Brasil. Ciênc. Saúde coletiva, Rio de Janeiro, v. 19, n. 2, p. 591-598, Feb. 2014. Available from $<$ http://www.scielo.br/scielo.php?script=sci_arttext\&pid=S141 $3-81232014000200591 \& \operatorname{lng}=$ en\&nrm=iso $>$. access on 04 May 2015.

FIGUEIREDO, Tatiana Aragão; OSORIO-DE-CASTRO, Claudia Garcia Serpa; PEPE, Vera Lúcia Edais. Evidencebased process for decision-making in the analysis of legal demands for medicines in Brazil. Cad. Saúde Pública, Rio de Janeiro, v. 29, supl. 1, Nov. 2013. Available from $<$ http://www.scielosp.org/scielo.php?script=sci_arttext\&pid=S 0102-311X2013001500014\&lng=en\&nrm=iso $>$. access on 05 May 2015.

FLEURY, Sonia. Reforma sanitária brasileira: dilemas entre o instituinte e o instituído.Ciênc. Saúde coletiva, Rio de Janeiro, v. 14, n. 3, p. 743-752, June 2009. Available from <http://www.scielo.br/scielo.php?script=sci_arttext\&pid=S141 3-81232009000300010\&lng=en\&nrm=iso>. access on $30 \mathrm{Apr}$. 2015.

FLEURY, Sonia. Desigualdades injustas: o contradireito à saúde. Psicol. Soc., Florianópolis, v. 23, n. spe, p. 45-52, 2011. Disponível em <http://www.scielo.br/scielo.php?script=sci_arttext\&pid=S010 2-71822011000400007\&lng=pt\&nrm=iso>. Acessos em 04 maio 2015.

FONSECA, Ana Maria Medeiros da; VIANA, Ana Luiza d'Ávila. Direito à saúde, atenção básica e transferências condicionadas de renda na América Latina. Ciênc. Saúde coletiva, Rio de Janeiro, v. 12, n. 6, p. 1505-1512, Dec. 2007. Available

from <http://www.scielo.br/scielo.php?script=sci_arttext\&pid=S141 $3-81232007000600012 \& \operatorname{lng}=e n \& n r m=i s o>$. access on 05 ay 2015.

GARBOIS, Júlia Arêas; VARGAS, Liliana Angel; CUNHA, Fátima Teresinha Scarparo. O direito à saúde na Estratégia Saúde da Família: uma reflexão necessária. Physis, Rio de Janeiro, v. 18, n. 1, p. 27-44, 2008. Available from <http://www.scielo.br/scielo.php?script=sci_arttext\&pid=S010 3-73312008000100003\&lng=en\&nrm=iso > . access on $30 \mathrm{Apr}$. 2015.

GASTAL, Cláudio Luis da Cunha; GUTFREIND, Celso. Um estudo comparativo de dois serviços de saúde mental: relações entre participação popular e representações sociais relacionadas ao direito à saúde. Cad. Saúde Pública, Rio de Janeiro, v. 23, n. 8, p. 1835-1844, Aug. 2007. Available from <http://www.scielo.br/scielo.php?script=sci_arttext\&pid=S010 $2-311 X 2007000800010 \& \operatorname{lng}=$ en $\& n r m=$ iso $>$. access on 05 May 2015.

GUIZARDI, Francini Lube; PINHEIRO, Roseni. Novas práticas sociais na constituição do direito à saúde: a experiência de um movimento fitoterápico comunitário. Interface (Botucatu), Botucatu, v. 12, n. 24, p. 109-122, Mar. 2008. 
Available

from

$<$ http://www.scielo.br/scielo.php?script=sci_arttext\&pid=S141

4-32832008000100009\&lng=en\&nrm=iso>. access on 05 May 2015.

GOMES, Dalila F. et al. Judicialização da saúde e a audiência pública convocada pelo Supremo Tribunal Federal em 2009: o que mudou de lá para cá?. Saúde debate,Rio de Janeiro, v. 38, n. 100, p. 139-156, Mar. 2014. Available from <http://www.scielo.br/scielo.php?script=sci_arttext\&pid=S010 3-11042014000100139\&lng=en\&nrm=iso >. access on 05 May 2015.

GOMES, Vanessa Santana; AMADOR, Tânia Alves. Estudos publicados em periódicos indexados sobre decisões judiciais para acesso a medicamentos no Brasil: uma revisão sistemática. Cad. Saúde Pública, Rio de Janeiro, v. 31, n. 3, Mar. 2015. Available from $<$ http://www.scielosp.org/scielo.php?script=sci_arttext\&pid=S 0102-311X2015000300451\&lng=en\&nrm=iso $>$. access on 05 May 2015.

HUNT, Paul; KHOSLA, Rajat. Acesso a medicamentos como um direito humano. Sur, Rev. int. direitos human., São Paulo, v. 5, n. 8, p. 100-121, June 2008 . Available from <http://www.scielo.br/scielo.php?script=sci_arttext\&pid=S180 6-64452008000100006\&lng=en\&nrm=iso >. access on 04 May 2015.

LEITE, Silvana Nair; MAFRA, Ana Cristina. Que direito? Trajetórias e percepções dos usuários no processo de acesso a medicamentos por mandados judiciais em Santa Catarina. Ciênc. saúde coletiva, Rio de Janeiro , v. 15, supl. 1, p. 16651672, June 2010. Available from <http://www.scielo.br/scielo.php?script=sci_arttext\&pid=S141 3-81232010000700078\&lng=en\&nrm=iso>. access on 05 May 2015.

LEITE, Renata Antunes Figueiredo et al. Acesso à informação em saúde e cuidado integral: percepção de usuários de um serviço público. Interface (Botucatu), Botucatu, v. 18, n. 51, p. 661-672, Dec. 2014. Available from $<$ http://www.scielo.br/scielo.php?script=sci_arttext\&pid=S141 4-32832014000400661\&lng=en\&nrm=iso > access on 05 May 2015.

LIMA, Rita de Cássia Gabrielli Souza et al. A construção do direito à saúde na Itália e no Brasil na perspectiva da bioética cotidiana. Saude soc., São Paulo, v. 18, n. 1, p. 118-130, Mar. 2009. Available from

<http://www.scielo.br/scielo.php?script=sci_arttext\&pid=S010

4-12902009000100012\&lng=en\&nrm=iso > . access on 04 May 2015.

KERBER, Nalú Pereira da Costa et al. Direito do cidadão e avaliação nos serviços de saúde: aproximações teórico-práticas . Revista Latino-Americana de Enfermagem, [S.1.], v. 18, n. 5, p. 1013-1019, out. 2010. ISSN 1518-8345. Disponível em: <http://www.revistas.usp.br/rlae/article/view/4252/5349>.

Acesso em: 04 Mai. 2015.

MACEDO, Eloisa Israel de; LOPES, Luciane Cruz; BARBERATO-FILHO, Silvio. Análise técnica para a tomada de decisão do fornecimento de medicamentos pela via judicial.Rev. Saúde Pública, São Paulo, v. 45, n. 4, p. 706-713, Aug. $2011 \quad$ Available from $<$ http://www.scielo.br/scielo.php?script=sci_arttext\&pid=S003 4-89102011000400010\&lng=en\&nrm=iso>. access on 05 May 2015. Epub July 01, 2011.

MACHADO, Felipe Rangel de Souza. O direito à saúde na interface entre sociedade civil e Estado. Trab. educ. saúde, Rio de Janeiro, v. 7, n. 2, p. 355-371, Oct. 2009. Available from $<\mathrm{http} / / / \mathrm{www}$.scielo.br/scielo.php?script=sci_arttext\&pid=S198 1-77462009000200009\&lng=en\&nrm=iso>. access on $30 \mathrm{Apr}$. 2015.

MACHADO, Felipe Rangel de Souza; DAIN, Sulamis. A Audiência Pública da Saúde: questões para a judicialização e para a gestão de saúde no Brasil. Rev. Adm. Pública, Rio de Janeiro, v. 46, n. 4, p. 1017-1036, Aug. 2012. Available from <http://www.scielo.br/scielo.php?script=sci_arttext\&pid=S003 4-76122012000400006\&lng=en\&nrm=iso>. access on 30 Apr. 2015.

MACHADO, Marina Amaral de Ávila et al . Judicialização do acesso a medicamentos no Estado de Minas Gerais, Brasil. Rev. Saúde Pública, São Paulo, v. 45, n. 3, p. 590-598, June 2011. Available from $<$ http://www.scielo.br/scielo.php?script=sci_arttext\&pid=S003 4-89102011000300018\&lng=en\&nrm=iso>. access on 05 May 2015. Epub Apr 01, 2011.

MARTINS, Élida Lúcia Carvalho et al . O contraditório direito à saúde de pessoas em privação de liberdade: o caso de uma unidade prisional de Minas Gerais. Saude soc., São Paulo, v. 23, n. 4, p. 1222-1234, Dec. 2014. Available from <http://www.scielo.br/scielo.php?script=sci_arttext\&pid=S010 4-12902014000401222\&lng=en\&nrm=iso >. access on 05 May 2015.

SILVA, Marcos Alex Mendes da; FERREIRA, Efigênia Ferreira e; SILVA, Girlene Alves da. O direito à saúde: representações de usuários de uma unidade básica de saúde.Physis, Rio de Janeiro , v. 20, n. 4, p. 1183-1207, Dec. $2010 . \quad$ Available from <http://www.scielo.br/scielo.php?script=sci_arttext\&pid=S010 3-73312010000400007\&lng=en\&nrm=iso>. access on 04 May 2015.

SILVA, Sílvio Éder Dias da et al. Constituição cidadã e representações sociais: uma reflexão sobre modelos de assistência à saúde. Rev. esc. enferm. USP, São Paulo, v. 44, n. 4, p. 1112-1117, Dec. 2010. Available from <http://www.scielo.br/scielo.php?script=sci_arttext\&pid=S008 $0-62342010000400037 \& \operatorname{lng}=\mathrm{en} \& \mathrm{nrm}=\mathrm{iso}>$. access on $30 \mathrm{Apr}$. 2015.

SOUSA, Cristina Maria Miranda de et al. Os direitos dos usuários da saúde em casos de infecção hospitalar. Rev. bras. enferm., Brasília, v. 61, n. 4, p. 411-417, Aug. 2008. Available from <http://www.scielo.br/scielo.php?script=sci_arttext\&pid=S003 $4-71672008000400002 \& \operatorname{lng}=e n \& n r m=i s o>$. access on 05May 2015.

SOUSA, Cristina Maria Miranda de et al. Representações Sociais das implicações legais da infecção hospitalar e de seu controle. Rev. bras. enferm., Brasília, v. 60, n. 4, p. 428-433, Aug. $2007 . \quad$ Available from <http://www.scielo.br/scielo.php?script=sci_arttext\&pid=S003 4-71672007000400013\&lng=en\&nrm=iso>. access on 05 May 2015.

PAULA, Patrícia Aparecida Baumgratz de et al. O uso do medicamento na percepção do usuário do Programa Hiperdia. 
Ciênc. saúde coletiva, Rio de Janeiro , v. 16, n. 5, p. 26232633, May 2011 Available from <http://www.scielo.br/scielo.php?script=sci_arttext\&pid=S141 $3-81232011000500032 \& \operatorname{lng}=e n \& n r m=i s o>$. access on 04 May 2015.

PEPE, Vera Lúcia Edais et al. A judicialização da saúde e os novos desafios da gestão da assistência farmacêutica. Ciênc. saúde coletiva, Rio de Janeiro, v. 15, n. 5, p. 2405-2414, Aug. 2010. Available from $<$ http://www.scielo.br/scielo.php?script=sci_arttext\&pid=S141 $3-81232010000500015 \& \operatorname{lng}=\mathrm{en} \& n \mathrm{~nm}=\mathrm{iso}>$. access on 05 May 2015.

PEPE, Vera Lúcia Edais et al. Caracterização de demandas judiciais de fornecimento de medicamentos "essenciais" no Estado do Rio de Janeiro, Brasil. Cad. Saúde Pública, Rio de Janeiro, v. 26, n. 3, p. 461-471, Mar. 2010. Available from $<$ http://www.scielo.br/scielo.php?script=sci_arttext\&pid=S010 $2-311 X 2010000300004 \& \operatorname{lng}=$ en $\& n r m=$ iso $>$. access on 05 May 2015.

PETEAN, Elen et al. Trajetória de busca por cuidado na vivência do evento traumático e sua cronificação. Saude soc., São Paulo, v. 22, n. 4, p. 1257-1268, Dec. 2013. Available from

<http://www.scielo.br/scielo.php?script=sci_arttext\&pid=S010 4-12902013000400026\&lng=en\&nrm=iso>. access on 04 May 2015.

PROVIN, Mércia Pandolfo; LEITE, Silvana Nair; AMARAL, Rita Goreti. Social inequalities in lawsuits for drugs. Braz. J. Pharm. Sci., São Paulo, v. 49, n. 3, p. 465-474, Sept. 2013. Available

$<$ http://www.scielo.br/scielo.php?script=sci arttext\&pid=S198 4-82502013000300008\&lng=en\&nrm=is

SORATTO, Jacks; WITT, Regina Rigatto; FARIA, Eliana Marília. Participação popular e controle social em saúde: desafios da Estratégia Saúde da Família. Physis, Rio de Janeiro, v. 20, n. 4, p. 1227-1243, Dec. 2010. Available from $<$ http://www.scielo.br/scielo.php?script=sci_arttext\&pid=S010 3-73312010000400009\&lng=en\&nrm=iso $>$. access on $30 \mathrm{Apr}$. 2015.

SORATTO, Jacks; WITT, Regina Rigatto. Participação e controle social: percepção dos trabalhadores da saúde da família. Texto contexto - enferm., Florianópolis, v. 22, n. 1, p. 89-96, Mar. 2013. Available from $<$ http://www.scielo.br/scielo.php?script=sci_arttext\&pid=S010 4-07072013000100011\&lng=en\&nrm=iso>. access on 30 Apr. 2015.

VARGAS, Liliana Angel; OLIVEIRA, Thaís Fonseca Veloso de; GARBOIS, Júlia Arêas. O direito à saúde e ao meio ambiente em tempos de exclusão social. Rev. Latino-Am. Enfermagem, Ribeirão Preto, v. 15, n. spe, p. 850-856, Oct. 2007. Available from <http://www.scielo.br/scielo.php?script=sci_arttext\&pid=S010 4-11692007000700021\&lng=en\&nrm=iso > access on $30 \mathrm{Apr}$. 2015.

VASCONCELOS, Camila, et al. "Direito ao conhecimento da origem biológica na reprodução humana assistida: reflexões bioéticas e jurídicas." Revista Bioética 22.3 (2014).

VENTURA, Miriam et al. Judicialização da saúde, acesso à justiça e a efetividade do direito à saúde. Physis, Rio de Janeiro, v. 20, n. 1, p. 77-100, 2010. Available from
<http://www.scielo.br/scielo.php?script=sci_arttext\&pid=S010 3-73312010000100006\&lng=en\&nrm=iso>. access on 05 May 2015.

VIEIRA, Fabiola Sulpino; ZUCCHI, Paola. Demandas judiciais e assistência terapêutica no Sistema Único de Saúde. Rev. Assoc. Med. Bras., São Paulo, v. 55, n. 6, p. 672-683, 009. Available from $<$ http://www.scielo.br/scielo.php?script=sci_arttext\&pid=S010 $4-42302009000600011 \& \operatorname{lng}=$ en\&nrm=iso>. access on 05 May 2015.

VIEIRA, Fabiola Sulpino. Ações judiciais e direito à saúde: reflexão sobre a observância aos princípios do SUS. Rev. Saúde Pública, São Paulo, v. 42, n. 2, abr. 2008. Disponível em $<$ http://www.scielosp.org/scielo.php?script=sci_arttext\&pid=S 0034-89102008000200025\&lng=pt\&nrm=iso>. Acessos em 05 maio 2015.

TRAVASSOS, Denise Vieira et al. Judicialização da Saúde: um estudo de caso de três tribunais brasileiros. Ciênc. saúde coletiva, Rio de Janeiro , v. 18, n. 11, p. 3419-3429, Nov. 2013. Available from <http://www.scielo.br/scielo.php?script=sci_arttext\&pid=S141 3-81232013001100031\&lng=en\&nrm=iso>. access on 04 May 2015.

VELEZ ARANGO, Alba Lucía. POR UN SISTEMA DE SALUD QUE GARANTICE LA PROTECCIÓN DEL DERECHO. UN REQUISITO DE JUSTICIA SOCIAL. Hacia promoc. Salud, Manizales, v. 16, n. 1, July 2011. Available from

$<$ http://www.scielo.org.co/scielo.php?script=sci_arttext\&pid=S 0121-75772011000100011\&lng=en\&nrm=iso $>$. access on 30 Apr. 2015.

VENTURA, Carla Aparecida Arena et al. Aliança da enfermagem com o usuário na defesa do SUS. Rev. bras. enferm., Brasília, v. 65, n. 6, p. 893-898, Dec. 2012. Available

from <http://www.scielo.br/scielo.php?script=sci_arttext\&pid=S003 $4-71672012000600002 \& \operatorname{lng}=e n \& n r m=$ iso $>$. access on 04 May 2015.

VIEIRA, Ana Cristina de Souza et al. A epidemia de HIV/Aids e a ação do Estado. Diferenças entre Brasil, África do Sul e Moçambique. Revista Katálysis, Florianópolis, v. 17, n. 2, p. 196-206, dez. 2014. ISSN 1982-0259. Disponível em: <https://periodicos.ufsc.br/index.php/katalysis/article/view/362 46>. Acesso em: 04 Mai. 2015.

XAVIER, Daiani Modernel et al. A família revelando-se como um ser de direitos durante a internação hospitalar da criança. Rev. bras. enferm., Brasília, v. 66, n. 6, p. 866-872, Dec. 2013. Available from <http://www.scielo.br/scielo.php?script=sci_arttext\&pid=S003 $4-71672013000600009 \& \operatorname{lng}=$ en\&nrm=iso $>$. access on 05 May 2015.

\section{COPYRIGHT}

Direitos autorais: Os autores são os únicos responsáveis pelo material incluído no artigo. 


\title{
ESPORTISMO - COMPETÊNCIAS ADQUIRIDAS NO ESPORTE QUE AUXILIAM O ATINGIMENTO DA ALTA PERFORMANCE PROFISSIONAL
}

\author{
ESPORTISMO - COMPETENCIES ACQUIRED IN SPORTS PRACTICE THAT \\ ARE HELPFUL TO ACHIEVE HIGH PROFESSIONAL PERFORMANCE
}

\author{
RODRIGO GUIMARÃES MOTTA ${ }^{1}$; WAGNER CASTROPIL ${ }^{2}$; NEUSA SANTOS ${ }^{3}$ \\ DOUTORANDO PUC-SP; DOUTOR USP; DOUTORA PUC-SP \\ rodrigo-motta@uol.com.br;castropil@vita.org.br;admneusa@pucsp.br
}

\begin{abstract}
Resumo - Esse é um estudo qualitativo de teoria fundamentada, onde os autores propõem que além da formação teórica necessária para a formação de um executivo, da formação prática, que a prática esportiva pode contribuir para o sucesso do executivo no ambiente desafiador e complexo dos dias atuais. A partir de entrevistas realizadas com cento $e$ vinte $e$ cinco executivos em posições de liderança em suas organizações $e$ que tinham uma experiência esportiva pregressa, os autores propõem um modelo, que os autores chamam de "Esportismo", composto de cinco competências que podem ser apreendidas através do esporte e que são utilizáveis em sua vivência profissional de forma a que eles obtenham melhores resultados em suas atividades no trabalho. Essas seguem uma ordem lógica e são a atitude, a visão, a estratégia, a execução e o teamwork. No contexto do estudo das competências organizacionais, o artigo apresenta alternativas para as diferentes competências individuais a serem trabalhadas dentro do modelo de gestão por competências.
\end{abstract}

Palavras-chave: Competências. Esportismo. Gestão.

Abstract - This is a qualitative study of grounded theory, where the authors demonstrate that beyond the academic studies needed to prepare an executive and the years of practice, practicing sports may contribute for his success. Due to the challenges of the economy, the changing business environment, the switch of the consumer habits and the organizational changes, the objective of this papers is to propose a contribution to the development of the executives through sports practice. The authors interviewed one hundred and twenty five executives and found five key competencies acquired in sports that can be used in business by executives: Atitude, Vision, Strategy, Execution and Teamwork. The sum of this competencies was called by the authors "Esportismo", and can be used to better prepare executives for the years ahead.

Keywords: Competencies. Esportismo. Management.

\section{INTRODUÇÃO}

Há diversos estudos que exploram a importância da gestão por competências para o sucesso das empresas e dos seus executivos. Livros como Carbone et al (2009), Dutra (2004), Fleury (2001), demonstram e ressaltam a importância da contratação de executivos que possuam as competências necessárias para sua função. Uma vez contratado, ele pode ser treinado, avaliado e reconhecido pelo desenvolvimento dessas competências, que contribuirão para o sucesso da organização.
Diversos autores, entre os quais Durand (2000), já destacaram em seus estudos que a posse de certas competências por parte dos executivos e por consequência das organizações aos quais os mesmos fazem parte, confere aos mesmos e as empresas uma performance superior $\mathrm{e}$ permite que os resultados dos negócios seja maximizado e supere àqueles dos seus concorrentes.

A linha americana que estuda as competências, composta por autores como Boyatzis (1982), enfatiza que a competência é formada por conhecimentos, habilidades e atitudes, que formam o CHA que permite ao executivo enfrentar os desafios que o trabalho apresenta e superá-los a contento das suas carreiras e da organização ao qual trabalha.

Os conhecimentos de acordo com Carbone et al (2009) são "informações que ao serem reconhecidas e integradas pelo indivíduo em sua memória, causam impacto sobre seu julgamento ou seu comportamento. Já as habilidades, segundo os autores, estão associadas "a aplicação do conhecimento, ... a capacidade da pessoa de instaurar conhecimentos armazenados em sua memória e utilizá-los em ação. Por fim as atitudes segundo Durand (2000) estão relacionadas a "aspectos sociais e afetivos relacionados ao trabalho".

O conhecimento de quais competências fazem a diferença para a performance de um indivíduo em seu trabalho permite que a organização na qual estão inseridos faça uma gestão dessas competências, as levando em consideração para a contratação de talentos, para a avaliação do desempenho do profissional, para a realização de treinamentos estruturados para capacitar a equipe, servir como plataforma para programas de remuneração e reconhecimento e como subsídio para a orientação profissional.

A necessidade de formar pessoas mais competentes e a utilização da gestão por competências é uma prática cada vez mais disseminada nas empresas, dado o cenário altamente competitivo, com mudanças relevantes no perfil do consumidor e dos segmentos empresariais, que estão brevemente descritas a seguir.

Ao analisar os novos consumidores, percebe-se que os mesmos não se satisfazem com as formas convencionais de divulgação dos produtos, como foi colocado por Calliari e Motta (2012). Novas ferramentas, como as mídias sociais, são mais atraentes, envolventes e podem oferecer um 
resultado de maior impacto. Hoje de acordo com Godoi, Las Casas e Motta (2015), resultados melhores para construir relacionamento com o consumidor podem ser obtidos pelo facebook, por exemplo, do que com mídias convencionais, como a televisão, o rádio e a propaganda de rua. Pulizzi (2015) ainda defende que não basta identificar essas novas ferramentas, é necessário construir competências para se comunicar com os novos consumidores através dessas ferramentas, como por exemplo o storytelling.

$\mathrm{O}$ aumento da competitividade em segmentos empresariais, tema extensamente abordado por autores como Porter (1989), continua a se acirrar nas duas últimas décadas, como exemplificado por Motta, Santos e Serralvo (2008) e não demonstra que vá se reduzir nos próximos anos. Novos entrantes sejam multinacionais ou empresas locais impulsionadas por inovações de impacto aparecem em diversos segmentos. $O$ desafio de crescer a receita e a rentabilidade nessa situação está presente no dia a dia das empresas e isso não é algo trivial.

Desta forma, cabe aos gestores conhecer quais as competências podem fazer a diferença para os executivos de suas organizações frente ao cenário altamente competitivo e em transformação que todos estão enfrentando. E a partir da experiência e das pesquisas dos autores, o esporte pode oferecer uma direção e uma sugestão de quais são essas competências.

Hoje, é possível encontrar diversos livros voltados para a formação executiva, escritos por esportistas ou por executivos com vivência no esporte. Autores desses livros podem ser treinadores de reconhecido sucesso e de diferentes modalidades, como os técnicos de volleyball Bernardinho (2006), de futebol americano Dungy (2011) e de basquete Wooden (2010). Podem também ser atletas também vitoriosos, como o lutador de MMA Vitor Belfort (2012), o lutador de boxe Foreman (2007), o jogador de basquete Michael Jordan (2001). Esses autores descrevem sua trajetória bem-sucedida no esporte e propõe como elas poderiam ser aplicadas no ambiente de negócios. Ao lado deles, executivos como Diniz (2004) apresentam a contribuição que o esporte deu a sua trajetória. Observa-se que ainda que possam ser livros interessantes e com aceitação perante o público, são relatos de experiências individuais, carentes de pesquisa acadêmica e que não possuem uma relação lógica e imediata com as competências que devem ser adquiridas pelos executivos e organizações para serem bem-sucedidas no atual cenário.

Os autores, eles próprios acadêmicos, executivos e praticantes de esportes, estudam o tema desde 2006 pelo menos. A partir desses estudos, foi detectado que competências são adquiríveis na prática esportiva (como sugere a literatura anteriormente mencionada, sem, todavia, explorar o tema com rigor acadêmico) em um processo de desenvolvimento chamado de Esportismo. Uma definição para Esportismo foi feita no livro "Esportismo - valores do esporte para a alta performance pessoal e profissional", escrito por Castropil e Motta (2010). Ao atualizar a definição encontrada nesse livro, chega-se a “o Esportismo é a aquisição de competências através da prática esportiva que podem contribuir não apenas para a melhora do desempenho da prática esportiva, mas também no atingimento das metas profissionais daqueles que as utilizam em seu trabalho e vida pessoal". O desafio da pesquisa, descrita a seguir é detectar quais são essas competências e qual a contribuição de cada uma e do conjunto combinado para o sucesso do executivo.

\section{PROCEDIMENTOS}

O foco desse artigo é o desenvolvimento de uma teoria fundamentada em dados de campo que demonstre se através da prática esportiva é possível formar melhores empresários e executivos para trabalhar no atual ambiente de negócios do Brasil e em caso afirmativo, quais são essas competências adquiridas no esporte e aplicadas na vida profissional com sucesso. Estudos qualitativos de teoria fundamentada tem como objetivo adquirir novos conhecimentos de um determinado campo do conhecimento e inferir possíveis aplicações práticas desses, expandindo a teoria desenvolvida até o momento sobre o objeto de estudo.

Para a elaboração de uma teoria fundamentada, segundo Creswell (2013), devem-se realizar entrevistas em indivíduos que componham uma amostra intencional, o que foi feito no trabalho. Foram realizadas cento e vinte e cinco entrevistas, com um protocolo previamente estruturado, o qual para sua elaboração baseou-se nas recomendações feitas por Lakatos e Marconi (2005), com empresários e executivos que tivessem uma prática pregressa ou presente da atividade esportiva e ocupassem cargos de liderança e destaque em suas organizações. $48 \%$ dos entrevistados eram empresários, proprietários de empresas de médio ou grande porte e $52 \%$ eram executivos de médias e grandes empresas nacionais e multinacionais. Destes entrevistados, $61 \%$ tinha até 40 anos e $39 \%$ acima de 40 anos.

Segundo Creswell (2010) essa quantidade de entrevistas oferece uma amostra adequada para a elaboração de uma teoria fundamentada. As entrevistas foram gravadas com a ciência dos participantes, sendo que o material foi enriquecido com anotações feitas durante a realização das entrevistas.

Para validar os dados obtidos seguiu se a recomendação de Creswell (2010), onde estratégias diversas foram feitas de forma a tornar o conteúdo robusto. Desta forma, os autores utilizaram a triangulação das fontes de dados, verificação das anotações junto aos entrevistados, utilização de uma descrição densa dos resultados, esclarecimento do viés do pesquisador, compartilhamento das informações discrepantes ou negativas e revisão do conteúdo por pessoas independentes. Todos os dados (transcrições e gravações) foram armazenados eletronicamente para posterior consulta para a elaboração do trabalho. O tratamento dos resultados foi feito a partir da análise do conteúdo das entrevistas.

\section{RESULTADOS}

Os autores, durante suas entrevistas, puderam observar que os executivos entrevistados descreviam determinadas competências de forma frequente. $\mathrm{Na}$ perspectiva dos entrevistados, nenhuma delas sozinha foi a razão do seu sucesso esportivo e ao transpô-la para sua vida profissional, foi de forma isolada a chave de sua trajetória profissional. Segundo os mesmos, as competências adquiridas no esporte, as quais serão descritas com mais detalhe a seguir, são interdependentes e relacionadas. A utilização das cinco competências, encontradas na pesquisa, contribuíram para o sucesso esportivo dos entrevistados e eles reconhecem que a transposição destas cinco competências para suas carreiras contribuiu, junto com a formação acadêmica e a experiência profissional, para o sucesso na superação dos desafios que enfrentaram. E quais são essas competências? A atitude 
(estabelece uma abordagem não-conformista para a resolução de problemas), visão (constrói uma visão inspiradora do que pode atingir a partir dos seus esforços), estratégia (elabora um plano de ação que permita atingir a visão), execução (executa o plano de ação proposto com rigor e método), teamwork (cerca-se de pessoas qualificadas que o auxiliam na execução do plano de ação). De acordo com Creswell (2010), uma forma de se apresentar uma teoria fundamentada é através de uma imagem que demonstre os principais pilares que compõe essa teoria. Os autores levaram essa sugestão em consideração e essas competências foram estruturadas em uma imagem, a medalha do Esportismo, que apresenta as cinco competências adquiríveis na prática esportiva que contribuem para o desempenho profissional (figura 1).

Figura 1 - A Medalha do Esportismo

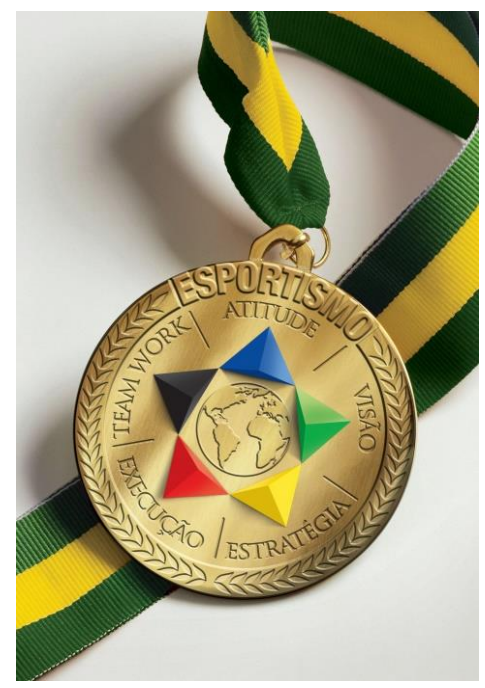

Fonte: Desenvolvido pelos autores.

A seguir cada uma das competências mencionadas acima e que compõe o Esportismo serão descritas de acordo com a pesquisa realizada e fundamentadas com depoimentos feitos pelos entrevistados, para compor essa teoria fundamentada que é o objetivo desse trabalho.

\section{1-Atitude (estabelece uma abordagem não-conformista para a resolução de problemas)}

A atitude é uma característica não conformista e que busca tirar o indivíduo da sua zona de conforto. Muitas vezes é inata e aparece em pessoas que não praticaram esporte de forma competitiva, porém segundo os respondentes, tendo ou não essa característica, a prática esportiva a ressaltou e potencializou. Desafios são enfrentados por esportistas todos os dias, como descreve um dos entrevistados, que após um acidente durante a prática do Judô, teve que passar por doze cirurgias para retornar as competições. E durante os cinco anos que demorou seu processo de recuperação e reabilitação, o que o animou foi a possibilidade de voltar a participar das competições de Judô.

Outro dos entrevistados reconhece que além dos esportes, sua grande referência profissional é Jorge Paulo Lehman. E nos apresentou uma reportagem publicada na edição de Jan/Fev. de 2008 da revista HSM, onde Lehman, que entre outros empreendimentos construiu o gigante multinacional AB INBEV e foi tenista profissional, é descrito por José Salibi Neto, executivo da revista:
"O que move Jorge Paulo é o gosto por competir. A mesma competitividade que o levou a costurar, com os sócios, a ousada fusão entre Brahma e Antarctica, e mais tarde entre Ambev e Interbrew. É a competitividade que o faz disputar nossos jogos de tênis às 06:30 da manhã como se estivesse em uma final de Roland Garros".

Essa competência existe em todos aqueles que praticaram o esporte competitivo. Quando surge um desafio aparentemente intransponível em seu trabalho, ele está experimentado em enfrentar situações como essa no esporte, e usa sua experiência de forma a superar aquele obstáculo.

\section{2 - Visão (constrói uma visão inspiradora do que pode atingir a partir dos seus esforços)}

Esportistas bem-sucedidos, não só tem a atitude positiva e corajosa para enfrentar os desafios, como também eles sonham com metas ambiciosas, arrojadas. Um título mundial, uma medalha olímpica, muitos campeões começaram sua trajetória sonhando com realizações como essas. Um dos entrevistados lembrou de um depoimento de Pelé em sua autobiografia (p. 101):

\begin{abstract}
"Em 1958, finalmente, depois das amargas decepções de 1950 e 1954, éramos pela primeira vez os campeões do mundo. Era um sentimento indescritível, que eu queria muito poder sentir mais uma vez, ou mais duas".
\end{abstract}

Durante as entrevistas, os executivos e empresários demonstraram possuir essa competência, de construir uma visão inspiradora do que podem atingir a partir dos seus esforços, seja para inspirar suas carreiras executivas, seja como o motor para impulsionar as empresas em que trabalham rumo a novas conquistas e patamares. Um ponto relevante mencionado nas entrevistas é a necessidade de que a visão seja inspiradora o suficiente e que aquele que a possui, empresário, esportista ou executivo, seja capaz de ignorar as condicionantes que podem fazê-lo se afastar de sua visão. Fatores como a falta de parceiros de treinos de alto nível (para esportistas), dificuldade de acesso ao crédito (empresários) e não ter cursado um MBA em uma escola de primeira linha (executivo), devem ser reconhecidos, mas não podem barrar o avanço e a perseguição dos objetivos que permitam a realização da sua visão.

Uma vez possuidor da visão, que pode ser adquirida durante a prática esportiva, e ignorada as condicionantes limitadoras, o executivo terá um norte para suas ações e um fator de motivação para persistir em seu trabalho

\section{3 - Estratégia (elabora um plano de ação que permita atingir a visão)}

É necessário, uma vez estabelecida a visão, que o esportista tenha a capacidade de estruturar e organizar um plano de ação para se aproximar e atingir a visão. Essa competência de elaborar um plano de ação que o permita atingir a visão é facilmente associada a elaboração do plano de treinamento e competições preparatórias para o atleta, assim como ao estudo e planejamento para derrotar seus oponentes, seja em um esporte individual ou coletivo. Mas a estratégia é algo ainda mais ampla e pode até alterar o futuro de toda uma modalidade, como conta um dos entrevistados, atleta olímpico de judô durante a Olímpiada de Barcelona de 1992. Durante o chamado ciclo olímpico, a elite dos judocas 
brasileiros tomou uma decisão ousada e que poderia ter custos irreparáveis para o futuro profissional daqueles atletas. Porém, a visão aliada à estratégia fez com que o país conquistasse o seu segundo ouro olímpico, desta vez com Rogério Sampaio na categoria meio-leve:

"Em 1989, o judô brasileiro vivia sob a hegemonia da família Mamede. O que mais havia na modalidade eram mandos e desmandos. Não tínhamos nenhuma condição de treinamento. O banho era gelado, a comida é melhor nem dizer. Todo patrocínio que você conseguia, e era um sofrimento para conseguir, ele exigia que ficasse com um percentual. Isso sem falar das seletivas para as competições, que não tinham regras claras, não obedeciam às normas da Federação Internacional de Judô. Não tinha placar, não tinha juiz, eram fechadas para público e imprensa.... Em determinado momento, a equipe titular de atletas, o que o judô brasileiro tinha de melhor naquele momento, por não concordar com aquela situação resolveu abandonar as competições oficiais. Criamos assim o Movimento para a Renovação do Judô e passamos a apontar todos os podres, todas as mazelas do judô nacional. Voltamos a competir apenas em 92 e nesse ano viria a segunda medalha de ouro olímpica do judô brasileiro, conquistada pelo Rogério Sampaio. E ele fazia parte do grupo, também não tinha disputado competições oficiais nos anos anteriores. E aquele grupo de atletas gerou um estremecimento tamanho na situação que vigorava no judô que anos depois a família Mamede deixaria a confederação - foi punida com o corte de verbas de todas as instâncias - e de lá para cá o Brasil sempre conquista medalhas olímpicas na modalidade. Nós tivemos atitude, visão e estratégia. No fim, nosso objetivo tornou-se real. Hoje o esporte colhe os frutos".

Nas empresas, assim como no esporte, os empresários e executivos devem levar em consideração essa competência como sendo relevante para o desenvolvimento de sua carreira e de seus negócios. E se ele houver adquirido essa capacidade durante sua prática esportiva, já terá um diferencial que o destacará no mercado de trabalho. Um dos participantes do estudo, que pratica futebol e possui uma agência de propaganda, relata que aprendeu durante as competições futebolísticas a observar os pontos fortes e fracos de cada time e desenvolver estratégias de acordo com os mesmos. Ao abrir sua agência, agiu da mesma forma, analisou os concorrentes no nicho em que pretendia atuar, desenvolveu seus diferenciais e serviços a partir das lacunas detectadas e obteve sucesso.

Outro entrevistado, diretor comercial de uma das maiores empresas varejistas do Brasil, relata sua experiência de utilização da estratégia nos esportes (no caso dele o jiu jitsu) e a transposição bem-sucedida dessa competência para seu ambiente profissional:

\footnotetext{
"Acredito que realmente fez e faz a diferença no meu dia a dia a habilidade que desenvolvi no jiu jitsu de elaborar uma estratégia para conduzir o oponente a uma posição a partir da qual você possa tomar uma ação definitiva. Isso vale para vencer uma luta ou para fechar um grande negócio. Estudar, observar, para então perceber a hora exata em que o golpe ou ação deve ocorrer. Em jiu jitsu, como em vendas, é fundamental possuir uma estratégia bem definida".
}

3.4 Execução (executa o plano de ação proposto com rigor $e$ método)

Durante as entrevistas realizadas, os autores desse artigo perceberam que a execução do plano de ação elaborado e proposto durante a concepção da estratégia, era a hora da verdade no esporte e também nos negócios. É onde o atleta coloca em prática tudo o que se propôs a fazer e conquista sua medalha, quando o empresário fecha aquele negócio que faz a diferença para o crescimento da sua empresa. A partir dos depoimentos obtidos, percebeu-se que três fatores combinados permitem a excelência na execução: o perfeccionismo, a disciplina e o autocontrole.

O perfeccionismo, essa obsessão pela perfeição transposta do esporte para os negócios, permite que empresas melhorem seus produtos, sua estrutura e sua gestão. Tudo pode e deve ser constantemente aprimorado. Foi assim que um entrevistado, praticante do ciclismo, ao elaborar os alimentos e bebidas de sua empresa, não se conformou em fazer produtos similares aos líderes de mercado. Inspirado na sua busca incessante pela perfeição nas corridas de bicicleta, ele terminou por desenvolver produtos superiores que foram como tal reconhecidos pelos consumidores e obtiveram relevante participação de mercado em um prazo curto de tempo.

Quanto à disciplina, quem pratica esporte competitivo sabe a partir de sua experiência que precisará treinar cansado, com dor, de manhã, à tarde, à noite. Um dos respondentes, praticante de natação, relata que utilizou a disciplina para obter sucesso em um processo seletivo para a vaga de diretor que estava concorrendo. Em um processo longo, que durou vários meses, ele estudou a empresa, os potenciais candidatos rivais, se preparou cuidadosamente para cada uma das entrevistas e acabou sendo selecionado para dirigir aquela empresa no Brasil.

Finalmente, o último pilar da competência de executar o plano de ação com rigor e método é o autocontrole. Muitas vezes a busca pelo perfeccionismo faz o atleta treinar cada vez mais, e isso pode gerar, por exemplo, lesões, o que ao invés de o aproximar de sua visão, irá afastá-lo. Então, a partir da sua experiência, ele adquire o autocontrole que o faz saber dosar a intensidade, o ritmo e os treinos para ter o melhor desempenho nas competições que se propõe a participar. Esse autocontrole não só pode ser útil para o desempenho profissional, mas também para que executivos e empresários, habituados a trabalhar por longas horas, consigam equilibrar sua vida pessoal e profissional e assim atingir uma realização plena de suas atividades, como pode ser visto no relato abaixo, por um diretor de empresa de serviços e praticante por muitos anos de esportes competitivos:

\begin{abstract}
"Se não fosse o esporte na minha vida, muito provavelmente já teria sucumbido a toda a pressão externa que a mídia e a sociedade de consumo atual colocam para que desde jovem sejamos afetados por algum tipo de droga, vício ou comportamento desvirtuado. Graças ao esporte sou saudável, não bebo e nem fumo; minhas três filhas pequenas já adoram praticar esporte e estão aprendendo desde cedo que também poderão escolher ser saudáveis, profissionais felizes e realizadas".
\end{abstract}

\section{5 - Teamwork (cerca-se de pessoas qualificadas que o auxiliam na execução do plano de ação)}

A necessidade de trabalhar em equipe de forma eficiente é evidente em esportes coletivos, mas também é imprescindível nos esportes individuais. Para os atletas que 
buscam ter a melhor performance, é necessário cercar-se por técnicos, nutricionistas, psicólogos por exemplo, além de parceiros de treino competentes. Fundamentado nos relatos obtidos a partir das entrevistas realizadas, os autores chegaram a conclusão que são necessárias cinco etapas para que o teamwork ou trabalho em equipe aconteça no ambiente esportivo e profissional.

Unir-se aos melhores significa se cercar da melhor equipe possível. Ao reconhecer a importância que o resultado em uma competição ou que o atingimento de uma meta de vendas tem para sua carreira, esportistas e executivos devem e vão buscar os melhores profissionais para que o ajudem a atingir seu objetivo. Um entrevistado, diretor comercial de uma indústria de bens de consumo e praticante de handebol, relata como buscar cercar-se dos melhores profissionais foi importante em sua carreira:

"Eu tive uma atitude vencedora ao entender o valor
fundamental de ter uma equipe altamente
qualificada e permitir que cada um dos membros
dessa equipe desenvolvesse seu potencial ao
máximo. Tudo isso em prol do nosso objetivo
conjunto. A engrenagem passou a funcionar bem
melhor assim e trouxe os resultados que
desejávamos. Esta forma de pensamento
estratégico eu aprendi durante os 12 anos em que
pratiquei handebol, um esporte coletivo no qual a
performance da equipe é fundamental. Muito mais
que o brilho individual".

Uma vez reunida uma equipe competente, cabe ao líder acompanhar e motivar o time rumo ao atingimento dos seus objetivos. Um dos entrevistados, proprietário de uma produtora e diretor de cinema, atribui sua capacidade de liderar e motivar as equipes que coordena à experiência de ter sido capitão de times de polo aquático. Ele faz a analogia com a direção de um filme, no trecho abaixo destacado da entrevista:

"Muitas vezes fui capitão dos times de polo aquático, que atuam com sete atletas por vez. Nas disputas sempre foi fundamental que eu conseguisse motivar a equipe. Esse era um fator fundamental para que obtivéssemos bons resultados. Hoje, como diretor de cinema, em um set de filmagem tenho de liderar e motivar a todos o tempo inteiro. Sem dúvida a experiência de liderar pessoas sob forte pressão emocional no período de competições me ajudou imensamente a encarar o desafio de dirigir com mais naturalidade".

Esse esforço de liderança, para ser mais efetivo, envolve a construção de uma visão comum. É quando aquela visão inspiradora do líder esportivo, empresarial ou executivo é compartilhada e inspira a todos da equipe, que trabalharão em conjunto para o atingimento das metas estabelecidas. Isso leva tempo, é um processo de amadurecimento, que é a quarta etapa do desenvolvimento dessa competência. E esse amadurecimento levará a equipe a identificar novas oportunidades de melhoria, o que pode a fazer buscar se aperfeiçoar cada vez mais, em um círculo virtuoso que aproximará o time dos seus objetivos. Por último, os respondentes, sejam os praticantes de modalidades individuais ou coletivas concordaram que para a formação de uma equipe bem-sucedida, há que se investir tempo em sua formação e aprimoramento e que o mesmo pode e deve ser feito com as equipes das empresas onde os mesmos são líderes.

\section{CONCLUSÕES}

Uma vez que a prática da gestão por competências é algo já adotado pelas empresas brasileiras que buscam uma melhor gestão e resultado, é muito importante definir quais são as competências que devem ser utilizadas para a formação do quadro de executivos da empresa e que serão desenvolvidas pelos gestores das áreas e pelo departamento de recursos humanos. Ter equipes com as competências certas é ainda mais necessário nesse momento, onde há um cenário econômico adverso e uma modificação do perfil e do hábito dos consumidores, aliado a um aumento da competitividade na maior parte dos setores econômicos.

Esse trabalho, um estudo qualitativo de teoria fundamentada, onde foram entrevistados cento e vinte e cinco empresários e executivos em posição de liderança com experiência esportiva, demonstrou que existem competências adquiridas a partir da prática de esportes que podem ser úteis para o desempenho profissional de executivos e empresários. O conjunto destas é o que compõe o Esportismo e são: a atitude, visão, estratégia, execução e temor. Se estas forem analisadas a partir da perspectiva do CHA, podem ser identificadas principalmente com as habilidades (visão, estratégia, execução e temor) e com as atitudes (atitude).

Por se tratar de um estudo qualitativo que propôs uma teoria fundamentada para agregar uma contribuição teórica ao que já foi desenvolvido no âmbito da gestão por competências, espera-se que esse artigo sirva de ponto de partida para investigações mais específicas e conclusivas sobre o tema. Essas investigações podem não só detalhar ainda mais as competências adquiridas no esporte e que contribuem para um melhor desempenho profissional, como podem também propor como melhor utilizá-las para a realização de todas as atividades envolvidas em um plano de trabalho integrado para a efetiva gestão por competências: a contratação de talentos, a avaliação do desempenho do profissional, treinar através de programas estruturados de forma a capacitar a equipe, servir como plataforma para programas de remuneração e reconhecimento e como subsídio para a orientação profissional.

Espera-se que esse trabalho seja relevante para acadêmicos que estudam a área de recursos humanos e que queiram se aprofundar e buscar alternativas para aprimorar o modelo de gestão por competências. Com o desenvolvimento desta discussão e novos estudos, quantitativos inclusive, sobre as competências que compõe o Esportismo, esse material pode ser útil para empresários e executivos interessados em aprimorar suas equipes de trabalho com a aquisição e desenvolvimento destas competências por suas equipes.

\section{REFERÊNCIAS BIBLIOGRÁFICAS}

ANDRADE, Bernardo Rocha de Rezende. Transformando suor em ouro. Rio de Janeiro: Sextante, 2006.

ARANTES, Edson. Pelé, a autobiografia. Rio de Janeiro: Sextante, 2006.

BELFORT, Vitor. Lições de garra, fé e sucesso. Rio de Janeiro: Thomas Nelson Brasil, 2012. 
BOYATZIS, Richard E. The competente management: a modelo for efetive performance. New York: John Wesley, 1982.

BRANDÃO, Hugo Pena; CARBONE, Pedro Paulo; LEITE, João Batista Diniz; VILHENA, Rosa Maria de Paula. Gestão por competências e gestão do conhecimento. Rio de Janeiro: FGV, 2009.

CAlliaRI, Marcos; MOTTA. Alfredo. Código Y decifrando a geração que está mudando o Brasil. São Paulo, Évora, 2012.

CASTROPIL, Wagner; MOTTA, Rodrigo Guimarães. Esportismo. Valores do esporte para a alta performance pessoal e profissional. São Paulo: Gente, 2010.

CRESWELL, John. Projeto de pesquisa. Método qualitativo, quantitativo e misto. Porto Alegre: Artmed, 2010 .

CRESWELL, John. Investigação qualitativa e projeto de pesquisa. Escolhendo entre cinco abordagens. Porto Alegre: Pensa, 2013.

DINIZ, Abílio. Caminhos e escolhas: o equilíbrio para uma vida mais feliz. São Paulo, Elzevir, 2004.

DUCASSE, François. Cabeça de campeão. Como a psicologia forma vencedores no esporte e na vida. Rio de Janeiro: Casa da Palavra, 2009

DUNGY, Tony; WHITAKER, Nathan. Fora do comum. Lições de integridade, ética e coragem de um dos maiores treinadores de futebol americano. Rio de Janeiro: Sextante, 2011.

DURAND, Thomas. L'alchimie de la compétence. Revue Française de Gestion, Paris, n. 127, p. 84-102, jan/fev. 2000.

DUTRA, Joel Souza. Competências: conceitos e instrumentos para a gestão de pessoas na empresa moderna. São Paulo: Atlas, 2004.

FLEURY, Afonso; FLEURY, Maria Tereza Leme. Estratégias empresariais e formação de competências: um quebra cabeça caleidoscópico da indústria brasileira São Paulo: Atlas, 2001.

FOREMAN, George. Sem nunca jogar a toalha. Uma história de sucesso, boxe e espiritualidade. Rio de Janeiro: Thomas Nelson Brasil, 2007.

GODOI, Alexandre; LAS CASAS, Alexandre, MOTTA, Alfredo. A utilização do facebook como ferramenta de marketing para construir relacionamento com o consumidor - um estudo de fan pages no Brasil. Business and Management Review, Londres: v.5 n.1, 9. P. 97-112, junho, 2015.

JAMISON, Steve; WOODEN, John. Jogando para vencer. A filosofia de sucesso do maior técnico de basquete de todos os tempos. Rio de Janeiro: Sextante, 2010.

JORDAN, Michael. Mi filosofia del triunfo. Cidade do Mexico: Selector, 2001.

LAKATOS, Eva Maria; MARCONI, Marina de Andrade. Fundamentos de metodologia científica. São Paulo: Atlas, 2005.
MOTTA, Rodrigo Guimarães; SANTOS, Neusa; SERRALVO, Francisco. Trade marketing - teoria e prática para gerenciar os canais de distribuição. São Paulo: Campus, 2008.

NETO, José Salibi. O legado da competitividade. Revista HSM Management, São Paulo, jan./fev. 2008.

PORTER, Michael. Vantagem competitiva. Rio de Janeiro: Campus-Elsevier, 1989.

PULIZZI, Joe. Epic content marketing - how to tell a diferente story, break through clutter, and win more customers by marketing less. Nova York: McGraw Hill, 2014.

\section{COPYRIGHT}

Direitos autorais: Os autores são os únicos responsáveis pelo material incluído no artigo. 


\title{
UMA ALTERNATIVA PARA SE INTERNACIONALIZAR: ESTUDO DE CASO DE EMPRESA DE MÉDIO PORTE DO AGRONEGÓCIO BRASILEIRO
}

\author{
AN ALTERNATIVE TO INTERNATIONALIZE: CASE STUDY OF MID-SIZED \\ COMPANY OF BRAZILIAN AGRIBUSINESS
}

\author{
VÂNIA MARGARIDA FERREIRA ${ }^{1}$; HELDER ANTÔNIO DA SILVA²; NICÁSSIA FELICIANA NOVÔA²; \\ CLÁUDIA MARIA MIRANDA DE ARAÚJO PEREIRA² \\ 1 - GRADUADA EM ADMINISTRAÇÃO PELO IF SUDESTE, MG; 2 - PROFESSORES DO IF SUDESTE \\ MG - CAMPUS BARBACENA \\ helder.silva@ifsudestemg.edu.br
}

\begin{abstract}
Resumo - A inserção de empresas no mercado internacional via internacionalização é um tema recente, especialmente para as empresas vindas de países emergentes. Os modelos de internacionalização conhecidos foram criados com base no comportamento das empresas sediadas em países desenvolvidos. Já o comércio exterior é um tema antigo e apresenta-se como alternativa à internacionalização. $O$ presente estudo objetiva avaliar a estratégia de entrada em mercados internacionais via comércio exterior adotado por uma empresa do agronegócio brasileiro. A metodologia usada foi o estudo de caso. Foi identificado que a empresa optou pelo comércio exterior, como meio de inserir seus produtos no mercado externo. Pode-se concluir que o comércio exterior, em alguns casos, é a porta para a organização internacionalizar-se, uma vez que a exportação é o elemento comum entre o comércio internacional $e$ a internacionalização de empresas.
\end{abstract}

Palavras-chave: Agronegócio. Internacionalização. Comércio Internacional. Operação Back To Back.

Abstract - The inclusion of companies in the international market via internationalization is a recent theme, especially for companies from emerging countries. Internationalization templates known were created based on the behavior of companies based in developed countries. Foreign trade already is an old theme and presents itself as an alternative to globalization. The present study aims to assess the strategy of entry into international markets via foreign trade adopted by a company of Brazilian agribusiness. The methodology used was the case study. It was identified that the company opted for foreign trade, as a means to insert their products in external markets. It can be concluded that the foreign trade, in some cases, is the door to internationalize organization, once the export is the common element between international trade and the internationalization of companies.

Keywords: Agribusiness. Internationalization. International Trade. Operation Back To Back.

\section{INTRODUÇÃO}

Com a abertura dos portos em 1990, as empresas brasileiras viram-se ameaçadas pela crescente entrada de concorrentes estrangeiras em seu próprio país. Produtos com a qualidade de seus países de origem chegam ao mercado brasileiro para competir com os nacionais. As empresas tinham duas alternativas: fechar as portas ou utilizar a mesma estratégia das concorrentes, ou seja, internacionalizar-se.

Bueno e Domingues (2011) destacam que no Brasil, depois dos anos 2000, a competitividade das empresas brasileiras e a visão da gestão passaram a ser cada vez mais voltadas para o mercado global. Tal fato demonstra a necessidade de as empresas brasileiras planejarem suas estratégias, contemplando a possibilidade da internacionalização de suas empresas. Antes visto como local para a instalação de subsidiárias de multinacionais, o Brasil tem se apresentado no cenário internacional com a expansão de empresas brasileiras que, por meio de processos de aquisição, fusão, parcerias ou instalação de subsidiárias, têm aumentado sua atuação e operação ao redor do mundo, o que traz à tona a necessidade da ampliação de estudos sobre as estratégias adotadas pelos diversos tipos de empresas.

O sucesso e as oportunidades internas, no entanto, poderão limitar a capacidade das empresas para conceber e prosseguir a internacionalização. Como as empresas encontraram sucesso doméstico, elas tendem a se concentrar em cultivar redes domésticas, em oposição a investigar potenciais mercados internacionais (ARBAUGH et al., 2008).

Recentemente, muitos estudos (CHILD; HSIEH, 2014; FERNÁNDEZ-ORTIZ et al, 2015) sobre internacionalização têm avaliado principalmente a capacidade de pequenas e médias empresas se envolver no processo de internacionalização em relação a suas características específicas. Em comparação com as grandes empresas, as pequenas e médias empresas são mais flexíveis, assim, sua reação às mudanças em seu ambiente pode ser mais rápida. No entanto, estas empresas têm acesso limitado às informações, falta de recursos financeiro e pessoal, além de liderança individualizada (FERNÁNDEZORTIZ et al., 2015). As médias empresas também possuem a sua hierarquia organizacional mais simples e facilmente tendem a criar redes com empresas apropriadas. Portanto, estas características específicas podem influenciar comportamento de internacionalização, via exportação, das médias empresas.

Conforme Fleury e Fleury (2007), a maneira com que as condições econômicas influenciaram e influenciam a internacionalização é visível quando se trata das 
competências. No caso do Brasil, as características intrínsecas dos ambientes econômicos e institucional levaram as empresas locais a desenvolver competências para sobreviver e prosperar. Estas competências são importantes para sustentar o movimento de internacionalização. O comércio internacional, por sua vez, não é um assunto novo. As trocas entre as nações já aconteciam no período das grandes navegações. A operação back to back, uma forma de exportação, surge como alternativa à internacionalização ou como um primeiro passo rumo a internacionalização, exigindo muito menos das organizações, mas, em contrapartida, oferecendo também muito pouco.

Portanto, o objetivo geral deste estudo é avaliar as estratégias de entrada de uma média empresa do agronegócio brasileiro em mercados internacionais, seja via internacionalização ou operação back to back. Por questões éticas, o nome da empresa não é citado. Para tanto, a literatura e a pesquisa de campo ofereceram ferramentas adequadas para a análise necessária.

\section{FUNDAMENTAÇÃO TEÓRICA}

\section{Exportação}

Conforme Sobeet (2008), as empresas brasileiras que estão iniciando o processo de internacionalização comercial, através das exportações, têm buscado diferentes métodos de identificar as reais necessidades do mercado-alvo. Estes mecanismos dependem de fatores como seu custo, complexidade, comprometimento e da atual situação internacional de cada empresa.

Rocha (2002) destaca alguns fatos que motivam a internacionalização através da exportação:

- Aproveitar-se de incentivos governamentais;

- Escoar excedentes da produção nacional;

- Obter maiores margens;

- Melhorar a imagem do produto no mercado doméstico;

- Diversificar os mercados de atuação;

- Melhorar a competitividade da firma.

A exportação é uma das melhores formas de lidar com a sazonalidade e com o excedente da produção. Uma vez abastecido o mercado interno, esse excedente ganha lugar no mercado externo, evitando-se desperdícios de recursos e sobrecarga de depósitos e armazéns. Além disso, o contato com o mercado externo torna a empresa menos dependente do mercado interno e de suas variações, já que é capaz de absorver parte da produção não demandada pelo mercado doméstico, reduzindo os riscos e as incertezas deste mercado, além de ampliar o número de compradores e divulgar sua imagem e produto.

Segundo Lopez (2005), há várias razões pelas quais as empresas procuram atuar no mercado externo:

- Ampliar sua carteira de clientes e mercados;

- Diluir os riscos dos mercados;

- Adquirir melhores condições de competir com os entrantes estrangeiros no mercado interno;

- Aumentar/melhorar a programação da produção;

- Prolongar o ciclo de vida do produto;

- Extrair vantagens de aspectos sazonais;

- Incorporar novas tecnologias;

- Dispor de know-how internacional;

- Obter maiores lucros;

- Valorizar a marca.
As exportações diretas (exportação in-house) são realizadas pela própria empresa. A pesquisa de mercado, a seleção de canal no exterior, a seleção de financiamento, o transporte e a documentação são feitos pela própria organização exportadora (RUIZ, 2005). Conforme Garrido (2007), essas operações podem ser feitas por intermédio do próprio departamento interno de exportação, subsidiárias de vendas no exterior e agentes ou distribuidores no mercadoalvo. Ainda segundo o mesmo autor, as exportações diretas oferecem maior controle das atividades sobre o planejamento de marketing, exigem maiores investimentos iniciais e estão sujeiras a maiores riscos.

Segundo Ruiz (2005), a empresa deve levar dois fatores em consideração, ao se decidir pela exportação direta: se vale ou não a pena despender maiores recursos internos para obter maiores preços de venda e controle total do processo de exportação e se os funcionários responsáveis pelas atividades de exportação possuem o conhecimento necessário para atender o mercado externo, com suas peculiaridades.

As exportações indiretas ocorrem quando a empresa utiliza-se de intermediário local, podendo ser esta uma empresa de exportação, uma trading ou um corretor. Oferecem, segundo Garrido (2007), baixos volumes de investimento e de riscos. Porém, o prejuízo cai no prêmio a ser pago ao intermediário, seja na forma de comissões, na própria venda ao intermediário a preços mais baixos que os de mercado ou por taxas pré-determinadas.

A empresa produtora deve analisar e investigar a qualificação do intermediário. De nada adianta o produtor se aperfeiçoar se o interveniente não prestar um bom serviço ao importador. Como consequência, as importações poderão cessar atingindo fortemente o produtor (GARCIA, 2011; LOPEZ e GAMA, 2011).

De acordo com Amatucci et al. (2009), nada impede que a empresa realize um modelo misto (exportação direta e indireta), de acordo com as características de cada mercado e volumes transacionados. Defendem ainda que esses dois modelos são os mais comuns entre as micro, pequenas e médias empresas, sendo a exportação direta mais usada pelas grandes empresas.

Embora essa forma de entrada ofereça vantagens como aumento do volume de vendas e da participação de mercado e pouco comprometimento de recursos, também apresenta desvantagens. Cavusgil, Knight e Riesenberger (2010) destacam como desvantagens a falta de contato direto com os clientes no mercado externo, o que faz com que não perceba oportunidades e ameaças, não adquirindo conhecimento necessário para o sucesso no longo prazo e, ainda, a sensibilidade da exportação a barreiras tarifárias e não-tarifárias e a oscilações cambiais.

\section{Teorias de Internacionalização}

Hymer (1960) defende que o IDE é determinado pela extensão das operações internacionais de cada firma, no sentido de explorar a situação de propriedade (ownership) e seu respectivo controle de uma empresa num país por parte de outra em seu país de origem.

Hymer (1960) apontou duas razões para explicar o IDE: primeiro, as empresas podem ter uma vantagem real de eficiência e explorar múltiplos mercados; e, segundo, as empresas tentariam eliminar a competição entre dois mercados ocupando ambos. Somando-se a isso, haveria a 
diversificação internacional dos mercados como razão para o investimento direto.

Segundo Amatucci et al. (2009), Vernon foi o primeiro a abandonar o pressuposto de que o conhecimento era universalmente disponível, em favor de transformá-lo em variável independente na decisão de exportar ou investir. Além do conhecimento, também considera a tecnologia nos negócios internacionais.

Buckley e Casson (1992) rompem com a teoria econômica ortodoxa de produção, cujos pressupostos são a maximização do lucro e as condições de concorrência perfeita, e passam a considerar as imperfeições do mercado. Argumentam que a teoria ortodoxa não explica o comportamento das multinacionais. De acordo com Buckley e Casson (1998), há duas variáveis interdependentes para a entrada da empresa em outro país: a localização e o modo de controle. A primeira diz respeito à escolha do país e de sua região. Há duas estratégias genéricas: diversificação de mercados e concentração de mercados (BRADLEY; GANNON, 2000). Ao diversificar, a intenção é alcançar um alto retorno com baixo comprometimento de recursos em vários mercados. Ao concentrar, há um grande esforço de marketing para cada um dos poucos mercados, a fim de se obter participação significativa neles. A empresa somente explora outros mercados após ter uma posição forte no mercado inicial.

O paradigma eclético de Dunning (1998) também conhecido como paradigma OLI, devido às variáveis ownership, location e internalization. Define se vale a pena uma empresa se instalar em determinado país para explorar vantagem competitiva própria ou se é melhor repassar esse ativo a uma empresa local, através de licença ou exportação (STAL e CAMPANÁRIO, 2011). De acordo com Dunning (2000), o conjunto das vantagens de propriedade divide-se em estáticas e dinâmicas. As primeiras aparecem sob a forma de receita extraordinária para a organização por um período de tempo, enquanto as segundas provêm da capacidade da organização de amentar sua renda além do normal ao longo do tempo.

O modelo de Uppsala surgiu em meados da década de 70, a partir de um estudo realizado por pesquisadores da Universidade de Uppsala (HÖRNELL, VAHLNE e WIEDERSHEIM-PAUL, 1973; JOHANSON e WIEDERSHEIM-PAUL, 1975; JOHANSON e VAHLNE, 1977), onde analisaram e reuniram elementos e fenômenos que caracterizavam a internacionalização de empresas suecas, baseados na teoria da firma de CYERT e MARCH (1963).

A suposição básica do modelo de Uppsala é a de que a falta de conhecimento sobre mercados estrangeiros é o maior obstáculo para operações internacionais, mas tal conhecimento pode ser adquirido (JOHANSON e VAHLNE, 1977). Adquirir conhecimento é a primeira de todas as questões de ser ativo em um novo mercado, mais do que coletar e analisar informações. Ao operar no mercado, a firma não somente adquire informação sobre aquele mercado, mas também se torna mais conectada a ele. Conforme Penrose (1959), há dois tipos de conhecimento: conhecimento objetivo, que pode ser ensinado, e conhecimento empírico, que pode somente ser adquirido através de experiência pessoal.

\section{Comércio Internacional}

O comércio internacional já ocorria no período das grandes navegações, com a descoberta da América, onde já aconteciam as trocas entre as nações (COHEN, 2006). Segundo Cavusgil, Knight e Riesenberger (2010), o comércio internacional refere-se à troca de bens e serviços através de fronteiras nacionais, a qual envolve tanto os bens quanto os serviços. Essa troca pode ocorrer por meio da exportação (estratégia de entrada que consiste na venda de bens e serviços a clientes localizados no exterior, a partir de uma base no país de origem ou em um terceiro) e da importação (aquisição de bens e serviços de fornecedores localizados no exterior para consumo no país de origem ou em um terceiro) (CAVUSGIL, KNIGHT e RIESENBERGER, 2010).

Luna (2008) entende o comércio internacional como o fluxo do intercâmbio de bens e serviços entre países ou empresas desses países, resultantes em grande proporção da divisão internacional do trabalho, as leis que regem o comércio internacional, as relações que integram as entidades econômicas internacionais e a harmonização dos interesses dos países entre si no campo do comércio.

A organização, ao aumentar seu catálogo de compradores, buscando-os no mercado externo, pode elevar seus lucros nas vendas e ainda reduzir a dependência do mercado interno. Com as vendas destinadas ao mercado externo, a empresa não corre riscos de prejuízos ou falência em decorrência de uma crise nacional, como reduções de preços e de consumo, mudanças de hábitos ou pela política governamental (KEEDI, 2015).

Segundo Ashikaga (2016), o comércio exterior, mais especificamente a operação back to back, é uma alternativa que poderia ser denominada imprescindível às atividades empresariais, especialmente no caso de países em desenvolvimento, onde sua sobrevivência torna-se impossível sem a importação de insumos para venda e elaboração de seus produtos. A seguir é apresentada uma breve descrição da operação back to back.

\section{Operação back to back}

Segundo a definição do Banco do Brasil (2011), a operação Back to Back ocorre quando uma empresa estabelecida no Brasil compra produto no exterior e vende-a a um terceiro, sendo que tanto a aquisição quanto a entrega ocorrem no exterior, sem trânsito pelas fronteiras o país, e tudo sob o comando da empresa brasileira, a qual efetuará o pagamento mediante o recebimento dos valores da venda.

A operação Back to Back caracteriza-se pela aquisição de um produto no exterior, por uma empresa brasileira, sendo a entrega realizada em um outro país, sem que a mercadoria transite pelo Brasil, embarcando-a diretamente para o cliente no exterior (ADUANEIRAS, 2011). Dessa forma, a operação Back to Back compreende tanto atividades de importação quanto de exportação.

Dessa forma, para a caracterização de uma operação Back to Back deve haver ganho financeiro por parte do exportador brasileiro, uma vez que este efetua inicialmente um acordo comercial de fornecimento de mercadoria junto ao importador.

A empresa brasileira não tem que ser necessariamente a importadora. Esse tipo de operação gera diferentes combinações de negócios, como, por exemplo, exportar o produto do Brasil, agregar alguma parte ao produto no exterior e de lá finalizar o processo de exportação para um terceiro país (BANCO DO BRASIL, 2011). 


\section{METODOLOGIA}

A estratégia de pesquisa utilizada foi o estudo de caso explicativo, definido por Gil (2008) como o estudo de um ou mais objetos de maneira exaustiva e profunda, de forma que se possa obter um conhecimento detalhado sobre esses objetos. No método de estudo de caso são adotados vários meios para a coleta de dados, conforme a estratégia de triangulação de dados recomendado por Yin (2015).

A coleta de dados foi realizada por meio de entrevista com membros da empresa que são responsáveis pelos negócios internacionais da empresa. Foi também realizada uma pesquisa telematizada, por meio do site da empresa, sobre as características da empresa, que em comparado com a teoria advinda da pesquisa bibliográfica permite a triangulação de dados.

Para a coleta de dados foi utilizado um roteiro semiestruturado para entrevista, onde o rumo é dado por uma pergunta inicial, sondagens do entrevistador e pelas respostas do entrevistado, para descobrir crenças, motivações, atitudes e sensações subjacentes sobre um tópico (MALHOTRA, 2011). Foram entrevistados dois funcionários responsáveis pela área de negócios internacionais da empresa.

A empresa foi selecionada por ser do agronegócio e ser exportadora de produtos derivados do frango para diversos países em todos os continentes. Além disto, a empresa apresenta uma alternativa para internacionalização ainda pouco estudada até o momento. A empresa emprega mais de 1000 funcionários, e se consideram uma média empresa brasileira do setor do agronegócio. Por questão de sigilo, os dados relativos à empresa e seu volume de exportação não podem ser divulgados. $\mathrm{O}$ comitê de ética autorizou a realização do estudo uma vez que a identidade das pessoas entrevistadas não foi divulgada.

\section{UMA ALTERNATIVA PARA SE INTERNACIONALIZAR: O CASO DA EMPRESA DO AGRONEGÓCIO BRASILEIRA}

A empresa estudada foi fundada em 1985, no interior do Brasil, na região sudeste, uma região bastante industrializada. $\mathrm{O}$ início das exportações de frango, em 2003, abriu novos caminhos para a empresa, ajudando a contribuir para o sucesso do agronegócio brasileiro, que levou o país a se firmar como o maior exportador de carne de aves no mundo. A empresa recebeu em 2008 o certificado internacional de qualidade, exigido para realizar exportações para os países europeus. Atualmente a empresa exporta para vários países em todos os continentes.

Por meio da entrevista com funcionários da empresa, responsáveis pela área de negócios internacionais, verificou-se vários fatores que levaram a empresa buscar a exportação com objetivo de melhoria no desempenho da empresa como um todo. Para os responsáveis pelos negócios internacionais da empresa, o que levou a empresa a optar pelo comércio de seus produtos para o exterior foi a "diversificação de mercado, diminuição da dependência do mercado interno e de suas variações (sazonalidade) e aumento de oportunidades".

De acordo com Rocha (2002), a diversificação de mercados e o escoamento de excedentes da produção nacional estão entre os fatores que levam as empresas a exportarem. Assim, há a diminuição da dependência do mercado interno e redução dos impactos de suas variações. A carteira de clientes torna-se maior, gerando mais oportunidades e maiores lucros para a firma.
De acordo com a declaração dos funcionários responsáveis pelos negócios internacionais, as razões que levaram a empresa a escolher algum mercado em detrimento de outro:

Cada país tem uma particularidade de aceitação de produto, seja na questão de embalagens, de documentos. Quando se trata de alimento, esse só precisa ser viável em questão de custos, a não ser que o país esteja em guerra, tornando complicada a exportação. Alimento não é um produto diferenciado e todos precisam de alimento, portanto, satisfeitas as principais exigências, é um produto fácil de se vender externamente

A questão da diferenciação, nesse caso, cai sobre o preço final. Como a empresa arca com todos os custos de exportação direta e com custos relativos à exportação indireta (mercados mais difíceis), o preço final acaba se tornando mais alto em relação aos produtos que já estão naquele mercado, sejam eles de empresas domésticas ou empresas internacionalizadas instaladas naquele mercado, comprometendo a competitividade de determinado produto.

O mercado externo é capaz de satisfazer às principais necessidades ou expectativas da empresa, de acordo com o depoimento dos responsáveis pelos negócios internacionais da empresa, "nunca houve problemas com o mercado externo. Ao optarmos pela exportação, diminuiu bastante a dependência do mercado interno e de suas variações".

Embora haja a diminuição da dependência do mercado interno e das suas variações, há, porém grande dependência com relação às políticas praticadas naqueles países de destino, além das exigências de certificações e adequação cultural. Quando se trata de exportação indireta, a dependência maior cai sobre o interveniente.

As funcionárias responsáveis pelos negócios internacionais afirmam que "as exportações começaram em 2006, primeiramente para os países mais difíceis de se exportar, devido às exigências. Os mercados-alvo são alguns países asiáticos, a maioria da Europa e alguns países africanos".

O que mudou internamente com a exportação, segundo as funcionárias responsáveis pelos negócios internacionais, "foi mais a parte burocrática, documentos no departamento financeiro, adequação da planta para exportação. Mas o processo produtivo, seja o produto para o mercado interno ou externo, é o mesmo. O padrão é de exportação". As maiores dificuldades enfrentadas foram "a falta de infraestrutura nos portos e rodovias, burocracia e ônus federal".

Para o futuro, as funcionárias entrevistadas afirmam: "estamos sempre expandindo". Sendo assim, há intenção de expansão para outros mercados; porém, tal expansão não deverá ser por meio de alianças, pois, segundo estas funcionárias "as alianças de qualquer natureza podem fazer com que o produto perca a sua essência, faz com que se distancie da política da empresa”.

As alianças em geral podem contribuir muito para que uma empresa se insira no mercado internacional. Uma vez que detém pelo menos parte da propriedade e do controle dos ativos tangíveis e intangíveis, torna-se mais fácil a tomada de decisão e a participação nos processos gerenciais, defendendo seus interesses. Uma vez instalada naquele mercado, os preços tornam-se mais acessíveis aos consumidores e diminui a dependência do intermediário nas transações, além de driblar as barreiras tarifárias e não-tarifárias.

Nos mercados onde seus produtos encontraram dificuldades de entrada, seja por questões políticas ou culturais, 
a empresa encontrou na operação Back to Back a solução para esse problema.

A operação Back to Back é mais vantajosa, conforme Hortmann (2009), para o intermediário, uma vez que ele define o valor da revenda. Já o fornecedor fica com todos os encargos referentes à exportação, e, portanto, com um lucro menor, além da grande dependência com relação ao interveniente. $\mathrm{O}$ intermediário exerce um papel muito importante nessa operação, uma vez que ele é quem repassa o produto e o revende a determinado mercado, exigindo muita confiança.

As outras formas de entrada via internacionalização não são interessantes para a empresa, pois esta não conta ainda com uma planta de produção suficiente para competir na condição de empresa internacionalizada. Os riscos e o comprometimento de recursos exigidos pela internacionalização, especialmente via IDE, são altos.

A implantação de uma subsidiária de vendas necessita de pessoal qualificado e familiarizado com o produto e os processos produtivos, além de constante visita dos responsáveis à subsidiária, incorrendo em grandes custos para a empresa.

A empresa não se mostra simpática, também, ao licenciamento, uma vez que o produto pode perder sua identidade, além do risco de os licenciados ao conhecerem o processo, tornarem-se fortes concorrentes.

Com relação aos riscos e ao comprometimento de recursos, a exportação é uma das opções que oferece menor risco, porém menor retorno. Mas a dependência de intermediários em certos mercados pode comprometer a qualidade do produto e sua imagem nos mercados para onde a empresa não exporta diretamente. $\mathrm{O}$ licenciamento seria uma alternativa a parte, oferecendo menores riscos, uma vez que o licenciado também entra com uma parte do capital. A razão pela qual a empresa não é favorável ao licenciamento é a possibilidade de o licenciado de alguma forma "descaracterizar" o produto, além de necessidade de treinamento dos licenciados. Porém ao se analisar com mais profundidade, percebe-se que a operação Back to Back oferece os mesmos riscos e incertezas quanto ao intermediário.

A inserção dessa empresa no mercado internacional, segundo o modelo de Uppsala, seria, por agora, através de uma subsidiária de vendas, passo seguinte ao das exportações. Conforme o modelo de Uppsala, o próximo passo seria a abertura de uma subsidiária de vendas, podendo vender diretamente aos clientes, diminuindo a dependência do intermediário e driblando o protecionismo, utilizando as imperfeições de mercado a seu favor, segundo Hymer (1976). O comprometimento de recursos é maior, porém o retorno advindo desta operação também.

\section{CONSIDERAÇÕES FINAIS}

O objetivo geral deste estudo é avaliar as estratégias de entrada de uma média empresa do agronegócio brasileiro em mercados internacionais, seja via internacionalização ou operação back to back.

A alternativa para internacionalização, encontrada pela empresa estudada, é a operação back to back, ou seja, a troca de bens ou serviços entre as empresas sediadas em países diferentes. A empresa inserida nesse contexto realiza suas operações via exportação, importação ou ambos. Esta forma de entrada no mercado internacional, em alguns casos, é a porta para a organização internacionalizar-se com menor risco, uma vez que a exportação é o elemento comum de início do processo de internacionalização em si.
A organização em estudo iniciou e mantém suas atividades no exterior via exportação, por esse tipo de operação oferecer menor risco, além de garantir a independência do mercado interno e de suas variações. Durante a entrevista constatou-se que a empresa utiliza a operação back to back como estratégia para entrada em mercados mais difíceis, sejam por questões políticas ou culturais, de forma que consiga alcançar esses países e explorar esses mercados. Porém verificou-se que a empresa em estudo não é a intermediária, mas sim a fornecedora no processo. Esta vende seus produtos a um intermediário e este repassa ao comprador final, obtendo maiores lucros.

A dependência do intermediário é muito grande, uma vez que somente ele conhece e lida diretamente como comprador final. A relação deve ser de extrema confiança, com risco de perda daquele mercado, caso haja algum erro por parte do interveniente. A empresa, portanto, arca com todos os encargos de exportação, repassando esses custos ao intermediário, o qual também repassa esse custo ao consumidor, impactando bastante no preço final, comprometendo a competitividade do produto. Como a empresa exporta para vários mercados, a entrada em um país relativamente próximo aos outros mercados diminui também os gastos com transportes e reduz o tempo de espera.

Entretanto, como a internacionalização oferece seus riscos, assim também ocorre com as operações back to back, como é o caso da empresa pesquisada. O risco, assim como o retorno, é bem menor, se comparado às estratégias de internacionalização como o IDE. No entanto, há maior dependência do intermediário, pois este conhece o mercado e controla a operação final, além de receber os maiores lucros. A independência do mercado interno se transforma em dependência do interveniente.

$\mathrm{O}$ estudo de caso não permite a generalização para o agronegócio; sendo assim, como sugestão para futuras pesquisas, uma análise de outras empresas do mesmo porte do agronegócio brasileiro pode trazer discussões sobre alternativas de entrada no mercado internacional que contribua para facilitar e motivar mais empresas deste porte a buscar o caminho da internacionalização com menor risco e com maior retorno financeiro.

\section{REFERÊNCIAS BIBLIOGRÁFICAS}

ADUANEIRAS. Operações Back to Back. São Paulo, 2011. Disponível em <http://www.aduaneiras.com.br>. Acesso em 22 dez. 2016

ARBAUGH, J.B., CAMP, S.M.; COX, L.W. Why don't entrepreneurial firms internationalize more? Journal of Management Issues, (3), 366-382. 2008.

AMATUCCI, M. (org.). Internacionalização de empresas: teorias, problemas e casos. São Paulo: Atlas, 2009.

ASHIKAGA, C. E. G. Análise da tributação: na importação e na exportação. 8. Ed. São Paulo: Aduaneiras, 2016.

BANCO DO BRASIL. Operações back to Back. (2011) Disponível em: <http://www.bb.com.br>. Acesso em 25 fev. 2014.

BRADLEY, F.; GANNON, M. Does the firm's technology and marketing profile affect foreign market entry? Journal of International Marketing, v. 8, n. 4, p. 12-36, jul. 2000.

BUCKLEY, P. J.; CASSON, M. C. The future of the multinational enterprise. Houndmills: Macmillan, $1992\left(2^{\mathrm{a}}\right.$ reimpressão da 2. ed. de 1991 1. ed. 1976). 
BUCKLEY, P.r J.; CASSON, M. C. Analyzing foreign market entry strategies: extending the internalization approach. Journal of International Business Studies, Basingstoke v. 29, n. 3, p. 539-561, 1998.

BUENO, J. M.; DOMINGUES, C. R. Estratégias de internacionalização de empresas emergentes: um estudo comparativo de casos brasileiros. Future Studies Research Journal. São Paulo, v. 3, n. 2, pp. 59 - 87, Jul./Dez. 2011.

CAVUSGIL, S. T.; KNIGHT, G.; RIESENBERGER, J. R. Negócios internacionais: estratégia, gestão e novas realidades. São Paulo: Pearson Prentice Hall, 2010.

CHILD, J.; HSIEH, L. Decision mode, information and network attachment in the internationalization of SMEs: A configurational and contingency analysis. Journal of World Business, 49, 598-610. 2014.

COHEN, D. Globalization and its enemies. Cambridge, MA: The MIT Press, 2006.

CYERT, R. D.; MARCH, J. G. A behavioral theory of the firm. Prentice Hall, Englewood Ciffs, NJ, 1963.

DUNNING, J. H. Location and the multinational enterprise: a neglected factor. Journal of International Business Studies, v. 29, n. 1, p. 45-66, 1998.

DUNNING, J., H. The eclectic paradigm as an envelope for economic and business theories of MNE activity. International Business Review, vol. 9, n. 1, 2000.

FERNÁNDEZ-ORTIZ， R.， ARTEAGA-ORTIZ， J.; CLAVEL S. E. M. Factors That Foster Export Commitment: an Empirical Study in Small and Medium-Sized Enterprises. Engineering Economics, 26 (3), 272-283. 2015.

FRANCISCHINI, A., S. N. et al. Estratégias de internacionalização: análise de empresas brasileiras no setor alimentício. Revista Jovens Pesquisadores, vol. 7, n. 1 (12), jan./jul. 2010.

GARCIA, L. M. Exportar: rotinas e procedimentos, incentivos e formação de preços. 8. ed. São Paulo: Aduaneiras, 2011.

GARRIDO, I. L. A relação entre orientação para mercado externo, estratégias de internacionalização e performance exportadora. Rio Grande do Sul: UFRGS, 2007. 181 f. Tese de Doutorado (Doutorado em Administração) - Escola de Administração, Universidade Federal do Rio Grande do Sul, 2007.

GIL, A. C. Métodos e técnicas de pesquisa social. 6. ed. São Paulo: Atlas, 2008.

HÖRNELL. E.; VAHLNE, J.; WIEDERSHEIM-PAUL, F. Exports and foreign establishments. Stockholm: Almqvist \& Wiksell, 1973.

HYMER, S. H. The international operations of national firms: a study of foreign direct investment. Cambridge: MIT Press, 1960. Tese de Doutorado, Massachusetts Institute of Technology, published in 1970.

HYMER, S. H. The efficiency (contradictions) of multinational corporations. American Economic Review, vol. 60, n. 2, p. 441-448, 1976.

JOHANSON, J.; VAHLNE, J. E. The internationalization process of the firm - a model of knowledge development and increasing foreign market commitments. Journal of International Business Studies, v. 8, n. 1, p. 23-32, 1977.

JOHANSON J.; VAHLNE, J. E. The mechanism of internationalization. International Marketing Review, v. 7, n. 4, p. 11-24, 1990.

JOHANSON, J.; VAHLNE, J. E. Business relationship learning and commitment in the internationalization process. Journal of International Entrepreneurship, 1, p. 83-101, 2003.

KEEDI, S. ABC do comércio exterior. 5 ed. São Paulo: Aduaneiras, 2015.

LOPEZ, J. M. C. Exportação brasileira: a real participação das empresas. São Paulo: Aduaneiras, 2005.

LOPEZ, J. M. C.; GAMA, M. Comércio exterior competitivo. 4. ed. São Paulo: Aduaneiras, 2011.

LUNA, E. P. Essencial de comércio exterior de A a Z. São Paulo: Aduaneiras, 2008.

MALHOTRA, N. K. Pesquisa de marketing: uma orientação aplicada. 6. ed. Porto Alegre: Bookman, 2011.

PENROSE, E. The theory of the growth of the firm. Oxford: Basil Blackwell, 1959.

ROCHA, A. (Org.) A internacionalização das empresas brasileiras: estudos de gestão internacional. Rio de Janeiro: Mauad, 2002.

ROCHA, A. Expansão internacional das empresas brasileiras: revisão e síntese. In: FLEURY, Antônio; Fleury, Maria T. (Org.). Internacionalização e os países emergentes. São Paulo: Atlas, 2007.

RUIZ, F. M. Exportações brasileiras: fatores explicativos da participação das micro e pequenas empresas (MPE). São Paulo: UPS, 2005. 167 f. Tese de Mestrado (Mestrado em Administração) - Departamento de Administração, USP, São Paulo, 2005

SOBEET. Internacionalização das empresas brasileiras. São Paulo: Clio, 2008.

STAL, E.; CAMPANÁRIO, M. A. Inovação em subsidiárias de empresas multinacionais: aplicação do paradigma eclético de Dunning em países emergentes. REAd, ed. 69, v. 17, n. 2, p. 560-591, mai./ago. 2011.

VERNON, R. International investment and international trade in the product cycle. Quarterly Journal of Economics, v. 80, n. 2, p. 190-207, 1966.

YIN, R. K. Estudo de caso: Planejamento e métodos. $5^{\text {a }}$ edição. Porto Alegre: Bookman, 2015.

\section{COPYRIGHT}

Direitos autorais: Os autores são os únicos responsáveis pelo material incluído no artigo. 


\title{
BIOCOMBUSTÍVEIS NO BRASIL: PROSPECÇÃO TECNOLÓGICA SOB O ENFOQUE DE PEDIDOS DE PATENTES
}

\author{
BIOFUELS IN BRAZIL: TECHNOLOGICAL PROSPECTING UNDER THE \\ PATENT APPLICATIONS APPROACH
}

\author{
MARIA GABRIELA BEILFUSS ROCHA JORGE'; DAVID CALHAU JORGE²; LÚCIA MARINA \\ SCATENA $^{3}$; MÔNICA HITOMI OKURA ${ }^{4}$ \\ 1 - INSTITUTO FEDERAL DE EDUCAÇÃO, CIÊNCIA E TECNOLOGIA DO TRIÂNGULO MINEIRO; \\ 2 - UNIVERSIDADE FEDERAL DO TRIÂNGULO MINEIRO; 3 - UNIVERSIDADE FEDERAL DO \\ TRIÂNGULO MINEIRO; 4 UNIVERSIDADE FEDERAL DO TRIÂNGULO MINEIRO \\ mgabrielabeilfuss@gmail.com; david.jorge@uftm.edu.br; lmscatena@uol.com.br;moni@mednet.com.br
}

\begin{abstract}
Resumo - Este artigo apresenta uma análise sobre a atividade de patenteamento relativa a biocombustíveis no Brasil, utilizando informações obtidas em depósitos de pedidos nacionais de patentes submetidos ao Instituto Nacional de Propriedade Industrial (INPI) no periodo de 01/01/2004 a 31/12/2014, publicados até 05 de abril de 2016. Foi utilizado um critério de busca textual para a obtenção dos dados. $O$ objetivo deste trabalho é apresentar a importância da prospecção tecnológica como instrumento de obtenção de informações tecnológicas $e$ competitivas, que podem auxiliar os países na busca pela inovação e pelo desenvolvimento científico e tecnológico.
\end{abstract}

Palavras-chave: Patentes. Informações Tecnológicas. Biocombustíveis.

\begin{abstract}
This article presents an analysis of the patenting activity related to biofuels in Brazil, using information obtained from national patent application filings submitted to the National Institute of Industrial Property (Instituto Nacional de Propriedade Industrial - INPI) from 01/01/2004 to 12/31/2014, published up to April 5, 2016. A textual based search criterion was used to obtain the research data. The objective of this work is to present the importance of technological prospecting as an instrument for obtaining technological and competitive informations, which can help countries to search for innovation and scientific and technological development. .
\end{abstract}

Keywords: Patents. Technological Information. Biofuels.

\section{INTRODUÇÃO}

Um dos maiores desafios do Brasil e de vários outros países é se transformar em uma nação efetivamente desenvolvida, com uma economia próspera e dinâmica, capaz de gerar empregos e renda e apta para enfrentar um mercado globalizado e competitivo. A inovação é a principal ferramenta do progresso, pois decorre da concretização do conhecimento técnico e científico junto ao setor produtivo.

A utilização da documentação de patentes como fonte de informação tecnológica apresenta diversas vantagens significativas em relação a outras fontes. Como exemplo, pode-se citar a estrutura de dados padronizada internacionalmente, a divulgação de tecnologias alternativas e o acesso de informações disponíveis a um grande número de usuários, conforme destacado por Tomioka, Lourenço e Facó (2010).

Para a realização deste trabalho foi escolhido o setor de biocombustíveis, por ser uma área estratégica para assegurar o abastecimento energético e um segmento caracterizado por sucessivas mudanças tecnológicas de um grupo diversificado de matérias-primas (BOINTNER, 2014; COSTANTINI et al., 2015), no qual o Brasil se destacou pelo pioneirismo e visão estratégica de pesquisadores como Expedito José de Sá Parente (PARENTE, 2003) e pelo desempenho dos programas de desenvolvimento deste segmento (NOGUEIRA; CAPAZ, 2013).

Conforme definição de Demirbas (2008, p. 2106):

\begin{abstract}
"O termo biocombustível se refere a combustíveis líquidos, gasosos e sólidos produzidos predominantemente a partir de biomassa. Os biocombustíveis incluem razões de segurança energética, preocupações ambientais, economia de divisas e questões socioeconômicas relacionadas com o setor rural. Os biocombustíveis incluem bioetanol, biometanol, óleos vegetais, biodiesel, biogás, gás bio-sintético (bio-syngas), bio-óleo, bio-carvão, líquidos de Fischer-Tropsch, e biohidrogênio.”
\end{abstract}

Segundo estudo sobre a dimensão do setor sucroenergético (NEVES; TROMBIN, 2014) estimou-se em U\$ 43,36 bilhões o Produto Interno Bruto (PIB) deste setor para a safra $2013 / 14$, equivalente a aproximadamente $2 \%$ do PIB nacional no ano de 2013 e em U\$ 107,72 bilhões a movimentação financeira na safra 2013/14. Esses dados demonstram a importância do setor sucroenergético, que abrange a produção de biocombustíveis derivados da canade-açúcar, no contexto econômico nacional, além da sua contribuição para o meio-ambiente e a melhoria da saúde pública (NEVES; SALDIVA; MACEDO, 2014).

A expectativa de expansão para o setor de biocombustíveis no Brasil é promissora de acordo com os dados do Plano Decenal de Expansão de Energia 2024 (BRASIL, 2015), com estimativa de crescimento para a demanda nacional de biocombustíveis e de investimentos 
globais na oferta de biocombustíveis líquidos. Observa-se no cenário atual a maior participação dos biocombustíveis na comercialização de combustíveis no país, decorrente dos percentuais de adição obrigatória previstos na Lei Federal $n^{\circ}$ 13.033/2014 (BRASIL, 2014).

Segundo dados da Agência Nacional do Petróleo, Gás Natural e Biocombustíveis (ANP) (BRASIL, 2016) no ano de 2015 a produção total de etanol apresentou crescimento de $6,26 \%$ em relação ao ano anterior, correspondendo a 29,9 milhões de $\mathrm{m}^{3}$, abrangendo em sua produção todas as regiões brasileiras. A produção da região sudeste representou $57,40 \%$, da produção nacional, sendo que o volume produzido pelo estado de São Paulo correspondeu a $45,92 \%$ do total produzido pelo país.

Este artigo apresenta um panorama sobre a atividade de patenteamento relativa a biocombustíveis no período de 2004 a 2014, de acordo com o critério de pesquisa explicitado mais adiante, destacando-se a evolução da atividade de patenteamento no período, os países e estados brasileiros com maior representatividade, as principais características observadas nos pedidos de patentes analisados, entre outras informações.

\section{PROCEDIMENTOS}

Foi realizada uma pesquisa quantitativa e descritiva da prospecção tecnológica relativa ao setor de biocombustíveis, com a análise de dados disponíveis ao público utilizando a base de dados do Instituto Nacional de Propriedade Industrial (INPI) (BRASIL, [2016]).

A prospecção tecnológica é o instrumento que permite identificar as tecnologias já desenvolvidas, seu estágio atual, as tecnologias concorrentes, as principais empresas depositantes, os países de origem das patentes, viabiliza a análise de potenciais parcerias, entre outras relevantes informações (QUINTELLA et al., 2011).

A utilização da prospecção tecnológica em base de patentes é observada em artigos científicos nas mais diversas áreas, como nanotecnologia (TOMIOKA; LOURENÇO; FACÓ, 2010), saúde animal (OLIVEIRA et al., 2013), aeronaves remotamente pilotadas (LAJÚS et al., 2016), atuação de instituições de ensino (MENEZES et al., 2015), entre outras. O critério de pesquisa adotado na base de dados do INPI (BRASIL, [2016]), foi a utilização como palavra-chave do termo "biocomb", que abrange as palavras "biocombustível" e seu plural "biocombustíveis" no título e no resumo dos pedidos de patentes publicados até o dia 05 de abril de 2016, data em que o levantamento foi realizado.

Destaca-se que os pedidos recuperados não representam a totalidade de pedidos de patentes em relação a biocombustíveis depositados junto ao INPI. O banco de dados disponibilizado pelo INPI permite diversos critérios de pesquisa, possibilitando a busca por palavras-chave, classificação internacional de patente (CIP), nome de depositante, entre outros, com resultados variados de acordo com o critério utilizado na pesquisa e as informações constantes nos pedidos de patentes formulados pelo depositante.

A utilização do termo "biocomb" no título e no resumo visa à obtenção dos pedidos de patentes em que foram apresentados a palavra biocombustível ou biocombustíveis nos mesmos, podendo indicar de forma inequívoca a sua relação com a proteção patentária de produtos relativos a esta tecnologia específica.
Determinou-se o período de 01/01/2004 a 31/12/2014, no intuito de abranger a evolução da atividade no mínimo em uma década. Observou-se um total de 220 depósitos de pedidos nacionais de patentes realizados nesse período, tendo sido verificadas e removidas as ocorrências de duplicidades decorrentes do critério de busca utilizado.

Os dados obtidos junto ao INPI foram coletados manualmente e implementados em uma planilha de cálculo para obtenção das informações pertinentes ao seu conteúdo e subsequente elaboração de análises estatísticas dos resultados obtidos. Foram observadas, entre outras, as seguintes informações nos pedidos de patentes analisados:

- Número do pedido e data do depósito;

- Título;

- Resumo;

- Classificação Internacional de Patentes (CIP);

- Depositante;

- Inventor;

- País;

- Estado brasileiro, se o depositante for de origem nacional;

- Situação atual do pedido junto ao INPI.

\section{RESULTADOS}

Por meio da análise das informações extraídas da base de dados de acesso público do INPI (BRASIL, [2016], segundo o critério adotado pela pesquisa, verificou-se os seguintes resultados:

\section{1 - Evolução da atividade de patenteamento}

Observa-se na figura 1 a expressiva participação de países estrangeiros na atividade de patenteamento junto ao INPI, superando a quantidade de depósitos de origem brasileira nos anos de 2005 e no período de 2007 a 2011. Do total de 220 depósitos de pedidos nacionais de patentes analisados, $39,55 \%$ são de origem brasileira e $60,45 \%$ de origem estrangeira, indicando que a quantidade de pedidos apresentados por estrangeiros foi $20,90 \%$ maior do que a quantidade de pedidos apresentados por depositantes de origem nacional

Figura 1 - Evolução de pedidos de patentes no INPI com o termo "biocomb*".

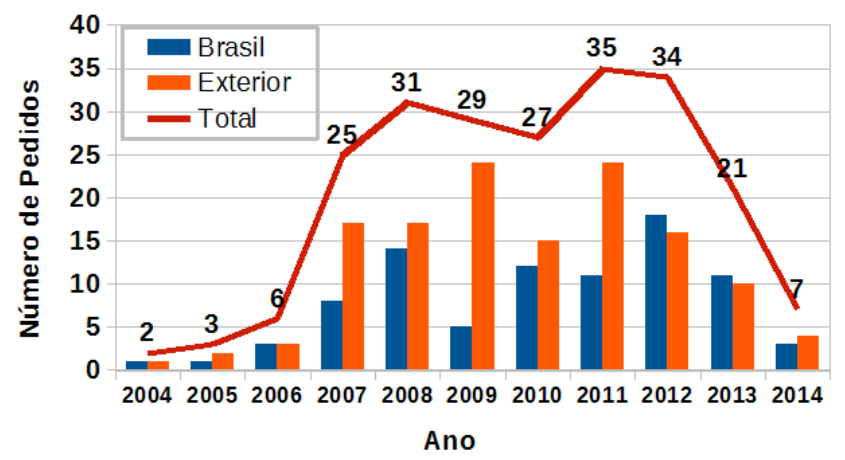

Fonte: Elaborado pelos autores com base em dados do INPI (BRASIL, [2016]).

Infere-se da figura 1 que a partir do ano de 2007 houve um expressivo crescimento na atividade de patenteamento relativa a biocombustíveis, representando um aumento de $316,67 \%$ em relação ao ano anterior, refletindo o interesse 
nacional e estrangeiro de pesquisas e investimentos no setor no período.

Távora (2011) relata que entre os fatores que contribuíram para o renascimento da produção de biocombustíveis no Brasil na última década destacam-se a comercialização de veículos com motor flexível a combustível em 2003 e o bom desempenho de suas vendas; o lançamento no ano de 2005 do Programa Nacional de Produção e Uso do Biodiesel, que determinou a adição gradativa de biodiesel ao diesel fóssil; a aprovação do zoneamento agroecológico da cana-de-açúcar no país, a partir da safra 2009/2010 pelo Governo Federal, no intuito de assegurar condições propícias para uma agricultura sustentável.

No ano de 2008 houve um aumento de $24 \%$ em relação ao ano anterior, seguido de uma queda de $6,45 \%$ e $6,89 \%$, respectivamente, nos anos de 2009 e 2010 , considerando os anos anteriores como referência. Essa variação ocorreu possivelmente em virtude da crise econômica mundial ocorrida no período de 2007/2009 (LIN; MARTIN, 2009).

$O$ ano de 2011 evidencia uma retomada do crescimento na atividade de patenteamento, seguida por uma desaceleração de 2,94\% no ano de 2012 e de 38,23\% no ano de 2013, comparada com os anos anteriores.

O resultado do ano de 2014 apresenta uma queda acentuada em relação ao ano de 2013, mas destaca-se a existência do período de sigilo de 18 meses assegurado aos pedidos de patentes, contados da data de depósito ou da prioridade mais antiga, conforme prevê o art. 30 da Lei Federal $\mathrm{n}^{\circ}$ 9.279/1996 (BRASIL, 1996) e a constante atualização do banco de dados do INPI.

A queda evidenciada na atividade de patenteamento de biocombustíveis a partir do ano de 2012 reflete a redução de investimentos que atingiu o setor, destacada por Pierro (2013). Além da crise econômica de 2008, vários fatores contribuíram para um momento desfavorável ao setor, como problemas climáticos e aumento de custos e principalmente, a baixa competitividade do etanol decorrente da intervenção governamental nos preços da gasolina (NOGUEIRA; CAPAZ, 2013).

A figura 2 demonstra a redução na venda do etanol no Brasil a partir do ano de 2010, fator que pode ter contribuído para a redução de investimentos no setor e refletido na diminuição da atividade de patenteamento de biocombustíveis a partir do ano de 2012, visualizada na figura 1.

Figura 2 - Vendas de etanol (inclui hidratado e anidro) e gasolina A no Brasil - 2006 a 2015.

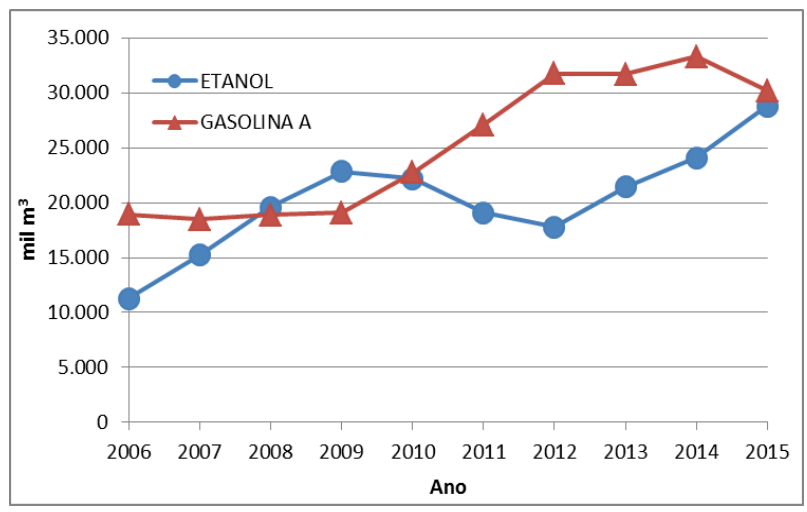

Fonte: Elaborado pelos autores com base em dados da ANP/SPD (BRASIL, 2016).
Conforme dados extraídos do Anuário Estatístico Brasileiro do Petróleo, Gás Natural e Biocombustíveis (BRASIL, 2016), na figura 2 observa-se a expansão das vendas de etanol no período de 2006 a 2009, seguida de um período de queda a partir do ano de 2010 até 2012, retomando o seu crescimento a partir do ano de 2013. O ano de 2015 apresenta um aumento de 19,56\% na venda do etanol e uma redução de $9,22 \%$ na venda da gasolina, comparados com o ano anterior, evidenciando um cenário atual mais favorável ao comércio de biocombustíveis.

\section{2 - Países envolvidos na atividade de patenteamento}

A tabela 1 apresenta a representatividade dos países na atividade nacional de patenteamento, considerando o país de origem dos depositantes dos pedidos de patentes.

Tabela 1 - Número de depósitos de pedidos de patentes por países no INPI com o termo "biocomb*"

\begin{tabular}{lcc}
\hline \multicolumn{1}{c}{ País } & $\begin{array}{c}\text { Quantidade de } \\
\text { depósitos } \\
\text { realizados }\end{array}$ & $\begin{array}{c}\text { Percentual em } \\
\text { relação ao total }\end{array}$ \\
\hline Brasil (BR) & 87 & $39,55 \%$ \\
\hline \hline Estados Unidos (US) & 60 & $27,27 \%$ \\
\hline \hline Grã-Bretanha (GB) & 13 & $5,91 \%$ \\
\hline \hline Holanda (NL) & 10 & $4,55 \%$ \\
\hline \hline Alemanha (DE) & 8 & $3,64 \%$ \\
\hline \hline Espanha (ES) & 5 & $2,27 \%$ \\
\hline \hline Índia (IN) & 4 & $1,83 \%$ \\
\hline \hline Finlândia (FI) & 4 & $1,83 \%$ \\
\hline \hline Japão (JP) & 3 & $1,36 \%$ \\
\hline \hline Dinamarca (DK) & 3 & $1,36 \%$ \\
\hline \hline Austrália (AU) & 3 & $1,36 \%$ \\
\hline \hline França (FR) & 3 & $1,36 \%$ \\
\hline \hline Diversos & 17 & $7,71 \%$ \\
\hline \hline Total & 220 & $100 \%$ \\
\hline \hline
\end{tabular}

Fonte: Elaborado pelos autores com base em dados do INPI (BRASIL, [2016]).

Observa-se na tabela 1 a diversidade de países envolvidos no desenvolvimento de novas tecnologias relativas a biocombustíveis, abrangendo tanto países em desenvolvimento como a Índia e o Brasil, quanto países desenvolvidos como os Estados Unidos, Alemanha, Finlândia, Japão, entre outros.

Evidencia-se o interesse desses países no patenteamento de biocombustíveis no Brasil de forma a obter a proteção jurídica assegurada pelo registro patentário e a possibilidade de comercialização desses produtos no mercado interno.

\section{3 - Análise da atividade de patenteamento por estados brasileiros.}

Dentre os pedidos de patentes de origem brasileira o estado de São Paulo tem se destacado como o principal depositante de pedidos de patentes na área analisada, representando $36,78 \%$ dos pedidos depositados no INPI, como se observa na Figura 3. Em seguida, os pedidos originários dos estados do Paraná e do Rio de Janeiro 
representaram $14,94 \%$ e $11,49 \%$ dos depósitos, respectivamente. A importância das pesquisas realizadas em universidades reflete no resultado apresentado por estado na atividade de patenteamento.

Figura 3 - Depósitos de pedidos de patentes por estados brasileiros com o termo "biocomb".

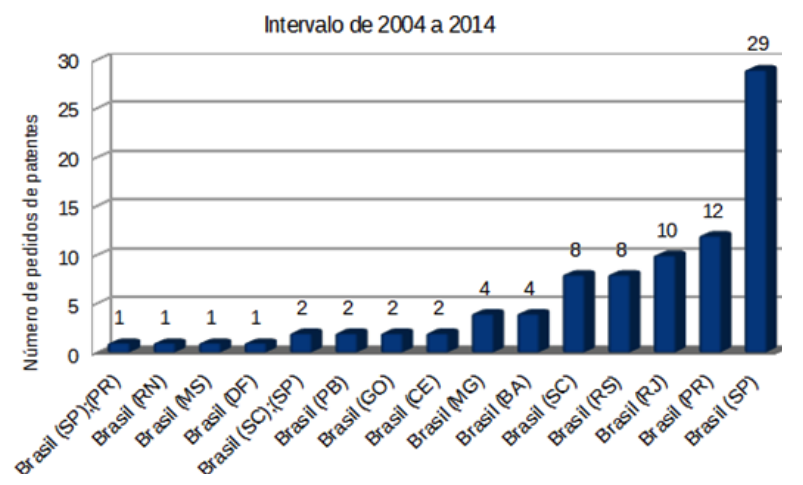

Fonte: Elaborado pelos autores com base em dados do INPI (BRASIL, [2016]).

A tabela 2 apresenta a participação de institutos e universidades brasileiras na atividade de patenteamento segundo os dados obtidos. Dentre os principais depositantes destacam-se a Universidade Estadual de Campinas Unicamp, a Universidade Federal do Paraná, o Instituto Nacional de Tecnologia, a Universidade Estadual do CentroOeste, a Universidade Federal da Bahia, entre outros.

Tabela 2 - Número de depósitos de pedidos de patentes de instituições e universidades brasileiras no INPI com o termo "biocomb*"

\begin{tabular}{ccc}
\hline Quantidade & $\begin{array}{c}\text { Percentual em } \\
\text { de } \\
\text { relação ao } \\
\text { total de } \\
\text { pedićsitos }\end{array}$ \\
\hline
\end{tabular}

\begin{tabular}{lcc}
$\begin{array}{l}\text { Universidade Estadual de } \\
\text { Campinas - (BR/SP) }\end{array}$ & 7 & $3,18 \%$ \\
\hline $\begin{array}{l}\text { Universidade Federal do } \\
\text { Paraná - (BR/PR) }\end{array}$ & 4 & $1,81 \%$ \\
\hline $\begin{array}{l}\text { Instituto Nacional de } \\
\text { Tecnologia - (BR/RJ) }\end{array}$ & 3 & $1,37 \%$ \\
\hline $\begin{array}{l}\text { Universidade Estadual do } \\
\text { Centro-Oeste - (BR/PR) }\end{array}$ & 3 & $1,37 \%$ \\
\hline $\begin{array}{l}\text { Universidade Federal da } \\
\text { Bahia - (BR/BA) }\end{array}$ & 3 & $1,37 \%$ \\
\hline $\begin{array}{l}\text { Solicitações com mais de um } \\
\text { depositante }\end{array}$ & 10 & $4,55 \%$ \\
\hline $\begin{array}{l}\text { Universidades e instituições } \\
\text { com 2 ou menos depósitos } \\
\text { por solicitante }\end{array}$ & 14 & $6,35 \%$ \\
\hline Total & 44 & $20,00 \%$ \\
\hline
\end{tabular}

Fonte: Elaborado pelos autores com base em dados do INPI (BRASIL, [2016]).

Observa-se na tabela 2 que os depósitos realizados por universidades e instituições nacionais de pesquisa correspondem a $20 \%$ do total dos 220 pedidos de patentes analisados, demonstrando a relevância dessas instituições no desenvolvimento de pesquisas relativos ao setor de biocombustíveis. Destaca-se um expressivo número de universidades e instituições envolvidas em pesquisas relativas a biocombustíveis no Brasil, abrangendo pesquisadores de várias regiões.

\section{4 - Características observadas nos dados analisados}

Nos pedidos analisados foram apresentados 96,36\% de reivindicações de patentes de invenção, 2,73\% de modelo de utilidade e $0,93 \%$ de certificado de adição, demonstrando uma concentração de pesquisas e investimentos no desenvolvimento de invenções relativas a biocombustíveis e um reduzido interesse na área de desenvolvimento de novos modelos ou disposições de objetos por parte dos depositantes.

Dos 220 pedidos de patentes analisados apenas três obtiveram a patente concedida (PI 0403235-7 C8/PI 06026338 B1/BR 1020130339237 B1), até a data do levantamento dos dados junto ao INPI. A maior parte dos depósitos foi realizada por pessoas jurídicas, representando $82,73 \%$ dos pedidos de patentes apresentados. As pessoas físicas apresentaram 14,55\% dos depósitos e 2,72\% foram realizados em parceria entre pessoas físicas e empresas.

Apurou-se que $45 \%$ dos depositantes apresentaram atividade continuada de patenteamento no setor, considerando o depósito de dois ou mais pedidos de patentes. Parte expressiva dos depositantes, correspondente a $55 \%$ do seu total, apresentou apenas um pedido de patente no período analisado.

O desempenho das universidades e instituições nacionais e estrangeiras de pesquisas é relevante neste segmento. Dentre os 87 pedidos de patentes realizados por depositantes de origem brasileira, 44 foram apresentadas por universidades e instituições de pesquisas, correspondendo a $50,57 \%$ dos depósitos nacionais de pedidos de patentes de origem nacional. Dentre os 133 pedidos de patentes realizados por depositantes de origem estrangeira, 27 foram apresentados por institutos e universidades estrangeiros, correspondendo a 20,30\% dos depósitos realizados de origem estrangeira. Esta constatação demonstra que embora a participação de universidades e institutos de pesquisa seja também relevante no contexto internacional, no Brasil ela é mais expressiva e evidencia a necessidade de investimentos do setor privado na pesquisa e no desenvolvimento de inovações e tecnologias.

\section{CONCLUSÃO}

A evolução histórica da solicitação de patentes na área de biocombustíveis no Brasil reflete a situação econômica nacional e mundial e os investimentos em novas tecnologias que vêm sendo realizados por vários países em busca de alternativas energéticas.

Os resultados obtidos na atividade de patenteamento nacional evidenciam que embora a atividade de patenteamento neste setor tenha crescido no país, é necessária a sua expansão diante do desenvolvimento de inovações e tecnologias realizadas em vários países, possíveis concorrentes de um mesmo mercado.

É necessário incentivar uma atividade contínua de patenteamento junto aos depositantes brasileiros e a realização de pesquisas aplicadas entre as instituições de ensino e empresas privadas.

Recomenda-se a disseminação de uma cultura de empreendedorismo e inovação na sociedade brasileira no intuito de expandir o desenvolvimento de inovações e tecnologias, requisitos indispensáveis para o crescimento econômico e o progresso dos países. 
Como demonstrado neste trabalho, o banco de dados do INPI disponibiliza informações que possibilitam o acompanhamento do desenvolvimento da atividade de patenteamento no Brasil e o investimento em novas funcionalidades de seu sistema de informações e na sua força de trabalho poderá contribuir para o acompanhamento e gestão de informações tecnológicas e a expansão da atividade intelectual no país.

Sugere-se para futuros trabalhos a utilização de outros critérios de pesquisa, como a busca por classificações internacionais de patentes ou de combinações de palavras e utilização de operadores lógicos, no intuito de obter uma visão mais ampla deste importante segmento.

\section{REFERÊNCIAS BIBLIOGRÁFICAS}

BOINTNER, R. Innovation in the energy sector: Lessons learnt from R\&D expenditures and patents in selected IEA countries. Energy Policy, Surrey, v. 73, p. 733-747, out. 2014. Disponível em: $<$ http://www.sciencedirect.com/science/article/pii/S0301421 514003735>. Acesso em: 20 nov. 2016.

BRASIL. Agência Nacional do Petróleo, Gás Natural e Biocombustíveis. Anuário estatístico brasileiro do petróleo, gás natural e biocombustíveis: 2016. Rio de Janeiro: ANP, 2016. Disponível em: $<$ http://www.anp.gov.br/wwwanp/images/publicacoes/Anua rio_Estatistico_ANP_2016.pdf>. Acesso em: 22 dez. 2016.

BRASIL. Presidência da República. Casa Civil. Subchefia para Assuntos Jurídicos. Lei n. 9.279, de 14 de maio de 1996. Regula direitos e obrigações relativos à propriedade industrial. Brasília: Presidência da República, 1996. Disponível

$<$ http://www.planalto.gov.br/ccivil_03/Leis/L9279.htm>.

Acesso em: 20 nov. 2016.

BRASIL. Presidência da República. Casa Civil. Subchefia para Assuntos Jurídicos. Lei n. 13.033/2014. Dispõe sobre a adição obrigatória de biodiesel ao óleo diesel comercializado com o consumidor final; altera as Leis $\mathrm{n}^{\text {os }} 9.478$, de 6 de agosto de 1997 , e 8.723 , de 28 de outubro de 1993; revoga dispositivos da Lei $n^{\circ} 11.097$, de 13 de janeiro de 2005; e dá outras providências. Brasília: Presidência da República, 2014. Disponível em: < https://www.planalto.gov.br/ccivil_03/_ato2011-

2014/2014/lei/113033.htm>. Acesso em: 20 nov. 2016.

BRASIL. Ministério da Indústria, Comércio Exterior e Serviços. Instituto Nacional de Propriedade Industrial. Base de dados de patentes. Rio de Janeiro: INPI, [2016]. Disponível em: <http://www.inpi.gov.br>. Acesso em: 05 abr. 2016

BRASIL. Ministério de Minas e Energia, Empresa de Pesquisa Energética. Plano Decenal de Expansão de Energia 2024. Brasília: MME, 2015. Disponível em: $<$ http://www.epe.gov.br/PDEE/Relat\%C3\%B3rio\%20Final \%20do\%20PDE\%202024.pdf>. Acesso em: 02 jan. 2017.

COSTANTINI, V. et al. Demand-pulland technology-push public support for eco-innovation: the case of the biofuels sector. Research Policy, Amsterdam, v. 44, n. 3, p. 577595, abr. 2015. Disponível em: $<$ http://www.sciencedirect.com/science/article/pii/S0048733 314002418>. Acesso em: 20 nov. 2016.
DEMIRBAS, A. Biofuels sources, biofuel policy, biofuel economy and global biofuel projections. Energy Conversion and Management, Oxford, v. 49, n. 8, p. 21062116, ago. 2008.

LAJÚS, C. R. et al. Prospecção de patentes relacionadas ao uso de aeronave remotamente pilotada como inserção tecnológica aplicada em agricultura de precisão. Revista Sodebras [on line], v. 11, n. 129, set. 2016. Disponível em: $<$ http://www.sodebras.com.br/edicoes/N129.pdf $>$. Acesso em: 03 nov. 2016

LIN, J. Y.; MARTIN, W. The financial crisis and its impact on the global agricultural landscape. In: International Association of Agricultural Economists. 2009, Beijing. Procedings... Beijing: World Bank, 2009. Disponível em: $<$ https://www.researchgate.net/publication/237796645_The _Financial_Crisis_and_Its_Impact_on_the_Global_Agricult ural_Landscape $>$. Acesso em: 20 nov. $201 \overline{6}$.

In: XXVII conference of the International Association of Agricultural Economists, Beijing, 2009.

MENEZES, C. C. N. et al. Prospecção tecnológica no Brasil: um mapeamento da Propriedade Industrial nos Institutos Federais de Educação. Cadernos de Prospecção, Salvador, v. 8, n. 1, p. 19-26, jan./mar. 2015. Disponível em: $<$ https://portalseer.ufba.br/index.php/nit/article/view/11587/ pdf_85>. Acesso em: 20 nov. 2016.

NOGUEIRA, L. A. H.; CAPAZ, R. S. Biofuels in Brazil: evolution, achievements and perspectives on food security. Global Food Security, Amsterdam, v. 2, n. 2, p. 117-125, 2013.

NEVES, M. F.; SALDIVA, P.; MACEDO, I. Etanol: estudos reforçam amplos ganhos econômicos, sociais e ambientais do etanol de cana. São Paulo: ÚNICA, 2014. Disponível em:

http://www.unica.com.br/noticia/1762967392033158412/est udos-reforcam-amplos-ganhos-economicos-por-cento2Csociais-e-ambientais-do-etanol-de-cana/. Acesso em: 20 nov. 2016.

NEVES, M. F.; TROMBIN, V. G. (Coord.) A dimensão do setor sucroenergético: mapeamento e quantificação da safra 2013/14. Ribeirão Preto: Markestrat, Fundace. FEARP/USP, 2014. Disponível em:

$<$ http://www.brasilagro.com.br/imagens/pdf/Mapeamento Quantificacao_Setor_Sucroenergetico_Safra_2013-14.pdf $>$. Acesso em: 20 nov. 2016.

OLIVEIRA, L. B. et al. Prospecção tecnológica sobre a brucelose bovina (Brucella abortus). GEINTEC-Gestão, Inovação e Tecnologias, São Cristóvão, v. 3, n. 5, p. 372382, 2013. Disponível em:< http://www.revistageintec.net/portal/index.php/revista/articl e/view/313/363>. Acesso em: 20 nov. 2016.

PARENTE, E. J. S. Biodiesel: uma aventura tecnológica num país engraçado. Fortaleza: Tecbio, 2003. Disponível em:

$<$ http://www19.iadb.org/intal/intalcdi/PE/2008/01430.pdf $>$. Acesso em: 20 nov. 2016.

PIERRO, Bruno de. Do bagaço à inovação. Revista Fapesp, São Paulo, edição 208, jun. 2013. Disponível em: $<$ http://revistapesquisa.fapesp.br/2013/06/05/do-bagaco-ainovacao/> Acesso em: 20 nov. 2016. 
QUINTELLA, C. M. et al. Prospecção tecnológica como uma ferramenta aplicada em Ciência e Tecnologia para se chegar à inovação. Revista Virtual Química, Niterói, v. 3, n. 5, p. 406-415, 2011.

TÁVORA, F. L. História e Economia dos Biocombustíveis no Brasil. Centro de Estudos da Consultoria no Senado. Brasília: Senado Federal, 2011. Disponível em: $<$ http://www12.senado.gov.br/publicacoes/estudoslegislativos/tipos-de-estudos/textos-para-discussao/td-89historia-e-economia-dos-biocombustiveis-no-brasil $>$.

Acesso em: 20 nov. 2016.

TOMIOKA, J.; LOURENÇO, S. R.; FACÓ, J. F. B. Patentes em nanotecnologia: prospecção tecnológica para tomada de decisão. Revista Ingepro, Santa Maria, v. 2, n. 10, p. 1-12, out. 2010. Disponível em: $<$ http://ingepro.com.br/Publ_2010/Out/278-875-1-PB.pdf $>$. Acesso em: 20 nov. 2016.

\section{COPYRIGHT}

Direitos autorais: Os autores são os únicos responsáveis pelo material incluído no artigo. 


\title{
LEVANTAMENTO DO USO DE BUSINESS INTELLIGENCE COMO FERRAMENTA DE TOMADA DE DECISÃO NOS INSTITUTOS FEDERAIS DE EDUCAÇÃO
}

\section{LIFTING THE USE OF BUSINESS INTELLIGENCE AS A DECISION-MAKING TOOL IN THE FEDERAL INSTITUTES OF EDUCATION}

\author{
JEFFERSON STEIDEL DOS SANTOS ${ }^{1}$; DENISE FUKUMI TSUNODA ${ }^{2}$ \\ $1 ; 2$ - UNIVERSIDADE FEDERAL DO PARANÁ - UFPR \\ jeffersonsteidel@yahoo.com.br; dtsunoda@gmail.com
}

\begin{abstract}
Resumo - Este artigo objetiva identificar o uso de ferramentas de Business Intelligence (BI) nos Institutos Federais de Educação de forma a descobrir os beneficios e dificuldades para implementação da ferramenta. A população consistiu de 38 institutos, obtendo respostas de 24 instituições, que constituíram a amostra da pesquisa, representando $63,15 \%$ de taxa de retorno, sendo que apenas $25 \%$ das instituições utilizam a ferramenta. Com base no estudo realizado, foi possível identificar como principais benefícios: praticidade na visualização dos resultados das análises por meio de gráficos e diagramas, maior assertividade nas tomadas de decisões baseadas na análise de dados, e possibilidade de gerar relatórios e gráficos adaptados às necessidades. Foram identificadas como principais dificuldades a falta de capacitação da equipe em ferramentas de BI e a existência de dados redundantes em seus bancos de dados.
\end{abstract}

Palavras-chave: Business Intelligence. Institutos Federais de Educação. Benefícios. Dificuldades.

\begin{abstract}
This article aims to identify the use of Business Intelligence (BI) tools in the Federal Institutes of Education in order to discover the benefits and difficulties of implementing the tool. The population consisted of 38 institutes, obtaining answers from 24 institutions, which constituted the research sample, representing a rate of return of $63.15 \%$, with only $25 \%$ of the institutions using the tool. Based on the study, it was possible to identify as main benefits: practicality in visualizing the results of the analyzes through graphs and diagrams, greater assertiveness in decision making based on data analysis, and the possibility of generating reports and graphs adapted to the needs. The main difficulties identified were the lack of training of the team in BI tools and the existence of redundant data in their databases.
\end{abstract}

Keywords: Business Intelligence. Federal Institutes of Education. Benefits. Difficulties.

\section{INTRODUÇÃO}

O avanço do uso de sistemas de informação vem fomentando a adoção de tecnologias alternativas para potencializar o uso do grande volume de dados gerado. Assim, surgem as chamadas ferramentas de Business Intelligence.

$\mathrm{O}$ conceito de $\mathrm{BI}$, de forma mais ampla, pode ser entendido como a utilização de várias fontes de informação para definir estratégias de competitividade nos negócios da instituição (BARBIERI, 2011).
No âmbito dos Institutos Federais de Educação existem sistemas de informação que produzem expressivo volume de dados diariamente, podendo ser classificados em dois grupos: o acadêmico, que se refere a registros de alunos, frequências, notas, conteúdos programáticos, entre outros e o segundo grupo chamado administrativo que se refere aos dados de funcionários, compras, patrimônio, licitações, etc.

Gerir essa quantidade de dados é um desafio, muitos dos sistemas utilizados pelos Institutos Federais são preparados para processar milhares de transações o mais rápido possível, suprindo as necessidades operacionais do dia a dia da instituição, mas deixando de lado outras vertentes como a capacidade de análise, gestão estratégica ou até mesmo a tática.

Este artigo tem por objetivo identificar o uso de ferramentas de BI nos Institutos Federais de Educação, os benefícios alcançados com o seu uso e as dificuldades encontradas durante a sua implantação.

\section{BUSINESS INTELLIGENCE}

Segundo Turban et al., (2009) Business Intelligence (BI) é um termo "guarda-chuva" que inclui arquiteturas, ferramentas, bancos de dados, aplicações e metodologias. O instituto Gartner Group (2016), descreve o BI como um termo genérico que inclui as aplicações, infraestrutura, as ferramentas e melhores práticas que permitem o acesso e a análise de informações para melhorar e aperfeiçoar decisões e desempenho.

O BI favorece a integração de dados, proporcionando maior capacidade de análise, com contextualização e relação de causa e efeito, disponibilizando informações inteligentes e atualizadas às áreas interessadas, tornando melhor o acompanhamento de processos de negócios e agilizando as tomadas de decisões (BEZERRA et al., 2014).

Segundo Chen et al., (2012), o BI está sendo utilizado como base para tomar decisões que minimizem os riscos do negócio e para simular cenários futuros.

$\mathrm{O}$ objetivo do BI é fornecer às organizações inteligência que deve ser usada para criar vantagem competitiva, integrando as capacidades de diferentes sistemas que eram anteriormente operados de forma independente (OLSZAK, 2014). A qualidade da informação, a partir do uso do BI, possibilita que os tomadores de 
decisão direcionem suas ações de acordo com a estratégia da instituição, estabelecendo assim uma estrutura de gerenciamento de desempenho que ajuda a definir seus objetivos, analisar seu progresso, agir e medir seus resultados (CARNEIRO, 2015).

\section{INTITUTOS FEDERAIS DE EDUCAÇÃO}

Em 29 de dezembro de 2008, pela Lei $n^{\circ} 11.892$, o governo federal, fortalecendo a sua política de inclusão social, criou 38 Institutos Federais de Educação, Ciência e Tecnologia (IF). Tais institutos foram criados a partir da união de Escolas Técnicas, Escolas Agro Técnicas, Centros Federais de Educação Tecnológica (CEFET) e suas Unidades de Ensino Descentralizadas (UNED). Com isso, definiu-se que a finalidade desses institutos é ofertar educação profissional e tecnológica em todos os níveis e modalidades do ensino, promover a pesquisa aplicada, desenvolver a tecnologia e atuar na formação de professores, nas áreas de ciências, matemática e educação profissional. Essas instituições são vinculadas à Rede Federal de Educação Profissional, Científica e Tecnológica e apresentam autonomia administrativa e didáticopedagógica.

\section{PROCEDIMENTOS E METODOLOGIA}

O presente trabalho consiste em uma pesquisa quantitativa, utilizando um levantamento de dados por amostragem. A coleta de dados ocorreu de forma eletrônica, sendo utilizando survey online. Como instrumento de coleta de dados foi encaminhado, via e-mail, dois questionários aos gestores dos Institutos Federais, sendo que um desses questionários era direcionado aos que já utilizam de ferramentas de BI e outro destinado aos que não utilizam, cabendo a cada gestor optar por responder um questionário.

$\mathrm{O}$ primeiro questionário era direcionado a institutos que já utilizavam ferramentas de BI e foi composto de 10 questões fechadas e uma aberta, onde buscou-se analisar qual a ferramenta utilizada, o tempo de utilização, a área em que foi aplicada, os usuários, a quantidade de pessoas capacitadas para desenvolver as aplicações de BI, os benefícios alcançados e as dificuldades encontradas durante a implantação.

O segundo foi composto de nove questões fechadas e uma aberta, foi direcionado aos institutos que não utilizam nenhuma das ferramentas de BI, sendo analisado quais ferramentas de BI eram conhecidas pelos gestores, qual área da instituição poderia ser aplicada, qual software a instituição utiliza para gerar relatórios, gráficos e indicadores; se existem pessoas capacitadas para desenvolver as aplicações de BI, quem seriam os usuários, os benefícios que poderiam ser obtidos e as dificuldades encontradas.

A análise do questionário foi o resultado quantitativo em porcentagem da frequência de todas as respostas dos entrevistados a cada uma das questões. Por meio da utilização do editor de planilha eletrônica foram criadas tabelas reunindo os dados extraídos dos questionários e os gráficos utilizados nesse trabalho foram gerados pela ferramenta Qlikview.

O grau de aceitação da ferramenta também foi analisado, através de uma escala de 5 pontos, os gestores interpretaram o grau de aceitação de acordo com os seguintes níveis: 1) não aceito; 2) indiferente; 3) aceito parcialmente; 4) aceito; 5) aceito totalmente.

\section{RESULTADOS E ANÁLISES}

Com relação à amostra, os questionários foram encaminhados a 38 gestores dos Institutos Federais de Educação, obtendo uma taxa de retorno de aproximadamente 63,15\%. Com a análise desses questionários, verificou-se que $75 \%$ dos Institutos não utilizam nenhuma ferramenta de BI e $25 \%$ utilizam ao menos uma.

\section{1 - Análise do questionário encaminhado aos Institutos Federais que utilizam ferramentas de BI}

O questionário encaminhado aos Institutos Federais que já utilizam a ferramenta foi dividido em duas partes, a primeira analisou a ferramenta utilizada, o tempo de utilização, a área em que foi aplicada, o grau de aceitação da ferramenta, os usuários e a quantidade de pessoas capacitadas para desenvolver as aplicações de BI. Na análise da primeira parte do questionário, $50 \%$ dos entrevistados utilizam somente a ferramenta Pentaho; 33,3\% utilizam somente a ferramenta Qlikview e 16,7\% afirmou usar mais de uma ferramenta simultaneamente sendo o Pentaho e Tableau para auxiliar na tomada de decisão dos gestores, sendo que $66,7 \%$ utilizam o BI na instituição de 1 ano a 3 anos, $16,7 \%$ utiliza a menos de um ano e $16,7 \%$ de 3 a 5 anos. Conforme a Figura 1 se destacam algumas áreas da instituição em que a ferramenta é mais aplicada com 100\% na área acadêmica e 33,3\% nas áreas financeira e recursos humanos, esse resultado mostra o qual importante é a área acadêmica, visto que é atividade fim dos Institutos Federais.

Figura 1 - Percentual de aplicação do BI em cada uma das áreas.
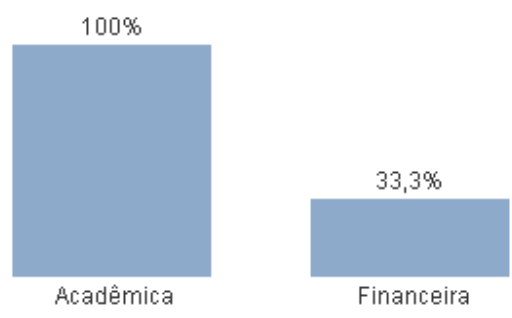

$33,3 \%$

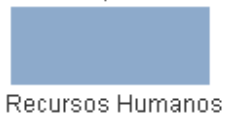

Fonte: Os Autores, 2016.

Já em relação a quantas pessoas trabalham com o desenvolvimento de aplicações BI na instituição, 66,7\% pesquisados responderam que apenas uma pessoa é habilitada para tal função, $16,7 \%$ responderam que apenas duas e $16,7 \%$ responderam que apenas três pessoas são aptas. A partir deste resultado, podemos verificar que existe um risco para a implantação da ferramenta, como a maioria dos entrevistados apontou que apenas uma pessoa é capacitada, no caso de uma ausência deste profissional, pode ocorrer a interrupção da implantação do BI, por isso o ideal é que mais de uma pessoa fosse capacitada na ferramenta. Com relação ao grau de aceitação da ferramenta, na maioria das instituições, a ferramenta foi aceita ou parcialmente aceita, conforme Tabela 1 . 
Tabela 1 - Percentual do grau de aceitação da ferramenta de BI.

\begin{tabular}{ccc}
\hline Grau de aceitação & $\begin{array}{c}\mathbf{N}^{\mathbf{0}} \mathbf{d e} \\
\text { entrevistados }\end{array}$ & $\mathbf{\%}$ \\
\hline Não aceito & 0 & $0 \%$ \\
Indiferente & 1 & $16,7 \%$ \\
Aceito parcialmente & 2 & $33,3 \%$ \\
Aceito & 2 & $33,3 \%$ \\
Aceito totalmente & 1 & $16,7 \%$ \\
\hline
\end{tabular}

Conforme a Figura 2, os principais usuários da ferramenta apontados pelos entrevistados são: os diretores com $83,3 \%$, reitores e pró-reitores com $50 \%$, que compõe a alta administração e são os responsáveis pela tomada de decisão na instituição.

Figura 2 - Percentual dos usuários que utilizam o BI.

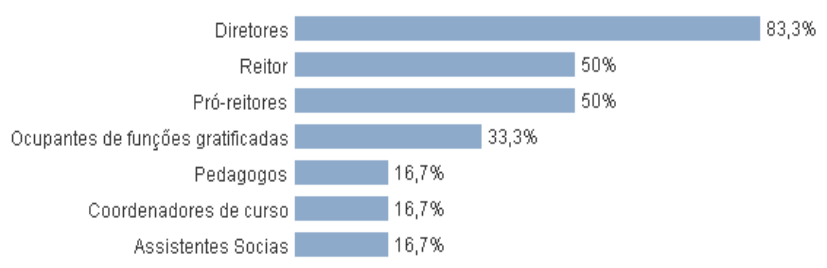

Fonte: Os Autores, 2016.

Analisando a segunda parte do questionário, a Tabela 2 apresenta as dificuldades encontradas pelos gestores na aplicação da ferramenta. Com relação à afirmativa 2 e 3,50\% dos gestores concordam que dados redundantes em seus bancos de dados e a falta de capacitação da equipe são uma dificuldade durante a implantação da ferramenta. Já na afirmativa 1 , a maioria dos gestores, 83,3\%, acredita que a falta de confiabilidade dos dados é um impedimento, devido a cadastros feitos de maneira errônea pelos usuários.

As alternativas 1, 2 e 4 referem-se ao problema de qualidade de dados, uma solução seria a conscientização destes, através de capacitação, sobre a importância do registro correto das informações nos bancos de dados. Esta solução pode resolver também o problema de dados redundantes e a ausência de dados.

Tabela 2 - Percentual com relação as dificuldades encontradas durante a implantação da ferramenta de BI.

\begin{tabular}{cc}
\hline Afirmativas & Porcentagem \\
\hline $\begin{array}{c}\text { 1. Falta de confiabilidade dos dados. } \\
\text { 2. Apresentava dados redundantes em seus } \\
\text { bancos de dados. }\end{array}$ & $83,3 \%$ \\
3. Falta de capacitação da equipe na & $50 \%$ \\
ferramenta de BI. & $50 \%$ \\
4. Falta de registros nos bancos de dados. & $33,3 \%$ \\
\hline
\end{tabular}

A Tabela 3 apresenta os benefícios do uso da ferramenta, sendo que $66,7 \%$ dos pesquisados apontam melhor assertividade nas tomadas de decisões baseadas em análise de dados, possibilidade de gerar relatórios e gráficos adaptados às necessidades e praticidade na visualização da informação como os principais benefícios. E, $50 \%$ dos entrevistados apontam as afirmativas 4 e 5 como vantagens do uso do BI em suas instituições.
Tabela 3 - Percentual em relação aos benefícios encontrados durante o uso da ferramenta de BI.

\begin{tabular}{cc}
\hline Afirmativas & Porcentagem \\
\hline $\begin{array}{c}\text { 1. Melhor assertividade nas tomadas } \\
\text { de decisões baseadas em análise de } \\
\text { dados. }\end{array}$ & $66,7 \%$ \\
$\begin{array}{c}\text { 2. Possibilidade de gerar relatórios e } \\
\text { gráficos adaptados às necessidades. } \\
\text { 3. Praticidade na visualização dos } \\
\text { resultados das análises por meio de } \\
\quad \text { gráficos e diagramas. }\end{array}$ & $66,7 \%$ \\
$\begin{array}{c}\text { 4. Agilidade na recuperação da } \\
\text { informação. }\end{array}$ & $50 \%$ \\
5. Centralização da informação. & $50 \%$ \\
\hline
\end{tabular}

Como benefícios podemos verificar que os gestores necessitam de interfaces amigáveis que facilitem a interação e o entendimento dos dados, a fim de, por exemplo, fornecer informações adequadas para a tomada de decisão, permitindo a sua manipulação, monitoração e compreensão.

\section{2 - Análise do questionário encaminhado aos Institutos Federais que não utilizam ferramentas de BI}

O questionário encaminhado aos Institutos Federais que não utilizam a ferramenta foi dividido em duas partes da mesma forma que o questionário enviado aos Institutos que utilizam a ferramenta. A primeira analisou quais ferramentas de BI eram conhecidas pelos gestores, qual área da instituição poderia ser aplicada, qual software a instituição utiliza para gerar relatórios, gráficos e indicadores; quantidade de pessoas capacitadas para desenvolver as aplicações de BI e quem seriam os usuários.

$\mathrm{Na}$ análise da primeira parte do questionário, 83,3\% dos entrevistados conhecem pelo menos uma ferramenta de BI, enquanto apenas $16,7 \%$ não conhece nenhuma, segundo a Figura 3. As ferramentas mais conhecidas pelos entrevistados são: o Pentaho, Qlikview e o Oracle Business Intelligence.

Figura 3 - Ferramentas de BI conhecida pelos gestores em percentual.

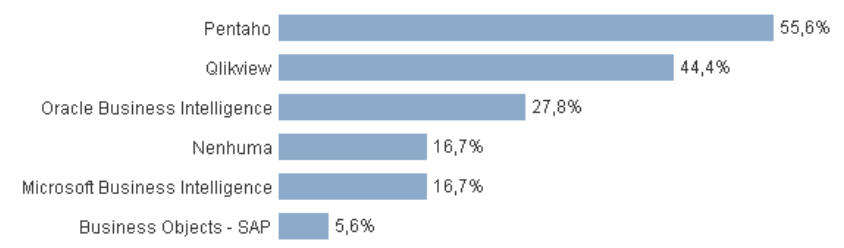

Fonte: Os Autores, 2016.

Segundo a Figura 4, algumas áreas da instituição em que a ferramenta poderia ser aplicada se destacam a área acadêmica com $100 \%$ dos respondentes, financeira com $94,4 \%$, planejamento com $88,9 \%$ e recursos humanos com $72,2 \%$. 
Figura 4 - Percentual das áreas em que o BI poderia ser aplicado.
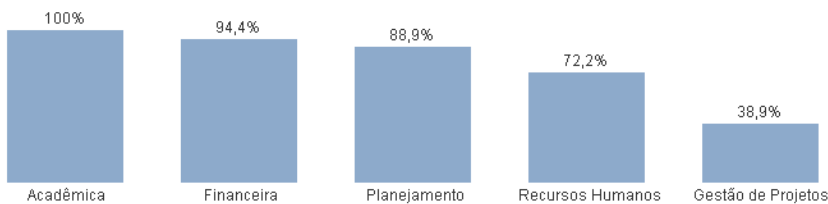

Fonte: Os Autores, 2016.

Para gerar relatórios e indicadores, 72,2\% dos gestores informaram que atualmente utilizam sistemas desenvolvidos internamente, enquanto $66,7 \%$ apontaram que realizam consultas diretamente aos bancos de dados e 44,4\% utilizam planilhas eletrônicas. Já 94,4\% dos entrevistados apontam que não existem profissionais com capacitação na TI para realizar o desenvolvimento e implantação de um sistema BI na instituição, sendo um problema pois consideraram que os possíveis usuários da ferramenta seriam os pró-reitores com $94,4 \%$ dos respondentes, reitores $89,9 \%$ e diretores $72,2 \%$ de acordo com a Figura 5.

Figura 5 - Possíveis usuários do BI em percentual.

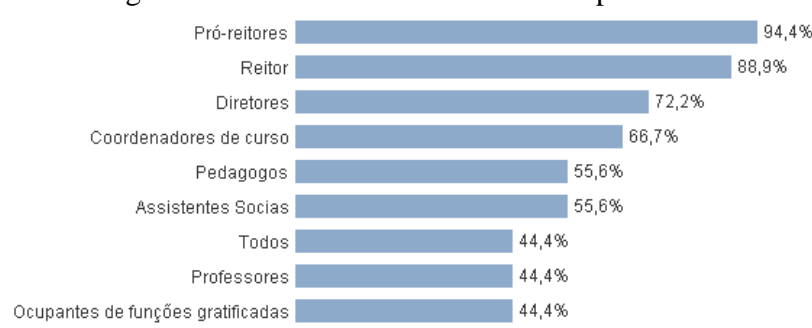

Fonte: Os Autores, 2016.

Analisando a segunda parte do questionário, 77,8\% dos pesquisados apresentam a falta de capacitação da equipe como principal motivo para não implantar a ferramenta, $72,2 \%$ alegam ter problemas de redundância de dados, $44,4 \%$ mencionam a ausência de dados no banco de dados e $38,9 \%$ citam a falta de confiabilidade dos dados.

A Tabela 4 apresenta os benefícios do uso da ferramenta caso fosse implantada, sendo que $100 \%$ dos respondentes apontam a praticidade na visualização dos resultados das análises por meio de gráficos e diagramas como principal benefício. Enquanto, $94,4 \%$ e $88,9 \%$ dos entrevistados citam a melhor assertividade nas tomadas de decisões baseadas em análise de dados e possibilidade de gerar relatórios e gráficos adaptados às necessidades, respectivamente. Apenas $66,7 \%$ dos entrevistados mencionam a agilidade na recuperação de informação.

Tabela 4 - Percentual em relação aos benefícios do uso da ferramenta caso fosse implantada.

\section{Afirmativas}

Porcentagem

1. Praticidade na visualização dos resultados das análises por meio de gráficos e

$100 \%$ diagramas.

2. Melhor assertividade nas tomadas de decisões baseadas em análise de dados.

3. Possibilidade de gerar relatórios e gráficos adaptados às necessidades.

4.Agilidade na recuperação da informação.

5.Centralização da informação com a integração das bases de dados.

6.Segurança de acesso aos dados através de níveis de permissão.
Finalmente, como sugestão sobre o uso das ferramentas de BI, um dos institutos pesquisados informou que trabalharia na construção de um portal de transparência, dando ênfase no primeiro momento aos indicadores relacionados ao ensino.

\section{CONCLUSÃO}

Podemos concluir, à vista dos resultados da pesquisa empreendida, obtidos junto aos questionários aplicados aos gestores, que existem algumas assertivas mais evidentes, apontando os benefícios e as dificuldades no uso da ferramenta, tanto por aqueles que a utilizam, quanto os que não utilizam, sendo os principais benefícios: praticidade na visualização dos resultados das análises por meio de gráficos e diagramas; maior assertividade nas tomadas de decisões baseadas na análise de dados; e possibilidade de gerar relatórios e gráficos adaptados às necessidades. É visível que os gestores precisam de algum sistema que seja capaz que trabalhar com um grande volume de dados de forma amistosa e permita uma interface que mostre gráficos e gere relatórios conforme a necessidade. Já como principais dificuldades, foram identificadas a falta de profissionais capacitados na TI para realizar o desenvolvimento e implantação de um sistema BI na instituição e a existência de problemas relacionados ao banco de dados como falta de registros, redundâncias e falta de confiabilidade dos dados.

Estas dificuldades apontam que deve existir um treinamento das equipes de TI dos Institutos Federais em ferramentas de BI e dos usuários que cadastram as informações nos sistemas para uma maior qualidade dos dados, visto que para um sistema de BI é importante que os dados sejam confiáveis e estejam corretos, caso contrário pode levar a tomada de decisões equivocadas.

Por fim, $100 \%$ dos pesquisados acreditam que a aplicação do BI se destaca na área acadêmica, que é a área fim dos Institutos Federais, sendo seus principais usuários os reitores, pró-reitores e diretores da instituição, cargos mais altos da instituição. Sugere-se para um próximo estudo a elaboração de um modelo de BI voltado para a esfera acadêmica, visto que todos os entrevistados apontaram a aplicação para esta área.

\section{REFERÊNCIAS BIBLIOGRÁFICAS}

BARBIERI, C. BI2 - Business Intelligence: modelagem e qualidade. 1. ed. Rio de Janeiro: Elsevier, 2011.

BEZERRA, A. A. et al. Business Intelligence: uma perspectiva de soluções aplicadas no contexto da Gestão da Informação. In: ENCONTRO DE ESTUDOS SOBRE TECNOLOGIA, CIÊNCIA E GESTÃO DA INFORMAÇÃO, 5., 2014, Recife. Anais... Recife: InFoco Consultoria Júnior/UFPE, 2014.

BRASIL. Ministério da Educação. Lei n ${ }^{\circ} 11.892$, de 29 de dezembro de 2008. Institui a Rede Federal de Educação Profissional, Científica e Tecnológica, cria os Institutos Federais de Educação, Ciência e Tecnologia, e dá outras providências. Diário Oficial da União, Brasília, DF, 29 dezembro 2008. Disponível em: <https://www.planalto.gov.br/ccivil_03/_ato2007-

2010/2008/lei/111892.htm>. Acesso em: 22 de nov 2016. 
CARNEIRO, C. M. C. D.; Relação entre o uso do Business Intelligence e os benefícios organizacionais percebidos. 100 f. Dissertação (Mestrado em Administração) - Centro de Ciências Jurídicas e Econômicas, Universidade Federal do Espírito Santo, Vitória, 2015.

CHEN, H., CHIANG, R. H. L, STOREY, V. C. Business Intelligence and analytics: From big data to big impact. MIS Quarterly, v. 36, n.4, p. 1-24, 2012.

GARTNER GROUP. Business Intelligence. Disponível em: <http://www.gartner.com/it-glossary/businessintelligence-bi/> Acesso em: 22 de novembro de 2016.

OLSZAK C. M. An overview of information tools and technologies for competitive intelligence building: Issues in Informing Science and Information Technology, 11, 139$153,2014$.

TURBAN, E. et al. Business Intelligence: um enfoque gerencial para a inteligência do negócio. São Paulo: Bookman, 2009.

\section{COPYRIGHT}

Direitos autorais: Os autores são os únicos responsáveis pelo material incluído no artigo. 


\title{
ABORDANDO UM DOS MAIORES ACIDENTES NUCLEARES DA HISTÓRIA ATRAVÉS DA INTERDISCIPLINARIDADE
}

\author{
DISCUSSING ONE OF THE BIGGEST NUCLEAR ACCIDENTS OF HISTORY \\ USING INTERDISCIPLINARITY
}

\author{
ROSANA PETINATTI DA CRUZ'; MARIA LÚCIA TEIXEIRA GUERRA DE MENDONÇA ${ }^{2}$; ADRIANA \\ RAMOS PINHEIRO²; ARAMIS DAVID CORREA²; JOSÉ CARLOS FERNANDES COSTA²; \\ RAIMUNDO NONATO DA SILVEIRA JÚNIOR ${ }^{2}$ \\ 1 - CTUR, UNIVERSIDADE FEDERAL RURAL DO RIO DE JANEIRO; 2 - IFRJ - CAMPUS RIO DE JANEIRO \\ rosanapetinatti@gmail.com;maria.mendonca@ifrj.edu.br;adriana.pinheiro@ifrj.edu.br;jose.costa@ifrj.edu.br \\ ;raimundo.silveira@ifrj.edu.br
}

\begin{abstract}
Resumo - O trabalho teve como objetivo desenvolver a consciência crítica sobre o acidente de Chernobyl, a energia nuclear e os conceitos sobre radioatividade. Foi um trabalho de interdisciplinaridade, com a participação das disciplinas de Artes, Biologia, Física e Química. Foram realizadas várias atividades: aulas sobre o conteúdo de radioatividade, exposição de fotos $e$ cartazes, palestra e peça de teatro. Como resultado, observamos, em termos quantitativos, uma relevante melhora do desempenho, nas disciplinas envolvidas, com a redução do baixo rendimento em mais da metade dos alunos, comparando-se as médias das avaliações do ano em que foi realizado o trabalho interdisciplinar com as do ano anterior, o que demonstra o quanto a apreensão do conteúdo foi significativa. Concluímos que este trabalho gerou uma consciência crítica nos alunos sobre as questões nucleares.
\end{abstract}

Palavras-chave: Interdisciplinaridade. Acidente de Chernobyl. Conscientização.

\begin{abstract}
The aim of the work was to develop a critical awareness of the Chernobyl accident, nuclear energy and the concepts of radioactivity. It was a work of interdisciplinarity between the disciplines of Arts, Biology, Physics and Chemistry, several activities were carried out: classes on the content of radioactivity, exhibition of photos and posters, lecture, and play. As a result we observed in quantitative terms a significant improvement in the disciplines involved in the work with the reduction of more than half of the students with low income, comparing the averages of the evaluations of the year in which the interdisciplinary work was done, with the previous year, showing how much the apprehension of the content was significant. We conclude that this work has generated critical awareness among students about nuclear issues.
\end{abstract}

Keywords: Interdisciplinary. Chernobyl Accident. Awareness.

\section{INTRODUÇÃO}

Em 2016, completa 30 anos um dos piores acidentes da história numa usina nuclear. No dia 26 de abril de 1986 , uma série de falhas provocou um superaquecimento num dos reatores da usina nuclear de Chernobyl, na Ucrânia, antiga URSS, culminando numa explosão, que lançou na atmosfera uma nuvem radioativa que se alastrou por vários países da Europa (DUPPUY, 2007).
Este trabalho foi norteado pelo livro Vozes de Chernobyl (SVETLANA, 2016), que traz depoimentos de cientistas, de soldados e de viúvas das vítimas do acidente, assim como do casal Ludmila e Vassíl Ignatenko.

A proposta do trabalho foi de interdisciplinaridade, com um grupo de professores engajados em desenvolver o aprendizado dos alunos, através da ligação entre os conteúdos, o que é recomendado nas Orientações Curriculares para o Ensino Médio (BRASIL, 1998).

A interdisciplinaridade foi realizada com $O$ envolvimento das disciplinas de Artes, Biologia, Física e Química e com a participação dos alunos do segundo período do curso Técnico do Instituto Federal do Rio de Janeiro, do Campus Rio de Janeiro.

A propósito da referida modalidade, constata-se, na literatura, certo número de trabalhos interdisciplinares entre disciplinas diversas no Ensino Médio e que alcançaram bons resultados.

Mendonça et al. (2010), por exemplo, realizaram um trabalho de interdisciplinaridade entre as disciplinas de Língua Portuguesa e Química, utilizando reportagens de jornais e revistas para a criação de textos explicativos e expositivos (jornalísticos), com os conteúdos relacionados a petróleo e com uma visão química, econômica e ambiental. Esse trabalho atestou o sucesso de trabalhos interdisciplinares, com o conteúdo abordado de uma maneira mais ampla, despertando a consciência crítica em relação ao conteúdo "petróleo", que está intrinsecamente ligado ao setor econômico e social. O mesmo foi verificado na obra de Cruz et al. (2016), que também realizaram um estudo interdisciplinar com a criação de textos na disciplina de Língua Espanhola, com os conteúdos apreendidos nas disciplinas de Química Ambiental e Segurança Alimentar, em relação ao reaproveitamento de óleo para a fabricação de sabão. No caso, houve, novamente, a conexão dos conteúdos com a sustentabilidade, o que é de extrema importância no mundo atual.

Rua e Souza (2010) realizaram uma abordagem interdisciplinar entre as disciplinas de Educação Ambiental e Estudos Regionais do curso Técnico em Administração de Empresas, estudando o ecossistema ambientalmente degradado da Baía de Guanabara. Aqui, similarmente, 
observa-se o êxito de trabalhos interdisciplinares na formação crítica do aluno, principalmente, quando se aproximam da realidade do mesmo.

Freitas Filho et al. (2013) efetuaram um trabalho interdisciplinar que compreendeu as disciplinas de Biologia, Física e Química, utilizando o rio Capibaribe como contexto de estudo, através de vivências experimentais, com discussões e a construção de conceitos envolvidos nessas três áreas. Da mesma forma nota-se que houve um melhor rendimento dos alunos em todas as disciplinas envolvidas no trabalho.

Rianelli et al (2016) efetuaram um trabalho no Ensino de Jovens e Adultos (EJA) produzindo um shampoo na disciplina de Química, elaborando o rótulo na Língua Portuguesa e determinando o volume do frasco utilizado, na disciplina de Matemática. Mendonça et al. (2015) também realizaram um trabalho com a confecção de shampoo com essências e corantes na disciplina de Química e a elaboração do rótulo e do manuseio do shampoo em Língua Francesa e Espanhola, em ambos os trabalhos, mesmo envolvendo alunos de diferentes segmentos. Foi constatada maior interação entre os conteúdos apreendidos e a experimentação, além de aumento da autoestima, visto que o aluno participou de todas as etapas de fabricação do produto, desde a sua formulação até o seu design.

Cruz et al (2016) realizaram um trabalho interdisciplinar envolvendo as disciplinas de Química Ambiental e Microbiologia, em que os alunos apreenderam os conteúdos sobre o sistema respiratório e digestivo dos Anelídeos, através do crescimento ou não das hortaliças em várias condições diferentes. $\mathrm{Na}$ disciplina de Química Ambiental, foram feitas algumas análises de solo nessas diferentes condições. Nesse estudo verificou-se que disciplinas consideradas difíceis (Química Ambiental e Microbiologia) pelos alunos da instituição apresentaram um melhor rendimento depois da atividade interdisciplinar.

Cruz et al (2016) elaboraram, ainda, outro trabalho interdisciplinar visando a despertar a consciência crítica sobre a alimentação e o consumo de açúcar através do preparo de geleias, envolvendo as disciplinas de Indústrias Rurais e de Química Ambiental, ressaltando também o quanto é importante despertar a conscientização crítica do aluno para tudo o que possa afetar sua saúde.

Vale ressaltar que Florentino Novo (2014), em seu estudo, chama a atenção para o fato de que, a cultura de interdisciplinaridade é um desafio a ser vencido em diferentes campos do saber. $\mathrm{O}$ autor constata a existência de diversas experiências interdisciplinares sendo conduzidas no país, mas admite a necessidade de diálogo e a participação de várias áreas do conhecimento, que às vezes não eram dantes previstas.

Raynaut (2011) também aborda, em seu trabalho, as fronteiras disciplinares que criam divisões e podem converter-se em verdadeiras "redes de interações privilegiadas, quadros de afirmação de identidade intelectual e, por fim, em territórios de poder" (Raynaut (2011, p 86). Isto mostra o empoderamento do docente diante de sua disciplina, criando resistências para a realização de trabalhos interdisciplinares.

Neste trabalho foi utilizado o conceito de interdisciplinaridade com o objetivo central de desenvolver a consciência crítica sobre o acidente de Chernobyl, a energia nuclear e as aplicações da radioatividade. Os objetivos específicos foram: para a disciplina de Química, estudo das emissões alfa, beta e gama; para a disciplina de Física, fissão e fusão nuclear; para a disciplina de Biologia, transmutação genética e, para a disciplina de Artes, elaboração da peça de teatro baseada no livro Vozes de Chernobyl.

\section{PROCEDIMENTOS}

O trabalho foi realizado com os alunos da turma do segundo período do curso Técnico do Instituto Federal do Rio de Janeiro, do Campus Rio de Janeiro, sendo realizado em etapas. Primeiramente o professor da disciplina de Biologia sugeriu aos alunos e aos professores a leitura de um dos contos do livro Vozes de Chernobyl (SVETLANA, 2016). Depois a disciplina de Química realizou o estudo das emissões alfa, beta e gama e a disciplina de Física efetuou os conteúdos sobre fissão e fusão nuclear. Os conteúdos abordados nessas duas disciplinas eram os conteúdos sobre radioatividade existentes no texto, necessários para a compreensão da leitura do livro.

A disciplina de Química também realizou uma palestra em que o palestrante novamente enfatizou os conteúdos e aplicações da radioatividade. Houve, ainda, a apresentação do filme A Batalha de Chernobyl e, por último, um debate sobre as referidas questões.

A disciplina de Biologia, além de abordar os conteúdos sobre transmutação genética, realizou uma exposição de fotos e cartazes sobre $\mathrm{o}$ acidente e as consequências ocorridas nos animais e nos seres humanos, devido à exposição elevada de radioatividade.

Depois que os alunos já estavam dominando os conteúdos, a disciplina de Artes teve a incumbência de orientá-los para a construção do roteiro e elaboração da peça de teatro, baseada num conto do livro Vozes de Chernobyl, nos conteúdos adquiridos nas disciplinas e na palestra ministrada por um professor convidado. A peça teve a atuação do professor da disciplina de Física, como um engenheiro, do professor da disciplina de Biologia, como um cientista e a professora da disciplina de Química foi representada por uma aluna. A professora da disciplina de Língua Portuguesa fez a contribuição de participar como a narradora da peça.

Em suma as etapas do trabalho foram realizadas na seguinte ordem:

1. Leitura do conto do livro (para todas as partes envolvidas: alunos/professores);

2. Estudo das emissões alfa, beta e gama (disciplina de Química);

3. Estudo sobre fissão e fusão nuclear (disciplina de Física);

4. Estudo sobre transmutação genética (disciplina de Biologia);

5. Realização da exposição de fotos e cartazes sobre o acidente (disciplina de Biologia);

6. Palestra, filme e debate com um convidado conhecedor do assunto (disciplina de Química);

7. Construção do roteiro e elaboração da peça de teatro (disciplina de Artes).

\section{RESULTADOS}

Como a quantificação deste trabalho é tarefa difícil de ser feita, foi proposta pelos professores uma comparação entre as avaliações realizadas pelos alunos no segundo bimestre do ano de 2016 com as avaliações deste mesmo 
bimestre, mas no ano anterior (2015), para poder se ter uma estimativa do desenvolvimento dos alunos. Comparando os resultados (Tabela 1), observa-se uma significativa melhora nas disciplinas de Química, Física e Biologia, com a redução do baixo rendimento de mais da metade dos alunos, o que atesta o quanto os alunos apreenderam, de maneira expressiva, mostrando-se bastante interessados nas aulas das três disciplinas, em relação aos conteúdos abordados, fazendo uma série de perguntas sobre o assunto. Não foi possível fazer a mesma analogia com a disciplina de Artes, porque a avaliação foi realizada através da construção e montagem de uma peça de teatro diferente, com temas e abordagens diversas em cada ano.

Tabela 1 - Comparação das porcentagens de alunos com avaliação abaixo da média no segundo bimestre do ano de 2015 e 2016.

\begin{tabular}{lllll}
\hline Disciplinas & $\begin{array}{l}\text { \% de alunos } \\
\text { abaixo da média } \\
(\mathbf{2 0 1 5})\end{array}$ & $\begin{array}{l}\% \text { de } \\
\text { abaixo } \\
(\mathbf{2 0 1 6})\end{array}$ & $\begin{array}{l}\text { alunos } \\
\text { média }\end{array}$ \\
\hline Química & 35 & 12 & \\
Física & 37 & 11 & \\
Biologia & 26 & 5 & \\
\hline
\end{tabular}

A exposição das fotos e cartazes realizada pelos alunos mostrou uma criatividade enorme e como essa exposição foi feita nos corredores da instituição, gerou curiosidade e mobilização também nos outros alunos de outras turmas.

A palestra, o filme e o debate (Figura 1) foram abertos para todos os alunos e, devido à mostra de fotos e cartazes, apresentou um número enorme de participantes, que fizeram várias perguntas sobre o filme e sobre o cotidiano (principalmente a exposição à radiação em exames) ao palestrante.

Foi solicitada aos alunos uma avaliação sobre o trabalho interdisciplinar realizado (Tabela 2), da qual foram selecionadas "falas" de alguns alunos, já que o número de alunos por turma é grande. Por essas "falas" pode-se verificar o quanto foi proveitoso o trabalho, porque os alunos passaram a ter uma visão crítica e diferenciada sobre o assunto, tanto do acidente, como da aplicação e exposição da radioatividade no dia a dia, o que pode ser constatado, principalmente, pela "fala" do aluno E (Tabela 2), que mostra o quanto o assunto era desconhecido para ele e o quanto ele aprendeu e de forma "emocionante". Também pela "fala" do aluno F (Tabela 2), que apresenta como aspecto negativo, nada relativo ao trabalho interdisciplinar, mas sim pelo conhecimento de que a energia nuclear pode ser utilizada para o "mal".

Quanto à peça de teatro (Figura 2), baseada no texto do supervisão do professor da disciplina de Artes, foi o marco do trabalho, porque o texto além de tratar de um assunto tão complexo e triste, conseguiu ter momentos de humor, principalmente com a presença dos professores das disciplinas de Física e Biologia na atuação da peça de teatro.

Tabela 2 - Avaliação feita pelos alunos, destacando aspectos positivos e negativos do trabalho interdisciplinar

Quais foram os aspectos positivos e negativos que você gostou ou não sobre o trabalho interdisciplinar?

\begin{tabular}{lll}
\hline Alunos & Resposta (Gostou) & $\begin{array}{l}\text { Resposta (Não } \\
\text { gostou) }\end{array}$ \\
\hline A & Foi o acesso da & $\begin{array}{l}\text { As explicações do } \\
\text { palestrante não foram } \\
\end{array}$ \\
palestra para todos & os alunos, já que é & suficientes para
\end{tabular}
livro Vozes de Chernobyl, elaborada pelos alunos e com a um tema muito

importante e que

deve ser conhecido

por todos, o tema

foi brilhante.

Achei muito

interessante a

palestra, o

palestrante soube

explicar direito o

que aconteceu no

acidente e o filme

era muito bom.

Gostei muito da

peça de teatro, pois

foi uma

oportunidade de

aprender mais e de

uma forma

interativa. A

palestra também foi

muito informativa e

emocionalmente.

Prendeu a atenção.

Um dos pontos

fortes foi $o$

palestrante,

praticamente deu

uma aula sobre

radioatividade

mostrou a gravidade

do acidente.

Gostei muito da

palestra e da peça,

pois foi uma

oportunidade de

aprender mais de

uma forma

interativa. A

palestra foi bem

informativa e

emocionante,

prendeu a todos,

gostei de tudo, do

filme que foi

passado, da forma

que o palestrante

conversou conosco

e principalmente

das informações

passadas, que

muitos

desconheciam até

então.

De saber os motivos daquilo ter ocorrido, afinal quando se conhece os erros, pode-se tentar evitálos

entender o filme.

$\mathrm{O}$ auditório ficou

pequeno pra

quantidade de pessoa

de conteúdo s que

foram.

Não vi nenhum ponto negativo.

A superlotação do auditório

Não vi nenhum ponto negativo.

Não gostei de saber da parte em que apesar de a energia nuclear poder servir para o bem, também pode acabar com milhares de vidas se usada para o mal.

Eu gostei do evento Não pude assistir até porque nele entendi melhor, como se faz uma bomba atômica e como ela é

fornecida.

Era muito

interessante, $\mathrm{o}$ palestrante soube o final.

O auditório ficou

pequeno pra

quantidade de pessoas 
explicar direito o que aconteceu no acidente e o filme era muito bom.

Gostei muito da peça, pois foi uma oportunidade de aprender mais e de uma forma interativa. E também da palestra foi muito

informativa e emocionante. Prendeu a atenção.

L
Eu gostei do palestrante, porque foi muito informativo e se mostrou bem receptivo.

O palestrante foi excelente, sendo possível entender todo o processo do acidente e o filme foi bem explicativo. Um dos pontos fortes foi a peça e o palestrante, praticamente deu uma aula sobre radioatividade e mostrou a gravidade do acidente. A parte mais importante foi quando ocorreu a fissão do Urânio, liberando muita energia. Eu gostei do tema, porque sempre me interessei pelo acidente de Chernobyl.

Figura 1 - Cartaz da palestra e do filme sobre Chernobyl

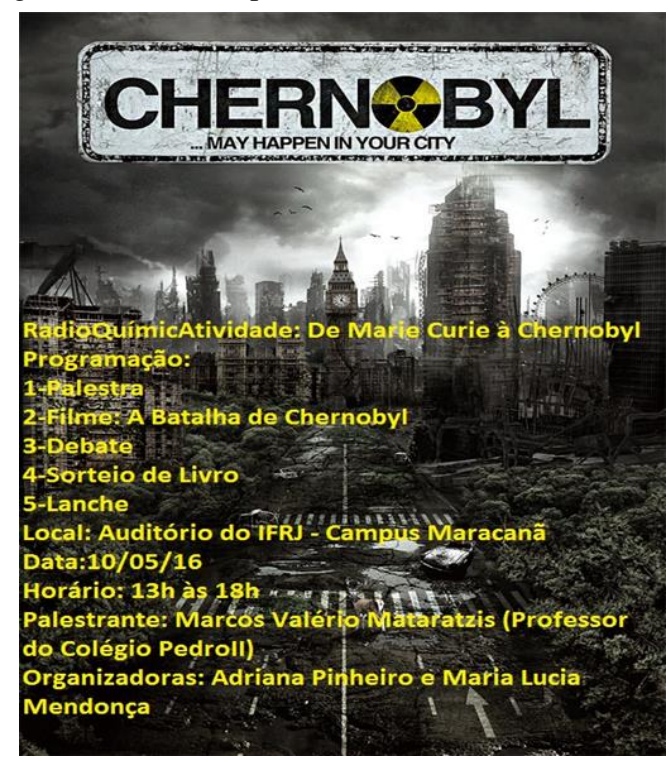

Fonte: Mendonça, 2016. longo sem nenhum que foram ao evento.

Não vi nenhum ponto negativo.

Não gostei de saber dos impactos biológicos que podem existem até hoje em dia.

Foi que eu tive que ir embora antes.

A superlotação do auditório

A parte final da palestra foi monótona.

A palestra foi muito tipo de pausa.
Figura 2 - Peça de teatro sobre Chernobyl elaborada pelos alunos.

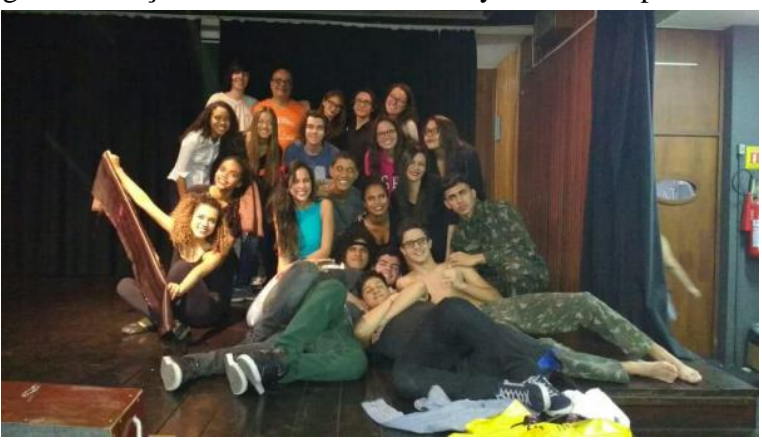

Fonte: Mendonça, 2016.

\section{CONCLUSÃO}

Foi concluído que trabalhos interdisciplinares permitem um diálogo e uma integração entre conhecimentos, possibilitando aos alunos e também aos professores terem um olhar mais totalizante, tanto dos conteúdos, como do mundo.

Em decorrência deste trabalho, ocorreu uma expressiva melhora dos alunos nas três disciplinas (Química, Física e Biologia) com a redução de mais da metade dos alunos com baixo rendimento, em relação ao ano anterior (2015), indicando o quanto os alunos apreenderam os conteúdos no ano (2016) em que foi realizado o trabalho interdisciplinar.

Concluiu-se também que os objetivos traçados nesse trabalho foram alcançados, porque gerou uma consciência crítica nos alunos sobre a questão da energia nuclear, dos acidentes nucleares e também da importância das aplicações relativas à radioatividade.

Trabalhos interdisciplinares, semelhante a este, poderiam ser realizados, com o aproveitamento de datas comemorativas, em que ocorrem grandes mobilizações através das mídias.

As limitações do trabalho deveram-se à resistência de alguns professores em participarem, apesar de todos terem sido convidados. Com o decorrer do tempo, somente os professores das disciplinas de Artes, Biologia, Física e Química acabaram envolvendo-se, o que demonstra a aceitação da cultura da compartimentalização dos conteúdos, por grande parte, ainda, dos docentes.

\section{AGRADECIMENTOS}

Os autores agradecem aos alunos da turma TM-222 do Instituto Federal do Rio de Janeiro, do Campus Rio de Janeiro, em especial: ao aluno Arthur Veríssimo; ao professor Marcos Valério Mataratzis do Colégio Pedro II do Campus Tijuca II, pela palestra brilhante, e à professora Margareth Morais, da disciplina de Língua Portuguesa do Instituto Federal do Rio de Janeiro, do Campus Rio de Janeiro, que foi a narradora da peça de teatro.

\section{REFERÊNCIAS BIBLIOGRÁFICAS}

BRASIL, Parâmetros Curriculares Nacionais. Brasília, DF: MEC, 1998.

CRUZ, Rosana Petinatti; MENDONÇA Maria Lucia Teixeira Guerra; RODRIGUES, Liliane Garcia da Silva Moraes; SILVA, Isabella. Oliveira; SANTOS, Estela Silva Atividade interdisciplinar entres as disciplinas de Química Ambiental e a Microbiologia: Relato de uma experiência. In: $\mathrm{XV}^{\mathrm{a}}$ ENCONTRO REGIONAL RIO DE 
JANEIRO DA SOCIEDADE BRASILEIRA DE QUÍMICA, 15., 2016, Rio de Janeiro, Rio de Janeiro. Anais... Rio de Janeiro, 2016.

CRUZ, Rosana Petinatti; ALBIERI, Suzete Maria Micas Jardim; MENDONÇA, Maria Lucia Teixeira Guerra; AZEVEDO, Egon Cavalcante; SILVA, Isabella Oliveira; SANTOS, Estela Silva. Despertar a consciência crítica sobre a alimentação de diabéticos: relato de uma experiência. In: $39^{a}$ REUNIÃO ANUALDA SOCIEDADE BRASILEIRA DE QUÍMICA, 39., 2016, Goiânia, Goiás, 2016.

CRUZ, Rosana Petinatti; DURIGON, Maria do Socorro Guedes Freitas; VASQUEZ, Renato Pazos; MENDONÇA Maria Lucia Teixeira Guerra. Despertar a consciência crítica sobre descarte de óleos vegetais e o seu impacto no meio ambiente: relato de uma experiência interdisciplinar. In: III CONGRESSO NACIONAL DE EDUCAÇÃO, 3., 2016, Natal, Rio Grande do Norte. Anais... Natal, 2016.

DUPPY, Jean-Pierre. Estudos Avançados. 21 (59), 2007. Disponível em:

http://www.scielo.br/pdf/ea/v21n59/a18v2159.pdf. Acesso em: 20 jun. 2016.

NOVO, Luciana Florentino. Cultura de interdisciplinaridade e desafios no contexto institucional: uma reflexão inicia, Revista Eventos Pedagógicos, v.5, n.3 (12. ed.), edição especial temática, p. 47 - 62, ago./out. 2014. Disponível em: https://sinop.unemat.br/projetos/revista/index.php/eventos/ar ticle/viewFile/1547/1195. Acesso em: 14 dez. 2016.

FREITAS FILHO, João Rufino; ALMEIDA, Maria Ângela Vasconcelos; PINA, Maria Socorro Lopes; REIS FILHO, Afonso Feitosa; OLIVEIRA, Mirancy Gomes; ARRUDA, Avani Martins; DANTAS, Valter Assis; SOUZA, Marcus Vinicius Juliano. Relato de uma Experiência Pedagógica Interdisciplinar: Experimentação Usando como Contexto o Rio Capibaribe, Química Nova na Escola, v. 35, n. 4, p. 247-254, novembro 2013.

MENDONÇA Maria Lucia Teixeira Guerra; CRUZ, Rosana Petinatti; SANTOS, Gisele Abreu Lira; SALLES, Ana Luisa. Petróleo: interdisciplinaridade entre as disciplinas de Língua Portuguesa e Química - relato de uma experiência. In: REUNIÃO ANUAL DA SOCIEDADE BRASILEIRA DE QUÍMICA, 33, 2010, Águas de Lindóia, São Paulo. Anais... Águas de Lindóia, 2010.

MENDONÇA Maria Lucia Teixeira Guerra; CRUZ, Rosana Petinatti; KELECOM, Katharina Jeanne; PRETA Luziana Gatta. Confecção de shampoo e rótulo: interdisciplinaridade entre as disciplinas de Química e Língua Estrangeira. In: REUNIÃO ANUAL DA SOCIEDADE BRASILEIRA DE QUÍMICA, 38. 2015, Águas de Lindóia, São Paulo. Anais.. Águas de Lindóia, 2015.

RIANELLI, Renata; MENDONÇA Maria Lucia Teixeira Guerra; CRUZ, Rosana Petinatti; TEIXEIRA, Paulo Jorge; BEAUCLAIR, Marcelo; SILVA, Isabella Oliveira; SANTOS, Estela Santos. Interdisciplinaridade entre as disciplinas de Química, Língua Portuguesa e Matemática: relato de uma experiência no EJA. In: $39^{\mathrm{a}}$ REUNIÃO ANUAL DA SOCIEDADE BRASILEIRA DE QUÍMICA, 39. 2016, Goiânia, Goiás, 2016.
RUA, Emílio; SOUZA, Paulo Sergio Alves; Educação Ambiental em uma Abordagem Interdisciplinar e Contextualizada por meio das Disciplinas Química e Estudos Regionais, Química Nova na Escola, v. 32, n. 2, maio 2010.

RAYNAUT, Claude. Interdisciplinaridade: mundo contemporâneo, complexidade e desafios à produção e à aplicação de conhecimentos. In: PHILIPPI JR, Arlindo; SILVA NETO, Antônio J. Silva. (Editores). Interdisciplinaridade em Ciência, Tecnologia e Inovação. Barueri: Manole, 2011.

SVETLANA, Alekseiêvitch. Vozes de Chernobyl História de um desastre nuclear. Editora: Companhia das Letras. São Paulo. 2016.

\section{COPYRIGHT}

Direitos autorais: Os autores são os únicos responsáveis pelo material incluído no artigo. 


\title{
Revista SODEBRAS - Volume 12 \\ $\mathrm{N}^{\circ} 134$ - FEVEREIRO/ 2017
}

\section{O USO DA TECNOLOGIA NO ENSINO SUPERIOR: UM OLHAR PARA AS MEDIAÇÕES EXISTENTES NAS AULAS DE UM CURSO DE PEDAGOGIA}

\section{USE OF TECHNOLOGY IN HIGHER EDUCATION: A LOOK AT EXISTING MEDIATIONS IN THE CLASSROOMS OF A PEDAGOGY COURSE}

\author{
ADRIANA RECLA ${ }^{1,2}$; ANDRÉS BARRIOS ROCHA ${ }^{1}$; FÉLIX FORERO GARCÍA A $^{2,3}$ \\ 1 - FACULDADES INTEGRADAS DE ARACRUZ - FAACZ; 2 - CORPORACIÓN UNIFICADA \\ NACIONAL DE EDUCACIÓN SUPERIOR - CUN \\ arecla@fsjb.edu.br; andres.barrios@cun.edu.co;felix_forero@cun.edu.co
}

\begin{abstract}
Resumo - O uso da tecnologia tem permeado todas as formas de relacionamento e comunicação e a sua relação com o processo educativo está presente em todos os níveis de formação exigindo uma reflexão sobre as mediações existentes entre o uso da tecnologia da informação e comunicação - TIC nas aulas $e$ práticas comunicativas que possam surgir, especialmente no ensino superior. Portanto, é necessário estudar como são mediadas pela construção do conhecimento das TIC e da vida cotidiana dos alunos e professores que vivem em meio aos constantes avanços tecnológicos, para que possamos fazer uma integração adequada entre os dois, identificar a suas contribuições e otimizar a sua utilização.
\end{abstract}

Palavras-chave: Tecnologias da Informação e Comunicação. Ensino Superior. Processo de Aprendizagem.

\begin{abstract}
The use of technology has permeated all forms of relationship and communication, its relationship with the educational process is present at all levels of training and demand a reflection on the existing mediations between the use of information and communications technology - ICT in classes and communicative practices that they arise, especially in higher education. Therefore, it is necessary to study how are mediated by ICT knowledge construction and daily life of students and teachers living amid the constant technological advances, so that it can make a proper integration between the two, identify their contributions, and optimize its use.
\end{abstract}

Keywords: Information Technology and Comunication. Higher Education. Learning Process.

\section{INTRODUÇÃO}

$\mathrm{Na}$ sociedade atual todos os níveis de relacionamento estão mediados pelas Tecnologias da Informação e da Comunicação- TIC. É inegável o avanço contínuo neste campo que obriga a estar atento a sua evolução. No ambiente educacional esta realidade não é distinta, visto que no processo de ensino e aprendizagem é observado que é necessário fazer a inclusão das tecnologias. Isto tem promovido muitas reflexões sobre a integração das TIC na educação, principalmente no ensino Fundamental e Médio.

Hoje em dia, na educação Superior, tem-se questionado sobre a adequada união entre os avanços tecnológicos e a produção de conhecimentos: "Ninguém imagina um professor do século XXI utilizando os instrumentos virtuais de uma maneira asséptica, desatualizada ou simplesmente como elemento superficial de transmissão de conteúdos" (Leiva, Juan J.; Martínez, Noelia Moreno; Rosaura Gutierrez, Jorge A. Nigenda; 2015) Sendo assim, este estudo propõe uma reflexão sobre as mediações existentes entre o uso da tecnologia e o desenvolvimento das aulas do curso de pedagogia das Faculdades Integradas de Aracruz - FAACZ ${ }^{1}$ tendo em conta a importância de encontrar uma maneira de como ela influencia no processo de aprendizagem dos estudantes. Para esta pesquisa, apoiamo-nos no conceito de mediações que sugere Jesús Martín Barbero: "O lugar de articulação entre as práticas comunicativas e os movimentos sociais" (BARBERO, 1987) no qual, a prática comunicativa se configura na aula e os movimentos sociais em comportamentos e formas de se relacionar dos alunos.

Baseado no que foi dito anteriormente, surge a necessidade de analisar o uso atual da tecnologia nas aulas, na procura de aperfeiçoar seu relacionamento e seu papel no processo de ensino. Porém esta pesquisa não buscava pôr a tecnologia como única forma para ensinar, mas sim como uma ferramenta importante no contexto atual: "As TIC se convertem em dispositivos facilitadores e articuladores de muitas tarefas que devem realizar os profissionais de nossa geração" (ROMANÍ, 2009)

Esse tipo de estudo, ajuda a responder o questionamento sobre a relação entre a educação Superior e o uso das tecnologias, que já foi amplamente discutido na educação à distância $(\mathrm{EaD})$ e que ainda tem muitos pontos para serem discutidos na educação presencial, contando com o uso cotidiano das TIC e o desafio de articular esse uso com o ambiente acadêmico.

\footnotetext{
${ }^{1}$ As Faculdades Integradas de Aracruz - FAACZ estão localizadas no Sudeste do Brasil, no estado de Espirito Santo, na cidade de Aracruz. A instituição possui mais de 25 anos de experiência na formação de profissionais, oferecendo 9 cursos autorizados pelo MEC. O Curso de Pedagogia da FAACZ recebeu autorização de funcionamento pelo MEC em 1998, cujo programa curricular está organizado atualmente em 5 módulos distribuídos em 7 ciclos ou períodos. Atualmente tem inscritos estudantes em três turmas de II, IV, VI período e conta com uma planta docente composto por 8 professores.
} 
Tendo presente que o uso da tecnologia tem causado um conjunto de mudanças nas diversas formas de percepção e interação humana (GOMES, 2015) nos ambientes como o acadêmico onde se podem ver muitos esforços na integração dos avances das TIC procurando sempre superar as limitações que estavam representadas em os modelos tradicionais de educação, se busca compreender como esses recursos são capazes de fornecer um feedback adequado no que se refere à construção do conhecimento (CRUZ, 2015) revisando aspectos como a correta escolha das melhores ferramentas e dispositivos nos momentos e conteúdo que ajuda nessa construção de saber, isto não implica uma obrigatoriedade do uso das TIC nas aulas, porém, significa sim uma descoberta por explorar mais e novos usos destes recursos para a melhora dos processos de ensinoaprendizagem..

\section{PROCEDIMENTOS}

$\mathrm{O}$ estudo realizado foi de cunho exploratório/descritivo, em que se procurou conhecer o fenômeno do uso da tecnologia nas aulas do curso de pedagogia tanto com os estudantes como os professores, participando 70 estudantes e 7 professores, em cada uma das etapas da pesquisa, utilizando técnicas de avaliação quantitativas e qualitativas que foram aprovadas e que surgiram das variáveis e categorias estabelecidas nos objetivos gerais e específicos: Identificar as diversas mediações que se apresentam no uso das TIC nas aulas do curso de Pedagogia da FAACZ. A) Conhecer as experiências dos professores e estudantes sobre ao uso das TIC nas aulas. B) Estabelecer como as práticas comunicativas através do uso das TIC reflexam nos estudantes uma apropriação dos conteúdos desenvolvidos nas mesmas. C) Analisar como as práticas comunicativas em torno ao uso das TIC se configuram em mediações.

Essas técnicas de avaliação tiveram uma etapa de testes e aplicação final, que permitiu recolher informações que foram analisadas na pesquisa. Estes instrumentos foram questionários e entrevistas semiestruturadas que foram feitas através da ferramenta do Google Forms e Drive para facilitar a sistematização e a organização da informação. Para o questionário, realizou-se sua aplicação em 3 turmas de aproximadamente 20 estudantes em um laboratório de informática em períodos de aproximadamente 20 minutos, tempo suficiente para a aplicação da prova. A ferramenta utilizada armazenava os dados em tempo real e entregava os resultados estatísticos do mesmo.

As entrevistas foram realizadas com 5 estudantes e 2 professores, sendo realizadas perguntas distintas para cada grupo, sendo gravadas e transcritas. Tanto os questionários quanto as entrevistas têm registros e autorização dos participantes.

Para a análise dos resultados se triangulou as informações, com a teoria, os resultados quantitativos e a informações qualitativas, o que permitiu ter uma visão completa do objeto de investigação da pesquisa; e, finalmente foram obtidas as conclusões que cumpriram com a finalidade proposta por este estudo.

\section{RESULTADOS}

No estudo, em sua etapa quantitativa participaram 69 estudantes dos quais $88 \%$ eram mulheres e somente $12 \%$ homens, $77 \%$ dos participantes se encontram entre 17 e 25 anos; os períodos participantes estiveram distribuídos da seguinte forma: Segundo período 38\%; quarto período $29 \%$ e sexto período $33 \%$.

Os $91 \%$ dos participantes, provém de escolas públicas e $70 \%$ atualmente não possuem emprego, com respeito aos estudos universitários ou técnicos prévios $93 \%$ estão tendo acesso pela primeira educação superior e $64 \%$ já realizaram algum curso técnico.

Sobre o tema específico da pesquisa $78 \%$ dos participantes conhecem o que são as TIC, também em uma escala de 1 a 4 em que 1: insuficiente, 2: regular, 3: bom, 4: excelente, $38 \%$ opinam que os conhecimentos adquiridos sobre as TIC no ensino fundamental ou médio são insuficientes. Enquanto, $78 \%$ afirmam que recebem conteúdos sobre as TIC na faculdade, $72 \%$ falam que recebem outra formação sobre as TIC fora da faculdade.

Com respeito aos dispositivos, foi feito uma revisão, em primeiro lugar sobre os mais usados pelos participantes no dia-a-dia, encontrou-se que os smartphones, computadores de mesa, e notebooks são os dispositivos mais utilizados, principalmente pelos motivos de facilidade de acesso, agilidade e portabilidade; isto foi selecionado pelos participantes fazendo a escolha dentro de uma lista que foi apresentado para eles, com a opção de escolher até 3 respostas. Logo, foram avaliados os dispositivos aos quais eles tinham acesso em 3 lugares propostos nos questionários: casa, trabalho e faculdade. Foi encontrado como resposta $51 \%$ excelente os dispositivos da casa, $53 \%$ entre insuficiente e regular os dispositivos do trabalho, e só $36 \%$ entre bom e excelente os dispositivos da faculdade.

Quando foram questionados pelos dispositivos mais usados nas aulas as respostas foram Datashow com $100 \%$, notebooks com $50 \%$ e laboratório de informática com $47 \%$. Avaliando como os principais motivos para fazer o uso destes: Agilidade, acessibilidade e qualidade da imagem. Também foi avaliado o nível de inovação dos dispositivos utilizados nas aulas que teve como resultado $63 \%$ entre insuficiente e regular. Por último, na avaliação dos dispositivos nas aulas os participantes expressaram que 51\% dos professores tem bom domínio na utilização.

Também foi feita uma revisão sobre as ferramentas tecnológicas entendidas como os programas, aplicativos e demais instrumentos que contam com os dispositivos. Foram observados que $71 \%$ dos estudantes possuem bom domínio e conhecimento das ferramentas tecnológicas; as ferramentas mais utilizadas nas aulas são: Power point, vídeos/filmes e Word.

Em seguida, foram conhecidas as principais características que deve ter uma ferramenta tecnológica para ajudar no desenvolvimento das aulas segundo os estudantes: Facilidade de acesso 53\%, clareza dos conteúdos $49 \%$ e facilidade para o uso $42 \%$. Vale ressaltar que os principais motivos que tem os estudantes para usar as ferramentas tecnológicas são: Complemento acadêmico/pesquisa 91\%, interesse pessoal $72 \%$ e trabalho $34 \%$.

Também foram avaliados alguns aspectos sobre as ferramentas utilizadas nas aulas de pedagogia, no qual se encontrou que $96 \%$ dos participantes acham que as ferramentas utilizadas nas aulas são úteis; e $67 \%$ consideram inovadoras as mesmas.

Depois de conhecer essa realidade foi feita uma abordagem sobre a atualidade do uso das TIC na vida dos estudantes encontrando que $46 \%$ deles possuem acesso por mais de 7 horas diárias, em lugares como a casa $94 \%$ e a rua 
(uso de dados móveis) 18\%; os principais motivos para ter estes usos são as pesquisas $84 \%$, a comunicação $69 \%$ e redes sociais $64 \%$.

Com respeito ao uso das TIC nas aulas $99 \%$ afirmam que se faz o uso das tecnologias, $46 \%$ manifesta que esse uso se faz uma vez por semana; por sua vez os participantes avaliaram o uso das TIC como $50 \%$ bom.

Dentro dos resultados, também foi encontrado que quando se faz o uso de tecnologias para explicar algum tema nas aulas as informações são $93 \%$ claras; e a compreensão dos conteúdos é $37 \%$ excelente; as sensações que geram as TIC nos estudantes são; Interessado $69 \%$, curioso $47 \%$ e otimista $39 \%$; os estudantes acham que a ajuda das tecnologias ao processo de aprendizagem é $49 \%$ boa; $48 \%$ dos estudantes consideram que a participação deles na aulas melhoram o uso das TIC e $40 \%$ acha boa a interação quando se faz o uso destas.

Os $100 \%$ dos participantes consideram que os conhecimentos e domínios das TIC têm ajudado em seu processo de desenvolvimento profissional e pessoal; $23 \%$ acham excelente a aplicação em sua vida familiar, $17 \%$ excelente no trabalho, $41 \%$ insuficiente em sua vida amorosa e $17 \%$ excelente em sua vida de amizades dos conteúdos vistos nas aulas quando se faz o uso de tecnologias.

Os $100 \%$ acham que é importante fazer o uso da tecnologia nas aulas e os mesmos $100 \%$ acham que deve melhorar seu uso em aspectos como: melhores dispositivos $53 \%$, inovação nas ferramentas $50 \%$ e maior uso nas aulas $49 \%$. Além de ser feita revisão sobre a aplicação dos conhecimentos sobre as TIC no ambiente de estágio, em que $87 \%$ dos estagiários consideram que os conhecimentos adquiridos sobre as tecnologias na faculdade têm ajudado no desenvolvimento do seu estágio.

Os resultados encontrados no instrumento qualitativo correspondem a 5 entrevistas feitas aos estudantes dos períodos participantes da pesquisa e 2 professores do curso, nelas encontrou-se o complemento para algumas das questões identificadas nas categorias e variáveis que possibilitaram os objetivos, incluindo exemplos para reforçar a importância dos uso das tecnologias nas aulas, e aspectos que podem melhorar em sua aplicação operacional e como complemento do processo de ensino e aprendizagem

\section{DISCUSSÃO}

Neste estudo, observa-se uma geração de "nativos digitales" (LÓPEZ \& FRANCO, 2014), como mostra o estudo feito pela Universidade Santo Tomás de Aquino da cidade de Bogotá em função dos investigadores Juan Sebastián López López e Didier Arnulfo Santiago Franco, no qual se identifica o uso cotidiano que se faz das tecnologias, em que todas as relações sócias são mediadas pelas mesmas; pode ser observada uma participação importante das mulheres na pesquisa. Isto deixa uma impressão relevante sobre a participação dela no desenvolvimento dos novos educadores e na formação das novas gerações na região. Assim é uma responsabilidade continuar um caminho de inclusão no qual a mulher é amplamente representada e, portanto, determinante na construção de novas dinâmicas de educação.

$\mathrm{O}$ grupo de participantes pontuou que os conhecimentos sobre as TIC tem uma porcentagem importante que deve ser lido a partir das diferentes fontes de formação e informação que podem ter os estudantes, quer dizer que não se pode assegurar que os conhecimentos atuais sobre tecnologia que tem os alunos seja necessariamente fruto dos conteúdos oferecidos pela faculdade, observando a quantidade de dados aos quais têm acesso permanente cada um dos estudantes em todos os momentos e contextos de sua vida.

Fernandez Muñoz (2009), em seu conceito sobre as TIC faz distinção entre os dispositivos e as ferramentas, deixando claro que além de serem elementos distintos estão em constante dependência mútua. Por esta razão analisamos aqui estes dois elementos componente do conceito de TIC separadamente tendo a clareza de sua interdependência. Seguindo a recomendação do estudo feito no estado da Bahia, no qual, se estudou um fenômeno similar ao desta pesquisa, este estudo começou sua abordagem questionando o uso cotidiano e a proximidade dos dispositivos e ferramentas na vida dos estudantes, dado que não se pode separar a relação das TIC na vida atual e o uso no ambiente acadêmico.

Neste ponto, se faz uma descoberta a partir dos dispositivos e ferramentas com os quais já contam os estudantes, o que significa uma nova concepção sobre os equipamentos que deveriam prover a instituição educativa, o que representaria maior capacitação e não uma inversão em novos dispositivos e ferramentas.

Manoel Castells em seu livro "Comunicação e poder" (CASTELLS, 2009) introduz como uma grande preocupação a existência de uma brecha tecnológica, que para o início deste século mostrava um acesso de apenas $8 \%$ na América do Sul, e que hoje, segundo estes estudos foi superado tanto no acesso aos dispositivos quanto no acesso à internet, propiciados pelos mesmos avanços tecnológicos que atualmente mostram as conexões na rede como um serviço público básico.

Esta realidade, nos mostra que o uso da tecnologia vai além dos fins acadêmicos e suprem mais necessidades a cada dia, isto significa que os dispositivos e as ferramentas que os estudantes possuem atendem aos usos básicos e complementam o trabalho educativo, evidências do que foi visto anteriormente é o uso primordial dos smartphone e notebooks.

Quando se fala de ferramentas mais utilizadas nas aulas pode ser observado que existe uma sobrevalorização dos slides no Datashow, o que mostra a percepção de insuficiência em inovação que avaliam os estudantes.

O papel do professor, segundo Facinholc (2008) tem a responsabilidade de orientar o domínio dessas ferramentas e sua integração no processo de ensino, de modo a facilitar a aprendizagem nas aulas, ou seja, o professor deve estar sempre atualizado e consciente de fazer o uso adequado das ferramentas apropriadas para os temas determinados. Nas palavras de um dos professores entrevistados deve-se ter planejamento e coerência no momento de pensar e usar a tecnologia em suas aulas. Porém, isto é tanto responsabilidade do professor tanto quanto da instituição, que deve fornecer condições e materiais para o desenvolvimento deste assunto.

As mediações identificadas neste estudo mostram como os usos das tecnologias utilizadas nas aulas contribuem, segundo os estudantes, em seu desenvolvimento pessoal e profissional ajudando a tornar os conteúdos vistos nas aulas de uma maneira mais familiar e acessível, quer dizer que este uso das TIC até certo ponto não é algo 
simplesmente instrumental, ao contrário, vai mostrando resultados na vida cotidiana dos estudantes, contribuindo para mudanças nas maneiras de perceber $o$ mundo criticamente.

Existe uma citação que deve ser abordada pelos orientadores sobre o uso das tecnologias, Neri e Fernández falam que pode ocorrer o detrimento de algumas funções superiores do cérebro como a memória e atenção, frente à exposição permanente das TIC, dado que elas oferecem um banco ilimitado de informações que diminuem a necessidade de se utilizar as funções ditas, quer dizer que as TIC ajudam e podem trazer algumas consequências (NERI \& SALAZAR, 2015).

A pesquisa realizada tem aberto uma percepção, que leva a revisar e continuar analisando o processo de ensino/aprendizagem desde o uso das TIC como uma ferramenta útil que pode contribuir positivamente para a formação dos novos profissionais, em que, as aulas ajudam a criar novas hipertextualidades, no quais, professores e alunos convergem para a construção do conhecimento e desenvolvimento pessoal de cada um.

\section{CONCLUSÃO}

A) O uso da tecnologia não deve ser necessariamente um condicionante para o processo de ensino, pelo contrário é uma ferramenta que se bem utilizada contribui na construção do conhecimento, mediando entre os conteúdos e as práticas sociais dos estudantes.

B) Usar as TIC nas aulas requer profissionais interessados e capacitados, de tal forma que essa utilização atenda às necessidades dos estudantes estando no auge destes avanços tecnológicos.

C) O uso cotidiano das ferramentas e dispositivos tecnológicos tanto de professores quanto de estudantes é uma oportunidade para unir o que se quer desde o ensino acadêmico, desvincular o uso diário do uso nas aulas pode significar perder um pressuposto em conhecimento e dispositivos com os que já contam os estudantes, portanto a preocupação deve estar embasada na otimização dos recursos já existentes.

D) A elaboração dos conteúdos, quando se faz o uso das tecnologias deve levar em conta o design estético destes. Usar as TIC deve mostrar uma diferença dos modelos tradicionais de educação, mantendo o interesse dos alunos e possibilitando o aprofundamento dos conhecimentos.

E) Seja qual for o recurso utilizado nas aulas para o desenvolvimento da aprendizagem, este deve permitir que os estudantes apliquem os conhecimentos em diferentes níveis de relacionamento, de modo que possam fazer narrativas de sua realidade social a partir do conhecimento. Frente à realidade atual, a tecnologia é um ótimo recurso para alcançar esse objetivo.

\section{REFERÊNCIAS BIBLIOGRÁFICAS}

BARBERO, J. M. De los Medios a las Mediaciones. Comunicación, cultura y hegemonía. Barcelona: Editorial Gustavo Gili S.A, 1987.
NERI, Carlos; SALAZAR, Diana Fernández. Apuntes para la revisión teórica de las TIC en el ámbito de la educación superior. RED. Revista de Educación a Distancia. 1-8, 2015.

CASTElls, M. Comunicación y Poder. Madrid: Alianza Editorial S.A, 2009.

CRUZ, N. V. O que me ensina a aprender? Uma análise do uso da tecnologia da informação e comunicação no processo de ensino-aprendizagem em contabilidade no estado da Bahia. Programa de Pós-Graduação em Contabilidade. Universidade Federal da Bahia. Salvador, Bahia, Brasil. 2015

GOMES, L. R. Cultura Digital, Esfera Pública e Educação. IXTLI - Revista Latinoamericana de Filosofía de la Educación, 129-145, 2015.

LEIVA, JUAN J.; MARTÍNEZ, NOELIA MORENO; ROSAURA GUTIÉRREZ, JORGE A. NIGENDA; Projeto "digiculturalidad": Uma experiência de inovação educativa para a utilização das TIC e as redes sociais no ensino universitário. Revista Educação: Temas e Problemas. 3553, 2015.

LÓPEZ, J. S. \& FRANCO, D.A.S. TIC y mediaciones culturales en la educación superior: hacia un programa multidimensional. ANALISIS, 191-213, 2014.

ROMANÍ, J. C. El concepto de tecnologías de la información. Benchmarking sobre las definiciones de las TIC en la sociedad del conocimiento. ZER, 295-318, 2009.

FAINHOLC, B. (2008). De cómo las tics podrían colaborar en la innovación socio-tecnológico-educativa en la formación superior y universitaria presencial. RIED, 53-79.

MUÑOZ, R. F. (2007). Experiencias de aprendizaje colaborativo en la formación de futuros maestros a través de entornos virtuales. Revista Latinoamericana de Tecnología Educativa, 77-90.

\section{COPYRIGHT}

Direitos autorais: Os autores são os únicos responsáveis pelo material incluído no artigo. 


\title{
A IMPORTÂNCIA DA INTERAÇÃO ESCOLA-FAMÍLIA PARA O DESENVOLVIMENTO DE CRIANÇAS SUPERDOTADAS
}

\author{
THE IMPORTANCE OF SCHOOL-FAMILY INTERVENTION FOR THE \\ DEVELOPMENT OF SUPERDOTED CHILDREN
}

\author{
MÁRCIA STEFANELLO FISCHBORN ${ }^{1}$, PROFA. DRA. DÉSIRÉE GONÇALVES RAGGI ${ }^{2}$ \\ 1 - MESTRANDA DO PROGRAMA DE PÓS-GRADUAÇÃO STRICTO SENSU - MESTRADO \\ PROFISSIONAL EM GESTÃO SOCIAL, EDUCAÇÃO E DESENVOLVIMENTO REGIONAL - \\ FACULDADE VALE DO CRICARÉ - FVC; 2 - PROFESSORA DO MESTRADO PROFISSIONAL EM \\ GESTÃO SOCIAL, EDUCAÇÃO E DESENVOLVIMENTO REGIONAL. \\ mstefanello20@hotmail.com;desireeraggi@yahoo.com.br
}

\begin{abstract}
Resumo - Este artigo tem o objetivo de discutir o caso de uma criança superdotada. Analisa as dificuldades e desafios enfrentados pelos pais e as condições de preparo dos educadores para atendimento de alunos superdotados. Metodologicamente é caracterizado como estudo de caso, cujos dados foram coletados por meio de entrevistas semiestruturadas com os pais $e$ professora, aliem de observações comportamentais no lar $e$ na escola. Através desse estudo percebeu-se que a atenção da família é de extrema importância na identificação e que os educadores precisam ter conhecimento sobre o tema para trabalharem com esses alunos. Nesse estudo de caso, constatouse que a familia é quem tem ajudado bastante no desenvolvimento e aprendizagem da aluna. Já, a escola, bem como a professora, não estão preparadas para o atendimento de crianças/alunos com altas habilidades/superdotação.
\end{abstract}

Palavras-chave: Escola. Familia. Desenvolvimento. Superdotados.

This article aims to discuss the case of a gifted child. It analyzes the difficulties and challenges faced by the parents and the conditions of preparation of the educators for the care of gifted students. Methodologically, it is characterized as a case study, whose data were collected through semi-structured interviews with parents and teacher, along with behavioral observations in the home and at school. Through this study it was noticed that family attention is extremely important in identification and that educators need to have knowledge about the subject to work with these students. In this case study, it was verified that the family is who has helped a lot in the development and learning of the student. Already, the school, as well as the teacher, are not prepared for the care of children / students with high skills / giftedness.

Keywords: School. Family. Development. Gifted.

\section{INTRODUÇÃO}

A família constitui um dos pilares na formação e no desenvolvimento emocional, físico e social de toda criança, requerendo de toda sociedade reconhecimento e compreensão. A sala de aula é um lugar privilegiado, pois lá se encontram os alunos com as mais diversas características, limitações, aptidões e interesses, onde cada um idealiza seu mundo, faz suas escolhas e traça seus objetivos.
Conforme descrição da Secretaria de Educação Especial (2006), muitas vezes os alunos superdotados não são percebidos e são pouco compreendidos. Estes se destacam pelo alto gral de capacidade intelectual e pela elevada potencialidade em qualquer dos seguintes aspectos, isolados ou combinados: capacidade intelectual geral; aptidão acadêmica específica; pensamento criativo ou produtivo; capacidade de liderança; talento especial para artes e capacidade psicomotora, mas que necessitam de igual atenção, dadas suas peculiaridades.

Por falta de conhecimento por parte dos atores escolares, os superdotados não são caracterizados como crianças com necessidades especiais e, normalmente, são ignorados ou mesmo discriminados. Essa situação impede que seus sentimentos, expectativas sejam considerados e as dificuldades enfrentadas pelos pais sejam ignoradas pela escola. Tais circunstâncias concorrem para que os professores não recebam formação adequada e se sintam despreparados para lidar com sujeitos portadores de altas habilidades/superdotação. Dessa forma, suas potencialidades não são devidamente reconhecidas e exploradas, concorrendo assim para o prejuízo do seu pleno desenvolvimento.

Este artigo discute o caso de Maria Cecília, uma criança superdotada e analisa as dificuldades e desafios enfrentados pelos pais e as condições de preparo dos educadores para atendimento de alunos superdotados.

\section{METODOLOGIA}

Para o desenvolvimento desta pesquisa optou-se pelo método de Estudo de Caso, o qual permitiu compreender a realidade, o cotidiano e a vida escolar de Maria Cecília, buscando coletar informações acerca do processo vivenciado por ela, pelos pais e professora, nos âmbitos educativo e familiar. Foi realizado um levantamento bibliográfico a fim de compreender esse fenômeno que tanto instiga a curiosidade da academia e das pessoas de modo geral. O levantamento de dados foi realizado por meio entrevistas semiestruturas, gravadas e por observações. 


\section{CONTEXTO}

Desde os primeiros meses do nascimento, a mãe começou a acompanhar, com a ajuda do tio fisioterapeuta, a movimentação motora da filha. Desde bem pequena perceberam que ela tinha um desenvolvimento diferente de outros bebês da mesma idade, pois fazia movimentos atípicos para sua idade. Outro comportamento que chamou a atenção dos pais foi o interesse por livros com gravuras, quando Maria Cecília tinha poucos meses. A mãe afirma que falava o nome dos animais nas gravuras e a menina apontava com os dedos. Maria Cecília começou a falar muito cedo com clareza e entendimento.

Crianças com altas habilidades adquirem habilidades específicas precocemente devido ao seu interesse em aprender. Desde que começou a falar demonstrou interesse pela leitura e letras, com 1 ano e 4 meses já reconhecia a letra de seu nome. Sempre assistiu a DVDs educativos, a mãe não sabe exatamente quando ela descobriu o alfabeto. Com a idade de 3 anos e oito meses Maria Cecília já sabia ler. Seus pais optaram por tê-la em casa até fazer 4 anos. A mãe, sempre presente, começou a anotar tudo o que percebia de diferente na filha: seus movimentos, comportamentos, atitudes. Por vezes, a mãe se questionava se sua filha era possuidora de Síndrome de Asperger, pois apresentava comportamentos, cujo nível de dificuldade era superior à sua idade, tais como: separar brinquedos por tipos e cores, não aceitar mudança de objetos da casa de lugar, não aceitar que suas roupas estivessem fora de um padrão, não aceitar mudança na rotina, não interagir socialmente, sensibilidade de olfato, tato e paladar.

Aos 4 anos e 6 meses de idade, Maria Cecília foi matriculada na primeira escola. Ao percorrer as dependências, ela lia as placas espalhadas pelo caminho, fato que despertou a atenção da coordenadora escolar, que imediatamente sinalizou para a mãe que a filha era realmente diferente e necessitava de um atendimento diferenciado. Após essa observação, a mãe, que já desconfiava e pretendia procurar ajuda profissional para a filha, resolveu que era hora de ir em busca de um diagnóstico mais esclarecedor. Nesse sentido, Fontes (2012) orienta aos pais que se perceberem que seu filho está diferente de seus amigos e que sua capacidade de aprendizagem e habilidade mental são elevadas, é aconselhável levá-lo para uma avaliação específica com um psicólogo experiente no assunto. Segundo o autor, uma avaliação neuropsicológica é necessária, se as potencialidades estão realmente acima da média de outras crianças.

Para isso a família fez inúmeras viagens à Vitória - ES com a finalidade de consultar uma neuropediatra que, para alívio dos pais, descartou a possibilidade de Maria Cecília portar síndrome de Asperger e, já na primeira consulta, sinalizou que ela possuía altas habilidades. O próximo passo foi levar a menina para ser avaliada por uma equipe multidisciplinar para serem feitas avaliações mais precisas. Maria Cecília participou de uma avaliação neuropsicológica, em uma clínica especializada em desenvolvimento cognitivo. Nessa ocasião, foram avaliadas as principais áreas do desenvolvimento através de anamnese psicológica das Escalas de CCMS, Raven, instrumentos psicológicos entre outros.

De acordo com relato da mãe, Maria Cecília apresentava sintomas de ansiedade desde bebê, não dormia e era muito agitada. Além disso, era muito tímida e aparentava apego com rotinas. Tais traços comportamentais fizeram com que seus pais decidissem levá-la com regularidade mensal, a fim de fazer terapia com uma psicóloga especializada, aconselhada pela médica neuropediatra, na tentativa de ajudá-la a ser mais independente, perder a timidez e a se desprender da necessidade de que tudo acontecesse dentro de uma rotina. Segundo relato da mãe, ainda hoje, ela "rói unhas e quando ela quer falar, "estala os dedos". Contudo a terapia ajudou-a a diminuir a timidez, a ansiedade e a se desapegar das rotinas que ela fazia questão que ocorressem em várias situações que envolvessem ela ou alguém da família: sempre a mesma festa de aniversário, sempre o mesmo café na cama ( no dia do aniversário), sempre ganhar flores no dia da mulher( sua mãe, avó).

$\mathrm{O}$ ambiente para o desenvolvimento da pesquisa foi a sala de aula, residência e vários contatos com Maria Cecília.

Maria Cecilia, oito anos de idade, aluna o $2^{\circ}$ Ano, no Colégio Adventista de Eunápolis- BA, diagnosticada com QI de 155, por uma psicóloga e uma equipe multidisciplinar. Seus pais possuem pós-graduação, sendo a mãe professora de Língua Portuguesa e o pai funcionário público da Secretaria da Fazenda.

\section{OS DESAFIOS DA PROFESSORA DE MARIA CECÍLIA}

Conforme determina a legislação, os alunos com altas habilidades/superdotação devem receber atendimento que valorize e respeite suas necessidades educacionais diferenciadas quanto aos talentos, aptidões e interesses. Logo, se pressupõe que, por mais excepcionais que se apresentem tais aptidões e talentos, se não houver estímulos e atendimentos adequados, os indivíduos dificilmente atingirão um nível de excelência. Contudo os professores não se sentem preparados para esse tipo de atendimento, sendo necessário que lhe sejam proporcionados cursos de aperfeiçoamento e conhecimentos adequados e atualizados (COSTA, 2012).

A professora de Maria Cecília tem formação em Pedagogia e é habilitada para trabalhar com crianças do ensino fundamental I. Relatou que durante todo o curso de graduação, houve apenas um período em que foram explorados conteúdos de Educação Inclusiva e que "pouco foi mencionado sobre altas habilidades".

A coordenadora e a orientadora educacional afirmaram que desconhecem em profundidade o tema da superdotação e que não tinham ciência de que Maria Cecília é uma criança com altas habilidades, ainda que haja dois anos que a menina estuda nessa escola e que tenha sido diagnosticada como superdotada. No entanto, o site da escola disponibiliza informações a respeito da sua proposta pedagógica enfatizando que o projeto educacional "visa atender as necessidades gerais de aprendizagens, estimulando a criticidade e a criatividade, objetivando transformar conhecimentos e atitudes, a partir de soluções de problemas que remetem à realidade da vida".

Para melhor atender e promover o bom relacionamento entre alunos superdotados é imprescindível que a escola considere as diferenças e que os professores compreendam esse aluno como sujeito singular, portador de subjetividades e possuidor de múltiplas inteligências. Estudiosos como Costa (2012); Piske e Bahia (2012), afirmam que é preciso perceber que seu aprendizado acontece de diferentes maneiras, e que seu ritmo também é diferenciado. Esses 
aspectos se fazem importantes quando se opta por realizar o processo de inclusão.

Estudos têm mostrado que o comportamento questionador do aluno com altas habilidades, muitas vezes, desequilibra a atuação do professor, que por falta de preparo e conhecimento insuficiente sobre determinados assuntos, sente-se ameaçado e passa a ver nesse tipo de situação, um grande desafio (ALENCAR, 2003; FISCHBORN, 2016).

Porém, essa professora já havia conversado com sua antecessora e com a mãe de Maria Cecília, e tenta ajudar como pode, pois, se sente limitada por fatores como: turma bastante heterogênea; falta de apoio pedagógico e infraestrutura inadequada. Afirmou que, desde o começo do ano letivo, busca formas de conquistar a aluna com atividades extras e solicitando sua colaboração para auxiliar seus colegas que possuem dificuldades de aprendizagem . Dessa maneira, explora suas capacidades superiores ao solicitar sua colaboração junto aos colegas na conclusão das tarefas, pois Maria Cecília aprende com facilidade e a professora encontrou essa forma para ocupá-la.

Esse contexto permite inferir que o professor deva ser um dos principais agentes no processo de inclusão, pois apesar dos superdotados estarem inseridos nas salas de aula regulares, faz-se necessária a utilização de estratégias apropriadas que propiciem o desenvolvimento pleno desses sujeitos. É o professor quem atua diretamente com os educandos, podendo contribuir de maneira especial na identificação dos superdotados, observando e analisando seu desempenho que é distinto dos demais alunos.

O professor, através do contato diário, também é capaz de detectar características peculiares do superdotado, que é um sujeito complexo, único e instigante e portador de características diferenciadas. A partir dessa identificação, é importante se fazer o encaminhamento adequado, com o objetivo de desenvolver as habilidades identificadas e oferecer uma formação ampla ao indivíduo, explorando bem as suas potencialidades (SABATELLA; CUPERTINO, 2007).

Contudo, é necessário que ao professor seja oferecida a formação continuada na área de educação especial a fim de prepará-lo para fazer essa identificação e efetivar práticas pedagógicas específicas. Mesmo não sendo um assunto novo, há uma enorme deficiência nas ofertas de cursos relacionados à área de superdotação. Quando o professor não detém conhecimento sobre esse assunto “[...] é comum que os alunos mais capazes sintam-se desestimulados, desperdiçando suas potencialidades criativas em ambientes não desafiadores" (FLEITH, 2007, p. 25).

A professora de Maria Cecília relata suas dificuldades em atender a aluna, pois não tem conhecimento sobre esse assunto. Por outro lado, ela sabe das necessidades da aluna e a descreve como: atenta, rápida nas atividades, tem senso de organização acentuado, mantem seu caderno muito organizado e realiza suas atividades com muito zelo.

As manifestações da professora permitem compreender que, apesar do seu esforço em atendê-la bem, Maria Cecília, se mantem boa parte do tempo isolada e quieta. Como precisa dar atenção a toda a turma, a professora se vê limitada para desenvolver as potencialidades dessa criança que exige uma atenção especial.
O professor é o ator principal no processo ensino aprendizagem e cabe a ele cria estratégias e oportunidades para que o aluno com altas habilidades desenvolva suas potencialidades. Nesse sentido, ao elaborar seu planejamento didático, o professore deve levar em conta as habilidades criativo-produtivas desses alunos, que, em geral, são ávidos pelo conhecimento; manifestam um desejo maior pelo aprendizado, possuem extenso vocabulário e boa memória. Tem grande capacidade de produzir ideias originais e uma forte vontade de se dedicar aos estudos, na área da sua preferência.

Delpretto e Zardo (2010) afirmam que a adoção de uma abordagem colaborativa deve ser compreendida como uma das atribuições do professor, entre a comunidade escolar e o professor da Sala de Recursos Multifuncionais (SRM). As Salas de Recursos Multifuncionais são espaços localizados nas escolas de educação básica e foram criadas para atender os alunos com necessidades especiais. São organizadas com mobiliários, materiais didáticos e pedagógicos, recursos de acessibilidade e equipamentos específicos, que atendem em turno contrário à escolarização os alunos da Educação Especial (ROPOLI et al., 2010, p. 31).

Silveira e Figueiredo (2010, p.20) ressaltam a importância do desenvolvimento da cultura da cooperação, nas instituições escolares. Destarte, afirmam: “[...] quando funcionam, as culturas colaborativas contribuem para transformar o aprendizado individual em coletivo".

Para que o professor esteja preparado para atender a esse grupo de estudantes, não basta que domine a sua área de conhecimento, sobretudo é importante que conheça e saiba utilizar estratégias que favoreçam o desenvolvimento integral do aluno. Desse modo, deve realizar uma prática pedagógica que promova o exercício de habilidades cognitivas diversas e saiba criar, em sala de aula, um ambiente favorável à exploração e à descoberta, à produção de ideias e de conhecimento.

A partir do momento em que a criança é identificada como superdotada, é necessário que se converse com os professores e com a turma de alunos, para que haja estímulo ao seu desenvolvimento. Uma criança superdotada, que não é bem acolhida pelo professor e pelos colegas, pode desenvolver timidez e desinteresse, se for desprezada pelos colegas. Consequentemente, isso acarretará um desenvolvimento social, afetivo e cognitivo altamente prejudicial a si mesmo e para todos os envolvidos.

Enfim, a escola é o espaço adequado para que alunos com necessidades especiais (superdotação) sejam educados e tenham suas capacidades cognitivas desenvolvidas e assim possam contribuir com a sociedade.

\section{A IMPORTÂNCIA DA INTERAÇÃO ENTRE FAMÍLIA E ESCOLA NO APOIO ÀS CRIANÇAS COM ALTAS HABILIDADES}

A família é o primeiro ambiente que propicia ao indivíduo as oportunidades de interagir sócio e emocionalmente, a fim de que obtenha formação integral e as condições de participar da vida em sociedade. É da família a responsabilidade de promover a proteção do funcionamento biológico, da sobrevivência, da transmissão de valores, tradições para garantir seu desenvolvimento. Cabe à família a responsabilidade de promover a proteção do funcionamento biológico, a sobrevivência e a 
transmissão de valores e tradições. Nesse sentido, para garantir seu desenvolvimento pleno, o ambiente familiar precisa promover estímulos adequados.

Para se entender como acontece o processo de desenvolvimento do individuo com altas habilidades, é necessário conhecer e entender seu contexto de desenvolvimento primário: origem, valores, cultura. Para tanto, o funcionamento da família tem grande influência no desenvolvimento dos talentos dos filhos, pois conforme for estimulado, ou não, acontecerá seu desenvolvimento cognitivo, motor e psicológico.

O ambiente familiar - pai e mãe - se prepara para a chegada do filho, pois se sabe que a rotina já estabelecida mudará com a chegada do bebê. No lar de Maria Cecília também aconteceu uma preparação para sua chegada, pois era aguardada com ansiedade e muita alegria pelos pais, que já estavam casados há alguns anos.

De acordo com Aspesi (2007), os pais de possuidores de altas habilidades/superdotação prestam apoio de várias maneiras para seu melhor desenvolvimento. Em relação ao apoio material e emocional, os pais fornecem apoio financeiro para aulas, materiais e equipamentos, instrumentos, cursos extraclasse, dedicam seu tempo auxiliando os filhos em pesquisas e atividades de interesse, sugerem programas interessantes para fazer com eles nos tempos livres, dirigem ou levam-nos para suas atividades, monitoram as suas práticas e dão apoio e suporte emocional quando os filhos estão diante de desafios.

Quanto ao apoio acadêmico, os pais participam ativamente dos assuntos escolares: estabelecem contato frequente com os professores, demonstram suas expectativas quanto ao desempenho dos filhos e ao cumprimento das tarefas acadêmicas. Na realidade, os pais parecem preocupar-se com o desenvolvimento global dos filhos e desejam que a experiência acadêmica seja algo que contribua para outros contextos da vida dos filhos.

Estudos indicam que crianças com altas habilidades adquirem habilidades específicas precocemente devido ao seu interesse em aprender.

É importante que a família esteja informada dos avanços legais que a sociedade brasileira já conquistou e dos direitos que a criança e o adolescente com altas habilidades/superdotação já adquiriram. "Assim, a família poderá requerer o atendimento educacional especializado mais adequado à sua criança ou adolescente (DELOU, 2007, p.53)".

Fontes (2012) orienta aos pais que se perceberem que seu filho está diferente de seus amigos e que sua capacidade de aprendizagem e habilidade mental são elevadas, é aconselhável levá-lo para uma avaliação específica, com um psicólogo experiente no assunto. Segundo o autor, uma avaliação neuropsicológica é necessária, se as potencialidades estão realmente acima da média de outras crianças.

Quando a criança apresenta diagnóstico de altas habilidades requer dos pais que proporcionem aos seus filhos oportunidades que enriqueçam e desenvolvam mais suas potencialidades. Boer e Fontes sugerem um ambiente com recursos que estimulem continuamente as capacidades mentais da criança; que se evite a supervalorização e as expectativas quanto ao desempenho da criança - em geral, ela já é muito exigente - e os pais devem aceitar falhas e ajudar a criança a enfrentar dificuldades de qualquer ordem; ajuda apara a criança a lidar com frustrações emocionais, pois apesar do superdotado não passar por dificuldades no aspecto acadêmico o fracasso faz parte de outros contextos da vida, e prepará-lo para isso é favorecer seu desenvolvimento emocional saudável; lembrar que, embora possua capacidades avançadas para sua idade, o superdotado deve ser tratado de acordo com a sua faixa etária de desenvolvimento.

Cabe aos pais entrarem em contato com a escola a fim de promover uma maior interação, o sentido de solicitar apoio e orientação, tão logo percebam comportamentos diferentes em seus filhos. Depois de uma avaliação do caso, os docentes devem encaminhar a criança à observação de um orientador educacional, e se for o caso, a um especialista. Se realmente se confirmar que a criança é superdotada, esta necessitará da compreensão e ajuda dos pais, bem como bem como do empenho dos agentes escolares responsáveis.

\section{CONCLUSÃO}

Este estudo permitiu constatar a visível escassez em estudos referentes ao desenvolvimento, atendimento e identificação de educandos com altas habilidades/superdotação, que permitissem compreender as emoções, ritmos e as dinâmicas de aprendizagem que poderiam propiciar um trabalho educativo mais elaborado e voltado para esses alunos.

Com a investigação sobre as dificuldades enfrentadas pelos pais de Maria Cecília, desde seu nascimento até os dias atuais, constatou-se que muitos foram os desafios para se esclarecer e se obter um diagnóstico sobre sua necessidade especial. Os pais observaram precocemente algumas peculiaridades no comportamento da filha, catalogaram, pesquisaram e fizeram viagens em busca de saídas que os ajudassem a entender e auxiliar a filha. No momento em que Maria Cecília iniciou sua vida escolar, seus pais também precisaram enfrentar situações como inadaptação, resistência e desmotivação da filha em ir à escola.

A família tem um papel importante na identificação, pois é no seio familiar que o sujeito se sentirá estimulado a desenvolver seu interesse pelo conhecimento. Quando a família não percebe ou não se mobiliza, cabe ao professor, que passa bastante tempo com a criança, auxiliar nessa identificação e fazer os devidos encaminhamentos, com o auxílio dos responsáveis da comunidade escolar.

A respeito das condições e preparo dos educadores de sua escola, especificamente de sua professora, verificou-se que a mesma não possui conhecimento suficiente do tema, que a torne capaz de trabalhar com de acordo com suas necessidades e desenvolver as potencialidades de Maria Cecília. Isso ficou evidente nas observações feitas durante as aulas e na entrevista com a professora. Apesar de admitir que Maria Cecília se destaca muito em relação aos demais colegas, a professora não tem apoio da equipe escolar, para ajudá-la. Contudo, a educadora demonstrou ser esforçada e atenciosa com a aluna em sala de aula.

Apesar da instituição de aparatos legais favoráveis e do avanço em pesquisas e teorias sobre o assunto, as políticas públicas relacionadas à inclusão ainda são ineficientes, uma vez que os educadores não possuem capacitação adequada para lidar com a inclusão escolar. A sociedade precisa compreender que a inclusão dos alunos com de altas habilidades deve contribuir para que esses sujeitos possam manifestar suas identidades, suas 
subjetividades e desenvolver suas potencialidades, tornando-se pessoas realizadas. Mais que isso, as pessoas com altas habilidades podem contribuir para um mundo mais livre e justo. Se a família e a escola souberem explorar todo o seu elevado potencial criativo, seu afinco pelos estudos, sua curiosidade e interesse pelo conhecimento, seu raciocínio verbal e numérico, sua capacidade de reflexão e imaginação vívida, certamente estarão contribuindo para a construção de uma sociedade mais avançada moral e socialmente.

É necessário que haja essa parceria para que o indivíduo com altas habilidades/superdotação não fique desestimulado e incapaz de desenvolver sempre mais suas potencialidades e contribuir de forma significativa com a sociedade.

\section{REFERÊNCIAS}

ALENCAR, E.M.L.S. de. O aluno com altas habilidades no contexto da Educação Inclusiva. 2003. Disponível em: http://www.ut.com.br/altashabilidades/upload/publicacoes_c ontexto\%20da\%20edu.\%20inc lusiva_144939.doc. Acesso em: 15 dez. 2016.

ASPESI, Cristina de Campos. A família do aluno com altas habilidades/superdotação. In: FLEITH, Denise de Souza (Org). A construção de práticas educacionais para alunos com altas habilidades/superdotação. v.1.Brasília, 2007.

BOER, Selma; FONTES, Maria Alice. Crianças Superdotadas: como identificar e lidar com elas. 2012 http://www.plenamente.com.br/artigo.php?FhIdArtigo=166 \#.WFCEHrIrIdU

BRASIL, Ministério da Educação. Secretaria de Educação Especial. Saberes e práticas da inclusão: desenvolvendo competências para 0 atendimento às necessidades

educacionais especiais de alunos com altas habilidades/superdotação. $\quad 2^{\mathrm{a}}$ ed. Brasília, 2006. http://portal.mec.gov.br/seesp/arquivos/pdf/altashabilidades. pdf

COSTA, A. S. O professor reflexivo e o reconhecimento das altas habilidades/superdotação. 2012. IX ANPED Sul.

DELPRETTO, Bárbara Martins de Lima; ZARDO, Sinara Pollom. Alunos com altas habilidades/superdotação no contexto da educação inclusiva. p.19-27. In: DELPRETTO, Bárbara Martins de Lima; GIFFONI, Francinete Alves; ZARDO, Sinara Pollom. A Educação Especial na Perspectiva da Inclusão Escolar. Altas Habilidades/Superdotação. v.10. Brasília, 2010.

DELOU, Cristina Maria Carvalho. O Papel da Família no Desenvolvimento de Altas Habilidades/Superdotação. In: FLEITH, Denise de Souza (Org). A construção de práticas educacionais para alunos com altas habilidades/superdotação. v.1.Brasília, 2007.

FISCHBORB, Márcia Inês Stefanello. A superdotação e o desafio da escola: um estudo do caso de Maria Cecília.2016

FLEITH, Denise de Souza. A Construção de Práticas Educacionais para Alunos com Altas Habilidades /
Superdotação. Ministério da Educação/ Secretaria de Educação Especial. Brasília 2007.

FONTES, M.A. BOER, S. Crianças superdotadas: como identificar e lidar com elas. 2012.

http://www.plenamente.com.br/artigo/166/criancassuperdotadas-como-identificar-lidarcom.php\#.WBKADSOrIdV

ROPOLI, Edilene Aparecida et al. A educação Especial na perspectiva da Inclusão Escolar: A escola comum inclusiva. Brasília: Ministério da Educação, Secretaria de Educação Especial. Fortaleza: Universidade Federal do Ceará, 2010.

PISKE, Fernanda H. R. e BAHIA, Sara. Criatividade e Inovação: A Importância de uma boa Formação Docente para desenvolver as Altas Habilidades. In: Actas do I Seminário Internacional "Contributos da Psicologia em Contextos Educativos” (pp. 79-86). Braga: Universidade do Minho, 2012.

SABATELLA,M.L.;CUPERTINO,C.M.B.

Práticas educacionais de atendimento ao aluno com altas habilidades/superdotação. In: FLEITH, Denise de Souza (Org) V.1.Orientação a professores. A construção de práticas educacionais para alunos com altas habilidades/superdotação. v.1.Brasília, 2007

SILVEIRA, S. M.; FIGUEIREDO, R. V. de. A educação interativa, a cooperação $\mathrm{e}$ ensino de atenção às diferenças. In: FIGUEIREDO, R. V. de (Org.) Escola, Diferença e Inclusão. Fortaleza, Edições UFC, 2010.

\section{COPYRIGHT}

Direitos autorais: Os autores são os únicos responsáveis pelo material incluído no artigo. 


\title{
ESTRATÉGIAS PEDAGÓGICAS OBSERVADA NA SALA DE RECURSOS: ESTUDANTE COM TRANSTORNO GLOBAL DO DESENVOLVIMENTO
}

\section{EDUCATIONAL STRATEGIES OBSERVED IN ROOM FEATURES: STUDENT WITH GLOBAL DEVELOPMENT DISORDER}

\author{
ADRIANA DE SOUZA CARREIRA; GABRIELY CABESTRÉ AMORIM²; VERA LÚCIA MESSIAS \\ FIALHO CAPELLINI ${ }^{3}$ \\ $1 ; 2 ; 3$ - UNIVERSIDADE ESTADUAL PAULISTA - UNESP \\ adrisouza.souza8@gmail.com; gcabestre@gmail.com;verinha@fc.unesp.br
}

\begin{abstract}
Resumo - São necessárias nas salas de aulas estratégias pedagógicas para o ensino do estudante com Transtorno Global do Desenvolvimento (TGD) para que haja uma aprendizagem de qualidade com auxílio do professor especializado. Neste estudo o objetivo foi observar e descrever as estratégias utilizadas pelo professor no atendimento de um estudante com $T G D$ realizado na Sala de Recursos por uma professora itinerante $e$ as experiências vivenciadas por uma professora regente. Foi utilizado um roteiro de observação durante dois meses na sala de recursos e itinerância com atendimento de um estudante do $6^{\circ}$. ano do Ensino Fundamental II. Foi possível vivenciar o cotidiano de maneira enriquecida na prática diária, evidenciando a qualidade de ensino, além das políticas públicas educacionais que regem as escolas, assim como a formação inicial e continuada do professor. Concluímos que faz-se necessário novos estudos que abordem outras realidades $e$ o aprofundamento de como trabalhar com os estudantes com TGD.
\end{abstract}

Palavras-chave: Educação Especial. Prática Pedagógica. Sala de Recursos. Ensino Fundamental.

Abstract - They are needed in the classroom teaching strategies for teaching students with Pervasive Developmental Disorder (PDD) so there is a quality learning with the aid of specialist teacher. In this study and described the strategies used by the teacher in the care of a student with TGD held in the Resource Room for a traveling teacher and the experiences of a regent teacher. an observation script was used for two months in the resource room and roaming service with a student 6. year of elementary school II. It was possible to experience the daily life so enriched in daily practice, highlighting the quality of education, in addition to educational policies governing schools, as well as initial and continuing teacher training. We conclude that it is necessary to further studies dealing with other realities and the deepening of working with students with TGD.

Keywords: Special Education. Pedagogical Practice. Resource Room.

\section{INTRODUÇÃO}

A atividade pedagógica propicia ao estudante os recursos materiais, humanos e metodológicos que possibilitam a compreensão dos fenômenos naturais e sociais que os circundam em sua vida cotidiana, sendo compartilhado com o professor da sala comum um Plano de Atendimento Individualizado (PAI), no intuito de organizar e direcionar a atividade pedagógica em sala de recursos e traçar diretrizes de ações com auxílio do professor da sala de aula comum.

Libâneo (2012, p.43) afirma que "a atividade pedagógica somente é pedagógica se ela mobiliza as ações mentais dos sujeitos, visando à ampliação de suas capacidades cognitivas e à formação de sua personalidade global".

Neste sentido, considerando a importância da atividade pedagógica, quais são as estratégias utilizadas para o ensino do estudante com TGD? Portanto, este estudo tem como objetivo observar e descrever as estratégias utilizadas pelo professor no atendimento de um estudante TGD realizado na Sala de Recursos por uma professora itinerante e as experiências vivenciadas por uma professora regente.

\section{1 - Definindo o Transtorno Global do Desenvolvimento} (TGD)

Kanner (1943) descreveu o TGD como uma síndrome que afeta as áreas da comunicação, do comportamento e interação social. Caracterizou-as sendo únicas e não pertencendo ao grupo de crianças com deficiência intelectual. Já, o médico austríaco Asperger descreveu crianças semelhantes, as que foram apresentadas por Kanner (1943), mas com o desenvolvimento intelectual e sem atraso no desenvolvimento da oralidade, conhecido como Síndrome de Asperger.

Nos últimos anos as pesquisas vêm descrevendo fatores que desencadeiam comportamentos observáveis em crianças com TGD. Segundo Mecca et al. (2011) o fenótipo (características observáveis ou caracteres de um organismo ou população) do TGD apresenta etiologia multifuncional e tem mostrado considerável influência na hereditariedade, que revela alterações neurocomportamentais entre irmãos com TGD.

Embora não tenham exames laboratoriais e de imagens que afirmam a presença de autismo ou de outros quadros da TGD, o importante é observar os sinais e sintomas o mais precocemente possível. Desta forma, é possível intervir terapeuticamente a partir das necessidades apresentadas pelas crianças. São tantas as combinações possíveis entre cada tipo de manifestação em seus diferentes graus e nuances, que nos impulsiona a individualizar a análise, a 
avaliação e os apoios a cada indivíduo com TGD (ZILBOVICUS; MERESSE; BODDAERT, 2006).

Tendo em vista este cuidado, nos cabe neste momento, aprofundar a descrição de algumas das manifestações comportamentais mais comuns do estudante com TGD em relação ao contexto escolar.

Conforme Zilbovicus, Meresse e Boddaert (2006), uma vez que todo comportamento produzido resulta, em parte, da interação do sujeito com o ambiente e com pessoas com as quais compartilha o contexto imediato, é fundamental que possamos refletir a respeito de como se expressam os sinais clínicos do transtorno nas diferentes oportunidades e situações próprias do universo escolar. É preciso compreender como os diferentes ambientes e situações podem afetar 0 comportamento do estudante com TGD e como desenvolver estratégias para atender suas necessidades de apoio.

A etiologia do TGD caracteriza o autismo por um comprometimento em várias áreas do desenvolvimento sem apresentar comprovada etiologia. Em tese os dados indicam um funcionamento anormal do cérebro em pessoas com autismo, sugerindo intervenção precoce nas diferentes áreas do desenvolvimento infantil (ZILBOVICUS; MERESSE; BODDAERT, 2006).

Os autores Zilbovicus, Meresse e Boddaert (2006) partem do pressuposto de que autismo é uma disfunção cerebral orgânica devido a um grave transtorno de desenvolvimento. Tais disfunções trazem prejuízos ao processo de comunicação (verbal e não verbal) e as interações sociais, além de comportamentos estereotipados e limitações em atividades e interesses.

Segundo Mercadante, Van der Gaag e Schwartzman (2006), a Síndrome de Asperger - uma das classificações de TGD -, refere-se a um prognóstico melhor e mais promissor, uma vez que as crianças tendem a desenvolver a fala normal, muitas vezes se manifesta melhor que seus pares.

Para Chamberllain, Kassari e Rotheram-Fuller (2007) tanto na Síndrome de Asperger como no Autismo de alto funcionamento os quadros são caracterizados pelo comprometimento na comunicação, dificuldades nas habilidades sociais e repertório restrito de interesses. Até o momento, a principal diferença nos critérios diagnósticos, é que algumas pessoas com Asperger não apresentam atraso no desenvolvimento da linguagem, aprendem a ler sozinha antes da idade escolar, por volta de três anos de idade.

Em relação a pesquisas recentes, nos últimos cinco anos, foi possível encontrar estudos sobre a inclusão escolar de alunos com TGD (MAROCCO, 2012; MENEZES, 2012; GOES, 2012; RIBEIRO, 2013; LISBÔA, 2015), e sobre estratégias de ensino (MINATEL, 2013; FERNANDES, 2014; AMARAL, 2014; PASCHOAL, 2016). O que demonstra que a temática vem sendo pesquisada, porém a muito a ser explorado.

\section{2 - Os marcos da Educação Inclusiva}

O Brasil do período colonial teve ações das leis portuguesas. No século XVIII, surgia a era da Institucionalização com a "Roda dos expostos" em algumas cidades brasileiras. Até então, pessoas com deficiências eram abandonadas ou cuidadas em casa. Em 1854 surge Instituto dos Meninos Cegos (atual Benjamin Constant) e do Instituto dos Surdos - Mudos, em 1857, hoje chamado de Instituto Nacional de Educação de Surdos (INES) ambos foram fundados na cidade do Rio de Janeiro, por iniciativa do governo Imperial (JANNUZZI,1992; BUENO,1993; MAZZOTTA,1996).
Em 1874, o Hospital Juliano Moreira, localizado em Salvador, na Bahia, inicia os atendimentos às pessoas com deficiência intelectual. Outras instituições deste tipo surgem no começo do século XX nas cidades de São Paulo e Rio de Janeiro (RODRIGUES; MARANHE,2010).

Na década de 1930, chegava ao Brasil, Helena Antipoff, psicóloga e educadora que coordenou cursos de formação de professores e fundou os diagnósticos e classes especiais nas escolas públicas no estado de Minas Gerais e posteriormente em demais estados e federações. Em 1945, esta profissional iniciou o primeiro atendimento educacional especializado às pessoas com deficiências.

Com o aparecimento de estudantes superdotados e o trabalho da Sociedade Pestalozzi para educação de estudantes com deficiência intelectual, contribuiu-se para a criação da Fundação da Associação de Pais e Amigos dos Excepcionais (APAE), no Rio de Janeiro, no ano de 1954 (BRASIL, 2007). Em 1949, cerca de 40 estabelecimentos de ensino prestavam atendimento às pessoas com deficiência intelectual no país. Em 1959, o número de instituições para pessoas com deficiência era de 190 , sendo $77 \%$ delas públicas, o que caracterizava a responsabilidade do estado pela educação de crianças com deficiência, ainda que a maioria não tivesse diagnóstico claro (RODRIGUES; MARANHE, 2010).

A partir de 1961, o atendimento educacional às pessoas com deficiências passou a ser fundamentado pela Lei de Diretrizes e Bases da Educação Nacional (LDBEN), que aponta o direito dos "excepcionais" à educação, preferencialmente dentro do sistema geral de ensino (BRASIL, 1961).

A Lei de Diretrizes e Bases (LDB) (BRASIL, 1961) foi alterada em 1971 (BRASIL, 1971), quando foi especificado "tratamento especial" para os estudantes que apresentassem deficiências físicas, intelectuais, atraso escolar considerando sua idade e, também, os superdotados. Como resultado, por volta de 1970, havia mais de 800 estabelecimentos de ensino especial no Brasil (BRASIL, 2007).

Em 1973 foi criado o Centro Nacional de Educação Especial (CENESP) com a responsabilidade de gerenciar a educação especial no Brasil, com intenção de integrar os serviços, impulsionou as ações educacionais voltadas às pessoas com deficiência e às pessoas com altas habilidades/superdotação, mas ainda configuradas por campanhas assistenciais e iniciativas isoladas do Estado.

A partir da Constituição Federal (1988) surgem algumas diretrizes a respeito da democratização da educação brasileira. Assegurando que educação de pessoas com deficiência deveria ocorrer preferencialmente, na rede regular de ensino. Assumindo formalmente a Declaração Universal dos Direitos Humanos. Um dos objetivos fundamentais da Constituição no artigo $3^{\circ}$, inciso IV é "promover o bem de todos, sem preconceitos de origem, raça, sexo, cor, idade e quaisquer outras formas de discriminação" (BRASIL, 1988).

Assim, educação foi definida como um direito de todos, garantindo o pleno desenvolvimento da pessoa, o exercício da cidadania e a qualificação para o trabalho. No artigo 206, inciso 1 , estabelece a "igualdade de condições de acesso e permanência na escola" como um dos princípios para ensino e garante como dever do Estado, a oferta do atendimento educacional especializado, preferencialmente na rede regular de ensino (BRASIL, 1988).

Em 1990 o Brasil assina a Declaração de Jomtien (BRASIL, 1990) assumindo perante os demais signatários o compromisso de erradicar o analfabetismo e universalizar o 
ensino fundamental no país. Foram elaboradas ações norteadoras com o objetivo de tornar os sistemas educacionais inclusivos nos três domínios públicos: municipal, estadual e federal. Nesta década, documentos como a Declaração de Salamanca (UNESCO, 1994) passam a influenciar a formulação das políticas públicas da educação inclusiva (BRASIL, 2007). Em 1999, com o objetivo de orientar os profissionais da educação no processo de ajuste para o "educar na diversidade" foram elaborados os Parâmetros Curriculares Nacionais-Adaptações Curriculares: Estratégias para a educação de Alunos com Necessidades Educacionais Especiais (BRASIL, 1999).

Em 2001, diretrizes, decretos e políticas foram implementados com o objetivo de garantir a inclusão das crianças com deficiência no sistema regular de ensino. Em 14 de Setembro de 2001, são divulgadas as Diretrizes Nacionais para a Educação Especial na Educação Básica (BRASIL, 2001). Ações foram observadas no sentido de garantir o cumprimento das metas estabelecidas pelo Plano Nacional de 2001/2011 (BRASIL, 2001).

Entre outras conquistas para o oferecimento de condições de ensino favorável ao desenvolvimento das crianças com deficiência, Língua Brasileira de Sinais (LIBRAS), (BRASIL, 2002a) foi conhecida pela Lei $n^{\circ}$. 10.436/02 como meio legal de comunicação e expressão, determinando que sejam garantidas formas institucionalizadas de apoiar seu uso de difusão. Na mesma linha, a Portaria $n^{\circ}$. 2.678/02 (BRASIL, 2002b) aprova as diretrizes e normas para o uso, o ensino, a produção e a difusão do sistema Braille em todas as modalidades de ensino, a produção da Grafia Braille para a Língua Portuguesa e a recomendação para o uso em todo território nacional.

No ano de 2005 a Secretaria de Educação Especial/MEC, criou o programa de implantação de Salas de Recursos Multifuncionais (SRMs) para às escolas da rede pública de ensino, como complemento a escolarização dos alunos PúblicoAlvo da Educação Especial (PAEE). Em 2008 a proposta da Política de Educação Especial na Perspectiva da Educação Inclusiva, foi consolidada com o Decreto $\mathrm{n}^{\circ}$. 6.571 (BRASIL, 2008), versando sobre o Atendimento Educacional Especializado (AMORIM, 2015).

Neste sentido, o Atendimento Educacional Especializado foi definido no Decreto $\mathrm{n}^{\circ}$. 6.571/08 como um conjunto de atividades, recursos de acessibilidade e pedagógicos para complementar e/ou suplementar o ensino comum, portanto não vem com o caráter substitutivo e, sim, como um auxílio, sendo que, o atendimento implica na eliminação de barreiras que possam existir ao aluno com deficiência (BRASIL, 2008).

Recentemente foi criada a lei $\mathrm{n}^{\circ}$. 13.146 (BRASIL, 2015) que institui a lei brasileira de inclusão da pessoa com deficiência (estatuto da pessoa com deficiência) destinada a assegurar e promover condições de igualdade, o exercício dos direitos fundamentais da pessoa com deficiência, visando a inclusão social.

\section{3 - O papel do professor e as ações inclusivas}

De acordo com Brito e Misquiatti (2013) os alunos com TGD podem beneficiar-se socialmente e academicamente ao estarem em ambientes educacionais inclusivos, pois possibilita o desenvolvimento de linguagem, assim como a interação social.

A sala de recursos é um dos suportes necessários para a inclusão. Todavia [...] é preciso propiciar a formação para que o professor compreenda o processo de aprendizagem do seu aluno e o papel e a importância da prática pedagógica para que ele realize (MORI, 2007, p. 10).

Barroco (2012, p. 283), em relação à sala de recursos, afirma que "ela deve ser mediadora para o desenvolvimento daquilo que é propriamente humano, as funções psicológicas superiores", como linguagem, o controle deliberado das ações, as atividades planejadas, com ênfase na linguagem verbal como impulsionadora do pensamento.

Para Barroco (2012, p. 296) o trabalho docente na sala de recursos "[...] deve encaminhar [...] situações de emprego de recursos psicológicos mais simples àquelas que requerem maior complexidade, requisitando da criança que empregue, intencional e autonomamente, [...] apoiadas na linguagem verbal".

\section{METODOLOGIA}

A pesquisa de abordagem qualitativa realizada em uma Escola Estadual de Ensino Fundamental e Médio, do interior paulista, está vinculada ao Programa Redefor Educação Especial e Inclusiva intitulada "Rede de educação inclusiva: Formação de Professores nos âmbitos de Pesquisa, Ensino e Extensão", aprovada pelo Comitê de Ética em Pesquisa (CAAE), da Faculdade de Ciências e Tecnologia (FCT), UNESP, campus de Presidente Prudente, SP, sob o $\mathrm{n}^{\circ}$ 26341614.3.0000.5402, cujo parecer $n^{\circ} 173.558$ é datado de 07 de dezembro de 2012.

Participaram deste estudo: Um estudante de 11 anos diagnosticado com TGD que frequenta o ensino regular Fundamental II; Uma professora da sala de Recursos/Itinerância que o acompanha o estudante no contraturno. A participante é Pedagoga com especialização em Psicopedagogia e efetiva da sala de Recursos, está em fase Capacitação e período Probatório pela Rede Estadual de Ensino do Estado de São Paulo; Uma professora de Artes da classe regular, com formação inicial em Magistério (CEFAM), graduação em Psicologia, especialização em Deficiência Intelectual, Didática do Ensino Superior e Transtorno Global do Desenvolvimento.

Foi utilizado como instrumento de coleta de dados um roteiro de observação que contemplou a descrição das estratégias e intervenções pedagógicas, além de vincular os protagonistas deste contexto educacional e seu desenvolvimento. Após o aceite e assinatura do Termo de Consentimento Livre e Esclarecido dos participantes, foi definido o período e horário das observações (segunda-feira a quinta-feira, com duração de 2 horas por dia, nos meses de setembro e outubro de 2015).

Durante as observações foram analisadas as estratégias, comunicação, interação e aprendizagem, além dos materiais e recursos disponíveis na escola.

Para análise de dados foram transcritas as observações conforme os itens contemplados no roteiro: comportamentos observados do estudante durante seu percurso até sua sala de aula e trajeto; durante as atividades e sua interação com a professora da Sala de Recurso. Após a compilação, os dados foram agrupados nas categorias: características gerais do estudante; características gerais do atendimento; experiências vivenciadas

\section{RESULTADOS E DISCUSSÕES}

Os dados serão apresentados por categoria (Características gerais do estudante; Características gerais do atendimento; Experiências vivenciadas): 


\section{1- Características gerais do estudante}

Foi possível identificar que o estudante cumprimenta todos os funcionários da escola (profissionais da limpeza, secretaria, inspetores...), durante o seu trajeto até a sala de aula.

$\mathrm{O}$ estudante não possui coordenação motora fina adequada para a idade, o mesmo gosta de desenhar, colorir, palavras cruzadas, fazer história em quadrinhos, tenta desenhar sequências, gosta de ler e apresentar seus trabalhos para os demais durante as aulas em sala regular. Observou-se que o estudante é alfabetizado e trabalha com o concreto e lúdico na matemática.

Em sua rotina diária, foi evidenciado o comportamento ansioso do estudante para adentrar a sala, mesmo sendo o horário em que a professora está organizando a sala para recebê-lo. Além disso, o estudante apresentou responsabilidade de horário e rotina.

Foi possível perceber que o estudante direciona o olhar quando é feito um diálogo, mas não chega a fixar com o olhar da pessoa com quem está falando. Outro fato observado foi que pela manhã (na Sala de Recursos) ele tem atenção, enquanto que no período da tarde, na sala regular, prefere ficar isolado.

Para Gomes e Mendes (2010) as crianças com TGD apresentam níveis que variam de uma criança para outra de: interesses restritos; pouco ou nenhum contato visual; ecolalia (repetição de elementos da fala); não respondem quando são chamadas (com frequência); dificuldades para expressar necessidades; apego a rotinas (rejeição às mudanças); movimentos esteriotipados repetitivos; não gostam do toque físico, sentem-se incomodados (com frequência); podem andar nas pontas dos pés; auto-agressão (podem morder-se, bater-se); preferem brincadeiras de giros ou balanços, além de enfileirar ou empilhar coisas; podem ter habilidades específicas bem desenvolvidas ou ilhotas de habilidades; aversão a barulhos altos; dificuldades em manter atenção por longo tempo; instabilidade de humor; limiares de dor elevados; dificuldades em coordenação motora fina. Alguns desses comportamentos foram observados no estudante deste estudo, reforçando as características das pessoas com TGD.

Vários comportamentos do estudante desta pesquisa reforçam o que é apresentado pelos autores Butter-Worth e Jarret (1995, p. 22) como dificuldades das crianças em algumas situações como "apontar coisas para outros; estabelecer contato visual; seguir o olhar de outro indivíduo o quando ele fala sobre algum objeto que estão olhando; usar gestos de maneira social; entender emoções em rostos alheios; usar variação normal de expressões emocionais no próprio rosto [...]". Sendo que esses comportamentos prejudicam o funcionamento adaptativo da criança.

\section{2- Características gerais do atendimento}

Durante o período de observação, o estudante atendido participou de 8 horas semanais de atividade em Sala de Recursos (período matutino), totalizando 64 horas no período da pesquisa. Os atendimentos na Sala de Recurso foram individuais.

Foi observado que o ambiente era favorável ao estudante para sua aquisição cognitiva, contendo ambientação, estímulos visuais, material adaptado confeccionado em conjunto pela professora e estudante, atividades lúdicas e materiais que tem no armário que são de coleções pedagógicas adaptadas. Com essa mesma ideia Cerizara (2000) aborda a concepção de homem nesse âmbito:
[...] a visão de homem é eminentemente social e a concepção de aprendizagem é um processo social em que a atividade humana e mediadora das relações com o homem com os outros homens e a natureza. Assim, dentro desta perspectiva, o desenvolvimento das funções mentais superiores na criança se dá o social, nas ações compartilhadas com o outro (plano interpsíquico), para o individual (plano intrapsíquico), processo a que Vygottsky determinou de "processo de internalização" [...] (CERIZARA, 2000, p. 86).

A partir da explicitação supracitada, destaca-se a importância das brincadeiras lúdicas na escola e o que ela pode proporcionar aos sujeitos envolvidos.

Para Wajskop (2005) a criança desenvolve-se pela experiência social, nas interações que estabelece desde cedo, dessa forma, a brincadeira é uma atividade humana na qual as crianças são introduzidas construindo-se em um modo de assimilar e recriar a experiência sócio-cultural dos adultos. Amplia a discussão acerca de outros aspectos envolvidos no brincar: uma atividade paradoxal, livre, imprevisível e espontânea, porém, ao mesmo tempo, regulamentada; meio de superação da infância; maneira de apropriação do mundo de forma ativa e direta, mas também através da representação, ou seja, da fantasia e da linguagem.

Quanto a organização de materiais, foi observado que o estudante tem auxílio da agenda (caderno de anotações) da mãe e das adaptações realizadas pela professora de Sala de Recursos, com o objetivo de facilitar a compreensão do aluno na execução atividades de outras disciplinas. Existe uma comunicação entre a mãe, professores da sala comum e da Sala de Recursos.

Ao iniciar a aula na Sala de Recursos, era realizada a leitura da agenda e a rotina no painel decorado, com o objetivo de facilitar a fixação visual.

Nos atendimentos foram realizadas atividades de discriminação visual, classificação de objetos, além da Atividade de Vida Diária (AVD) que corresponde a itens de higiene, uso correto do banheiro, lavar as mãos, antes e após sua utilização, reforçado também o escovar os dentes, banho. Este tipo de atividade aconteceu por meio de figuras, recortes e colagem.

A professora no período dos atendimentos acompanhava o estudante até o refeitório, onde o mesmo lavava as mãos para almoçar, escovava os dentes e aguardava para ir a sua aula do período da tarde.

A escola possui a dinâmica de sala ambiente, ou seja, cada sala tem as suas características de acordo com a disciplina. Devido a essa organização escolar, o estudante apresentou dificuldade em seguir a mudança da sala e o horário, apresentando comportamento agressivo. Antes do final da observação, o estudante adequou-se a rotina da escola, fez colegas e conseguiu ir de uma sala a outra com os colegas de classe. A sala de aula de ensino regular comum era repleta de materiais, estímulos para as atividades em grupo visando estabelecer vínculo.

\section{3 - Experiências vivenciadas}

As experiências vividas com os professores deste estudante foram desenvolvidas em reuniões de Atividade Trabalho Pedagógico Coletivo (ATPC). O estudante era aluno da pesquisadora no Ensino Fundamental II, da disciplina de Arte, ele estabeleceu vínculo, embora não houve uma troca simultânea e diálogo contínuo, suas frases eram curtas, mas 
gostava de comentar o que aprendeu, demonstrando o quanto foi significativo.

Na semana do Folclore, no período da tarde, o estudante demonstrou estar muito contente com a pipa que confeccionou com auxílio da professora da Sala de Recurso. Outra participação relevante foi em uma apresentação teatral, embora fazendo parte do contingente da peça, sem fala, apenas encenando, utilizando gestos simples para atuação com os demais. O tema era sobre preservação do meio ambiente, flora, fauna e primavera. Foi uma apresentação interdisciplinar, que demonstrou um grande avanço, por ele estar em um palco iluminado e com outras crianças interagindo.

Para Miller (2003) é possível estabelecer vínculos e permitir que a criança com deficiência possa fazer parte de um grupo que tem por base as diretrizes da inclusão escolar.

\section{CONSIDERAÇÕES FINAIS}

Este trabalho possibilitou vivenciar o cotidiano de maneira enriquecida na prática diária. Esta pesquisa evidenciou que a qualidade de ensino possui ligação com a implementação de políticas públicas educacionais e que a qualidade do ensino ministrado nas escolas e seu sucesso na tarefa de tornar cidadãos capazes de participar da vida socioeconômica, política e cultural do país também se relacionam com a formação (inicial e continuada) do professor.

Sabe-se que a educação passa por vários problemas, como falta de capacitação dos educadores, de planejamento curricular atualizado, democrático e flexível, de um projeto políticopedagógico eficiente e eficaz que esteja inserido em seu contexto real, social e de interação.

Os problemas educacionais ocorrem em várias áreas, como financeiras, culturais, sociais e pedagógicas, mas para que haja mudança, deve ser feito um levantamento dessas dificuldades por meio de diagnóstico da realidade e da busca de melhores formas possíveis, estratégias, para a elaboração de um projeto eficiente e eficaz, contando com a participação de todos nas ações, uma escola colaborativa, coensino, é possível concretizar os objetivos para atingir a modificação e transformação desse desequilíbrio e melhorar a qualidade de ensino.

Concluiu-se, que o professor especializado que possui as estratégias diversificadas, capacitação especifica em TGD, deve rever pontos julgados negativos e promover uma autocrítica, atacando-os e procurando uma atuação colegiada mais eficaz e qualificada, que resolva os problemas identificados na avaliação, tendo como uma das metas buscar a construção da autonomia, tratando todos como verdadeiros sujeitos que elaboram e respeitam as normas para que tenham liberdade de exigir seus direitos e cumprir suas obrigações. Faz-se necessários novos estudos que abordem outras realidades e estratégias pedagógicas utilizadas em sala de aula, além disso, aprofundar tais maneiras de trabalhar com os estudantes com TGD.

\section{REFERÊNCIAS BIBLIOGRÁFICAS}

AMARAL, L. D. D. Revisão sistemática e avaliação metodológica de intervenções analítico-comportamentais para o enfraquecimento de estereotipia em indivíduos com autismo, publicadas nos últimos 15 anos. Dissertação (Mestrado em Psicologia Experimental: análise do comportamento) - Pontifícia Universidade Católica de São Paulo, Psicologia, 2014.
AMORIM, G. C. Organização e funcionamento do atendimento educacional especializado na educação infantil: estudo de caso. Dissertação (Mestrado em Educação) - Universidade Estadual Paulista, Faculdade de Filosofia e Ciências, 2015

APA (2013). Associação Americana de Psiquiatria. Disponível em: <www.apa.org/.../2013/.../volume-32-issue-5>. Acesso em outubro de 2015

BARROCO, S.M.S. Sala de recursos e linguagem verbal: em defesa do desenvolvimento do humano no aluno. In: FACCI, M.G.D.; MEIRA, M.E.M;

BRASIL. Ministério da Educação. Lei de Diretrizes e Bases da Educação Nacional. LDB 4.024, de 20 de dezembro de 1961.

BRASIL. Ministério da Educação. Lei de Diretrizes e Bases da Educação Nacional. LDB 5.692, de 11 de agosto de 1971.

BRASIL. Constituição (1988). Constituição da República Federativa do Brasil. Brasília, DF: Senado Federal, 1988.

BRASIL. Estatuto da Criança e do Adolescente no Brasil. Lei $n^{\circ} 8.069$, de 13 de julho de 1990.

BRASIL. Declaração de Salamanca e linha de ação sobre necessidades educativas especiais. Brasília: UNESCO, 1994.

BRASIL. MINISTÉRIO DA EDUCAÇÃO. Salto para o futuro: Educação especial, tendências atuais. Secretaria da educação, SEED, 1999.

BRASIL. Ministério da Educação. Diretrizes nacionais para educação especial na educação básica / Secretaria de Educação Especial - MEC; SEESP, 2001.

BRASIL. Lei $\mathbf{n}^{0}$. 10.436 de 24 de abril de 2002. Dispõe sobre a Língua Brasileira de Sinais - Libras e dá outras providências. Brasília. 2002a.

BRASIL. Ministério da Educação. Portaria N 2.678, de 24 de setembro de 2002. Brasília. 2002b.

BRASIL. SECRETARIA DA EDUCAÇÃO. Saberes e prática da inclusão. Caderno do coordenador e do formador especial. Brasília, 2006.

BRASIL. Plano Nacional de Educação em Direitos Humanos / Comitê Nacional de Educação em Direitos Humanos. - Brasília: Secretaria Especial dos Direitos Humanos, Ministério da Educação, Ministério da Justiça, UNESCO, 2007. 76 p. 2007

BRASIL. Decreto $\mathbf{n}^{0}$. 6.571 de 17 de setembro de 2008 Dispõe sobre $\mathrm{o}$ atendimento educacional especializado. Presidência da República/Casa Civil/Subchefia para Assuntos Jurídicos. Brasília. 2008.

BRASIL. Lei no 13.146 de 6 de julho de 2015. Institui a Lei Brasileira de Inclusão da Pessoa com Deficiência (Estatuto da Pessoa com Deficiência). Brasília. 2015.

BRITO, M. C.; MISQUIATTI, A. R. N. Considerações sobre a atuação junto aos Transtornos Globais do Desenvolvimento na escola regular. In: MILANEZ, S. G. C.; OLIVEIRA, A. A. S.; MISQUIATTI, A. R. N.(ORG.) Atendimento educacional especializado para alunos com deficiência intelectual e transtornos globais do desenvolvimento. São Paulo: Cultura Acadêmica; Marília: Oficina Universitária, 2013, p.101-110. 
BUENO, J. G. S. Educação especial brasileira: integração/segregação do aluno diferente. São Paulo: EDUC, 1993.

BUTTER-WORTH, G.; JARRETT, N. What minds have in common is space: Spatial mechanisms serving joint visual attention in infancy. British Journal of Developmental Psychology: Special Issue, [S.1.], v. 9, p. 55-72, 1991.

CERIZARA, A. B. A educação infantil e as implicações pedagógicas do modelo históricocultural. Cadernos Cedes. Campinas: UNICAMP, n. 35, jul. 2000.

CHAMBERLAIN, B.; KASARI, C.; FULLER E, R. (2007). Envolvimento ou isolamento? As redes sociais de crianças com autismo em salas de aula regulares. J.Autism. Dev.Disord.2007 Feb; 37(2):2030-42 Pub.Med.gov. PIMID:16855874[Pub Med-indexado ${ }^{\circ}$ MEDLINE

FERNANDES, R. M. M. Narrativas docentes sobre o método Teacch: o autismo na gestão do conhecimento. Dissertação (Mestrado em Gestão de Organizações Aprendentes) - Universidade Federal da Paraíba, 2014.

GOES, R. S. de. A escola de educação especial: uma escolha para crianças autistas e com deficiência intelectual associada de 0 a 5 anos. Dissertação (Mestrado em Psicologia Escolar e do Desenvolvimento Humano) - Universidade de São Paulo, Instituto de Psicologia 2012.

GOMES, C. G. S.; MENDES, E. G. Escolarização inclusiva de alunos com autismo na rede municipal de ensino de Belo Horizonte. Revista Brasileira de Educação Especial, v. 16, n. 3, p. 375-396, 2010. Disponível em: <http://www.scielo.br/pdf/rbee/v16n3/v16n3a05.pdf>. Acesso em: 12 fevereiro 2016

JANNUZZI, G. A luta pela educação do deficiente mental no Brasil. Campinas, São Paulo: Editores Associados, 1992.

KANNER, L. (1943). Autistic Disturbances of Affective Contact. Nervous Child, n. 2, p. 217-250.

LIBÂNEO, J. C. O dualismo perverso da escola pública brasileira: escola do conhecimento para os ricos, escola do acolhimento social para os pobres. Educação e Pesquisa, São Paulo, v. 38, n. 1, p. 13-28, 2012.

LISBÔA, E. R. A tutoria clínico-escolar no processo de inclusão escolar: um estudo de caso. Tese (Doutorado em Psicologia Escolar e do Desenvolvimento Humano) Universidade de São Paulo, Instituto de Psicologia, 2015.

MAROCCO, V. Sujeitos com autismo em relações: educação e modos de interação. Dissertação (Mestrado em Educação) - Universidade Federal do Rio Grande do Sul, Faculdade de Educação, 2012.

MAZZOTTA. M. J. S. Educação especial no Brasil: história e políticas públicas. São Paulo: Cortez, 1996.

MENEZES, A. R. S. de. Inclusão escolar de alunos com autismo: quem ensina e quem aprende? Dissertação (Mestrado em Educação) - Universidade do Estado do Rio de Janeiro, 2012.

MECCA, T. P.; BRAVO, R. B; VELLOSO, R. L.; SCHWARTZMAN, J. S.; BRUNONI, D.; TEIXEIRA, M. C. T. V. (2011). Rastreamento de sinais e sintomas de transtornos do espectro do autismo em irmãos. Disponível em: <www.scielo.br/pdf/rprs/v33n2/v33n2a09> Acesso em $30 / 11 / 2015$

MERCADANTE, M. T.; GAAG, R. J. V. der; SCHWARTZMAN, J. S. Transtornos invasivos do desenvolvimento não-autísticos: síndrome de Rett, transtorno desintegrativo da infância e transtornos invasivos do desenvolvimento sem outra especificação. Rev Bras Psiquiatr. 2006; 28 (Supl I): S12-20

MILLER, J. A. Uma partilha sexual. O sexo e seus furos. Clique -Revista dos Institutos Brasileiros de Psicanálise do Campo Freudiano, 2, 13 - 29. 2003.

MINATEL, M. M. Cotidiano, demandas e apoio social de famílias de crianças e adolescentes com autismo. Dissertação (Mestrado em Terapia Ocupacional) - Universidade Federal de São Carlos, 2013.

MORI, N. N. R. Educação escolar inclusiva: a prática pedagógica nas salas de recursos. Anais do Congresso Brasileiro Multidisciplinar de Educação Especial. Londrina. 2007

PASCHOAL, L. P. Retraimento social em bebês: um estudo exploratório sobre os irmãos mais novos de crianças com transtorno do espectro do autismo. Dissertação (Mestrado em Psicologia Escolar e do Desenvolvimento Humano) Universidade de São Paulo, Instituto de Psicologia, 2016.

RIBEIRO, E. L. A comunicação entre professores e alunos autista no contexto da escola regular: desafios e possibilidades. Dissertação (Mestrado em Educação) Universidade Federal da Bahia, Faculdade de Educação, 2013.

RODRIGUES, O. M. P. R.; MARANHE, E. A. A história da inclusão social e educacional da pessoa com deficiência. In: CAPELINI, V. L. M. F.; RODRIGUES, O. M. P. R. (Orgs.). Marcos históricos, conceituais, legais e éticos da educação inclusiva. Bauru: Unesp; MEC, 2010. v. 2. (Coleção Formação de Professores na Perspectiva da Educação Inclusiva).

ZILBOVICIUS, M.; MERESSE, I.; BODDAERT, N. Neuroimaging in autism. Rev Bras Psiquiatr. 2006;28(Supll I):22-9.

WAJSKOP, G. Brincar na Pré-escola. $6^{\mathrm{a}}$ ed. São Paulo: Cortez, 2005.

\section{COPYRIGHT}

Direitos autorais: Os autores são os únicos responsáveis pelo material incluído no artigo. 


\title{
ESTUDO DAS POSSIBILIDADES DE CONEXÃO DA SUSTENTABILIDADE, COM O ENSINO DE QUÍMICA, AS PRÁTICAS EDUCATIVAS E O DESENVOLVIMENTO LOCAL
}

\section{STUDY OF THE POSSIBILITIES OF CONNECTING SUSTAINABILITY, WITH CHEMISTRY EDUCATION, EDUCATIONAL PRACTICES AND LOCAL DEVELOPMENT}

\author{
EDWARD AREDES SILVA JÚNIOR ${ }^{1}$, ADILENE GONÇALVES QUARESMA ${ }^{2}$ \\ 1, 2 - CENTRO UNIVERSITÁRIO UNA \\ edwardaredes@hotmail.com,adilene.quaresma@prof.una.br
}

\begin{abstract}
Resumo - O artigo apresenta a revisão bibliográfica sobre a pesquisa "Práticas Educativas de Inclusão da temática da Sustentabilidade Ambiental nas aulas de Química do Ensino Médio da rede pública estadual de Minas Gerais", desenvolvida no Programa de Pós-Graduação em Gestão Social, Educação e Desenvolvimento Local do Centro Universitário Una. O objetivo deste estudo é identificar práticas educacionais de inserção da temática da Sustentabilidade nas aulas de Química em escolas da Rede Pública. Utilizou-se de abordagem qualitativa, com pesquisa bibliográfica sobre aspectos históricos da Sustentabilidade, estudos da literatura científica e legislação quanto a sua correlação com o ensino de Química, o Ensino Médio e o Desenvolvimento Local. Os principais resultados apontam na viabilidade da construção de uma proposta de inovação educacional tendo a Sustentabilidade como norteadora.
\end{abstract}

Palavras-chave: Química. Sustentabilidade. Desenvolvimento Local.

Abstract - This article presents a bibliographical review on the research "Educational Practices for Inclusion of Environmental Sustainability in the High School Chemistry Classes of the State Public School of Minas Gerais", developed in the Postgraduate Program in Social Management, Education and Local Development of Centro Universitário Una. The objective of this study is to identify educational practices of insertion of the theme of Sustainability in the classes of Chemistry in schools of the Public Network. A qualitative approach was used, with bibliographical research on historical aspects of Sustainability, studies of the scientific literature and legislation regarding their correlation with the teaching of Chemistry, High School and Local Development. The main results point to the feasibility of building a proposal for educational innovation, with Sustainability as the guiding principle.

Keywords: Chemistry. Sustainability. Local Development.

\section{INTRODUÇÃO}

A sociedade atual apresenta um número crescente de cidadãos que buscam participar da discussão sobre as questões ambientais, estando de uma forma cada vez mais inserida na realidade de todos, por exemplo, no que se refere ao aquecimento global, que tem provocado uma intensa alternância climática no planeta, potencial geradora do risco eminente de conflitos locais e até mesmo entre nações na disputa pelos recursos hídricos, na questão da exploração mineral e seus impactos ambientais, no aumento sistemático da poluição atmosférica, principalmente nas grandes metrópoles, exigindo a implantação dos chamados rodízios de veículos automotores.

Este artigo toma por referência a revisão bibliográfica da pesquisa realizada no Programa de Mestrado Profissional em Gestão Social, Educação e Desenvolvimento Local, do Centro Universitário Una, linha de pesquisa Educação e Desenvolvimento Local, intitulada "Práticas Educativas de inclusão da temática da Sustentabilidade Ambiental nas aulas de Química do Ensino Médio da Rede Pública Estadual de MG".

O objetivo geral da pesquisa foi analisar as propostas que inserem a temática da Sustentabilidade na prática dos docentes de Química tendo em vista o desenvolvimento de contribuição técnica na área de educação voltada ao Desenvolvimento Local e com características de inovação social.

Enumera-se como objetivos específicos, identificar, na bibliografia especializada, qual é o entendimento de pesquisadores do ensino de Química sobre como deve-se inserir a temática da Sustentabilidade na prática educativa dos docentes dessa disciplina no Ensino Médio, investigar o entendimento dos professores da rede pública estadual a respeito, e por fim, desenvolver um material didático em mídia eletrônica (cartilha, site ${ }^{1}$ e/ou aplicativo) que propicie efetivamente a construção de práticas sustentáveis a partir das aulas de Química.

Nesse artigo analisa-se a Sustentabilidade sobre quatro referenciais, inicialmente na construção histórica da Educação Ambiental, na relação com o Ensino de Química, na discussão sobre as Práticas Educativas que possibilitariam a inclusão da temática, e por fim, na conceituação de Desenvolvimento Local a partir de uma escola mais articuladora dos múltiplos espaços de conhecimento de cada território, sendo menos lecionadora, educando os alunos dentro de uma realidade com a qual eles familiarizam e a qual possam melhorar (DOWBOR, 2007). 


\section{BREVE RELATO SOBRE A CONSTRUÇÃO HISTÓRICA DA EDUCAÇÃO AMBIENTAL}

No âmbito educacional, no ano de 1889, o escocês Patrick Geddes, considerado o pai/fundador da Educação Ambiental, expôs a ideia de que ensinar uma criança em contato com a realidade do seu ambiente poderia ser um agente facilitador do seu aprendizado e consequentemente desenvolver em si atitudes mais criativas perante o mundo ao seu redor (DIAS, 2010).

$\mathrm{Na}$ década de 50, a temática ambiental no ensino de Ciências teve um maior impulso, em virtude das reformas que compunham as novas políticas públicas educacionais, desencadeadas a partir de uma grave tragédia ambiental, que culminou com a morte de aproximadamente 1600 pessoas devido ao ar densamente poluído da cidade de Londres chamado de smog (smoke + fog). A crescente discussão sobre o meio ambiente culminou com a inserção do chamado ambientalismo nos Estados Unidos, a partir da década de 1960 (DIAS, 2010).

Segundo Jacobi (2003), o enfoque, neste momento, era ainda reducionista e simplista, pois nesta época os estudos eram realizados dentro de uma realidade micro, deveras distante da multiplicidade e diversidade do meio ambiente, no que se refere aos fatores que o compõem e as inúmeras variáveis que interveem diretamente nele.

O ambientalismo foi conceituado por Manuel Castells (2001) como:

\begin{abstract}
"Formas de comportamento coletivo que em seus discursos como na prática, visam corrigir formas destrutivas de relacionamento entre o homem e seu ambiente natural, contrariando a lógica estrutural e institucional predominante (CASTELLS, 2001, p.143)."
\end{abstract}

O ano de 1962 marcou o lançamento do livro Primavera Silenciosa, de Rachel Carson, que reuniu relatórios de conceituados pesquisadores das áreas de Farmacologia, Química e Biologia. Tal literatura é considerada um clássico na história do movimento ambientalista. $\mathrm{O}$ foco da sua crítica foi à introdução de substâncias não orgânicas na natureza, com ênfase nos inseticidas e herbicidas, entre eles o DDT (diclorodifenil-tricloro-etano) e o BHC (hexacloreto de benzeno). Ela não propõe nesta obra, o abandono da produção de alimentos, mas enfatiza que é possível controlar danos à agricultura gerados por pragas, concomitantemente, com a preservação da fauna e da flora (ARAÚJO, SILVA, 2012).

Os primeiros registros da utilização do termo Educação Ambiental datam do ano de 1948 , numa reunião da União Internacional para a Conservação da Natureza (UICN) em Paris (JACOBI, 2005).

Formalmente, o termo Educação Ambiental só apareceu em meados de 1965, na Conferência de Educação na Universidade Keele/Grã-Bretanha, já sendo entendido como algo importante na formação educacional do cidadão (BOTELHO, 1998).

Sete anos depois foi apresentado o Relatório do Clube de Roma ou Relatório Meadows, elaborado por uma equipe do Massachusetts Institute of Technology, MIT, um estudo aprofundado de variáveis essenciais para a humanidade, dentre elas, a energia, a poluição, o ambiente e a tecnologia (MEADOWS et al., 1972).

1.Endereço eletrônico do site criado como produto técnico: http://www.quimicaesustentabilidade.com
Dando continuidade a um ano muito ativo no debate das questões ambientais, a chamada Conferência de Estocolmo, também marcou o ano de 1972:

\begin{abstract}
"Chegamos a um ponto na História em que devemos moldar nossas ações em todo o mundo, com maior atenção para as consequências ambientais. Defender e melhorar o meio ambiente para as atuais e futuras gerações se tornou uma meta fundamental para a humanidade (ONU, 2014)."
\end{abstract}

Diante dos resultados da Conferência de Estocolmo, a Assembleia Geral da ONU criou, em dezembro de 1972, o Programa das Nações Unidas para o Meio Ambiente (PNUMA), com foco na atuação como motivador das atividades que visam promover a preservação do meio ambiente no mundo (ONU, 2014).

A Organização das Nações Unidas para a Educação, Ciência e Cultura (UNESCO) promoveu no ano de 1975 em Belgrado, na antiga Iugoslávia, o Encontro Internacional sobre a Educação Ambiental, com a proposta elaborada de um ensino multidisciplinar, que contemplasse as diferenças regionais e interesses nacionais (BRASIL, 2001).

A Conferência de Tbilisi realizada no ano de 1977 é considerada, ainda nos dias atuais, o evento decisivo para os rumos da Educação Ambiental no mundo, destacando a contextualização e a contribuição para o processo educativo:
“A educação ambiental deve ser dirigida à comunidade despertando o interesse do indivíduo em participar de um processo ativo no sentido de resolver os problemas dentro de um contexto de realidades específicas, estimulando a iniciativa, o senso de responsabilidade e o esforço para construir um futuro melhor. Por sua própria natureza, a educação ambiental pode, ainda, contribuir satisfatoriamente para a renovação do processo educativo (MMA, 2015).,

No Brasil, a inclusão da temática ambiental no Ensino Médio ocorreu em 1979, a partir do documento chamado de Ecologia, apoiado numa base equivocadamente reducionista, que não contemplava a interação da temática ambiental com os aspectos sociais, econômicos, culturais, éticos e outros, que poderiam desde já propiciar uma visão multidimensional ao ensino da Educação Ambiental em nosso país (DIAS, 2010).

Em 1983, o Secretário-Geral da ONU convidou a médica Gro Harlem Brundtland, para estabelecer e presidir a Comissão Mundial sobre o Meio Ambiente e Desenvolvimento. Em 1987, esta comissão publicou um documento importante chamado de "Nosso Futuro Comum" - que introduziu o conceito de desenvolvimento sustentável para o discurso público na sua essência (ONU, 2014):

\footnotetext{
“[...] o desenvolvimento sustentável é um processo de mudança no qual a exploração dos recursos, o direcionamento dos investimentos, a orientação do desenvolvimento tecnológico e a mudança institucional estão em harmonia e reforçam o atual e futuro potencial para satisfazer as aspirações e necessidades humanas."
}

Não há um consenso, ainda nos dias de hoje, sobre a conceituação dos termos Desenvolvimento Sustentável e Sustentabilidade, há correntes de pesquisadores que defendem a ideia que o Desenvolvimento Sustentável seria 
um caminho para se alcançar a Sustentabilidade, como objetivo final, numa perspectiva de um longo prazo, para outros, o Desenvolvimento Sustentável é o objetivo almejado, sendo que a Sustentabilidade é o processo para alcança-lo, por outro lado, quase todas as definições de Desenvolvimento Sustentável utilizam princípios da Sustentabilidade (SARTORI, LATRONICO, CAMPOS, 2014; DOVERS, RADMER, 1992).

Moacir Gadotti (2008, p.75), destaca a relação entre a sociedade e o meio ambiente ao afirmar que a "Sustentabilidade é equilíbrio dinâmico com o outro e com o meio ambiente, é harmonia entre os diferentes".

Com um maior detalhamento, Ignacy Sachs define que:

“[...] a sustentabilidade ambiental é baseada no duplo imperativo ético de solidariedade sincrônica com a geração atual, e de solidariedade diacrônica com as gerações futuras (SACHS, 2004, p. 13).”

Apontando diante disto os cinco pilares do chamado desenvolvimento sustentável - o Social, o ambiental, o territorial, o econômico e o político (SACHS, 2004, p. 15).

No dia 11 de março de 1987 houve a aprovação, pelo Plenário do Conselho Federal de Educação, do parecer 226/87 que considerou a Educação Ambiental conteúdo necessário nas propostas curriculares do $1^{\circ}$ e $2^{\circ}$ grau (MININNI-MEDINA, 1994).

A Constituição Brasileira, promulgada em 1988, estabeleceu as diretrizes da política nacional ambiental, estabelecendo as responsabilidades do cidadão e do governo:

\begin{abstract}
"Todos têm direito ao meio ambiente ecologicamente equilibrado, bem de uso comum do povo e essencial à sadia qualidade de vida, impondo-se ao Poder Público e à coletividade o dever de defendê-lo e preservá-lo para as presentes e futuras gerações (BRASIL, 1988, art. 225)."
\end{abstract}

Em 1992, ocorreu a culminância dos trabalhos iniciados em 1972, com a realização da ECO-92 no Brasil, uma Conferência das Nações Unidas sobre o Meio Ambiente e o Desenvolvimento, que propiciou a elaboração da Agenda 21, que consistiu na sistematização de propostas com o intuito de prover a proteção e o desenvolvimento sustentável do nosso planeta. Tal evento foi o responsável pela popularização do termo Desenvolvimento Sustentável (MMA, 2015).

Sobre a Agenda 21, destaca-se:

"A Agenda 21 é um plano de ação para ser adotado global, nacional e localmente, por organizações do sistema das Nações Unidas, governos e pela sociedade civil, em todas as áreas em que a ação humana impacta o meio ambiente (MMA, 2015)."

$\mathrm{O}$ ambiente escolar é um dos locais que pode funcionar como um espaço propício para debates que culminem na elaboração de uma Agenda 21 local, a partir do estabelecimento de ações capazes de trazer a discussão da Sustentabilidade a determinado território, com foco na associação entre o meio ambiente e o desenvolvimento, da preservação da qualidade atmosférica, do planejamento e gerenciamento de recursos naturais, da gestão dos recursos hídricos, da gestão ambiental com tratativas para o manejo das substâncias químicas tóxicas e resíduos perigosos, da gestão ambiental dos resíduos radioativos e da ciência como catalisador do Desenvolvimento Sustentável (MMA, 2015).

O Ministério da Educação e Cultura (MEC) criou em 1997 um banco de dados reunindo mais de mil e duzentas experiências com a temática ambiental já implementadas no Brasil (DIAS, 2010), mostrando que o compartilhamento de experiências exitosas é uma importante ferramenta de trabalho no contexto educacional.

Com a promulgação da lei no $9795 / 99$ que dispôs sobre a educação ambiental, instituindo a Política Nacional de Educação Ambiental, novos avanços foram registrados:

\begin{abstract}
"Entendem-se por educação ambiental os processos por meio dos quais o indivíduo e a coletividade constroem valores sociais, conhecimentos, habilidades, atitudes e competências voltadas para a conservação do meio ambiente, bem de uso comum do povo, essencial à sadia qualidade de vida e sua sustentabilidade (BRASIL, 1999)."
\end{abstract}

No ano 2000, a partir da reunião de 189 países, foram estabelecidos os 8 Objetivos do Milênio (ODM), com enfoque no pleno combate à extrema pobreza e outros problemas que atingem a sociedade, inclusive na questão ambiental. Um dos objetivos era relacionado ao meio ambiente e a qualidade de vida, posteriormente o termo foi ressignificado, assumindo o conceito da Sustentabilidade (UNICEF, 2015; PNUD, 2014).

No que tange à essa questão, na relação com a educação formal, os Cadernos Temáticos da Secretaria de Educação Continuada, Alfabetização e diversidade (SECAD/MEC), em 2007, destacam que:

"[..] ainda no âmbito internacional, a iniciativa das Nações Unidas de implementar a Década da Educação para o Desenvolvimento Sustentável (2005-2014), cuja instituição representa uma conquista para a Educação Ambiental, ganha sinais de reconhecimento de seu papel no enfrentamento da problemática socioambiental, na medida em que reforça mundialmente a sustentabilidade a partir da Educação (BRASIL, 2007, p.13).”

Os ODM deram lugar a uma nova agenda pós-2015 de desenvolvimento, quando a ONU trabalhou com governos, a sociedade civil e outras entidades na construção destes novos alvos de transformação que foram denominados Objetivos de Desenvolvimento Sustentável (ODS), fruto das discussões realizadas na Rio+20 - a Conferência da ONU sobre Desenvolvimento Sustentável - que foi realizada em junho de 2012 no Rio de Janeiro, Brasil (ONU, 2015).

\section{PRÁTICAS EDUCATIVAS PARA A INCLUSÃO DA TEMÁTICA DA SUSTENTABILIDADE NO ENSINO MÉDIO}

O ensino de Química no Brasil é trabalhado no Ensino Médio, desde o ano de 1931, quando foi publicado o decreto 20.158/31, também conhecido como a reforma Francisco Campos (LIMA, 2013).

As décadas seguintes não trouxeram inovações significativas no ensino de Química em nosso país, apenas no auge do regime militar, vieram mudanças com a implantação da Lei de Diretrizes e Bases da Educação (LDB) $n^{\circ} 5692 / 71$ onde a disciplina passou a fazer parte do chamado Ensino Médio profissionalizante ganhando, de 
forma exclusiva, a dimensão técnica-científica (DIAS, 2010).

Forte guinada ocorreu no ensino de Química com a promulgação da nova LDB $\mathrm{n}^{\circ}$ 9394/96, buscando habilidades e competências que propiciem alcançar os quatro pilares da educação do século XXI - "aprender a conhecer, aprender a fazer, aprender a viver juntos e aprender a ser" (DELORS, 2001, p.89-90).

O foco dado para o Ensino Médio já no início do século XX propunha desenvolver no aluno o gosto pelo estudo de Química sempre vinculando ao cotidiano (MACEDO; LOPES, 2002).

Em seu artigo 35 a LDB estabelece as finalidades do Ensino Médio:

“[...] a consolidação e o aprofundamento dos conhecimentos adquiridos no ensino fundamental, possibilitando o prosseguimento de estudos; a preparação básica para o trabalho e a cidadania do educando, para continuar aprendendo, de modo a ser capaz de se adaptar com flexibilidade a novas condições de ocupação ou aperfeiçoamento posteriores; o aprimoramento do educando como pessoa humana, incluindo a formação ética e o desenvolvimento da autonomia intelectual e do pensamento crítico; a compreensão dos fundamentos científico-tecnológicos dos processos produtivos, relacionando a teoria com a prática, no ensino de cada disciplina (BRASIL, 1996)."

O ensino de química apresenta características particulares que credenciam a sua utilização como ferramenta de construção do pensamento crítico, sendo entendido por Freire (2007, p.26) como:

"[...] a capacidade de analisar profundamente, questionar, discutir problemas e buscar soluções racionais adequadas, levando em consideração as diferentes opiniões sobre um mesmo assunto."

Quais seriam, portanto, as competências a serem trabalhadas no ensino de Química no Ensino Médio? Os Parâmetros Curriculares Nacionais para o Ensino Médio (BRASIL, 2000, p.10) respondem esta questão de forma objetiva, como sendo as "necessárias à integração do seu projeto individual ao projeto da sociedade em que se situa".

O ensino de Química deve ser um instrumento capaz de contribuir para a formação humana, aprimorando a percepção, interação e a intervenção no mundo, não se limitando meramente a leitura de fórmulas, cálculo de concentrações ou a escrita de equações químicas, busca-se ao fim do Ensino Médio que a plena construção de um conhecimento permita ao indivíduo relacioná-lo com as suas implicações ambientais, sociais, políticas e econômicas (BRASIL, 2000, 2002).

O foco é a formação de um aluno e cidadão capaz de pensar o que ocorre ao seu redor de forma sistêmica:

“O aprendizado de Química pelos alunos de Ensino Médio implica que eles compreendam as transformações Químicas que ocorrem no mundo físico de forma abrangente e integrada e assim possam julgar com fundamentos as informações advindas da tradição cultural, da mídia e da própria escola e tomar decisões autonomamente, enquanto indivíduos e cidadãos (BRASIL, 2000, p.31).”
O estudo da Química ativa a visão do mundo de uma forma mais articulada e menos fragmentada, sendo que o "conhecimento pertinente é aquele capaz de situar toda informação em seu contexto e, se possível, no conjunto em que se insere" (MORIN, 2002, p.15).

Os conteúdos no Ensino Médio permitem a contextualização em muitas situações, por exemplo, na abordagem de temas como energia, lixo, agricultura orgânica, alimentos, metalurgia, chuva ácida, descarte de baterias e pilhas, tratamento de esgoto e água, camada de ozônio, efeito estufa, chuva ácida, plásticos, mineração, combustíveis etc.

Como explicar, no entanto, que ainda temos muitos professores com uma visão meramente conteudista? Será que as novas tendências no ensino de Química não estão chegando aos professores? Um estudo realizado em 2011 apontou o seguinte:

\begin{abstract}
"As tendências do ensino de Química, apresentadas em revistas especializadas da área, em livros e teses, como resultado das pesquisas em ensino de Química, não estão chegando até os professores. É preciso engajá-los nesta pesquisa, para que ele construa a crença de que o seu trabalho pode ser melhor (QUADROS et al., 2011, p.174)."
\end{abstract}

No caso específico de Minas Gerais, com a mudança de governo na última eleição estadual, optou-se em 2015 pelo retorno ao Conteúdo Básico Curricular (CBC) da Secretaria de Educação de MG (SEE-MG) referente ao ano de 2007, não dando continuidade ao modelo proposto na Resolução SEE-MG, No 2030, de 25 de janeiro de 2012, que readequava o $\mathrm{CBC}$ em virtude do programa Reinventando o Ensino Médio.

Na versão 2007 do $\mathrm{CBC}$, percebe-se a presença de algumas temáticas ambientais, sobretudo, nos projetos paralelos ao currículo tradicional, dispostos como sugestão e não como parte obrigatória do programa, num volume aquém do que poderia ser trabalhado no Ensino Médio.

No contexto da Base Nacional Comum Curricular se espera que o documento final contemple quantitativamente $\mathrm{e}$ qualitativamente uma maior e melhor inserção da temática ambiental, como já pode ser visto na primeira e na segunda versão disponibilizada durante as fases inicias de discussão no portal que trata deste tema, propiciando uma proposta de ensino mais próxima daquilo que se imagina como cerne desta pesquisa.

Outro ponto de destaque nas pesquisas educacionais relativas ao ensino de Química é o estabelecimento de novas metodologias e técnicas que abordem a Sustentabilidade, a partir da eliminação ou da menor produção de resíduos tóxicos ao ambiente e a saúde humana, o que tem sido chamado de Química Verde (CORREA; ZUIN, 2009).

A Química Verde é orientada por doze princípios, elaborados a partir de discussões que englobam as fontes de energia renováveis, a eliminação ou redução do uso das substâncias persistentes, tóxicas e bioacumulativas, culminando com a mínima geração de descartes e no tratamento adequado de resíduos de forma ambientalmente correta.

Tais princípios apresentam conteúdo para subsidiar no estudo e construção de uma proposta inovadora para o ensino de Química, por exemplo, no que se refere ao pilar de número 7 que trata do uso de matérias-primas e recursos renováveis de preferência a não renováveis. 


\section{O DESENVOLVIMENTO LOCAL E A SUSTENTABILIDADE}

O Desenvolvimento Local pode ser descrito como um processo de construção do desenvolvimento de determinado território, sem a obrigatoriedade da limitação das fronteiras geográficas, tendo como um dos seus objetivos o constante desenvolvimento das habilidades e competências dos seus agentes humanos visando a melhoria da qualidade de vida da comunidade, que passa certamente a adotar uma identidade territorial (ÁVILA, 2001).

Nesse contexto a cidadania, tem um papel primordial:

"O Desenvolvimento Local deve se dar por dentro de processos participativos nos quais a cidadania, de forma individual ou por meio de seus diferentes agentes da sociedade civil, em diálogo com o poder público e o mercado, propõe soluções planejadas em prol do local/regional (TENÓRIO, 2007, p. 101)."

Diante disso, a educação exerce um papel fundamental, pois se espera que, a partir do conhecimento adquirido durante o percurso escolar, o cidadão seja capaz de tomar decisões que gerem transformações na sua comunidade, com o consequente Desenvolvimento Local, enfatizando-se que a formação é de suma importância para o exercício pleno da cidadania. A prática educativa pode possibilitar mudanças profundas numa comunidade pois a:

“[...] educação não deve servir apenas como trampolim para uma pessoa escapar da sua região: deve dar-lhe os conhecimentos necessários para ajudar a transformá-la (DOWBOR, 2007, p.76).”

Diante das dificuldades impetradas pela globalização, esses territórios precisam buscar a Sustentabilidade continuamente, e nesse aspecto, a educação contextualizada permite o estabelecimento de avanços nessa direção.

A inserção da Sustentabilidade no ensino traz pressupostos críticos, pois busca estabelecer espaços de convivência, onde se destaca o estudo das práticas cotidianas e de contextos reais da vida do discente, visando a compreensão e transformação da realidade (JACOBI, 2009).

O ensino sobre a Sustentabilidade deve contribuir principalmente para o exercício da cidadania:

"[...] ao buscar aprofundar os conhecimentos sobre as questões ambientais de melhores tecnologias, estimular a mudança de comportamento e a construção de novos valores éticos menos antropocêntricos (BERNA, 2004 p.18).”

É imprescindível a aquisição do conhecimento da temática da Sustentabilidade por parte dos agentes de um território, pois permite a quebra da fronteira entre a escola e a comunidade, traz as discussões sobre aspectos socioambientais para dentro do eixo pedagógico, visando solucionar problemas locais e desenvolver melhorias na comunidade a partir das análises, debates e estudos realizados (JACOBI, 2009).

Dowbor (2007) diz que:

"A dificuldade central, é de se inserir na escola um conhecimento local que os professores ainda não têm. Neste sentido, parece razoável, enquanto se organiza a produção de material de apoio para os professores e alunos - as diversas informações e estudos sobre a realidade local e regional - ir gradualmente inserindo o estudo da realidade local através de um contato maior com a comunidade profissional local (DOWBOR, 2007, p.16)."

Aliar a educação e a Sustentabilidade à busca do Desenvolvimento Local possibilita a redescoberta da riqueza de conhecimentos de uma comunidade, do seu território; trazendo sentido ainda maior para a sua valorização e transmissão para as próximas gerações. "Conhecimentos técnicos são importantes, mas têm de ser ancorados na realidade que as pessoas vivem, de maneira a serem apreendidos na sua dimensão mais ampla" (DOWBOR, 2007, p.90).

\section{CONCLUSÃO}

Conforme as observações feitas neste artigo, a Sustentabilidade junto ao ensino de Química constitui-se como importante instrumento para a construção de uma proposta de inovação educacional para o Ensino Médio.

Destaca-se a importância histórica dada a discussão ambiental e sobre os passos futuros na busca de uma Sustentabilidade capaz de prover condições favoráveis de existência e melhor qualidade de vida para todos, inclusive no que tange ao ODS.

Apontou-se, também, que o Ensino de Química tem sido repensado por inúmeros pesquisadores, mas que ainda há um vácuo entre a informação e o professor da rede pública, sendo necessário estabelecer formas de ampliar as possibilidades de acesso aos conhecimentos inovadores.

Efetivamente, demonstrou-se que para inovar o ensino de Química, a partir da inserção da temática da Sustentabilidade, também é necessária a reformulação das práticas educativas. Nesse sentido, a literatura analisada indica que a prática educativa deve compreender conteúdos que propiciem conhecimentos significativos ao aluno para possibilitar a sua atuação como agente de transformação de sua comunidade.

No que tange ao Desenvolvimento Local, ficou evidenciado que ao aliar o ensino de Química à Sustentabilidade, cria-se um ambiente favorável a inovações nas próprias comunidades onde a escola está inserida.

Por fim, os principais resultados apontam na viabilidade da construção de uma proposta de inovação no Ensino de Química a partir da Sustentabilidade como seu eixo norteador.

\section{REFERÊNCIAS BIBLIOGRÁFICAS}

ARAÚJO, A.; SILVA, M.. Ciência, Tecnologia e Sociedade; Trabalho e Educação: Possibilidades de integração no currículo de educação profissional e tecnológica. Ensaio Pesquisa em Educação em Ciências, América do Norte, 1424042012.

ÁVILA, Vicente Fídeles de. (Org.) Formação Educacional em Desenvolvimento Local: Relato de Estudo em Grupo e Análise de Conceitos. Campo Grande: $2^{\mathrm{a}}$ ed. UCDB, 2001

BERNA, Vilmar. Como fazer educação ambiental. 2. ed. São Paulo: Paulus, 2004.

BOTELHO, José Maria Leite. A educação ambiental na formação do professor para o ensino fundamental em Porto Velho - RO. UFRJ, 1998. 
BRASIL. Constituição da República Federativa do Brasil 1988. Organização de Alexandre de Moraes. 16.ed. São Paulo: Atlas, 2000.

BRASIL. Lei 9.795, de 27.04.1999. Dispõe sobre Educação Ambiental e institui a Política Nacional de Educação Ambiental, e dá outras providências. DOU 28.04.1999. Disponível em <http://portal.mec.gov.br/dmdocuments /publicacao13.pdf>. Acesso em 08 de agosto de 2014.

BRASIL. Lei 9394/96. Ldb Nacional. Disponível em <http://www.mec.gov.br>. Acesso em 17 de julho de 2014.

BRASIL. Ministério da Educação. Educação Ambiental: Aprendizes de Sustentabilidade. Cadernos SECAD 1/MEC. 2007.

BRASIL. Ministério da Educação. Secretaria de Educação Média e Tecnológica. Parâmetros Curriculares Nacionais (EM). Brasília: MEC, 2000.

BRASIL. Panorama da educação ambiental no ensino fundamental /Secretaria de Educação Fundamental Brasília: MEC/SEF, 2001.149 p.: il.

BRASIL. Ministério da Educação. Secretaria da Educação Média e Tecnológica. Parâmetros Curriculares Nacionais + $(\mathrm{PCN}+)$ - Ciências da Natureza e suas Tecnologias. Brasília: MEC, 2002.

CASTELLS, Manuel. O Poder da Identidade. São Paulo: Paz e Terra. 2001.

CORREA, A. G.; ZUIN, V. G. (Org.). Química Verde: Fundamentos e Aplicações. 1 ed. São Carlos: EDUFSCar, 2009 , v. 1, p. 9-22.

DELORS, Jacques. Educação: Um Tesouro a Descobrir. Relatório para a UNESCO da Comissão Internacional sobre educação para o século XXI - 6 Edição. - São Paulo: UNESCO, MEC, Editora Cortez, Brasília, DF, 2001, p. 82-104.

DIAS, Genebaldo Freire. Educação Ambiental, Princípios e Práticas. 9. ed. São Paulo: Gaia, 2010.

DOVERS, S.R.; HANDMER, J.W. Uncertainty, sustainability and change. Global Environmental Change, v.2, n.4, p.262-276, 1992.

DOWBOR, Ladislau. Educação e apropriação da realidade local. Estud. av. [online]. 2007, vol.21, n.60, pp. 75-90. Disponível em: <http://www.scielo.br/scielo.php? script=sci_arttext\&pid=S0103-40142007000200006\&lng=e n\&nrm=iso>. Acesso em 14 de set. 2014.

FREIRE, L. I. F. Pensamento crítico, enfoque educacional CTS e o ensino de química. Dissertação (mestrado em Educação Cientifica e Tecnológica) - Universidade Federal de Santa Catarina. Florianópolis - SC 2007.

GADOTTI, Moacir. Educar para Sustentabilidade: Uma contribuição à Década da Educação para o Desenvolvimento Sustentável. São Paulo: Ed, L, 2008

JACOBI, Pedro Roberto. Educação ambiental: o desafio da construção de um pensamento crítico, complexo e reflexivo. Educ. Pesqui. [online]. 2005, vol.31, n.2, pp. 233250. ISSN 1678-4634.Disponível: em:<http://dx.doi.org/ 10.1590 /S1517-97022005000200007>. Acessado em 03 de dezembro de 2014.
JACOBI, Pedro; TRISTAO, Martha and. FRANCO, Maria Isabel Gonçalves Correa. A função social da educação ambiental nas práticas colaborativas: participação e engajamento. Cad. CEDES [online]. 2009, vol.29, n.77, pp.63-79 . Disponível em: <http://www.scielo.br/ scielo.php ?script=sci_arttext\&pid=S0101-3262200900010 0005 \&lng $=$ en\&nrm =iso $>$. Acesso em 23 de ago. 2014.

JACOBI, Pedro. Educação ambiental, cidadania e sustentabilidade. Cad. Pesqui. [online]. 2003, n.118 pp. 189-206.Disponível em: <http://www.scielo.br/scielo.php ?script $=$ sci_ arttext\&pid $=$ S0100-15742003000100008\&l ng=en\&nrm=iso>. Acesso em 22 de ago. 2014.

LIMA, J. O. G., Do período colonial aos nossos dias: uma breve história do Ensino de Química no Brasil. Revista Espaço Acadêmico, v. 16, n. 140, p. 71-79, 2013.

MACEDO, E. F.; LOPES, A. C. A estabilidade do currículo disciplinar: o caso das ciências. In: LOPES, A. C.; MACEDO, E. (Org.). Disciplinas e integração curricular: história e políticas. Rio de Janeiro, DP\&A, 2002. p. 73-94.

MEADOWS, D. L., MEADOWS, D. H., RANDERS, J. \& BEHRENS, W.W. Limites do crescimento - um relatório para o Projeto do Clube de Roma sobre o dilema da humanidade. São Paulo: Ed. Perspectiva, 1972.

MININNI-MEDINA, Nana. Elementos para a introdução da dimensão ambiental na educação escolar $-1^{\circ}$ grau. Amazônia: uma proposta interdisciplinar de educação ambiental. Brasília, IBAMA, 1994.

MMA. Ministério do Meio Ambiente. BRASIL. Disponível em: 〈http://www.mma.gov.br>. Acesso em 14 de janeiro de 2015 .

MORIN, Edgar. A cabeça bem-feita: repensar a reforma, reformar o pensamento. Rio de Janeiro: Bertrand Brasil, 2002.

ONU. A ONU e o Meio ambiente. Disponível em: <http://www.onu.org.br/a-onu-em-acao/aonu-e-o-meio ambiente/>. Acesso em 16 de agosto de 2014.

ONU. Agenda Pós-2015. Disponível em: <http://nacoes unidas.org/pos2015//>. Acesso em 31 de outubro de 2015.

PNUD. ODM. Disponível em: <http://www.pnud.org.br/ ODM. aspx/>. Acesso em 09 de agosto de 2014.

QUADROS, Ana Luiza de et al. Ensinar e aprender Química: a percepção dos professores do Ensino Médio. Educ. rev. [online]. 2011, n.40, pp.159-176. ISSN 0104-4060. http://dx.doi.org/10.1590/S0104-40602011000 200011.

SACHS, Ignacy. Desenvolvimento includente, sustentável, sustentado. Rio de Janeiro: Garamond, 2004.

SARTORI, Simone; LATRONICO, Fernanda and CAMPOS, Lucila M.S.. Sustentabilidade e desenvolvimento sustentável: uma taxonomia no campo da literatura. Ambient. soc. [online]. 2014, vol.17, n.1, pp. 01-22. ISSN 1809-4422.

TENÓRIO, Fernando Guilherme. Cidadania e desenvolvimento local. Rio Grande do Sul: Unijuí, 2007. 
UNICEF, 2015. Objetivos de Desenvolvimento do

Milênio. Disponível em: <http://www.unicef.org/ brazil/ pt/overview_9540.htm>. Acesso em 10 de Jan. 2015.

\section{COPYRIGHT}

Direitos autorais: Os autores são os únicos responsáveis pelo material incluído no artigo. 


\title{
O ENSINO-APRENDIZAGEM DE CIÊNCIAS DE UM ALUNO COM SÍNDROME DE DOWN
}

\section{THE TEACHING-LEARNING SCIENCE OF A STUDENT WITH DOWN SYNDROME}

\author{
GIANCARLO SILVA COSTA ${ }^{1}$; NILSON SANTOS TRINDADE ${ }^{1}$ \\ 1 - UNIVERSIDADE FEDERAL DO PARÁ \\ giancarlosilvacosta@gmail.com; nilsonufpa17@gmail.com
}

\begin{abstract}
Resumo - O desenvolvimento em alunos especiais, principalmente em crianças com síndrome de Down, apresenta certas dificuldades, tanto no relacionamento interpessoal quanto no âmbito educacional. O processo de alfabetização, entre outros se torna algo desafiador, sendo indispensável o uso de estratégias no ensino-aprendizagem em suas distintas fazes. A pesquisa buscou compreender os processos de ensino e aprendizagem de ciências de um aluno com Síndrome de Down. A metodologia realizada é caracterizada como pesquisa participante com abordagem qualitativa. Foram utilizadas entrevistas semiestruturadas e anotações no diário de campo para a coleta de dados. Os resultados evidenciaram que os processos de ensinoaprendizagem de ciências de um aluno com síndrome de Down ocorrem satisfatoriamente, pois os professores não medem esforços para que se tenha um resultado positivo.
\end{abstract}

Palavras-chave: Síndrome. Down. Ensino-Aprendizagem.

Abstract- The development in special students, especially in children with Down syndrome, presents certain difficulties, both in the interpersonal relationship as in the educational scope. The literacy process, among others, becomes challenging, being indispensable the use of strategies in teaching-learning in its different fields. The research sought to understand the processes of teaching and learning the sciences of a student with Down Syndrome. The methodology is characterized as a participatory research with a qualitative approach. Semi-structured interviews and field diary annotations were used to collect data. The results showed that the processes of science teaching and learning of a student with Down syndrome occur satisfactorily, because teachers do not measure efforts to have a positive result.

Keywords: Syndrome. Down. Teaching-Learning.

\section{INTRODUÇÃO}

A trissomia do cromossomo 21 (síndrome de down) foi diagnosticada pela primeira vez no século XIX, em 1866 na Inglaterra. O Dr. John Langdon Down diagnosticou observando características fisionômicas em crianças com atraso neuropsicomotor, geralmente ocorrendo em mães com mais de 35 anos. O ser humano normalmente possuí 46 cromossomos, sendo 23 herdados do pai e 23 da mãe, crianças com a síndrome de down possuem 1 cromossomo a mais, que por sua vez se uni ao cromossomo 21 , ocorrendo o que chamamos de trissomia do cromossomo 21. Pueschel
(1999, apud BASSANI, 2012) afirma que: no decorrer da história da humanidade ocorreram várias mutações de genes e modificações cromossômicas, inclusive a síndrome de Down. Crianças com síndrome de down eram consideradas incapazes de aprender, essas crianças eram vistas como: "um estado regressivo da evolução humana".

A aprendizagem de alunos com síndrome de down vem sendo desenvolvida há décadas, porém de maneira errônea, nos primórdios esses alunos eram postos em salas de aulas especiais, e com isso, limitados a uma metodologia de ensino, que os tornavam mais e mais incapazes, após estudos realizados nessa área, foi demonstrado à capacidade cognitiva dos mesmos.

Com novas metodologias de ensino-aprendizagem, os alunos com síndrome de Down são introduzidos em salas regulares, hoje é sabido que alunos inseridos em turmas regulares têm maior rendimento escolar, conseguem desenvolver autonomia, habilidades e competências com maior rapidez.

O processo de alfabetização, entre outros torna-se algo desafiador, mas isso, não o torna impossível, uma vez que crianças especiais, como qualquer outra, tem potencial a ser explorado, porém se faz necessário o uso de estratégias no ensino-aprendizagem em suas distintas fazes. De acordo com Silva (2009, p. 10580) "O desafio proposto ao professor na inclusão do aluno com necessidades especiais também está, muitas vezes, relacionado à sua própria formação inicial e continuada na perspectiva da educação inclusiva". Perante este cenário, esta pesquisa pressupõe a responder a seguinte problemática: Como está ocorrendo os processos de ensino e aprendizagem de ciências de um aluno com síndrome de Down?

Este trabalho tem como objetivo principal compreender os processos de ensino e aprendizagem de ciências de um aluno com síndrome de Down. Os objetivos específicos foram: Verificar as práticas didáticopedagógicas da professora de disciplinas integradas no contexto de ciências deste aluno com síndrome de Down; Avaliar a relação entre o aluno Down com a professora da sala regular e a professora do espaço de Atendimento Educacional Especializado (AEE); Demonstrar às relações sociais do aluno com de síndrome de Down no âmbito escolar. 


\section{CONSIDERAÇÕES METODOLÓGICAS}

A pesquisa realizada é caracterizada como pesquisa participante com abordagem qualitativa. Os dados foram coletados de maneira contínua, em forma de observações em sala de aula e entrevistas semiestruturadas com gravação de áudio, com perguntas abertas.

As entrevistas foram realizadas de forma individual, com coleta de informações, levando em conta o grau de instrução do entrevistado, objetivando o máximo de esclarecimento ao entrevistado, a fim de obter informações relevantes à pesquisa.

$\mathrm{O}$ uso de entrevistas em pesquisas qualitativas é de suma importância, a fim de uma completa e perfeita analise do material.

\begin{abstract}
"Dentre as questões que se referem ao planejamento da coleta de informações, estão presentes a necessidade de planejamento de questões que atinjam os objetivos pretendidos, a adequação da sequência de perguntas, a elaboração de roteiros, a necessidade de adequação de roteiros por meio de juízes, a realização de projeto piloto para, dentre outros aspectos, adequar o roteiro e a linguagem. (MANZINI, 2012, p. 01)."
\end{abstract}

As observações ocorreram em sala de aula entre os dias $\left(1^{\circ}\right)$ primeiro e (30) trinta de setembro de 2016, na escola Municipal de ensino fundamental Carlos Drummond de Andrade, no município de Parauapebas-Pa. Visando compreender a cognição, ou seja, o ensino aprendizagem no âmbito de ciências, de um aluno Down, para isso foi realizada varias observações do aluno no ambiente escolar.

A sala a qual a pesquisada foi realizada foi a sala da $2^{\circ}$ etapa do EJA, da escola, a escola conta com 1104 alunos, sendo 25 alunos na sala da $2^{\text {a }}$ etapa do EJA onde foi realizada a pesquisa, a pesquisa teve como amostra (01) um educando, além de pesquisas com a professora do aluno, professora de sala multifuncional de ensino e a mãe do aluno.

O aluno sujeito desta pesquisa tem vinte e oito anos, o que de acordo com especialistas, com um aluno dessa idade isso pode implicar de maneira negativa no processo de aprendizagem, acarretando danos futuros ao aluno, criando ainda mais barreiras à cognição destes.

Foram realizadas observações em sala de aula, objetivando a precisão das informações obtidas com as observações comportamentais sem que houvesse interferência, proporcionando uma observação real do comportamento deste aluno, avaliando a reação do aluno frente aos desafios do cotidiano escolar, dando importância a cada interação, participação e resposta do aluno,

Nas observações o pesquisador focou o desenvolvimento do aluno Down, a metodologia utilizada pala professora e as reações do aluno frente às barreiras encontradas no ensino-aprendizagem.

O pesquisador utilizou a estratégia de observar as aulas do ultimo lugar da sala, sem que interferisse em quaisquer feedback por parte do educando, deixando fluir naturalmente o processo de investigação.

Também foram observadas as formas de interações de Fernando com a turma e com a professora, além de seu relacionamento com a cuidadora, a prática de atividades educacionais realizadas pela turma, assim como o envolvimento do educando, observando o que estava sendo transmitido.

Foi utilizado um comprometimento de não revelação, pseudônimos e termo de consentimento livre e esclarecido. Esse termo é um documento, onde esclarece e informa o sujeito, de maneira que não haja nenhum constrangimento ao mesmo. Sendo assumida a responsabilidade do pesquisador.

Os pseudônimos são utilizados, a fim de manter a discrição de pessoas, que estão submetendo-se a pesquisa cientifica entre outras, ou seja, a preservação da identidade das pessoas envolvidas na pesquisa.

Goldim (1997) Diz que o aspecto ético é a caracterização de que não haverá discriminação na seleção dos indivíduos nem a exposição a riscos desnecessários aos indivíduos.

$\mathrm{O}$ aluno sujeito de pesquisa é mencionado neste trabalho com o pseudônimo de: Fernando, as professoras apenas como: professora da sala regular e professora da sala multifuncional

A pesquisa foi realizada sob a autorização da mãe do aluno Down, com a confirmação de autorização assinada pela mesma. É bom lembrar que este estudo passou por um Comitê de Ética em Pesquisa.

\section{RESULTADOS E DISCUSSÃO}

As entrevistas foram devidamente analisadas, onde foram ouvidas as gravações de áudio e transcritas na integra, objetivando uma analise com precisão.

As observações em sala de aula foram de suma importância para evidenciar as práxis de ensinoaprendizagem da docente que foram devidamente anotadas.

Os dados foram analisados de forma qualitativa a partir de uma análise descritiva explanando as falas dos pesquisados e, ao mesmo tempo, expondo ideias de autores que versam sobre o assunto.

As entrevistas colhidas para esta pesquisa foram transcritas na integra, objetivando o máximo de precisão na interpretação das mesmas.

As observações em sala de aula foram realizadas sem nenhuma interferência pelo observador, atentando aos menores detalhes no decorrer das aulas.

De posse do material coletado, com analise nas observações e entrevistas foram obtidos os seguintes resultados:

\section{TRECHOS DA ENTREVISTA COM A MÃE DE FERNANDO}

$\mathrm{Na}$ opinião da mãe de Fernando, quando foi entrevistada, foi perguntado o que ela achava da inclusão de alunos down em sala regular de ensino. A mãe do aluno diz: 
outras crianças com a mesma síndrome, ele não aprendia quase nada."

A mãe diz ter passado enumeras dificuldades na tentativa de escolarização do filho, que não conseguia sequer a matrícula em rede pública de ensino. Acarretando prejuízos ao desenvolvimento cognitivo de Fernando.

Para Bassani (2012, p. 09) "Outro motivo da dificuldade na aprendizagem é o déficit de atenção, que desde os primeiros anos de vida prejudica o seu envolvimento em várias tarefas".

Ao ser questionada a respeito do progresso de Fernando após frequentar a escola inclusiva, a mãe relata:

"Sim, houve um progresso sem dúvidas, ele melhorou, pouco, mas ouve melhora, o que mais melhorou foi que ele agora senta à mesa pra comer, antes ele fazia as refeições sempre no chão. Ele também já conseguiu trocar de roupa sozinho, antes não conseguia fazer sem que as roupas ficassem do lado do avesso, os sapatos ele coloca ,mas ainda falta apender a amarrar os cadarços.'

$\mathrm{Na}$ opinião da mãe, Fernando fez progressos desde que passou a frequentar a escola inclusiva, mesmo sabendo das limitações do filho, a mãe acredita em seu desenvolvimento.

Durante a entrevista, a mãe de Fernando responde a pergunta sobre o grau da síndrome de down em seu filho, ela esclarece: "Bom, o medico nós disse que é do grau mais baixo, não é totalmente afetado pela síndrome, ele consegue falar, ele entende o que falamos e é capaz de realizar algumas tarefas".

De acordo com Silva (2009, p. 21) "É importante lembrar que há crianças com Síndrome de Down com um grau mais elevado e outras com menos e isso é importante no momento de mesclar as turmas".

A mãe de Fernando evidenciou seu aprendizado, demonstrado no cotidiano, além disso, recomenda a inclusão escolar para crianças com síndrome de Down, que segundo ela, deve começar o quanto antes.

A integração envolve a questão psicossocial e se refere às relações dos alunos com deficiências com os outros alunos, que é importante para que ocorram interações. (CARVALHO, 2007 apud SILVA, 2009).

A partir de observações realizadas na sala de aula do aluno Fernando, foi evidenciada a forma de ensinoaprendizagem ao qual o aluno recebia estímulos e era incentivado a participar da aula, contribuindo com respostas, nas aluas de ciências, o aluno interage sempre que convidado.

\section{TRECHOS DA ENTREVISTA COM UMA PROFESSORA DE SALA MULTIFUNCIONAL DE ENSINO}

De acordo com a professora, quando questionada quanto aos benefícios de introduzir alunos com síndrome de down em sala de aula regular disse a professora:

"Sim, o primeiro é a socialização com alunos ditos normais, segundo passo, nós trabalhamos de forma diferenciada, de forma que o aluno consiga assimilar conteúdo, utilizando uma metodologia onde os alunos consigam aprender a lê, escrever e etc."
Quanto às dificuldades na disciplina de ciências, segundo a professora da sala multifuncional:

\begin{abstract}
"Existe uma decadência, quando se fala em ensinar conteúdo de ciências com alunos down, nós temos deixado a desejar. Trabalhar ciências, mas como trabalhar ciências? $\mathrm{O}$ aluno precisa aprender a socializar ciências, dentro das ciências temos dois termos: quando se fala do aluno conhecer as partes do corpo humano, devemos trabalhar de forma diferenciada, o aluno down necessita de ser ensinado de forma diferente, um exemplo: a perna, o pé, quando se fala de doenças sexualmente transmissíveis (DST) o aluno down é desprovido de qualquer conhecimento nessa área, essa aula deve ser trabalhada com atividades adaptadas a fim dos alunos obterem conhecimento na área."
\end{abstract}

A educadora discorre a respeito do que acontece na sala multifuncional de ensino, onde os alunos down entre outros recebem um tratamento diferenciado com adequação às suas necessidades frente à ministração do conteúdo de ciências.

A professora ressalta que há um defect. Em relação à transmissão do ensino de ciências quando falamos de alunos down, podemos perceber um contraste entre a sala multifuncional de e a sala regular de ensino. A socialização com outras crianças no ambiente escolar faz-se necessária, uma vez que alunos especiais, espacialmente quando se trata de alunos com a síndrome de down, esses educandos têm dificuldades em se relacionar com colegas de classe, o que dificulta ainda mais a interação com o grupo. A escola deve criar um ambiente propicio a promover essa socialização.

O conteúdo ministrado em sala deve atender as mais diversas necessidades educacionais de cada educando.

"O desenvolvimento de crianças com Síndrome de Down não ocorre de forma espontânea. Não é um processo linear e, portanto, impossível de predizer. Dois aspectos influenciam fortemente o desenvolvimento cognitivo; aspectos exteriores (um ambiente estimulante, com muitas atividades), assim como aspectos interiores (motivação e processos interativos). Eles constituem uma reabilitação ecológica, pois é comum se observar na criança Down, severas alterações de internalizações de conceitos de tempo e espaço, que dificultarão muitas aquisições e refletirão especialmente em memória e planificação, além de causar muita dificuldade na aquisição da linguagem (WERNECK,, 1995 apud MARQUES; HARTMANN, 2012 ).”

\section{TRECHOS DA ENTREVISTA COM A PROFESORA DA SALA DE AULA REGULAR}

A professora de Fernando, quando questionada a respeito da absorção do conteúdo de ciências, relata: "Olha, eu vou ser sincera, ele não consegue acompanhar a turma no mesmo ritmo, não consegue guardar muita informação, mas se ele for estimulado sim, ele consegue".

A respeito de perguntas feitas a Fernando a professora $\operatorname{diz}$

"Quando perguntamos algo pra ele, sobre algum assunto passado, ele logo vai responder que não sabe, algumas coisas ele aprende, outras não, mas se você der tempo a ele, e fizer um esboço da

Volume 12 -n. 134 - Fevereiro/2017 
pergunta, ai sim ele irá pensar e depois te responde, é necessário dar certo tempo pra que ele possa processar a pergunta, e então ele da um retorno.

Para a professora da sala regular: "Fernando adquire interesse por algo concreto, ou seja, algo que se possa vê ou tocar. A atenção desses alunos é despertada com dinâmicas que visam à interação da turma".

As estratégias da educadora utilizadas em sala de aula, contribuíram para seu aprendizado, principalmente no que diz respeito a coordenação motora, na realização de tarefas do cotidiano. Estratégias criadas a fim de chamar a atenção dos alunos, são sempre bem vindas, ainda mais quando se trata de alunos com necessidades educacionais, essas dinâmicas são acompanhadas de brincadeiras, onde os alunos se divertem enquanto aprendem.

A professora não apenas discorre sobre o conteúdo oralizando, mas faz demonstrações com cartazes, logo após distribui perguntas á turma, sem que ninguém tenha alguma vantagem com relação ao outro. $\mathrm{O}$ que faz com que Fernando não se cinta inferior.

Para Bissoto (2005, p.86) "O desenvolvimento do indivíduo com síndrome de Down é, tanto quanto o de qualquer não portador, resultante de influencias social, cultural e genética".

$\mathrm{O}$ pesquisador faz uma pergunta à professora de Fernando, em relação à forma de trabalhar o conteúdo de ciências com a turma, de acordo com a educadora:

"O conteúdo de ciências é bastante martirizado, no semestre nós trabalhamos ciências duas vezes por semana, nós trabalhamos ciências da seguinte forma, por exemplo: saúde, reprodução, nós sentimos a necessidade de trabalhar esse conteúdo, não apenas com palavras ditas e escritas, mas também com vídeos, cartazes e imagens. Certo dia, a aula era sobre o sistema solar, fizemos uma dinâmica, da seguinte forma: pus Fernando no meio da roda, ele estava representando o sol no sistema solar, observei que ele passou a assimilar como funciona o sistema solar quando os colegas que representavam os planetas começaram a fazer os movimentos de rotação e translação, desta maneira ele percebeu o que esses movimentos de rotação e translação causam nos planetas."

\section{A professora acrescenta:}

"Com Fernando, eu vi a necessidade de trabalhar com dinâmicas, brincadeiras, porque eles gostam de algo que seja concreto, dessa forma eles conseguem entender melhor o conteúdo, com isso conseguem aprender. A questão da alimentação ele têm maior facilidade na aprendizagem, porque são coisas que eles convivem com isso todos os dias. Quando o assunto é cadeia alimentar, Fernando consegue assimilar melhor o conteúdo, fiz uma pirâmide alimentar, ele não lê, dessa forma é necessário trabalhar bastante com imagens, isso facilita muito em sua aprendizagem, o aluno down tem um déficit de atenção, se não houver estratégicas que chame a atenção desse aluno, ele não irá manter a atenção no que estar sendo transmitido à turma, mas sabendo que eles gostam de ilustrações como: vídeos, imagens e cartazes, trabalhamos de acordo com suas necessidades, sabemos que todos tem necessidades, mesmo os ditos normais, mas em se tratando de alunos Down, a metodologia deve ser diferenciada. Porque eles conseguem associar as palavras com as imagens."

Segundo a professora de Fernando, a escola não dispõe de material adequado, tornando um tanto dificultoso o ensino de ciências com a turma, espacialmente com Fernando, uma vez que o aluno tem dificuldade de concentração, o que torna a tarefa da educadora ainda mais árdua. Contudo a professora utiliza-se das mais diversas estratégias.

Fernando consegue atingir a cognição quando o conteúdo é transmitido de maneira pratica, através de dinâmicas, brincadeiras entre outros meios. Quando o assunto da aula é relacionado ao cotidiano, o aluno tem maior facilidade na absorção do conteúdo.

"A escola deve ter como foco tratar todas as crianças respeitando suas particularidades e diferenças. Essas peculiaridades e diferenças revelam o seu nível de desenvolvimento e caracterizam cada uma na sua singularidade dentro de uma pluralidade encontrada no cotidiano escolar e, em particular, na sala de aula. (MARQUES; HARTMANN, 2012, p. 1839)."

\section{OBSERVAÇÕES EM SALA DE AULA REGULAR}

Mediante as dificuldades no processo de ensinoaprendizagem de Fernando, a educadora encontra diversas barreiras, contudo, mediante esforços e criatividade, tem desempenhado com êxito a construção do conhecimento do aluno down incluído na turma, entretanto, Fernando responde de maneira eficiente às perguntas, quando estas estão relacionadas a algo que lhe chame atenção, ou mediante estímulos. Dessa forma acontece o ensinoaprendizagem, em meio a descontração, o que ratifica a informação da educadora de Fernando, que diz na entrevista: o que ele consegue aprender melhor é o que recebe estímulos, no caso de doenças como a dengue, ele sabe até mesmo falar sobre a doença, porque convive com isso na pratica, ou seja, é praticando que acontece a aprendizagem desse aluno. As coisas que são de seu cotidiano torna-se mais fácil de ser aprendida.

De acordo com Marques e Hartmann (2012, p. 1839).

"A escola deve proporcionar ao aluno condições para que ele possa desenvolver suas potencialidades, não é o aluno que se molda ou se adapta à escola, mas é ela que, consciente de sua função, coloca-se à disposição do aluno, tornando-se um espaço inclusivo."

É notório o contraste entre as salas de aula regular e a sala multifuncional de ensino, impondo mais barreiras ao processo de aprendizagem dos alunos Down. Enquanto na sala multifuncional o aluno Down dispõe de mecanismos estratégicos, metodologia diferenciada entre outras contribuições. A sala regular de Fernando não dispõe de recursos multimídia, material três $\mathrm{D}$, tornando o ensinoaprendizagem do aluno Down uma tarefa árdua, com menos resultados em seu desenvolvimento intelectual. 


\section{CONSIDERAÇÕES FINAIS}

É sabido que as questões norteadoras surgem dos objetivos específicos, então, neste trabalho vamos fazer referências a eles que consequentemente responderão as nossas questões.

Em relação ao primeiro objetivo especifico (verificar as práticas didático-pedagógicas da professora de disciplinas integradas no contexto de ciências deste aluno com síndrome de Down). Observou-se que as praticas didáticopedagógicas da professora de Fernando ocorre de maneira simples e divertida, porém de forma eficaz, Fernando tem um bom desempenho quando é estimulado a pensar, interagir nas aulas. O uso de recursos como: imagens, ilustrações, dinâmicas, materiais 3D, entre outros foi de suma importância.

Em resposta ao segundo objetivo (avaliar a relação entre o aluno com de síndrome de Down com a professora da sala regular, e a professora do espaço de atendimento da educação especializada) foi constatado que a relação entre Fernando com a professora da sala regular de ensino é como qualquer outra relação envolvendo aluno e professor, uma vez que Fernando não tem privilégios em sala de aula, a fim de que não haja discriminação para o educando, o aluno reage sempre que é provocado com estimulo, tem bom comportamento nas aulas de ciências, interage com a professora e com a turma.

Com a professora do espaço de atendimento da educação especializada, Fernando tem mais intimidade, mas sempre mantendo o respeito, respondendo às perguntas sempre que questionado.

No que diz respeito ao terceiro objetivo (demonstrar às relações sociais do aluno com de síndrome de Down no âmbito escolar) nas relações sociais apresentadas por Fernando no âmbito escolar, o educando interage pouco com colegas de sala, a não ser que haja iniciativa dos colegas de turma, não obstante, Fernando tem um bom relacionamento com todos da sala e também com sua cuidadora e professora.

Notou-se, então, que os processos de ensino e aprendizagem de ciências de um aluno com síndrome de Down ocorrem satisfatoriamente, pois os professores não medem esforços para que se tenha um resultado positivo.

Frente às adversidades, porém, não obstante de atingir o clímax no ensino-aprendizagem em alunos com síndrome de Down, a educação inclusiva surgiu como um novo paradigma no contexto educacional, desempenhando seu papel com êxito, criando meios capazes de despertar o interesse em alunos com necessidades especiais.

Ainda há muito que ser investigado a respeito do ensino-aprendizagem aos discentes com síndrome de Down em relação ao conteúdo de ciências, havendo variações entre indivíduos com esta síndrome.

Ao trabalhar ciências em alunos Down, é recomendável que o educador utilize os mais variados recursos, prendendo a atenção destes educandos, mediante estímulos, incentivos objetivando a compreensão, alcançando a cognição destes alunos.

\section{REFERÊNCIAS BIBLIOGRÁFICAS}

BASSANI, Cecília da Silva. A síndrome de Down e as dificuldades de aprendizagem, 2012. Disponível em:〈http://www.pixfolio.com.br/arq/1401280042pdf>.

Acesso em: 16 de maio 2016.

BISSOTO, Maria Luíza. O desenvolvimento cognitivo e o processo de aprendizagem do portador de síndrome de Down: revendo concepções e perspectivas educacionais. Ciências \& cognição. v. 04, 2005. Disponível em: <http://www.cienciasecognicao.or pdf>. Acesso em: 20 de maio 2016.

GOLDIM, José Roberto. Projeto de pesquisa: aspectos éticos e metodológicos, 1997. Disponível em: <http:// UFRGS https://www.ufrgs.br/bioetica/projeto.htm>. Acesso em: 16 de maio 2016.

MANZINI, Eduardo José. Entrevista semi-estruturada: análise de objetivos e de roteiros, 2012. Disponível em: www.sepq.org.br/IIsipeq/anais/pdf/gt3/04.pdf. Acesso em: 10 set. 2016.

MARQUES, Regina Rodrigues; HARTMANN, Angela Maria. Escolarização de alunos com síndrome de Down: um estudo de caso, 2012. Disponível em: <http://periodicos.ufsm.br/remoa/article/download/6191/369 1pdf $\rangle$. Acesso em: 20 de maio de 2016.

SILVA, Brígida Karina Liechocki Nogueira. Inclusão escolar de uma criança com síndrome de Down, 2009. Disponível

em:<http://www.pucpr.br/eventos/educere/educere2009/anai s/pdf/2465_1462.pdf >Acesso em: 21 ago. 2016.

\section{COPYRIGHT}

Direitos autorais: Os autores são os únicos responsáveis pelo material incluído no artigo. 


\title{
FORMAÇÃO CONTINUADA DE EDUCADORES DO CAMPO: PROBLEMATIZANDO A RELAÇÃO ENTRE FORMAÇÃO E DESENVOLVIMENTO PROFISSIONAL
}

\author{
CONTINUED TRAINING OF FIELD EDUCATORS: PROBLEMATIZING \\ RELATIONSHIP BETWEEN TRAINING END PROFESSIONAL \\ DEVELOPMENT
}

\author{
MARIA JUCILENE LIMA FERREIRA \\ UNIVERSIDADE DO ESTADO DA BAHIA \\ juci.ferreira@bol.com.br
}

\begin{abstract}
Resumo - Objetivamos com este artigo discutir os dados de formação e atuação de um grupo de docentes vinculados a uma Escola do Campo na região do extremo sul da Bahia, focalizando as relações entre formação, condições de trabalho $e$ as perspectivas de desenvolvimento profissional. Para tanto, ancoramo-nos em estudos que tratam sobre o projeto de Educação do Campo e as matrizes pedagógicas que o norteiam $e$, também, em estudos que tratam da relação entre formação de educadores, função e profissionalidade docente. A metodologia de pesquisa pautou-se em analisar as informações coletadas em rodas de conversa e documentos, como o projeto pedagógico da escola. Por fim, as considerações apontam que a formação continuada de professores não pode prescindir de princípios formativos relacionados ao aprofundamento teórico sobre o campo de atuação e as questões da luta dos trabalhadores.
\end{abstract}

Palavras-chave: Formação Continuada. Docência. Desenvolvimento Profissional.

\begin{abstract}
The article's objective is discuss the training and performance of a group of teachers linked to a field school in the extreme south of Bahia, focusing on the relationships between training, working conditions and professional development perspectives. To do so, we are anchored in studies that deal with the Field Education project and the pedagogical matrixes that guide it, and also in studies that deal with the relationship between training of educators, teacher function and professionalism. The research methodology was based on analyzing the information collected in talk wheels and documents, such as the school's pedagogical project. Finally, the considerations point out that the continuous formation of teachers can not do without training principles related to the theoretical deepening on the field of action and the issues of workers' struggle.
\end{abstract}

Keywords: Continuing Education. Teaching. Professional Development.

\section{INTRODUÇÃO}

A discussão sobre a formação continuada de educadores da Educação Básica constitui fundamental importância para a produção do conhecimento sobre a Educação e os fenômenos educativos oriundos da escola nesse nível de ensino. Isso porque a formação continuada é uma das dimensões mais elementares para o desenvolvimento profissional docente, no sentido da melhoria da qualidade do ensino e de suas funções na escola, bem como para a materialização de uma política para a valorização profissional dos educadores, coordenadores e gestores escolares, na medida em que esteja acompanhada de condições de trabalho satisfatórias, salário e carreira.

Ademais, a docência, desde o vigor da Lei de Diretrizes e Bases da Educação Nacional - LDBEN 9394/96, tem sido alvo de inúmeras atribuições. Concordamos que:

\footnotetext{
"A docência é o trabalho do professor. Trata-se de um trabalho no qual os profissionais desempenham um conjunto de funções que, no nosso entendimento, vai além da tarefa de ministrar aulas. Inclui o ensino, mas não se limita a ele. (FERREIRA, p. 83, 2015)."
}

Por isso mesmo, não é um trabalho simplório, que qualquer profissional pode executar - de modo algum pode significar transmissão de conteúdo, transferência de conhecimento ou explicação do conteúdo sequencial do livro didático apenas. Para muito além dessas ações, "a docência carrega consigo o teor de uma atividade especializada, que requer conhecimento específico e vinculado ao projeto de desenvolvimento profissional da categoria docente. [...]". (FERREIRA, p. 83, 2015).

Nesse sentido, faz-se imprescindível que o docente esteja em constante processo de formação, participando de cursos, grupos de estudos, reuniões pedagógicas e realizando pesquisa, de modo que seja possível o estabelecimento de um desenvolvimento profissional qualificado.

No caso dos educadores que atuam em Escolas do Campo, a urgência no estabelecimento do referido desenvolvimento é ainda maior, pois a história registra que a Educação no Campo brasileiro, sobretudo no baiano, em larga medida, esteve subsumida aos interesses políticos partidários, atrelada a princípios pedagógicos característicos das práticas educativas orientadas para as escolas urbanas. Não queremos aqui defender a cisão entre Escola do Campo e Escola da Cidade, mas acentuar que a Escola do Campo requer especificidades teóricas e metodológicas para que os 
processos educativos cumpram efetivamente as funções de ensino e de aprendizagem.

Cabe registrar que, desde a II Conferência Nacional de Educação do Campo, realizada em Luziânia - GO (2004) o movimento da Educação do Campo vem se consolidando, a partir do protagonismo dos Movimentos Sociais Populares do Campo, com a proposição de que os processos educativos devam partir da realidade social dos sujeitos em formação e, na sequência, a ela devam retornar, problematizando-a. Ademais, tem como pressuposto que o conteúdo, a apropriação e a produção do conhecimento somente se efetivam quando há o protagonismo dos estudantes e quando o conhecimento curricular se origina da realidade social concreta, visando a amplos estudos sobre esta a fim de transformá-la.

A partir dessa premissa, objetivamos com este artigo discutir os dados de formação e atuação de um grupo de docentes vinculados a uma Escola do Campo, na região do extremo sul da Bahia, focalizando as relações entre formação, condições de trabalho e as perspectivas de desenvolvimento profissional.

No desenvolvimento do artigo, abordamos uma discussão acerca das matrizes formativas para a docência no campo. Ademais, focalizamos o conceito de formação continuada e de desenvolvimento profissional, relacionandoo aos dados coletados sobre formação, formação continuada e trabalho pedagógico da escola. Por fim, apresentamos as considerações finais pertinentes.

\section{1-O Projeto de Educação do Campo e Matrizes Pedagógicas para a Docência}

O movimento da Educação do campo emerge do protagonismo dos trabalhadores camponeses quando passam a entender que a luta pela terra não pode se apresentar isolada de outras lutas contra a negação dos direitos sociais, a exemplo da educação no campo e para os povos do campo. Trata-se daquilo que se definiu como ato de "romper as três cercas: a do latifúndio, a da ignorância e a do capital" (STÉDILE, p. 16, 1997), ou seja, uma luta articulada às garantias dos direitos sociais usurpados, historicamente, pelos poderes dominantes.

Tal usurpação de direitos sociais se dá porque o sistema capitalista, no qual a sociedade brasileira se organiza e se desenvolve, tende cada vez mais a exigir que o estado cumpra cada vez menos com o atendimento dos direitos sociais de primeira necessidade, tais como saúde, educação, seguridade, previdência, entre outros. Dito de outra maneira, a proposta que está em jogo, na conjuntura política e econômica do nosso país, é a do Estado mínimo, no qual são transferidos para o mercado todas as políticas e serviços que antes eram vistos como direitos e como bens de serviços públicos e universais (BAVA, 2016).

Esta situação evidencia que há um processo acelerado de violação dos direitos sociais e políticos da classe trabalhadora adquiridos historicamente, bem como que há uma disputa por um projeto de país que negligencia a qualidade de vida do povo, minimiza a justiça, a igualdade social e a distribuição de renda em favor do mercado. Nesse sentido, coadunamos com o pensamento de Mésáros (2005):

“(...) De fato, o sistema do capital não conseguiria sobreviver durante uma semana sem as suas mediações de segunda ordem: principalmente o Estado, a relação de troca orientada para o mercado, e o trabalho, em subordinação estrutural ao capital. Elas (as mediações) são necessariamente interpostas entre indivíduos e indivíduos, assim como entre os indivíduos e suas aspirações, virando essas de "cabeça para baixo" e "pelo avesso", de forma a conseguir subordiná-los a imperativos fetichistas do sistema do capital. (MÉSÁROS, p. 72, 2005)."

Estamos, no atual momento histórico da política do país, vivenciando um refluxo das conquistas implementadas pelas lutas dos trabalhadores. Desse modo, a formação continuada dos educadores, sobretudo aqueles que atuam nas Escolas do Campo, pela especificidade das reivindicações do povo camponês, necessita ser planejada e intencionalmente definida em articulação com o movimento de Educação do Campo, a partir do qual os camponeses defendem e lutam por um projeto de campo e de país em que seja digno viver e estudar. Assim, poderão contribuir, em melhores condições, com o enfrentamento da luta.

Essa prerrogativa nos instiga a discutir as matrizes pedagógicas do projeto de Educação do Campo para a formação de educadores, bem como sua importância e pertinência para a orientação/organização do trabalho pedagógico na Escola do Campo.

Segundo Caldart (2012), as matrizes pedagógicas fundamentais são: trabalho; a luta social; organização coletiva; a cultura e a história.

Por matriz pedagógica, entendem-se os elementos teórico-práticos que orientam a organização do trabalho pedagógico, a relação dialética entre conteúdo/forma e objetivo/avaliação. Esses elementos também definem as características do agir humano, dos valores mobilizados nas relações entre os sujeitos coletivos e sociais em prol da transformação da realidade pelo pleno exercício da práxis pedagógica e social (CALDART, 2012; FREITAS, 2008).

A primeira matriz - trabalho - alinha-se à compreensão de que o trabalho é prática humana, fonte de criação da vida, atividade que exprime a relação entre homem e natureza, homem e homem, de forma equilibrada e não alienada. A escola deve tomar o trabalho como princípio educativo, envolvendo o estudante no cumprimento de tarefas socialmente necessárias dentro e fora da Escola do Campo, sob a compreensão do trabalho agrícola de orientação agroecológica e da politecnia, atentando ainda para as múltiplas formas de atividades produtivas e rompendo com a perspectiva dual do trabalho (um que pensa e o outro que executa).

A segunda matriz - a luta social - se alinha ao entendimento de que a luta social dos trabalhadores em geral e dos camponeses em particular é formativa, pedagógica e política. Implica adotar a luta dos trabalhadores como estudo científico, como material de análise crítica da realidade social, objetivando sua transformação.

A terceira matriz - organização coletiva - diz respeito à compreensão de que a organização coletiva é ferramenta elementar para o enfrentamento da luta de classe, para o aprimoramento das relações sociais na comunidade e na escola. Nesse sentido, impõe-se a importância da autoorganização dos estudantes, defendida pelo pedagogo russo M. M. Pistrak (1917-1932), a partir da qual os estudantes aprendem a conviver com distintos coletivos, a enfrentar conflitos e contradições e assumir a organização e luta por interesses da categoria estudantil. 
A quarta matriz - a cultura - é "entendida como experiência humana de participação em processos de trabalho, de luta, de organização coletiva que se traduz em um modo de vida que produz e reproduz conhecimentos." (CALDART, p. 42, 2012).

A quinta e última matriz - a história - diz respeito à compreensão de que a ação humana é prática social, sujeita às nuances que as condições materiais e contextos que impõem ao homem determinados atos. E, ao mesmo tempo, dialeticamente, esses atos são determinantes para novas ações humanas. Isso implica estabelecer leituras da realidade que articulam presente e passado e vice-versa. A historicidade deve ser o pressuposto basilar para o estudo, a luta e o trabalho.

Entendemos que as matrizes pedagógicas exigem que educadores do campo estejam em constante aprofundamento teórico-prático sobre os processos de ensino e de aprendizagem. A docência nesse contexto não deve abdicar do estudo continuado e crítico acerca da realidade social do campo, da luta dos camponeses, da sua cultura e da história que circunda a vida no campo.

De modo geral, a prática pedagógica qualificada exige sólida fundamentação teórica, o constante exercício de reflexão, bem como a análise e produção de conhecimentos sobre os processos pedagógicos que a escola e a docência realizam. Ou seja, diante da importância de um trabalho pedagógico e coletivo qualificado que alcance e fortaleça os princípios basilares do Projeto de Educação do Campo, fazse elementar que os Educadores do Campo estejam inseridos em um processo continuado de formação e atualização de seus conhecimentos, experiências e saberes produzidos no exercício da docência.

Nesse sentido, entendemos que a formação continuada de professores deva ser uma preocupação constante das pesquisas em educação, dos órgãos de fomento à pesquisa $\mathrm{e}$ dos gestores públicos da educação. Isso porque é dessa formação que a docência se insere no movimento qualificado de reflexão e análise sobre o fazer pedagógico, dos objetivos e intencionalidade dos processos educativos sobre o conteúdo e forma adotados no processo de ensino e aprendizagem (MORAIS, 2003; ROLDÃO, 2007; SILVA, 2011).

Ademais, o Conselho Nacional de Educação publicou, no dia 01 de julho de 2015, a Resolução $n^{\circ} 2$, que define as Diretrizes Curriculares Nacionais para a formação inicial, em nível superior e para a continuada. No teor da referida Resolução, Art. 16, encontra-se a seguinte definição:

\begin{abstract}
"A formação continuada compreende dimensões coletivas, organizacionais e profissionais, bem como o repensar do processo pedagógico dos saberes e valores, e envolve atividades de extensão, grupos de estudo, reuniões pedagógicas, cursos, programas e ações para além da formação mínima exigida ao exercício do magistério na Educação Básica, tendo como principal finalidade a reflexão sobre a prática educacional e a busca de aperfeiçoamento técnico, pedagógico, ético e político do profissional docente (BRASIL, p. 13, 2015).”
\end{abstract}

Dessa maneira, desenvolvemos um trabalho de pesquisa sobre as perspectivas formativas para um grupo de docentes que atua em uma Escola do Campo visando a problematizar a importância e as necessidades de processos formativos docentes.

\section{ASPECTOS METODOLÓGICOS}

A pesquisa se deu em uma Escola do Campo situada em um Assentamento de Reforma Agrária, na região do Extremo Sul da Bahia. No primeiro contato com a escola, foi apresentado o projeto de pesquisa intitulado: Formação Continuada de Educadores sob uma perspectiva crítica e emancipadora - Implicações para o trabalho pedagógico e coletivo em uma Escola do Campo no Extremo Sul da Bahia. Nesse momento, foi assinado, por cada participante da pesquisa, o termo de consentimento para o trabalho de campo e divulgação dos resultados obtidos. A direção da escola, por sua vez, assinou o termo de autorização exigido pelo Comitê de Ética da Universidade do Estado da Bahia (UNEB). Assim, foi assegurado no processo de análise o total sigilo sobre a identidade dos participantes e da instituição correspondente.

A metodologia do trabalho científico está ancorada no materialismo histórico dialético, a partir do qual percorreremos os caminhos para uma interpretação crítica sobre as relações de trabalho e as propostas pedagógicas existentes. Utilizamos, como instrumento de pesquisa, a observação direta in loco, roda de conversa com os sujeitos participantes da pesquisa e análise de documentos (PPP da escola).

A pesquisa se desenvolveu a partir das seguintes questões norteadoras: quais as características da formação dos docentes, participantes da pesquisa? Quais as perspectivas de formação continuada e a relação desta com o desenvolvimento profissional?

\section{1- Situando o Contexto da Pesquisa}

A escola oferece o Ensino Fundamental (séries finais) e Ensino Médio e conta com um quadro de 11 docentes para atender ao número aproximado de 80 estudantes, em tempo integral - vinculados ao Programa Mais Educação, e 90 estudantes no turno noturno, que cursam o Ensino Médio e a modalidade Educação de Jovens e Adultos - EJA. Todos os estudantes residem no Assentamento ou no seu entorno. Dentre os 11 docentes, 06 participaram da pesquisa.

As dependências físicas da instituição se apresentam em boas condições. Dispõe de uma sala de direção, uma secretaria, uma cozinha, 06 salas de aulas, sanitários e ampla área aberta em sua volta, onde se realizam atividades coletivas, como gincanas, assembleias e mística - atividade diária, artístico-cultural, coordenada e apresentada pelos estudantes.

Dentre as atividades programadas na jornada pedagógica 2016, destacamos o Projeto de Leitura, a ser elaborado e desenvolvido pelo coletivo de docentes, e as atividades do Programa Mais Educação, pois elas se destacam na medida em que buscam articular o trabalho pedagógico entre as áreas de conhecimento de Língua Portuguesa, Matemática, Geografia, História, Ciências, Biologia, entre outras, fortalecer o trabalho coletivo entre os docentes e orientar a auto-organização dos estudantes.

\section{RESULTADOS E DISCUSSÕES}

A formação inicial e continuada do profissional docente, não é um privilégio. Antes, configura-se como uma necessidade, um instrumento de trabalho, sem o qual não se faz possível assegurar qualidade pedagógica dos processos de ensino e de aprendizagem. A docência deve compreender o acúmulo de conhecimento científico e especializado sobre 
o objeto de ensino e as funções correspondentes ao exercício da profissão, e isso não se faz de uma só vez e sem estudo, mas em constante processo de ação, reflexão e ação-refletida - práxis.

Todavia, cabe, desde já, esclarecer que ambos os processos formativos não estão alheios ou à margem das condições de trabalhos que os docentes têm à sua disposição, à valorização salarial, à atenção que os gestores públicos dedicam aos planos de carreira da categoria e à valorização profissional. Em geral, são elementos que interferem diretamente no processo formativo docente e vice-versa.

De acordo com essa forma de pensamento, a formação docente compreende o processo inicial e continuado de aprendizagem sobre o ato de ensinar, o qual inclui, ao mesmo tempo, apreensão de um conhecimento especializado, a experiência da prática social entre os pares, a relação com o objeto de trabalho (o educando) e o exercício da práxis criadora visando a edificar processos da profissionalidade que contribuam com o fortalecimento do significado político e epistemológico do ofício de ensinar (FERREIRA, 2015).

A ação de ensinar é revolucionária na medida em que assume como pressuposto a produção de conhecimentos, a auto-organização dos estudantes e o trabalho coletivo entre pares e comunidade escolar em geral.

A partir das considerações supracitadas, vejamos a seguir as informações obtidas sobre o perfil profissional dos participantes da pesquisa:

Quadro 1 - Elementos do perfil profissional docente.

\begin{tabular}{clll}
\hline Identificação & Titulação & $\begin{array}{c}\text { Tempo } \\
\text { serviço }\end{array}$ & Vínculo \\
\hline E & Graduação & 05 anos & Temporário \\
I & $\begin{array}{l}\text { Cursando } \\
\text { Graduação }\end{array}$ & 15 anos & Temporário \\
R & Graduação & 10 anos & Temporário \\
J & Graduação & 13 anos & Temporário \\
L & Cursando & 03 anos & Temporário \\
P & Graduação & & \\
\hline
\end{tabular}

Consideramos que a intermediação entre formação docente, profissionalidade e desenvolvimento da escola envolve uma ampla rede de situações, contextos, referências, relações de poder, de conhecimento, de valores e de experiências que isenta os professores de sozinhos responsabilizarem-se pelo desenvolvimento profissional. Ancora-se nas condições estruturais e políticas que favoreçam os processos de identidade pessoal, profissional, profissionalidade e profissionalização da docência.

Nesse sentido, analisamos que os aspectos da formação, do tempo de serviço e do vínculo empregatício dos docentes estão imbricados entre si e têm implicações diretas no desenvolvimento profissional e no aspecto da valorização da docência. Isso porque o exercício docente exige conhecimento especializado, ou seja, o domínio teórico de conceitos e saberes acerca dos fenômenos educativos que possibilitem a capacidade criativa dos profissionais para tomar decisões e agir em diferentes situações de trabalho. Diante dessa prerrogativa, a formação e os saberes mobilizados no próprio exercício da docência são elementares para o aprimoramento do ofício, para interrogar tanto a prática quanto a teoria sobre a intencionalidade e os resultados da ação pedagógica. Isso significa dizer que "um elemento central do conhecimento profissional docente é a capacidade de mútua incorporação, coerente e transformadora, de um conjunto de componentes de conhecimento" (ROLDÃO, p. 100, 2007).

Tal capacidade, articulada ao tempo de exercício profissional, dedicado à reflexão crítica sobre os processos de ensino e de aprendizagem, amplia o arcabouço teórico-prático do profissional, orienta outras possibilidades de conhecimento e atitudes no desenvolvimento da profissão.

No entanto, o vínculo efetivo ou temporário interfere no conteúdo e forma que o trabalho assume, pois a carreira é um dos condicionantes relacionados ao desenvolvimento da profissão e ainda caracteriza o processo de valorização da docência. Quanto mais se está inserido em uma perspectiva de trabalho em que há possibilidades de aprofundamento de conhecimentos e o reconhecimento do processo e resultado aí mobilizados, mais se ampliam as condições satisfatórias para o desempenho desses resultados. Essa afirmação diz respeito ao fato de que o pertencimento efetivo do profissional a uma instituição, embora não seja uma regra geral, faz a diferença quanto à definição de objetivos e ações correspondentes. Ou seja, a rotatividade ou itinerância do quadro docente desfavorece a consolidação do trabalho pedagógico escolar, na sua inteireza (SAMPAIO; MARIN, 2004).

Ademais, as condições de precarização a que o trabalho docente, comumente, está submetido em nada favorece ao desempenho e valorização qualitativa do ofício e sim, o seu contrário (FERREIRA, 2015; FREITAS, 2008; (SILVA, 2011).

Outro aspecto relacionado à formação, valorização e desenvolvimento da profissão, identificado no processo de pesquisa diz respeito aos cursos de especialização e de "capacitação" realizados pelos docentes, os quais se encontram listados no Quadro 2:

Quadro 2 - Cursos realizados pelos docentes.

\begin{tabular}{|c|c|c|c|}
\hline Identificação & Cursos & $\begin{array}{l}\text { Carga } \\
\text { horária }\end{array}$ & Período \\
\hline $\mathrm{E}$ & $\begin{array}{l}\text { Língua Portuguesa } \\
\text { e interdisciplinaridade }\end{array}$ & 360 & 2014 \\
\hline I & $\begin{array}{l}\text { Alfabetização } \\
\text { multisseriada }\end{array}$ & 180 & 2015 \\
\hline $\mathrm{R}$ & Gestão escolar & 360 & 2014 \\
\hline \multirow[t]{2}{*}{$\mathbf{J}$} & $\begin{array}{l}\text { Programa Nacional } \\
\text { de Alfabetização na } \\
\text { Idade Certa-PNAIC }\end{array}$ & 360 & $\begin{array}{l}2011 \\
2014\end{array}$ \\
\hline & Gestão escolar & & \\
\hline $\mathrm{L}$ & $\begin{array}{l}\text { Letramento } \\
\text { alfabetização }\end{array}$ & 50 & 2015 \\
\hline $\mathrm{P}$ & Sem informação & - & - \\
\hline
\end{tabular}


Retomamos, a partir das informações do quadro 2, a discussão acerca da formação docente como processo inicial e continuado de aprendizagem sobre o ato de ensinar e desenvolver o trabalho pedagógico na escola. Consideramos que os trabalhos docente e pedagógico da escola requerem apreensão de um conhecimento especializado, a experiência da prática social entre os pares, a relação com o objeto de trabalho (o educando), intencionalmente articulados a processos de transformação do próprio conhecimento e da realidade social.

Nesse sentido, a atualização de conhecimentos se faz sempre importante e necessária. No primeiro aspecto, porque a produção de conhecimento contribui com o aprofundamento teórico-prático de questões relativas aos fenômenos da educação; e, no segundo aspecto, porque propicia condições de autonomia para orientar o trabalho pedagógico, atualiza conhecimentos, amplia possibilidades de acesso e uso de recursos didáticos-pedagógicos.

A pesquisa evidenciou que os docentes desejam e se esforçam para estudar, que compreendem a importância e a necessidade de aprofundamento de questões que envolvem processos educativos na escola.

Todavia, cabe destacar que não se trata de qualquer curso ou mera "capacitação", que tenha apenas o efeito acumulativo no currículo, mas de apreensão de conhecimento teórico prático que contribua para responder as demandas da comunidade escolar e, sobretudo, que subsidie, cada vez mais, o desenvolvimento qualitativo profissional - a profissionalidade do docente - objetivando o fortalecimento do significado político e epistemológico do ofício de professor.

A profissionalidade docente significa não só as formas de desempenho do ofício de ensinar, mas também a expressão dos valores e pretensões que se deseja alcançar e desenvolver nessa profissão. Trata-se da instituição de um conjunto de ações, valores, formas de sentir, pensar e agir que orientam as escolhas e decisões tomadas no processo de desenvolvimento profissional sobre situações, conhecimento, práticas na uma construção social e histórica do fazer dos professores - profissão em ato.

É nesse sentido que, ao mesmo tempo em que a profissionalidade se apresenta regulada pelo controle social e institucional, também conta com os próprios elementos de sua natureza para o enfrentamento e a superação dessa regulação. Ou seja, é um processo dialético de produção da profissão e da instituição escolar. No entanto, isso implica a busca individual, mas, sobretudo, coletiva e continuada pela articulação entre o desenvolvimento profissional e desenvolvimento da escola.

No caso dos docentes que atuam em Escolas do Campo, há um conjunto de especificidades teóricas e práticas que precisam ser consideradas nas perspectivas de cursos, de estudos e outras atividades que venham a ser planejadas pelos próprios docentes/ sujeitos em formação e instituições formadoras.

Assim, entendemos que as discussões apontadas na subseção inicial deste artigo indicam alguns desafios que se apresentam à formação e atuação do docente na escola do campo, qual seja tomar a escola da educação básica como objeto de estudo, assim como sua organização pedagógica e a referência do projeto mais amplo de educação da classe trabalhadora camponesa.

Tais desafios requerem processos formativos com sólido conhecimento teórico, compreensão política da luta de classe no país, articulação entre o conhecimento escolar e as formas de produção da vida. Nesse sentido, entendemos que os cursos de formação continuada devam subsidiar a atuação e o desenvolvimento profissional quanto à competência teórico, técnica e política.

Dentre os 05 cursos de formação continuada informados, destacamos os dois de natureza lato sensu (Língua Portuguesa e interdisciplinaridade e Gestão escolar), cursados por 03 docentes. Observamos que a temática é muito pertinente, pois ainda são muitos os desafios que se apresentam aos docentes e à escola propriamente dita para a realização de um trabalho pedagógico de perspectiva interdisciplinar, bem como o estudo sobre princípios e fundamentos da gestão democrática da escola representa uma necessidade ímpar para orientar os processos de funcionamento da instituição, as ações e atitudes pedagógicas.

Ressaltamos que, quando o curso apresenta uma carga horária maior, amplia-se a oportunidade de aprofundamento teórico-prático sobre a proposta curricular, assim como a inserção do estudante em atividades de pesquisa favorece à produção e apreensão de conhecimentos que venham contribuir diretamente com a qualidade da formação e, por conseguinte, com o desenvolvimento profissional do docente.

Segundo Paludo e Doll (2006),

“[...] o processo de pesquisa [...] tem que ser compreendido na sua potencialidade para a realização da formação humana, para a emancipação humana. Isto é, na possibilidade que propicia para a formação de sujeitos críticos, com capacidade de problematização, organização, manejo e produção de conhecimento que os coloca no patamar efetivo de poder se renovar permanentemente, com autonomia. Isso, independentemente do local de atuação, coloca o estudante em condições de garantir meios de sobrevivência e de ampliar as possibilidades de se colocar como sujeito frente aos desafios apresentados pela realidade, discutir estes desafios, tendo condições posicionar-se e de nela intervir (PALUDO; DOLL, p. 21, 2006)."

Faz-se necessário pontuar ainda a importância de cursos que oportunizem a relação de estudos sobre conjuntura política, econômica e social do país, de modo a subsidiar a compreensão do docente acerca dos projetos de campo e de agricultura postos para o país - um orientado pelos pressupostos do agronegócio e outro pela reforma agrária popular e agricultura familiar, ancorada nos princípios da agroecologia e soberania alimentar.

Portanto, a questão que se coloca aos programas de formação continuada e aos interesses dos docentes é: a formação continuada dos profissionais que atuam no campo deve ou não contribuir com a ampliação de leituras tanto sobre o campo profissional quanto sobre a conjuntura política e econômica que envolve o projeto de campo e a luta dos trabalhadores camponeses?

Trata-se de uma questão que provoca os gestores da educação sobre as finalidades dos processos formativos dos profissionais do ensino, sobre a natureza dos conhecimentos mobilizados nas atividades de formação, tendo como horizonte a qualificação do trabalho pedagógico que a Escola do Campo deseja construir. Portanto, deve constantemente ser formulado de maneira a estabelecer parâmetro de finalidade sobre a intenção, o programa 
curricular e perspectivas formativas que os cursos de formação continuada se propõem a realizar.

\section{CONSIDERAÇÕES CONCLUSIVAS}

No decorrer deste estudo, focalizamos aspectos da formação continuada de docentes e sua relação com o desenvolvimento profissional.

A pesquisa evidenciou que os docentes têm graduação na área de atuação ou estão concluindo o curso e se interessam em fazer cursos e estudos que ampliem seus conhecimentos acerca do campo profissional. No entanto, a Escola do Campo em construção, o Projeto de Educação do Campo e a luta dos trabalhadores camponeses necessitam, cada vez mais, de profissionais qualificados que contribuam com o fortalecimento dessa luta e dos projetos educativos protagonizados pelos sujeitos coletivos.

Destacamos os aspectos de precarização do trabalho docente, identificados no processo de pesquisa, como dado relevante para a problematização da relação entre formação continuada e o desenvolvimento profissional. Isso porque tanto o processo formativo de perspectiva emancipatória quanto as condições dignas para desempenhar as funções do ofício são imprescindíveis para a melhoria qualitativa da profissionalidadede docente e o desenvolvimento da profissão.

Consideramos que a formação continuada de professores não pode prescindir de princípios formativos como: uma consistente formação teórica e disciplinar específica da sua área de atuação; relação teoria-prática (práxis); participação e produção de pesquisa científica; garantia de espaços e situações de valorização do professor e do trabalho docente, discutindo a natureza do trabalho docente; e, por fim, articulação dos processos de formação, identidade, profissionalidade com a produção da escola. Ou seja, um trabalho articulado entre formação docente, desenvolvimento profissional e desenvolvimento organizacional da escola.

Trata-se de princípios e perspectivas formativas que exigem dos Educadores do Campo mergulhos profundos e continuados de teorias que subsidiem o trabalho pedagógico e a produção de conhecimento acerca da própria docência e dos desafios pedagógicos que se apresentam no cotidiano da escola e na comunidade em que a escola se insere, além do seu vínculo com a luta da classe trabalhadora.

O trabalho coletivo, portanto, pode se configurar como elemento fundamental no processo de formação dos Educadores do Campo para subsidiar o desenvolvimento profissional docente e o trabalho pedagógico na sua totalidade na medida em que este se caracterize como atividade criativa real, de participação efetiva, a partir do qual as pessoas traçam objetivas, propõem ações e as desenvolvem e avaliam, inserindo-se no movimento contínuo de unidade entre tória e prática - práxis.

\section{REFERÊNCIAS}

BAVA, Ś́lvio Caccia. Militância democrática. Editorial 113. In: Le Monde Diplomatique Brasil, n. 113, dez/2016.

BRASIL. Ministério da Educação. Resolução n. ${ }^{\circ}$ 2, de $1^{\circ}$ de julho de 2015. Define as Diretrizes Curriculares Nacionais para a formação inicial em nível superior (cursos de licenciatura, cursos de formação pedagógica para graduados e cursos de segunda licenciatura) e para a formação continuada. Diário Oficial [da] República Federativa do Brasil, Brasília, DF, 2 jul. 2015.

CALDART, Roseli S. Caminhos para a transformação da escola. In: AUED, Bernadete Wrublevski; VENDRAMINI, Célia Regina. (Orgs). Temas e problemas no ensino em escolas do campo. São Paulo: Outras expressões, 2012. p. $23-58$.

FERREIRA, Maria Jucilene Lima. Docência na escola do campo e formação de educadores: Qual o lugar do trabalho coletivo? 2015, 244f. Tese de Doutorado (Programa de Pós-Graduação em Educação)_ Universidade de Brasília, Brasília, 2015.

FREITAS, Luiz Carlos de. Crítica da Organização do Trabalho Pedagógico e da Didática. 9. ed. São Paulo: Papirus, 2008.

MÉSZÁROS, Istevan. A educação para além do capital. São Paulo: Boitempo, 2005.

MORAES, Maria Célia Marcondes de. [Org.] Iluminismo às avessas: produção de conhecimento e políticas de formação docente. Rio de Janeiro: DP\&A, 2003.

PALUDO, Conceição; DOLL, Johannes. Pesquisa e formação de educadores nos movimentos sociais do campo. In: CALDART, Roseli Salete; PALUDO, Conceição; DOLL, Johannes. (Orgabuzadores). Como se formam os sujeitos do campo? Idosos, adultos, jovens, crianças e educadores. Brasília: PRONERA: NEAD, 2006.

PISTRAK, Moisey M. Fundamentos da escola e do trabalho. 5. ed. Tradução de Daniel Aarão Reis Filho. São Paulo: Expressão Popular, 2000.

ROLDÃO, Maria do Céu. Função docente: natureza e construção do conhecimento profissional. In: Revista Brasileira de Educação, v. 12, n. 34, jan./abr. 2007.

SAMPAIO, Maria das Mercês F.; MARIN, Alda Junqueira. Precarização do trabalho docente e seus efeitos sobre as práticas curriculares. Educação e Sociedade, Campinas, vol. 25, n. 89, p. 1203-1225, set/dez. 2004.

SILVA, Kátia Augusta Curado Pinheiro Cordeiro da. A formação de professores na perspectiva críticoemancipadora. Linhas Críticas: Revista da Faculdade de Educação. Brasília-DF, v.17, n.32, p. 13-32, jan./abr. 2011.

\section{COPYRIGHT}

Direitos autorais: A autora Maria Jucilene Lima Ferreira é a única responsável pelo material incluído no artigo. 


\title{
PROJETOS DE LETRAMENTO: ESTRATÉGIAS INTEGRADORAS DE APRENDIZAGEM
}

\author{
PROJECTS FOR LITERACY: LEARNING STRATEGIES INCLUSIVE
}

\author{
ELZA R. BARBOSA PEIXOTO ${ }^{1}$; 2-MARIA JOSÉ DE PINHO² \\ 1; 2 - UNIVERSIDADE FEDERAL DO TOCANTINS -UFT \\ elza.peixoto21@gmail.com; mjpgon@mail.uft.edu.br
}

\begin{abstract}
Resumo - Neste artigo, temos como objetivo lançar olhares mais amplos sobre as formas de ensinar $e$ aprender, refletindo $e$ revendo conceitos $e$ metodologias que apontam para os caminhos da integração dos saberes. Com embasamento teóricometodológico pautado nos estudos da interdisciplinaridade de Fazenda (2005), Morin (2002, 2003, 2009), Santos (2008); nos Estudos do Letramento de Street (2014), Soares (2002), Rojo (2009) e gêneros textuais de Marcuschi (2006), buscou-se discutir sobre as possibilidades do trabalho de articulação dos saberes para responder a algumas indagações: Mesmo em um currículo tradicional, é possível desenvolver um trabalho articulado entre os saberes? Como se poderia vencer o caráter de ensino fragmentado tão enraizado no contexto escolar? Além dos princípios e pressupostos teóricos levantados, que responderam afirmativamente à primeira questão, foi apresentado como resultado prático de estratégia integradora, os projetos de letramento, numa abordagem aplicada no ensino fundamental, anos iniciais.
\end{abstract}

Palavras-chave: Letramentos. Interdisciplinaridade. Gêneros textuais 3.

\begin{abstract}
In this article, we aim to introduce broader perspectives on ways of teaching and learning, reflecting and reviewing concepts and methodologies that point to the ways of integrating knowledge. With a theoretical-methodological basis based on the interdisciplinary studies of Fazenda (2005), Morin (2002, 2003, 2009), Santos (2008); In the Studies of the Letture Street (2014), Soares (2002), Rojo (2009) and textual genres of Marcuschi (2006), we tried to discuss about the possibilities of the articulation work of the knowledge to answer some questions: Even in a traditional curriculum Is it possible to develop an articulated work among knowledge? How could we overcome the fragmented and fragmenting education so rooted in the school context? In addition to the principles and theoretical assumptions raised, which answered affirmatively to the first question, it was presented as a practical result of integrative strategy, the literacy projects, in an applied approach in elementary school, initial years.
\end{abstract}

Keywords: Literacies. Interdisciplinarity. Transdisciplinary. Genres.

\section{CONSIDERAÇÕES INICIAIS}

Nessas últimas décadas, embora a temática de práticas integradoras, como a interdisciplinaridade, estar presente no contexto da formação inicial e da continuada, não tem sido fácil para muitos professores se envolverem ou promoverem a compreensão de um processo formativo que objetive um ensino comprometido com o desenvolvimento de ações formativas integradoras (em oposição às práticas fragmentadoras do saber), capazes de promover a autonomia e ampliar os horizontes das práticas pedagógicas e da interação professor-aluno, principalmente.

Com base nesse contexto, constitui-se como problemática fundamental deste artigo as indagações sobre quais as possibilidades de desenvolver um trabalho articulado entre os saberes em uma escola de currículo tradicional e quais estratégias têm se apresentado como viáveis para ultrapassar o caráter de ensino fragmentado e fragmentador tão enraizado no contexto escolar.

Com o objetivo de apresentar uma resposta fundamentada para esses questionamentos, este artigo pautou-se, principalmente, na discussão sobre as possibilidades do trabalho de articulação dos saberes, trazida pelos estudos da interdisciplinaridade de Fazenda (2006), Morin (2002,2003,2009) e Santos (2008); pelos Estudos do Letramento Street (2014), Soares (2002) e Rojo (2009) e pelo ensino por meio dos gêneros textuais (Marcuschi, 2006).

Mesmo que essa forma de pensar integradora já esteja subsidiando, teoricamente, os fundamentos dos Parâmetros Curriculares Nacionais (PCN) desde 1998, no âmbito da prática docente não constitui, ainda, tarefa fácil. Neste sentido, e, considerando a proposta dos Estudos do Letramento, desenvolvemos este texto com o objetivo mostrar que é possível, mesmo em escolas com currículos tradicionais, despertar para conceitos mais amplos e integradores como os da interdisciplinaridade.

Apesar do termo não ser novidade e já figurar há algum tempo no contexto educacional, sua concretização ainda é relativamente lenta e limitada. Por isso, há a urgente necessidade de ressignificar, de rever procedimentos inerentes às práticas de ensino e aprendizagem, de modo que se identifique nelas, certa "ecologia" das práticas de letramento (RIBEIRO, 2014, p.75). É desta relação entre o mundo e a escola que partimos para nossas reflexões.

Nas seções deste artigo, procuramos, primeiramente, trazer para a discussão a interdisciplinaridade como perspectiva que vai muito além do currículo, e que demanda uma nova maneira de pensar e perceber o complexo mundo que nos rodeia. Depois, passa-se a situar as práticas de letramento na dinâmica da integração dos saberes, por meio dos projetos de letramento, que neste artigo apresentará uma abordagem em andamento no ensino fundamental, anos iniciais. 
Ao discutirmos nessa linha, buscamos contribuir para promover reflexões e ressignificar práticas relativas ao processo ensino-aquisição da leitura e da escrita, em uma perspectiva sociocultural. Espera-se que as discussões apresentadas neste texto tragam perspectivas para um caminho pedagógico viável no ensino de leitura e escrita em sala de aula, especialmente, no ensino fundamental, anos iniciais, pois no momento em que se constata uma rota possível, metodologicamente, esta passa a contribuir para o enriquecimento das práticas educacionais.

\section{PARA ALÉM DA DISCIPLINARIDADE: UMA EXIGÊNCIA DO MUNDO CONTEMPORÂNEO}

Ao acompanharmos, hoje, uma nova postura frente aos desafios da contemporaneidade, vemos o surgimento de um outro paradigma, denominado por Boaventura Santos (2004) de "emergente", que traz em seu bojo a interdisciplinaridade como metodologia viável para este tempo.

Realidade que requer novas metas para a educação e, à medida que se tornam perceptíveis as emergências educacionais, revelam mais inquietações sobre o fazer pedagógico, pois os paradigmas tradicionais não conseguem responder às demandas da sociedade atual. Assim como afirma Moraes (2003, p. 167)

[...] este momento revela-se de grande e extrema oportunidade para se catalisar mudanças educacionais importantes, transformar a maneira como pensamos e concebemos a escola, a educação e a própria vida.

Contudo, isso só será possível com a reforma do pensamento, para se romper com a lógica do reducionismo, da simplificação, da linearidade e da fragmentação. Segundo Morin (2009, p.21) "A reforma do pensamento é aquela que gera um pensamento do contexto e do complexo" nas suas inter-relações.

Dessa forma, romper com o paradigma da fragmentação implica em movimentos que "transgridam as fronteiras epistemológicas das disciplinas", como nos aponta Santos e Sommerman (2014, p.71), ou como assevera Raynaut (2014)

É necessária uma mudança que cale fundo na base epistemológica dos currículos, superando a construção de conhecimentos dicotômicos que erguem um mundo de falsos opostos, cegando a possibilidade de elucidar o dinâmico continuum que apresenta a realidade, dando origem a uma prática pedagógica organizada nos moldes da disjunção dos pares binários: simples-complexo, parte-todo, local-global, unidade-diversidade, particular-universal, sujeito-objeto, conteúdométodo, ensino-aprendizagem (RAYNAUT,2014, p.139).

Esta proposta vem em consonância com a multidimensionalidade e contextualização do conhecimento que dão o caráter da proposta de um novo paradigma. Mas não se trata apenas de conceitos, trata-se de um desafio, pois de nada adianta colocar dois professores de áreas distintas a planejar em conjunto, se o foco continuar sendo a transmissão do conhecimento apenas na exposição de conteúdo, sem desvelar a complexidade do processo de ensino aprendizagem, sem aproximar o estudo da realidade (RAYNAUT, 2014, p.137).
Ainda assim, é possível perceber, mesmo que lentamente, atitudes inovadoras articulando a religação dos saberes, mesmo no seio de uma estrutura social e educacional de natureza disciplinar. Mas é preciso ressaltar que, para se conectarem os fios, duas noções são importantes: primeira que não se trata de eliminar a disciplinaridade, mas de "ir além, de ultrapassá-la"; segunda, que não se trata de uma mudança no "fazer", mas no "ser". O educador é chamado a uma atitude transdisciplinar. Assim, aceitando a ambiguidade podemos, "por meio da interdisciplinaridade e transdisciplinaridade, inaugurar um tempo em que conhecer não é dominar, esgotar, exaurir, mas acima de tudo dialogar e conviver" (SANTOS E SOMMERMAN, 2014, p.28).

Inaugurado na década de 60, do século XX os estudos sobre a interdisciplinaridade marcariam sua incursão na educação na década seguinte, tendo como campo investigativo a interdisciplinaridade e linguagem (FAZENDA, 2006). De lá para cá, ampliou campo, ganhou força no discurso dos PCN e aproximou-se mais das salas de aula:

A interdisciplinaridade supõe um eixo integrador, que pode ser o objeto de conhecimento, um projeto de investigação, um plano de intervenção. Nesse sentido, ela deve partir da necessidade sentida pelas escolas, professores e alunos de explicar, compreender, intervir, mudar, prever, algo que desafia uma disciplina isolada e atrai a atenção de mais de um olhar, talvez vários (BRASIL, 2002, p. 88-89).

Mesmo assim, "Na prática, a interdisciplinaridade tem sido "utopia", sonhada por muitos, procurada por alguns" (FAZENDA, 2006, p.63). E neste enfrentamento de múltiplos desafios epistemológicos e sociais configurados até agora, especialmente nos questionamentos em torno do currículo que é adotado pela maioria das escolas, é necessário romper com as bases da racionalização e da fragmentação do saber que é a marca registrada do paradigma da modernidade, conforme Doll Jr. (2002).

No entanto, ao voltarmos nossos olhos para os letramentos ${ }^{1}$, concordamos com Thadei (2006, p. 66) que, tanto os seus aspectos conceituais como metodológicos evidenciam um caráter transdisciplinar, enquanto objeto que não pode ser reduzido a uma única ciência, e como o conhecimento gerado interdisciplinarmente se amplia ao tratar dos contextos envolvidos nas práticas de leitura e escrita, integrando saberes.

\section{O LETRAMENTO E OS GÊNEROS DISCURSIVOS EM UMA PERSPECTIVA INTEGRADORA}

Embora tratar de conceito de letramento seja algo bastante complexo, nos filiamos à abordagem dos Novos Estudos do Letramento (Street, 1984; Rojo, 2009; Soares, 2006), ou simplesmente como se fixou no Brasil 'Estudos do Letramento', (KLEIMAN, 2008, p.7). Esses estudos partem dos pressupostos que o aluno é um sujeito de linguagem que já traz para a escola suas práticas de

${ }^{1} \mathrm{O}$ termo "letramentos" se deve à visão do letramento como um fenômeno plural, usado como reconhecimento de que não existe apenas um tipo de letramento, mas letramentos, que vão surgindo de acordo com o desenvolvimento da sociedade e da tecnologia. Retornaremos a essa questão mais adiante. 
letramentos não-escolares, vistos que esses sujeitos estão expostos, constantemente, a diversas situações de uso da leitura e da escrita no contexto das relações sociais às quais convivem na família, na igreja, etc.

Dentre os pesquisadores do campo do letramento, Street (1984) apresenta sua concepção de letramento pautado em dois modelos: o modelo autônomo, que pressupõe uma única forma de letramento, cujas práticas se ligam apenas à lógica interna do texto, desvinculadas do contexto social; e o modelo ideológico, que toma o texto como um objeto linguístico-social e o entende como uma pluralidade de práticas letradas, social e culturalmente determinadas.

Aproximando das concepções trazidas por Street (1984), Soares (2009) aborda as dimensões individual e social do letramento.

Segundo Soares,

“[...] Letramento não é pura e simplesmente um conjunto de habilidades individuais; é um conjunto de práticas ligadas à leitura e à escrita em que os indivíduos se envolvem em seu contexto social" (SOARES, 2009, p.72).

Decorrente da perspectiva ideológica, a concepção de letramentos, no plural (Soares, 2009; Barton, Hamilton \& Ivanic, 2000; Rojo, 2009) vêm se firmando. Nela, não se prevê uma única forma de letramento, mas uma diversidade de letramentos, inclusive inter-relacionando a fala e a escrita como modalidades complementares da língua.

À escola, agência de letramento por excelência, cabe o compromisso com um processo contínuo, que proponha graus de desafios diferentes, arquitetados em conformidade com as várias faixas etárias e segmentos de ensino. Uma das possíveis maneiras de realizar essa tarefa é tratar o ensino da língua como interação, num processo dialógico (BAKHTIN, 2003), realizado pelos gêneros discursivos, que ocorrem na relação com os contextos.

É nesse ponto que a abordagem com os gêneros se encaixa e se faz necessária, pois por meio deles, é possível desenvolver um trabalho com a função social da linguagem, que deve ser tratada como ferramenta de interação e ação social. $\mathrm{O}$ trabalho com gêneros possibilita que a língua seja refletida em contextos reais de uso, garantindo o princípio do sentido e da interação nas práticas escolares, de modo que os conhecimentos advindos desse processo possibilitem uma efetiva inserção em práticas sociais, fazendo usos da leitura e da escrita de forma consciente e adequada a cada contexto, interagindo no mundo conforme necessidades comunicativas apresentadas. Assim, podemos abranger variedades linguísticas amplas com as quais os alunos irão se deparar em seu cotidiano,

Nesta perspectiva, ao organizar seu planejamento, ou mesmo definir o programa de ensino, o professor pode considerar quais gêneros de quais esferas (e com que práticas letradas, capacidades de leitura e produção agregadas) devem/ podem ser selecionados para abordagem e estudo (ROJO, 2009). Desta forma, por meio dos gêneros, é que a escola torna possível as práticas de letramento, pois, como nos pontua Marcuschi (2006, p.25)

"Quando ensinamos a operar com um gênero, ensinamos um modo de atuação sócio-discursiva numa cultura e não um simples modo de produção".
Tal procedimento corrobora para uma melhor assimilação, potencializando a eficácia das práticas de leitura e escrita, por meio de uma maior interatividade na relação professor x aluno; consequentemente, haverá um maior envolvimento com o conteúdo por parte do aluno. Sem contar que é uma excelente oportunidade que se abre, mesmo em escolas de currículo tradicional, para projetos integradores de interdisciplinaridade. Ainda assim é preciso levar em conta que:

\section{É impossível a construção de uma única, absoluta e geral teoria da interdisciplinaridade, mas é necessária a busca ou o desvelamento do percurso teórico pessoal de cada pesquisador que se asseverou a tratar as questões desse tema (FAZENDA, 2008, p.13).}

Trabalhar nessa linha requer muito esforço mesmo porque, na prática, sabemos que articular constructos teóricos diferentes é bastante complexo, tanto no campo das pesquisas, como ainda mais para os que buscam caminhos mais efetivos, tanto para ensino, quanto para a aprendizagem. Exemplo disso é o dilema teoria x prática, ou discurso x ação apresentada por Oliveira (2010), "na voz dos professores o que se ensina agora são os gêneros textuais (...) segundo uma perspectiva de letramento", meros discursos que não tem se efetivado na prática do professor, "discursos vazios" (OLIVEIRA, 2010, p. 326, grifos do autor). É notório que, ainda hoje, vivenciamos resistências por parte daqueles que se mantêm firmes às práticas tradicionais nas formas de ensinar. Sendo assim, como promover uma ação mais significativa na realização da mudança do discurso para uma prática mais efetiva?

Chartier (2000) trabalha essa questão no sentido de dispor as mudanças ocorridas em dois planos distintos: a primeira relativa à "natureza didática", os conteúdos por ensinar; e a segunda, de "natureza pedagógica", que dizem respeito à organização do trabalho, do fazer pedagógico. Nesse sentido, podemos entender que uma verdadeira aprendizagem de leitura e escrita necessita de um docente que cumpra uma função de mediador de competências pedagógicas e didáticas que seja capaz de fazer boas escolhas metodológicas.

Portanto o desafio que se coloca para os professores aponta para a direção de como desenvolver efetivamente o processo de aprendizagem da leitura e escrita na perspectiva do letramento, ou seja, um ensino que possibilite um olhar para as atividades realizadas pelos sujeitos dentro e fora do contexto escolar, afim de que o seu aprendizado o potencialize para as diversas situações comunicativas em suas práticas sociais diárias.

\section{UMA PERSPECTIVA INTEGRADORA: PROJETOS DE LETRAMENTO}

Por tudo que compreendemos sobre as concepções de interdisciplinaridade, acreditamos que é um objeto nunca completamente alcançado ou integralmente observado, visto que é uma prática derivada de uma atitude, normalmente concretizada em experiências reais de trabalho em equipe. Daí a dificuldade de alcançar um maior engajamento da escola, mas por isso mesmo, deve ser constantemente buscado.

Uma das maneiras de efetivação da interdisciplinaridade é o projeto pedagógico (DEWEY, 1997; HERNANDEZ E VENTURA, 1998), podendo tanto 
estar relacionado ao trabalho em grupos ou turmas, como a um grande projeto da escola. Essa pedagogia é bem vista pelo seu caráter potencializador de interdisciplinaride, pois permite integrar saberes, rompendo com as fronteiras das disciplinas e ampliando o universo de aprendizagem.

Isso equivale dizer que, ressignificar a sua prática conforme o que Kleiman (2007, p.16) denomina de projeto de letramento, resgatando seu próprio conceito

[...] um conjunto de atividades que se origina de um interesse real na vida dos alunos e cuja realização envolve o uso da escrita, isto é, a leitura de textos que, de fato, circulam na sociedade e a produção de textos que serão realmente lidos, em um trabalho coletivo de alunos e professor, cada um segundo sua capacidade (KLEIMAN, 2000, p. 238).

Dessa maneira, partimos do princípio que, de uma maneira geral, o trabalho com os gêneros textuais que, por natureza, é aberto a vários campos disciplinares, apresentase, naturalmente, como potencialidade de integração de saberes (interdisciplinaridade). Da mesma maneira, que ao se projetar como uma prática social de escrita, como uma forma de interação verbal e social, o texto passa a ser visto, concebido como ação e não mero instrumento de comunicação.

Dessa forma, adotamos a abordagem dos Projetos de Letramento (PL) como estratégia eficiente para a aprendizagem significativa da perspectiva interdisciplinar.

Assim, o sentido dos PL é contribuir para uma dinâmica mais interativa em sala de aula (professor- aluno), como para uma aprendizagem mais efetiva de prática de leitura e escrita, por partirem de questões ou problemas identificados pelos alunos ou de interesse do grupo e orientados pelo professor. Assim,

A aprendizagem funciona, então, como uma forma de construção do conhecimento que se instaura a partir de um processo dialético (relação do passado-presente-futuro; individual-coletivo; localglobal). Algo que se constrói num espaço de movimento (OLIVEIRA, 2014, p. 48).

A elaboração didática que apresentaremos para ilustrar um projeto de letramento envolve uma turma de $5^{\circ}$ ano de uma escola pública de Araguaína ${ }^{2}$. Importa registrar que tal iniciativa se deu após alguns encontros de formação que a equipe da escola teve sobre leitura e escrita na perspectiva dos letramentos. Diante das discussões suscitadas nos encontros, uma professora do $5^{\circ}$ ano resolveu aproveitar e se lançar num projeto integrador, partindo de um problema sempre recorrente ao final do ano letivo e a causa de muitas faltas na escola: a dengue.

Para o encaminhamento de um projeto de letramento, o primeiro passo é a identificação de um problema. Pode partir aleatoriamente no dia-a-dia da sala, como de uma escolha prévia; nos dois casos, os encaminhamentos devem partir, preferencialmente, dos próprios alunos, pois neste tipo de projeto é a parceria entre professor e alunos que os tornam protagonistas.

O tema foi trazido para a sala de aula com uma conversa iniciada pela professora sobre os alunos que

${ }^{2} \mathrm{O}$ acompanhamento desse projeto se deu na escola onde a autora desenvolve sua pesquisa de doutorado, devidamente aprovada pelo Comitê de Ética em Pesquisa. estavam faltando às aulas por causa da dengue. Vários questionamentos foram feitos, destaque para a quantidade de familiares que já ficaram enfermos por causa da doença, entre outras questões que apontaram para os conhecimentos da turma sobre o assunto e suas opiniões, chegando à questão: $\mathrm{O}$ que poderíamos fazer para solucionar este problema? Questão essa que foi o guia do projeto, pois não se tratou apenas do tema Dengue (posteriormente acrescido da Zika e Chikungunya), mas a busca de soluções para um problema real na vida dos alunos e seus familiares.

O passo seguinte foi a pesquisa sobre o problema e as possíveis soluções. Para essa etapa, os alunos trouxeram vários textos sobre o assunto e trabalharam em grupos. A professora distribuiu nos grupos vários outros textos em seus suportes, para lerem e debaterem com o grupo (reportagens - jornal, infográficos- revista, panfletos). Para a aula da semana seguinte, a professora contou com a palestra-teatro de um grupo de especialistas da Secretaria da Saúde, convidados pela coordenação da escola, para trabalhar o tema com todas as turmas.

O próximo passo foi a elaboração de uma lista de ações sugeridas para o problema. Dessa lista, foram escolhidas as ações que seriam realizadas. É importante nessa etapa o levantamento de todos os gêneros envolvidos nas ações, assim como as relações interdisciplinares que podem ser realizadas a partir das sugestões dos alunos.

A seguir, apresentamos um quadro que sintetiza o planejamento do projeto.

Quadro-síntese: etapas do projeto

\begin{tabular}{|c|c|c|}
\hline \multicolumn{3}{|c|}{$\begin{array}{l}\text { Tema: Dengue, Zika e chikungunya } \\
\text { Projeto: Todos contra o mosquito }\end{array}$} \\
\hline \multirow{2}{*}{ Etapa 1: pesquisa } & \multicolumn{2}{|c|}{$\begin{array}{l}\text { Etapa 2: Soluções } \\
\text { escolhidas }\end{array}$} \\
\hline & Ação 1 & Ação 1 \\
\hline $\begin{array}{l}\text { A fase de pesquisa e } \\
\text { debates em busca de } \\
\text { conhecimento sobre } \\
\text { soluções foi marcada } \\
\text { pela leitura de } \\
\text { diversos generos } \\
\text { textuais: }\end{array}$ & $\begin{array}{c}\text { Campanha de } \\
\text { combate ao } \\
\text { mosquito na escola } \\
\text { e com os familiares } \\
\text { e vizinhos para o } \\
\text { combate ao } \\
\text { mosquito. }\end{array}$ & $\begin{array}{c}\text { Receitas } \\
\text { caseiras de } \\
\text { repelentes e } \\
\text { armadilhas } \\
\text { para o } \\
\text { mosquito }\end{array}$ \\
\hline Genêros envolvidos & Genêros envolvidos & $\begin{array}{c}\text { Genêros } \\
\text { envolvidos }\end{array}$ \\
\hline $\begin{array}{l}\text { Notícias, reportagens, } \\
\text { infográficos, gráficos, } \\
\text { seminário, etc. }\end{array}$ & $\begin{array}{l}\text { Entrevista, cartaz, } \\
\text { panfletos, folhetos } \\
\text { explicativos, } \\
\text { informativos }\end{array}$ & Receita \\
\hline
\end{tabular}

Produto final: produção de materiais mais adequados para a campanha

Como um aspecto favorável à perspectiva discursiva das práticas situadas, podemos citar, ainda, a exploração interdisciplinar dos temas, envolvendo Matemática (tabulação de dados e produção de gráficos), Língua Portuguesa (leitura e produção de textos em diferentes gêneros); Ciências (saúde: as doenças, os tratamentos, a prevenção, o meio ambiente, saneamento básico ); Informática (uso da ferramenta computacional para edição de diferentes textos) e Artes (teatro de fantoches e produção de mosquitos com garrafas pet). 
Ainda na perspectiva das condições de produção dos textos, foi possível observar as possibilidades abertas com o projeto de letramento. Na definição do suporte da campanha de conscientização (cartaz e panfleto), nos gêneros que fizeram parte da pesquisa e serão produzidos (tabela, gráfico, entrevista/questionário) e as possibilidades do uso de gêneros orais (seminário, debate), entre outros.

Nossa intenção, em trazer este projeto como exemplo, foi de apresentar questões práticas relativas ao processo didático de aprendizagem significativa, mostrando que é possível integrar saberes, embora a análise do resultado efetivo do projeto tenha que ficar para um próximo momento, visto que o referido projeto ainda está em andamento.

\section{CONSIDERAÇÕES FINAIS}

A discussão que moveu este trabalho, a partir das teorias e dos conceitos apresentados, pretendeu pontuar os propósitos teóricos que justificam a necessidade da ação interdisciplinar, apontando os princípios e aspectos que caracterizam os Projetos de Letramento, concebidos como ferramenta que favorece uma aprendizagem contextualizada e integradora.

Conceber que as práticas sociais situadas no domínio escolar, exigem que os professores considerem-se agentes de letramento, sabedores de que não há uma disciplina específica para desenvolver os letramentos, é fundamental para dar prosseguimento a um trabalho voltado para o exercício de novas práticas, valorizando as vivências que os estudantes trazem de seu meio cultural e social, mediando a interação do aluno com o mundo da cultura escrita, promovendo a formação de alunos leitores e escritores competentes.

Com isso, esperamos contribuir para um amplo debate acerca das possibilidades e potencialidades da abordagem interdisciplinar dos projetos de letramento, como estratégias para vencer o caráter fragmentador, mesmo dentro de um currículo tradicional.

\section{REFERÊNCIAS BIBLIOGRÁFICAS}

BAKHTIN, M. (1979) Estética da criação verbal. 2. ed. São Paulo: Martins Fontes, 2003.

BARTON, David; HAMILTON, Mary; IVANIC, Roz (Org.) Situated literacies. London: Routledge, 2000.

BRASIL. Lei n. 9.394, de 20 de dezembro de 1996. Estabelece as diretrizes e bases da educação nacional. Disponível em:

<http://www.planalto.gov.br/ccivil_03/leis/19394.htm Acesso em: 26 ago. 2015.

Ministério da Educação e da Cultura. Secretaria de Educação do Ensino Fundamental. Parâmetros Curriculares Nacionais. Brasília: MEC/SEF, 1998.

CHARTIER, Anne-Marie. Réussite, échec et ambivalence de l'innovation pédagogique: le cas de l'enseignement de la lecture. Recherche et Formation pour les professions de l'éducation. Innovation et réseaux sociaux, INRP, n. 34, p. 41-56, 2000

DEWEY, J. Experiência e Educação. $3^{\mathrm{a}}$ Edição. São Paulo: Cia. Editora Nacional, 1979.
DOLL Jr, W. E. Currículo: uma perspectiva pósmoderna. Porto Alegre: Artmed, 2002.

FAZENDA, Ivani. Interdisciplinaridade: qual sentido? 2.ed. São Paulo: Paulus, 2006. 2008. O que é interdisciplinaridade? São Paulo: Cortez,

KLEIMAN, A. Preciso ensinar o letramento? Não basta ensinar a ler e a escrever? São Paulo: Produção Editorial, 2002.

Processos identitários na formação profissional. $O$ professor como agente de letramento. In: CORRÊA, M. L. G.; BOCH, F. (orgs.). Ensino de Língua: representação e letramento. Campinas, SP: Mercado de Letras, 2006.

Preciso "ensinar" o letramento? Não basta ensinar a ler e escrever? Campinas: Cefiel - Unicamp; MEC, 2005.

Professores e agentes de letramento: identidade e posicionamento social. Revista Filologia e Linguística Portuguesa, no . 08, 2006a, p. 409-424.

Letramento e suas implicações para o ensino de língua materna. Signo. Santa Cruz do Sul, v. 32 n 53, p. 1 25, dez, 2007.

Modelos de letramento e as práticas de alfabetização na escola. In: KLEIMAN, Angela B. (Org.). Os significados do letramento: uma nova perspectiva sobre a prática social da escrita. Campinas: Mercado da Letras, 2008.

KLEIMAN, A, B. In: MATENCIO, M, L, P. (Orgs) Letramento e formação do professor: práticas discursivas, representações e construção do saber. Campinas, SP: Mercado de letras, 2005. (Coleção Idéias sobre linguagem).

HERNÁNDEZ, F; VENTURA, M. A Organização do Currículo por Projetos de Trabalho. $5^{\text {a }}$ Edição. Porto Alegre: ArtMed, 1998.

MARCUSCHI, Luiz Antonio. Gêneros textuais: configuração, dinamicidade e circulação. In: BRITO, K. S.; GAYDECZKA, B.; KARWOSKI, A. M. Gêneros textuais. Reflexões e ensino. 2.ed. Rio de Janeiro: Lucerna, 2006.

MORAES, Maria Cândida. O paradigma educacional emergente. 10. ed. São Paulo: Papirus, 2003.

MORIN, Edgar. Religação dos saberes. Rio: Bertrand Brasil, 2002.

. Educação e complexidade: os sete saberes e outros ensaios, 5 ed. - São Paulo: Cortez: 2009.

Cabeça bem-feita: repensar a reforma, reformar o pensamento.8.ed. Rio de Janeiro:Bertrand Brasil, 2003.

OLIVEIRA, M. S. Gêneros textuais e letramento. RBLA, Belo Horizonte, v. 10, n. 2, p. 325- 345, 2010.

OLIVEIRA, Maria do Socorro. Projetos de letramento e formação de professores de língua materna Natal: EDUFRN, 2014.

RAYNALT, Claude. Interdisciplinaridade: mundo contemporaneo, complexidade e desafios à produção e à aplicação de conhecimento. In: Philippi Jr, A.; Silva 
Neto, A.J. Interdisciplinaridade em ciência, tecnologia \& inovação. Barueri-SP, Manole. 2014.p. 70-105

RIBEIRO. Alexandre Amaral. Práticas de letramento escolar na perspectiva integradora: por um meio ambiente linguístico cultural favorável à aprendizagem. In: AMARAL, Amélia Escotto do amaral. Formação para o Letramento: contextos, práticas e atores. Rio de Janeiro: Wak Editora, 2014.p.75-88.

ROJO, R. Letramentos múltiplos, escola e inclusão social. São Paulo: Parábola Editora, 2009.

SANTOS, Boaventura de Sousa. Para uma sociologia das ausências e uma sociologia das emergências. Revista Crítica de Ciências Sociais, n. 63, p. 237-280, 2002c.

SANTOS, Akiko. Complexidade e transdisciplinaridade em educação: cinco princípios para resgatar o elo perdido. Revista Brasileira de Educação v. 13 n. 37 jan./abr. 2008.

SANTOS. A, SOMMERMAN.A. Ensino disciplinar e transdisciplinar: uma coexistência necessária. Rio de Janeiro: Wak Editora, 2014.

SOARES, Magda. Novas práticas de leitura e escrita: letramento na cibercultura. Educ. Soc., Campinas, vol. 23, n. 81, p. 143-160, 2002.

2006.

. Alfabetização e Letramento. São Paulo: Contexto,

SOARES, Magda (1998). Letramento: um tema em três gêneros. 3 ed. Belo Horizonte: Autêntica, 2009.

STREET, B. V.(1984) Letramentos sociais: abordagens críticas do letramento no desenvolvimento, na etnografia e na educação. Trad.: Marcos Bagno. São Paulo: Parábola Editorial, 2014.

THADEI, Jordana Lima De Moura. Temas transversais e letramento nas séries Iniciais do ensino fundamental: para além da Transversalidade temática. Pontifícia Universidade Católica De São Paulo São Paulo 2006.

\section{COPYRIGHT}

Direitos autorais: Os autores são os únicos responsáveis pelo material incluído no artigo. 


\section{Área: Ciências Agrárias e Biológicas}

\begin{tabular}{|c|c|}
\hline $2-1$ & $\begin{array}{l}\text { ALIMENTAÇÃO SAUDÁVEL COMO METODOLOGIA DE ENSINO DE BIOLOGIA } \\
\text { HEALTHY FOOD AS BIOLOGICAL EDUCATION METHODOLOGY } \\
\text { Josiane Da Silva Brito; Carolina Lomando Cañete }\end{array}$ \\
\hline $4-1$ & $\begin{array}{l}\text { AVALIAÇÃO DE CRIANÇAS POR DOENÇAS RESPIRATÓRIAS EM UMA } \\
\text { UNIDADE DE PRONTO ATENDIMENTO EM MARINGÁ- PR } \\
\text { EVALUATION OF CHILDREN FOR RESPIRATORY DISEASES IN A EMERGENCY } \\
\text { UNIT IN MARINGA- PR } \\
\text { Viviane Fonseca Bungart'; José Paulo Garcia Cortez; Eraldo Schunk Silva; Ana Lúcia } \\
\text { Da Silva; Lucia Elaine Ranieri Cortez }\end{array}$ \\
\hline $4-6$ & $\begin{array}{l}\text { PERFIL EPIDEMIOLÓGICO DA INFECÇÃO PELO VÍRUS DA HEPATITE B NO } \\
\text { MUNICÍPIO DE PARAGOMINAS-PA } \\
\text { EPIDEMIOLOGICAL PROFILE OF HEPATITIS B VIRUS INFECTION IN THE } \\
\text { COUNTY OF PARAGOMINAS-PA } \\
\text { Eliete Soares Moreira; Nilcinete Pereira Da Silva; Rogério Valois Laurentino; Nilson } \\
\text { Santos Trindade }\end{array}$ \\
\hline $4-6$ & $\begin{array}{l}\text { USUÁRIOS DOS SISTEMAS DE SAÚDE: A PERCEPÇÃO E AVALIAÇÃO DOS } \\
\text { SERVIÇOS RECEBIDOS } \\
\text { USERS OF HEALTH SYSTEMS: THE PERCEPTION AND EVALUATION OF } \\
\text { RECEIVED SERVICES } \\
\text { Izabelle Cristina Garcia Rodrigues; Ivana França; Vera Lucia Pereira Dos Santos; } \\
\text { Daniel De Christo; João Luiz Coelho Ribas }\end{array}$ \\
\hline $4-8$ & $\begin{array}{l}\text { PARÂMETROS PREDITIVOS DO USO DE NARGUILÉ E SUAS CONSEQUÊNCIAS } \\
\text { PREDICTIVE PARAMETERS OF THE USE OF NARGHILE AND ITS } \\
\text { CONSEQUENCES } \\
\text { Eliane Gouveia De Morais Sanchez; Nayara De Paula Guerreiro; Beatriz Ribeiro } \\
\text { Farinha; Katiuscia Pereira De Resende; Hugo Machado Sanchez }\end{array}$ \\
\hline $5-1$ & $\begin{array}{l}\text { TRATAMENTOS PRÉ-GERMINATIVOS DE SEMENTES DE COENTRO } \\
\text { CULTIVADAS NO SUBMÉDIO SÃO FRANCISCO } \\
\text { PRE-GERMINATING TREATMENTS OF CORIANDER SEEDS CULTIVATED IN } \\
\text { SUBMÉDIO SÃO FRANCISCO } \\
\text { Gilmario Noberto De Souza; Isa Gabriela Vieira De Andrade; Sâmela Deise De Pinho } \\
\text { Gonçalves; Glória Caroline Santos Barbosa Da Silva; Antônio Bruno Nunes Oliveira; } \\
\text { Willian Costa Bezerra; Carlos Alberto Aragão }\end{array}$ \\
\hline
\end{tabular}


5-7 CARACTERIZAÇÃO DE SEMENTES E PRODUÇÃO DE MUDAS DE PTEROGYNE NITENS EM DIFERENTES AMBIENTES E SUBSTRATOS

CHARACTERIZATION OF SEEDS AND SEEDLINGS PRODUCTION PTEROGYNE NITENS IN DIFFERENT ENVIRONMENTS AND SUBSTRATES

Ana Lúcia Becker Rohlfes; Nádia De Monte Baccar; Liliane Marquardt; Valeriano Antonio Corbellini; Raquel Cassel Tassinari; Bruno Engel; Júlia Muller Trevisan 


\title{
Revista SODEBRAS - Volume 12 \\ $\mathrm{N}^{\circ} 134$ - FEVEREIRO/ 2017
}

\section{ALIMENTAÇÃO SAUDÁVEL COMO METODOLOGIA DE ENSINO DE BIOLOGIA}

\author{
HEALTHY FOOD AS BIOLOGICAL EDUCATION METHODOLOGY \\ JOSIANE DA SILVA BRITO ${ }^{1,2}$; CAROLINA LOMANDO CAÑETE21 \\ 1 - FACULDADE VALE DO CRICARÉ; 2 - IFES \\ Josianebrito@gmail.com,carollcanete@gmail.com
}

\begin{abstract}
Resumo - A vivência como docente permitiu-nos observar que os discentes do Ensino Médio apresentam maus hábitos alimentares, pois não associam bem o conhecimento adquirido em sala de aula, estando assim sujeitos a uma alimentação pobre em nutrientes. Este artigo tem como objetivo apresentar a correlação entre alimentação saudável no ensino de Biologia e um exemplo de atividade didático-pedagógica, desenvolvida nas aulas. $O$ corpus da pesquisa é composto por uma sequência didática. $O$ diagnóstico foi constituído de questionários respondidos por 385 alunos do Ensino Médio, da Escola Estadual de Ensino Fundamental e Médio Antônio José Peixoto Miguel, município de Serra, durante o ano letivo 2016. A análise dos questionários estava centrada na conexão entre os hábitos alimentares não saudáveis e a alfabetização científica. Os resultados das análises indicaram que a escola deve refletir $e$ explorar os conhecimentos relacionados aos hábitos alimentares apontando que a construção do conhecimento proporcionou mudança nos hábitos dos alunos entrevistados.
\end{abstract}

Palavras-chave: Ensino Médio. Hábitos Alimentares Saudáveis. Alfabetização Científica.

\begin{abstract}
The experience as a teacher allowed us to observe that the students of the High School have poor eating habits, because they do not associate well the knowledge acquired in the classroom, and are thus subject to a nutrient poor diet. This article aims to present the correlation between healthy eating in Biology teaching and an example of didactic-pedagogical activity, developed in class. The research corpus is composed of a didactic sequence. The diagnosis consisted of questionnaires answered by 385 high school students, from the State Primary and Secondary School Antônio José Peixoto Miguel, municipality of Serra, during the 2016 school year. The analysis of the questionnaires was centered on the connection between non-food habits And scientific literacy. The results of the analyzes indicated that the school should reflect and explore the knowledge related to eating habits, pointing out that the construction of the knowledge provided a change in the habits of the students interviewed.
\end{abstract}

Keywords: High School. Healthy Eating Habits. Scientific Literacy.

\section{INTRODUÇÃO}

A trajetória do ensino de Biologia é marcada por diferentes etapas, desde sua origem, até os dias atuais. Desde o início, ainda na Antiguidade (384 - 322 a.C.), o que tem incomodado tanto os pesquisadores quanto os professores que atuam em sala de aula, é elencar conteúdos adequados e inseri-los dentro do contexto de uma instituição de ensino (BIZZO 2012).

Bizzo e Chassot (2013) dizem que a história da ciência se tornou um componente acadêmico depois do ano de 1945. No início do século XX, havia uma classificação de conteúdos ligada ao programa de História Natural, claramente dominada pelo ensino europeu. A intenção do ensino de ciências, nesse período, era considerar diferentes organismos isoladamente e suas relações filogenéticas. Segundo Bizzo (2012), a discussão relacionada à classificação de conteúdos permaneceu até 1980, sendo que a partir da Constituição Federal de 1988 e da Lei de Diretrizes e Bases (LDB) em 1996, ficou estabelecido que, em todo o país, deveria haver uma base comum a ser complementada em cada sistema de ensino e em cada estabelecimento escolar.

É importante que a disciplina de Biologia seja um veículo que permita aos alunos ampliar cientificamente seus conhecimentos e os orientem a desenvolver uma vida com hábitos saudáveis. Sendo assim, é imprescindível priorizar a educação científica para que o aluno passe a refletir sobre o conhecimento adquirido e assim poder usar esse conhecimento na sua vida cotidiana. Faz-se necessário também a investigação das percepções dos alunos que cursam o Ensino Médio sobre os conteúdos ministrados com base na alfabetização científica. Neste contexto, Zabala (1998) afirma que o incentivo à prática da alimentação saudável é uma das variáveis metodológicas para elucidar a alfabetização científica, porque comer bem dá prazer ao ser humano e unido ao ensino, garante um resultado eficiente.

Nos últimos anos, o Brasil tem sofrido mudanças no padrão de saúde e consumo alimentar. O país ainda enfrenta doenças crônicas, como o diabetes, ocasionadas pela má alimentação de sua população e tem-se observado um aumento significativo do sobrepeso e da obesidade em todas as faixas etárias, principalmente em adolescentes. Basta estarmos inseridos na educação básica para perceber o quanto os adolescentes se alimentam mal, o que acarreta um alto índice de alunos com diversos problemas de saúde advindos dessa má alimentação. PRIORE (2010)

Segundo Chipkevitch (1995), a adolescência é a fase em que a maior parte dos jovens são espontaneamente atraídos pelos prazeres momentâneos. Esse prazer se estende à alimentação, onde os mesmos fazem uso de alimentos atrativos, de fácil acessibilidade, porém pobres em nutrientes. Para que haja uma transformação deste panorama, o incentivo a uma alimentação saudável tem sido apontado como uma das 
práticas educacionais mais promissoras e incluir esse tema no ensino de biologia se torna imprescindível (BRASIL, 2014).

Este artigo objetiva identificar o papel atribuído ao ensino da alimentação saudável na disciplina de biologia no Ensino médio, através de uma atividade didático-pedagógica desenvolvida em aulas de biologia da Escola Estadual de Ensino Fundamental e Médio no município da Serra/ES. Essa atividade teve como propósito promover uma aprendizagem sobre bioquímica, nutrição e diversidade dos seres vivos aos alunos para que os mesmos usem o conhecimento adquirido na intenção de modificar seus hábitos alimentares.

\section{ENSINO DE BIOLOGIA NOS PCNs, OCNs E NO CURRÍCULO BÁSICO DAS ESCOLAS ESTADUAIS DO ESPÍRITO SANTO}

Conseguir correlacionar os conteúdos propostos nos documentos oficiais do país é importante e Bizzo (2012) ressalva que, mais do que direcionar conhecimentos científicos, é basal que o ensino de biologia se volte ao desenvolvimento de competências que possibilitem ao aluno assimilar com esforço e perseverança as informações, compreendê-las, produzi-las e rejeitá-las, quando for o caso. Marandino (2009) completa, afirmando que o aluno deve apreender o mundo e se ver como possível agente dessa mudança, praticando uso dos conhecimentos adquiridos em sala de aula, em disciplinas como a biologia e suas tecnologias.

O Currículo Básico Comum/ES é enfatizado nesta pesquisa nas áreas de qualidade de vida das populações humanas e identidade dos seres vivos, especificamente envolvendo os conteúdos de bioquímica e nutrição, pretendendo, assim, fomentar a alfabetização científica e tecnológica dos cidadãos por intermédio de certa imersão na cultura científica e tecnológica, fundamental para a formação de cidadãos e cidadãs críticos que, no futuro, participarão na tomada de decisões. É igualmente fundamental para que os futuros homens e mulheres consigam uma melhor apropriação dos conhecimentos elaborados pela comunidade científica (PRAIA, PÉREZ E VI-LHES, 2007).

Os Parâmetros Curriculares Nacionais ( $\mathrm{PCNs}$ ) orientam o educando a se apropriar do autoconhecimento, valorizando e adotando hábitos saudáveis como um dos aspectos básicos da qualidade de vida e agindo com responsabilidade em relação à sua saúde e à saúde coletiva (BRASIL, 1998)

Os PCNs e o currículo básico das Escolas Estaduais estão em acordo em relação ao ensino de biologia, direcionando os profissionais quanto ao que se deve ser ensinado aos alunos, promovendo uma aprendizagem adequada dos conceitos científicos da disciplina, tornando-os conscientes de que suas atitudes trarão benefício para si e para o meio em que estão inseridos.

Bizzo (2012) ressalta que em 2010, entraram em vigor os eixos reformulados como seis grandes grupos de objetos de conhecimento, na matriz de referência do Novo Exame Nacional do Ensino médio, cuja ordem de apresentação não indica necessariamente uma sequência lógica de estudo no Ensino médio: moléculas, células e tecidos; hereditariedade e diversidade da vida; identidade dos seres vivos; ecologia e ciências ambientais; origem e evolução da vida e qualidade de vida nas populações humanas.

Gava (2008) corrobora com Valente (2003) no que é ressaltado pelos PCNs sobre os nutrientes que são evidenciados em todos os grandes grupos de objetos de conhecimento. $\mathrm{O}$ aluno alfabetizado cientificamente tem oportunidade de conhecer a si próprio e entender que os nutrientes adquiridos através dos alimentos e por ele ingeridos possuem o intuito de aprovisionar ao corpo humano a energia e os materiais designados ao desenvolvimento e à sustentação do organismo.

Mayr (2008) comenta que as abordagens em biologia são fundamentalmente diferentes e são necessárias novas explicações para que se alcance a apreensão deste ou daquele conteúdo. Temas complexos como bioquímica, nutrição e diversidade de seres vivos, infelizmente é repassado aos alunos de uma forma não atrativa e, consequentemente se transforma em um conteúdo intrincado, causando muitas vezes aversão à matéria. O estudo do metabolismo, regulação e estrutura de biomoléculas são, muitas vezes, conceitos sem sentido e desconectados para o educando, porém, são essenciais para o seu desenvolvimento integral.

Os PCNs ressaltam que a chegada do aluno ao Ensino Médio tem que ser impactante, ajudando-o no conhecimento do geral, proporcionando a ele se perceber como parte do ambiente, o que faz com que compreenda isso, tornando-o mais expressivo. Nicolini (2008) diz que a fisiologia é como é também responsável pela nutrição e é importante entender que os organismos são decorrentes de interações entre órgãos, aparelhos e sistemas, e estes são formados por células que interagem entre si.

As Orientações Curriculares Nacionais para o Ensino Médio (2006, v.2, p.23) sugerem que "o professor deve conduzir o aluno à compreensão de que todos os organismos estão sujeitos aos mesmos processos, como recepção de estímulos do meio" tendo assim uma compreensão ampla do auxílio de produtos que a biodiversidade proporciona. Corroborando com as OCN, Santos (2005) afirma que, tendo maior contato com as informações, os estudantes terão consequentemente uma sensibilização em relação ao autocuidado e à associação entre nutrientes, biodiversidade e saúde.

Os PCN, as OCN e o CBC/ES reforçam que são muitas as metodologias que devem ser empregadas, tais como desenvolvimento de projetos, jogos, seminários, debates, simulação, contextualização, interdisciplinaridade, diálogo, problematizações, experiências, pesquisas de campo e bibliográficas, produção e utilização de texto.

Os alunos devem compreender que os nutrientes são absorvidos pelo corpo e, a partir daí a nutrição envolve os sistemas do organismo humano e demais seres vivos. Marandino (2009) ressalta a necessidade de trabalhar o corpo humano sem fragmentar o mesmo. Concordando com ela, Bizzo (2012) afirma como os alunos ainda têm poucos elementos que os conduzam a cursar todo o ciclo empírico. Para isso, este mesmo autor ainda sugere que a escola deve definir seus projetos pedagógicos, seguindo as orientações curriculares. Tem-se aqui a necessidade de transpor o conhecimento, pois conteúdos tais como funções vitais básicas, realizados por diferentes estruturas, órgãos e sistemas, fazem com que o educando reflita sobre como está o seu desenvolvimento. Com isso, o aluno conhecerá as características que permitem sua adaptação nos diversos meios, entendendo que é possível compreender as relações de origem entre diferentes grupos de seres vivos e o ambiente em que essas relações ocorrem.

Ao destrinchar as funções, relacionando-as entre si na manutenção do ser vivo, o aprendiz conseguirá relacioná-las com o ambiente em que vive. Os diferentes seres vivos constituem conexão de origem entre os diversos grupos de 
seres vivos, cotejando essas diferentes estruturas. Com isso, poderão ser multiplicadores de conhecimentos da teoria da evolução, na explanação dessas relações, que são algumas das habilidades que esses estudos consentem desenvolver.

\section{1 - Metodologias de Ensino Biologia}

Tanto Krasilchik (1986) quanto Delizoicov e Angotti (2000) concordam que relacionar os conteúdos curriculares com o cotidiano dos alunos tem sido tarefa árdua para os profissionais da educação e os conteúdos que elucidam os nutrientes bioquímicos e biodiversidade associam-se às novas tecnologias. E como afirma Stryer (1999), uma forma que tornaria esse caminho menos doloroso seria pautá-los com a saúde. Bizzo (2012) sugere ressaltar as abordagens que associem o corpo humano à sexualidade, e também estimular estudos e definições de saúde e doença.

Bizzo (2012) estimula o professor a desenvolver um papel ativo, que busque no seu entorno elementos que possam ser reconhecidos pelos alunos e por seus familiares como interessantes, motivando com isso a aprendizagem referida a um contexto, seja qual for a modalidade didática escolhidacontextualização didática. Essa forma de contextualização depende quase exclusivamente da iniciativa do professor que não pode esperar protocolos prontos, uma vez que cada realidade é, em certo sentido, única. Corroborando com esses argumentos, os autores Delizoicov e Angotti (2000) e Gonzales (2006) acrescentam que é imprescindível ao professor a sua formação em Ciências Naturais, ou seja, aquele que assume o papel de atuar frente aos desafios propostos pela disciplina de biologia. E todos os seus objetivos devem estar devidamente preparados para o trabalho, não faltando com os compromissos em seus aspectos pedagógicos.

Dilizoicov, Angotti e Pernambuco (2002), discutem como contextualizar conhecimentos, complexos ou não, como micromoléculas dos nutrientes e sua ação dentro do organismo humano, para garantir o conhecimento científico. O CBC/ES (2009) e Bizzo (2012) sugerem que a contextualização diz respeito ao próprio conhecimento contextualização epistemológica. Nela, ressalta-se que o contexto do próprio desenvolvimento do conhecimento científico, que é situado historicamente em um tempo e lugar, ou filosoficamente, como uma forma de ver o mundo, se contrapõe a outras. Nesse caso, as fontes bibliográficas disponíveis para os alunos e para o professor têm papel decisivo.

É necessário que o aluno tenha a possibilidade de alcançar o conhecimento de forma clara e transformá-lo em atitudes que lhe trarão benefícios no presente e no futuro. $\mathrm{O}$ conteúdo de bioquímica e nutrição proposto pelo currículo da disciplina de biologia tem essa finalidade dentro das instituições. O que vemos são possibilidades de maior esclarecimento para conteúdos complexos. Através da alimentação, propende-se desenvolver a reflexão, o debate e a participação ativa dos estudantes no processo de sua aprendizagem e Bizzo (2012) ressalta que os alunos têm que apreender os conhecimentos da física, da química e da biologia e aplicar esses conhecimentos para ilustrar o funcionamento do mundo natural, projetar e sopesar ações de intervenção na realidade "natural", sem alusão alguma à repartição de conteúdos conceituais por séries ou anos.

Realizar atividades práticas que enfoquem os nutrientes, a relação destes com os conteúdos curriculares da disciplina de biologia permite que o aluno construa o conceito necessário e adequado. Os autores Bizzo (2012) e Krasilchik (1986) afirmam que as aulas experimentais e práticas proporcionam, através de um modelo prático e simples, um esclarecimento maior do que um longo texto explicativo ou uma aula expositiva, pois propicia um contato direto dos alunos com os fenômenos, dando aos mesmos possibilidades de manejar os materiais e equipamentos para analisar os organismos. Righi (2011) sugere as aulas práticas para facilitar aos alunos conhecer os componentes dos alimentos como uma metodologia eficiente que pode favorecer o hábito de ingestão de nutrientes saudáveis, contribuindo assim para a melhoria da saúde individual e coletiva.

A alimentação é um tema que possibilita a inserção das mídias e tecnologias para promover o ensino. Marandino (2009) e Bizzo (2012) sugerem o uso dessas tecnologias para reforçar a apreensão de conceitos tão complexos. Os filmes, os documentários, as produções cinematográficas abordam temas de nutrição em diferentes aspectos, podendo ser metodologias efetivas na produção do conhecimento. A interação entre aulas expositivas e diferentes tecnologias, reforçadas com debates e seminários que aprofundem ainda mais os conceitos e apresentem diferentes visões sobre um assunto garantem a alfabetização científica.

Conteúdos aglomerados e atuais, como os da disciplina de biologia, permeiam o universo escolar e fora dele, sempre, pois estão diretamente relacionados ao cotidiano de alunos e professores, que precisam de metodologias certas dentro das instituições para garantir a educação científica tão almejada pelos educadores. Zabala $(1998$, p.53) propõe a sequência didática como "série ordenada e articulada de atividades que formam as unidades didáticas", esclarecendo que esta é uma metodologia que permite expor o tema, observar, debater e avaliar. Também, Sasseron (2008) afirma que uma sequência planejada com o objetivo de permitir que os alunos trabalhem ativamente no processo de construção do seu conhecimento sobre o mundo, além de possibilitar discussões acerca dos benefícios e prejuízos que as Ciências e suas Tecnologias podem trazer para a Sociedade e Ambiente, unindo os pensamentos desses autores, estabelecem relações entre o uso de uma sequência didática de bioquímica, nutrição, diversidade de seres vivos e o processo de Alfabetização Científica.

O uso de metodologias diversificadas para o ensino de biologia se faz necessário através de um professor que é azado, inventivo e produtivo. Ele se apodera do aprimoramento da competência em dialogar, principalmente sobre esse conteúdo tão próximo do cotidiano do aluno, que também é um dos propósitos da profissão, o que acarretará em resultados nos educandos, quando estes forem requisitados a propalar o seu pensamento, constituindo uma aproximação ideal entre professor-aluno e aluno-mundo.

$\mathrm{O}$ aluno muitas vezes não associa os conhecimentos adquiridos no ensino básico ao seu cotidiano por falta de aproximação dos conteúdos do currículo à sua vida, então se faz necessário adotar diferentes práticas, de forma que o ensino seja realmente eficaz.

\section{METODOLOGIA}

Esse estudo teve a preocupação de ponderar sobre a Educação Científica nos alunos do Ensino Médio, da Escola Estadual de Ensino Fundamental e Médio no município d Serra/ES por meio dos componentes do currículo na área de Ciências da Natureza associados a averiguação da percepção dos alunos sobre a relação destes conteúdos com a 
alimentação e os acréscimos deste conhecimento científico que avalizará hábitos alimentares mais saudáveis e consequentemente uma boa saúde. Caracteriza-se como uma ação colaborativa, por acreditar no seu caráter emancipatório na construção e reconstrução do conhecimento socialmente elaborado. A pesquisa-ação é um tipo de metodologia de pesquisa na qual o pesquisador deve estar empenhado em solucionar algum problema através de uma ação. Portanto, para este tipo de pesquisa, o problema a ser solucionado torna-se objeto de estudo que segundo Thiollent (2005), uma das possíveis definições para esse tipo de estudo é uma "pesquisa social com base empírica" para solucionar situações coletivas.

\section{1- Instrumentos e Procedimentos Metodológicos}

Para obtenção dos dados de análise desta pesquisa, durante o período de 03 de março a 30 de setembro de 2016, na atuação à frente da disciplina de biologia para as turmas do Ensino Médio, da Escola Estadual de Ensino Fundamental e Médio, no município de Serra, foi elaborada uma sequência didática para cada série do Ensino Médio e ao final foi aplicado um questionário contendo 8 questões abertas para verificar a aprendizagem de 385 alunos de 15 a 18 anos, sendo 148 do $1^{\circ}$ ano, 129 do $2^{\circ}$ ano e 108 do $3^{\circ}$ ano, no turno matutino.

Esta pesquisa se enquadra na Resolução $n^{\circ} 510$, de abril de 2016, do Conselho Nacional de Saúde (CNS), como pesquisa envolvendo seres humanos. Entretanto, a primeira medida adotada ao iniciar a pesquisa foi quanto ao cumprimento da exigência ética de esclarecer aos participantes e aos seus responsáveis sobre os procedimentos a serem adotados durante toda a pesquisa e sobre os benefícios. Todos os participantes da pesquisa levaram para os responsáveis assinar a liberação para que cada um deles pudessem ceder, voluntariosamente, suas percepções quanto ao protótipo didático.

Sendo assim, seguindo a estrutura básica para a sequência didática (SD) proposta, definimos esquematicamente as etapas, compostas pela apresentação da situação, aulas expositivas e práticas e uma produção final. Assim, a sequência foi organizada com uma estrutura progressiva de construção conceitual daquilo que permitiria esclarecer os conteúdos de bioquímica, fisiologia humana e biodiversidade fomentando hábitos alimentares saudáveis nos alunos.

Dolz, Noverraz e Schneuwly (2004, p.93), ressaltam que um princípio geral de uma SD é a modularidade e a diferenciação, e esta "supõe a realização de atividades intencionais, estruturadas e intensivas que devem adaptar-se às necessidades particulares dos diferentes grupos de aprendizes". Assim, a etapa de apresentação da situação foi estruturada para que a SD se adequasse ao público-alvo desta pesquisa, sem produzir qualquer modificação nas demais etapas quanto à proposta de sua criação: uma ferramenta para o ensino de bioquímica, nutrição e hábitos alimentares saudáveis no ensino básico.

A etapa de apresentação da situação indicava as perspectivas sob as quais foram fundamentadas a SD e os alunos responderam a um questionário subjetivo, que possibilitou a professora avaliar as capacidades já adquiridas ajustando as atividades e os exercícios previstos em sala de aula na sequência às possibilidades e dificuldades reais das turmas. Além disso, foi definido o significado da sequência para os alunos, isto é, as capacidades que deveriam desenvolver para compreenderem o principal objeto das SDs, que era entender a bioquímica, nutrição e a diversidade dos seres vivos, com vistas a alcançar hábitos alimentares saudáveis.

As sequencias didáticas foram constituídas por várias atividades: aulas práticas, seminários, apresentação de vídeos e exercícios, fornecendo aos alunos instrumentos necessários para o domínio dos conceitos de bioquímica, nutrição e diversidade dos seres vivos, para permitir um desenvolvimento sistemático e aprofundado do tema "hábitos alimentares saudáveis", alguns alunos, entretanto, ainda tiveram dificuldades devido à desintegração dos conteúdos anteriormente aplicados e explicados a eles.

As atividades de experimentação envolveram processos como a montagem da estrutura de um carboidrato simples, a glicose (monossacarídeo de fórmula molecular C6H12O6), para identificar o carbono como o elemento fundamental das substâncias orgânicas. A verificação da ação da enzima amilase salivar que ressaltava a reação química entre a saliva e o amido iniciando a quebra deste nutriente na boca e terminava no final do processo da digestão, e o processo de especiação que ampliava o conhecimento dos alunos dando noções práticas da formação de novas espécies resultando na diversidade de seres vivos. A simulação de conceitos consistiu em criação de cardápios saudáveis tais como sucos naturais no lugar de refrigerante, salada de fruta no lugar de doces, biomassa de banana verde como ingrediente do brigadeiro no lugar do leite condensado. Foram desenvolvidas leitura e interpretação de textos, sempre associados diretamente às atividades de simulação de conceitos vinculados a nutrição. Visualização de vídeos ilustrativos de problemas e/ou conceitos relacionados à cada bioquímica, sistema digestório e diversidade dos seres vivos. A visita técnica foi feita no supermercado do bairro em Nova Almeida, Serra/ES para identificar alimentos que representassem os diversos seres vivos com possibilidade de entender as características dos diferentes seres vivos e como podem estar presentes em nossa alimentação.

\section{RESULTADOS}

Na primeira etapa do trabalho, que consistiu em aplicar atividades das SD em cada série do Ensino Médio da Escola Estadual de Ensino Fundamental e médio no município de Serra, os estudantes não tiveram dificuldades em participar e percebeu-se o interesse deles em adquirir informações referentes à bioquímica $\left(1^{\circ}\right.$ ano), nutrição $\left(2^{\circ}\right.$ ano), diversidade dos seres vivos ( $3^{\circ}$ ano). $\mathrm{Na}$ aplicação dos conceitos necessários para a realização dos exercícios propostos, 67 alunos ( $1^{\circ}$ ano), 23 alunos ( $2^{\circ}$ ano) e 17 alunos ( $3^{\circ}$ ano) ainda tiveram dificuldades devido à fragmentação dos conteúdos aplicados e explicados a eles.

Essa dificuldade ocorreu no primeiro ano quando os alunos não conseguirem associar os nutrientes aos componentes bioquímicos que compõem a pirâmide alimentar por exemplo. Nos alunos do segundo ano a dificuldade era em associar os nutrientes às etapas da digestão e no terceiro ano os alunos não imaginavam que alguns alimentos advinham de seres dos diferentes reinos dos seres vivos.

Bizzo (2012) afirma que se pode perceber que cada conteúdo do currículo traz complexidades que devem ser aproximadas do aluno possibilitando-o compreender as conexões da aprendizagem ao cotidiano de cada um, o que foi proporcionado com o decorrer das SDs e foram sendo 
corrigidas as dificuldades que surgiram anteriormente durante a aplicação das primeiras atividades. Na ocasião de aplicação dos exercícios seguintes os resultados foram mais satisfatórios.

A aplicação das aulas seguintes da SD foi essencial para avalizar a aprendizagem dos alunos. Foram passados vídeos em cada série e em seguida realizados seminários que deram aos alunos voz e os mesmos puderam expor suas opiniões e críticas a respeito do conteúdo aprendido. Estas aulas buscaram enfatizar as conexões existentes do que foi exposto a uma alimentação saudável.

Após os seminários, foram realizadas as aulas práticas. No primeiro ano os alunos montaram um monossacarídeo, um dissacarídeo e um polissacarídeo. Nas três turmas de $2^{\circ}$ ano as aulas práticas foram de verificação da enzima amilase salivar no amido. Os alunos conseguiram associar o amido como um componente bioquímico e sua necessidade de ser degradado ao ser ingerido nas refeições.

No terceiro ano, além das aulas teóricas e práticas, foi feita a visita técnica a um supermercado para identificação dos organismos pertencentes a cada reino de seres vivos. Os alunos saíram em grupos em dias alternados e fizeram um levantamento das espécies presentes em cada alimento e como elas poderiam fazer parte de nossa dieta de uma maneira equilibrada. Os adolescentes observavam os nutrientes e a associação destes aos alimentos do nosso cotidiano. Alguns estudantes questionaram o porquê das bactérias compor o Reino Monera, pois tinham dificuldade em visualizá-los. Esses alunos fizeram pesquisas na internet e nos livros didáticos para identificar qual alimento representava cada reino.

Os alunos muitas vezes não associam os conhecimentos adquiridos no ensino básico ao seu cotidiano, por falta de estratégias de aprendizagem que permitam essa aproximação. Essa dificuldade em fazer a associação implica numa alimentação inadequada. Krasilchik (1986) afirma que o professor usa muitos termos técnicos que sobrecarregam os alunos e o distanciam das conexões ideais de um conteúdo. Apoiando a autora, Marandino (2009) ressalta que o diálogo e a expressão por meio da fala são indispensáveis para a aprendizagem em suas dimensões cognitivas e afetivas, sendo essencial garantirem abertos os espaços para a manifestação dos alunos.

$\mathrm{Na}$ segunda etapa, usando como base as informações das aulas teóricas, os vídeos, seminários e as aulas práticas, os alunos organizaram um café da manhã que foi denominado "saber com sabor". Cada turma do Ensino Médio organizou uma mesa com cores diferenciadas e placas informativas para os alimentos saudáveis. Nas mesas haviam pratos como saladas de fruta, sanduiche natural, bolo sem cobertura, suco natural, torta de legumes, gelatinas, brigadeiro de biomassa de banana verde e frutas. Um momento importante nesta etapa foi a organização dos alunos em grupos, o que permitiu o momento da partilha entre os grupos e funcionários da escola, a compreensão dos conteúdos quando questionados, pois, pois assim, houve mais segurança em associar o que compunha a alimentação diária deles com os conteúdos trabalhados em sala de aula e nas demais atividades pela professora da disciplina. Tais aquisições possibilitaram aos estudantes desenvolver conceitos próximos da realidade e integrá-los ao seu dia a dia, possibilitando a compreensão bioquímica e nutricional dos alimentos e a e diversidade dos seres vivos, componentes da dieta alimentar. Ponto de destaque também foi a limpeza da escola ao finalizar o café da manhã. Durante toda a execução do trabalho o que chamou atenção foi a demonstração constante de curiosidade e entusiasmo por parte dos estudantes.

A terceira etapa constituiu em aplicar um questionário final aberto com o objetivo verificar a eficácia da aprendizagem de bioquímica, nutrição e seres vivos. A análise deste questionário permitiu verificar que a partir da aplicação das sequências didáticas os alunos conseguiram compreender os conteúdos propostos para cada série do Ensino Médio e a partir das ações desenvolvidas na escola, alcançaram um senso crítico com relação à alimentação. Os alunos definiram conceitos de biologia propostos no currículo e associaram a alimentação saudável a estes conteúdos. Os discentes também conseguiram analisar criticamente a qualidade dos alimentos consumidos por eles e que a mudança nos hábitos alimentares depende deles.

Bizzo (2012, p.8) afirma que "[...] o conhecimento provoca mudanças em nosso aparato cognitivo e mexe com nossas emoções e sentimentos [...]" e Leite (1987) relata que uma vida saudável está associada à ingestão correta dos nutrientes. Sendo assim a professora percebeu que, após participarem do MC, os alunos demonstravam ter adquirido a devida aprendizagem sobre Bioquímica e Nutrição, pois conseguiram estabelecer a relação entre os nutrientes e uma alimentação saudável, compreenderam que alimentos, nutrientes e bioquímica são assuntos interligados e as frases abaixo comprovam que os alunos conseguiam fazer essa relação: "Se você sabe o que seu corpo precisa você vai saber o que comer e ele vai funcionar regularmente" (Aluno primeiro ano). "Para ter uma alimentação saudável é importante conhecer os nutrientes para poder evitar que haja excesso de um, e a falda de outro, nos prejudicando." (Aluno do segundo). "Uma alimentação saudável é aquela que rica e variada em nutrientes" (Aluno do terceiro).

A participação dos alunos produzindo ações críticas que cooperaram para a construção coletiva do conhecimento e Bizzo (2012) afirma que desta forma o aluno compreende a saúde como resultado do bem estar físico, mental e cultural próprios e como consequência produz hábitos alimentares saudáveis. Corroborando com o autor acima Zabala (1998) afirma que a prática do trabalho em grupos favorece a aprendizagem e instiga as atitudes essenciais ao ser humano o que avaliza hábitos saudáveis.

Entendemos que a prática de metodologias diversificadas e alternativas em sala de aula promovem hábitos alimentares saudáveis a partir dos componentes do currículo da disciplina de biologia em alunos do Ensino Médio.

\section{CONSIDERAÇÕES FINAIS}

As diferentes atividades desenvolvidas durante a aplicação das SD's propiciaram relevante relação entre o teórico e o real. Esta relação é também significativa no contexto educacional, pois permite que os estudantes possam utilizar em outras situações os conhecimentos adquiridos na escola. Isso se maximiza quando a atividade é organizada e mediada pelo professor de forma que permita uma participação ativa do estudante e um espaço para reflexão e tomada de decisão. É importante ressaltar que a alimentação no ensino de biologia está fortemente pautada na promoção de hábitos alimentares saudáveis, no entanto, a associação de alimentos aos conteúdos do currículo das ciências da natureza assume uma importância significativa para o desenvolvimento da aprendizagem desta 
disciplina. Desta maneira, acreditamos que os hábitos saudáveis são significativos para o ensino da biologia e os alunos com esse conhecimento, podem associar os nutrientes com a qualidade ou não dos alimentos ingeridos e assim entender as doenças adquiridas com a má alimentação.

Julgamos que é importante a ocorrência desta discussão em diferentes níveis educacionais, sejam eles voltados à educação básica (ensino fundamental e médio) ou à profissional (formação inicial e continuada de professores de biologia). Neste sentido, acreditamos que a promoção de hábitos alimentares saudáveis se configura em um campo propício para futuras pesquisas na educação científica, sobretudo na área de ensino de biologia.

\section{REFERÊNCIAS BIBLIOGRÁFICAS}

BIZZO, N. Metodologia de Ensino de Biologia e estágio supervisionado. São Paulo: Ática, 2012.

BIZZO, N., CHASSOT, A., ARANTES, A., Ensino de Ciências: pontos e contrapontos. São Paulo: Summus, 2013.

BRASIL. Ministério da Saúde. Secretaria de Atenção à Saúde. Guia alimentar para a População Brasileira. Brasília, DF: 2014.

BRASIL. Ministério da Educação. PCN+ ensino médio: Orientações Educacionais Complementares aos Parâmetros Curriculares Nacionais. Ciências da Natureza, Matemática e suas Tecnologias. Brasília: Semtec, 2002.

CHIPKEVITCH, E. Puberdade \& adolescência: aspectos biológicos, clínicos e psicossociais. São Paulo: Roca, 1995. Parte 1.

DELIZOICOV, D.; ANGOTTI, J. A. Metodologia do Ensino de Ciências. São Paulo: Cortez, 2000.

DELIZOICOV, D.; ANGOTTI, J. A. PERNAMBUCO, M. M. Ensino de Ciências: fundamentos e métodos. São Paulo: Cortez, 2002.

DOLZ, J.; NOVERRAZ, M.; SCHNEUWLY, B. Sequências didáticas para o oral e a escrita: apresentação de um procedimento. In: ROJO, R.; CORDEIRO, G. S. (Org.). Gêneros orais e escritos na escola. 3. ed. Campinas: Mercado de Letras, 2004. p. 81-108.

GAVA, A. J., SILVA, C.A.B; FRIAS, J.R.G. Tecnologia de alimentos: princípios e aplicações. São Paulo: Nobel, 2008.

Gonzalez, F. G.; PALEARI, L. M. O ensino da digestão-nutrição na era das refeições rápidas e do culto ao corpo. Ciência \& Educação, v. 12, n. 1, p. 13-24, 2006.

KRASILCHIK, M. Prática de Ensino de Biologia. São Paulo: Harbra,1986.

LEITE, C. E. Nutrição e doença: um estudo da conexão entre alimentos e moléstias. São Paulo. IBRASA, 1987.

MAYR, E. Isto é biologia: a ciência do mundo vivo. Tradução: Cláudio Angelo. São Paulo: Companhia das Letras, 2008.

MARANDINO, M.; SELLES, S. E., FERREIRA, M. S. São Paulo: Coleção docência em formação. Série Ensino Médio, 2009.

$\mathrm{MEC} /$ secretaria de Educação Básica. Orientações Curriculares para o Ensino Médio. Brasília, DF, 2006, v. 2. Disponível em:http://portal.mec.gov.br/seb/arquivos/pdf/book_volume_02 _internet.pdf
NICOLINI, E. S, ARAÚJO, N., CALUZI, J.J., CALDEIRA. A.M. A. Práticas integradas para o ensino de biologia. São Paulo: Escrituras Editora, 2008.

PRAIA, J.; GIL-PÉREZ, D.; VILCHES, A. O papel da natureza da ciência na educação para a cidadania. Ciência e Educação, Bauru, v. 13, n. 2, p. 141-156, jun. 2007.

PRIORE, Silvia Eloiza, OLIVEIRA, Renata Maria S., FARIA, Eliane Rodrigues, FRANSCESCHINI, Sylvia do Carmo C., PEREIRA, Patrícia Feliciano. Nutrição e saúde na adolescência. Rio de Janeiro. Editora Rubio, 2010.

RIGUI, M. M. T.; FOLMER, V., SOARES, F. A. A. Concepções de estudantes do ensino fundamental de escolas públicas sobre alimentação. VIDYA, v. 31, n. 1, p. 63-76, jan. /Jun., Santa Maria, 2011.

SANTOS, L. A. S. "Educação alimentar e nutricional no contexto da promoção de práticas alimentares saudáveis". Revista de Nutrição, Campinas, 18(5): 681-692, setembro/outubro, 2005.

SASSERON, L. H.; Carvalho, A. M. P. Almejando a alfabetização científica no ensino fundamental: a proposição e a procura de indicadores do processo Investigações em Ensino de Ciências - V13(3), pp.333-352, 2008.

STRYER, L. (1999) Biochemistry. 4th ed., W.H. Freeman and Company, New York, xxvii p. 9.

ZABALA, A. A prática educativa: como ensinar. Tradução: Esnari F. da F. Rosa. Porto Alegre: Artmed, 1998.

Penso, 2014.

A prática educativa: como ensinar. Porto Alegre:

\section{COPYRIGHT}

Direitos autorais: Os autores são os únicos responsáveis pelo material incluído no artigo. 


\title{
AVALIAÇÃO DE CRIANÇAS POR DOENÇAS RESPIRATÓRIAS EM UMA UNIDADE DE PRONTO ATENDIMENTO EM MARINGÁ- PR
}

\author{
EVALUATION OF CHILDREN FOR RESPIRATORY DISEASES IN A \\ EMERGENCY UNIT IN MARINGA- PR
}

\author{
VIVIANE FONSECA BUNGART'1; JOSÉ PAULO GARCIA CORTEZ2; ERALDO SCHUNK SILVA ${ }^{3}$; \\ ANA LÚCIA DA SILVA ${ }^{4}$, LUCIA ELAINE RANIERI CORTEZ ${ }^{5}$. \\ 1 - ACADÊMICA DO CURSO DE MEDICINA DO UNICESUMAR, MARINGÁ - PARANÁ. \\ BOLSISTA DO PROGRAMA DE INICIAÇÃO CIENTÍFICA (PROBIC); 2 - MÉDICO- CO-ORIENTADOR; \\ 3-PROFESSOR ADJUNTO NA UNIVERSIDADE ESTADUAL DE MARINGÁ - UEM, MARINGÁ PR \\ BRASIL; 4 - MÉDICA OTORRINOLARINGOLOGISTA, DOCENTE DO CURSO DE MEDICINA DA \\ UNICESUMAR E MESTRANDA EM PROMOÇÃO DA SAÚDE PELA UNICESUMAR; 5 - PROFESSORA \\ DOUTORA DO CURSO DE MEDICINA E MESTRADO EM PROMOÇÃO DA SAÚDE DO CENTRO \\ UNIVERSITÁRIO CESUMAR - UNICESUMAR. ORIENTADORA \\ vivi_bungart@hotmail.com;jprcortez@gmail.com;essilva@uem.br;analu_orl@hotmail.com; \\ lucia.cortez@unicesumar.edu.br
}

\begin{abstract}
Resumo - As doenças respiratórias destacam-se entre a população infantil. $O$ objetivo deste trabalho é categorizar registros de atendimentos em urgência e emergência por doença respiratória (DR) em indivíduos que procuram os serviços da UPA zona Sul na cidade de Maringá-PR. $O$ estudo foi descritivo e retrospectivo dos registros de atendimentos das crianças por doença respiratória $(D R)$ em janeiro de 2015.A amostra foi constituída por prontuários dos pacientes entre 0 e 14 anos incompletos atendidos que apresentaram pelo menos um sintoma respiratório no mês de janeiro, 2015. Foram verificadas as variáveis: idade, sexo, data, dia da semana e horário da procura do serviço, quadro respiratório, exames complementares pedidos e prescrição médica. Foram incluídas no modelo para controle as variáveis referentes à tendência temporal, sazonalidade, temperatura máxima e mínima, umidade relativa do ar e precipitação de chuva, a partir de dados do instituto nacional de meteorologia (INMET). Os dados foram analisados por meio de prontuários das crianças entre 0 e 12 anos incompletos que foram atendidos na UPA zona Sul. Sendo estes digitados e armazenados em uma planilha eletrônica utilizando recursos de informática (Microsoft Excel $₫$ - versão Office 2007®) e importados para o programa Statistical Package for the Social Sciences - SPSS (versão 12,0 for Windows), tabulados e apresentados em forma de tabelas $e$ gráficos. Utilizou-se o teste qui-quadrado para verificar possíveis associações significativas entre as variáveis de interesse. As infecções agudas das vias aéreas superiores, foram as mais diagnosticadas, $e$ correspondem ao CID J00-J06. Ressalta-se a importância de medidas preventivas e cuidados com o intuito de promoção da saúde desta população infantil. Nesse sentido, objetiva-se garantir atenção a esses pacientes, além de interferir na qualidade do acolhimento bem como do atendimento clínico. Uma implicação negativa na realização de tal estudo baseou-se na elevada taxa de casos clínicos que não tinham relação com sintomas respiratórios. Além disso, a idade dos pacientes também teve caráter relevante visto que o perfil igual ou superior a 14 anos foi excluído, o que diminuiu o valor da amostra.
\end{abstract}

Palavras-chave:Quadros Respiratórios. População Infantil.UPA.

Abstract - Respiratory diseases stand out among the child population. The objective of this study is to categorize emergency and emergency

Volume 12 - n. 134 - Fevereiro/2017 care records for respiratory disease $(D R)$ in individuals seeking the services of UPA south zone in the city of Maringá-PR. The study was descriptive and retrospective of the records of children's attendance due to respiratory disease $(\mathrm{DR})$ in January, 2015. The sample consisted of records of patients between 0 and 14 years old who were attended and who presented at least one respiratory symptom in January, The variables: age, sex, date, day of the week and time of demand of the service, respiratory picture, complementary exams requested and medical prescription were verified. The variables related to the temporal trend, seasonality, maximum and minimum temperature, relative humidity and precipitation were included in the model for control, based on data from the National Institute of Meteorology (INMET). The data were analyzed by means of medical records of children between 0 and 12 years of age who were attended at the UPA South Zone. These were typed and stored in a spreadsheet using computer resources (Microsoft Excel ${ }^{\circledR}$ - Office $2007{ }^{\circledR}$ version) and imported for The Statistical Package for the Social Sciences - SPSS (version 12.0 for Windows), tabulated and presented in the form of tables and graphs. The chi-square test was used to verify possible significant associations between the variables of interest. Acute infections of the upper respiratory tract were the most diagnosed, and correspond to the ICD J00-J06. It emphasizes the importance of preventive measures and care with health promotion purpose of this child population. I $n$ this sense, it is aimed to guarantee attention to these patients, besides interfering in the quality of the host as well as the clinical care. A negative implication in such a study was based on the high rate of clinical cases that were unrelated to respiratory symptoms. In addition, the age of the patients was also relevant since the profile of 14 years or more was excluded, which decreased the value of the sample.

Keywords: Respiratory Conditions. Child Population. ECU.

\section{INTRODUÇÃO}

Dentre os componentes da rede de Atenção Básica, as Unidades de Pronto Atendimento (UPA) 24 horas, se constituem como estruturas de complexidade intermediária entre as unidades básicas de saúde, unidades de saúde da família e a rede hospitalar. Funcionam 24 horas, e todos os 
dias da semana, compõe uma rede organizada de atenção às urgências e emergências, com pactos e fluxos previamente definidos. Tem como objetivo garantir o acolhimento aos pacientes, intervir em sua condição clínica e contra referenciá-los para os demais pontos de atenção da Rede de Atenção à Saúde (RAS), para os serviços da atenção básica ou especializada ou para internação hospitalar, proporcionando a continuidade do tratamento com impacto positivo no quadro de saúde individual e coletivo da população (MINISTÉRIO DA SAÚDE, 2013).

Segundo o Ministério do Planejamento (2014), as UPAs podem resolver grande parte das urgências e emergências, como problemas de pressão, febre alta, fraturas, cortes, infarto e derrame. Com isso ajudam a diminuir as filas nos prontos-socorros dos hospitais. A UPA inova ao oferecer estrutura simplificada, com raio-X, eletrocardiografia, pediatria, laboratório de exames e leitos de observação. Nas localidades que contam com UPA, 97\% dos casos são solucionados na própria unidade. Quando o paciente chega às unidades, os profissionais de saúde prestam socorro, controlam o problema, detalham o diagnóstico, e analisam a necessidade do encaminhamento do paciente a um hospital ou mantê-lo em observação por 24 horas. As doenças das vias aéreas despontam como uma das principais causas de atendimento de urgência e emergência no Brasil, acometendo principalmente as crianças (PEREIRA et al, 2011).

Segundo a Organização Mundial da Saúde (2005), a infância é um processo que vai desde a concepção, envolvendo vários aspectos, indo desde o crescimento físico, passando pela maturação neurológica, comportamental, cognitiva, social e afetiva da criança. Tem como produto tornar a criança competente para responder as suas necessidades e às do seu meio, considerando seu contexto de vida. No entanto, as mesmas são muitas vezes acometidas por problemas de saúde, sendo os respiratórios os mais comuns.

Segundo BENÍCIO et al, (2000) a tendência secular da doença respiratória na infância é de acometimento do trato respiratório superior. Silva et al, (2013) em um estudo no setor de emergência do Hospital de Clínicas de Porto Alegre (HCPA) verificou que a prevalência de atendimentos por sintomas respiratórios foi de 28,7\% (6.942/24.189) entre os pacientes adultos e 38,9\% (5.011/12.870) entre os pediátricos, demonstrando o maior acometimento no público infantil.

É relatado altos índices de internação infantil por pneumonia, sendo que em todo o Brasil no Sistema Único de Saúde (SUS) no ano de 2016 na faixa etária entre 1 e 9 anos por 10.000 habitantes foi de 71,49, correspondendo a 714.990 internações(DATASUS, 2016).É visto uma maior ocorrência de doenças respiratórias em crianças devido a alterações de temperatura, um estudo realizado por Moura et al, (2008) nos setores de emergência de três hospitais públicos no município do Rio de Janeiro- RJ entre abril de 2002 a março de 2003, observou-se evidente crescimento no número de atendimentos pediátricos no início dos meses de clima mais frio. Baconyi, et al, (2004), relatam também o aumento de incidência de doenças respiratórias nos períodos mais frios na cidade de Curitiba-PR, em crianças de 0-14 anos, justificando-se este as baixas temperaturas e os aumentos nas concentrações dos poluentes primários.

Desta forma este trabalho surgiu da reflexão referente a relação entre a procura por atendimentos nos serviços de urgência e emergência na UPA ZONA SUL MARINGÁ $\mathrm{PR}$, e as variações de temperatura e umidade.

\section{METODOLOGIA}

Trata-se de um estudo quantitativo descritivo retrospectivo dos atendimentos de crianças em urgência e emergência de crianças por doença respiratória (DR) na Unidade de Pronto Atendimento Zona Sul de Maringá-PR. A amostra foi constituída por prontuários de pacientes entre 0 e 14 anos incompletos atendidos com sintoma respiratório no mês de janeiro, 2015. Foram verificadas as variáveis: idade, sexo, data, dia da semana e horário da procura do serviço, quadro respiratório, exames complementares pedidos e prescrição médica. Foram incluídas no modelo para controle as variáveis referentes à tendência temporal, temperatura máxima e mínima, umidade relativa do ar e precipitação de chuva, a partir de dados do instituto nacional de meteorologia (INMET). Como critério de exclusão foi analisado primeiramente todos os prontuários de pessoas que tivessem idade maior ou igual a 14 anos, e em seguida foram excluídos todos os prontuários que possuíam como diagnóstico comorbidades que não afetassem o trato respiratório superior e inferior.

O referido trabalho foi analisada e aprovada pelo Comitê Avaliador de Pesquisa instituído pela Portaria/Saúde $n^{\circ}$ 004/2013; e COPEP no 1.292 .698 de 22/10/2015, Comitê de Ética em Pesquisa do UniCesumar em com número de aprovação1292698.Os dados foram digitados de forma única e armazenados em uma planilha eletrônica utilizando recursos de informática(Microsoft Excel @ - versão Office 2007®) e importados para o programa Statistical Package for the Social Sciences - SPSS (versão 12,0 for Windows), tabulados e apresentados em forma de tabelas e gráficos. Utilizou-se o teste qui-quadrado para verificar possíveis associações significativas entre as variáveis de interesse $\mathrm{O}$ nível de significância adotado foi de $5 \%$, ou seja, consideradas significativas as associações cujo $\mathrm{p}<0,05$

\section{RESULTADOS E DISCUSSÃO}

No mês de janeiro de 2015 foram realizados 10.252 atendimentos na UPA Zona Sul de Maringá, sendo que 1.830 destes foram em crianças até 14 anos incompletos. Quanto aos atendimentos por afecções do trato respiratório, este foi representado por $23 \%$ (421), destacando a importância deste estudo.

Quanto ao sexo e faixa etária foi verificado uma maioria dos atendimentos para o sexo masculino, com $51,7 \%$ do total. Rosaet al, (2008) também obtiveram uma prevalência dos atendimentos pelo sexo masculino, com52,6\% do total. Já a faixa etária de crianças com até 2 anos de idade, foram responsáveis por até metade dos atendimentos. Contudo a menor procura é observada na faixa etária dos 10 aos 14 anos incompletos também para o sexo masculino e feminino. Considerando-se até os 5 anos de idade, a ocorrência de 74,5\% do total de atendimentos por problemas respiratórios.

Duarte e Botelho (2000) relatam que 25,6\% dos atendimentos em crianças menores de 5 anos foram por infecções respiratórias agudas. 
Tabela 1- Número de atendimentos realizados em crianças de até 14 anos de idade incompletos por faixa etária e por diagnósticos no mês de janeiro de 2015 na UPA zona Sul na cidade de Maringá - PR

\begin{tabular}{|c|c|c|c|c|c|c|c|c|c|c|}
\hline \multirow{3}{*}{ CID } & \multicolumn{10}{|c|}{ Faixa etária (anos) } \\
\hline & \multicolumn{2}{|c|}{$<1$ ano } & \multicolumn{2}{|c|}{1 a 2} & \multicolumn{2}{|c|}{3 a 5} & \multicolumn{2}{|c|}{6 a 9} & \multicolumn{2}{|c|}{10 a 14} \\
\hline & $\mathbf{n}$ & $\%$ & $\mathbf{n}$ & $\%$ & $\mathbf{n}$ & $\%$ & $\mathbf{n}$ & $\%$ & $\mathbf{n}$ & $\%$ \\
\hline $\mathrm{J} 00$ & 30 & 32,97 & 119 & 13,87 & 9 & 10,47 & 83 & 11,11 & 4 & 11,43 \\
\hline J01 & 1 & 1,10 & 8 & 5,84 & 3 & 3,49 & 9 & 12,50 & 5 & 114,29 \\
\hline $\mathrm{J} 02$ & 3 & 3,30 & 9 & 6,57 & 13 & 15,12 & 15 & 20,83 & 6 & 117,14 \\
\hline J03 & 3 & 3,30 & 35 & 25,55 & 24 & 27,91 & 17 & 23,61 & 8 & 22,86 \\
\hline J04 & 0 & 0,00 & 3 & 2,19 & 1 & 1,16 & 1 & 1,39 & 0 & 0,00 \\
\hline \begin{tabular}{|l|l|} 
J06 \\
\end{tabular} & 41 & 45,05 & 46 & 33,58 & 30 & 34,88 & 13 & 118,06 & 8 & 22,86 \\
\hline putros & 13 & 14,29 & 17 & 12,41 & 6 & 6,98 & 9 & 12,50 & 4 & 11,43 \\
\hline Total & 91 & 100,00 & 137 & 100,00 & 86 & 100,00 & 72 & 100,00 & 35 & 100,00 \\
\hline
\end{tabular}

A tabela 1 apresenta o número de atendimentos por CID e faixa etária. As infecções agudas das vias aéreas superiores (CID J00-J06) foram as mais frequentes, sendo as de localizações múltiplas e não especificadas (J06) a mais ocorrente em todas as faixas etárias. Em menores de 1 ano a nasofaringite aguda, mais conhecida como resfriado comum (J00) foi a segunda afecção com maior ocorrência, já nas crianças entre 1 à 14 anos a amigdalite aguda (J03) foi a segunda afecção com maior frequência. Outras afecções que tiveram grande expressividade foram faringite aguda (J02), sinusite aguda (J01) e laringite e traqueíte agudas (J04).

Quanto aos outros diagnósticos destaca-se a pneumonia por microorganismos não especificados $(\mathrm{J} 18)(\mathrm{n}=12)$, asma (J45) ( $\mathrm{n}=8)$, bronquite aguda (J20) $(\mathrm{n}=6)$, bronquite não especificada como aguda ou crônica (J40) $(\mathrm{n}=6)$, bronquiolite aguda $(\mathrm{J} 21)(\mathrm{n}=6)$, rinite alérgica e vasomotora (J30) $(n=6)$, pneumonia em doenças classificadas em outras partes $(\mathrm{J} 17)(\mathrm{n}=4)$ e síndrome do desconforto respiratório do adulto (J80) $(\mathrm{n}=1)$.Pode ser observado a maioria dos atendimentos por doenças da via aérea superior (DVAS) $(89,7 \%)$ e o restante em decorrência de doenças da via aérea inferior (DVAI) (10,3\%). Em estudo semelhante, Rosa et el, (2008) registraram $83 \%$ dos atendimentos por DVAS e $17 \%$ por DVAI. Em estudo realizado por Toyoshimaet al, (2005) averiguando o número de internações por doenças respiratórias na faixa etária até os 4 anos de idade no município de São Paulo de 1995 a 2000 constatou-se que dentre as 85498 internações que ocorreram nessa faixa etária no período, $52388(61,27 \%)$ deveu-se a casos de pneumonia, seguidos de $12328(14,42 \%)$ de internações por asma.

Verificou-se uma maior procura por atendimento durante a noite (18h às 23:59h), com 174 atendimentos, seguido do período vespertino (12h às $17: 59 \mathrm{~h})$ com $(n=122)$, matutino (06h às 11:59h) $(\mathrm{n}=87)$ e na madrugada (00:00h às $05: 59 h)(n=38)$. Quanto ao dia da semana foi possível inferir que o sábado demandou um maior número de atendimentos $(n=95)$, seguidos da sexta-feira $(n=70)$. A terça-feira foi o dia da semana com menor procura pelo público infantil acometido por afecções respiratórias, com apenas 37 atendimentos durante janeiro de 2015. Em todos os dias da semana fazem-se presentes em proporções variadas os CIDs J00, J01, J02, J03, J04 e J06
Segundo dados meteorológicos $\left(\mathrm{T}^{\mathrm{o}} \mathrm{C}\right.$ e UR) do mês de janeiro de 2015 na cidade de Maringá-PR, ocorreram dois períodos úmidos, que foram relacionados a maiores índices de precipitações entre os dias 01 a 12/01/2016 e entre 26a $31 / 01 / 2016$, bem como o período mais seco com menores índices de precipitações entre os dias 13 a 25/01/2016 (INMET, 2015).Segundo gráfico 1 as DVAS nos dias mais úmidos perfazem um total de 219 (88,3\%) dos 248 atendimentos ocorridos nesse período e as DVAI são responsáveis por $29(11,6 \%)$ destes. Já nos dias mais secos as DVAS englobam $159(91,9 \%)$ dos 173 atendimentos desse período enquanto que as DVAI perfazem $14(8,09 \%)$ do total dos mesmos. Em estudo semelhante, Rosa et al, (2008) obtiveram que em período de seca os atendimentos por DVAS perfizeram $42,43 \%$ dos atendimentos realizados no período e as DVAI 52,26\%, enquanto que em período chuvoso as DVAS totalizaram $57,57 \%$ dos atendimentos nesse período e as DVAI $47,74 \%$ dos atendimentos. Em estudo no Pronto Socorro Municipal de Cuiabá-MT, a distribuição das crianças menores de 5 anos estudadas por tipo de atendimento, segundo o agravo diagnosticado e o período climático em 1999 tem-se que a IRA (Infecções Respiratórias Agudas) teve maior proporção de tratamento hospitalar no período seco $(\operatorname{seco}=9,9 \%$; chuvoso $=6,2 \%)$, sendo as diferenças significantes $(\mathrm{p}=0,001)$, já quanto ao tratamento ambulatorial a proporção não varia tanto, tendo sido $90,8 \%$ no período seco e $93,8 \%$ no chuvoso. Ao analisarmos segundo a localização anatômica tem-se que no tratamento hospitalar foram $2,2 \%$ de atendimentos no período seco e $1,6 \%$ no chuvoso por DVAS e $18,5 \%$ no período seco e $11,4 \%$ no chuvoso por DVAI, já no tratamento ambulatorial o montante de atendimentos por DVAS foi de $97,8 \%$ no período seco e $98,4 \%$ no chuvoso, enquanto que nos atendimentos por DVAI foram $81,5 \%$ no período seco e $88,6 \%$ no período chuvoso (BOTELHO et al, 2003). 
Gráfico 1- Número de atendimentos conforme estrutura anatômica nos dias úmidos e secos no mês de janeiro de 2016.

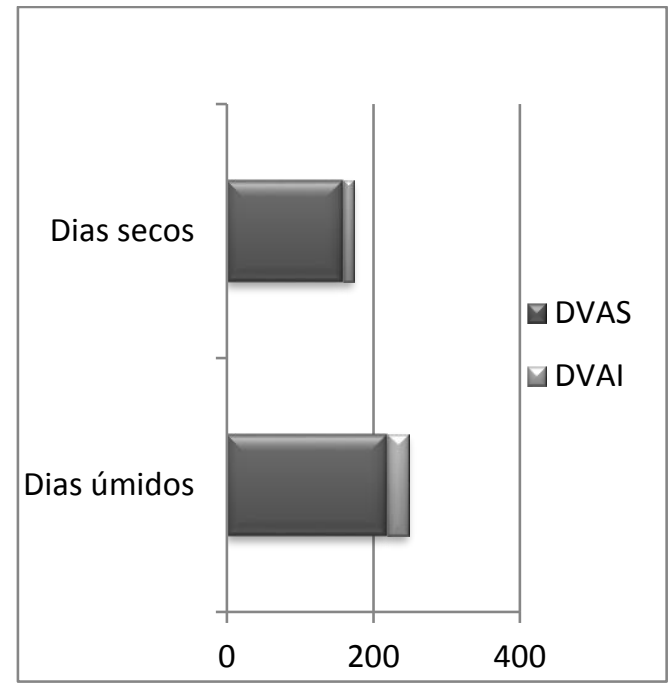

Outra questão que se faz importante ressaltar advém do fato de que dos 1830 prontuários de crianças até 14 anos incompletos que foram analisados nesta pesquisa, 202 (11\%) não tinham diagnóstico. Portanto, infere-se que alguns quadros respiratórios acabaram sendo omitidos por não ter-se a certeza do diagnóstico dado pelo profissional médico, mesmo com 115 destes prontuários tendo prescrição.

\section{CONCLUSÕES}

As afecções do trato respiratório constituíram $23 \%$ dos atendimentos na UPA Zona Sul de Maringá. As infecções agudas das vias aéreas superiores foram as mais frequentes. Crianças com até 2 anos de idade são responsáveis por mais da metade de todos os atendimentos. Em crianças menores de 1 ano, o resfriado comum é a segunda principal causa, enquanto que nas maiores de 1 ano, a segunda maior ocorrência é de amigdalite. A maior procura se dá no período noturno e aos sábados. A prevenção dessas patologias inicia-se com a conscientização e entendimento, principalmente, por parte dos pais, sobre a doença.

\section{REFERÊNCIAS}

AIRES, Margarida de Mello. Fisiologia. 3. ed. Rio de Janeiro: Guanabara: Koogan, 2008.

BACONYI, Sonia Maria Cipriano; OLIVEIRA, Inês Moresco Danni-; MARTINS, Lourdes Conceição; BRAGA, Alfésio Luís Ferreira. Poluição atmosférica e doenças respiratórias em crianças na cidade de Curitiba, PR. Rev. Saúde Pública. São Paulo, v. 38, n. 5, p. 695-700, 2004.

BENÍCIO, Maria Helena D`Aquino; CARDOSO, Maria Regina Alves; GOUVEIA, Nelson da Cruz; MONTEIRO, Carlos Augusto. Tendência Secular da Doença Respiratória na Cidade de São Paulo (1984-1996). Rev Saúde Pública. São Paulo, v. 34, p. 91-101, 2000.

BOTELHO, Clóvis; CORREIA, Ademir Lopes; SILVA, Ageo Mário Cândido da; MACEDO, Alex Gonçalves;
SILVA, Clystenes Odir Soares. Fatores Ambientais e Hospitalizações em Crianças Menores de Cinco Anos com Infecção Respiratória Aguda. Cad. Saúde Pública. Rio de Janeiro, v. 19, n. 6, p. 1771-1780, nov/dez, 2003.

COSTA, Pollyana Correia; MIRANDA, Juliana de Oliveira Freitas; SOUZA, kleize Araujo Oliveira. Pediatric Prehospitalar Assistance Conducted by the Mobile Emergency Care Service (SAMU). J. Res.: fundam. care. online. Rio de Janeiro, v. 5, n. 4, p. 614-621, 2013.

DUARTE, Dirce M. G; BOTELHO, Clóvis. Perfil Clinico de Crianças Menores de Cinco Anos com Infecção Respiratória Aguda. J Pediat. (Rio J). Rio de Janeiro, v.76, n. 3, p. 207-212, 2000.

IPARDES. Caderno Estatístico Município de Maringá. Disponível em: <http://www.ipardes.gov.br/cadernos/Montapdf.php?Muni cipio $=87000$ > . Acessado em: 13 maio. 2014

MINISTÉRIO DA AGRICULTURA, PECUÁRIA E ABASTECIMNTO. INMET - Instituto Nacional de Meteorologia. Disponível em <www.inmet.gov.br.> Acessado em 24 abr. 2015.

MINISTÉRIO DA SAÚDE. Datasus - Sistema de Informações Hospitalares do SUS. Morbidade Hospitalar do SUS - por local de internação. BRASÍLIA, 2012. Disponível em: <http://tabnet.datasus.gov.br/cgi/deftohtm.exe?sih/cnv/nip r.def >. Acessado em: 09 abr. 2014.

MINISTÉRIO DA SAÚDE. Secretaria de Atenção à Saúde - Manual Instrutivo da Rede de Atenção às Urgências e Emergências no Sistema Único de Saúde (SUS). Brasília, 2013, 85p.

MOURA, Marisa; JUNGER, Washington Leite; MENDONÇA, Gulnar Azevedo e Silva; LEON, Antonio Ponde De. Qualidade do Ar e Transtornos Respiratórios Agudos em Crianças. Rev de Saúde Pública. São Paulo, v. 42, n. 3, p. 503-511, 2008.

ORGANIZAÇÃO MUNDIAL DA SAÚDE. Organização Pan-Americana da Saúde. Manual para Vigilância do Desenvolvimento Infantil no Contexto da AIDPI. Washington, D.C, 2005, 54p.

PAC2. Desenvolvido pelo Ministério do Planejamento. Apresentação de Projetos e serviços Realizados pelo Programa de Aceleração do Crescimento. Disponível em: http://www.pac.gov.br/comunidade-cidada/upaunidade-de-pronto-atendimento. Acesso em 08 maio 2014.

PEREIRA, Viviane Solange; ROSA, Antonia Maria; HACON, Sandra de Souza; CASTRO, Hermano Albuquerque de; IGNOTTI, Eliane. Análise dos Atendimentos Ambulatoriais por Doenças Respiratórias no Município de Alta Floresta - Mato Grosso: - Amazônia brasileira. Epidemiol. Serv. Saúde. Brasília, v. 20, n. 3, p. 393-400, jul/set, 2011.

ROSA, Antonia Maria; IGNOTTI, Eliane; BOTELHO, Clóvis; CASTRO, Hermano Albuquerque de; HACON, 
Sandra de Souza. Respiratory Diseade and Climatic Seasonality in Children Under 15 Years Old in a Town the Brazilian Amazon. Jornal de Pediatria. Rio de Janeiro, v. 84, n. 6, p. 543-549, 2008.

SILVA, Denise Rossato; VIANA, Vinícius Pellegrini; MÜLlER, Alice Mânica; COELHO, Ana Cláudia; DEPONTI, GracieliNadalon; LIVI, Fernando Pohlmann; DALCIN, Paulo de Tarso Roth. Perfil Epidemiológico dos Atendimentos de Emergência por Sintomas Respiratórios em um Hospital Terciário. J. bras. pneumol. São Paulo, v. 39, n. 2, p. 164-172, mar/abr, 2013.

SILVERTHORN, Dee Unglaub. Fisiologia Humana. $5^{\text {a }}$ ed. Porto Alegre: Artmed

TOYOSHIMA, Marcos TadashiKakitani; ITO; Gláucia Munemasa; GOUVEIA Nelson. Morbidade por Doenças Respiratórias em Pacientes Hospitalizados em São Paulo/SP. Rev. Assoc Med Bras. São Paulo, v. 51, n. 4, p. 209-213, 2005.

Indicador de Vulnerabilidade Socioambiental na Amazônia Ocidental. O Caso do Município de Porto Velho, Rondônia, Brasil. Rio de Janeiro/RJ Revista Ciência \& Saúde Coletiva da Associação Brasileira de Saúde Coletiva, 2014. Disponível em: <http://www6.ensp.fiocruz.br/repositorio/sites/default/files /arquivos/IndicadorVulnerabilidade.pdf >. Acesso em: 12 dez. 2016.

Epidemiologia de Desfechos na Saúde Humana Relacionados à Poluição Atmosférica no Brasil: Uma Revisão Sistemática. Rio de Janeiro/RJ: Cad. Saúde Colet. Vol.23 No.2, 2015. Disponível em: <http://www.scielo.br/scielo.php?pid=S1414462X2015000200091\&script=sci_arttext\&tlng=pt $>$.

Acesso em: 12 dez. 2016.

Bronquiolite Obliterante Pós-Infecciosa em Crianças. Rio de Janeiro/RJ: J. Pediatr. Vol.87 No.3 Porto Alegre May/June 2011, 2011.

A Poluição do Ar e o Sistema Respiratório. São Paulo (SP): Jornal Brasileiro de Pneumologia: V. 38 N: 5, 2012.

\section{COPYRIGHT}

Direitos autorais: Os autores são os únicos responsáveis pelo material incluído no artigo. 


\title{
PERFIL EPIDEMIOLÓGICO DA INFECÇÃO PELO VÍRUS DA HEPATITE B NO MUNICÍPIO DE PARAGOMINAS-PA
}

\author{
EPIDEMIOLOGICAL PROFILE OF HEPATITIS B VIRUS INFECTION IN THE \\ COUNTY OF PARAGOMINAS-PA
}

\author{
ELIETE SOARES MOREIRA ${ }^{1}$; NILCINETE PEREIRA DA SILVA ${ }^{1}$; ROGÉRIO VALOIS LAURENTINO ${ }^{1}$; \\ NILSON SANTOS TRINDADE ${ }^{1}$ \\ 1 - UNIVERSIDADE FEDERAL DO PARÁ \\ elie-te05@hotmail.com; nilci010@hotmail.com; rogvalois@hotmail.com; nilsonufpa17@gmail.com
}

\begin{abstract}
Resumo: O presente trabalho é observacional, transversal, descritivo. Tem como objetivo descrever o perfil epidemiológico da infecção pelo VHB no Município de Paragominas-Pa, no período de 2011 a 2015. Os resultados revelaram que o Município de Paragominas notificou a frequência de 14 infeções de 2011 a 2015, sendo 2012, o ano com mais notificações (37\%). $O$ sexo masculino foi o mais afetado $(57,1 \%)$. A faixa etária mais notificada constituiu dos $20-34$ anos $(57,14 \%)$. A forma crônica registrou maior frequência $(50 \%)$ e (14\%) das notificações não foram identificadas a forma clínica. A fonte/mecanismo de infecção mais frequente foi por via sexual $(35,70 \%)$, sendo que $(21,42 \%)$, não se identificou o meio de transmissão. Sendo assim, conclui-se com este trabalho que, no Município de estudo há falha no preenchimento de campos na hora da notificação $e$ a frequência registrada é insignificativa.
\end{abstract}

\section{Palavras-chave: Infecção. Hepatite B. VHB}

Abstract- The present work is observational, transversal, descriptive. It aims to describe the epidemiological profile of $H B V$ infection in they county of Paragominas-PA, from 2011 to 2015. The results revealed that the Municipality of Paragominas notified the frequency of 14 infections from 2011 to 2015, being 2012, the year with the most notifications (37\%). The male sex was the most affected (57.1\%). The most reported age group was 20-34 years (57.14\%). The chronic form recorded a higher frequency $(50 \%)$ and (14\%) of the reports the clinical form was not identified. The most frequent source / mechanism of infection was sexual intercourse (35.70\%), and (21.42\%) the transmission medium was not identified. Therefore, it is concluded with this work that, in the study city, there is a failure to fill in fields at the time of notification and the frequency recorded is insignificant.

Key words: Infection. Hepatitis B. HBV

\section{CONSIDERAÇÕES INICIAIS}

A infecção hepática causada pelo agente etiológico vírus da hepatite B (VHB OU HBV) é conhecida como hepatite $\mathrm{B}$, é o tipo mais grave de hepatite viral, que leva a morte de milhares de pessoas. Melo (2010), ressalta que mais de dois bilhões de pessoas no mundo já se infectaram com o VHB, cerca de mais de 600 mil vão a óbito por ano e em média 360 milhões sofrem de infecção crônica por esse agente. "A hepatite B pode ser considerada uma das mais importantes doenças sexualmente transmissíveis do homem", (FERREIRA, 2000, p.390).
Considerando que há escassez de dados a frequência epidemiológica de infecção causada pelo vírus da hepatite $\mathrm{B}$, o presente trabalho propõe uma investigação de base descritiva para suprir uma provável lacuna existente, fornece ainda subsídios teóricos para auxílio ás políticas públicas de saúde e servirá para consulta acadêmica. Diante deste cenário, esta pesquisa apresenta a seguinte problemática: Qual o perfil epidemiológico da infecção pelo vírus da hepatite $\mathrm{B}$ no município de Paragominas-Pa?

O objetivo principal deste trabalho é descrever o comportamento da infecção pelo VHB no Município de Paragominas-Pa, no período de 2011 a 2015. Identificar a frequência de notificações da infecção causada pelo VHB (hepatite B) no município de Paragominas no período de 2011 a 2015; Especificar o percentual da infecção pelo VHB no município de Paragominas de acordo com a faixa etária e sexo no município de Paragominas; Estabelecer o percentual da infecção causada pelo VHB de acordo a fonte/ mecanismo de infecção e as formas clínicas: aguda e crônica no Município de Paragominas são os objetivos específicos.

\section{FUNDAMENTAÇÃO TEÓRICA}

A descoberta do VHB como agente causador de hepatite B se deu por Baruch Blumberg em 1965, descoberta essa tão importante que lhe deu o prêmio Nobel de Medicina de 1978, (FONSECA, 2010).

$\mathrm{O}$ vírus da hepatite $\mathrm{B}$, o Hepatitis B Virus, está classificado na família Hepadnaviridae, e gênero Orthohepadnavirus, popularmente conhecido como vírus B ou Vírus da Hepatite B (VHB).

Segundo Melo (2010), estruturalmente, o VHB mede aproximadamente $42 \mathrm{~nm}$ e consiste de um cerne (core) representado por um nucleocapsídeo icosaédrico. Que por sua vez é uma estrutura simétrica contendo 12 faces de vértices de morfologia ligeiramente esférica (MADIGAN, 2010).

O genoma compõe-se de Ácido Desoxirribonucléico (DNA) circular de fita parcialmente dupla de peso molecular de $3.2 \mathrm{~kb}$ e 3.200 nucleotídeos. Possui envelope, composto por uma proteína chamada antígeno de superfície (HBsAg), além dos antígenos (HBcAg) e (HBeAg) (MELO, 2010). A partícula viral madura, onde está o genoma viral é 
denominada partícula de DANE, podendo ser filamentosa ou esférica (MADIGAN, 2010).

É um vírus de DNA, replica-se por meio de transcriptase reversa, a proteína copia o mRNA para sintetizar o DNA viral, a sua replicação ocorre nos hepatócitos, ao entrar em contato com o sangue circula na corrente sanguínea, logo é absorvida pelo macrófago (célula de defesa), posteriormente chega ao fígado, onde invade os hepatócitos, uma vez alojada reproduz-se causando inflamação (SILVA, 2013).

A prevalência de infecção pelo VHB no mundo oscila bastante, isto se deve ao fato de que quase sempre é assintomático. O sudeste da Ásia, china, África subsaariana, na Amazônia, parte do Oriente Médio e ilhas do Pacífico caracterizam- se como de alta endemicidade, assim como a Região Norte do Brasil, (MIRANDA, 2008).

Rocha et al (2015) discorrem que o Acre é o Estado com a maior taxa de hepatite $\mathrm{B}$ do país, com uma incidência de 56,8 casos por 100 mil habitantes, com ênfase nos jovens de 17 e 25 anos, majoritariamente no sexo feminino.

O conhecimento adequado sobre a frequência do vírus B e a implementação de estratégias indicadas para a sua prevenção exigem métodos complexos de vigilância epidemiológica, (FERREIRA; SILVEIRA, 2004). A imunização ativa através de vacinas é uma arma poderosa no combate a infecção pelo $\mathrm{HBV}$, tal como o controle rigoroso dos bancos de sangue e das relações sexuais protegidas, dentre outras medidas (FERREIRA, 2000).

A hepatite $B$ apresenta-se na forma clínica aguda e crônica, além da fulminante. Têm diversas formas de contágios e grande potencial de infecção, com capacidade de uma única partícula viral infectar o ser humano e em muitos casos desenvolvendo-se de forma silenciosa. Do total de pessoas infetadas na fase aguda, 8 a $10 \%$ se evoluem para a forma crônica, podendo evoluir para cirrose hepática e hepatocarcinoma, que por sua vez, constitui-se mundialmente a décima causa de morte (LOPES SCHINONI, 2010).

\section{MATERIAL E MÉTODOS}

Esta pesquisa é de natureza observacional, com abordagem quantitativa descritiva tipo transversal. Foi realizada em Paragominas-Pa, cujo município situa-se "na mesorregião sudeste do Pará, a 320 quilômetros da cidade de Belém (PINTO et al, 2009); com população estimada em 2010 era de 97.819 habitantes, com estimativa de 108.547 para o ano de 2016, de acordo com o Instituto Brasileiro de Geografia e Estatística, (IBGE, 2010).

A coleta de dados ocorreu no setor de epidemiologia da Secretaria Municipal de Saúde (SEMS) e por meio do sistema Nacional de Notificações (SINAN).
A população estudada corresponde aproximadamente aos 103,991 mil habitantes do Município de ParagominasPA. A amostra são os pacientes que foram notificados com infecção hepatite VHB no período de 2011 a 2015. O período de coletas de dados se deu de agosto a outubro de 2016. Para a construção do banco de dados amostrais utilizou-se os dados disponibilizados nos arquivos da SEMS de Paragominas PA.

Os dados coletados foram armazenados na plataforma Excel (Microsoft Office 2013). As frequências das variáveis obtidas foram calculadas e expressas em percentuais.

\section{RESULTADOS}

Os resultados da Figura 1 demonstram que o município de Paragominas, de 2011 a 2015, apresentou a frequência de 14 infecções causada pelo vírus VHB.

Figura 1-Frequência de notificação por ano.

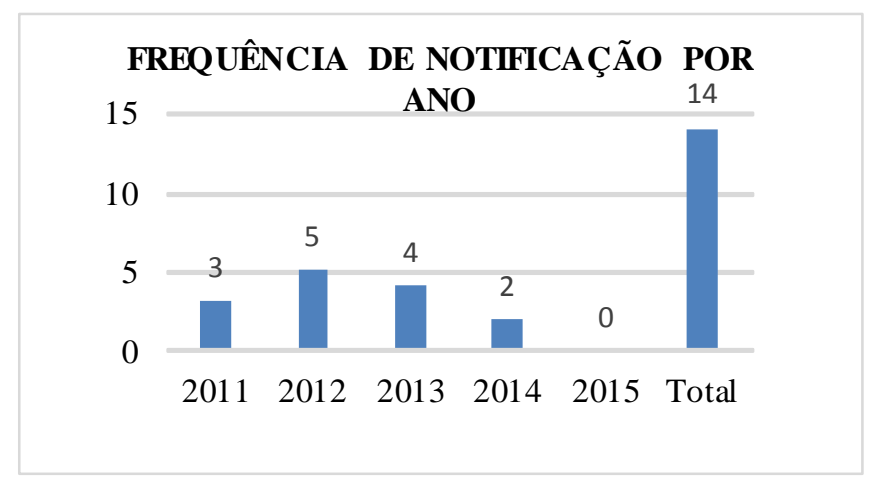

Tabela 1-Percentual de frequência de infecção segundo o ano de notificação.

\begin{tabular}{cc}
\hline Ano da notificação & Percentual \\
\hline 2011 & $21 \%$ \\
2012 & $37 \%$ \\
2013 & $28 \%$ \\
2014 & $14 \%$ \\
2015 & $0 \%$ \\
\hline Total & $100 \%$ \\
\hline Fonte: SINAN-NET/ SEMES, 2016.
\end{tabular}

Conforme a Tabela 1, os anos com maiores percentuais de notificações de hepatite B foram 2012 com 37\% e 2013 com $28 \%$.

A Tabela 2 mostra que sexo masculino foi o mais afetado com infecção pelo vírus VHB, sendo 2012 e 2013 os anos mais frequentes, ambos com $37,5 \%$ de notificações. 
Tabela 2- Percentual de frequência por sexo segundo ano das notificações.

\begin{tabular}{ccccc}
\hline Ano & Masc. & Percentual & Fem. & Percentual \\
\hline 2011 & 01 & $12,5 \%$ & 02 & $33,33 \%$ \\
2012 & 03 & $37,5 \%$ & 02 & $33,33 \%$ \\
2013 & 03 & $37,5 \%$ & 01 & $16,67 \%$ \\
2014 & 01 & $12,5 \%$ & 01 & $16,67 \%$ \\
2015 & 00 & $0,0 \%$ & 00 & $0,0 \%$ \\
\hline Total & 08 & $100 \%$ & 06 & 100 \\
\hline \multicolumn{5}{c}{ Fonte: SINAN-NET/ SEMES, 2016. }
\end{tabular}

A faixa etária mais afetada foi de 20 a 34 anos com 08 notificações como descrito na Tabela 3.

Tabela 3 - Frequências por faixa etária segundo ano das notificações.

\begin{tabular}{ccccccc}
\hline Ano & $<\mathbf{2 0}$ & $\mathbf{2 0 - 3 4}$ & $\mathbf{3 5 - 4}$ & $\mathbf{5 0 - 6 4}$ & $\mathbf{6 5 - 7 9}$ & Total \\
\hline 2011 & 00 & 02 & 01 & 00 & 00 & 03 \\
2012 & 00 & 02 & 01 & 01 & 01 & 05 \\
2013 & 00 & 02 & 01 & 01 & 00 & 04 \\
2014 & 00 & 02 & 00 & 00 & 00 & 02 \\
2015 & 00 & 00 & 00 & 00 & 00 & 00 \\
\hline Total & 00 & 08 & 03 & 02 & 01 & 14 \\
\hline \multicolumn{7}{c}{ Fonte: SINAN-NET/ SEMES, 2016. }
\end{tabular}

Percebe-se na Tabela 4 que a faixa etária de 20-34 anos obteve notificação de $57,14 \%$ de notificações de infecções pelo VHB.

Tabela 4-Percentual de notificação de acordo com a faixa etária.

\begin{tabular}{cc}
\hline Faixa etária & Percentual (\%) \\
\hline$<20$ & $0,00 \%$ \\
$20-34$ & $57,14 \%$ \\
$35-49$ & $21,42 \%$ \\
$50-64$ & $14,30 \%$ \\
$65-79$ & $7,14 \%$ \\
\hline Total & $100 \%$
\end{tabular}

Fonte: SINAN-NET/ SEMES, 2016.

A Tabela 5 indica a frequência de notificações segundo a forma clínica da infeção causada pelo VHB, se deu: infecção aguda 06, crônica 07 e nenhuma na forma fulminante, além de 01 não identificada.

Tabela 5 - Frequência por forma clínica segundo ano das notificações.

\begin{tabular}{cccccc}
\hline Ano & Ignor./bran & Aguda & Crônica & Fulm. & Total \\
\hline 2011 & 00 & 01 & 02 & 00 & 03 \\
2012 & 01 & 01 & 03 & 00 & 05 \\
2013 & 00 & 04 & 00 & 00 & 04 \\
2014 & 00 & 00 & 02 & 00 & 02 \\
2015 & 00 & 00 & 00 & 00 & 00 \\
\hline Total & 01 & 06 & 07 & 00 & 14 \\
\hline \multicolumn{7}{l}{ Fonte: SINAN-NET/ SEMES, 2016. } \\
\end{tabular}

A fonte/mecanismo de infecção está descrita na figura 2, o sexo foi a principal causa de infecção com 05 notificações e 2011 e 2012 foram os anos de maiores registros.

Figura 2 - Frequência por fonte/mecanismo de infecção segundo ano de notificação.

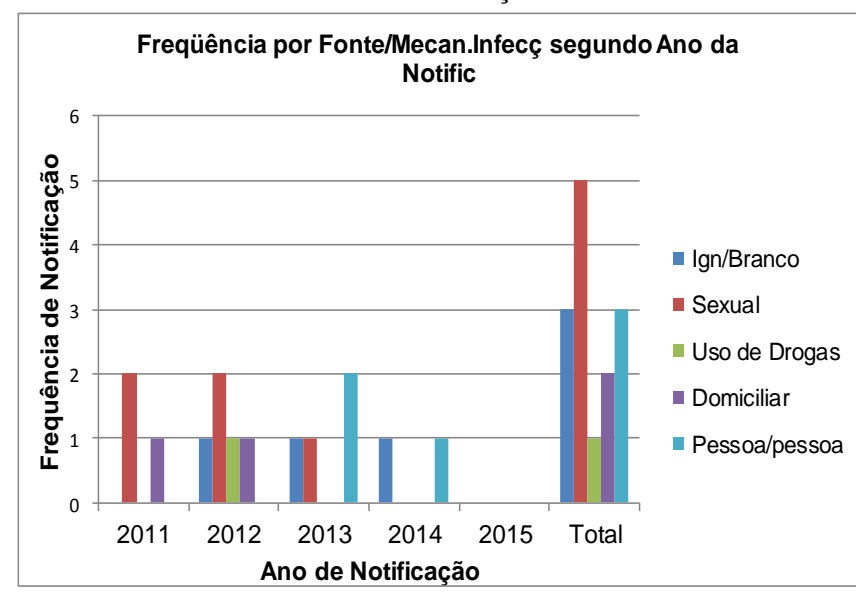

Fonte: SINAN-NET/ SEMES, 2016.

\section{DISCUSSÃO}

Os resultados da Figura 1 demonstram que foram notificados poucos casos anualmente de infecção pelo VHB no Município de Paragominas, de 2011 a 2015. Levando em consideração a média da população nos 05 anos de estudo com aproximadamente 102,415 habitantes (IBGE, 2010), o resultado das infecções por ano de notificação é ínfimo (0,00013), em desacordo com os resultados encontrados por Costa Junior et al (2013) em Santarém, Região Norte do Pará, com frequência de 68 infecções $(0,0362 \%)$ em apenas três anos (2008, 2009 e 2010).

É explícito na Tabela 2, que o sexo masculino neste estudo foi o mais afetado com infecção pelo vírus VHB, com $(57,10 \%)$ assim o resultado de infecção por sexo corroborou com estudos de Costa Júnior et al (2013) e Cruz; Shirassu e Martin (2009).

Provavelmente o maior percentual de notificações no sexo masculino neste estudo se dá devido ao comportamento sexual, ou simplesmente representam um viés amostral homens (AQUINO, 2012).

Conforme os resultados contidos na Tabela 3 e 4, a infecção pelo VHB, no Município de Paragominas, foi mais frequente na faixa etária dos 20-34 anos e não houve ocorrência de infecção na faixa etária $<20$ anos, assim como em trabalho realizado por Nunes et al (2010), em um hospital no Município de Juriti-Pa. Ainda segundo Nunes et al (2010), a não detecção de portadores do VHB em crianças está relacionada as medidas de controle da infecção.

$\mathrm{Na}$ Tabela 5, constata-se que a frequência de notificação de hepatite $\mathrm{B}$ na forma clínica crônica foi mais elevada, totalizando (50\%) das infecções. Supõem que o alto percentual de notificação na forma clínica em Paragominas, tenha ocorrido devido ao comportamento da infecção, ou seja, vem ocorrendo assintomaticamente, dificultando assim o diagnóstico.

Ferreira e Silveira (2004), afirmam que grande parte dos indivíduos infectados são assintomáticos e nos indivíduos sintomáticos as notificações são insuficientes, 
portanto, a frequência de notificações da hepatite $B$, no Município de Paragominas certamente, ainda é subestimada.

A hepatite crônica pode acarretar graves problemas de saúde, para Ferreira (2000) a persistência da infecção pode acarretar em cirrose, insuficiência hepática e carcinoma hepatocelular.

Pode-se visualizar também na Tabela 5, que $(7,14 \%)$ das notificações de acordo com a forma clínica está classificada como Ignor./branco, isto é, que não foi preenchido o campus necessário ou não foi feito o exame sorológico que detecta a forma clínica. Portanto, o Município de Paragominas poderia promover a formação continuada aos seus profissionais de saúde, pois assim diminuiria essas falhas.

$\mathrm{Na}$ Figura 2, observa que a Fonte/Mecanismo de infecção, mais pertinente foi por via sexual, assim como no trabalho realizado por Cruz, Shirassu e Martins (2009), Passos (2003), Carneiro e Cangassu (2009), demonstram também quase que unanimemente a transmissão do VHB pela via sexual e $21,43 \%$ não identificada a via de transmissão.

Tais resultados revelam que a transmissão da infecção do VHB, por via sexual é mais prevalente na população de Paragominas, porque é possível que os mesmos ainda não estão conscientes quanto ao uso de preservativo, como forma de previr a doença, assim como afirma Carneiro; Cangussu (2009, p.9), "não usar preservativos durante as relações sexuais é um fator de risco".

\section{CONSIDERAÇÕES FINAIS}

O presente estudo revelou que de 2011 a 2015, houve frequência 14 notificações VHB, o sexo masculino apresentou maior frequência de infecção $(57,1 \%)$, a faixa etária mais afetada consistiu dos 20-34 anos (57,14\%), a forma Clínica Crônica apresentou-se mais recorrente (50\%) e as relações sexuais constituiu a fonte /mecanismo de infecção de maior frequência $(35,71 \%)$.

Diante dos resultados alcançados no presente estudo, observou-se que o Município de Paragominas apresenta frequência reduzida de infecção causada pelo vírus VHB, em 2015, não ocorreu nenhuma notificação, o que leva a mencionar que há uma subnoticação, ou que as notificações são insuficientes.

$\mathrm{O}$ pesquisador precisa reconhece a limitação de sua pesquisa, então o seguinte trabalho poderia ser enriquecido caso a coleta de dados fosse realizada diretamente com os pacientes suspeitos da infecção pelo vírus VHB.

Sendo assim, propõem-se como desafio para o Município de Paragominas organizar, treinar e qualificar as pessoas que fazem notificações, pois, ocorreram notificações sem preenchimento dos campos fonte/mecanismo de infeção e forma clínica da doença, como registrado no SINAN como ignorados/branco, por não constar a especificação, já que o sexo masculino é o mais afetado devem-se intensificar políticas públicas a eles e maior divulgação sobre a hepatite $\mathrm{B}$ para a população em geral.

\section{REFERÊNCIAS BIBLIOGRÁFICAS}

AQUINO, J. A.; PEGADO, K. A.; BARROS, L. P.; MACHADO, L. F. A. Soroprevalência de infecções por vírus da hepatite $\mathrm{B}$ e vírus da hepatite $\mathrm{C}$ em indivíduos do
Estado do Pará. Revista da Sociedade Brasileira de Medicina Tropical. v. 41, n.4, 2008. Disponível em: http://www.baip.ufpa.br/arquivos_baip/publicacoes/artigo_6 4.pdf. Acesso em: 29 de out. 2016.

CARNEIRO, G. G. V. S.; CANGUSSU, M. C. T. Prevalência presumível, cobertura vacinal, conhecimentos e atitudes relativos à hepatite $\mathrm{B}$ em graduandos de Odontologia da Universidade Federal da Bahia. Revista de Odontologia da UNESP. v. 38, n.1, 2009. Disponível em: www.revodontolunesp.com.br/files/v38n1/v38n1a02.pdf. Acesso em: 30 nov. 2016.

COSTA JÚNIOR, P. R. S.; OLIVEIRA, H. S.; DA SILVA, L. E; L.; BARBOSA, R. F. M. Infecção por Hepatites B e C em um Município do Estado do Pará. Revista Paraense de Medicina (Impressa). v.27, n.2, 2013. Disponível em: http://files.bvs.br/upload/S/0101-

5907/2013/v27n2/a3673.pdf. Acesso: em 29 out. 2016.

CRUZ, C. R. B; SHIRASSU, M. M; MARTINS, W. P. Comparação do perfil epidemiológico das hepatites B e C em um serviço público de São Paulo. Revista Arquivos Gastroenterol. v. 46, n.3, 2009. Disponível em: http://www.redalyc.org/pdf/260/26021120006.pdf. Acesso em: 23 nov. 2016.

FERREIRA, C. T.; DA SILVEIRA, T. R. Hepatites virais. Aspectos da epidemiologia e da prevenção. Revista Brasileira de Epidemiologia. v. 7, n. 4, 2004. Disponível em:

https://www.nescon.medicina.ufmg.br/biblioteca/imagem/04 58.pdf. Acesso: 24 jul. 2016.

FERREIRA. M. S. Diagnóstico e tratamento da hepatite B. Revista da Sociedade Brasileira de Medicina Tropical. v. 33, n.4, 2000. Disponível: em: http://www.scielo.br/pdf/rsbmt/v33n4/2493.pdf. Acesso em: 25 out. 2016.

FONSECA, J. C. F. Histórico das hepatites virais. Revista da Sociedade Brasileira de Medicina Tropical. v. 43, n.3, $2010 . \quad$ Disponível em: http://www.scielo.br/pdf/rsbmt/v43n3/22.pdf. Acesso em: 25 jul. 2016.

IBGE. Instituto Brasileiro de Geografia e Estatística, $2010 . \quad$ Disponível em: http://ibge.gov.br/cidadesat/xtras/perfil.php?lang=\&codmun $=150550 \&$ search=para\%7Cparagominas. Acesso: em 28 out. 2016 .

LOPES, T. G. S. L.; SCHINONI, M. I. Aspectos gerais da hepatite. Revista de Ciências Médicas e Biológicas. v. 10, n.3, 2011 Disponível em: https://repositorio.ufba.br/ri/bitstream/ri/5715/1/589916364-1-PB\%5B1\%5D.pdf. Acesso em: 14 ago. 2016.

MADIGAN, M. T.; MARTINKO, J. M.; BENDER, K. S.; BUCKLEY, D. H.; STAHL, D. A. Microbiologia de Brock. 12. ed. Porto Alegre: ARTMED, 2010.

MELO, L. V. L. Perfil soroepidemiológico da infecção pelo vírus da hepatite $B$ e cobertura vacinal em jovens de 12 a 20 anos matriculados em escolas públicas de Barra 
do Garças - MT, 2010. 86 f. Dissertação (Mestrado em Ciência da Saúde) Universidade Federal de Mato GrossoMT, 2010. Disponível em: http://livros01.livrosgratis.com.br/cp153346.pdf. Acesso: em 25 jul. 2016.

MIRANDA, T. G. P. Soroprevalência da Infecção pelo Vírus da Hepatite B e Vírus da Hepatite C em Mulheres Profissionais do Sexo em Augusto Correia, Barcarena, Belém e Bragança- Pará, Brasil. Disponível em: http://repositorio.ufpa.br/jspui/bitstream/2011/4851/1/Disser tacao_SoroprevalenciaInfeccaoVirus.pdf. Acesso em: 29 out. 2016.

NUNES, H. M.; SOARES, M. C. P.; SARMENTO, V. P.; MALHEIROS, A. P.; BORGES, A. M.; DA SILVA, I. S.; DA PAIXÃO, J. F. Prevalência de infecção pelos vírus das hepatites A, B, C e D na demanda de um hospital no Município de Juruti, oeste do Estado do Pará, Brasil.

Revista Pan-Amazônica de Saúde. v. 1, n.2, 2010. Disponível:

http://scielo.iec.pa.gov.br/scielo.php?script=sci_arttext\&pid =S2176-62232010000200013. Acesso em: 28 out. 2016.

PASSOS, A. D. C. Aspectos epidemiológicos das hepatites virais. Medicina, Ribeirão Preto. v. 36, 2003. Disponível em: http://www.revistas.usp.br/rmrp/article/view/523/523. Acesso: em 09 ago. 2016.

PINTO, A.; AMARAL, P.; JÚNIOR, C. S.; VERÍSSIMO, A.; SALOMÃO, R.; GOMES, G.; BALIEIRO, C. Diagnóstico Socioeconômico e Florestal do Município de Paragominas. Relatório Técnico. Belém/PA: Instituto do Homem e Meio Ambiente da Amazônia - Imazon, 2009 Disponível em: http://imazon.org.br/PDFimazon/Portugues/outros/iagnostic o-socioeconomico-e-florestal-do.pdf. Acesso em: Acesso em: 28 out. 2016.

ROCHA D. S.; ZIONI, F.; CAETANO, A. C. A. Sanitária, Cidadania e Participação Social: Análise, Histórico Advocacia e Conquistas da Associação dos Portadores de Hepatite do Acre. Revista de Direito Sanitário, São Paulo, v. 15, n.3, 2015. Disponível em: http://www.revistas.usp.br/rdisan/article/view/97331/96343. Acesso em: 22 jul. 2016.

SILVA, J. O. Hepatite oculta: Série de casos. $2013.42 \mathrm{f}$. Dissertação (Graduação em Medicina) - Universidade de Medicina da Bahia. Salvador, 2013. Disponível em: https://repositorio.ufba.br/ri/bitstream/ri/14216/1/Jefferson\% 20Oliveira\%20Silva.pdf. Acesso em: 25 jul. 2016.

\section{COPYRIGHT}

Direitos autorais: Os autores são os únicos responsáveis pelo material incluído no artigo. 


\title{
USUÁRIOS DOS SISTEMAS DE SAÚDE: A PERCEPÇÃO E AVALIAÇÃO DOS SERVIÇOS RECEBIDOS
}

\author{
USERS OF HEALTH SYSTEMS: THE PERCEPTION AND EVALUATION OF RECEIVED \\ SERVICES
}

\author{
IZABELLE CRISTINA GARCIA RODRIGUES ${ }^{1}$; IVANA FRANÇA ${ }^{1}$; VERA LUCIA PEREIRA DOS \\ SANTOS $^{1}$; DANIEL DE CHRISTO ${ }^{1}$; JOÃO LUIZ COELHO RIBAS ${ }^{1}$ \\ 1 - ESCOLA SUPERIOR DE SAÚDE, MEIO AMBIENTE, SUSTENTABILIDADE E HUMANIDADES, \\ CENTRO UNIVERSITÁRIO INTERNACIONAL UNINTER \\ jlcribas@yahoo.com.br
}

\begin{abstract}
Resumo - O Sistema Único de Saúde (SUS) oferece de forma universal os serviços de saúde aos usuários, entretanto a escassez de recursos financeiros e humanos associados a má gestão pública, pode resultar em atendimento de qualidade insatisfatória. Devido a insatisfação com os serviços oferecidos pelo SUS e a demasiada oferta da saúde suplementar, os usuários de serviço de saúde estão migrando de um serviço para o outro, em busca de qualidade no atendimento. Entretanto devido a extensa demanda de sobre-utilização, associado aos elevados custos dos procedimentos médicos e de diagnósticos, os planos de saúde não estão conseguindo of ertar um serviço com a qualidade esperada pelos usuários. Portanto, há que se analisar na visão dos usuários qual serviço de saúde oferece melhor custo beneficio. Trata-se de um estudo transversal, no qual utilizou-se um questionário. O SUS obteve a pior avaliação entre os sistemas de saúde. $O$ índice que se destacou com o pior desempenho foi o tempo médio de espera no consultório médico. Já na saúde suplementar, o serviço particular obteve melhores resultados que o plano de saúde; principalmente, com relação ao índice custobenefício. Concluiu-se que apesar do plano de saúde apresentar melhor avaliação dos usuários que o SUS, há deficiências que geram insatisfação.
\end{abstract}

Palavras-chave: Planos de saúde. Saúde Suplementar. Avaliação.

Abstract - The Unified Health System (SUS) offers universal health services to users, but the scarcity of financial and human resources associated with poor public management can result in unsatisfactory quality care. Due to insatisfaction with the services offered by the SUS and the increasing supply of supplementary health, health service users are migrating from one service to the other, in search of quality care. However, due to the extensive demand, associated with the high costs of medical and diagnostic procedures, health plans are not able to offer a service with the quality expected by users. Therefore, it is necessary to analyze in the view of the users which health service offers the best costbenefit. This is a cross-sectional study, in which a questionnaire was used. SUS achieved the worst evaluation among health systems. The index that stood out with the worst performance was the average waiting time in the doctor's office. In the supplementary health, the private service performed better than the health plan, mainly in relation to the cost-benefit index. It was concluded that although the health plan presents better evaluation of the users than the SUS, there are deficiencies that generate insatisfaction.

Keywords: Health plans. Supplementary Health. Evaluation.

\section{INTRODUÇÃO}

A Constituição Federal do Brasil de 1988, no artigo 198, dispõe que a saúde é um direito de todos e dever do Estado, porém há tempos nota-se o sucateamento da saúde pública, trazendo uma grande insatisfação aos usuários. A precariedade dos serviços públicos de saúde pode ser notada através de aspectos básicos, como a falta de estrutura física, materiais (como medicamentos e equipamentos) e de recursos humanos, além disso, existem relatos dos atendimentos precários na Atenção Primária de Saúde (MADEIRO, 2013).

O resultante dessa falta de acesso, precária estrutura e serviços ineficazes são as filas de atendimentos, superlotação em hospitais e consequentemente o descontentamento dos usuários desse serviço (MADEIRO, 2013).

Analisando a proposta do sistema público de saúde, seria uma contrariedade afirmar que a saúde pública precisa da complementariedade do serviço de saúde suplementar, porém diante da realidade do país onde o sistema público não comporta toda a demanda, o Governo viu-se pressionado a regulamentar a Saúde Suplementar, em 1998, para auxiliar a suprir a defasagem do sistema público. Inicialmente, o serviço suplementar ganhou destaque devido a qualidade no serviço prestado, bem como a quantidade de procedimentos realizados, porém com o passar dos anos a saúde suplementar apresenta dificuldades em manter o padrão dos serviços prestados. Estudos apontam que essa dificuldade vem de encontro com a imposição de rigorosos marcos regulatórios (ZIROLDO, GIMENES e CASTELO JÚNIOR, 2013). De acordo com a Agência Nacional de Saúde Suplementar (ANS) a cada ano registram-se mais e mais reclamações dos usuários desse tipo de serviço. Logo, percebe-se a insatisfação por parte dos usuários com os dois serviços oferecidos (BRASIL, 2015).

Segundo o IBGE o Brasil gastou R \$ 448,1 bilhões em 2014, relativos à despesa total com saúde. Esse valor equivale a $8,1 \%$ do PIB que atingiu cerca de $\mathrm{R} \$ 5,5$ trilhões. $\mathrm{O}$ investimento das despesas privadas está aproximadamente $51 \%$ acima dos investimentos públicos. Indicando que o financiamento público está muito aquém do necessário para viabilizar uma saúde universal (LEVI, MENDES, 2015). 
Rossi (2015) afirma que em 2012 o investimento na saúde pública foi inferior a U\$ 490,00 por habitante e Weber (2016) menciona ainda que comparando o investimento do Brasil na saúde com outros países desenvolvidos, que utilizam o mesmo sistema de universalidade, é possível comprovar a insuficiência de recursos destinados ao setor o que torna inviável um sistema de qualidade. Atribuído a isso, ainda há que se preocupar com a má gestão e a corrupção, que consumiu R $\$ 14$ bilhões no período de 2002 a 2015. O valor desviado é superior ao que foi destinado ao Ministério da Saúde para investimentos no ano de 2015 (R \$ 10 bilhões) (CFM, 2016).

Corroborando com a teoria supracitada, o caos da saúde pública está atrelado a deficiência das políticas públicas que não fornecem subsídios necessários para um financiamento adequado e isto impede que o SUS seja universal. "Hoje, o SUS é destinado para a população de baixa renda. Então o SUS é pobre, pois não é pensado para todos como usuários" (SOUZA, p. 10, 2014).

Em contrapartida, devido a legislação comercial, os planos de saúde não são obrigados a apresentar os custos de seus serviços. Sendo que os custos têm um impacto direto na mensalidade paga pelos usuários, com isso, não é possível saber se os reajustes das mensalidades condizem com a real necessidade das operadoras (CARVALHO, CECÍLIO, 2007).

Ao analisar a perspectiva do usuário da saúde suplementar, o qual arca com os custos do plano de saúde, onde o valor investido por pessoa é em média $\mathrm{R} \$ 180,00$ por mês, subentende-se que a saúde suplementar tem infinita superioridade à saúde pública, contudo, não é isso que vem sendo registrado na ouvidoria da ANS, pois devido à má remuneração aos médicos, os profissionais se veem obrigados a atender uma grande quantidade de pacientes em um único dia para que possam ter uma boa remuneração, além da pressão das operadoras pela diminuição de custos, com redução de exames, o que reflete na qualidade do atendimento. Para Aloisio Tibiriça, Vice-Presidente do CFM "estamos falando de um setor que, apesar de lucrar bilhões, deixa a desejar nos serviços prestados aos pacientes, não valoriza seus profissionais e ainda onera o SUS" (TIBIRIÇA, p. 21, 2014).

Outro ponto que agrega custos aos sistemas de saúde é a sobre-utilização, quando o usuário utiliza mais os serviços de saúde do que seria necessário, apenas porque não tem um custo direto, ponto abordado tanto na saúde pública quanto na privada (MAIA; ANDRADE; OLIVEIRA, 2004).

Apesar da proximidade que o sistema de saúde deveria ter dos usuários, devido a sua importância, em um estudo do CONASS, foi possível verificar que $55 \%$ dos entrevistados nem mesmo sabem o significado da palavra SUS, além disso, $22 \%$ dos entrevistados desconheciam que os serviços do SUS não são pagos diretamente (BRASIL, 2003).

Contudo, com o passar dos anos é possível verificar que os usuários do sistema suplementar de saúde também não estão satisfeitos com a qualidade dos serviços oferecidos. Diariamente são notificados casos de demora no agendamento das consultas, valores exorbitantes para determinadas coberturas, serviços não autorizados pelos planos, entre outros. Atualmente, as operadoras de planos de saúde lideram o ranking de reclamações dos serviços de proteção aos consumidores (GLOBO, 2016).

Diante disso, surge a seguinte problemática: Qual sistema de saúde tem a melhor avaliação para seus usuários?
Buscando responder a esse questionamento o objetivo do trabalho é analisar a percepção dos usuários dos serviços de saúde, com relação à qualidade prestada pelo sistema de saúde utilizado por ele, analisando sob a ótica do usuário os pontos positivos e negativos de cada sistema e também as expectativas na qualidade de atendimento dos planos utilizados.

\section{PROCEDIMENTOS}

O estudo foi realizado foi por meio de uma pesquisa de campo, com caráter quantitativo. A pesquisa foi direcionada aos alunos de cursos de pós-graduação residentes no município de Curitiba e Região metropolitana de uma Instituição de Ensino Superior.

Trata-se de um estudo transversal por meio de um questionário elaborado especificamente para a presente pesquisa, contendo perguntas fechadas e disponibilizado de forma on line, por meio do Google Docs Off line Esse questionário foi composto por dez perguntas contendo de duas a cinco altenativas de resposta sobre a percepção que os entrevistados tem da qualidade do serviço prestado pelo sistema de saúde utilizado por ele.

Nesse questionário as pessoas eram indagadas quanto a sua idade; gênero; a respeito do sistema de saúde que utiliza; a classificação do atendimento recebido em caso de emergência e no caso de consultas eletivas, o tempo médio de agendamento de consulta com um médico especialista; a avaliação pessoal da relação custo benefício de seu sitema de saúde em uso; qual a frenquencia de utilização durante o ano, dos serviços disponibilizados; o tempo médio de espera para o atendimento no consultório médico e qual o serviço mais utilizado.

O questionário foi aplicado a 731 alunos não identificados, residentes no Municipio de Curitiba e região metropolitana, de uma determinada instituição de ensino superior.

As respostas obtidas com a aplicação do questionário de pesquisa foram tabuladas e analisadas estatisticamente através de análise bivariada utilizando o qui-quadrado e conduzidas pelo GraphPad Software V.2.01, GraphpadInstat-TM (1990-1993). O nível de significância adotado foi de $5 \%(\alpha=0,05)$.

\section{RESULTADOS}

Das 731 pessoas as quais o questionário foi ofertado, 299 indivíduos retornaram, sendo que desses 162 eram conveniados a planos de saúde, 14 utilizavam apenas o serviço particular e 123 faziam o uso do Sistema Público de Saúde.

Estudos denotam que o sistema de Saúde Brasileiro conta com duas vertentes, a pública e a privada. A saúde suplementar agrega apenas $25 \%$ da população os demais, $75 \%$ da população, contam apenas com a saúde pública (ROSSI, 2015).

Os testes estatísticos demonstram que a maioria dos entrevistados fazem uso do sistema de saúde complementar e apenas $41 \%$ dos indivíduos, que responderam, à pesquisa fazem a utilização do Sistema Público de Saúde. A causa disso é devido ao fato de que o sistema de saúde no Brasil sofreu influência de duas propostas opostas, o projeto da Reforma Sanitária Brasileira e o Projeto Neoliberal. A reforma sanitária apostava em saúde para todos e obrigação do Estado em prover esse serviço, já no neoliberalismo 
predominava a influência do setor privado, para auxiliar os ajustes econômicos. O resultado disso foi um sistema universal, como solicitava a reforma sanitária, mas implantada por orientação de neoliberalistas. Com isso, o sistema tornou-se contraditório com características dos dois sistemas, culminando em um sistema sem um modelo fidedigno (BISPO JÚNIOR e MESSIAS, 2005), justificando assim a alta influência dos planos de saúde acarretando na grande aderência da população a esse sistema, mesmo o Brasil tendo um sistema de saúde que contrarie esse princípio.

No entanto, a saúde suplementar no Brasil é financiada pelos usuários e com subsídios públicos. O usuário que optar por pagar para obter a seguridade desse serviço, não estará isento da manutenção da seguridade social, sendo assim, ele permanece com o direito de utilizar os serviços do Sistema Único de Saúde, diferentemente do que acontecem em outros países desenvolvidos. Porém, apesar do usuário ter direito a usar o SUS, a ANS determina que o plano de saúde deve ressarcir o SUS, caso seu usuário utilize os serviços públicos (PIETROBON, PRADO e CAETANO, 2008).

A regulamentação da saúde suplementar iniciou na década de 50, por meio de empresas multinacionais que "prestavam serviços de forma direta" aos seus colaboradores. Devido a essa iniciativa, na década de 60 boa parte dos trabalhadores já possuíam esse serviço, nos anos de 1970 houve mais um avanço na saúde suplementar no Brasil, com a criação do SINPAS (Sistema Nacional de Previdência e Assistência Social), já nos anos 80, devido crises políticas, sociais e econômicas cresce o movimento sanitário brasileiro, que culmina na criação do SUS, porém há também a ampliação a manutenção do setor suplementar, que obteve somente em 1998 a criação da Agência Nacional da Saúde Suplementar (ANS) (PIETROBON, PRADO e CAETANO, 2008; ZIROLDO, GIMENES e CASTELO JÚNIOR, 2013).

Atualmente, o número de usuários na Saúde Suplementar passa de 50 milhões. O mais expressivo foi que em curto período (6 anos) o número de adeptos aumentou 18 milhões, ou seja, mesmo que os cidadãos tenham, pela constituição, o direito à saúde garantida pelo Estado, elas preferiram filiar-se ao Serviço de Saúde Suplementar. Atualmente são 1.728 operadoras nesse ramo, sendo que apenas 45 operadoras concentram $50 \%$ dos usuários (ZIROLDO, GIMENES e CASTELO JÚNIOR, 2013).

Apesar disso, o SUS torna-se um dos maiores sistemas públicos de saúde do mundo. Sendo um serviço público, por diversas vezes há uma incoerência em acreditar que é um serviço gratuito, pois não havendo pagamento direto, os usuários não percebem o pagamento indireto desse serviço, por meio de impostos. A Lei da universalidade determina que o SUS cubra $100 \%$ dos brasileiros e de fato é a maior cobertura entre todos os planos de saúde no Brasil, mas ainda é deficitária, pois nenhum estado brasileiro conseguiu a cobertura de todas as cidades. Apenas os estados do Piauí e Paraíba conseguiram estender para $90 \%$ do estado. Já estados do Sul do país são os que apresentam as menores coberturas, em média apenas $20 \%$ dos estados estão cobertos, isso reflete na saúde suplementar onde, por usa vez, esses estados estão com os maiores índices de agregados a esse serviço (ROSSI, 2015; MALTA, s/d;).

$\mathrm{O}$ perfil quanto a distribuição das faixas etárias, do indivíduos que responderam à pesquisa, as faixas etárias de

20 a 29 anos e 30 a 39 anos envolvem a maioria dos participantes, representando juntas $67 \%$ dos entrevistados. Conforme dados do IBGE (2013), a maior porção da população brasileira está na faixa etária entre 20 e 39 anos, o que corrobora com os resultados obtidos pela pesquisa. A terceira faixa etária com maior incidência foi de 40 a 49 (21\%), seguida de 50 a 59 (8\%) e então acima de 60 anos (3\%).

Em todos os grupos a participação das mulheres foi muito superior que a de homens, representando em torno de $84 \%$ dos entrevistados. O Instituto de Pesquisa de Economia Aplicada (IPEA, 2013) menciona que até o ano de 2013 o número de homens economicamente ativos era superior ao número de mulheres, porém estudos como o de Guedes (2008) sugerem que ao longo dos anos as mulheres fazem-se mais presentes nas instituições de ensino, logo explica-se a diferença entre os gêneros na pesquisa.

Quando os entrevistados foram questionados quanto ao atendimento recebido em casos de emergência, fica nítida a maior satisfação dos usuários de planos de saúde e serviço particular em relação aos usuários do SUS (p<0,001). Entre os usuários dos planos de saúde e particular, $38 \%$ e $50 \%$ respectivamente indicaram como bom o atendimento recebido em casos de emergência. Por outro lado, apenas $15 \%$ dos usuários do SUS considerou bom o atendimento prestado.

Quanto as filas e atendimentos desumanizados não são exclusivos do SUS, pois quanto maior o fluxo de atendimento pior será a sua qualidade (BITTENCOURT, 2010). A superlotação é um problema mundial, porém pode ser amenizado aumentando o desempenho organizacional da equipe, por isso, o sistema de classificação de risco bem executado faz-se tão importante nesses ambientes. Já Souza e Dall'Agnol (2013) defendem que a reestruturação das estratégias de gestão é a saída para minimizar as filas nas salas de emergências. Por meio da conscientização da população para tomarem certas precauções as enfermidades podem ser minimizadas acarretando, assim, na diminuição das filas.

$\mathrm{Na}$ cartilha "Novas possibilidades de organizar o Acesso eSMS a Agenda na Atenção Primária à Saúde", divulgada pela Prefeitura Municipal de Curitiba, há o reconhecimento de que para uma boa avaliação do sistema de saúde é necessário que o paciente obtenha um atendimento rápido, preferencialmente em até 48 horas, após o contato com a equipe de referência (SMS, 2014). Contudo, apesar de reconhecer a importância de um breve atendimento, por meio dos resultados deste estudo, nota-se que ainda faltam alguns ajustes a serem feitos nos agendamentos, pois apenas $22 \%$ dos entrevistados que fazem uso do sistema público de saúde consideram, como bom o atendimento recebido nas consultas eletivas, já entre os usuários de planos de saúde e particular, 62\% e 57\% respectivamente consideram o serviço bom. Considerando que nos planos de saúde a consulta básica deve ser realizada em até 7 dias após o contato, conforme a Resolução Normativa ${ }^{\circ} 259$ de 17 de junho de 2011 (BRASIL, 2011).

Tabela 1 - Classificação do atendimento recebido nos casos de consultas eletivas

\begin{tabular}{lccc} 
& Plano de Saúde & Particular & Público \\
\hline Bom & $62 \%$ & $57 \%$ & $22 \%$ \\
\hline Médio & $28 \%$ & $29 \%$ & $50 \%$ \\
\hline Ruim & $7 \%$ & $14 \%$ & $8 \%$ \\
\hline Nunca utilizei & $2 \%$ & $0 \%$ & $20 \%$ \\
\hline
\end{tabular}


Na Tabela 2 os entrevistados indicaram o tempo médio de agendamento de consulta com um médico especialista. A grande maioria dos usuários de plano de saúde e particular, $53 \%$ e $71 \%$ respectivamente, conseguem fazer o agendamento com menos de 21 dias. Infelizmente, é possível observar que a maioria dos usuários do SUS (51\% $\mathrm{p}=0,047$ ) leva mais de 2 meses para conseguir agendar a consulta.

A Resolução Normativa n n $^{2} 259$ de 17 de junho de 2011 determina os prazos para agendamento de consultas, de acordo com a especialidade e urgência de cada modalidade (BRASIL, 2011):

Art. $3^{\circ} \mathrm{A}$ operadora deverá garantir o atendimento integral das coberturas referidas no art. $2^{\circ}$ nos seguintes prazos:

I - consulta básica - pediatria, clínica médica, cirurgia geral, ginecologia e obstetrícia: em até 7 (sete) dias úteis;

II - consulta nas demais especialidades médicas: em até 14 (quatorze) dias úteis;

IV - consulta/sessão com nutricionista; psicólogo; terapeuta ocupacional; fisioterapeuta; fonoaudiólogo: em até 10 (dez) dias úteis; (...)

IX - serviços de diagnóstico por laboratório de análises clínicas em regime ambulatorial: em até 3 (três) dias úteis;

$\mathrm{X}$ - demais serviços de diagnóstico e terapia em regime ambulatorial: em até 10 (dez) dias úteis;

XI - procedimentos de alta complexidade - PAC: em até 21 (vinte e um) dias úteis;

(...)

XIII - atendimento em regime de internação eletiva: em até 21 (vinte e um) dias úteis; e

XIV - urgência e emergência: imediato.

Analisando os prazos estabelecidos pela ANS e os resultados obtidos na presente pesquisa, pode-se afirmar que os usuários de planos de saúde são tolerantes com os prazos recebidos, pois em nenhuma das situações mencionadas pela ANS o prazo de 21 dias pode ser ultrapassado, sendo que a pesquisa demonstra que $30 \%$ dos usuários de planos de saúde afirmam que uma consulta com especialista pode levar de um mês até mais de dois meses. Porém, corroborando com os resultados da pesquisa em questão, os usuários de planos de saúde pouco reclamam deste quesito, pois esse item consta em quinto lugar no ranking de notificações intermediação preliminar da ANS (BRASIL, 2015).

No SUS não há uma determinação legal que defina o prazo máximo para agendamento de consultas, com isso, os usuários chegam a ficar aguardando até 4 meses por uma consulta (GLOBO, 2013).

No Município de Curitiba e região Metropolitana a espera por uma consulta com um oftalmologista pode chegar até 2,2 anos para casos prioritários e os casos mais simples são atendidos em média em 7 meses (GAZETA DO POVO, 2013). Em alguns municípios o Ministério Público está acionando judicialmente os municípios à adotarem um sistema de controle de espera das filas de espera. Esse sistema permitiria que o usuário pudesse acompanhar a sequência de chamada (JUSBRASIL, 2016).

O Sistema único de Saúde possui mais de 20 anos e apresenta-se cada vez mais presente na vida da população. Contudo, "torna-se necessário a geração de conhecimento, métodos e tecnologia que deem suporte" para o seu pleno funcionamento e ampliação (SILVA, et al., p. 3183, 2011).

Tabela 2 - Tempo médio de agendamento de consulta com um médico especialista

\begin{tabular}{lccc}
\hline & $\begin{array}{c}\text { Plano de } \\
\text { saúde }\end{array}$ & Particular & Público \\
\hline 1 A 7 dias & $14 \%$ & $21 \%$ & $2 \%$ \\
8 A 20 dias & $39 \%$ & $50 \%$ & $14 \%$ \\
21 A 30 dias & $17 \%$ & $21 \%$ & $11 \%$ \\
1 A 2 meses & $20 \%$ & $7 \%$ & $23 \%$ \\
Mais de 2 meses & $10 \%$ & $0 \%$ & $51 \%$ \\
\hline
\end{tabular}

Lembrando que o sistema público de saúde é pago por impostos, os entrevistados foram questionados sobre a relação custo benefício de seu sistema de saúde, conforme a Tabela 3. Os usuários de serviços particulares demonstraram ser os mais satisfeitos pois $57 \%$ consideram boa a relação custo benefício e apenas $7 \%$ consideram ruim. Os usuários do SUS demonstraram a maior insatisfação $(\mathrm{p}<0,001)$ uma vez que apenas $12 \%$ consideram a relação custo benefício boa e $50 \%$ consideram ruim.

Zucchi, Nero e Malik (2000) afirmam que os sistemas de saúde deveriam se preocupar em "gastar menos e melhor", pois os governantes e operadoras condicionam a qualidade do serviço prestado aos altos custos dos serviços de saúde (equipamentos, exames, etc.), além da alta demanda em busca dos serviços (crescimento por uma qualidade de vida melhor e longevidade da população).

Tabela 3 - Avaliação da relação custo benefício de seu sistema de saúde

\begin{tabular}{lccc}
\hline & Plano de saúde & Particular & Público \\
\hline Bom & $35 \%$ & $57 \%$ & $12 \%$ \\
Médio & $44 \%$ & $36 \%$ & $38 \%$ \\
Ruim & $21 \%$ & $7 \%$ & $50 \%$ \\
\hline
\end{tabular}

Na Tabela 4 são apresentados os resultados com relação à frequência que os entrevistados utilizam o sistema de saúde durante o ano. É possível observar que os usuários do SUS utilizam com maior frequência $(\mathrm{p}<0,001)$, pois $41 \%$ dos entrevistados utilizam o serviço mensalmente. Por outro lado, mensalmente apenas $10 \%$ dos usuários do plano de saúde e $21 \%$ particular fazem uso do sistema de saúde. Fica evidente uma menor utilização do sistema de saúde pelos usuários de serviços particulares. Dentre estes entrevistados $21 \%$ utilizam o sistema de saúde apenas em situações de emergência, enquanto apenas $7 \%$ dos usuários de planos de saúde e $8 \%$ dos usuários do SUS fazem uso exclusivamente nesta situação. Isso pode ser justificado, devido ao fato dos programas públicos de saúde trabalharem intensamente com a prevenção e promoção da saúde, assim, condiciona-se, principalmente os pacientes de doenças crônicas não transmissíveis (DCNT), a apresentarem-se periodicamente para acompanhamento de sua enfermidade, evitando-se assim que o quadro se agrave ou mesmo que desenvolvimento novas enfermidades (SILVA, COSTA e ROSA, 2013).

Para os planos de saúde a ANS elaborou em 2007 um manual técnico de promoção e prevenção de riscos e doenças na saúde suplementar, porém conforme mencionado por Rodrigues (2015), nem todas as operadoras tem programas de prevenção e promoção à saúde e algumas possuem, mas não os registraram na Agência Nacional de 
Saúde Suplementar. Isso demonstra a falta de investimento nessa área por parte alguns operadores desse sistema de saúde.

Tabela 4 - Frequência que os usuários utilizam seu sistema de saúde no período de um ano

\begin{tabular}{lccc}
\hline & $\begin{array}{c}\text { Plano de } \\
\text { saúde }\end{array}$ & Particular & Público \\
\hline Todos os meses & $10 \%$ & $21 \%$ & $41 \%$ \\
A cada 2 meses & $18 \%$ & $7 \%$ & $9 \%$ \\
A cada 4 meses & $24 \%$ & $14 \%$ & $12 \%$ \\
A cada 6 meses ou mais & $40 \%$ & $36 \%$ & $29 \%$ \\
Somente em emergências & $7 \%$ & $21 \%$ & $8 \%$ \\
\hline
\end{tabular}

O tempo médio de espera para atendimento no consultório médico está indicado na Tabela 5. O tempo de espera entre os usuários do plano de saúde e particular é muito parecido, sendo que a minoria espera mais de 60 minutos, $12 \%(\mathrm{p}=0,023)$ e $14 \%(\mathrm{p}=0,039)$ respectivamente. Já entre os usuários do SUS, a maioria $(54 \%$ - p<0,001) espera mais de 60 minutos para o atendimento, demonstrando o caos que vive o sistema público de saúde do país.

No Parecer N $N^{\text {o } 2151 / 2010 ~ o ~ C o n s e l h o ~ R e g i o n a l ~ d e ~}$ Medicina do Paraná, informa que não há legislação que determine o tempo máximo de espera no consultório médico, seja atendimento público ou privado. Ainda segundo o parecer, o profissional de medicina pode ter várias intercorrências em seu dia, seja uma consulta mais demorada devido sua complexidade ou uma emergência médica que precisou atender, o que o impediria a cumprir a agenda (CRM-PR, 2010). Porém, conforme relato em noticiário, a demora no atendimento tornou-se constante e a discussão vem ganhando destaque. Em países como os Estados Unidos, alguns médicos estão oferecendo brindes aos pacientes que foram prejudicados com o atraso, já aqui no Brasil, alguns médicos concordam que não há como evitar o atraso, mas para que não haja um desestímulo as consultas, eles buscam meios alternativos de compensar os pacientes, oferecendo um lanche para quem esperar mais de 30 minutos ou mesmo a isenção do valor da consulta quando o atraso superar 60 minutos (COSTA, 2011).

Tabela 5 - Tempo médio de espera para atendimento no consultório médico

\begin{tabular}{lccc}
\hline & $\begin{array}{c}\text { Plano de } \\
\text { saúde }\end{array}$ & Particular & Público \\
\hline Até 10 minutos & $6 \%$ & $0 \%$ & $2 \%$ \\
Até 20 minutos & $25 \%$ & $29 \%$ & $5 \%$ \\
Até 30 minutos & $35 \%$ & $36 \%$ & $17 \%$ \\
$\begin{array}{l}\text { Até 60 minutos } \\
\text { Mais de 60 }\end{array}$ & $22 \%$ & $21 \%$ & $22 \%$ \\
minutos & $12 \%$ & $14 \%$ & $54 \%$ \\
\hline
\end{tabular}

Deve-se levar em consideração que na visão dos usuários os serviços de saúde oferecidos, independente da modalidade, são vistos como ruins, péssimos ou regulares. No SUS o tempo de espera por uma consulta é o ponto de maior insatisfação, e no plano de saúde a cobertura dos serviços é citada como a maior deficiência. Com isso, o resultado é de $93 \%$ dos entrevistados apontam estarem insatisfeitos com os serviços de saúde, seja público ou privado (GLOBO, 2013).
Em 2008, no estudo realizado por Castro et al., $45 \%$ os usuários do SUS acreditavam que o sistema apresentava potencial para melhorar e a reclamação dificilmente era voltada ao médico e sim ao sistema ou local de atendimento, porém com o passar dos anos é possível perceber que a insatisfação dos usuários se sobrepõem, além de se expandir para os médicos, sistema, infraestrutura, entre outros (PONTES et al., 2009). No plano de saúde a reclamação inicial era com relação aos custos, contudo com o passar dos anos a além da insatisfação com os reajustes de mensalidades, que são frequentes, há também a insatisfação coma qualidade do atendimento e com a cobertura dos serviços (VIEIRA JUNIOR, 2013).

As diferenças entre usuários de plano de saúde e SUS foram testadas estatisticamente e demonstraram ser significativas. $\mathrm{O}$ grupo de indivíduos que faz uso de serviços particulares não foi incluído na análise estatística devido ao pequeno tamanho da amostra $(n=14)$.

\section{CONCLUSÃO}

O presente estudo feito por meio de pesquisa de campo com alunos de uma IES, residentes no município de Curitiba e Região Metropolitana demonstra diferentes opiniões com relação ao sistema de saúde dessa região.

Resultados evidenciam que os usuários dos serviços de saúde particular são os mais satisfeitos, pois foi o que apresentou os melhores resultados, até mesmo quando questionados com relação ao custo-benefício desse sistema. O plano de saúde foi o segundo melhor avaliado, mesmo apresentando algumas deficiências, como na questão voltada para a periodicidade de consultas obteve melhores resultados que o Sistema Público de Saúde.

Verificou-se ainda que todos os sistemas de saúde analisados apresentaram pontos positivos e negativos, apesar do plano de saúde apresentar melhores resultados que o Sistema Público de Saúde, isso não significa total satisfação por parte dos seus usuários. O sistema público, que não requer nenhum pagamento direto pelo serviço prestado, não satisfaz a população entrevistada.

Contudo, deve-se destacar que a pesquisa foi realizada com moradores de uma pequena região do estado do Paraná, não podendo ser extrapolada para todo o sistema de saúde do país.

\section{REFERÊNCIAS BIBLIOGRÁFICAS}

ANS. Agência Nacional de Saúde Suplementar. Promoção da saúde e prevenção de riscos e doenças na saúde suplementar: manual técnico/Agência Nacional de Saúde Suplementar. 2. ed. rev. e atual. Rio de Janeiro: ANS, 2007. $168 \mathrm{p}$.

BITTENCOURT, R.J. A superlotação dos serviços de emergência hospitalar como evidência de baixa efetividade organizacional. 2010. 152 f. Tese (Doutorado em Ciências na área de Saúde Pública). Escola Nacional de Saúde Pública Sérgio Arouca. Fiocruz, Rio de Janeiro.

BISPO JÚNIOR, J.P.; MESSIAS, K.L.M. Sistemas de serviços de saúde: principais tipologias e suas relações com o sistema de saúde brasileiro. Rev. Saúde Com., v. 1, n. 1, p. 79-89, 2005

BRASIL. Ministério da Saúde (MS). Agência Nacional de Saúde Suplementar. ANS divulga índice de desempenho das operadoras de planos de saúde. Brasília: ANS; 2015. 
BRASIL. Conselho Nacional de Secretários de Saúde. A Saúde na opinião dos brasileiros: um estudo prospectivo. Brasília: CONASS; 2003.

BRASIL. Ministério da Saúde (MS). Agência Nacional de Saúde Suplementar (ANS). Resolução Normativa - RN n 259, de 17 de junho de 2011. Dispõe sobre a garantia de atendimento dos beneficiários de plano privado de assistência à saúde e altera a Instrução Normativa - IN n ${ }^{\circ} 23$, de $1^{\circ}$ de dezembro de 2009, da Diretoria de Normas e Habilitação dos Produtos - DIPRO.

BRASIL. Resolução Normativa - RN N ${ }^{\circ}$ 259, de 17 de junho de 2011. Dispõe sobre a garantia de atendimento dos beneficiários de plano privado de assistência à saúde e altera a Instrução Normativa - IN $n^{\circ} 23$, de $1^{\circ}$ de dezembro de 2009, da Diretoria de Normas e Habilitação dos Produtos DIPRO

CASTRO, H.C.O.; MACHADO, L.Z.; WALTER, M.I.M.T.; RANINCHESKI, S.M.; SCHMIDT, B.V.; MARINHO, D.N.C.; CAMPOS, T.M.A. A Satisfação dos Usuários com o Sistema Único de Saúde (SUS). Sociedade em Debate, v. 14, n. 2, p. 113-134, 2008.

CARVALHO, E.B.; CECÍLIO, L.C.O. A regulamentação do setor de saúde suplementar no Brasil: reconstrução de uma história de disputas. Cad. Saúde Pública, v. 23, n. 9, p. 2167-2177, 2007.

COSTA, R. Um basta ao atraso médico. Revista Isto É, 2011; Jan 21.

CFM. Má Gestão no SUS. Jornal Medicina, 25 Abr. 2016 , p. 6.

CFM. Conselho Federal de Medicina. Weber, C.A.T. A saúde, o cafezinho e a população. Brasília: CFM; 2016.

CRM-PR. Conselho Regional de Medicina do Paraná Atendimento médico - consulta eletiva - cumprimento de horário de agendamento. Parecer No 2151/2010 CRM-PR. Processo Consulta N. ${ }^{\circ}$ 189/2009. Protocolo N. ${ }^{\circ} 21149$ /2009. Curitiba: CRM; 2010.

GAZETA DO POVO. Consulta pelo SUS demora até 3 anos, 30 set. 2013.

GLOBO. Prazo com consultas no SUS chega a quatro meses na região de Campinas. 2013. Disponível em: http://g1.globo.com/sp/campinas-

regiao/noticia/2013/06/prazo-para-consultas-no-sus-chegaquatro-meses-na-regiao-de-campinas.html

GLOBO. Entenda o que deve ser avaliado na hora de contratar um plano de saúde. 2016. http://g1.globo.com/sao-paulo/sorocaba-jundiai/tem-

noticias-1edicao/videos/v/entenda-o-que-deve-ser-avaliadona-hora-de-contratar-um-plano-de-saude/5045185/

GUEDES, M.C. A presença feminina nos cursos universitários e nas pós-graduações: desconstruindo a ideia da universidade como espaço masculino. Hist. Cienc. Saúde, v. 15, p. 117-132, 2008.

IBGE. Instituto Brasileiro de Geografia e Estatística. População jovem no Brasil: a dimensão demográfica. Brasília: IBGE; 2013.

IPEA. Instituto de Pesquisa Econômica Aplicada. Retrato das desigualdades de gênero e raça. Brasília: IPEA; 2013.
JUSBRASIL. Municípios do Vale do Itajaí terão que implantar sistema de controle das filas de espera do SUS. 2016. Disponível em: http://trf4.jusbrasil.com.br/noticias/351907510/municipios-do-valedo-itajai-terao-que-implantar-sistema-de-controle-das-filasde-espera-do-sus

LEVI, M.L.; MENDES, A. Gasto Total com Saúde no Brasil: a importância e o esforço de medi-lo. 2015. Disponível em: http://www.abrasco.org.br/site/wpcontent/uploads/2015/06/Domingueira-da-Sa\%C3\%BAde008-2015-24-05-2015.pdf

MADEIRO, R.C.V. Crise na Saúde Pública. Revista Jurídica Consulex, n. 397, 2013.

MAIA, A.C.; ANDRADE, M.V.; OLIVEIRA, A.M.H.C. O Risco Moral no Sistema de Saúde Suplementar Brasileiro. 2004. Disponível em: http://www.anpec.org.br/encontro2004/artigos/A04A099.pd $\underline{f}$

MALTA, D.C. Saúde Suplementar e Modelos Assistenciais. Disponível em: http://www.epsjv.fiocruz.br/upload/d/Saude_Suplementar_e ModelosAssistenciais.pdf

PIETROBON. L.; PRADO, M.L.; CAETANO, J.C. Saúde suplementar no Brasil: o papel da Agência Nacional de Saúde Suplementar na regulação do setor. Physis, v. 18, n. 4, p. 767-783, 2008.

PONTES, A.P.M.; CESSO, R.G.D.; OLIVEIRA, D.C.; GOMES, A.M.T. O princípio de universalidade do acesso aos serviços de saúde: o que pensam os usuários? Esc. Anna Nery Rev. Enferm., v. 13, n. 3, p. 500-07, 2009.

RODRIGUES, A.T.; SILVA, K.L.; SENA, R.R. Programas de promoção da saúde na saúde suplementar em Belo Horizonte, MG, Brasil: concepções e práticas. Interface Comunicação Saúde Educação, v. 19, n. 54, p. 455-66, 2015.

ROSSI, M. Saúde pública no Brasil ainda sofre com recursos insuficientes. 2015. Disponível em: http://www2.camara.leg.br/camaranoticias/noticias/SAUDE/ 480185-SAUDEPUBLICA-NO-BRASIL-AINDA-SOFRECOM-RECURSOS-INSUFICIENTES.html

SILVA, L.S.; COSTA, R.M.M.; ROSA, C.O.B. Estratégias de promoção da saúde e prevenção primária para enfrentamento das doenças crônicas: revisão sistemática. Rev. Panam. Salud. Publica, n. 34, v. 5, p. 343-50, 2013.

SILVA, Z.P.; RIBEIRO, M.C.S.A.; BARATA, R.B.; ALMEIDA, M.F. Perfil sociodemográfico e padrão de utilização dos serviços de saúde do Sistema Único de Saúde (SUS), 2003-2008. Ciência \& Saúde Coletiva, v. 16, n. 9, p. 3807-3816, 2011.

SMS. Secretaria Municipal da Saúde de Curitiba. Departamento de Atenção Primária à Saúde. Coordenação do Acesso e Vínculo. Novas possibilidades de organizar o Acesso e a Agenda na Atenção Primária à Saúde. Curitiba: SMS; 2014.

SOUZA, D.B.; DALL'AGNOL, C.M. Emergência de saúde pública: representações sociais entre gestores de um hospital universitário. Rev. Latino-Am., v 21, v. 4, p. 01-07, 2013. 
SOUZA, P.H. Notícias do Front. Revista Medicina CFM, n. 5, p. 8-15, maio/agosto, 2014.

VIEIRA JUNIOR, W.M. Idosos e planos de saúde no Brasil: análise das reclamações recebidas pela Agência Nacional de Saúde Suplementar .2013. Dissertação (Mestrado em Ciências na área de Saúde Pública). Escola Nacional de Saúde Pública Sérgio Arouca. Fiocruz, Rio de Janeiro.

ZIROLDO, R.R.; GIMENES, R.O.; CASTELO JÚNIOR, C. A importância da Saúde Suplementar na demanda da prestação dos serviços assistenciais no Brasil. O Mundo da Saúde, v. 37, n. 2, p. 216-221, 2013.

ZUCCHI, P.; DEL NERO, C.; MALIK, A.M. Gastos em saúde: os fatores que agem na demanda e na oferta dos serviços de saúde. Saúde e Sociedade. v. 9, n. 1/2, p. 127$150,2000$.

\section{COPYRIGHT}

Direitos autorais: Os autores são os únicos responsáveis pelo material incluído no artigo. 


\title{
Revista SODEBRAS - Volume 12 \\ $\mathrm{N}^{\circ} 134$ - FEVEREIRO/ 2017
}

\section{PARÂMETROS PREDITIVOS DO USO DE NARGUILÉ E SUAS CONSEQUENCIAS}

\author{
PREDICTIVE PARAMETERS OF THE USE OF NARGHILE AND ITS \\ CONSEQUENCES
}

\author{
ELIANE GOUVEIA DE MORAIS SANCHEZ1; NAYARA DE PAULA GUERREIRO²; BEATRIZ RIBEIRO \\ FARINHA $^{3}$; KATIUSCIA PEREIRA DE RESENDE ${ }^{4}$; HUGO MACHADO SANCHEZ ${ }^{5}$ \\ 1 - DOCENTE DO CURSO DE BIOLOGIA, UNIVERSIDADE DE RIO VERDE; $2 ; 3 ; 4$ - GRADUANDAS \\ DO CURSO DE MEDICINA, UNIVERSIDADE DE RIO VERDE; 5 - DOCENTE DO CURSO DE \\ FISIOTERAPIA, UNIVERSIDADE DE RIO VERDE \\ egmfisio@yahoo.com.br; nayaradepaulaguerreiro@gmail.com; beatrizribeirofarinha@gmail.com; \\ katiuscia.pereira@gmail.com; hmsfisio@yahoo.com.br
}

\begin{abstract}
Resumo - O narguilé é um cano de água utilizado para fumar, no qual o tabaco é aquecido e a fumaça gerada passa por um filtro de água antes de ser aspirada pelo fumante. Estima-se que cerca de 100 milhões de pessoas no mundo fazem uso do narguilé. $O$ uso de produtos derivados do tabaco é a principal causa de morte evitável no mundo. Desta forma, o objetivo da presente revisão de literatura foi levantar os principais fatores preditivos para a utilização narguilé $e$ os principais acometimentos pulmonares e extrapulmonares decorrentes de seu uso. Trata-se de uma revisão bibliográfica, realizada por meio de levantamento de artigos científicos nacionais $e$ internacionais, publicados nos últimos dez anos. Conclui-se que há uma lista bem estabelecida de doenças cardiopulmonares $e$ extrapulmonares decorrentes do uso de narguilé, fato que deve ser entendido como preocupante, uma vez que o seu uso se destaca, principalmente entre os mais jovens.
\end{abstract}

Palavras-chave: Narguilé. Epidemiologia. Doenças Cardiorrespiratórias. Pneumopatias Obstrutivas. Tabaco.

\begin{abstract}
The hookah is a water pipe used for smoking, not which tobacco is heated and a smoke generated passes through a water filter before being aspirated hair smoker. It is estimated that about 100 million people in the world make use of the hookah. The use of tobacco derived products and the leading cause of preventable death in the world. Thus, the objective of the present literature review was to raise the main predictive factors for the use of narghile and the main pulmonary and extrapulmonary disorders resulting from its use. This is a narrative bibliographical review, carried out by means of a survey of national and international scientific articles published in the last ten years. It is concluded that there is a wellestablished list of cardiopulmonary and extrapulmonary diseases resulting from the use of narghile, a fact that MUST be understood as worrying, once its use stands out, especially among the youngest.
\end{abstract}

Keywords: Narghile. Epidemiology. Health-Disease Process. Cardiopulmonary Diseases. Respiratory Failure. Obstructive Lung Disease. Smoking.

\section{INTRODUÇÃO}

O narguilé é um instrumento utilizado para fumar tabaco, conhecido também como cachimbo d'água que, quando aquecido, gera uma fumaça que passa por um filtro de água antes de ser aspirada pelo fumante, por meio de uma mangueira (VIEGAS, 2008; CHAOUACHI, 2009; SAAD, 2009).

Esse instrumento foi criado na Índia, no Século XVIII, por Hakim Abul Fath, supondo-se que, se o fumo do tabaco passasse por um pequeno recipiente com água antes de ser inalado, geraria menos danos à saúde, resultando na convicção atual de que o cachimbo d'água, conhecido como narguilé, hookah, shisha, hubble-bubble, water pipe, argileh (CRISTOVAM et al., 2013; MARTINS et al., 2014; KIM et al., 2016) é uma forma menos prejudicial de se fumar tabaco (MARTINS et al., 2014). No entanto, tal argumento é considerado errôneo.

O uso de Narguilé vem sendo utilizado há séculos na África, no Oriente Médio (RAAD et al., 2011) e em certos países da Ásia (CHAOUACHI, 2007; HELEN et al., 2014; MENEZES et al., 2015). E, nos últimos anos, tem-se observado um crescimento exponencial de seu uso (MAZIAK, 2013; MAZIAK et al., 2014), principalmente entre jovens (VIEGAS, 2008).

Esse crescimento se tornou mais expressivo, a partir do ano 1980. (SAAD, 2009; SALVI, 2016; STRULOVICIBAREL et al., 2016). Entretanto, o conhecimento sobre os efeitos da fumaça do narguilé na saúde é parcial e, muitas vezes, contraditório (SAAD, 2009).

Estima-se que atualmente no mundo cerca de 100 milhões de pessoas utilizem Narguilé diariamente (MENEZES et al., 2015), sendo inclusive mais prevalente que o uso de cigarros em alguns locais do mundo. No Líbano, 14,6\% dos adultos e 32\% dos jovens universitários utilizam-no regularmente.

$\mathrm{Na}$ Síria, uma pesquisa com universitários, demonstrou que $62,6 \%$ dos homens e $29,8 \%$ das mulheres já haviam fumado narguilé alguma vez na vida e que 25,5\% dos homens e $4,9 \%$ das mulheres o faziam de forma habitual (VIEGAS, 2008).

A relação existente entre o hábito de fumar e uma ampla série de enfermidades tem sido demonstrada ao longo dos anos. Já se sabe que o uso de produtos derivados do tabaco é a principal causa de morte evitável no mundo. Não 
obstante, ainda, não é difundida a informação de que o tabaco mata, a cada ano, mais de cinco milhões de pessoas no mundo e 200 mil pessoas no Brasil (BECKERT et al. 2016). A absorção de nicotina em quantidades comparáveis a um cigarro de fumo indica potencial de dependência; e a absorção de quantidades significativas de substâncias cancerígenas levanta preocupações relacionadas ao risco de desenvolvimento de câncer em pessoas que fumam narguilé (JACOB et al., 2011).

O tabagismo - incluindo a exposição passiva de não fumantes ao ar contaminado pela fumaça do cigarro ocupou o segundo lugar, entre os maiores fatores de risco para a carga de doenças, no mundo, em 2010. O uso do tabaco foi responsável por $6,3 \%$ dos anos de vida vividos com incapacidade, no mundo, no ano de 2010. Nos Estados Unidos da América, estima-se que metade dos adultos fumantes morre prematuramente devido a doenças relacionadas ao tabaco, como câncer e doença cardiovascular (BARRETO et al., 2014; HELEN et al., 2014). Além disso, os tabagistas apresentam aumento na frequência cardíaca, na pressão arterial e valores alterados nos testes de função pulmonar, bem como em relação às condições de saúde, tais como alterações no estresse oxidativo, imunidade, e a interferência do ciclo celular (HADDAD et al., 2016).

A despeito da tendência decrescente do tabagismo na maioria dos países da América do Sul, principalmente no Brasil, o tabaco ainda ocupa o quarto lugar no ranque dos fatores de risco mais importantes no continente. Em primeiro lugar, está a obesidade, seguida do uso de álcool e da hipertensão arterial (BARRETO et al., 2014). Esta epidemia mundial é provavelmente impulsionada por: (i) introdução de tabaco aromatizado; (ii) intersecção entre a dimensão social do uso do narguilé e próspera cultura dos bares; (iii) evolução dos meios de comunicação; e (iv) falta de regulamentação política - quadro específico para controle desta forma de tabagismo. Fumar narguilé está se tornando o método de uso do tabaco mais popular entre os jovens no Oriente Médio, e, rapidamente, está ganhando popularidade em outras localidades (MAZIAK et al., 2014).

O tabagismo ainda se apresenta como um importante problema de saúde pública em razão da alta prevalência de fumantes e da morbimortalidade das doenças relacionadas ao uso do tabaco (MAZIAK, 2013; REVELES et al., 2013). O usuário de narguilé está susceptível a maior parte dos efeitos nocivos do tabagismo, é viciante, e pode servir como uma ponte para cigarros. Devido a suas características únicas, intervenções e políticas específicas de prevenção do uso desta forma de tabagismo são necessárias para conter sua disseminação mundial (MAZIAK, 2013). Desta forma, o objetivo deste trabalho foi levantar os principais fatores preditivos para a utilização do narguilé e os principais acometimentos pulmonares e extrapulmonares decorrentes de seu uso.

\section{PROCEDIMENTOS}

O presente estudo trata-se de uma revisão bibliográfica narrativa, realizada por meio de levantamento de artigos científicos, publicados nos últimos dez anos (2007 a 2016), sobre os efeitos locais e sistêmicos do uso de narguilé. A busca bibliográfica foi realizada, a partir de estudos indexados nas bases de dados internacionais - Literatura Latino-Americana e do Caribe em Ciências da Saúde (LILACS) e na coleção Scientific Eletronic Library Online
(SCIELO), após consulta às terminologias em saúde, a serem utilizadas na base de descritores da Biblioteca Virtual em Saúde (BVS), Descritores em Ciências da Saúde (DECS) e da Medical Subject Headings (MESH). Os descritores (palavras-chave) utilizados foram: "narguilé", "hoockah", "shisha", "narghileh" e "arghileh". Selecionaram-se artigos nacionais e internacionais, publicados nos idiomas português e inglês, no período mencionado, referentes às alterações da função pulmonar relacionadas ao uso de produtos derivados do tabaco. Os critérios de inclusão foram os seguintes: artigos publicados na íntegra, no período entre 2007 a 2016, que continham algum dos descritores selecionados. No que se refere aos critérios de exclusão, não foram considerados resumos de artigos e artigos não-disponíveis para download. Os artigos foram analisados e categorizados com vista à classificação e ao delineamento dos estudos.

\section{RESULTADOS}

O uso do narguilé vem crescendo mundialmente, adquirindo proporções alarmantes, sendo considerado como uma epidemia mundial, embora estudos representativos de países ainda sejam escassos (ASLAM et al., 2014; SAAD, 2010). Enquanto, antigamente, era uma prática utilizada por adultos, atualmente, está sendo mais frequente entre jovens, os quais consideram as sessões de narguilé como uma atividade de lazer a ser compartilhada. Ao contrário da prevalência do tabagismo está se mantendo estável ou até decrescendo em alguns países, outras formas de tabaco estão aumentando, sendo o narguilé uma das mais frequentes (MENEZES et al., 2015; SZKLO et al., 2011).

Um grande desafio para a saúde pública é prevenir ou pelo menos retardar a experimentação e uso regular do cigarro. A experimentação de cigarro geralmente ocorre na adolescência e, quanto mais cedo ela advém, maior a chance de adição ao tabaco (BARRETO et al., 2014). Estudos mostram que o álcool é a substância inicial, consumida para acompanhar os amigos, superar tristezas, obter prazer e coragem para enfrentar situações próprias da adolescência, momento no qual experimentam o cigarro e narguilé, com a possibilidade de agregar outros psicoativos, tais como a maconha e a cocaína (ROSSI, 2013).

A duração do uso e o número de cigarros requeridos para estabelecer dependência de nicotina são menores para adolescentes do que para adultos (BARRETO et al., 2014). A prevalência de experimentação do cigarro em um estudo realizado entre os escolares foi de 30,2\% (REVELES et al., 2013). Estudos realizados na Flórida demonstraram que os padrões importantes para o uso de narguilé incluem o predomínio entre os mais jovens, do sexo masculino, de alto nível socioeconômico e grupos urbanos (MAZIAK et al., 2014).

Menezes et al. (2015), em suas pesquisas, mostraram que a prevalência do uso de narguilé foi de $0,18 \%$ (IC95\% $0,11-1,36$ ) e $0,1 \%$ (IC95\% 0,05-0,20), em homens e mulheres, respectivamente, sendo mais frequente na faixa etária dos 15 aos 24 anos e na zona urbana; tanto em relação ao sexo masculino como ao feminino, ocupou o $9^{\circ}$ lugar em prevalência dentre os 13 centros avaliados, no Brasil. Entretanto, de acordo com estudos de Beckert et al. (2016), Curitiba, Florianópolis e Porto Alegre possuem as maiores taxas de prevalência do país entre as mulheres. Estudos realizados por Menezes et al. (2015) revelaram que o uso de narguilé, por unidade da federação, entre os homens foi 
maior em Mato Grosso do Sul $(9,9 \%)$ e menor na Bahia $(0,1 \%)$. Já, entre as mulheres, a maior frequência foi verificada em Mato Grosso $(5,9 \%)$ e as menores no Acre e Espírito Santo (0,3\%).

Há uma crença disseminada de que o narguilé seria menos prejudicial que fumar cigarros, induzindo o fumante à percepção de que esta forma possui menor poder aditivo ou até mesmo não gera riscos para a saúde (JACOB et al., 2013; REVELES et al., 2013; MENEZES et al., 2015; KIM et al., 2016). Tal crença advém da suposição de que nenhum carvão vegetal é usado e a água filtra a fumaça do tabaco (SHE et al., 2014). Porém, devido ao uso de carvão de rápido acendimento no uso desse dispositivo, a razão média entre monóxido de carbono e nicotina na fumaça de narguilé é de 50:1, em comparação com 16:1 na fumaça do cigarro. Entre fumantes de narguilé, existem casos relatados de intoxicação por monóxido de carbono, os quais se manifestam como cefaleia, tonturas, náuseas e astenia, seguidas de síncope (MARTINS et al., 2014).

Uma quantidade significativa de monóxido de carbono é produzida pelo carvão usado para aquecer e destilar a mistura de tabaco-melaço. Além de inalação direta, concentrações moderadas em alguns salões de narguilé e bares são particularmente elevadas. Ademais, os aditivos contidos nos carvões de iluminação rápida, amplamente utilizada, e sua inocuidade permanecem desconhecidos (CHAOUACHI, 2007).

Há evidências de que uma única sessão de uso de narguilé emite na coluna de fumo, aproximadamente quatro vezes, os hidrocarbonetos aromáticos policíclicos carcinogênicos (PAH) (JACOB et al., 2011; HELEN et al., 2014), quatro vezes, os aldeídos voláteis e, 30 vezes, o monóxido de carbono de um único cigarro. $\mathrm{Na}$ contabilização de fumo exalado, considerando uma taxa de fumo habitual de 2 cigarros por hora, durante uma sessão de uso de narguilé de uma hora típica, um fumante de narguilé gera agentes cancerígenos ambientais e substâncias tóxicas equivalentes a 2-10 fumantes de cigarros nesse mesmo intervalo de tempo, dependendo do composto em questão (DAR-ODEH; ABU-HAMMAD, 2009). A presença do carvão resulta na produção de algumas toxinas em maior nível pelo narguilé, quando comparado ao cigarro, sendo que, em uma única sessão de narguilé, a quantidade de fumaça inalada pode atingir 150 vezes aquela de um único cigarro (MENEZES, 2015)

Compostos de aldeído encontrados na fumaça do narguilé são conhecidos por serem substâncias tóxicas e cancerígenos. Uma sessão de fumo de narguilé libera maiores quantidades de formaldeído, acetaldeído, propionaldeído acroleína, metacroleína (DAR-ODEH; ABU-HAMMAD, 2009) e altos níveis de exposição ao benzeno (JACOB et al., 2013). Há, portanto, um motivo considerável para incluir o narguilé na proibição de fumar em locais públicos (DAHER et al., 2010).

As pesquisas disponíveis mostram que câncer de pulmão, doenças respiratórias, aumento da frequência cardíaca, aumento da pressão sistólica e diastólica, (KADHUM et al., 2015) e baixo peso ao nascer são algumas das doenças já bem estabelecidas, consequentes do uso do narguilé (ASLAM et al., 2014; MENEZES, 2015). A fumaça do narguilé contém muitas das toxinas também encontradas na fumaça do cigarro, incluindo a nicotina, que produz a adição, monóxido de carbono, que causa diversas doenças cardiovasculares, e hidrocarbonetos policíclicos, que causam câncer (MENEZES, 2015).

A fumaça derivada dos produtos do narguilé provoca uma redução da proliferação celular, causando pausa nas fases $\mathrm{G}_{0} / \mathrm{G}_{1}$ do ciclo celular e o aumento do tempo de duplicação celular (SHIHADEH et al., 2013).

Já, segundo uma pesquisa de Saad et al. (2009), 36\% dos indivíduos apresentaram hiperinflação pulmonar estática; $14 \%$ tinham pequenas vias aéreas com defeito restritivo ventilatório; $14 \%$ tinham defeito restritivo ventilatório e $6 \%$ apresentaram grande defeito ventilatórios obstrutivos das vias aéreas. A idade pulmonar estimada, neste estudo, foi maior do que a idade cronológica de pulmão, o que levou a conclusão de que o consumo narguilé acelera o envelhecimento pulmonar.

Na China, país onde é disseminado o uso do narguilé. Um estudo demonstrou que a exposição e o uso deste dispositivo para fumar tabaco estão associados com aumento significativo do risco de doença pulmonar obstrutiva crônica (DPOC). O aumento do risco de DPOC é de 10 vezes maior para chineses usuários do narguilé, 5 vezes maiores fumantes passivos de narguilé, 3 vezes maior fumantes de cigarro e 2 vezes maior para fumantes passivos, todos em comparação com indivíduos de controle não fumantes. Assim, sugere-se que o uso desta forma de tabagismo agrava mais os pulmões em relação ao uso de cigarros (SHE JUN et al., 2014).

Em comparação aos não fumantes, os fumantes de narguilé possuem mais tosse e expectoração, bem como uma capacidade de difusão pulmonar menor, células anormais epiteliais com perfil metaboloma no fluido de revestimento, aumento da proporção do epitélio das vias aéreas secretoras (SAE) e células intermediárias, reduzidas proporções de SAE ciliadas e basais, marcadamente níveis anormais SAE transcriptomes e macrófagos alveolares, e elevados níveis de micropartículas de células endoteliais apoptóticas (SALVI, 2016). O uso de narguilé afeta negativamente a função pulmonar e pode ser tão prejudicial quanto fumar cigarros. Por conseguinte, há susceptibilidade de ser uma causa de DPOC (RAAD et al., 2011)

Em um estudo, por Hakim et al. (2011), quarenta e cinco voluntários (30 homens, 15 mulheres), com idades $32.35 \pm 15,33$ anos, foram recrutados. Depois de uma sessão de narguilé, o nível de carboxihemoglobina aumentou significativamente, passando de $1,47 \% \pm 0,57 \%$ (mediana de 1,4 ) para $9,47 \% \pm 5,52 \%$ (mediana 7,4 ) e $p<0,001$. O nível da pressão arterial sistólica e diastólica aumentou significativamente após o fumo (sistólica 119,52 \pm 12,07 $\mathrm{mm} \mathrm{Hg}$ vs 131,98 \pm 17,8 mm Hg; diastólica 74,84 \pm 7,89 $\mathrm{mm} \mathrm{Hg}$ vs $82,98 \pm 12,52 \mathrm{~mm} \mathrm{Hg}$, respectivamente; $\mathrm{p}$ $<0,001)$. Os batimentos cardíacos aumentaram de 80,39 \pm 9,92 batimentos / min para 95,59 $\pm 17,41$ batimentos / min, p <0,001; e as taxas respiratórias aumentaram de 14,36 \pm 1,63 ciclos / min para $16,68 \pm 2,24$ respirações / min, $\mathrm{p}$ $<0,001$. Houve uma redução no fluxo expiratório forçado entre $25 \%$ e $75 \%$ da CVF, taxa de pico de fluxo expiratório e porcentagem de eosinófilos no sangue periférico. Este estudo mostra que uma sessão de narguilé provoca alterações biológicas agudas que podem resultar em problemas de saúde futuros. Acrescenta, ainda, a evidência de que esta forma de fumo é prejudicial e apoia intervenções para controlar a sua propagação global contínua, especialmente entre os jovens. 
As atividades de baixa intensidade contínuas melhoram o condicionamento cardiorrespiratório e reduz o declínio da função pulmonar tanto entre fumantes de cigarro quanto em fumantes de narguilé. Estas informações podem ter implicações importantes na prevenção e tratamento em programas para fumantes que não querem descontinuar o uso desse dispositivo (KOUBAA et al., 2016).

Koubaa et al. (2015) realizaram uma pesquisa com indivíduos fumantes que praticaram 30 minutos de exercícios físicos com intervalo de três vezes por semana, durante 12 semanas, a uma intensidade estimada em $70 \%$ da capacidade aeróbica máxima do sujeito (VO2max). Antes da intervenção por meio dos exercícios, os fumantes de cigarro e narguilé tinham significativamente função pulmonar menor do que os não-fumantes. $\mathrm{O}$ programa de treinamento físico durante 12 semanas não afetou significativamente a função pulmonar, no entanto, aumentou significativamente tanto o volume expiratório forçado em 1 segundo e o pico de fluxo expiratório (PFE), no grupo fumante de cigarro e PEF no grupo de fumantes de narguilé. Os resultados indicam que o programa de treinamento melhorou significativamente $\mathrm{VO} 2 \max (4,4$ e $4,7 \%$, respectivamente) VO2máx (6,7 e 5,6\%, respectivamente), e o índice de recuperação (7,9 e 10,5\%, respectivamente).

Além da falsa sensação de segurança, as razões para a propagação mundial do uso de narguilés podem incluir um aumento da consciência dos efeitos negativos do tabagismo (cigarros) sobre a saúde e a interação social que vem com sessões de uso de narguilé (JACOB et al., 2013; MARTINS et al., 2014; SZKLO et al., 2011). Tal uso compartilhado pode facilitar a propagação de doenças transmissíveis, como resfriados, infecções respiratórias, tuberculose, hepatite e herpes. Há relatos de casos na literatura de tuberculose resistente a medicamentos transmitida via narguilés (MARTINS et al., 2014).

Entre 1989 e 2010, o Brasil aumentou os impostos sobre o tabaco, instituiu restrições de comercialização e uso em ambientes públicos e advertências de saúde em maços de cigarro, entre outras medidas de controle. Como decorrência, o tabagismo vem diminuindo de forma consistente na população adulta. Entre 1999 e 2004, observou-se uma redução do uso de cigarro entre estudantes do ensino fundamental e médio em diversas capitais brasileiras. Apesar de o cigarro ser a principal forma de exposição ao tabaco no mundo, o uso de outros produtos derivados do tabaco, como o cachimbo de água (narguilé), vem aumentando consideravelmente (BARRETO et al. 2014; SZKLO et al., 2011), sendo que uma grande quantidade de jovens ainda experimenta diversas formas de uso do tabaco, destacando-se o narguilé, tornando-se vulneráveis à iniciação e, consequentemente, à dependência tabágica (REVELES et al., 2013, SZKLO et al., 2011). Um estudo, realizado em 2013, revelou que o narguilé é popular entre os adolescentes, de tal modo que $81 \%$ dos fumantes e ex-fumantes tiveram alguma experiência com esta forma de consumo do tabaco, desde a experimentação até o uso corrente (BERTANI, 2013).

Os profissionais da saúde desempenham o papel de cuidadores e promotores da saúde e, de certa forma, são referências de comportamento e exercem grande influência sobre a população que assistem. Contudo, estudos revelam que tais profissionais, sendo usuários de produtos derivados do tabaco, são menos propensos a orientar seus pacientes sobre os riscos associados a esses produtos e, os pacientes, por sua vez, são menos dispostos a aceitar orientações de profissionais da saúde que sejam usuários de produtos derivados do tabaco (BECKERT et al., 2016; MARTINS et al., 2014). Em contrapartida, Martins et al. (2014) relatam que, em uma pesquisa, a maioria dos entrevistados acreditava que a probabilidade de fumantes pararem de fumar aumenta, se eles são aconselhados a fazê-lo por profissionais de saúde.

Uma pesquisa realizada com estudantes de medicina, demonstrou que $64,5 \%$ e $71,6 \%$ dos estudantes de medicina não fumantes, no terceiro e sextos anos, respectivamente, acreditam que os profissionais de saúde que fumam são menos propensos a aconselhar seus pacientes fumantes a parar de fumar. No entanto, entre os estudantes fumantes, a proporção daqueles que acreditavam que os profissionais de saúde que fumam são menos propensos a aconselhar seus pacientes fumantes a parar de fumar aumentou de $30 \%$ no terceiro ano para $50 \%$ no sexto ano. Contudo, o mesmo estudo mostrou ainda que maioria dos futuros médicos que eram fumantes de cigarros não foi aconselhada a parar por um profissional de saúde: $15(79 \%)$ dos 19 fumantes, avaliados em seu terceiro ano, e $8(89 \%)$ dos 9 fumantes, avaliados em seu sexto ano (MARTINS et al., 2014).

A maioria dos entrevistados acreditava que os profissionais de saúde deveriam rotineiramente aconselhar seus pacientes a não utilizar quaisquer produtos derivados do tabaco, e que mais de $80 \%$ dos futuros médicos avaliados concordavam que os profissionais de saúde ocupam uma posição de liderança e são modelos de conduta para os seus pacientes e para a população em geral. (MARTINS et al., 2014).

\section{CONCLUSÃO}

De acordo com a revisão da literatura, infere-se que câncer de pulmão, doenças respiratórias, aumento da frequência cardíaca, aumento da pressão sistólica e diastólica e baixo peso ao nascer são algumas das doenças já bem estabelecidas consequentes do uso do narguilé. Dados epidemiológicos inferem um predomínio do uso desse dispositivo entre os mais jovens, do sexo masculino, de alto nível socioeconômico e grupos urbanos. Tal problemática deve ser entendida como preocupante, evidenciando a necessidade de estudos e prevenção do uso, em crescente expansão, desta forma de uso do tabaco, atuando na promoção da saúde pública, impactando no resguardo dessa utilização. Considerando a importância do tema e a falta de informações inerentes ao assunto, a realização de maiores estudos neste contexto é relevante, especialmente aqueles que preencham as lacunas de conhecimento sobre o assunto. Certamente, compreender melhor os efeitos do narguilé sobre o organismo podem trazer benefícios a curto e longo prazo, incluindo a redução da morbimortalidade, tempo de internação e gastos públicos, por meio de divulgações e campanhas públicas na prevenção de seu uso, sobretudo entre adolescentes e jovens. No entanto, políticas públicas voltadas para a prevenção e estudos dos malefícios que podem acometer o indivíduo ainda necessitam ser desenvolvidas, para que sejam realizadas aplicações imediatas no resguardo à saúde pública.

\section{REFERÊNCIAS BIBLIOGRÁFICAS}

ASLAM, H. et al. Harmful effects of shisha: literature review. Int Arch Med, v. 7, n. 1, p.16-25, 2014. 
BARRETO, S. M. et al. Experimentation and use of cigarette and other tobacco products among adolescents in the Brazilian state capitals (PeNSE 2012). Rev. Bras. Epidemiol., v. 17, n. 1, p.62-76, 2014.

BECKERT, N. et al. Características do uso de produtos derivados do tabaco entre universitários do curso de Odontologia em uma Universidade de Curitiba. Rev. Odontol. Unesp, v. 45, n. 1, p.7-14, 2016.

BERTANI, A. L. Caracteristics and knowledge about smoking in specific group: adolescents and pregnant women, Tese, Botucatu, 2013.

CHAOUACHI, K. Hookah (Shisha, Narghile) Smoking and Environmental Tobacco Smoke (ETS). A Critical Review of the Relevant Literature and the Public Health Consequences. International Journal of Environmental Research And Public Health, v. 6, n. 2, p.798-843, 2009.

CHAOUACHI, K. The medical consequences of narghile (hookah, shisha) use in the world. Revue D'Épidémiologie Et de Santé Publique, v. 55, n. 3, p.165-170, 2007.

CRISTOVAM, M.A.S. et al. Epidemiological profile of the use of psychoactive substances by adolescents. Pediatria Moderna, Cascavel, v. 49, n. 3, p.123-128, 2013.

DAHER, N. et al. Comparison of carcinogen, carbon monoxide, and ultrafine particle emissions from narghile waterpipe and cigarette smoking: Sidestream smoke measurements and assessment of second-hand smoke emission factors. Atmospheric Environment, v. 44, n. 1, p. 8-14, 2010.

DAR-ODEH, N. S.; ABU-HAMMAD, O. A. Narghile smoking and its adverse health consequences: a literature review. British Dental Journal, v. 206, n. 11, p.571-573, 2009.

HADDAD, L. et al. A Systematic Review of Effects of Waterpipe Smoking on Cardiovascular and Respiratory Health Outcomes. Tui, v. 9, n. 9, p.13-28, 2016.

HAKIM, F. et al. The Acute Effects of Water-Pipe Smoking on the Cardiorespiratory System. Chest, v. 139, n. 4, p.775-781, 2011

HELEN, G. St. et al. Nicotine and Carcinogen Exposure after Water Pipe Smoking in Hookah Bars. Cancer Epidemiology Biomarkers \& Prevention, v. 23, n. 6, p.1055-1066, 2014.

JACOB, P. et al. Comparison of Nicotine and Carcinogen Exposure with Water Pipe and Cigarette Smoking. Cancer Epidemiology Biomarkers \& Prevention, v. 22, n. 5, p.765-772, 2013.

JACOB, P. et al. Nicotine, Carbon Monoxide, and Carcinogen Exposure after a Single Use of a Water Pipe. Cancer Epidemiology Biomarkers \& Prevention, v. 20, n. 11, p.2345-2353, 2011.

KADHUM, M. et al. A review of the health effects of smoking shisha. Clinical Medicine, v. 15, n. 3, p. 263$266,2015$.
KIM, K.; KABIR, E.; JAHAN, S. A. Waterpipe tobacco smoking and its human health impacts. Journal of Hazardous Materials, v. 317, p.229-236, 2016.

KOUBAA, A. et al. Effect of low- intensity continuous training on lung function and cardiorespiratory fitness in both cigarette and hookah smokers. African Health Sciences, v. 15, n. 4, p.1170-1181, 2016.

KOUBAA, A. et al. Lung function profiles and aerobic capacity of adult cigarette and hookah smokers after 12 weeks intermittent training. Libyan Journal Of Medicine, v. 10, 2015.

MAZIAK, W. et al. The global epidemiology of waterpipe smoking. Tobacco Control, v. 24, n. 1, p.3-12, 2014.

MAZIAK, W. The Waterpipe: A New Way of Hooking Youth on Tobacco. The American Journal On Addictions, v. 23, n. 2, p.103-107, 2013.

MARTINS, S. R. et al. Experimentation with and knowledge regarding water-pipe tobacco smoking among medical students at a major university in Brazil. Jornal Brasileiro de Pneumologia, v. 40, n. 2, p.102-110, 2014.

MENEZES, A. M. B. et al. Frequência do uso de narguilé em adultos e sua distribuição conforme características sociodemográficas, moradia urbana ou rural e unidades federativas: Pesquisa Nacional de Saúde (PNS), 2013. Rev. Bras. Epidemiol., v. 18, p.57-67, 2015.

RAAD, D. et al. Effects of Water-Pipe Smoking on Lung Function: A Systematic Review and Metaanalysis. Chest, v. 139, n. 4, p.764-774, 2011.

REVELES, C. C.; SEGRI, N. J.; BOTELHO, C. Factors associated with hookah use initiation among adolescents. Jornal de Pediatria, v. 89, n. 6, p.583-587, 2013.

ROSSI, L. C. C. Moving between experimentation and drug addiction: the self as acomponent of the adolescent actor. Tese, Botucatu, 2013.

SAAD, H. B. L. Narguilé et ses effets sur la santé. Partie I: le narguilé, description générale et propriétés. Revue de Pneumologie Clinique, v. 65, n. 6, p.369-375, 2009.

SAAD, H. Ben. L. Narguilé et ses effets sur la santé. Partie II: les effets du narguilé sur la santé. Revue de Pneumologie Clinique, v. 66, n. 2, p.132-144, 2010.

$\mathrm{SAAD}$, Ben et al. Profil spirométrique des fumeurs de narguilé. Rev Mal Respir, v. 26, n. 3, p.299-314, 2009.

SALVI, S. The Perils of Waterpipe or Hookah Smoking: Time for Action, American Journal of Respiratory and Critical Care Medicine, Vol. 194, No. 5, p. 532-534, 2016.

SHE, J. et al. Chinese Water-Pipe Smoking and the Risk of COPD. Chest, v. 146, n. 4, p.924-931, 2014.

SHIHADEH, A. et al. Comparison of TobaccoContaining and Tobacco-Free Waterpipe Products: Effects on Human Alveolar Cells. Nicotine \& Tobacco Research, v. 16, n. 4, p.496-499, 2013.

STRULOVICI-BAREL, Y. et al. Pulmonary Abnormalities in Young, Light-Use Waterpipe (Hookah) 
Smokers. American Journal of Respiratory and

Critical Care Medicine, v. 194, n. 5, p.587-595, 2016.

SZKLO, A.S. et al. Perfil de consumo de outros produtos de tabaco fumado entre estudantes de três cidades brasileiras: há motivo de preocupação? Cadernos de Saúde Pública, v. 27, n. 11, p.2271-2275, 2011.

\section{COPYRIGHT}

Direitos autorais: Os autores são os únicos responsáveis pelo material incluído no artigo. 


\title{
TRATAMENTOS PRÉ-GERMINATIVOS DE SEMENTES DE COENTRO CULTIVADAS NO SUBMÉDIO SÃO FRANCISCO
}

\author{
PRE-GERMINATING TREATMENTS OF CORIANDER SEEDS CULTIVATED \\ IN SUBMÉDIO SÃO FRANCISCO
}

\author{
GILMARIO NOBERTO DE SOUZA ${ }^{1}$; ISA GABRIELA VIEIRA DE ANDRADE ${ }^{1}$; SÂMELA DEISE DE \\ PINHO GONÇALVES ${ }^{1}$; GLÓRIA CAROLINE SANTOS BARBOSA DA SILVA ${ }^{1}$; ANTÔNIO BRUNO \\ NUNES OLIVEIRA $^{1}$; WILLIAN COSTA BEZERRA ${ }^{1}$; CARLOS ALBERTO ARAGÃO $^{1}$ \\ 1 - UNIVERSIDADE DO ESTADO DA BAHIA \\ gilmario.souza.gs@gmail.com; isagva@hotmail.com; sameladeyse@hotmail.com; \\ bruno.xcv@outlook.com; willianuneb2014.2@gmail.com; carlosaragao@hotmail.com
}

\begin{abstract}
Resumo - O coentro é uma hortaliça amplamente consumida e de grande importância socioeconômica, cultivada normalmente por pequenos produtores que utilizam sementes sem nenhum tratamento prévio, o que resulta em canteiros desuniformes com plantas de baixa qualidade. $O$ artigo objetivou avaliar a eficiência de diferentes tratamentos alternativos aplicado a sementes de coentro. A pesquisa foi desenvolvida no Laboratório de Olericultura da Universidade do Estado da Bahia em Juazeiro-BA. $O$ delineamento experimental foi inteiramente casualizado com sete tratamentos alternativos e quatro repetições com 50 sementes cada. Ao fim do experimento foi possível observar que os tratamentos utilizados influenciaram de forma significativa a maioria das variáveis analisadas, sendo que os tratamentos a base de óleo de alho, Trichoderma e água sanitária se destacaram dos demais.
\end{abstract}

Palavras-chave: Hortícola. Coriandrum Sativum L. Tratamento Antifúngico.

Abstract - Coriander is a widely consumed vegetable and great socio-economic importance, usually grown by small producers using seeds without any prior treatment which results in disuniform beds with low-quality plants. The article aimed to evaluate the efficiency of different alternative treatments applied to coriander seeds. The research was conducted at Vegetable Crops Laboratory of Universidade do Estado da Bahia in Juazeiro-BA. The experimental design was completely randomized with seven alternative treatments and four replications with 50 seeds each. At the end of the experiment it was observed that the treatments affected significantly most of the variables analyzed, and the treatments garlic oil base, Trichoderma and sanitary water stood out from the rest.

Keywords: Horticultural.. Coriandrum Sativum L.. Antifungal treatment.

\section{INTRODUÇÃO}

O coentro (Coriandrum sativum L.) é uma hortícola anual pertencente à família Apiaceae. Esta planta, nativa do sul da Europa, norte da África e sudeste da Ásia, é muito utilizada na culinária com todas as partes comestíveis, desde folhas as sementes, bem como para usos medicinais (PAVLOVIC et al., 2014). O mesmo autor relata que na medicina popular, as sementes de coentros são usadas como um remédio para problemas gastrointestinais, insônia e ansiedade. Além de atuar como um agente analgésico e antirreumático. A mais importante e propriedade bem caracterizada do coentro é a sua utilização como antioxidante. Devido a seus usos multifuncionais e de proteção e ação preventiva contra várias doenças crônicas, o coentro pode ser chamado como "erva da felicidade" (BHAT et al, 2014).

A área cultivada com coentro no Brasil foi de aproximadamente 47.733 ha no ano de 2011, caracterizada pelo cultivo por pequenos e médios produtores (MACIEL et a.l, 2013). Nesse mesmo ano, cerca de 780 toneladas de sementes de coentro foram comercializadas no país, com valor superior a $\mathrm{R} \$ 17.400 .000$ (ABCSEM, 2012 citado por MACIEL et al., 2013). O que torno o coentro, uma hortaliça amplamente consumida e de grande importância socioeconômica, bastante utilizada na culinária da região Nordeste, seja em ramos verdes ou sementes moídas, conferindo um sabor especial a vários pratos.

O tratamento de sementes é um procedimento de revestimento que emprega a aplicação de produtos nas sementes, podem ser agrotóxicos, produtos biológicos, corantes, micronutrientes e outros aditivos (BRASIL, 2005). Esse processo é considerado eficaz, pois é capaz de minimizar de forma acentuada a presença de microrganismos e, consequentemente inibindo seus efeitos negativos na qualidade das sementes e na transmissão para plântulas (PEDROSO, 2012).

No Nordeste, em especial no Submédio do Vale do São Francisco, o cultivo do coentro é realizado normalmente por pequenos produtores em hortas comunitárias. Como meio de economizar recursos muitos produtores cultivam seus canteiros utilizando sementes da própria horta sem nenhum tratamento prévio e sementes sem emprego de tratamentos, que na maioria das vezes resulta em canteiros desuniformes com plantas de baixa qualidade. Como medida mitigadora para esse problema, o presente trabalho teve como objetivo avaliar a eficiência de diferentes tratamentos pré-germinativos e alternativos aplicado a sementes de coentro para o controle de fitopatógenos e melhorar o desempenho das mesmas. 


\section{PROCEDIMENTOS}

A pesquisa foi desenvolvida no Laboratório de Olericultura do Departamento de Tecnologia e Ciências Sociais - DTCS da Universidade do Estado da Bahia UNEB, Campus III, Juazeiro-BA, cujas coordenadas geográficas são: latitude $09^{\circ} 24^{\prime} 42^{\prime \prime} \mathrm{S}$, longitude $40^{\circ} 29^{\prime} 55^{\prime \prime}$ W e altitude 368m, no período de abril a agosto de 2016. Para a realização do experimento foram utilizados dois lotes de sementes de coentro da cultivar verdão, o lote 1 correspondeu as sementes sem tratamento e obtidas de um produtor da região, e o lote 2 foi constituído de sementes comerciais tratadas com fungicida Thiram a $0,15 \%$.

Foi utilizado o delineamento inteiramente casualizado, com sete tratamentos e quatro repetições de 50 sementes: T1- Sementes comerciais, tratadas com Thiram; T2Sementes não comerciais tratadas com hipoclorito de sódio a 5\% (água sanitária); T3- Sementes não comerciais tratadas com óleo de nim (Azadirachta indica Juss) a 5\%; T4Sementes não comerciais tratadas com óleo de algodão a 5\%; T5- Sementes não comerciais tratadas com óleo de alho a 5\%; T6- Sementes não comerciais tratadas com produto a base de Trichoderma a 5\% e T7- Testemunha, sementes não comerciais sem tratamentos. Todas as sementes, exceto as sementes comerciais, ficaram submersas aos tratamentos por um período de tempo de trinta minutos.

As sementes foram submetidas ao "blotter test", de acordo com metodologia descrita em Brasil (2009). Utilizou-se 200 sementes de cada tratamento dividido em quatro repetições de 50 sementes cada gerbox contendo papel filtro umedecido com ADE (água destilada e esterilizada), colocados em germinadores do tipo BOD sob regime fotoperiódico de 12 horas de luz e 12 horas de escuro, com temperatura de $25^{\circ} \mathrm{C}$ e variação de $3^{\circ} \mathrm{C}$ acima e abaixo da temperatura pré-estabelecida. 8 dias após a instalação do experimento, as sementes foram observadas individualmente sob microscópio estereoscópio para a visualização das características morfológicas das estruturas assexuais do fungo para a determinação do grau de infestação de fungos expresso em porcentagem.

Para avaliar o potencial das sementes, fora realizado em laboratório a avaliação de primeira contagem da germinação, consistindo do registro da porcentagem de plântulas normais encontradas na primeira contagem $\left(7^{\circ}\right.$ dia após a instalação do experimento); percentagem de plântulas anormais, aquelas que não tinham condições de sobrevivência aos $21^{\circ}$ dia após a instalação; índice de velocidade de germinação, segundo a metodologia proposta por Maguire (1962); porcentagem de germinação; tempo médio de germinação, conforme equação (1); comprimento da parte aérea; comprimento da raiz; massa da matéria seca da parte aérea e massa da matéria seca da raiz das plântulas.

$$
T M G=\sum(N i T i) / \sum N i
$$

Onde, Ni é número de sementes germinadas no i-ésimo dia e Ti é tempo (dias) Foram consideradas como emergidas as plântulas que apresentaram os cotilédones totalmente livres.

Os dados obtidos foram submetidos à Análise de variância (ANAVA) ao nível de 5\% de significância estatística segundo o Teste $\mathrm{F}$ e as médias comparadas pelo teste $\mathrm{T}(\mathrm{p}<0,05)$ com o auxílio do software Assistat, versão 7.7 .

\section{RESULTADOS}

Ao fim do experimento foi possível observar que os tratamentos utilizados influenciaram de forma significativa a maioria das variáveis analisadas. Na primeira contagem das sementes germinadas os valores obtidos variaram de 73 a 95,5 \% de sementes germinadas, valores próximos aos obtidos por Pereira; Munizii \& Nascimento (2005) em diferentes lotes de coentro cultivar verdão. A maior média foi obtida das sementes tratadas com Trichoderma, no entanto diferiu significativamente apenas do tratamento a base de óleo de nim. Os tratamentos influenciaram de forma significativa a variável última de contagem, a maior media absoluta foi obtida pelas sementes tratada com Trichoderma (98,0\% de germinação), no entanto diferiram significativamente dos tratamentos testemunha, água sanitária e sementes comerciais (Tabela 1).

As sementes tratadas com água sanitária apresentaram em média o menor índice de velocidade de germinação com 10,37, diferindo apenas do tratamento comercial, do testemunha e do Trichoderma. Alves et al.(2005) trabalhando com sementes de coentro cv. verdão conseguiram valores máximo de índice de velocidade de germinação igual a 5, mostrando que a qualidade fisiológica das sementes de coentro é influenciada pelas doses de esterco bovino. Para o tempo médio de germinação conforme a Tabela 1 é possível observar que o tratamento testemunha apresentou media de 2, 52 dias, no entanto, diferiu significativamente das sementes tratadas com água sanitária e óleo de algodão.

Tabela 1 - Valores médios de primeira contagem da germinação (PCG), germinação final (GF), índice de velocidade de germinação

(IVG) e tempo médio de germinação (TMG) de sementes de coentro tratadas com produtos alternativos. Juazeiro-BA, 2016.

\begin{tabular}{lcccc}
\hline Tratamentos & PCG $(\%)$ & GF $(\%)$ & IVG & TMG \\
\hline Comercial & $90.5 \mathrm{ab}$ & $94.5 \mathrm{bc}$ & $12.86 \mathrm{a}$ & $0.27 \mathrm{a}$ \\
Água sanitária & $80.0 \mathrm{ab}$ & $92.5 \mathrm{c}$ & $10.37 \mathrm{~b}$ & $0.22 \mathrm{~b}$ \\
Óleo de & $86.0 \mathrm{ab}$ & $95.5 \mathrm{abc}$ & $10.45 \mathrm{~b}$ & $0.22 \mathrm{~b}$ \\
Algodão & $73.0 \mathrm{~b}$ & $96.5 \mathrm{ab}$ & $11.55 \mathrm{ab}$ & $0.24 \mathrm{ab}$ \\
Óleo de Nim & $88.0 \mathrm{ab}$ & $96.5 \mathrm{ab}$ & $11.86 \mathrm{ab}$ & $0.24 \mathrm{ab}$ \\
Óleo de Alho & $95.5 \mathrm{a}$ & $98.0 \mathrm{a}$ & $13.40 \mathrm{a}$ & $0.27 \mathrm{a}$ \\
Trichoderma & $91.0 \mathrm{ab}$ & $93.0 \mathrm{c}$ & $12.72 \mathrm{a}$ & $0.27 \mathrm{a}$ \\
Testemunha & 15.15 & 2.46 & 12.82 & 11.98 \\
\multicolumn{1}{c}{$\mathrm{CV}(\%)$} & 86.2 & 95.21 & 11.88 & 0.249 \\
\hline \multicolumn{1}{c}{$\mathrm{Mg}$} &
\end{tabular}

Médias seguidas das mesmas letras não diferem entre si pelo teste t a $5 \%$ de probabilidade.

$\mathrm{Cv}$;- coeficiente de variação ; Mg- média geral.

A análise sanitária das sementes realizadas ao $8^{\circ}$ dia após a implantação do experimento revelou que em todos os tratamentos ocorreram o aparecimento de estruturas fúngicas (esporos). Conforme mostra a Figura 1, as sementes tratadas com água sanitária apresentaram uma menor incidência de fungos, aproximadamente $1 \%$ das sementes apresentaram infestação, no entanto, esse tratamento é estatisticamente similar ao comercial e as sementes tratadas com Trichoderma.

A utilização de Trichoderma tem alcançado sucesso no controle de fitopatógenos, devido a sua capacidade de proteger as plantas ou as sementes por meio de diferentes mecanismos de ação como o parasitismo, antibiose, competição e indução de resistência (PEDROSO, 2012).

Silva et al. (2005), encontraram resultados satisfatórios da ação fúngica de produtos a base de alho e nim em 
sementes de Chorão (Poecilanthe ulei), no então no presente estudo esses produtos não apresentaram grande eficiência no controle de fungos em sementes de coentro cv. Verdão.

Figura 1 - Incidência de fungos fitopatogênicos (\%) em sementes de coentro tratadas com produtos alternativos. Juazeiro-BA, 2016.

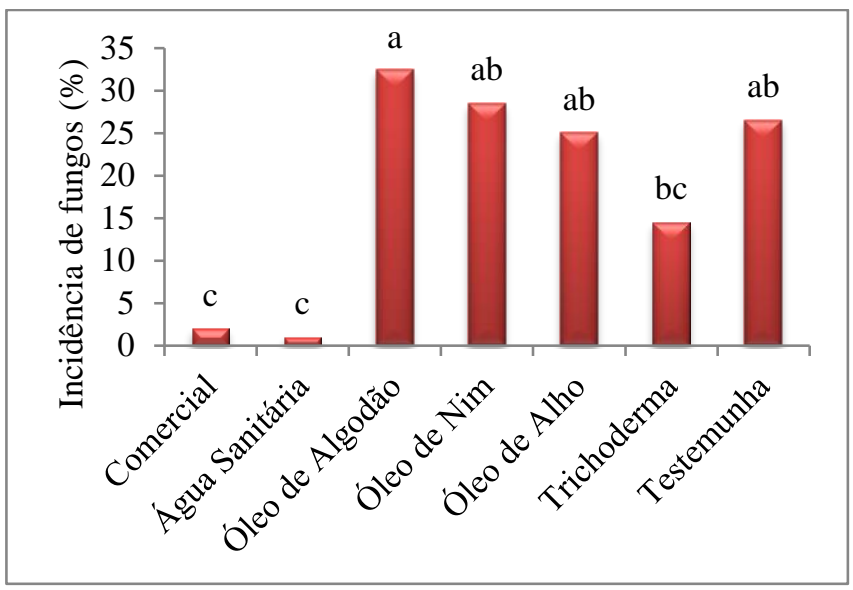

Para o comprimento médio da parte área das plântulas a maior media foi observada na testemunha com $3,392 \mathrm{~cm}$, não diferindo das sementes tratadas com água sanitária e óleo de alho, o menor comprimento da parte área foi observado nas plântulas das sementes provenientes das sementes comerciais com média de $1,175 \mathrm{~cm}$, diferindo de todos os tratamentos analisados. Os resultados obtidos na testemunha são similares aos observados por Pereira et al. (2011), em estudos com diferentes lotes de coentro cv. Super-verdão.

Para o comprimento radicular, conforme Tabela 2, os tratamentos que mais influenciaram de forma positiva foram o óleo de alho e o Trichoderma, apresentando maiores médias, 7, 120 e 6,860 respectivamente, diferindo dos demais tratamentos analisados.

Com relação à massa fresca das plântulas o tratamento testemunha diferenciou dos demais tratamentos apresentando em média 4,241 gramas para cada repetição, que constitui das plântulas oriundas das 50 sementes utilizadas no teste. Os tratamentos não influenciaram de forma significativa a massa seca das plântulas.

Tabela 2 - Valores médios de comprimento de parte aérea (CPA) e raízes (CR), massa seca (MSP) e fresca (MFP) de plântulas de coentro, proveniente de sementes tratados com produtos alternativos. Juazeiro-BA, 2016

\begin{tabular}{|c|c|c|c|c|}
\hline Tratamentos & CPA $(\mathrm{cm})$ & $\mathrm{CR}(\mathrm{cm})$ & $\begin{array}{c}\text { MFP } \\
\text { (g) }\end{array}$ & MS \\
\hline Comercial & $1.175 \mathrm{~d}$ & $1.787 \mathrm{~d}$ & $1.425 \mathrm{f}$ & 0.27 \\
\hline Água sanitária & $3.252 \mathrm{a}$ & $2.222 \mathrm{~d}$ & $3.191 \mathrm{~d}$ & 028 \\
\hline $\begin{array}{l}\text { Óleo de } \\
\text { Algodão }\end{array}$ & $1.932 \mathrm{c}$ & $3.310 \mathrm{c}$ & $2.915 \mathrm{e}$ & 0.2 \\
\hline Óleo de Nim & $1.880 \mathrm{c}$ & $4.560 \mathrm{~b}$ & $2.525 \mathrm{f}$ & $0.2^{\prime}$ \\
\hline Óleo de Alho & $3.382 \mathrm{a}$ & 7. $127 \mathrm{a}$ & $3.925 \mathrm{~b}$ & 0.32 \\
\hline Trichoderma & $2.775 \mathrm{~b}$ & $6.860 \mathrm{a}$ & $3.550 \mathrm{c}$ & 0.21 \\
\hline Testemunha & $3.392 \mathrm{a}$ & $3.992 \mathrm{~b}$ & $4.241 \mathrm{a}$ & 0.29 \\
\hline $\mathrm{CV}(\%)$ & 17.85 & 31.55 & 2.51 & 35.7 \\
\hline $\mathrm{Mg}$ & 2.54 & 4.26 & 3.256 & 0.27 \\
\hline
\end{tabular}

probabilidade.

$\mathrm{Cv}$;- coeficiente de variação ; $\mathrm{Mg}$ - média geral.
Com relação à percentagem de plantas anormais, ou seja, as plântulas que apresentavam alguma deformação que impediu seu desenvolvimento pleno, foi observado maior média nas sementes tratadas com óleo de algodão (aproximadamente $48 \%$ ), diferindo significativamente apenas do tratamento comercial, óleo de alho e testemunha (Figura 2). Os resultados encontrados foram semelhantes aos obtidos por Müller et al. (2008) em sementes de coentro tratadas com Trichoderma spp. e zinco.

Figura 2 - Porcentagem de plântulas anormais de coentro oriundas de sementes tratadas com produtos alternativos. Juazeiro-BA, 2016.

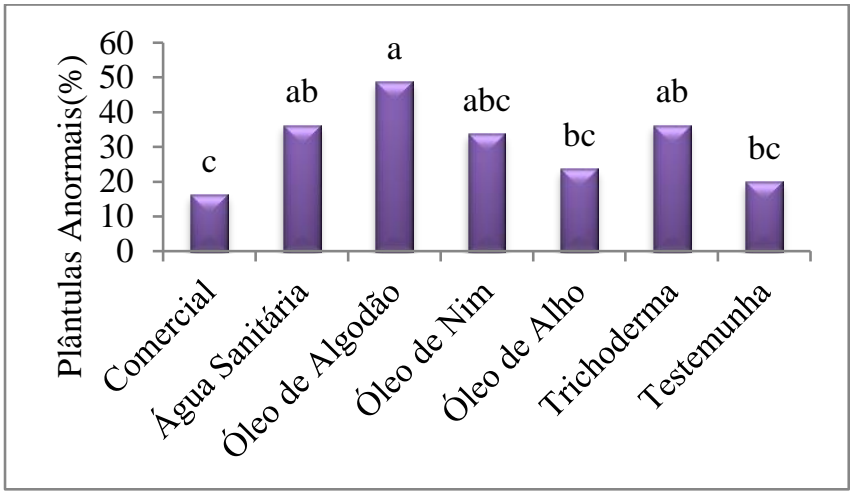

\section{CONCLUSÃO}

Sementes de coentro podem ser tratadas com produtos alternativos para melhorar o seu desempenho, sendo que os tratamentos a base de óleo de alho, Trichoderma e água sanitária apresentaram os melhores resultados para a maioria das variáveis analisadas.

\section{REFERÊNCIAS BIBLIOGRÁFICAS}

ABCSEM. Associação Brasileira de Sementes e Mudas, 2012. Disponível em: <http://www.abcsem.com.br>. Acesso em 24 jan. 2012.

ALVES, E. U., OLIVEIRA, A. P. D., BRUNO, R. D. L. A., SADER, R., \& ALVES, A. U. Rendimento e qualidade fisiológica de sementes de coentro cultivado com adubação orgânica e mineral. Revista Brasileira de Sementes, v. 27, n. 1, p. 132-137, 2005.

BRASIL. Ministério da Agricultura, Pecuária e Abastecimento. 2005. Produção e comércio de sementes. Anexo VII (Instrução Normativa, no 25 de 16 /12/2005).

BRASIL. Ministério da Agricultura, Pecuária e Abastecimento. Regras para análise de sementes. Ministério da Agricultura, Pecuária e Abastecimento. Secretaria de Defesa Agropecuária. Brasília, DF: Mapa/ ACS, 2009. 395p.

BHAT, S.; KAUSHAL, P.; KAUR, M; H. K. SHARMA, H. K. Coriander (Coriandrum sativum L.): Processing, nutritional and functional aspects. African Journal of Plant Science, v. 8, n.1, p. 25-33, 2014.

MACIEL, G. M., SALA, F. C., COSTA, C. P., \& MELO, O. D. Vigor e produtividade de sementes de coentro em função do tipo de semente. Scientia Plena, v.9, n.12, 2014. 
MAGUIRE, J.D. Seed of germination and relation evaluation for seedling emergence vigor. Crop Science, v.2, p.176-177, 1962.

MÜLLER, J.; PEDROSO, D.; MUNIZ, M.; JUNGES, E.; DUTRA, C.; SANTOS, R.; BASTOS, B. ; SILVA, G. B. P. Qualidade fisiológica e sanitária de sementes de coentro tratadas com micronutrientes, biocontrolador e polímero. Anais... XV SIMPEP, 2008.

PAVLOVIC, S.; STAROVIC, M.; ACIMOVIC, M.; ALEKSIC, G.; STOJANOVIC, S. Mycopopulations of coriander seeds. Anais ... Fifth International Scientific Agricultural Symposium, Agrosym, 2014.

PEREIRA, Roseane S.; MUNIZ, Marlove F. B. and NASCIMENTO, Warley M.. Aspectos relacionados à qualidade de sementes de coentro. Horticultura Brasileira [online]. 2005, vol.23, n.3, pp.703-706. ISSN 0102-0536. Disponível em :http://dx.doi.org/10.1590/S010205362005000300002 . Acesso 03 out 2016.

PEREIRA, M.F.S. ; TORRES, S.B.; LINHARES, P.C.F.; PAIVA, A.C.C.; PAZ, A.E.S.; DANTAS, A.H. Qualidade fisiológica de sementes de coentro [Coriandrum sativum (L.)]. Revista Brasileira de Plantas Medicinais [online]. 2011, vol.13, n.spe, pp.518-522.

PEDROSO, DANIELE CARDOSO. Apiáceas e alternarioses: tratamento de sementes, qualidade fisiológica e sanitária no armazenamento. Tese (doutorado)- universidade Federal de Santa Maria, Centro de ciências Rurias, Programa de pós graduação em agronomia, RS , 2012.

SILVA, G. H., DE SOUZA, P. F., HENRIQUES, Í. G. N., CAMPELO, J. G., \& ALVES, G. S. Extrato de alho e nim em diferentes concentrações com efeito fungicida em sementes de chorão (Poecilanthe ulei). Revista Verde de Agroecologia e Desenvolvimento Sustentável, v. 5, n. 4, p. 76-81, 2010.

\section{COPYRIGHT}

Direitos autorais: Os autores são os únicos responsáveis pelo material incluído no artigo. 


\title{
CARACTERIZAÇÃO DE PÃES ELABORADOS COM SUBSTITUIÇÃO PARCIAL DE FARINHA DE TRIGO POR FARINHA FUNCIONAL DE CENOURA (Daucus carota)
}

\author{
CHARACTERIZATION OF BREADS PREPARED WITH PARTIAL \\ REPLACEMENT OF WHEAT FLOUR BY CARROT (Daucus carota) \\ FUNCTIONAL FLOUR
}

\begin{abstract}
ANA LÚCIA BECKER ROHLFES ${ }^{1}$; NÁDIA DE MONTE BACCAR ${ }^{1}$; LILIANE MARQUARDT ${ }^{1}$; VALERIANO ANTONIO CORBELLINI ${ }^{1}$; RAQUEL CASSEL TASSINARI ${ }^{1}$; BRUNO ENGEL ${ }^{1}$; JÚLIA MULLER TREVISAN ${ }^{1}$

1 - UNIVERSIDADE DE SANTA CRUZ DO SUL - UNISC

albecker@unisc.br; nadia@unisc.br; liliane@unisc.br; valer@unisc.br; raquel.tassinari@hotmail.com; engelbrn@gmail.com; juliamt@mx2.unisc.br
\end{abstract}

\begin{abstract}
Resumo - A cenoura (Daucus carota) é um produto agrícola de elevado teor de fibras e minerais e está disponível como matéria-prima de baixo custo, podendo ser utilizada em produtos de panificação. Objetivou-se desenvolver um produto de panificação com características funcionais e avaliar sua preferência para consumo. Foram elaboradas cinco formulações de pão: uma padrão e quatro em que a farinha de trigo foi parcialmente substituída por farinha de polpa e casca de cenoura (5\% e 10\%). Os pães adicionados de farinha de cenoura apresentaram maior teor de fibras $e$ cinzas caracterizando-os como produtos funcionais. $A$ análise sensorial evidenciou a preferência dos provadores pelos pães elaborados com farinha de polpa de cenoura e, além disto, a elaboração de farinhas a partir de vegetais in natura é uma alternativa para diminuir o desperdício de alimentos, bem como de vegetais não conformes.
\end{abstract}

Palavras-chave: Alimentos Funcionais. Cenoura. Panificação.

Abstract - The carrot (Daucus carota) it's an agricultural product of elevated fiber e minerals content and it's available as low cost feedstock, being able to be utilized in bakery products. It was aimed to develop a bakery product for consumption. Were elaborated five formulations of bread: a pattern and four in which the wheat flour was partially replaced by pulp flour and carrot zest (5\% and 10\%). The carrot wheat flour added breads presented a higher fiber and ashes content, categorizing them as functional products. The sensory analysis evidenced the tasters preference for carrot pulp elaborated breads and, beyond that, the elaboration of flours from vegetables in nature it's an alternative to decrease food waste, as well as non-compliant vegetables.

Keywords: Functional Foods. Carrot. Bakery.

\section{INTRODUÇÃO}

Estudos técnicos apontam que é expressivo o desperdício alimentar em todas as fases da produção até o consumo, com uma previsão de atingir cerca de $25 \%$ da produção global de alimentos até 2050, aspecto importante que contribui para agravar a disponibilidade mundial de alimentos (BELIK; CUNHA; COSTA, 2012). O desperdício de produtos de origem vegetal in natura ocorre durante os processos de distribuição e comercialização, em virtude da perda de qualidade, do processo de preparação para o transporte ou venda (GUIMARÃES; FREITAS; SILVA, 2010).

Segundo Prim (2003), o desperdício está também associado ao não aproveitamento de todas as partes comestíveis, como folhas, cascas, flores, talos e raízes. Ainda, outro fator é o não aproveitamento de vegetais não conformes, caracterizados por apresentarem injúrias que apesar de estarem aptos ao consumo, acabam sendo descartados devido à perda do seu valor comercial (PEREIRA et al., 2003; ZANATTA; SCHLABITZ; ETHUR, 2010).

Muitos destes alimentos desperdiçados são alimentos funcionais ou nutracêuticos. Alimentos funcionais ou nutracêuticos caracterizam alimentos e/ou ingredientes alimentares que, além de fonte de energia e substrato para a formação de células e tecidos, possuem, em sua composição, substâncias capazes de melhorar as condições de saúde da população, promovendo o bem-estar e prevenindo o surgimento precoce de doenças (COELHO; WOSIACKI, 2010). Ainda, de acordo com Rohlfes et al. (2014), segundo a Resolução no 18, de 30 de abril de 1999 da Agência Nacional de Vigilância Sanitária (ANVISA, 1999), propriedade funcional é aquela relativa ao papel metabólico ou fisiológico que o nutriente ou não nutriente tem no crescimento, desenvolvimento, manutenção e outras funções normais do organismo humano. Nesse sentido, a utilização deste tipo de alimento vem crescendo, uma vez que a procura por produtos que, além de nutrir, também previnam doenças e aumentem o bem-estar físico e mental dos consumidores, vem sendo cada vez maior (COELHO; WOSIACKI, 2010).

Os vegetais, de um modo geral, são ricos em nutrientes reguladores e protetores e, por seu baixo valor 
calórico e elevado teor de fibras, oportunizam o desenvolvimento de produtos alimentícios com características funcionais ou nutracêuticas, estando associados, pelo elevado teor de fibras, à redução de doenças cardiovasculares, da hipertensão e de alguns tipos de câncer. Além disto, as fibras são benéficas para a regulação da flora intestinal, a prevenção da obstipação e da diverticulose, o controle dos níveis de gordura no sangue e a manutenção ou perda de peso. Adicionalmente, as fibras alimentares estão, também, presentes nas partes não convencionais dos vegetais, como cascas, sementes e talos (OLIVEIRA; PIROZI; BORGES, 2008; BARROSO; FREITAS; SILVA, 2009).

A cenoura (Daucus carota) é uma hortaliça da família Apiacea, pertencente ao grupo das tuberosas. Pode ser consumida crua ou cozida e é extremamente importante para a cadeia alimentar (CHITARRA; CARVALHO, 1984; OLIVEIRA et al., 2003) e por ser rica em nutrientes como potássio, ferro, sódio, cálcio e fósforo, proporciona equilíbrio ao organismo (QIN; XU; ZHANG, 2005). Também possui quantidades elevadas de $\beta$-caroteno e vitamina $A$, que ajudam a combater o envelhecimento dos tecidos, proporcionando saúde aos cabelos, pele, olhos e ossos (MANN; CUMMINGS, 2009; CEASA, 2013). Ajuda a amenizar riscos de doenças degenerativas, doenças cardiovasculares, degeneração muscular e catarata se ingerida com frequência (RODRIGUEZAMAYA; KIMURA; AMAYA-FARFAN, 2008).

A cenoura é reconhecida como uma boa fonte de fibras dietéticas, que por não sofrerem hidrólise, não são digeridas promovendo o bom funcionamento do organismo humano (MANN; CUMMINGS, 2009). Segundo Chau; Chen; Lee (2004), a cenoura, por ser rica em fibras insolúveis, apresenta uma elevada capacidade de absorção de glicose e redução da enzima amilase, o que a torna promissora para dietas de controle de níveis glicêmicos. Adicionalmente, estudos realizados por Hsu et al. (2006) resultaram na redução de níveis de triacilglicerol e colesterol total e aumento nos níveis do colesterol HDL em hamsters. Estes resultados evidenciam que as fibras da cenoura podem ser um potencial ingrediente funcional para controle do colesterol, caracterizando-as como constituinte alimentar com propriedades funcionais (SAURA-CALIXTO, 2010). Sua utilização poderia amenizar a falta de nutrientes na alimentação pela elaboração de produtos como sucos, doces, geleias, pastas e farinhas (GONDIM et al., 2005).

Boroski et al. (2011) destacam que as folhas de cenoura, usualmente não consumidas, são ricas em ácidos graxos, especialmente de ômega 3, e que sua farinha devido às suas propriedades antioxidantes, podem resultar em produtos alimentícios com elevados valores nutricionais e funcionais.

Segundo Barros; Barros (2010), estudos vêm sendo desenvolvidos para obtenção de farinhas de frutas e hortaliças, destacando-se as de cenoura, beterraba, espinafre, maracujá e maçã, como alternativa para minimizar o desperdício alimentar. Neste sentido, a cenoura apresenta-se como um produto agrícola que, além de possuir grande quantidade de compostos de interesse alimentar como fibras, carotenoides e minerais, está disponível como matéria-prima de baixo custo, podendo ser utilizada como substituta da farinha de trigo na elaboração de produtos de panificação (BRANCO et al., 2007).

A Associação Brasileira da Indústria do Trigo ABITRIGO (2016) estima que 56\% da produção de farinha consumida no Brasil são encaminhadas para as indústrias de panificação e confeitarias, outros $10 \%$ para consumo doméstico, $15 \%$ à produção de massas, $10 \%$ para produção de biscoitos e $9 \%$ para outros segmentos.

Dentre todas as etapas de processo unitário de obtenção de farinhas, a secagem é uma das mais importantes, pois melhora as características dos produtos, diminuindo a sua massa e volume e proporcionando condições adequadas de conservação e armazenamento (PARK et al., 2006). A secagem é uma alternativa para aumentar o tempo de vida de prateleira de muitos alimentos, principalmente de frutas e hortaliças. Os produtos secos não necessitam de refrigeração, apresentam maior concentração de nutrientes, sendo considerados alimentos saudáveis e com elevado valor agregado (CELESTINO, 2010).

Assim, devido ao fato da cenoura apresentar um elevado teor de fibra e considerando que o pão faz parte do hábito alimentar, o presente estudo objetivou empregar farinha da casca e da polpa da cenoura in natura na elaboração de pães com diferentes percentuais de substituição de farinha de trigo.

\section{PROCEDIMENTOS}

\section{1- Elaboração da farinha de cenoura}

As cenouras foram adquiridas em um supermercado da cidade de Santa Cruz do Sul/RS. As mesmas foram lavadas em água corrente e selecionadas, descartando-se partes que já apresentavam algum dano visual. Posteriormente, foram sanitizadas em solução de cloro ativo $150 \mathrm{mg} \mathrm{L}^{-1}$ por cerca de 10 minutos e lavadas novamente em água corrente. Em seguida, procedeu-se ao descascamento e separou-se a matéria-prima em casca e polpa.

Para o processo de secagem, utilizou-se uma desidratadora AG'MAC®, com circulação de ar a $60{ }^{\circ} \mathrm{C}$ (EMBRAPA, 2012) sendo testados os tempos de 5, 7 e 9 horas, empregando a polpa da cenoura. Para uma secagem mais efetiva, a cenoura foi ralada em pequenas partes em um multiprocessador Philips Walita ${ }^{\circledR}$.

Após a secagem, as cascas e as cenouras secas foram trituradas em liquidificador Philips Walita ${ }^{\circledR}$, analisadas quanto ao teor percentual de umidade e acondicionadas em embalagens herméticas.

\section{2-Produção de pães}

Neste ensaio foram empregadas as farinhas de casca e polpa obtidas por secagem em desidratadora à temperatura de $60^{\circ} \mathrm{C}$ por 7 horas. Para a elaboração dos pães, utilizou-se uma formulação de pão caseiro a partir da qual foram substituídos percentuais de 5 e $10 \%$ da farinha de trigo tanto por farinha de polpa (FP) como por farinha da casca (FC). A Tabela 1 apresenta a formulação dos pães. 
Tabela 1 - Formulação dos pães elaborados.

\begin{tabular}{cccccc}
\hline Matéria-prima & Pão Caseiro & $\mathbf{5 \%}$ de FC & $\mathbf{1 0 \%}$ de FC & $\mathbf{5 \%}$ de FP & $\mathbf{1 0 \%}$ de FP \\
\hline Farinha de trigo $(\mathrm{g})$ & 550,0 & 522,5 & 495,0 & 522,5 & - \\
FC $(\mathrm{g})$ & - & 27,5 & 55,0 & - & 27,5 \\
FP $(\mathrm{g})$ & - & - & 15,0 & 15,0 & 55,0 \\
Açúcar $(\mathrm{g})$ & 15,0 & 15,0 & 5,5 & 5,5 & 15,0 \\
Sal $(\mathrm{g})$ & 5,5 & 5,5 & 200,0 & 5,5 & 200,0 \\
Leite $(\mathrm{mL})$ & 200,0 & 200,0 & 10,0 & 200,0 & 10,0 \\
Fermento $(\mathrm{g})$ & 10,0 & 10,0 & 10,0 & 10,0 & 10,0 \\
Óleo $(\mathrm{mL})$ & 10,0 & 10,0 & 2 & 2 & 2 \\
Ovos (un.) & 2 & 2 & & \\
\hline
\end{tabular}

\section{3- Composição centesimal}

Tanto as farinhas produzidas como os diferentes pães elaborados foram analisados quanto aos teores de cinzas, umidade, fibras e proteínas seguindo os métodos da AOAC (1997). Por sua vez, para a quantificação dos teores de gordura, utilizou-se o método adaptado de Bligh; Dyer (1959).

\section{4- Análise sensorial}

Os pães produzidos com os diferentes percentuais de farinha de casca e farinha de cenoura foram avaliados por 50 provadores não treinados, de ambos os sexos, no Laboratório de Tecnologia dos Alimentos da Universidade de Santa Cruz do Sul, Santa Cruz do Sul, RS. Cada provador pode avaliar as amostras quanto à preferência segundo Minim (2010). As formulações foram codificadas conforme a Tabela 2 .

Tabela 2 - Códigos das amostras para análise sensorial.

\begin{tabular}{cc}
\hline Código & Tipo de pão \\
\hline 321 & Pão caseiro \\
654 & Pão com 5\% de farinha de polpa \\
987 & Pão com 10\% de farinha de polpa \\
210 & Pão com 5\% de farinha de casca \\
543 & Pão com 10\% de farinha de casca \\
\hline
\end{tabular}

Os pães foram elaborados considerando todas as normas de boas práticas na fabricação de alimentos e, no momento da análise sensorial, foram servidos à temperatura ambiente, em porções individuais em pratos plásticos descartáveis, codificados com números de três dígitos (Tabela 2). A pesquisa de análise sensorial foi aprovada pelo Comitê de
Ética em Pesquisa (CEP) da universidade sob número 25293013.0.0000.5343.

\section{5 - Análise estatística}

A análise estatística foi realizada para a composição centesimal da cenoura in natura, de suas farinhas e dos pães elaborados, através da Análise de Variância (ANOVA), com o emprego do Software Statistica ${ }^{\circledR}$ (versão 12.0).

\section{RESULTADOS}

\section{1- Tempo de secagem para elaboração da farinha de polpa}

Os teores percentuais de umidade obtidos para a polpa de cenoura desidratada à temperatura de $60^{\circ} \mathrm{C}$, nos tempos de 5,7 e 9 horas, foram, respectivamente, de $15,95 \%, 6,15 \%$ e $5,10 \%$. Segundo a Resolução RDC n ${ }^{\circ} 263$, de 22 de setembro de 2005 (ANVISA, 2005) a umidade máxima permitida para farinhas é de $15 \%$. Assim, foi estabelecido o tempo de 7 horas para secagem da polpa, sendo também empregada esta condição para a obtenção de farinha da casca da cenoura. No estudo realizado por Zanatta, Schlabitz; Ethur (2010), os autores empregaram temperatura de secagem da cenoura de $70^{\circ} \mathrm{C}$ e obtiveram um teor percentual de umidade de $4,1 \%$ após $9 \mathrm{~h}$ de processo.

\section{2- Composição centesimal da cenoura e das farinhas de cenoura}

A Tabela 3 apresenta os resultados obtidos na determinação da composição centesimal da cenoura in natura (FN) e das farinhas elaboradas com a casca (FC) e com a polpa da cenoura (FP).

Tabela 3 - Composição centesimal (g $\left.100 \mathrm{~g}^{-1}\right)$ da cenoura in natura (FN) e das farinhas elaboradas com casca (FC) e com polpa (FP).

\begin{tabular}{llllll}
\hline & Cinzas & Umidade & Fibras & Gordura & Proteínas \\
\hline FN & $0,77^{\mathrm{c}} \pm 0,05$ & $88,10^{\mathrm{a}} \pm 0,02$ & $3,84^{\mathrm{b}} \pm 0,67$ & $0,21^{\mathrm{b}} \pm 0,02$ & $1,06^{\mathrm{c}} \pm 0,18$ \\
FC & $8,35^{\mathrm{a}} \pm 0,26$ & $5,35^{\mathrm{c}} \pm 0,26$ & $14,66^{\mathrm{a}} \pm 1,42$ & $1,85^{\mathrm{a}} \pm 0,11$ & $6,58^{\mathrm{b}} \pm 0,10$ \\
FP & $5,86^{\mathrm{b}} \pm 0,52$ & $6,02^{\mathrm{b}} \pm 0,58$ & $13,70^{\mathrm{a}} \pm 0,66$ & $2,09^{\mathrm{a}} \pm 0,49$ & $8,08^{\mathrm{a}} \pm 0,52$ \\
\hline
\end{tabular}

Desvio padrão para $n=3$

Letras iguais na mesma coluna significa que não há diferença significativa nos resultados a $5 \%$ de probabilidade pelo teste de Tukey.

Os dados apresentados na Tabela 3 revelam que houve diferença significativa, ao nível de $5 \%$, entre os parâmetros analisados para a cenoura in natura e as farinhas elaboradas. Ao mesmo tempo, a avaliação estatística, comparando-se as farinhas de casca e de polpa de cenoura, remetem a diferenças significativas nos teores de umidade, cinzas e proteínas.

Em relação ao teor de umidade da cenoura in natura (Tabela 3) constata-se que a mesma apresenta teores muito próximos aos encontrados por De Andrade, Teodoro; Takase (2005) e Zanatta, Schlabitz; Ethur (2010), sendo de 89,3\% e $90,5 \%$, respectivamente. Ainda, o valor de fibras de $3,84 \mathrm{~g}$ $100 \mathrm{~g}^{-1}$ classifica a cenoura como fonte de fibras, uma vez que de acordo com a Portaria $n^{\circ} 27$ da Agência Nacional de Vigilância Sanitária de 1998 um alimento sólido é classificado como fonte de fibras quando apresenta, no mínimo, 3 g $100 \mathrm{~g}^{-1}$ (BRASIL, 1998).

Por outro lado, a desidratação da casca e da polpa da cenoura proporciona um incremento no teor de fibras, bem como nos teores de cinzas, gordura e proteínas, conforme pode ser visualizado nos resultados expressos para as farinhas de casca e polpa de cenoura.

Os elevados teores de fibra permitem classificar as farinhas elaboradas em produtos com alto teor de fibras, pois um produto é assim caracterizado se apresentar, no mínimo, 
$6 \%$ de fibras (BRASIL, 1998). Segundo CÓRDOVA et al. (2005), produtos alimentícios com a incorporação destas farinhas podem ser formulados para prevenir doenças relacionadas ao trato gastrointestinal e ao coração.

\section{3- Composição centesimal dos pães}

Os resultados encontrados na determinação da composição centesimal dos pães elaborados com os diferentes percentuais de farinha de casca e polpa de cenoura são apresentados na Tabela 4. Foram atribuídas as seguintes codificações: PC (pão caseiro), PP5 (pão com substituição de $5 \%$ de farinha de trigo por farinha de polpa de cenoura); PP10 (pão com substituição de $10 \%$ de farinha de trigo por farinha de polpa de cenoura); PC5 (pão com substituição de 5\% de farinha de trigo por farinha de casca de cenoura) e PC10 (pão com substituição de $10 \%$ de farinha de trigo por farinha de casca de cenoura).

A análise estatística realizada demonstrou que há diferença significativa $(p>0,05)$ entre cada uma das formulações de pães elaboradas com o emprego das diferentes farinhas.

Tabela 4- Composição centesimal (g $\left.100 \mathrm{~g}^{-1}\right)$ dos pães elaborados.

\begin{tabular}{llllll}
\hline Pão & Umidade & Cinzas & Gordura & Proteínas & Fibras \\
\hline PC & $29,53^{\mathrm{c}}$ & $0,93^{\mathrm{c}}$ & $5,27^{\mathrm{a}}$ & $10,92^{\mathrm{a}}$ & $2,67^{\mathrm{d}}$ \\
PP5 & $30,06^{\mathrm{bc}}$ & $1,31^{\mathrm{bc}}$ & $4,57^{\mathrm{bc}}$ & $10,28^{\mathrm{b}}$ & $3,92^{\mathrm{c}}$ \\
PP10 & $29,51^{\mathrm{c}}$ & $1,66^{\mathrm{b}}$ & $4,45^{\mathrm{cd}}$ & $9,95^{\mathrm{b}}$ & $5,84^{\mathrm{b}}$ \\
PC5 & $34,38^{\mathrm{a}}$ & $1,62^{\mathrm{b}}$ & $4,85^{\mathrm{b}}$ & $9,91^{\mathrm{c}}$ & $4,42^{\mathrm{c}}$ \\
PC10 & $31,98^{\mathrm{b}}$ & $2,17^{\mathrm{a}}$ & $4,28^{\mathrm{d}}$ & $9,96^{\mathrm{b}}$ & $6,04^{\mathrm{a}}$ \\
\hline
\end{tabular}

Letras iguais na mesma coluna significa que não há diferença significativa nos resultados a $5 \%$ de probabilidade pelo teste de Tukey.

Os pães elaborados apresentaram proteínas entre 9,91\% a 10,92\% e gordura de 4,28\% a 5,27\%. Em relação à umidade todas as amostras apresentaram valores enquadrados no limite definido pela RDC $\mathrm{n}^{\circ} 90$, de 18 de outubro de 2000 que estabelece teor máximo de 38\% (BRASIL, 2000).

Pode-se observar que nos pães com substituição parcial da farinha de trigo houve uma redução nos valores referentes aos teores de gordura e proteínas quando comparados com os valores do pão caseiro. Quando comparadas entre si, percebese uma maior redução dos valores de gordura nas amostras com substituição de $10 \%$ da farinha de trigo.

Em relação aos teores percentuais de cinzas percebe-se um incremento quando da substituição de farinha de trigo. Incrementos maiores estão associados ao maior percentual de substituição, bem como quando do emprego da farinha de casca de cenoura. Segundo Oliveira, Pirozi; Borges (2008) a

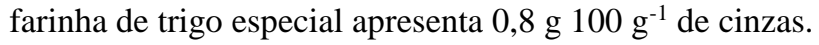

A diminuição observada em relação aos teores de proteínas quando da substituição da farinha de trigo por farinha de cenoura possivelmente está relacionada ao fato da farinha de trigo apresentar, em média, 10\% de proteína, enquanto as farinhas produzidas neste estudo são menos proteicas, uma vez que percentuais de 6,58 e 8,08 foram obtidos para as farinhas de casca e polpa de cenoura, respectivamente.

Por outro lado, a substituição levou à obtenção de produtos alimentícios classificados como fontes de fibras,

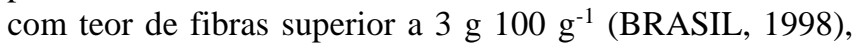
independente do percentual e tipo de farinha de cenoura empregado em sua elaboração. Ainda, o pão elaborado com $10 \%$ de farinha de casca de cenoura, segundo a Portaria $\mathrm{n}^{\circ} 27$ pode ser classificado como alimento com alto teor de fibras (BRASIL, 1998). Assim, os pães elaborados com emprego de farinha de cenoura apresentam a alegação de alimento funcional, conforme relatado por Gutkoski et al. (2007) ao estudarem barras de cerais adicionadas de flocos, farelo e farinha de aveia.

\section{4- Análise sensorial}

O gráfico apresentado na Figura 1 expressa os resultados obtidos quanto ao teste de preferência dos pães elaborados com diferentes percentuais de substituição da farinha de trigo por farinha de casca ou de polpa de cenoura.
Figura 1 - Gráfico referente ao resultado percentual de preferência.

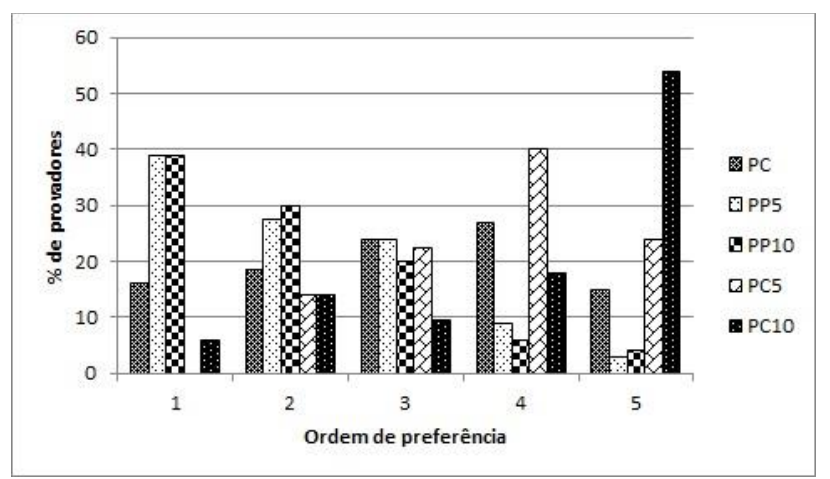

A análise do gráfico (Figura 1), permite observar que os pães preferidos, com $38 \%$ de preferência dos provadores não treinados, foram os elaborados com emprego de 5 e $10 \%$ de farinha de polpa de cenoura. Na sequência, em segunda colocação na ordem de preferência, mantiveram-se os mesmos tipos de pães, podendo-se inferir que os mesmos atingiram $68 \%$ de preferência.

Apesar do apelo funcional, os pães elaborados com farinha de casca apresentaram maior rejeição, onde 54\% dos provadores indicaram o pão elaborado com $10 \%$ desta farinha como o menos preferido.

\section{CONCLUSÃO}

A adição de farinha de polpa de cenoura ou de casca de cenoura, nas proporções de 5 e $10 \%$, em substituição à farinha de trigo, mostrou ser tecnicamente viável na elaboração de pães. Os pães elaborados com as farinhas de cenoura apresentam a alegação de alimento funcional em relação aos teores elevados de fibras. A análise sensorial evidenciou a preferência dos provadores pelos pães elaborados com farinha de polpa de cenoura demonstrando que os prováveis consumidores estão abertos a novos sabores e a produtos alimentícios funcionais. Além disto, a elaboração de farinhas a partir de vegetais in natura é uma alternativa para diminuir o desperdício de alimentos, bem como de vegetais não conformes. 


\section{AGRADECIMENTOS}

Os autores agradecem à Secretaria da Ciência, Inovação e Desenvolvimento Tecnológico do estado do Rio Grande do Sul (SDECT/RS) pelo financiamento da pesquisa, por intermédio do Projeto "Uso de resíduos vegetais na produção de farinhas funcionais e bioativas", Convênio DCIT 75/2015 e aos Laboratórios de Ensino do Curso de Química da Universidade de Santa Cruz do Sul.

\section{REFERÊNCIAS BIBLIOGRÁFICAS}

ABITRIGO. Sobre o trigo: Derivados. out, 2016. Disponível http://www.abitrigo.com.br/index.php?mpg=02.01.00. Acesso em: 31 out. 2016.

ANVISA. Agência Nacional de Vigilância Sanitária. Resolução RDC no 263, de 22 de setembro de 2005 . Regulamento técnico para produtos de cereais, amidos, farinhas e farelos. Disponível em: < http://portal.anvisa.gov.br/documents/33916/394219/RDC_ 263_2005.pdf/e9aa3580-f130-4eb5-91cb-8b8818bcf6b2> Acesso em: 05 jan. 2016.

AOAC. Official methods of analysis of AOAC International. 16.ed. Gaitheersburg: AOAC, 1997.

BArros, A. A. de; BARros, E. B. P. A química dos alimentos: produtos fermentados e corantes. São Paulo: Sociedade Brasileira de Química, v.4, 2010. 88 p.

BARROSO, Ana Karina Mauro; FREITAS, Maria Cristina Jesus; SILVA, Vera Lúcia Mathias. Avaliação das dietas contendo farinhas de talos de vegetais no trato gastrintestinal e parâmetros bioquímicos de ratos. Nutrire: Rev. Soc. Bras. Alim. Nutr. J. Brazilian Soc. Food Nutr., São Paulo, SP, v. 34, n. 3, p. 93-107, dez. 2009.

BELIK, Walter Belik, CUNHA, Altivo Roberto Andrade de Almeida, COSTA, Luciana Assis. Crise dos Alimentos e Estratégias para a Redução do Desperdício no Contexto de uma Política de Segurança Alimentar e Nutricional no Brasil. 2012. Disponível em: <http://www.uesb.br/eventos/semana_economia/2012/anais/ c01.pdf $>$. Acesso em: 26 out. 2016.

BLIGH, E. Graham; DYER, W. Justin. A rapid method of total lipid extraction and purufication. Canadian Journal of Biochemistry. v.37, p. 911-917. 1959.

BOROSKI, Marcela; AGUIAR, Ana Carolina de; BOEING, Joana Schuelter; ROTTA, Eliza Mariane; WIBBY, Camila Leite; BONAFÉ, Elton Guntendorfer; SOUZA, Nilson Evelázio de; VISENTAINER, Jesuí Vergílio. Enhancement of pasta antioxidant activity with oregano and carrot leaf. Food Chemistry, v. 125, n. 2, p. 696-700, 2011.

BRANCO, Ivanise Guilherme; SANJINEZ-ARGANDOÑA, Eliana Janet; SILVA, Melissa Massaroli da; PAULA, Talissa Martins de. Avaliação sensorial e estabilidade físico-química de um blend de laranja e cenoura. Ciência e Tecnologia de Alimentos, v. 27, n. 1, p. 7-12, 2007.

BRASIL. Ministério da Saúde, Agência Nacional de Vigilância Sanitária. Portaria $\mathbf{n}^{\mathbf{0}}$ 27, de 13 de janeiro de 1998. Regulamento técnico referente à informação nutricional complementar (declarações relacionadas ao conteúdo de nutrientes). Diário Oficial da União, de 16 de janeiro de 1998. Disponível em: <http://elegis.bvs.br/leisref/public/showAct.php〉. Acesso em: $01 \mathrm{dez}$. 2016.

BRASIL - Agência Nacional de Vigilância Sanitária. Resolução $n^{\circ} 18$, de 30 de abril de 1999. Aprova o regulamento técnico0020que estabelece as diretrizes básicas para análise e comprovação de propriedades funcionais e ou de saúde alegadas em rotulagem de alimentos. Diário Oficial da União da República Federativa do Brasil; 1999.

BRASIL. Ministério da Saúde. Agência Nacional de Vigilância Sanitária. Resolução RDC $\mathbf{n}^{0}$ 90, de 18 de outubro de 2000. Regulamento técnico para fixação de identidade e qualidade de pão. Disponível em: < http://www.anvisa.gov.br/anvisalegis/resol/2000/90_00rdc.h tm>. Acesso em: $01 \mathrm{dez} .2016$.

CEASA CAMPINAS. Como ter uma alimentação saudável. Out, 2013. Disponível em: http://www.ceasacampinas.com.br/novo/Serv_alimentacao_ saudavel.asp. Acesso em: 21 out. 2016.

CELESTINO, Sônia Maria Costa. Princípios de Secagem de Alimentos - Planaltina, DF: Embrapa Cerrados, 2010.

CHAU, Chi-Fai; CHEN, Chien-Hung.; LEE, Mao-Hsiang. Comparison of the characteristics, functional properties, and in vitro hypoglycemic effects of various carrot insoluble fiber-rich fractions. Lebensmittel-Wissenschaft Technol., v. 37, n. 2, p. 155-160, 2004.

CHITARRA, M. I. F.; CARVALHO, V. D. Cenoura: qualidade e industrialização. Informe Agropecuário, v.10, n.120, 1984.

COELHO, Laylla Marques; WOSIACKI, Gilvan. Avaliação sensorial de produtos panificados com adição de farinha de bagaço de maçã. Ciência e Tecnologia de Alimentos, v. 30, n. 3, p. 582-588, 2010.

CÓRDOVA, Katielle R. Voncik; GAMA, Thaís M. M. Tavares Bastos; WINTER, Cristina M. Guolo; KASKANTZIS NETO, Georges; FREITAS, Renato João Sossela de. Características físico-químicas da casca do maracujá amarelo (Passiflora edulis Flavicarpa Degener) obtida por secagem. B. CEPPA, v. 23, n. 2, p. 221-230, 2005.

DE ANDRADE, Édira Castello Branco; TEODORO, Anderson Junger; TAKASE, Iracema. Determinação dos teores de zinco em diferentes extratos de hortaliças dos tipos A e B. Ciênc. Tecnol. Aliment, v. 25, n. 2, p. 265-270, 2005.

EMBRAPA. Aproveitamento das raspas geradas na produção de minicenouras. Dez, 2012. Disponível em: http://www.cnph.embrapa.br/paginas/serie_documentos/pub licacoes2005/cot_33.pdf. Acesso em: 2 set. 2016.

GUIMARÃES, Renata Rangel; FREITAS, Maria Cristina Jesus de; SILVA, Vera Lucia Mathias da. Bolos simples elaborados com farinha da entrecasca de melancia (Citrullus vulgaris, sobral): avaliação química, física e sensorial. Ciência e Tecnologia de Alimentos, Campinas, v. 30, n. 2, p. 354-363, 2010.

GONDIM, Jussara A. Melo, MOURA, Maria de Fátima V., DANTAS, Aécia S., MEDEIROS, Rina Lourena S., SANTOS, Klécia M. Composição centesimal e de minerais em cascas de frutas. Ciência e Tecnologia de Alimentos. Campinas, v.25, p.825-827, 2005. 
GUTKOSKI, Luiz Carlos; BONAMIGO, Jane Maria de Almeida; TEIXEIRA, Débora Marli de Freitas; PEDÓ, Ivone. Desenvolvimento de barras de cereais à base de aveia com alto teor de fibra alimentar. Ciência e Tecnologia de Alimentos, v. 27, n. 2, p. 355-363, 2007.

HSU, Pang-Kuei; CHIEN, Po-Jung; CHEN, Chien-Hung; CHAU, Chi-Fai. Carrot insoluble fiber-rich fraction lowers lipid and cholesterol absorption in hamsters. LebensmittelWissenschaft Technol., v. 39, n. 4, p. 337-342, 2006.

MANN, J. I.; CUMMINGS, J. H. Possible implications for health of the different definitions of dietary fibre. Nutrition, Metabolism and Cardiovascular Diseases, v. 19, n. 3, p. 226-229, 2009.

MINIM, Valéria Paula Rodrigues. Análise sensorial-estudo com consumidores. 2.ed. Viçosa: Universidade Federal de Viçosa, 2010. 308p.

OLIVEIRA, Talita Moreira de; PIROZI, Mônica Ribeiro; BORGES, João Tomaz da Silva. Elaboração de pão de sal utilizando farinha mista de trigo e linhaça. Alimentos e Nutrição Araraquara, v. 18, n. 2, p. 141-150, 2008.

OLIVEIRA, Rubens A.; ROCHA, Ismael de B.; SEDIYAMA, Gilberto C.; PUIATTI, Mário; CECON, Paulo R.; SILVEIRA, Suely de F. R. Coeficientes de cultura de cenoura nas condições edafoclimáticas do Alto Paranaíba, no estado de Minas Gerais. Revista Brasileira de Engenharia Agrícola e Ambiental, v. 7, p. 280-284, 2003

PARK, K. J.; ANTONIO, G. C.; OLIVEIRA, R.A.; PARK, K. J. B. Conceitos de Processo e Equipamento de Secagem. $2006 . \quad$ Disponível em: http://www.feagri.unicamp.br/ctea/projpesq.html. Acesso em: 18 out. 2016.

PEREIRA, Gláucia Imaculada Soares; PEREIRA, Rosemary Gualberto F. Alvarenga; BARCELOS, Maria de Fátima Píccolo; MORAIS, Augusto Ramalho de. Avaliação química da folha da cenoura visando ao seu aproveitamento na alimentação humana. Ciência e Agrotecnologia, Lavras, v.27, p. 852-857, 2003.

PRIM, Maria Benedita da Silva. Análise do desperdício de partes vegetais consumíveis. 2003. 117f. Dissertação (Mestrado em Engenharia de Produção) - Universidade Federal de Santa Catarina, Florianópolis, 2003.

QIN, Lan; XU, Shi-ying; ZHANG, Wen-bin. Effect of enzymatic hidrolysis on the yield of cloud carrot juice and the effects of hidrocolloids on color and cloud stability during ambient storage. Journal of Food Science and Agriculture, v.85, p.505-512, 2005.

RODRIGUEZ-AMAYA, D. B.; KIMURA, M.; AMAYAFARFAN, J. Fontes brasileiras de carotenoides. Brasília: MMA/SBF, 2008. 99 p.

ROHLFES, Ana Lúcia Becker; BACCAR, Nádia de Monte; OLIVEIRA, Mari Silvia Rodrigues de; MARQUARDT, VIEIRA, Liliane; OLIVEIRA, Luisana. Produção de sorvete a partir de iogurte com propriedade probiótica. Revista Sodebras [online]. v. 9, n. 7, jan./2014, p. 9-14. ISSN 1809$3957 . \quad$ Disponível em: $\langle$ http://www.sodebras.com.br/edicoes/N97.pdf $>$. Acesso em 16 nov. 2016.
SAURA-CALIXTO, Fulgencio. Dietary fiber as a carrier of dietary antioxidants: an essential physiological function. Journal of agricultural and food chemistry, v. 59, n. 1, p. 43-49, 2010.

ZANATTA, Caroline Lima; SCHLABITZ, Cláudia; ETHUR, Eduardo Miranda. Physico-chemical and microbological evaluation of flour obtained from vegetable not conforming to marketing. Alimentos e Nutrição. Araraquara, v. 21, n. 3, p. 459-468, jul./set. 2010.

\section{COPYRIGHT}

Direitos autorais: Os autores são os únicos responsáveis pelo material incluído no artigo.
Submetido em:06/12/2016 Aprovado em: 30/12/2016 


\section{Área: Ciências Exatas e Engenharias}

\begin{tabular}{|c|c|}
\hline $1-2$ & $\begin{array}{l}\text { MÉTODO DE AVALIAÇÃO APROXIMADA PARA A PROBABILIDADE DA UNIÃO } \\
\text { DE EVENTOS INDEPENDENTES } \\
\text { APPROXIMATE EVALUATION METHOD FOR THE PROBABILITY OF THE } \\
\text { UNION OF INDEPENDENT EVENTS } \\
\text { Edson Luiz UrSini, Paulo S. Martins }\end{array}$ \\
\hline $1-4$ & $\begin{array}{l}\text { FORMAÇÃO DO ALN POR ASSOCIAÇÃO RADIATIVA } \\
\text { FORMATION OF ALN BY RADIATIVE ASSOCIATION } \\
\text { Carmen M. Andreazza; Amaury A. De Almeida; Demétrio T. Ceccatto }\end{array}$ \\
\hline 3-3 & $\begin{array}{l}\text { ESTUDO DA ESTABILIDADE DO ARCO ELÉTRICO GERADO PELA } \\
\text { SOLDAGEM DE REVESTIMENTO (FCAW) DEVIDO À VARIAÇÃO DA } \\
\text { TENSÃO/CORRENTE E VELOCIDADE DE SOLDAGEM } \\
\text { STUDY OF ARC STABILITY IN AN FCAW CLADDING WELDING PROCESS } \\
\text { THROUGH THE VARIATION OF CURRENT, CONTACT TIP-WORK PIECE } \\
\text { DISTANCE AND WELDING VELOCITY } \\
\text { Celso Alves Correa; João Roberto Sartori Moreno; Luiz Guilherme Marin }\end{array}$ \\
\hline $3-4$ & $\begin{array}{l}\text { COMPARAÇÃO DOS MÉTODOS DE GERAÇÃO DA SPWM VIA PONTO A } \\
\text { PONTO E MODULOS PWM DO MICROCONTROLADOR NO CONTROLE DE UM } \\
\text { MIT } \\
\text { COMPARISON OF THE METHODS OF GENERATION OF SPWM VIA POINT TO } \\
\text { POINT AND PWM MODULES MICROCONTROLLER IN A MIT } \\
\text { Luiz Carlos Gomes; Marcio Abud Marcelino }\end{array}$ \\
\hline $3-5$ & $\begin{array}{l}\text { CONCENTRAÇÃO DE TENSÕES EM PEÇAS E COMPONENTES } \\
\text { ESTRUTURAIS ATRAVÉS DO MÉTODO DOS ELEMENTOS FINITOS } \\
\text { CONCENTRATION OF STRESSES IN STRUCUTURAL PARTS AND } \\
\text { COMPONENTS THROUGH THE FINITE ELEMENT METHOD } \\
\text { Erick Siqueira Guidi; Fernando De Azevedo Silva; Caio Cavagioni; Carlos Alberto } \\
\text { Chaves }\end{array}$ \\
\hline $3-8$ & 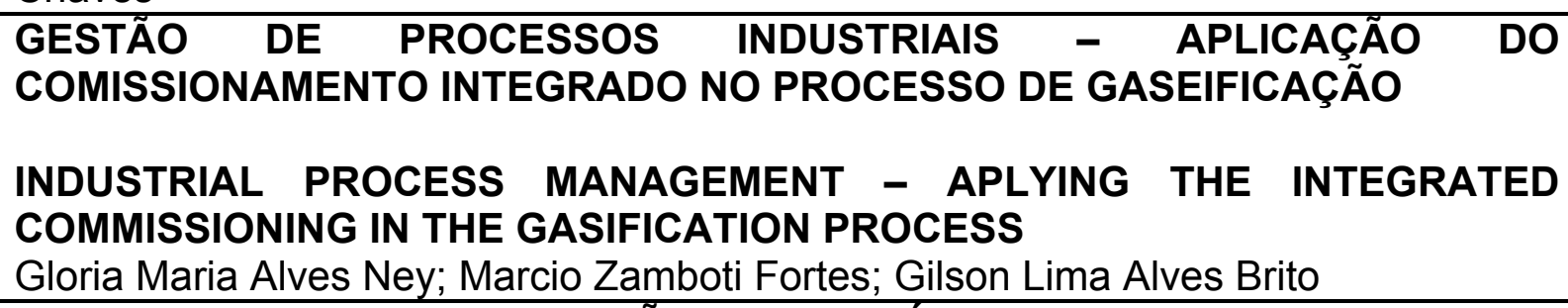 \\
\hline 3-8 & $\begin{array}{l}\text { ALTERNATIVAS PARA REDUÇÃO DOS RESÍDUOS FINAIS DA UNIDADE DE } \\
\text { VALORIZAÇÃO DE RECICLÁVEIS DE CURITIBA/PR } \\
\text { ALTERNATIVES FOR THE REDUCTION OF FINAL WASTE OF THE CURITIBA I } \\
\text { PR RECYCLABLE RECOVERY UNIT } \\
\text { Robson Seleme; Adriana De Paula Lacerda Santos; Eduardo Palmeira; Wiliam De } \\
\text { Assis Silva; Izabel Cristina Zattar; Alessandra De Paula }\end{array}$ \\
\hline
\end{tabular}




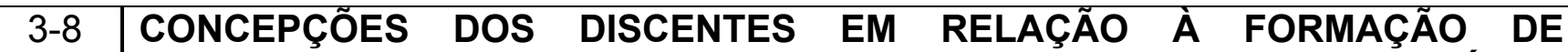
PROFESSORES DE BIOLOGIA NA MODALIDADE A DISTANCIA NO PERÍODO DE 2013-2016 EM PARAUAPEBAS - PA

THE STUDENTS' CONCEPTIONS REGARDING THE TRAINING OF BIOLOGY TEACHERS IN THE DISTANCE MODALITY IN THE PERIOD OF 2013-2016 IN PARAUAPEBAS - PA

Maiely Glenda Guimaraes Da Silva; Nilson Santos Trindade 


\title{
MÉTODO DE AVALIAÇÃO APROXIMADA PARA A PROBABILIDADE DA UNIÃO DE EVENTOS INDEPENDENTES
}

\section{APPROXIMATE EVALUATION METHOD FOR THE PROBABILITY OF THE UNION OF INDEPENDENT EVENTS}

\author{
EDSON LUIZ URSINI, PAULO S. MARTINS \\ FACULDADE DE TECNOLOGIA - UNICAMP \\ \{ursini, paulo\}@ft.unicamp.br
}

\begin{abstract}
Resumo - O cálculo da probabilidade de união de um grande número de eventos independentes requer várias combinações envolvendo o cálculo fatorial e exigindo o uso de computadores de alto desempenho e várias horas de processamento. Os limites da probabilidade de união e simplificações no seu cálculo são úteis na análise de problemas estocásticos em várias áreas como confiabilidade dos sistemas, sistemas biológicos, sistemas de tempo real com tolerância a falhas, teoria da probabilidade, teoria da informação, e comunicações dentre outros. Propomos uma aproximação que obtém a probabilidade da união de vários eventos independentes utilizando a média aritmética da probabilidade de todos eles. Os resultados aproximados têm um erro muito próximo, mas maior do que o erro verdadeiro. Isso permite um número muito menor de operações com um resultado semelhante e com maior simplicidade.
\end{abstract}

Palavras-chave: Probabilidade de União. Limites da Probabilidade de União. Eventos Independentes. Avaliação Aproximada.

\begin{abstract}
The evaluation of the probability of union of a large number of independent events requires several combinations involving the factorial and the use of high performance computers with several hours of processing. Bounds and simplifications on the probability of the union are useful in the analysis of stochastic problems across various areas including (but not limited to) systems reliability, biological systems, realtime fault-tolerant systems, probability theory, information theory and communications. We propose an approximation to evaluate the probability of the union of several independent events that uses the arithmetic mean of the probability of all of them. The approximate results are very close to, but larger than the exact values. The method allows a much smaller number of operations with a similar result and more simplicity.
\end{abstract}

Keywords: Probability of Union. Bounds on the Probability, Independent Events. Approximate Evaluation.

\section{INTRODUCTION}

Most systems are structured around a number of components, elements, parts or devices which as a whole provide the overall behavior. In this work, we use the word "system" in a holistic sense to encompass a large class of physical and non-physical systems such as mechanical (e.g. automobiles and aircraft), biological, computational (software and hardware), information systems, chains of command in military organizations, cyber-physical and realtime embedded systems among others. If we take one arbitrary but nevertheless relevant property of such systems, for example their reliability (for the sake of argument), its overall system reliability may be obtained from the individual reliability of its components. In particular, if the system components are arranged in series, failure of one component may compromise the overall system's reliability (clearly, if no form of redundancy is provided).

Within this context, the probability of failure of a system consisting of $n$ components in series is given by the probability of the union of the event of each component failing independently. However, the calculus of the probability of the union of a large number of independent and non-mutually exclusive events is computationally intensive, as it requires several combinations each involving the factorial. For example, in the case of 300 devices that may fail we need to resort to combinations of 300 taken $k$ at a time, where $k$ may vary from 1 to 300 . Therefore, the goal of our work is to provide a method that simplifies this calculus by avoiding the calculation of all of these combinations, i.e. the proposed method relies on an approximate calculus while also evaluating the error incurred by means of bounds of the probability of the union. More specifically, in this work we aim at calculating the approximate value of the probability of the union of independent events by using the mean value of the probability of the events. To our knowledge, we have found no work in the literature that has adopted this approach to the estimation of the probability of the union.

Notice that, although the main focus here is to show in a didactic way the application of the method to devices or components with estimated fault probabilities (e. g. resistors or devices in series such as in the realm of reliability theory or several serial links in a telecommunication system), our work accommodates far more general scenarios of the union of independent events than the one covered here.

One of the earliest papers on the topic is the work by Miller (1968), who focuses on issues related to processing time and memory space. However, unlike our work, in the author's traditional approach there is no reference to the use of the mean value to calculate the probability of the union of events. Legg et al (2011) address the problem of calculating a very large number of independent events, but they use true (real) values (i.e. not the average value as we propose in this work) which implies a very long processing time. For up to 100 items, their convergence is very fast. However, time 
grows exponentially beyond 100 devices. As an example, the calculation performed with 1000 devices (items) took more than 17 hours. Very often the processing time is a stringent requirement and a shorter processing time may be more important than exact precision. The last two papers specifically addressed the probability of the union of independent events.

The paper from Caen (1997) presents a lower bound on the probability of the union using only the individual probabilities and the probabilities of the joint events, two by two. In another work, Prékopa and Gao (2005) use two linear programming boundaries to establish another boundary for the probability of union of events since there is no complete knowledge of the joint probability of all events. The authors also generalize the work by De Caen (1997). The paper from Kuai et al (2000) also seeks to use the individual probabilities and the probability of the union of events, two by two, to establish the bounds for the probability of the union. The work by Veneziani (2009) improves upon the work of Prékopa and Gao (2005) by the inclusion of weights for the resolution of the linear system. Our approach is simpler because it assumes the independence between events. Furthermore, it seeks an approximate calculation by using the mean of the probability of occurrence of individual events.

The work of Kounias (1995) uses the Bonferroni inequality or the Poisson approximation to evaluate the error resulting from not knowing the joint probability of the events that are not independent. On the other hand, the paper by Yang et al (2016) derives lower bounds on the finite probability of union in terms of the individual event probabilities and a weighted sum of the pairwise event probabilities that have at most pseudo-polynomial computational complexity. This work also generalizes some recent works. Hollenback and Moss (2011) address the issue of approximation, and offer the calculus of the limits to the probabilities. However, unlike our work, they do not deal with the issue of using the mean value of probabilities. The objective of our work is mainly to attempt to cut down computational overheads such as processor time and memory. Concerning the independence of events, our approach may also be useful in cases where the events are approximately independent.

The remainder of this paper is organized as follows: Section II presents the background on the calculus of the probability of independent events; Section III specializes this calculus for the case where the devices have the same probability of failure; Section IV derives the incurred error when the devices have different probability of failure; Section V deals with the issue of the incurred error when a smaller number of terms are adopted; In Section VI we propose the use of the mean value of the probability of failure and we evaluate its corresponding approximation errors. Finally, Section VII addresses our remarks and conclusions.

\section{PROBABILITY OF THE UNION}

We consider a system with $n$ components (or devices) in series, for didactic purpose, $n$ resistors or $n$ telecommunication links (the same could be extended for probability of union of any independent sets). The events $A_{i}, i=1, \cdots, n$ correspond to the failure operation of each of the components. Thus, the failure probability of each component is $P\left(A_{i}\right)=p_{i}$.

In turn, $P\left(\bar{A}_{i}\right)=1-P\left(A_{i}\right)=1-p_{i}$ is the probability that the device $i$ do not fail. The probability of the union for $n$ independent devices, each with a probability of failure $p_{i}$, is given by (GAVIN, 2016):

$$
\begin{aligned}
& P\left(A_{1} \cup A_{2} \cup \cdots \cup A_{n}\right)=1-P \overline{\left(A_{1} \cap A_{2} \cap \cdots \cap A_{n}\right)}= \\
& =1-P\left(\overline{A_{1}}\right) P\left(\overline{A_{2}}\right) \cdots P\left(\overline{A_{n}}\right)= \\
& =1-\left(1-p_{1}\right)\left(1-p_{2}\right) \cdots\left(1-p_{n}\right)
\end{aligned}
$$

In the preceding expansion the De Morgan theorem was employed along with the knowledge that the events are independent (i.e. devices fail or survive independently of one another)

\section{PROBABILITY OF THE UNION FOR EVENTS WITH THE SAME PROBABILITY}

If the events have the same probability, then:

$P\left(A_{1} \cup A_{2} \cup \ldots \cup A_{n}\right)=1-(1-p)^{n}$

Equation (2) alone is not sufficient to find out the number of operations required to calculate the final probability. Thus, by further developing expression (2) for equal probabilities we have:

$P\left(A_{1} \cup A_{2} \cup \cdots \cup A_{n}\right)=\left(\begin{array}{l}n \\ 1\end{array}\right) p-\left(\begin{array}{l}n \\ 2\end{array}\right) p^{2}+\left(\begin{array}{l}n \\ 3\end{array}\right) p^{3}-\cdots(-1)^{n}\left(\begin{array}{l}n \\ n\end{array}\right) p^{n}$

The terms alternate their signal, starting from a positive sign. The first term corresponds to the case where the probabilities of failure are mutually exclusive. The positive sign (+) in the last term occurs for an odd $n$ and the negative (-) for an even value of $n$. The right-hand side of this summation may be written as:

$$
\sum_{i=1}^{n}(-1)^{i-1}\left(\begin{array}{l}
n \\
i
\end{array}\right) p^{i}
$$

However, we may expand this expression:

$$
\begin{array}{r}
\sum_{i=1}^{n}(-1)^{i-1}\left(\begin{array}{c}
n \\
i
\end{array}\right) p^{i}=\sum_{i=1}^{n}-\left(\begin{array}{c}
n \\
i
\end{array}\right)(-p)^{i}=-\sum_{i=1}^{n}\left(\begin{array}{l}
n \\
i
\end{array}\right)(-p)^{i} \\
\text { The summation } \sum_{i=0}^{n}\left(\begin{array}{l}
n \\
i
\end{array}\right)(-p)^{i} \text { is the Newton's binomial }
\end{array}
$$
which is equal to $(1-p)^{n}$. Thus, observing that in (3) we are missing only the first term of the binomial (which is 1),

$$
-\sum_{i=1}^{n}\left(\begin{array}{l}
n \\
i
\end{array}\right)(-p)^{i}=-\left[(1-p)^{n}-1\right]=1-(1-p)^{n}
$$

Therefore, the probability of the union for $n$ devices is obtained by different means as shown in (2):

$$
P\left(A_{1} \cup A_{2} \cup \ldots \cup A_{n}\right)=1-(1-p)^{n}
$$

This is the correct value for finding the probability of the union for $n$ statistically independent devices with the 
same probability of failure. On the other hand, if we want to use fewer terms, we must truncate equation (4) by

$-\sum_{i=1}^{m}\left(\begin{array}{l}n \\ i\end{array}\right)(-p)^{i} \quad m<n \quad(4 \mathrm{a})$

If we carried out the summation in $n$, we would obtain equation (2)

\section{PROBABILITY OF THE UNION FOR EVENTS WITH DIFFERENT PROBABILITIES}

When the probabilities of the components differ from each other, equation (3) has to be recast as:

$$
\begin{aligned}
& P\left(A_{1} \cup A_{2} \cup \cdots \cup A_{n}\right)= \\
& \left(p_{1}+\cdots+p_{n}\right)-\left(p_{1} p_{2}+p_{1} p_{3}+\cdots+p_{n-1} p_{n}\right)+ \\
& \left(p_{1} p_{2} p_{3}+p_{1} p_{2} p_{4}+\cdots+p_{n-2} p_{n-1} p_{n}\right)-\cdots \\
& +(-1)^{n}\left(p_{1} \cdots p_{n-2} p_{n-1} p_{n}\right)
\end{aligned}
$$

Each term corresponding to each parenthesis in (5) has $\left(\begin{array}{l}n \\ i\end{array}\right)$ combinations. The first term has $\left(\begin{array}{l}n \\ 1\end{array}\right)=n$ values and it corresponds to the particular case where the probabilities of failure are mutually exclusive. The second term has $\left(\begin{array}{l}n \\ 2\end{array}\right)=\frac{n(n-1)}{2 !}$ products of two probability values. The third term has $\left(\begin{array}{l}n \\ 3\end{array}\right)=\frac{n(n-1)(n-2)}{3 !}$ products of three probability values, and so on, until $\left(\begin{array}{l}n \\ n\end{array}\right)=1$ one product of $n$ probability values. All terms should be multiplied by $(-1)^{i-1}$.

\section{INCURRED ERROR}

In order to illustrate the concept, we now present the complete calculus for two and three independent devices.

For 2 devices we have: $\left(p_{1}+p_{2}\right)-\left(p_{1} p_{2}\right)$ or $2 p-p^{2}$ for equal probabilities; for 3 devices we have:

$$
\left(p_{1}+p_{2}+p_{3}\right)-\left(p_{1} p_{2}+p_{1} p_{3}+p_{2} p_{3}\right)+\left(p_{1} p_{2} p_{3}\right)
$$

$3 p-3 p^{2}+p^{3}$ when the probabilities are the same.

For a large number of devices the calculus of probability from equation (4) is a challenge due to the large number of combinations. Furthermore, the complete numeric calculus of the probability of the union of all devices requires substantial processing power. This task may be simplified by employing (3). If it is possible to find the probability of failure from (3) and the number of terms, for an error set a priori from (1), the resulting error is controlled by the user (in addition to allow efficient algorithms with relatively small approximations).

In order to evaluate the error incurred by neglecting the subsequent terms (in percentage), we apply the modulus of the percentage value obtained in a truncating point $m<n$ :

$$
\left|\frac{P\left(A_{1} \cup A_{2} \cup \ldots \cup A_{n}\right)-\sum_{i=1}^{m}\left(\begin{array}{l}
n \\
i
\end{array}\right) \operatorname{SUM} \operatorname{PROB}(i)}{P\left(A_{1} \cup A_{2} \cup \ldots \cup A_{n}\right)}\right| m<n
$$

SUM PROB $(i)$ in equation (5) means the following: $i=1$ corresponds to the particular case where the probabilities of failure are mutually exclusive, if $i=2$, there is a product of two probability values, and if $i=3$ there is a product of three probability values and so on until $m(m<n)$. If $m=n$, the calculation is complete and equation (5) is the same as equation (1) (if the probabilities are equal, $\operatorname{SUM} \operatorname{PROB}(i)$ is the same as in equation (4a).

Notice that the computation of all the terms in the equation above $(m=n)$ leads to a null/zero error. A numeric example, using equation (1), is the case for two devices with $p_{1}=0.1$ and $p_{2}=0.3$ where

$$
\begin{aligned}
& P\left(A_{1} \cup A_{2}\right)=1-\left(1-p_{1}\right)\left(1-p_{2}\right)=p_{1}+p_{2}-p_{1} p_{2}= \\
& =0.1+0.3-0.03=0.37
\end{aligned}
$$

\section{PROPOSED APPROACH}

Assuming devices with the same probability of failure, the mean probability $\bar{p}$ of failure for each device is $\bar{p}=\frac{p_{1}+p_{2}}{2}=0.2$. Thus, the probability of failure of the set for the mean value $\bar{p}=0.2$, and using equation (2), is $P\left(A_{1} \cup A_{2}\right)=1-(1-0.2)^{2}=0.2+0.2-0.04=0.36$.

The approximation (truncation) in this case can only be applied to the first term (it falls under the special case where we assume that the events are mutually exclusive). This is a special case, but shows an approximate error of $11 \%$ (due to

\begin{tabular}{|c|c|c|c|c|}
\hline $\begin{array}{c}\# \text { of } \\
\text { Devices } \\
\mathbf{n}\end{array}$ & $\begin{array}{l}\text { Probability } \\
\text { of failure }\end{array}$ & $\begin{array}{c}\text { Probability } \\
\text { (mean) } \\
(\bar{p})\end{array}$ & $\begin{array}{c}\text { Exact } \\
\text { value } \\
\text { equation } \\
\text { (1) }\end{array}$ & $\begin{array}{c}\text { Approxi- } \\
\text {-mate } \\
\text { value } \\
\text { equation } \\
(2)\end{array}$ \\
\hline 2 & 0.1 and 0.3 & 0.20 & 0.3700 & 0.3600 \\
\hline 3 & $\begin{array}{l}0.1,0.3 \\
\text { and } 0.5\end{array}$ & 0.30 & 0.6850 & 0.6570 \\
\hline 4 & $\begin{array}{c}0.1,0.2, \\
0.2 \\
\text { and } 0.3\end{array}$ & 0.20 & 0.5968 & 0.5904 \\
\hline 4 & $\begin{array}{c}0.5,0.8, \\
0.2 \\
\text { and } 0.4\end{array}$ & 0.48 & 0.9520 & 0.9240 \\
\hline 5 & $\begin{array}{l}0.1,0.2 \\
0.2,0.3 \\
\text { and } 0.2\end{array}$ & 0.20 & 0.6774 & 0.6723 \\
\hline
\end{tabular}
using a mean value) and a correct error of $8 \%$ when using only one term.

Table 1 introduces five examples of complete and approximate probability of failure (using the mean of failures and with all the terms).

Table 1 - Approximate and exact values of the probability of the union (failure). 
Table 2 illustrates the resulting errors for $n$ - 1 terms (term 1 corresponds to a simple probability, term 2 are probabilities represented as two-by-two products, ..., and so forth) for finding the probability of the union. Assuming $n$ devices with known probability of failure, the exact error that results when using $n-1$ terms is given by equations (5) and (6) (with 2 devices we have $n-1=1$, a single term; for three devices we have two terms, and so on). For the approximate error we use equations (2) and (6) because we work with the mean value, $\bar{p}$, so the error that would incur for the mean value is equation (2) for $1-(1-\bar{p})^{n}$ :

Table 2 - Incurred error values (\%) for $n-1$ terms in equation (5) or in equation (4).

\begin{tabular}{|c|c|c|c|c|}
\hline $\begin{array}{c}\text { \# of } \\
\text { devices } \\
n\end{array}$ & $\begin{array}{c}\text { Probability } \\
\text { of } \\
\text { failure }\end{array}$ & $\begin{array}{c}\text { Probability } \\
\text { (mean) } \\
(\bar{p})\end{array}$ & $\begin{array}{c}\text { Exact } \\
\text { error }(\%) \\
\text { eq. }(5 \& 6)\end{array}$ & $\begin{array}{c}\text { Approx. } \\
\text { error }(\%) \\
\text { eq. }(4 \& 6)\end{array}$ \\
\hline 2 & 0.1 and 0.3 & 0.20 & $\begin{array}{c}\text { one } \\
\text { term } \\
8.0\end{array}$ & $\begin{array}{l}\text { one } \\
\text { term } \\
11.0\end{array}$ \\
\hline 3 & $\begin{array}{l}0.1,0.3 \\
\text { and } 0.5\end{array}$ & 0.30 & $\begin{array}{c}\text { two } \\
\text { terms } \\
2.0\end{array}$ & $\begin{array}{l}\text { two } \\
\text { terms } \\
4.0\end{array}$ \\
\hline 4 & $\begin{array}{c}0.1,0.2 \\
0.2 \text { and } 0.3\end{array}$ & 0.20 & $\begin{array}{l}\text { three } \\
\text { terms } \\
0.2\end{array}$ & $\begin{array}{l}\text { three } \\
\text { terms } \\
0.27\end{array}$ \\
\hline 4 & $\begin{array}{c}0.5,0.8 \\
0.2 \text { and } 0.4\end{array}$ & 0.48 & $\begin{array}{c}\text { three } \\
\text { terms } \\
3.36\end{array}$ & $\begin{array}{l}\text { three } \\
\text { terms } \\
5.5\end{array}$ \\
\hline 5 & $\begin{array}{l}0.1,0.2, \\
0.2,0.3 \\
\text { and } 0.2\end{array}$ & 0.20 & $\begin{array}{c}\text { four } \\
\text { terms } \\
3.5 .10^{-4}\end{array}$ & $\begin{array}{c}\text { four } \\
\text { terms } \\
4.8 .10^{-4}\end{array}$ \\
\hline
\end{tabular}

Remarks:

(i) The errors of the approximated probabilities are very close to the exact ones, although always larger. This ensures that the actual error when connecting the actual operations will be less than the value obtained when calculating with the average probability because the operations obey the actual values (and not the mean values);

(ii) In general, the examples for the probability values 0.1 , 0.2 , etc., are already relatively large values for practical, real-world scenarios dealing with failures;

(iii) The larger the number of items (i.e. devices or terms in the approximation) the smaller the incurred error.

\section{1 - Incurred error as a function of the number of terms considered}

We analyze the evolution of the incurred errors, the difference between the exact values (i.e. the "correct value") in comparison to the approximate values. In any case, the approximate value is close to the real value but always worse than the former. Using the five examples from Table I, we show the evolution of the errors incurred term by term. For two components, Fig. 1 shows the estimated error as a function of the number of terms. Notice that the $x$ and $y$-axis have continuous values only for illustration purposes. However, these values are discrete and they correspond to the number of terms considered in the approximation. The Appendix A shows the Matlab code for calculating the approximate value (or the exact value if the items have the same probability of failure). The function ([error] = Prob_union_v2 (p, m, n]) has as input the values of $p, m$ (truncation) and $n$, and it returns the incurred error.

Figure 1- Estimated error for two devices

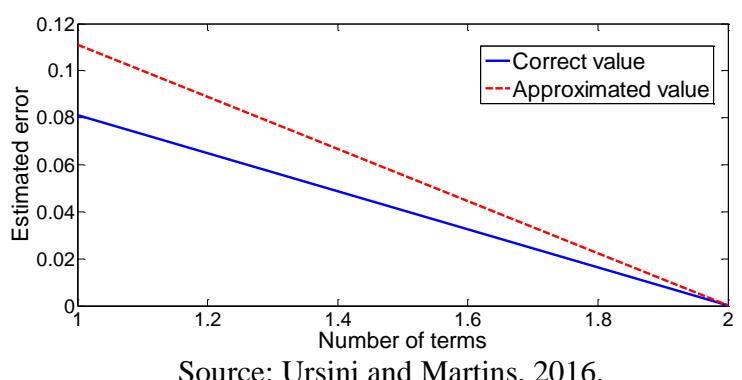

Consider an example for 3 devices with $p_{1}=0.1, p_{2}=$ 0.3 and $p_{3}=0.5$. Assuming that the devices have the same probability of failure, the mean value is $\bar{p}=\frac{p_{1}+p_{2}+p_{3}}{3}=0.3$. Fig. 2 shows that the correct error for a single term is $32 \%$ and the approximate error is $37 \%$. With two terms, the correct value is $2 \%$ and the approximate value is $4 \%$.

Figure 2 - Estimated error for three devices

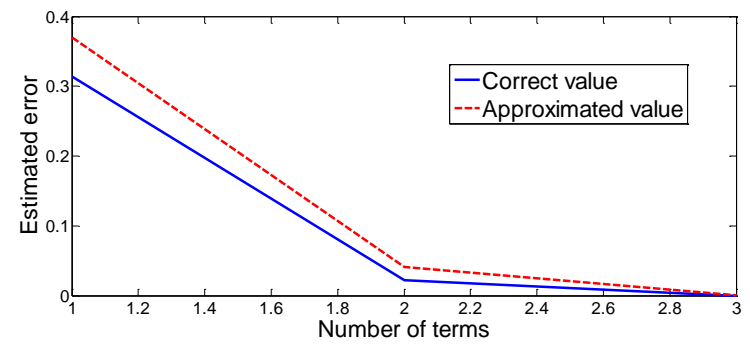

Source: Own Authorship, 2016.

The following example utilizes 4 devices and considers that $p_{1}=0.1, p_{2}=0.2, p_{3}=0.2$ and $p_{4}=0.3$ (fourth row in Tables I and II). Assuming devices with the same probability of failure, then $\bar{p}=\frac{p_{1}+p_{2}+p_{3}+p_{4}}{4}=0.2$.

Fig. 3 shows that for one term the correct error is $34 \%$ and the approximated error is $36 \%$. For two terms the correct error is $4.5 \%$ and the approximated value is $5 \%$.

Figure 3 - Estimation error for four devices

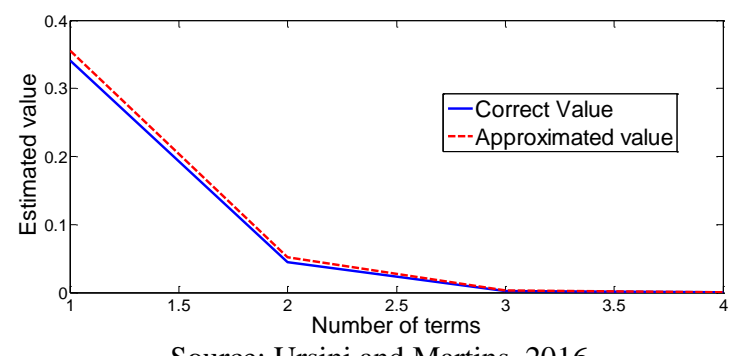

Source: Ursini and Martins, 2016.

In Tables I and II another example is included considering $p_{1}=0.5, p_{2}=0.8, p_{3}=0.2$ and $p_{4}=0.4$. This example was just to illustrate the fact that the error grows as we increase the difference between the probabilities. Nevertheless, these values are not common in component failure and their difference is not common either. 
The next example employs 5 devices considering $p_{1}=0.1$, $p_{2}=0.2, p_{3}=0.2, p_{4}=0.3$ and $p_{5}=0.2$. Assuming devices with the same probability of failure $p_{\mathrm{i}}$ we have $\bar{p}=\frac{p_{1}+p_{2}+p_{3}+p_{4}+p_{5}}{5}=0.2$. Fig. 4 shows that for just one term the correct error is $47 \%$ and the approximated one is $48 \%$. With only two terms the exact error is $10 \%$ and the approximate one is $11 \%$. For three terms both the exact and the approximate error values are only $1 \%$.

Figure 4 - Estimation error for five devices.

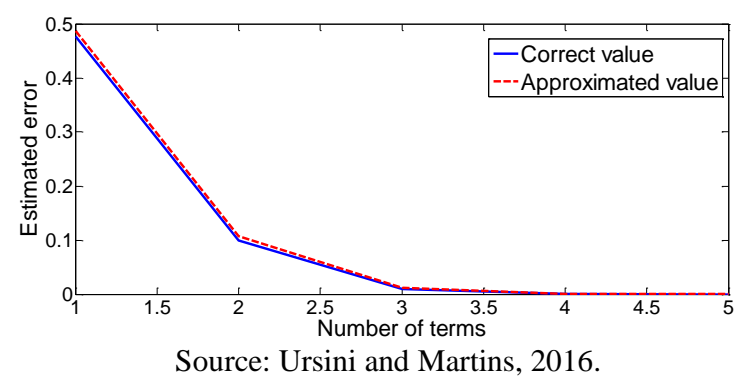

An important fact is that the approximate values are always "worse" than the real values (although close to). This ensures that the correct result will be better than (because the values, in fact, will be the real ones and not the average ones) stopping condition imposed on the algorithm that implements the proposed method (i.e. using the approximated calculus furnished by equations (4) and (6)). Table 3 illustrates an example using 100 items subject to failure for two different values of mean probability of failure $(0.1$ and 0.01$)$. The values of the maximum incurred error as a function of the number of terms in equation (4) may be evaluated.

\begin{tabular}{|c|c|c|}
\hline $\begin{array}{c}\bar{p} \\
\text { mean }\end{array}$ & \# of terms & $\begin{array}{l}\text { Maximum } \\
\text { Error (\%) }\end{array}$ \\
\hline 0.1 & 26 & 0.15 \\
\hline 0.1 & 27 & 0.04 \\
\hline 0.1 & 28 & 0.01 \\
\hline 0.1 & 29 & 0.002 \\
\hline 0.1 & 30 & 0.0005 \\
\hline 0.01 & 1 & 57.74 \\
\hline 0.01 & 2 & 20.34 \\
\hline 0.01 & 3 & 5.16 \\
\hline 0.01 & 4 & 1.02 \\
\hline 0.01 & 5 & 0.17 \\
\hline 0.01 & 6 & 0.023 \\
\hline
\end{tabular}

Source: Ursini and Martins, 2016.

An observation about the calculations is that the maximum value of the factorial in the processor in which they were made is $n !=170$. For values larger than 170 (for instance to calculate up to 300 devices), we may apply the Stirling's formula. However, in this case it is important that we perform a deeper analysis of the incurred error, which is deferred to a future work. When the probabilities involved are very large, using a few terms can lead to erroneous results, of the type with probability greater than one. In this case, it is important to use a program ([error, i] = Prob_union_rev2(p,n,re) in Appendix B) that calculates the number of terms (i) for the minimum required error (re). The Matlab algorithm which implements the method proposed in this work, with respect to the maximum permissible error, is found in the Appendix B.

\section{REMARKS AND CONCLUSIONS}

The estimation of the overall probability of union of events (such as in the reliability of telecommunication systems) relies on the calculus of the probability of the union of events - and it may require a high performance computational power. This work provided an alternative method that simplifies the calculation of the system probability of the union (of failure) concerning independent events, as it relies on a single value, i.e. the mean probability of failure for the devices, instead of the more traditional equations which often lead to a combinatorial explosion (and therefore high computational cost) particularly while estimating the probability of the union (failure) in large systems.

The approximate method allows that algorithms that correctly calculate the probability of $n$ independent events have a stop criterion that ensures a controlled error. In addition to the fact that the approximate calculus is much simpler to execute (equation (2) and mainly equation (4)), which is in itself a significant gain, it allows the calculation of probabilities of a large number of devices with a high precision. The approximate evaluation leads to probabilities that are larger than the values from the complete calculation, and this conservative behavior is appropriate in many areas such as safety, reliability and real-time systems. The actual values are smaller than these values from the approximation because the devices are those with real probabilities and not those with average probabilities. We must also consider that, if the probabilities of failure are too close (i.e. if devices have the same probability) the result is still better. However, it is always possible to use the terms of equation (4) instead of the ones from equation (5), i.e. to calculate the error using equation (4) knowing that the true error is smaller since it follows equation (5). The method may be used as a planning tool and to quickly (also with more simplicity) dimension the probability of failure.

The simplicity of the algorithm may be contemplated in the Appendix, where we present the Matlab code that implements the proposed calculus. Another fact worth pointing out is that the approximation is also strengthened by the fact that the calculus of the probability of system failure (or probability of the union of independent events) is intrinsically imprecise due to the estimation error of the individual (i.e. component) probabilities.

As future work, the approach could be extended to minimize operations in other types of configurations, e.g. parallel or serial-parallel devices, always aiming to use less computational resources such as processing time or memory allocation. As a last consideration, the approach could also be employed in the case where the probabilities of the involved components are nearly independent.

\section{REFERENCES}

Caen, D. de, A Lower Bound on the Probability of a Union, Discrete Mathematics 169, 217-220, Elsevier, 1997.

Gavin, Henri P., Summary of some Rules of Probability with Examples, CEE 201L., Uncertainty, Design, and 
Optimization Department of Civil and Environmental Engineering Duke University, pg. 5, Spring, 2016.

http://people.duke.edu/ hpgavin/cee201/ProbabilityRules.p df

Hollenback, Justin C., Moss, Robb E.S., Bounding the Probability of Failure for Levee Systems, Georisk 2011 Conference Proceedings: Atlanta, GA, June 26, 2011.

Kounias, S., Poisson Approximation and Bonferroni Bounds for the Probability of the Union of Events, Int. Journal of Mathematics and Statistics, Bol. 4, $\mathrm{N}^{\mathrm{o}}$ 1, june, 1995.

Kuai, H., Alajaji, F., Takahara, G., A lower bound on the probability of a finite union of events, Discrete Mathematics 215,147-158, Elsevier, 2000.

Legg, David E., Fidgen, Jeffrey G., Ryall, Krista L., Computing Union Probabilities of Many Independent Events: With a Case Study Example on Sampling of the Invasive Emerald Ash Borer, Agrilus planipennis, 2011, http://w3.uwyo.edu/ dlegg/union2.html

Miller, G. D., An algorithm for the probability of the Union of a Large Number of Events, Communications of the ACM, V. 11, N. 9, September/1968.

Prékopa, A., Gao, L., Bounding the probability of the union of events by Aggregation and Disaggregation in Linear Programs, Discrete Applied Mathematics 145, 444 - 454, Elsevier, 2005.

Veneziani, P., Upper bounds of degree 3 for the probability of the union of events via linear programming, Discrete Applied Mathematics 157, 858863, Elsevier, 2009.

Yang, J., Alajaji, F., Takahara, G., On Bounding the Union Probability Using Partial Weighted Information, arXiv: 1506.08331v3 [math.PR], 1 Feb, 2016.

Appendix:

A) Matlab algorithm depending on the number of terms

function [error] $=$ Prob_union_v2(p,m,n)

$\% \mathrm{~m}$ is the number of terms considered

$\% \mathrm{n}$ is the number of devices

$\%$ error is the numerical calculation mistake

$\mathrm{s}=0$;

for $\mathrm{i}=1: \mathrm{m}$,

$\mathrm{s}=\mathrm{s}+(-1)^{\wedge}(\mathrm{i}-1)^{*} \operatorname{prod}([1: \mathrm{n}]) /\left(\operatorname{prod}([1: \mathrm{i}])^{*} \operatorname{prod}([1: \mathrm{n}-\mathrm{i}])\right)^{*} \mathrm{p}^{\wedge} \mathrm{i} ; \%$

part of equation (4a)

end

prob_v $=1-(1-\mathrm{p})^{\wedge} \mathrm{n} ; \%$ equation $(2)$

error $=$ abs(s-prob_v)/prob_v; \% equation (6)

B) Matlab algorithm depending on required error

function $[$ error,i] $=$ Prob_union_rev2 $(\mathrm{p}, \mathrm{n}, \mathrm{re})$

$\% \mathrm{n}$ is the number of devices

$\% \mathrm{p}$ is the specified probability

$\%$ re is the specified error
$\%$ error is the returned error value

$\% \mathrm{i}$ is the number of terms considered

$\mathrm{s}=0 ;$ error $=1$;

$\mathrm{i}=1$;

while error $>$ re;

$\mathrm{s}=\mathrm{s}+(-1)^{\wedge}(\mathrm{i}-1) * \operatorname{prod}([1: \mathrm{n}]) /(\operatorname{prod}([1: \mathrm{i}]) * \operatorname{prod}([1: \mathrm{n}-\mathrm{i}])) * \mathrm{p}^{\wedge} \mathrm{i} ; \%$ part of equation (4a)

prob_v $=1-(1-\mathrm{p})^{\wedge} \mathrm{n} ; \%$ equation $(2)$

error=abs(s-prob_v)/prob_v;\% equation (6)

$\mathrm{i}=\mathrm{i}+1$;

end

$\mathrm{i}=\mathrm{i}-1$

\section{COPYRIGHT}

The authors are the sole subjects responsible by the contents in this paper. 


\title{
Revista SODEBRAS - Volume 12 \\ $\mathrm{N}^{\circ} 134$ - FEVEREIRO/ 2017
}

\section{FORMAÇÃO DO ALN POR ASSOCIAÇÃO RADIATIVA}

\author{
FORMATION OF ALN BY RADIATIVE ASSOCIATION
}

\author{
CARMEN M. ANDREAZZA ${ }^{1}$; AMAURY A. DE ALMEIDA ${ }^{2}$; DEMÉTRIO T. CECCATTO ${ }^{3}$ \\ 1 - UNESP/RIO CLARO-SP; 2 - IAG/USP/SÃO PAULO - SP; 3 - FACULDADES CLARETIANAS/ \\ RIO CLARO-SP. \\ carmenma@rc.unesp.br
}

\begin{abstract}
Resumo - Foram estimadas as constantes de taxa da reação de formação do nitreto de alumínio, AlN, através do processo de associação radiativa dos átomos Al e $\mathrm{N}$, utilizando-se um método semiclássico. Dentre as transições eletrônicas analisadas, a transição que envolve a aproximação dos átomos de alumínio e de nitrogênio ao longo do estado $A^{3} \Sigma$, o qual decai radiativamente para $o$ estado fundamental $X^{3} \Pi$, é a mais importante na formação do AlN. Os valores das constantes de taxa calculados variam de 3,46 x $10^{-19}$ a 4,16 $\times 10^{-19} \mathrm{~cm}^{3} \mathrm{~s}^{-1}$, para temperaturas entre 300 e $14.000 \mathrm{~K}$, respectivamente.
\end{abstract}

Palavras-chave: Astroquímica. Processos Atômicos e Moleculares. Estrelas.

Abstract: The rate coefficients for formation of aluminium nitride, AlN, through radiative association of $\mathrm{Al}$ and $\mathrm{N}$ atoms have been estimated by a semiclassical method. Among the analyzed electronic transitions, the approach of the aluminum and nitrogen atoms in the $A^{3} \Sigma$ state, which decays to the ground $X^{3} I$ state, is the most important transition in the formation of AlN. For temperatures ranging between 300 and $14,000 \mathrm{~K}$, the radiative association rate coefficients are found to vary from $3.46 x$ $10^{-19}$ to $4.16 \times 10^{-19} \mathrm{~cm}^{3} \mathrm{~s}^{-1}$, respectively.

Keywords: Atomic Data. Atomic Process. Circumstellar Matter. Astrochemistry.

\section{INTRODUÇÃO}

Até o momento, seis compostos contendo alumínio, $\mathrm{AlH}, \mathrm{AlF}, \mathrm{AlCl}, \mathrm{AlO}, \mathrm{AlNC}$ e $\mathrm{AlOH}$, bem como átomos neutros de alumínio foram detectados em estrelas gigantes e supergigantes (CERNICHARO, GUÉLIN, 1987; TENENBAUM, ZIURYS, 2009; ZIURYS et al. 2002; TENENBAUM, ZIURYS, 2010).

Linhas de emissão de $\mathrm{AlCl}, \mathrm{AlO}$ e $\mathrm{AlOH}$ foram observadas na parte interna do envoltório da estrela supergigante vermelha VY CMa (KAMIŃSKI et al., 2013). VY CMa é uma estrela oxigenada $(\mathrm{C} / \mathrm{O}<1)$ com temperatura efetiva em torno de 3.200-3.650 K (MASSEY, LEVESQUE, PLEZ, 2006; WITTKOWSKI et al. 2012). É observada uma grande e variável perda de massa da ordem de $0,5 \times 10^{-4}$ a $3,0 \times 10^{-3} \mathrm{M}_{\odot}$ ano ${ }^{-1}$, cujos mecanismos que resultam na grande quantidade de matéria ejetada não são ainda bem estabelecidos na literatura (MASSEY,
LEVESQUE, PLEZ, 2006; WITTKOWSKI et al. 2012). Essa perda de massa forma um extenso envoltório alcançando 1.500 a $3.000 \mathrm{R}_{\odot}$ (e. g. TENENBAUM, ZIURYS, 2009). Devido ao seu atual estágio de evolução, essa estrela pode se tornar uma supernova a qualquer momento (ROYER et al. 2010).

Os compostos AlF, AlCl e AlNC foram observados no envoltório da estrela gigante vermelha IRC+10216 (CW Leo). O AlF e o $\mathrm{AlCl}$ encontram-se confinados na parte interna do envelope e o AlNC foi observado na parte externa (TENENBAUM, ZIURYS, 2009; ZIURYS ET AL. 2002; TENENBAUM, ZIURYS, 2010).

A estrela CW Leo atingiu o ramo assintótico das gigantes, conhecido como AGB (Assimptotic Giant Branch). Trata-se de uma estrela carbonada $(\mathrm{C} / \mathrm{O}>1)$ com temperatura efetiva em torno de $2.500 \mathrm{~K}$ e perda de massa da ordem de 2,0-4,0 $x \quad 10^{-5} \mathrm{M}_{\odot}$ ano $^{-1}$ (e.g. AGÚNDEZ, CHERNICHARO, 2006; CHERCHNEFF, 2012).

Os compostos $\mathrm{AlH}, \mathrm{AlO}, \mathrm{AlOH}$ e átomos neutros de alumínio foram identificados próximo à fotosfera da AGB $o$ Ceti (KAMIŃSKI et al. 2016). Essa estrela possui uma temperatura efetiva em torno de $3.000 \mathrm{~K}$ e perda de massa da ordem de $3,0 \times 10^{-5} \mathrm{M}_{\odot}$ ano $^{-1}$ (JUSTTANONT et al. 2012).

AGBs são estrelas que estão nos estágios finais da sua evolução. Possuem massa inicial compreendida entre 1,0$8,0 \mathrm{M}_{\odot}$ e são caracterizadas por uma temperatura efetiva em torno de 2.000 a $3.500 \mathrm{~K}$ (IBEN, RENZINI, 1983; HERWIG 2005). Devido às instabilidades em seu interior, as estrelas AGBs pulsam e podem elevar o material acima da atmosfera estelar, provocando uma grande perda de massa (VASSILIADIS, WOOD, 1993), cujos mecanismos não são ainda bem estabelecidos na literatura. $\mathrm{O}$ aumento da taxa de perda de massa tem como principal consequência a formação de um extenso envoltório circunstelar, o qual pode alcançar várias unidades astronômicas (KWOK, 2000).

$\mathrm{Na}$ nossa galáxia as estrelas são ricas em oxigênio $(\mathrm{C} / \mathrm{O}<1)$. No entanto, a dragagem de carbono, sintetizado no interior da estrela, pode alterar a abundância superficial desse elemento, tornando as estrelas com massas iniciais entre 1,0 e 4,0 $\mathrm{M}_{\odot}$ em estrelas ricas em carbono (HERWIG 2005). Em estrelas com massas iniciais entre 4,0 e 8,0 $\mathrm{M}_{\odot}$, o carbono é convertido em nitrogênio via ciclo $\mathrm{CN}$, resultando em uma atmosfera mais rica em oxigênio que carbono (VASSILIADIS, WOOD, 1993; HERWIG 2005).

Linhas em emissão de AlF também foram detectadas nas atmosferas das estrelas carbonadas CRL 618, proto- 
planetária muito jovem, e proto-planetária CRL 2688 (HIGHBERGER, ZIURYS, 2003; HIGHBERGER et al. 2001).

Por fim, três compostos contendo alumínio, $\mathrm{Al}_{2} \mathrm{O}$, $\mathrm{MgAl}_{2} \mathrm{O}_{4}$ e $\mathrm{CaAl}_{12} \mathrm{O}_{19}$, foram encontrados em grãos présolares extraídos de meteoritos. Devido às abundâncias isotópicas encontradas nesses grãos, acredita-se que tenham sido formados em envoltórios de AGBs (e.g. NITTLER et. al., 2008)

Informações sobre a abundância de compostos que contêm metais são muito úteis para compreender os processos físico-químicos que ocorrem nesses ambientes, bem como a nucleossíntese dos elementos

Cálculos em equilíbrio químico mostram que o AlN é o primeiro composto que se condensa nos envoltórios das estrelas carbonadas (LODDERS, FEGLEY, 1999). No entanto, relativamente pouco é conhecido sobre seus mecanismos de formação em fontes astronômicas e dentre eles, a associação radiativa deve ser considerada. Nesse sentido, foram estimadas as constantes de taxa de formação do AlN por associação radiativa, em função da temperatura.

\section{METODOLOGIA}

A associação radiativa,

$$
A+B \rightarrow A B^{*} \rightarrow A B+h v,
$$

é o processo no qual duas espécies A e B se aproximam ao longo de uma curva de energia potencial de um estado molecular excitado, $\mathrm{AB}^{*}$, o qual pode emitir um fóton, formando a molécula AB (HERBST, BATES, 1988).

A taxa de ocorrência de tal processo pode ser expressa em termos da constante de taxa, $\alpha$, definida por

$$
\frac{d n(A B)}{d t}=\operatorname{an}(A) n(B),
$$

onde, $n$ é a concentração das espécies AB, A e B (BATES, 1951).

Um método semiclássico para o cálculo das constantes de taxa do processo em questão foi apresentado por Bates (1951). Essa aproximação pode ser aplicada às colisões entre reagentes pesados, onde os efeitos quânticos não são relevantes (ZYGELMAN, DALGARNO, 1988). Nesse caso, as espécies $A$ e $B$ encontram-se no contínuo de um estado molecular excitado $A B^{*}$ que, a qualquer momento, pode relaxar para um estado de menor energia, emitindo um fóton. Há, no entanto, uma probabilidade finita, $A(r)$, de que ocorra a emissão espontânea do fóton, dada por

$$
A(r)=2.03 \times 10^{-6} g|v(r)|^{2}\left|R_{e}(r)\right|^{2} \quad s^{-1}
$$

onde, $g=\left(2-\delta_{0, A^{x}+\Lambda^{i}}\right) /\left(2-\delta_{0, \Lambda} x\right)$ é o peso estatístico, $R_{e}(r)$ é o momento de transição eletrônica em unidades atômicas, $r$ é a distância internuclear e $v$ é a frequência (em $\mathrm{cm}^{-1}$ ).

A seção de choque em função de $E$, em unidade de área, que mede a probabilidade de que a colisão entre as espécies atômicas ou moleculares ocorra, é dada por

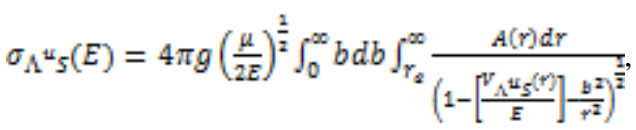

sendo, $E$ a energia do movimento relativo das duas partículas, $\mu$ a massa reduzida (em unidades de massa atômica), $V_{A}^{u}{ }_{S}$ é a curva de energia potencial do estado excitado de maior energia, $g$ é a probabilidade de aproximação das partículas ao longo da curva de energia potencial $V_{A}^{u} s, r_{e}$ é a menor distância de aproximação das duas partículas e $A(r)$ é a probabilidade de transição.

Supondo que os átomos tenham uma distribuição de velocidade Maxwelliana, a constante de taxa para a associação radiativa (em unidades de $\mathrm{cm}^{3} \mathrm{~s}^{-1}$ ), em função da temperatura $T$ (em K) (ZYGELMAN, DALGARNO, 1988), é dada por

$$
\alpha(T)=\left(\frac{1}{Q \mu \pi}\right)^{\frac{2}{2}}\left(\frac{1}{k_{E} T}\right)^{\frac{\pi}{2}} \int_{0}^{m e} E \sigma(E) \exp \left(-\frac{E}{k T}\right) d E,
$$

onde, $k_{B}$ é a constante de Boltzmann.

\section{RESULTADOS}

Nas partes internas dos envelopes das estrelas evoluídas a temperatura é da ordem de 2.000-3.700K. Assim sendo, para os cálculos dos valores das constantes de taxa de formação do AlN são importantes apenas os estados eletrônicos moleculares que se correlacionam com os estados fundamentais dos átomos de alumínio e nitrogênio.

$\mathrm{O}$ acoplamento dos átomos $\mathrm{Al}\left({ }^{2} \mathrm{P}\right)$ e $\mathrm{N}\left({ }^{4} \mathrm{~S}\right)$, ambos em seus estados fundamentais, pode ocorrer através dos estados eletrônicos moleculares $\Pi$ e $\Sigma$, com multiplicidades tripleto e quinteto. $\mathrm{O}$ estado $\mathrm{X}^{3} \Pi$ foi observado em laboratório (e.g. EBBEN, ter MUELEN, 1991) e os estados $A^{3} \Sigma^{-}, 1^{5} \Pi$ e $1^{5} \Sigma$ foram caracterizados teoricamente (e.g. LANGHOFF, BAUSCHLICHER, PETTERSSON, 1988; CLOUTHIER, GREIN, BRUNA, 2003)

$\mathrm{A}$ associação radiativa dos átomos $\mathrm{Al}\left({ }^{2} \mathrm{P}\right)$ e $\mathrm{N}\left({ }^{4} \mathrm{~S}\right)$ ambos em seus estados fundamentais, pode ocorrer através da aproximação dos dois átomos ao longo do estado excitado $\mathrm{A}^{3} \Sigma$, o qual pode decair radiativamente para $\mathrm{o}$ estado fundamental $\mathrm{X}^{3} \Pi$. A probabilidade de aproximação ao longo do estado $\mathrm{A}^{3} \Sigma^{-}$é $3 / 24$.

Os estados $1^{5} \Pi$ e $1^{5} \Sigma^{-}$são repulsivos (LANGHOFF, BAUSCHLICHER, PETTERSSON, 1988) e, portanto, sua contribuição na formação do AlN, através do processo de associação radiativa dos átomos $\mathrm{Al}$ e $\mathrm{N}$, é desprezível.

As curvas de energia potencial dos estados eletrônicos moleculares $\mathrm{A}^{3} \Sigma^{-}$e $\mathrm{X}^{3} \Pi$ do $\mathrm{AlN}$, necessárias para o cálculo das constantes de taxa da reação de formação do composto AlN, através do processo de associação radiativa dos átomos Al e N, foram modeladas usando-se a função de HulbertHirschfelder (1941) (Apêndice A) e mostradas na Figura 1. Essa função também foi utilizada em outros estudos similares para modelar as curvas de energia potencial (e.g. ANDREAZZA et al. 2012).

As constantes espectroscópicas utilizadas no cálculo da função Hulbert-Hirschfelder foram extraídas de Ebben e ter Muelen (1991) e Clouthier, Grein e Bruna (2003). Os valores dos momentos de transição eletrônica, utilizados no cálculo dos coeficientes de Einstein, foram extraídos de Langhoff, Bauschlicher e Pettersson (1988). 
Os valores das constantes de taxa de formação do AlN através do processo de associação radiativa estão ilustrados na Figura 2, os quais variam de $3,46 \times 10^{-19}$ a 4,16 $\times 10^{-19}$ $\mathrm{cm}^{3} \mathrm{~s}^{-1}$, para temperaturas entre 300 e $14.000 \mathrm{~K}$, respectivamente, e podem ser aproximados pelas equações (dentro de 5\%)

$$
\alpha(T)=3,768 \times 10^{-19}\left(\frac{T}{300}\right)^{0,099} e^{\left(\frac{20,07}{T}\right)} \mathrm{cm}^{3} \mathrm{~s}^{-1}
$$

para temperatura entre 300 e $1.000 \mathrm{~K} \mathrm{e}$

$$
\alpha(T)=2,233 \times 10^{-19}\left(\frac{T}{300}\right)^{0,1415} e^{\left(\frac{512, a \mathrm{~g}}{T}\right)} \mathrm{cm}^{\mathrm{a}} \mathrm{s}^{-1}
$$

para temperaturas maiores que $1.000 \mathrm{~K}$

Figura 1 - Curvas de energia potencial do estado excitado, $\mathrm{A}^{3} \Sigma^{-}$, e fundamental $\left(\mathrm{X}^{3} \Pi\right)$ do AlN.

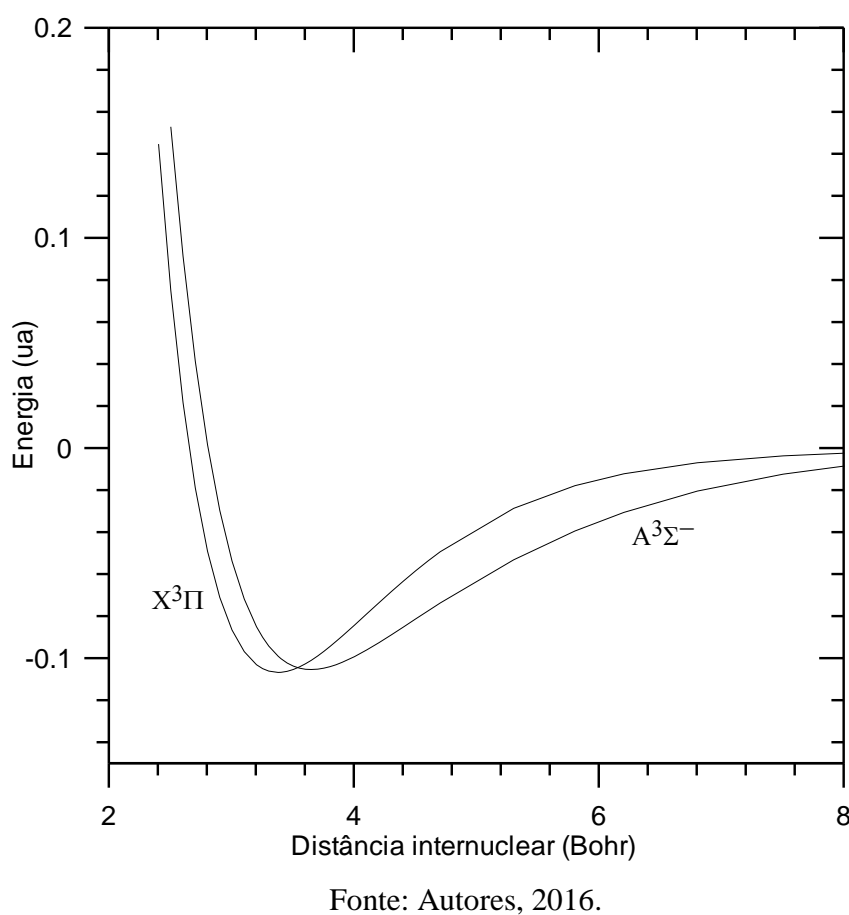

Figura 2 - Constantes de reação, em função da temperatura, para a formação do AlN através do acoplamento dos átomos $\mathrm{Al}$ e N.

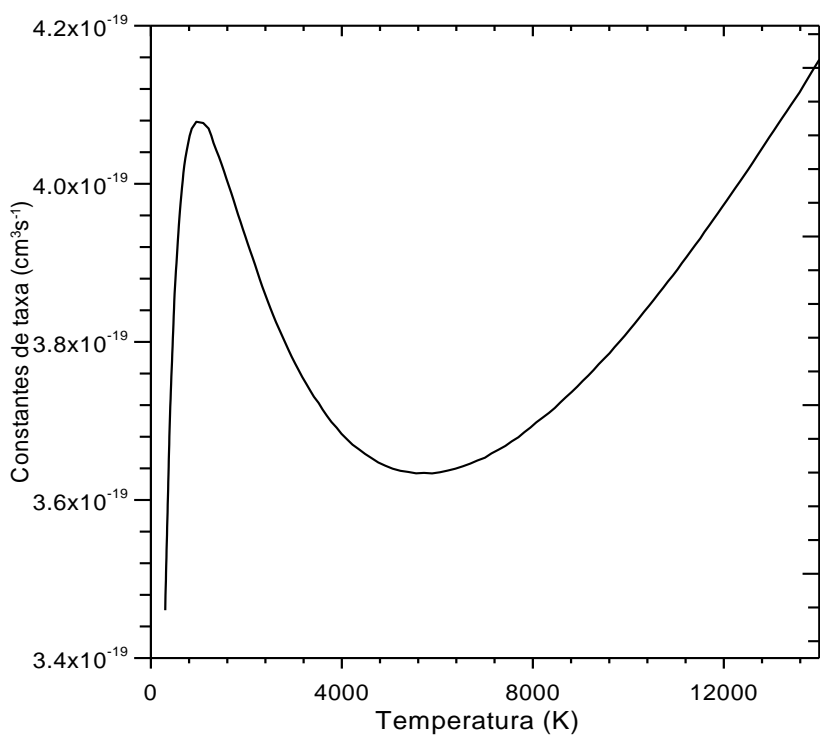

\section{CONCLUSÃO}

Dentre as transições eletrônicas analisadas o sistema $\mathrm{A}^{3} \Sigma^{-}-\mathrm{X}^{3} \Pi$ é o mais importante na formação do AlN através do acoplamento dos átomos de alumínio e nitrogênio. Os valores das constantes de taxa variam de $3,46 \times 10^{-19}$ a 4,17 $x 10^{-19} \mathrm{~cm}^{3} \mathrm{~s}^{1}$, para temperaturas entre 300 e $14.000 \mathrm{~K}$, respectivamente.

Para temperaturas encontradas na parte interna dos envelopes de estrelas evoluídas, ou seja, de 2.000 a $3.700 \mathrm{~K}$, os valores das constantes de taxa, para a formação do AlN, variam de $3,93 \times 10^{-19}$ a $3,71 \times 10^{-19} \mathrm{~cm}^{3} \mathrm{~s}^{1}$, respectivamente. Esses valores são muito pequenos para formar uma quantidade apreciável de nitreto de alumínio nesses ambientes astrofísicos. Portanto, outras reações químicas devem ser consideradas nos modelos de síntese do AlN em envelopes de estrelas evoluídas.

\section{REFERÊNCIAS BIBLIOGRÁFICAS}

AGÚNDEZ, M., CERNICHARO, J., Oxygen Chemistry in the Circumstellar Envelope of the Carbon-Rich Star IRC +10216. The Astrophysical Journal, 650, 374 - 393, 2006.

ANDREAZZA, C. M., de ALMEIDA, A. A., VICHIETTI, R. M., CECCATTO, D. T., Radiative association of Ti and O atoms, Monthly Notices of the Royal Astronomical Society, 427, 833-838, 2012.

BATES, D. R., Rate of formation of molecules by radiative association, Monthly Notices of the Royal Astronomical Society, 111, 303-314, 1951.

CERNICHARO, J., GUÉLIN, M., Metals in IRC+10216 Detection of $\mathrm{NaCl}, \mathrm{AlCl}$, and $\mathrm{KCl}$ and tentative detection of AlF, Astronomy \& Astrophysics, 183, L10-L12, 1987.

CHERCHNEFF, I., The inner of IRC+10216 revisited: New exotic chemistry and diagnostic for dust condensation in carbon stars, Astronomy \& Astrophysics, 545, 12-26, 2012

ClOUTHIER, C. M., GREIN, F., BRUNA, P. J., MRCI studies on the electronic structure of $\mathrm{AlN}$ and $\mathrm{AlN}^{-}$, and the electron affinity of AlN, Journal of Molecular Spectroscopy, 219, 58-64, 2003

EBBEN, M., ter MEULEN, J. J., Perturbations in the $C^{3} \Pi$ $\left(v^{\prime}=1\right)$ state of AlN studied by laser spectroscopy, Chemical Physics Letters, 177, 229-234, 1991

JUSTTANONT, K., KHOURI, T., MAERCHER M., et. al., Herschel/HIFI observations of O-rich AGB stars: molecular inventory, Astronomy \& Astrophysics, 537, A144, 2012

HERBST, E., BATES, D. R., Radiative association via excited electronic states: model calculations. The Astrophysical Journal, 329, 410-417, 1988.

HERWIG, F., Evolution of asymptotic giant branch stars, Annual Review of Astronomy and Astrophysics, 43, 435479, 2005.

HIGHBERGER, J. L., SAVAGE, C., BIEGING, J. H., ZIURYS, L. M., Heavy-metal chemistry in proto-planetary nebulae: detection of $\mathrm{MgNC}, \mathrm{NaCN}$ and $\mathrm{AlF}$ toward CRL 2688, The Astrophysical Journal, 562, 790-798, 2001.

HIGHBERGER, J. L., ZIURYS, L. M. Detection of MgNC in CRL 618: tracing metal chemistry with asymptotic giant

Fonte: Autores, 2016 
branch evolution, The Astrophysical Journal, 597, 10651069, 2003.

HULBERT, H. M., HIRSCHFELDER, J. O., Potential energy functions for diatomic molecules, Journal of Chemical Physics, 9, 61-69, 1941.

IBEN, I. Jr., RENZINI, A., Asymptotic giant branch evolution and beyond, Annual Review of Astronomy and Astrophysics, 21, 271-342, 1983.

KAMINSKI, T., GOTTLIEB, C. A., YOUNG K. H., MENTEN, K. M., PATEL, N., A., An Interferometric Spectral Line and Imaging Survey of VY Canis Majoris in the $345 \mathrm{GHz}$ Band, The Astrophysical Journal Supplement Series, 209, 38-85, 2013.

KAMISŃKI, K. T., WONG, K. T., SCHMIDT, M. R., MULLER, H. S. P., GOTTLIEB, C. A., CHERCHNEFF, I., MENTEN K. M., KELLER, D., BRUNKEN, S., WINTERS, J. M., PATEL N. A., An observational study of dust nucleation in Mira ( $o$ Ceti), Astronomy \& Astrophysics, 592, 42K, 2016.

KWOK, S., The Origin and Evolution of Planetary Nebulae. Cambridge University Press, Cambridge, 2000.

LANGHOFF, S. R., BAUSCHLICHER, C. W., PETTERSSON, L. G. M., Theoretical Spectrum of AIN, The Journal of Chemical Physics, 89, 7534-7362, 1988.

LODDERS, K., FEGLEY, B. Jr., Asymptotic Giant Branch Stars, IAU Symposium 191, Eds. T. Le Bertre, A. Lebre, C. Waelkens, Astron, Soc. Pac., San Francisco, p. 279, 1999

MASSEY, P., LAVESQUE, E., PLEZ, B., Bringing VY Canis Majoris down to size: an improved determination of its effective temperature, The Astrophysical Journal, 646, 1203-1208, 2006.

NITTLER, L. R., ALEXANDER, C. M. O’D., GALLINO, R., HOPPE, P., NGUYEN, A. N., STADERMANN, F. J., ZINNER, E. K., Aluminum-, calcium- and titanium-rich oxide stardust in ordinary chondrite meteorites, The Astrophysical Journal, 682, 1450-1478, 2008

ROYER, P., DECIN, L., WESSON, R., et al., PACS and SPIRE spectroscopy of the red supergiant VY CMa, Astronomy \& Astrophysics, 518, L145-L149, 2010.

TENENBAUM, E. D., ZIURYS, L. M., Millimeter detection of $\mathrm{AlO}\left(\mathrm{X}^{2} \Sigma^{+}\right)$: metal oxide chemistry in the envelope of VY Canis Majoris, The Astrophysical Journal Letters, 694, L59-L63, 2009.

TENENBAUM, E. D., ZIURYS, L. M., Exotic metal molecule in oxygen-rich envelopes: detection of $\mathrm{AlOH}$ $\left(\mathrm{X}^{1} \Sigma^{+}\right)$in VY Canis Majoris, The Astrophysical Journal Letters, 712, L93-L97, 2010.

VASSILIADIS, E., WOOD, P. R., Evolution of low- and intermediate-mass stars to the end of the asymptotic giant branch with mass loss, The Astrophysical Journal, 413, 641-657, 1993.

ZIURYS, 1. M., SAVAGE, J. L., HIGHBERGER, J. L., APPONI, A. J., GUÉLIN, M., CERNICHARO, J., More metal cyanide species detection of ALNC toward IRC +10216, The Astrophysical journal, 564, L45, 2002
ZYGELMAN, B., DALGARNO, A., Radiative quenching of He $\left(2{ }^{1} \mathrm{~S}\right)$ induced by collisions with ground-state helium atoms. Physical Review A, 38, 1877-1884, 1988.

WITTKOWSKI, M., HAUSCHILDT, P. H., ARROYOTORRES, B., MARCAIDE, J. M., Fundamental properties and atmospheric structure of the red supergiant VY Canis Majoris based on VLTI/AMBER spectro-interferometry, Astronomy \& Astrophysics, 540, L12-L17, 2012.

\section{Apêndice A}

Hulbert e Hirschfelder (1941) propuseram a seguinte função para modelar as curvas de energia potencial de moléculas ou radicais diatômicos

$$
V(x)=D_{e}\left[\left(1-e^{-x}\right)^{2}+c x^{3} e^{-2 x}(1+b x)\right]
$$

onde, $x$ é definido como

$$
x=\left(\frac{\omega_{e}}{2\left(B_{e} D_{e}\right)^{\frac{1}{2}}}\right)\left(\frac{r-r_{e}}{r_{e}}\right)
$$

e as constantes $b$ e $c$ são determinadas pelas seguintes relações,

$$
c=1+\left(-1-\frac{a_{2} \omega_{2}}{6 B_{s}^{2}}\right)\left(\frac{4 B_{s} D_{s}}{\omega_{2}^{2}}\right)
$$

e

$$
b=2-\left(\frac{7}{12}-\frac{2 D\left(B_{\alpha} D\right) \frac{1}{2}}{\omega_{\alpha}}\left[\frac{5}{4}\left(-1-\frac{Q_{\alpha} \omega_{\alpha}}{6 B_{2}^{2}}\right)^{2}-\frac{2 X_{\alpha} \omega_{\alpha}}{B_{\alpha}}\right]\right)
$$

sendo, $B_{e}, \omega_{e}, \alpha_{e}, r_{e}$ e $x_{e} \omega_{e}$ constantes moleculares.

\section{COPYRIGHT}

Direitos autorais: Os autores são os únicos responsáveis pelo material incluído no artigo. 


\title{
ESTUDO DA ESTABILIDADE DO ARCO ELÉTRICO GERADO PELA SOLDAGEM DE REVESTIMENTO (FCAW) DEVIDO À VARIAÇÃO DA TENSÃO/CORRENTE E VELOCIDADE DE SOLDAGEM
}

\author{
STUDY OF ARC STABILITY IN AN FCAW CLADDING WELDING PROCESS \\ THROUGH THE VARIATION OF CURRENT, CONTACT TIP-WORK PIECE \\ DISTANCE AND WELDING VELOCITY
}

\author{
CELSO ALVES CORREA ${ }^{l}$, JOÃO ROBERTO SARTORI MORENO ${ }^{l}$, LUIZ GUILHERME MARIN ${ }^{l}$ \\ 1 - UNIVERSIDADE TECNOLÓGICA FEDERAL DO PARANÁ - CAMPUS CORNÉLIO PROCÓPIO, \\ DEPARTAMENTO DE ENGENHARIA MECÂNICA, CORNÉLIO PROCÓPIO, PARANÁ, BRASIL. \\ cacorrea@utfpr.edu.br, joaosartori@utfpr.edu.br,luizmarin@alunos.utfpr.edu.br
}

\begin{abstract}
Resumo - Este trabalho tem por objetivo analisar a estabilidade do arco elétrico durante a soldagem de revestimento de aço inoxidável martensítico sobre uma base de aço baixo carbono AISI 1020 através do processo de soldagem a arco elétrico com arames tubulares (FCAW). Assim, através da variação da corrente de soldagem, velocidade de deslocamento da tocha e da distância bico de contato peça, foi verificado quais condições levaram a uma melhor estabilidade, tendo como base os dados gerados por ciclogramas de tensão/amperagem e oscilogramas dos sinais obtidos por um acelerômetro instalado na parte inferior da bancada de soldagem. Foi executada ainda, o tratamento dos sinais vibratórios através de uma Transformada Rápida de Fourier (FTR), produzindo então gráficos de aceleração que permitiram verificar de maneira mais precisa as condições de maior e menor estabilidade. Através da análise destes sinais, foi possível constatar uma melhor condição de estabilidade para uma corrente convencional igual a $230 \mathrm{~A}$.
\end{abstract}

Palavras-chave: FCAW. Revestimento Aço Inoxidável. Estabilidade do Arco. Transformada Rápida de Fourier.

\begin{abstract}
This work has as its main objective the analysis of the electric arc stability during a cladding welding of martensitic stainless steel over a low carbon (AISI 1020) surface through the flux cored welding process (FCAW). Through the variation of the welding current, torch displacement velocity and the contact tip-workpiece distance, it was possible to verify which conditions carried to a better stability by the analysis of the generated graphics of voltage/current oscillograms and the vibration oscillograms obtained by an accelerometer installed on the bottom of the welding bench. In addition, was conducted the treatment of the vibration signals through a Fast Fourier Transform (FFT), which generated acceleration graphics that assured the verification in a more precise way the stability conditions during the welding process. By the analysis of those signals, it was possible to verify a better stability condition for a conventional current of $230 \mathrm{~A}$.
\end{abstract}

Keywords: FCAW. Stainless Steel Cladding. Arc Stability. Fast Fourier Transform.

\section{INTRODUÇÃO}

A soldagem de revestimento é um processo que consiste na deposição de uma camada de um metal de maior qualidade, neste caso aço inoxidável, sobre um metal de base de aço com baixo teor de carbono (PALANI et al. 2007). Esse processo tem como principal vantagem, a obtenção de boas propriedades mecânicas oriundas do aço inoxidável com um custo muito menor. Para este trabalho, foi utilizado o processo de soldagem FCAW (Flux Cored Arc Welding) que consiste na utilização de um arame consumível contínuo em formato tubular conforme (MARQUES et al. 2005).

A proteção da poça de fusão é realizada através de um fluxo contínuo de gás de proteção, sendo que para a soldagem de aço inoxidável, é recomendada a utilização de um gás constituído de argônio com uma mistura de $2 \%$ de oxigênio (RODRIGUES, et al. 2008).

De forma que seja possível realizar o monitoramento da estabilidade do arco (KUMAR, 2014), foram utilizados sensores que permitiram a aquisição simultânea dos sinais referentes a corrente, voltagem e aceleração. Sendo esta adquirida através de um acelerômetro instalado diretamente no metal de base, possibilitando a aquisição de dados referentes a oscilação produzida pelo arco elétrico.

Através da variação dos dados de entrada, sendo eles a corrente, velocidade de soldagem e distância bico de contato peça, foi possível observar através dos sinais citados anteriormente, o comportamento do arco elétrico durante todo o processo de soldagem.

No que diz respeito ao método de análise de sinais vibratórios, estas são subdividas em técnicas baseadas em medidas no domínio do tempo e no domínio da frequência.

Assim, através da aplicação da Transformada Rápida de Fourier (FFT), é possível transportar esse sinal para o domínio da frequência, tornando a leitura dos resultados muito mais eficiente o que leva a uma melhor observância de comportamentos indesejáveis no processo em estudo (CAYO, 2008 e JEFF, et al. 2013).

Diversos trabalhos foram conduzidos tendo como interesse a análise da estabilidade do arco e consequente qualidade do cordão de solda através da análise de sinais de vibração (GRAD, et al. 2004). Os resultados se mostram muito mais satisfatório quando é feita a aquisição e análise simultânea da vibração e tensão (JOHNSON, 1991). Através destas informações, é 
possível inclusive determinar o modo de transferência metálica, informação esta que é imprescindível para a garantia de um revestimento de boa qualidade (WANG, et.al. 1995 e LIMA, et al. 2006).

\section{MATERIAIS E MÉTODOS}

Como metal de base, foi utilizado para este trabalho o aço SAE 1020 de dimensão (12,70 x 63,50 x 185,00 mm) e para o metal de adição foi utilizado um arame tubular inoxidável martensítico (EC410NiMo), classificado de acordo com a norma ASME 2007, seção II, parte C (AWS SFA 5-22), com diâmetro de 1,20 mm. A pesquisa será restrita ao processo de soldagem com arame tubular (FCAW) com corrente convencional na soldagem de revestimento. A Tabela 1 mostra a composição química de ambos os metais.

Tabela 1- Composição química dos metais de base e de adição.

\begin{tabular}{ccccccccc}
\hline Material & $\mathbf{C}$ & $\mathbf{M n}$ & $\mathbf{P}$ & $\mathbf{S}$ & $\mathbf{S i}$ & $\mathbf{N i}$ & $\mathbf{C r}$ & $\mathbf{M O}$ \\
\hline AISI 1020 & $0.18 / 0.23$ & $0.30 / 0.60$ & 0.03 & 0.035 & $0.10 / 0.30$ & 0.15 & 0.15 & $\ldots$ \\
EC410NiMo & 0.027 & 0.590 & 0.024 & 0.006 & 0.44 & 4.86 & 12.50 & 0.43 \\
\hline
\end{tabular}

Fonte: Catalogo da Eutectic Castolin.

A bancada de soldagem utilizada neste trabalho, consiste de um dispositivo de deslocamento linear onde é acoplada a tocha de soldagem, o que possibilita um controle da velocidade de soldagem e garante um cordão de melhor qualidade.

Um sistema modular de aquisição de dados também está presente, sendo constituído de um acelerômetro, um amperímetro e um voltímetro. Foi utilizado um acelerômetro piezoelétrico modelo KSD-80D, com sensibilidade de $100 \mathrm{mV} / \mathrm{g}$ e frequência de resposta na faixa de $0,13 \sim 22000 \mathrm{~Hz}$, montado na parte central do metal de base, embaixo da mesa de soldagem, de forma a proteger o sensor das altas temperaturas desenvolvidas durante o processo de soldagem.

O diagrama apresentado na Figura 1 mostra uma representação de todos os componentes da bancada de soldagem. É importante ressaltar, conforme pode ser observado neste diagrama, que o sistema de deslocamento da tocha não foi montado na mesma estrutura da mesa de soldagem, de forma que os ruídos provenientes deste movimento não fossem captados pelo acelerômetro.

Figura 1 - Diagrama mostrando o layout da bancada de soldagem.

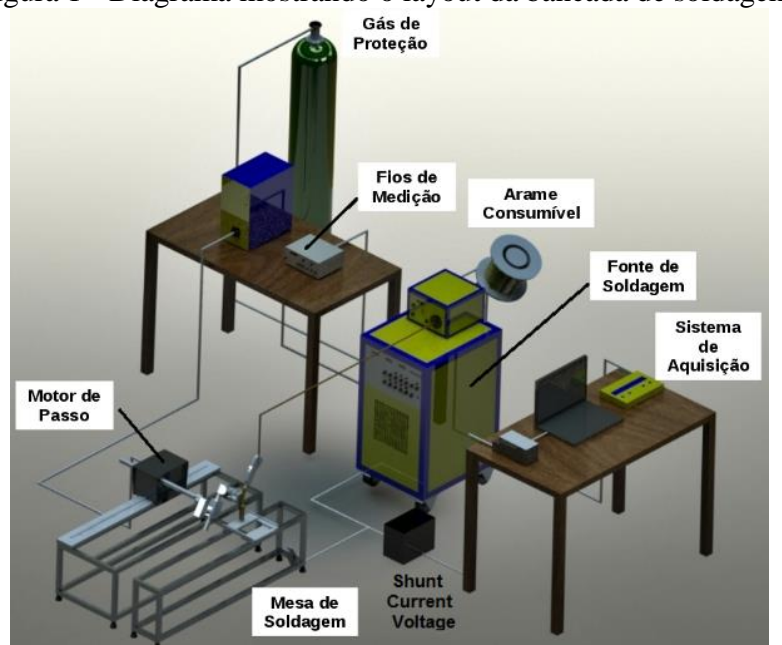

Fonte: Própria
Antes de iniciar o processo de soldagem, todos os corpos de prova passaram por um tratamento superficial, através de um processo de jateamento por partículas abrasivas G-25 S-280 de acordo com o determinado pela norma SAE J444 (1993) obtendo assim uma superfície livre de contaminantes. Ainda, cada peça foi pré-aquecida em um forno modelo NT-380 até a temperatura de $200^{\circ} \mathrm{C}$, e a partir de então controlada a temperatura para que o processo de soldagem se iniciasse quando a peça atingiu a temperatura de $150^{\circ} \mathrm{C}$ (KHATTER, et al. 2014).

A Tabela 2 mostra os parâmetros gerais utilizados durante o processo de soldagem.

Tabela 2 - Parâmetros ótimos utilizados para o processo de soldagem FCAW e seus respectivos valores.

\begin{tabular}{cc}
\hline Parâmetros & Valores \\
\hline Polaridade do Eletrodo & DCEP \\
Gás de Proteção & $\mathrm{O}_{2}+2 \% \mathrm{Ar}$ \\
Fluxo de Gás & $18 \mathrm{~L} / \mathrm{min}$. \\
Ângulo da Tocha & $90^{\circ}$ \\
Posição de Soldagem & Plana \\
Temperatura Entre Passes & $150^{\circ} \mathrm{C}$ \\
Quantidade de Cordões & 01 \\
Corrente de Pico (Ip) & $350 \mathrm{~A}$ \\
Tempo de Pico & $10 \mathrm{~ms}$ \\
\hline \multicolumn{2}{c}{ Fonte: Própria }
\end{tabular}

\section{RESULTADOS E DISCUSSÃO}

Os resultados referentes à velocidade de soldagem, corrente e tensão dos procedimentos analisados dentro do intervalo de 20 e 30 segundos estão dispostos nas Figuras 2 a 4 a seguir, onde foram utilizadas como parâmetros de soldagem, a corrente convencional de 170, 200 e 230 amperes, velocidades de deslocamento da tocha de soldagem de 300,350 e $400 \mathrm{~mm} / \mathrm{min}$, e distância bico de contato peça de 30, 36 e 33 $\mathrm{mm}$ respectivamente. $\mathrm{O}$ intervalo de análise dentro de 20 e 30 devido ao fato de que neste intervalo o arco elétrico já estava plenamente desenvolvido, produzindo um cordão mais contínuo o que possibilitou uma análise mais confiável e padronizada dos resultados.

Quando observamos o ciclograma de corrente e tensão para a corrente de 170 amperes na Figura 2, verificamos que entre as três condições de soldagem a corrente se comportou de forma irregular, sendo a menor de todas observada quando a velocidade de soldagem foi de $350 \mathrm{~mm} / \mathrm{min}$. e distância bico de contato peça de $36 \mathrm{~mm}$. 
Figura 2 - Gráficos de corrente e tensão e ciclogramas de corrente tensão para corrente convencional de 170 amperes.
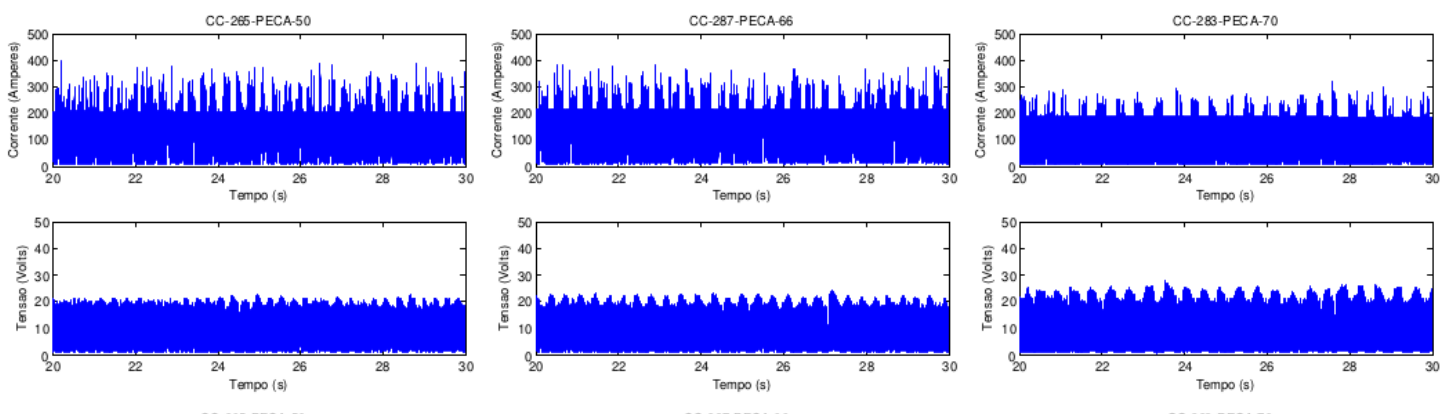

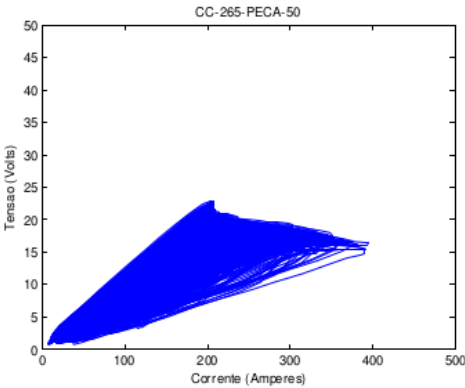

V.S.: $300 \mathrm{~mm} / \mathrm{min}$; DBCP: $30 \mathrm{~mm}$

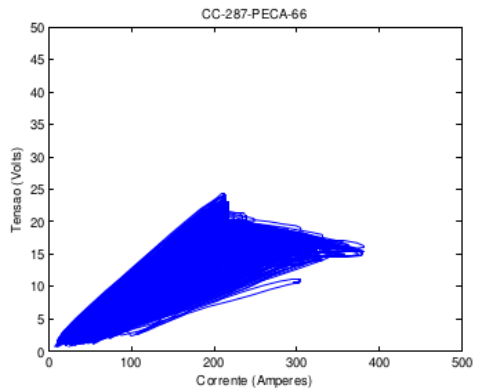

V. S.: $400 \mathrm{~mm} / \mathrm{min}$; DBCP: $33 \mathrm{~mm}$ Fonte: Própria

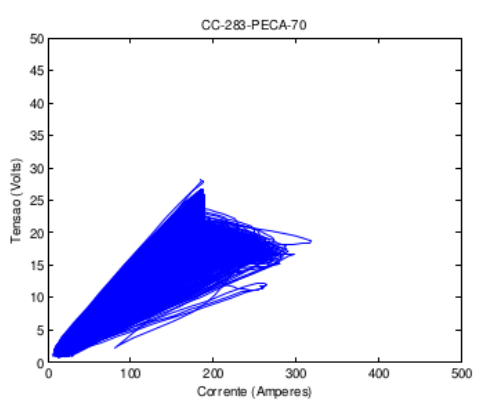

V.S.: $350 \mathrm{~mm} / \mathrm{min}$; DBCP: $36 \mathrm{~mm}$
Porém, em relação a tensão observamos que em todas as situações, houve uma oscilação devido à variação da corrente, com os ciclogramas evidenciando que para a corrente convencional de 170 amperes esta corrente foi ultrapassada, sendo que nas condições de velocidade de soldagem de
$300 \mathrm{~mm} / \mathrm{min}$, distância bico de contato peça $30 \mathrm{~mm}$ a maior corrente ficou perto de 400 amperes identicamente as condições de velocidade de $400 \mathrm{~mm} / \mathrm{min}$. e distância bico de contato peça de $33 \mathrm{~mm}$.

Figura 3 - Gráficos de corrente e tensão e ciclogramas de corrente tensão para corrente convencional de 200 amperes.
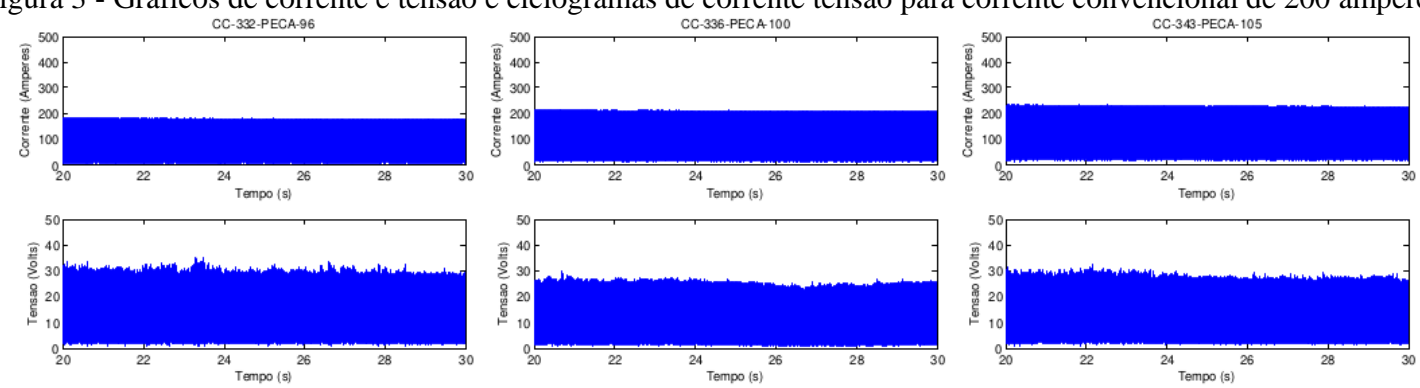

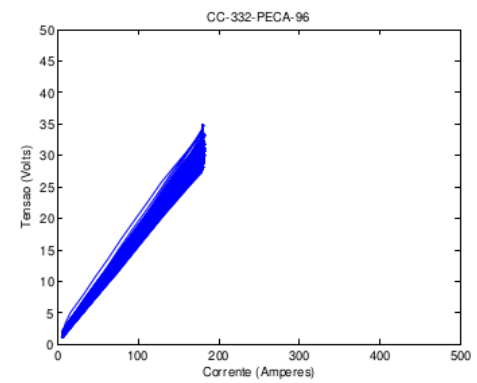

V.S.: $300 \mathrm{~mm} / \mathrm{min}$; DBCP: $33 \mathrm{~mm}$

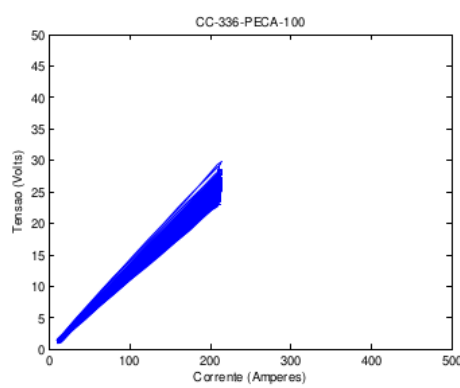

V.S.: $350 \mathrm{~mm} / \mathrm{min}$; DBCP: $30 \mathrm{~mm}$ Fonte: Própria

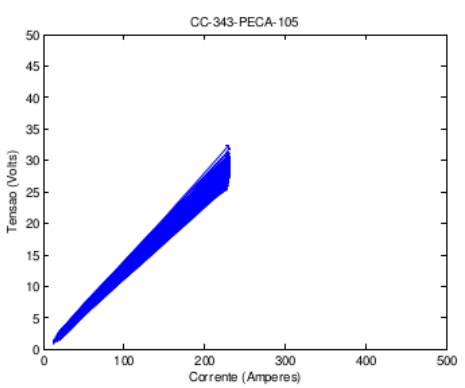

V.S.: $400 \mathrm{~mm} / \mathrm{min}$; DBCP: $36 \mathrm{~mm}$
Já na condição de velocidade de soldagem de 350 $\mathrm{mm} / \mathrm{min}$. e distância bico de contato peça de $36 \mathrm{~mm}$, a corrente máxima atingida não ultrapassou 300 amperes, evidenciando uma maior estabilidade para esta situação.

Para uma corrente convencional de 200 amperes como se pode observar na Figura 3, os ciclogramas de corrente e tensão se comportaram de maneira mais estável do que para 170 amperes, pois com velocidade de soldagem de $300 \mathrm{~mm} / \mathrm{min}$., distância bico de contato peça de $33 \mathrm{~mm}$, a corrente apresentou-se pouco inferior a 200 amperes.
Este comportamento, considerado mais estável, pode ser comprovado pelos ciclogramas nas três condições de soldagem, onde podemos notar que os ciclogramas estão mais estreitos e com variações de tensão e corrente menor do que para o caso anterior.

Por outro lado, a Figura 4 mostra os ciclogramas de tensão e corrente a corrente convencional de soldagem de 230 amperes. Podemos verificar que a corrente ficou estável nas três condições impostas e que a tensão oscilou menos do que 
nas correntes de 170 e 200 amperes como comprovado em outros trabalhos na soldagem GMAW (DUTRA, et.al. 2012).

Os ciclogramas para este caso, apresentam uma pequena variação nos gráficos de corrente, sendo possível observar que para a velocidade de soldagem de $350 \mathrm{~mm} / \mathrm{min}$. o ciclograma é mais estreito, evidenciando uma melhor condição de estabilidade do arco elétrico.

Figura 4 - Gráficos de corrente e tensão e ciclogramas de corrente tensão para corrente convencional de 230 amperes.
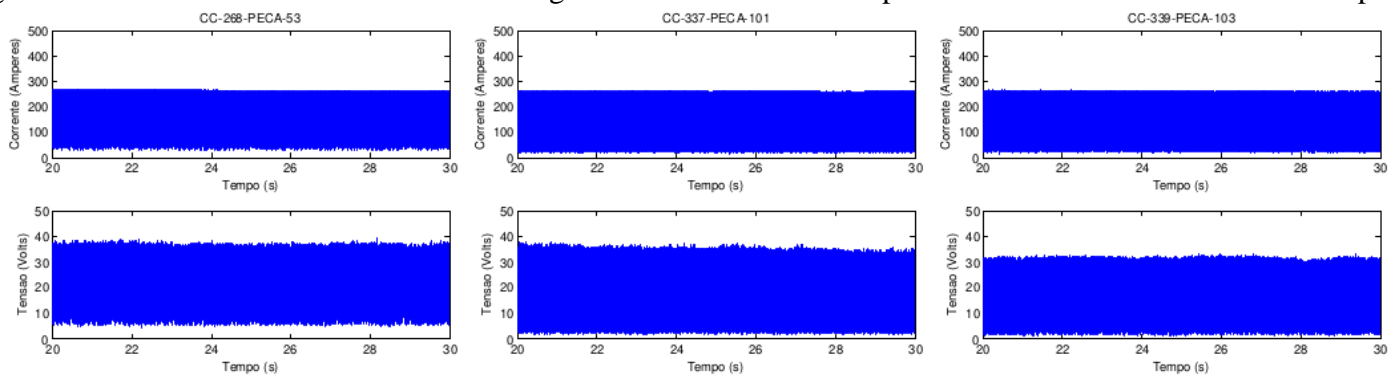

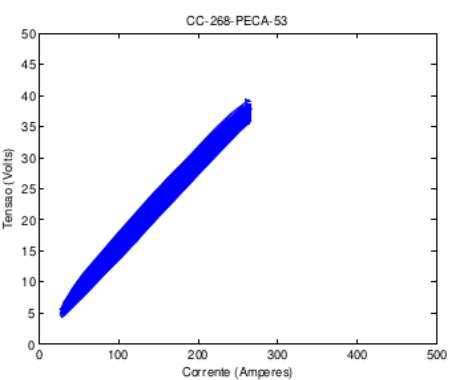

V.S.: $300 \mathrm{~mm} / \mathrm{min}$; DBCP: $36 \mathrm{~mm}$

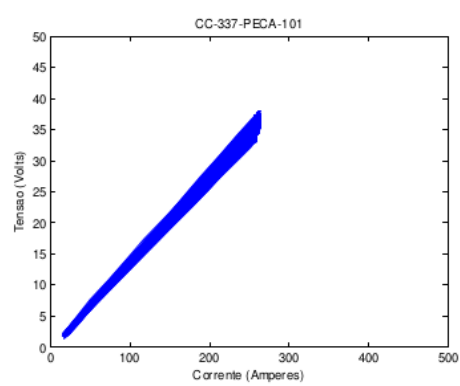

V.S.: $350 \mathrm{~mm} / \mathrm{min}$; DBCP: $33 \mathrm{~mm}$ Fonte: Própria

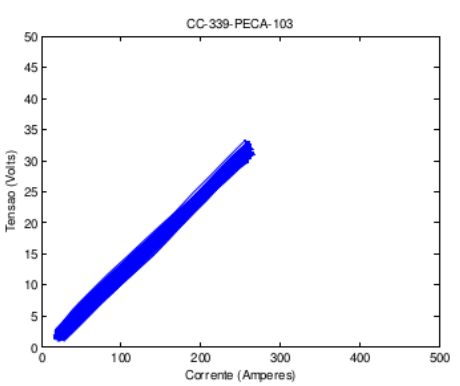

V.S.: $400 \mathrm{~mm} / \mathrm{min}$; DBCP: $30 \mathrm{~mm}$
Estão apresentados na Figura 5 os oscilogramas do acelerômetro para a corrente convencional de 170, 200 e 230 amperes. Na Figura 5a para a corrente de 170 amperes nas três condições de soldagem o acelerômetro oscilou de maneira similar, comprovando assim os resultados encontrados para um arco instável detectado nos oscilogramas anteriormente registrado na Figura 2.

Já na Figura 5b notamos o oscilograma de aceleração para a corrente de 200 amperes, e observamos que com a velocidade de soldagem de $300 \mathrm{~mm} / \mathrm{min}$. e distância bico de contato peça de $33 \mathrm{~mm}$, a instabilidade do arco foi mais acentuada.

Ao analisar a Figura 5c, é possível observar os oscilogramas para a corrente convencional de 230 amperes, que apresentaram uma menor variação para a velocidade de soldagem de $350 \mathrm{~mm} / \mathrm{min}$. e distância bico de contato peça de $33 \mathrm{~mm}$, onde a aceleração teve picos menores se comparado com os outros dois casos.

Figura 5 - Gráficos Oscilogramas de Aceleração RMS em função do tempo.
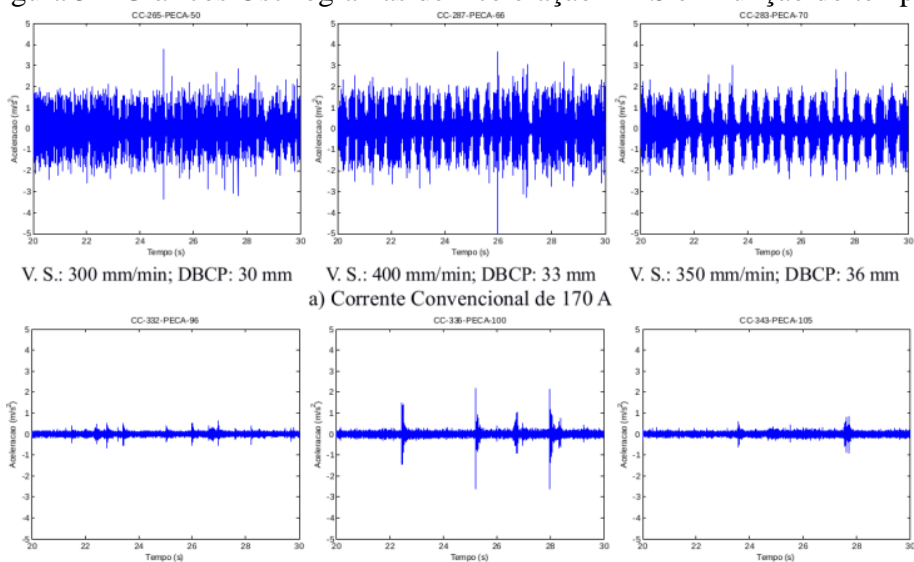
a) Corrente Convencional de $170 \mathrm{~A}$
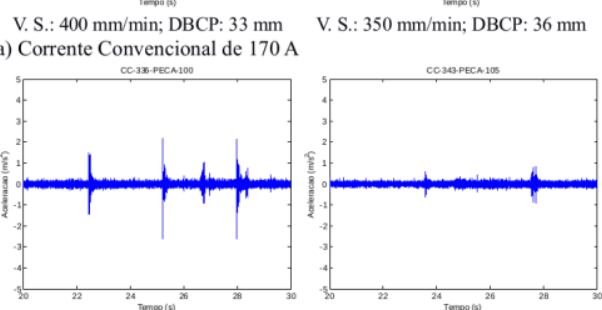

V. S.: $300 \mathrm{~mm} / \mathrm{min}$; DBCP: $33 \mathrm{~mm}$

V. S.: $350 \mathrm{~mm} / \mathrm{min}$; DBCP: $30 \mathrm{~mm}$ b) Corrente Convencional de $200 \mathrm{~A}$
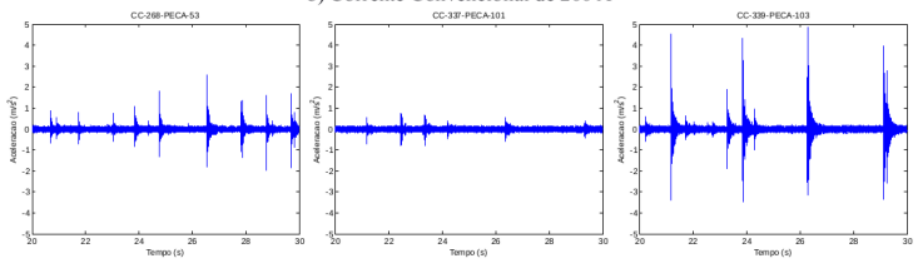

V. S.: $350 \mathrm{~mm} / \mathrm{min}$; DBCP: $33 \mathrm{~mm}$
c) Corrente Convencional de $230 \mathrm{~A}$

V. S.: $400 \mathrm{~mm} / \mathrm{min}$; DBCP: $30 \mathrm{~mm}$

Fonte: Própria 
Observa-se que os oscilogramas permitiram uma melhor visualização em relação aos ciclogramas em relação a estabilidade do arco. Dessa forma, para melhorar a visualização destes dados, foi aplicada a Transformada Rápida de Fourier (FTR) para o tratamento dos oscilogramas, que permitiram melhor apresentação destes dados em domínio do tempo em relação a frequência.

A Figura 8, por exemplo, apresenta estes gráficos da aceleração em função da frequência, para as correntes convencionais de 170, 200 e 230 amperes.
Entretanto na Figura 6a a instabilidade do arco elétrico a 170 amperes é notória, onde devido à presença de vários picos de aceleração mostram a intensidade mais acentuada desta instabilidade. Porém, na Figura $6 \mathrm{~b}$ com aceleração à corrente convencional de 200 amperes, percebe-se uma diminuição significativa dos picos de aceleração e também, que os comportamentos são muitos parecidos com uma maior variação na condição de velocidade de soldagem de $350 \mathrm{~mm} / \mathrm{min}$. e distância bico de contato peça de $30 \mathrm{~mm}$.

Figura 6 - Gráficos da Aceleração em relação a frequência gerados pela aplicação da TRF.

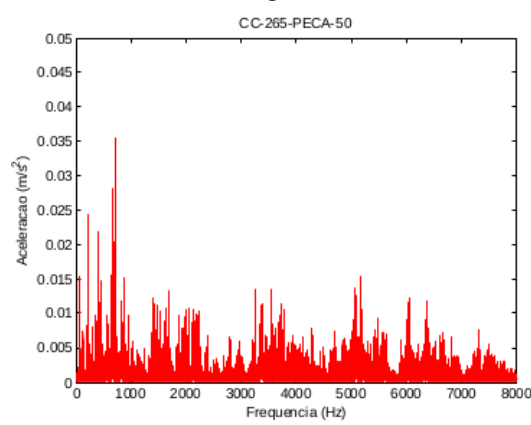

V. S.: $300 \mathrm{~mm} / \mathrm{min}$; DBCP: $30 \mathrm{~mm}$

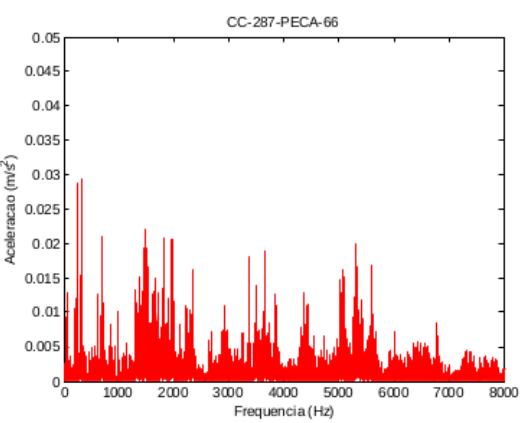

V. S.: $400 \mathrm{~mm} / \mathrm{min}$; DBCP: $33 \mathrm{~mm}$

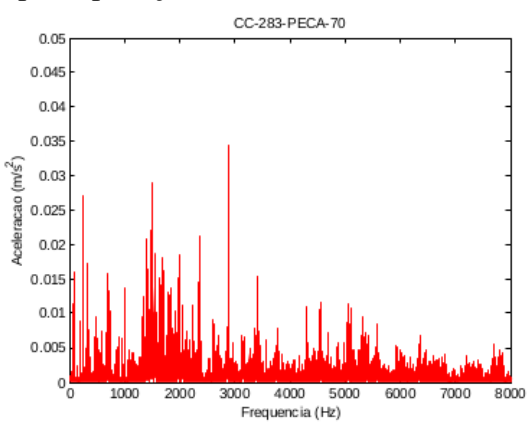

V. S.: $350 \mathrm{~mm} / \mathrm{min}$; DBCP: $36 \mathrm{~mm}$

a) Corrente Convencional de $170 \mathrm{~A}$

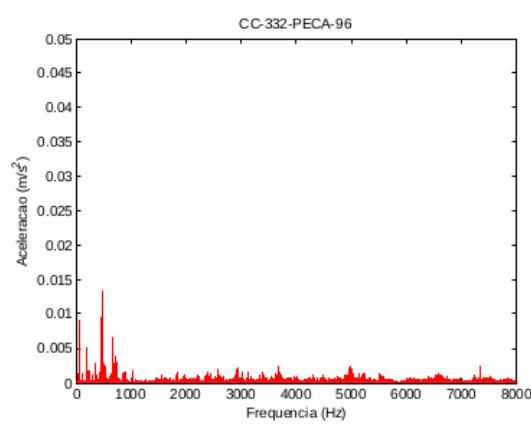

V. S.: $300 \mathrm{~mm} / \mathrm{min}$; DBCP: $33 \mathrm{~mm}$

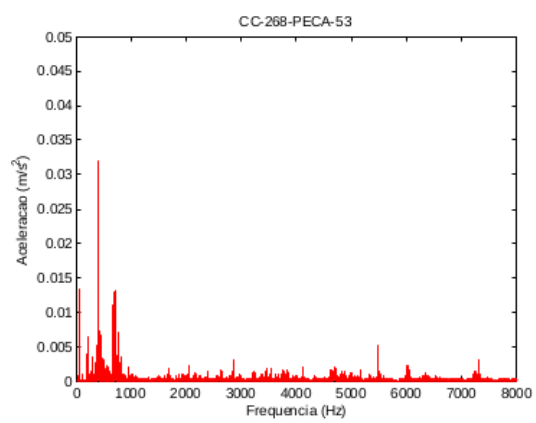

V. S.: $300 \mathrm{~mm} / \mathrm{min}$; DBCP: $36 \mathrm{~mm}$

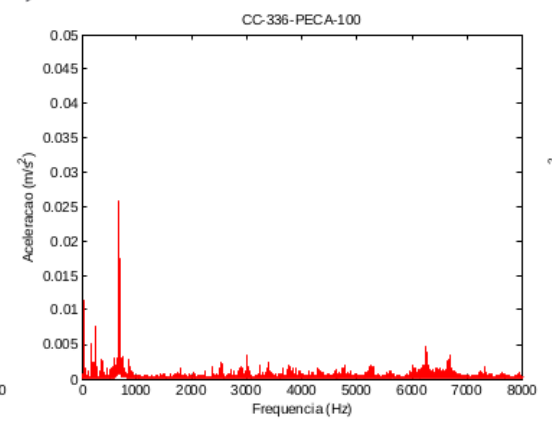

V. S.: $350 \mathrm{~mm} / \mathrm{min}$; DBCP: $30 \mathrm{~mm}$

b) Corrente Convencional de $200 \mathrm{~A}$

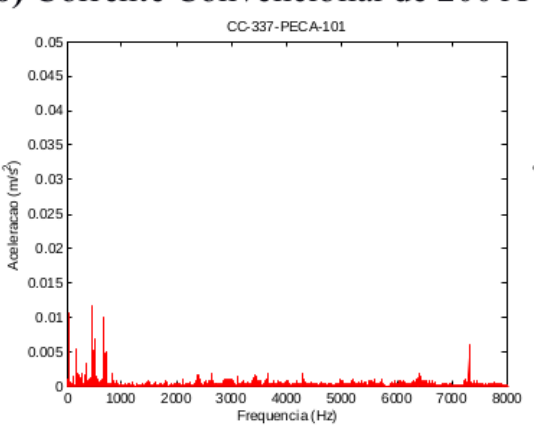

V. S.: $350 \mathrm{~mm} / \mathrm{min}$; DBCP: $33 \mathrm{~mm}$ c) Corrente Convencional de $230 \mathrm{~A}$

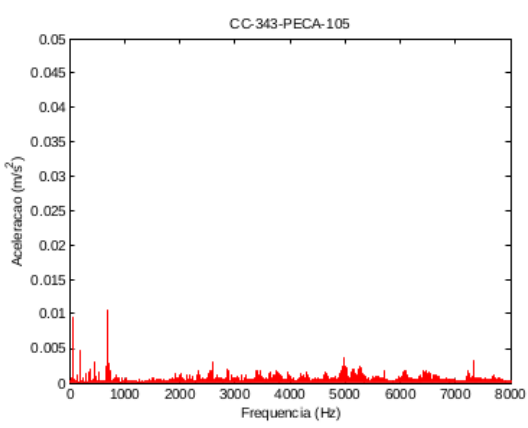

V. S.: $400 \mathrm{~mm} / \mathrm{min}$; DBCP: $36 \mathrm{~mm}$

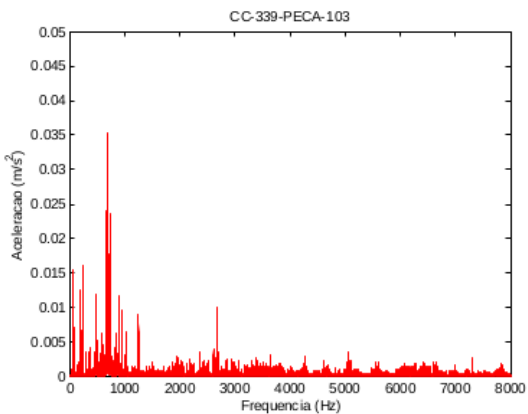

V. S.: $400 \mathrm{~mm} / \mathrm{min}$; DBCP: $30 \mathrm{~mm}$

Fonte: Própria

Por outro lado, a Figura 6c apresenta os gráficos de aceleração à corrente convencional de 230 amperes, onde podemos verificar que os resultados são mais estáveis e menos intensos quando comparados na corrente de 170 amperes.

Mas, é possível observar que os picos de aceleração para esta condição são muito próximos ao observado para corrente de 200 amperes e velocidade de $400 \mathrm{~mm} / \mathrm{min}$., mas se compararmos os oscilogramas para estas duas condições, veremos que a maior estabilidade se deu para a corrente convencional de 230 amperes.
Estes resultados estão de acordo com o apresentado em trabalhos de outros autores, onde a análise simultânea dos oscilogramas e ciclogramas levam a uma melhor decisão a respeito da melhor condição de estabilidade do arco elétrico em processos de soldagem (SUBAN, et al. 2003), além de podermos sugerir uma transferência possivelmente por curto-circuito sincronizada com corrente e tensão (LOPERA, et al. 2011). 


\section{CONCLUSÕES}

Através da análise dos ciclogramas de tensão versus corrente, foi possível identificar que a maior estabilidade do arco, procedeu a corrente de 230 A. Para esta corrente, os resultados mais satisfatórios foram para uma velocidade de $350 \mathrm{~mm} / \mathrm{min}$. e uma distância bico de contato a peça de 33 $\mathrm{mm}$. Esses resultados são reforçados pelo apresentado para a análise por acelerômetro, onde é possível observar um menor número de ruídos (pulsos) nos gráficos de aceleração para a mesma condição citada acima.

Porém, estes resultados favoráveis podem estar relacionados ao maior aporte térmico proporcionado pela corrente de soldagem mais elevada, que aumenta a temperatura do arame devido ao efeito Joule, facilitando assim o processo de transferência metálica.

O mesmo pode ser dito para a distância bico peça, já que uma distância menor, pode acarretar também um acréscimo na temperatura, porém, como pode ser observado, nem sempre a menor distância proporcionará uma maior estabilidade, sendo o melhor resultado para a distância intermediaria entre o bico e a peça.

Portanto pelas análises apresentadas, podemos concluir que a estabilidade do arco elétrico através da utilização de acelerômetros, pode ser uma técnica não destrutiva de análise e que tem a capacidade de prover resultados durante todo o processo de soldagem, de maneira confiável e rápida enfatizando o uso dos sinais, que tratados através da Transformada Rápida de Fourier (TRF) apresentam um resultado mais eficaz e de melhor visualização.

\section{AGRADECIMENTOS}

A UTFPR - Universidade Tecnológica Federal do Paraná pelo apoio prestado as nossas necessidades e investidas e ao Laboratório de Ensaios e Materiais da USP São Carlos.

\section{REFERÊNCIAS BIBLIOGRÁFICAS}

CAYO, EBER H.; Monitoramento, Detecção e Localização de Defeitos na Solda Baseada no Sensoriamento da Pressão Acústica do Arco Elétrico no Processo GMAW-S Dissertação de Mestrado em Sistemas Mecatrônicos, Publicação ENM.DM-02A/08, Departamento de Engenharia Mecânica, Universidade de Brasília, Brasília, DF, 124p, 2008.

DUTRA, J.C; MARQUES, C.; SILVA, R.H.G. Consonâncias e Dissonâncias Interpretativas no Interrelacionamento das Variáveis da Corrente Pulsada Aplicada à Soldagem com arame de Alumínio 4043; Soldagem e Inspeção, v.7(3): 201-209, 2012.

GRAD, L.; et al. Feasibility study of acoustic signals for online monitoring in short circuit gas metal arc welding. International Journal of Machine Tools \& Manufacture, v.44: 555-561, 2004.

JEFF T., TOM H., TERRI H.; Learn RF Spectrum Analysis Basics; Agilent Technologies., 2013
JOHNSON, J. A., et al. Process control of GMAW: sensing of metal transfer mode. Welding Journal 75(4): 91-s to 99-s, 1991.

KHATTER, A. KUMAR, P. and KUMAR, M.; Optimization of Process Parameter in TIG Welding Using Taguchi of Stainless Steel-304; InternatIonal Journal of Research In Mechanical Engineering \& Technology, V.4(1):31-36, 2014

KUMAR, V. Optimization of Weld Bead Width in Tungsten Inert Gas Welding of Austenitic Stainless Steel Alloy; American Journal of Mechanical Engineering, v.2(2): 50-53, 2014.

LIMA, A.C.; FERRARESI, V.A. Estudos dos modos de transferência metálica de um arame tubular auto protegido com variação na distância bico de contato-peça. Soldagem e Inspeção, v.11(3): 164-172, 2006.

LOPERA, J.E.P.; RAMOS, E.G.; CARVALHO, G.C.; ALFARO, S. C. A. Uso da técnica de perfilografia para visualização dos modos de transferência metálica no processo de soldagem GMAW usando uma câmera CMOS de alta velocidade. In: $6^{\circ}$ Congresso Brasileiro de Engenharia de Fabricação, Caxias do Sul, RS. ABCM; v.1: $1-9,2011$.

MARQUES, P. V.; MODENESI, P. J.; BRACARENSE, A. Q. Soldagem: fundamentos e tecnologia. Belo Horizonte: UFMG, 2005, 362 p.

PALANI, P. K.; MURUGAN, N. Optimization of weld bead geometry for stainless steel claddings deposited by FCAW; Journal of Materials Processing Technology, v.190(1-3): 291-299, 2007.

RODRIGUES, L. O.; PAIVA, A. P.; COSTA, S. C. Otimização do processo de soldagem com eletrodo tubular através da análise da geometria do cordão de solda. Soldagem \& Inspeção, v.13 (2): 118-127, 2008.

SUBAN, M.; TUŠEK, J. Methods for the Determination of arc Stability, Journal of Materials Processing Technology; v.143-144:430-437, Institut Za Varilstvo (Welding Institute), Ljubljana, Slovenia, 2003.

WANG, W.; LIU, S.; JONES, J.E. Flux Cored Arc Welding: Arc Sinals, Processing and Metal Transfer Characterization. Welding Journal, Welding Research Supplement; v.74 (11): 369s-377s, 1995.

\section{COPYRIGHT}

Direitos autorais: Os autores são os únicos responsáveis pelo material incluído no artigo. 


\title{
COMPARAÇÃO DOS MÉTODOS DE GERAÇÃO DA SPWM VIA PONTO A PONTO E MODULOS PWM DO MICROCONTROLADOR NO CONTROLE DE UM MIT
}

\section{COMPARISON OF THE METHODS OF GENERATION OF SPWM VIA POINT TO POINT AND PWM MODULES MICROCONTROLLER IN A MIT}

\author{
LUIZ CARLOS GOMES ${ }^{1}$; MARCIO ABUD MARCELINO ${ }^{1,2}$ \\ 1 - UNITAU; 2 - UNESP/GUARATINGUETÁ \\ englcgomes@gmail.com; abud@feg.unesp.br
}

\begin{abstract}
Resumo - Este trabalho apresenta uma abordagem na geração de um sinal SPWM, via módulos PWM do microcontrolador, para aplicações em controles de MIT com $o$ objetivo de reduzir o processamento de um microcontrolador, além de necessitar uma menor tabela préprogramada. $O$ microcontrolador utilizado foi $o$ PIC18F4331, por apresentar recursos de controle de PWM mais eficientes para esta aplicação, tais como, quatro módulos de geração de PWM por hardware. Para avaliar o seu desempenho também foi apresentado o método de geração da SPWM tradicional, o ponto a ponto, em seguida foi feito um comparativo entre os mesmos. Foram usadas três ferramentas de software, o EXCEL, o PROTEUS $e$ o MPLABX. O EXCEL permitiu fazer os cálculos, tabelas $e$ simulações estáticas, o PROTEUS permitiu fazer as simulações dinâmicas e o MPLABX permitiu escrever os programas em $\mathrm{C}$ e fazer as compilações. Os resultados mostraram que na geração de um sinal SPWM, através dos modulados PWM, mostrou-se mais eficiente, na distorção harmônica, e também no processamento e apresentou menor tabela pré-programada. Diante dessas vantagens, esse método mostrou-se mais promissor para aplicaç̃eses práticas e uma possível alternativa ao do método tradicional.
\end{abstract}

Palavras-chave: Gerador SPWM. Controle de Motor. Vetores.

\begin{abstract}
This paper presents an approach in generating SPWM signal, via PWM modules microcontroller, MIT controls applications with the goal of reducing processing of a microcontroller, besides a lower preset table needs. The microcontroller used was the PIC18F4331, PWM control capabilities more efficiently for this application, such as, four PWM generation modules for hardware. To evaluate their performance was also presented the method of generation of SPWM traditional, point-to-point, then was made a comparison between them. Three software tools were used, EXCEL, PROTEUS and the MPLABX. EXCEL allowed do the static calculations, tables and simulations, the PROTEUS allowed do dynamic simulations and MPLABX allowed write programs in $C$ and do the builds. The results showed that in the generation of a SPWM signal through the modulated PWM, proved to be more efficient, in harmonic distortion, and processing and also showed lower preset table. Given these advantages, this method proved to be more promising for practical applications and a possible alternative to the traditional method.
\end{abstract}

Keywords: SPWM Generator. Motor Control. Vectors.

\section{INTRODUÇÃO}

Mesmo com o aparecimento dos motores brushless os motores de indução, devido as suas características técnicas, ainda são muito utilizados nas mais diversas aplicações, sendo que os trifásicos (MIT) são muito usados quando potências maiores são envolvidas, porém, em decorrência de sua natureza física, requerem controladores mais complexos para o controle das suas principais grandezas, tais como: tensão, velocidade e torque, que os tradicionais motores de corrente contínua. No Brasil, $43 \%$ da energia é gasta pela indústria e, desse percentual, $55 \%$ são referentes aos motores elétricos (VIANA et al.2012) e, aliado a isso, existe a preocupação crescente com a eficiência energética. Esse binômio tem levado à busca de controladores de motores mais eficientes. Um efeito das harmônicas sobre os motores de indução é o aumento do aquecimento, decorrente das perdas no ferro e no fio de cobre, comprometendo a eficiência e o torque disponível, com um provável aumento do ruído no motor (BLOOMING \& CARNOVALE, 2006). Esse efeito tem levado a uma busca por controladores de MIT que gerem menos harmônicas e que possam rodar em microcontroladores para aplicações de baixo custo. Algumas técnicas foram utilizadas para o controle do MIT, sendo a modulação por largura de pulso (PWM) uma das mais encontradas. O PWM é um processo que varia a largura dos pulsos para controlar o nível da tensão e frequência na entrada do motor, buscando manter o torque constante (MARCELINO \& FIOROTTO, 1999) e, os pulsos são convenientemente gerados com o objetivo de resultar em um número mínimo de harmônicas sobre o motor. Para isso, alguns algoritmos foram criados para a geração desses pulsos, e o mais utilizado é o PWM senoidal (SPWM), que é gerado a partir de um sinal senoidal e um sinal triangular. A Figura 1 apresenta o conjunto de sinais do circuito SPWM. $\mathrm{Na}$ modulação SPWM a largura dos pulsos varia diretamente em função de um sinal senoidal (HAIDER et al.2012). A modulação SPWM é utilizada nas mais diversas aplicações, entre elas estão: controlador de geração de energia eólica, controle de potência de máquinas rotativas, máquinas de solda, controladores de energia fotovoltaica, entre outras (RAHMAN et al.2013). A modulação SPWM em geral é utilizada em sistemas de baixa e média potências, através de inversores de tensão com controle de frequência (YING et al.2009). Os microcontroladores estão evoluindo e 
incorporando circuitos para solução dos mais diversos tipos de problemas. $\mathrm{Na}$ área de controladores de motores, eles têm apresentado módulos otimizados de PWM. Este trabalho apresenta uma solução de utilização desses módulos no controle de um MIT e confronta com o método tradicional ponto a ponto. A geração ponto a ponto necessita do envio dos vetores em tempos muito curtos, geralmente da ordem poucas dezenas de microssegundos, no caso de motores de $60 \mathrm{~Hz}$, exigindo quase toda a capacidade de processamento do mesmo. A abordagem com os módulos PWM na geração da SPWM busca minimizar esse problema. Para comparação dessas duas técnicas de geração da SPWM, o EXCEL é utilizado como ferramenta de análise e simulação estática, o PROTEUS é utilizado como ferramenta de simulação dinâmica e o MPLABX é utilizado para edição e compilação dos programas.

Figura 1- Conjunto de sinais para geração SPWM.
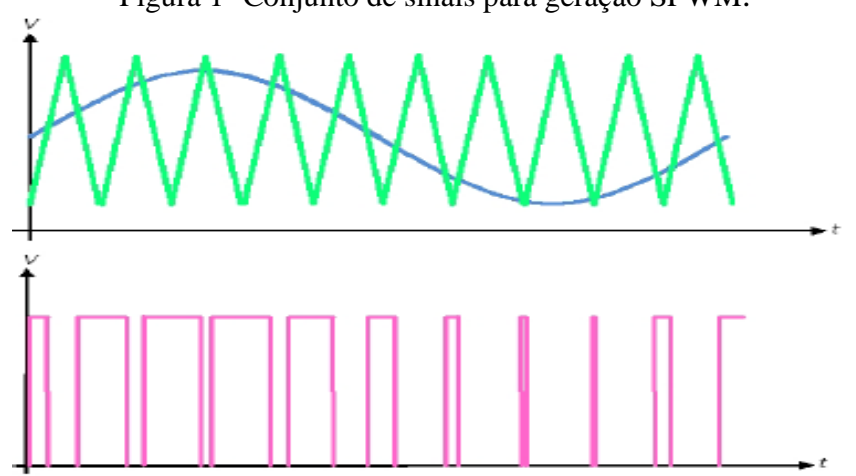

Fonte: RAHMAN et al (2013).

\section{PARÂMETROS do SPWM}

Para a construção do sinal SPWM o sinal senoidal ( modulante), é a referência e o triangular é a portadora. A variação do sinal senoidal determina a variação do sinal de saída do controlador, e a frequência da portadora determina a composição harmônica desse mesmo sinal de saída. Muitos trabalhos descrevem sobre essa técnica de modulação, mas poucos orientam na escolha da frequência da portadora. Souza e outros apresentaram um trabalho com uma proposta para a frequência da portadora (SOUZA et al.2011), definindo que o valor da portadora (fp) em relação ao sinal modulante (fm) deve ser $\mathrm{fp} / \mathrm{fm}=\mathrm{n} \geq 21$, ou seja, $\mathrm{fp} \geq 21 * \mathrm{fm}$, para um período do sinal modulante (senoidal). Esse número integra um conjunto de conceitos apresentados a seguir (MARCELINO \& FIOROTTO, 1999):

$\mathrm{n}$ : Precisa ser inteiro para ter periodicidade do sinal modulado, facilitar o sincronismo, e evitar sub-harmônicas ou componentes pulsadas; Precisa ser impar para eliminar as harmônicas pares; Precisa ser maior do que 20 para as harmônicas geradas estejam bem afastadas da frequência de rotação do motor, proporcionando uma onda de corrente quase senoidal; Precisa ser múltiplo de três para os motores trifásicos e, por fim, precisa ser um número pequeno para não comprometer o tempo de processamento e inviabilizar o uso em microcontroladores. Ou seja, o número mais indicado é o 21 e esse número promete minimizar a distorção harmônica total (THD).

A escolha da frequência de chaveamento é um fator determinante para a confiabilidade do motor, estudos mostram que quanto maior é a frequência de chaveamento do PWM mais rápida será a degradação do sistema de isolação. Estudos mostram que para uma frequência de chaveamento de até $5 \mathrm{KHz}$ a probabilidade de falha do isolamento é diretamente proporcional à frequência de chaveamento e, que acima dessa frequência, a probabilidade de falha guarda uma relação quadrática. Por outro lado, com aumento da frequência de chaveamento a distorção harmônica diminui melhorando a tensão fornecida ao motor e, consequentemente, melhora o desempenho do motor no quesito temperatura e ruído (WEG, 2016).

$\mathrm{O}$ índice de modulação, $m$, representa a relação entre a tensão do sinal modulante, sinal senoidal, e da portadora, sinal triangular, e sua variação determina a intensidade de corrente no motor e está representada pela equação (1) (THAKUR \& LODHI, 2014).

$m=\frac{V \text { seno }}{\text { Vtriângulo }}=\frac{V S p p}{V R}$

A modulação é dita síncrona quando $m \in \mathrm{N}$ (números naturais) e, é dita assíncrona quando $m \in \mathfrak{R}$ (números reais). Para a faixa: $0 \leq m \leq 1$, a técnica SPWM é chamada de domínio linear e a saída varia linearmente com $m$ ( NEACĂ, 2014). No caso em que $m>1$, ocorre o fenômeno da sobre modulação, condição em que a saída não varia proporcionalmente ao sinal modulante e, onde ocorre perda de informação.

\section{GERAÇÃO DIGITAL DA TÉCNICA SPWM}

Atualmente os inversores que usam a técnica e geram o sinal SPWM utilizam um hardware normalmente controlado por processadores, ou microcontroladores, e métodos de programação (YING et al.2009). O sinal senoidal pode ser gerado diretamente por meio de uma função matemática disponível no EXCEL. O sinal triangular não está disponível nas funções do EXCEL, assim sendo pode ser implementado por meio de retas adequadamente construídas, compostas de acordo com a Figura 1, os mesmos são discretizados no tempo e construídos a partir de três retas conforme apresentado na Figura 2.

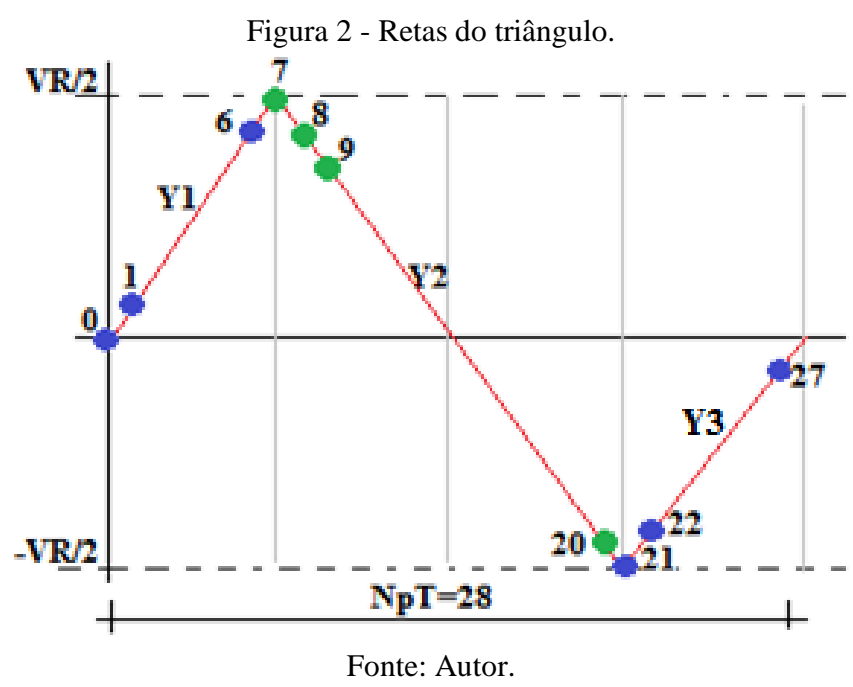

Sendo:

$N p T=$ Número de pontos do triângulo discretizada no tempo;

VR=Tensão máxima do triângulo;

A equação da reta Y1 é dada pela equação (2): 
$Y 1=\frac{V R / 2}{N p T / 4} * i \quad(\mathrm{i}=0$ a 6$)$

A equação da reta Y2 é representada pela equação (3):

$Y 2=\frac{V R / 2}{N p T / 4} *\left(i-\frac{N p T}{2}\right) \quad(\mathrm{i}=7$ a 20$)$

A equação da reta Y3 é representada pela equação (4):

$Y 3=\frac{V R / 2}{N p T / 4} *(i-N p T)(\mathrm{i}=21$ a 27$)$

O sinal modulante é construído a partir de uma função senoidal, conforme está apresentado na Figura 3.

Figura 3 - Período do sinal modulante discretizado no tempo.

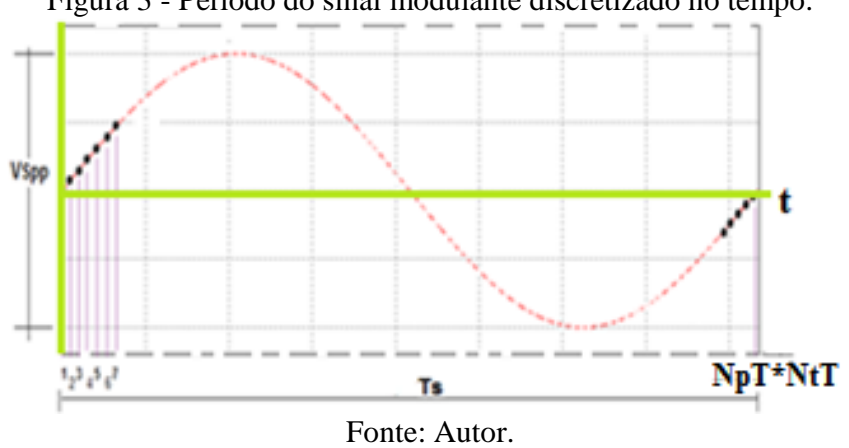

Sendo:

$N t T=$ Número total de triângulos contidos dentro do período de uma senoide;

VSpp $\rightarrow$ Tensão pico a pico da senoide;

$\mathrm{f}=$ frequência do sinal modulante;

$\mathrm{Ts}=$ período do sinal modulante;

O triângulo é discretizada em uma quantidade de pontos definida por $N p T$ e, dessa forma, um período do sinal modulante é construído através de um número total de pontos: $N t p m=\mathrm{NpT} * N t T$, sendo que a tensão em cada ponto é obtida através da equação (5).

$\mathrm{V} 1 \mathrm{~s}=\left(\left(\left(\frac{\mathrm{VSpp}}{2}\right) * \operatorname{sen}(\beta \mathrm{n})\right)\right)$

Onde:

$\mathrm{n}$ representa cada ponto do sinal modulante;

$\beta_{\mathrm{n}} \mathrm{o}$ ângulo acumulativo para cada ponto, de acordo com a equação (6) e,

$\beta_{\mathrm{n}}=\beta_{(\mathrm{n}-1)}+\mathrm{dx}$

\section{SIMULAÇÃO DA GERAÇÃO DA SPWM PONTO A PONTO}

Para a geração do sinal SPWM, em tempo real, uma das equações a serem calculadas é a (5). Essa equação é do tipo transcendental e se caracteriza por ser complexa para realização através de um microcontrolador e, consequentemente, demorada nas suas resoluções. Diante desse cenário surge uma preocupação em realizar o processamento dessas equações em tempo hábil, para geração de um sinal trifásico de $60 \mathrm{~Hz}$, ou seja, gerar um período de um sinal senoidal no tempo de 16,6666 ms. Para isso foi simulada no microcontrolador proposto a equação (5), em um programa em linguagem $\mathrm{C}$. O resultado foi de um tempo de $450 \mu \mathrm{s}$ e, se a esse valor for somado ao tempo gasto para o resto do algoritmo, multiplicado ao número de períodos do PWM, o resultado é muito superior ao período do sinal modulante. Essa simulação mostra a inviabilidade deste microcontrolador no controle de um MIT com modulação SPWM, com cálculos de suas variáveis sendo realizados em tempo real. Uma alternativa a essa modulação é o uso de tabelas pré-programadas (MARCELINO \& FIOROTTO, 1999). Para avaliar essa possibilidade, foi desenvolvido em linguagem $\mathrm{C}$ um programa que acessa uma tabela pré-programada com os devidos controles sobre mesma. O programa foi carregado e simulado no PROTEUS. O resultado apresentado foi um tempo de 3,6 $\mu$ s, para que um dado da tabela fosse enviado para uma determinada porta do microcontrolador. Esse tempo é compatível com a geração de um sinal trifásico de $60 \mathrm{~Hz}$.

\section{1 - Cálculo do NpT}

Para a técnica SPWM, o número de pontos do triangulo discretizada no tempo (NpT) ideal seria um número maior possível para que a forma de onda de corrente ficasse mais próxima de uma senoide, porém, para aplicações reais o NpT deve ser limitado e essa limitação está diretamente associada à capacidade de processamento e volume de memória do microcontrolador. Por outro lado, um número muito pequeno vai aumentar a distorção harmônica.

Neste trabalho adotou-se NpT igual a 36, conforme utilizado por MARCELINO (1999), dessa forma, para NT=21, tem-se uma tabela pré-programada de 756Bytes.

\section{2 - Geração da tabela pré-programada com 756 vetores}

A partir das equações (2) a (6) foi gerado na planilha do EXCEL, um conjunto de 756 vetores, capazes de gerar um sinal trifásico. Os seguintes dados de entrada foram utilizados:

$m=1$ (índice de modulação);

Obs: $m=1$, normalmente utilizado para $\mathrm{f}=60 \mathrm{~Hz}$ e

$\mathrm{V} / \mathrm{f}=$ constante.

fportadora $=21 \times$ fmolulante;

fmolulante $=60 \mathrm{~Hz}$.

A Figura 4 apresenta um conjunto de 756 vetores gerados no EXCEL e adaptado para ser usado no programa em Linguagem $\mathrm{C}$.

Figura 4 - 756 vetores para geração de um sinal trifásico.

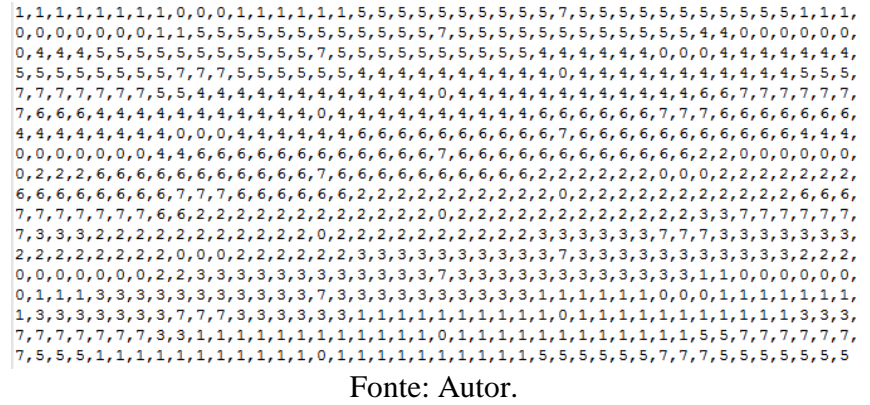

\section{SIMULAÇÕES E RESULTADOS}

A simulação foi realizada no PROTEUS com o microcontrolador PIC18F4331, circuitos de apoio, um circuito de potência e uma carga trifásica indutiva. Um software foi escrito em linguagem $\mathrm{C}$, com o objetivo de 
enviar, por interrupção, os vetores de estados descritos na Figura 4. O resultado foi a geração das três fases R-S-T, discretas no tempo, retiradas nos pinos E0, E1 e E2, conforme apresentado na Figura 5.

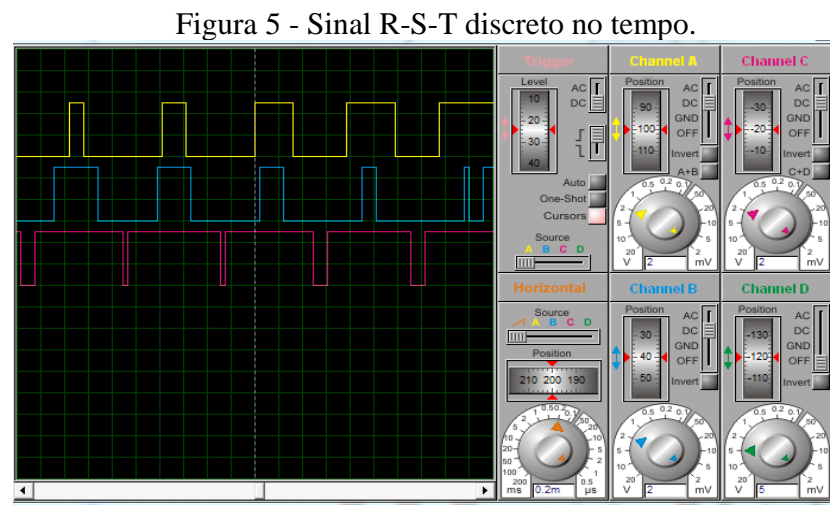

Fonte: Autor.

Os sinais apresentados na Figura 5 são injetados no circuito de potência trifásico, conforme apresentado na Figura 6, e a forma de onda gerada, está apresentada na Figura 7.

Figura 6 - Circuito de potência trifásico.

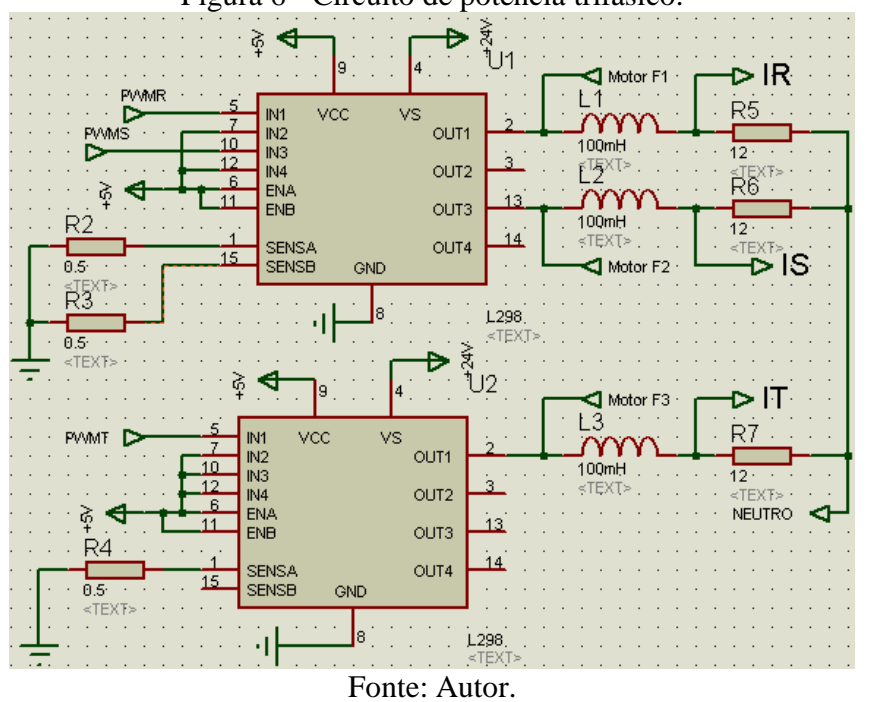

Figura 7 - Sinal SPWM gerado.

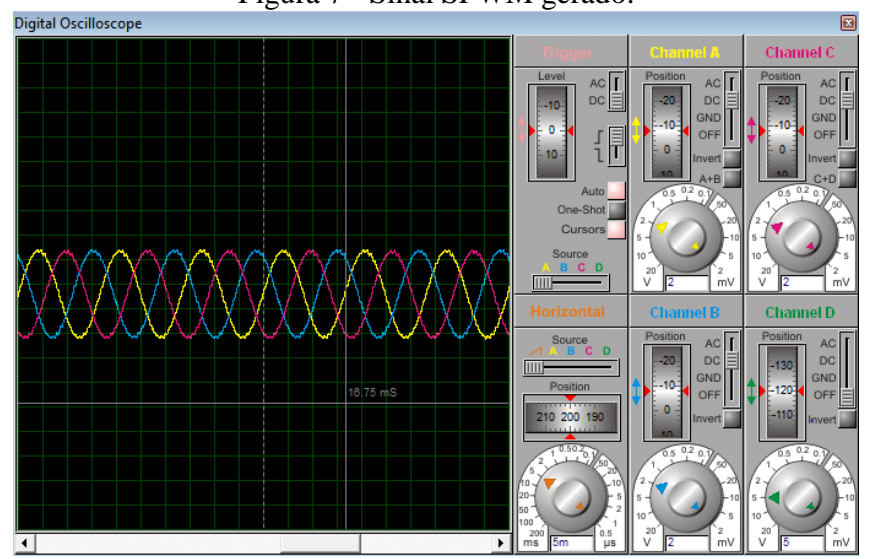

Fonte: Autor.

A análise espectral do sinal da Figura 7 está apresentada na Figura 8.
Figura 8 - Análise espectral do sinal SPWM.

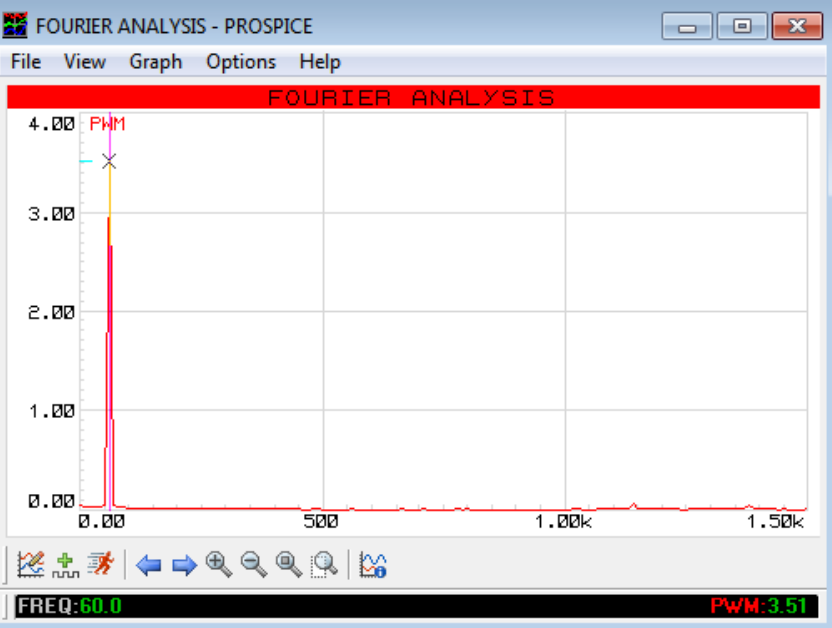

Fonte: Autor.

Pode-se observar que a componente fundamental está centrada em $60,0 \mathrm{~Hz}$ e o ruído harmônico visualmente é baixo. A THD pode ser calculada pela equação (6).

$T H D=\sqrt[2]{\frac{(\text { Soma_Harmônicas })^{2}}{(\text { Fundamental })^{2}}} \times 100 \sim 2,39 \%$

Faixa das harmônicas: $\mathrm{N} * 60$, onde $\mathrm{N}=1$ até 25

\section{GERAÇÃO SPWM VIA MODULO PWM}

A geração da SPWM pelo método ponto a ponto gera muitos vetores sequenciais repetitivos, conforme apresentado na Figura 4, sem acrescentar qualquer informação útil ao processo e, decorrente disso, consome grande capacidade de processamento motivando a busca por utilização melhor dos recursos do microcontrolador, visando atuar só no momento da atuação diferenciada, gerando apenas informações úteis. O recurso disponível em muitos microcontroladores para auxiliar nessa tarefa é o módulo gerador PWM. Tendo esse recurso disponível a dificuldade está em fornecer o padrão de informação para esse módulo que em geral, é o período e o duty cycle do sinal SPWM. Em busca dessa informação neste trabalho foi feita uma análise mais atenta ao processo da geração SPWM ponto a ponto, e foi possível abstrair algumas informações importantes. Entre elas estão: O sinal modulante sempre corta a portadora em dois pontos na formação de um período de um sinal SPWM. O duty cycle desse sinal varia de acordo com o sinal modulante. Essas caraterísticas podem ser geradas através dos módulos de PWM dos microcontroladores com auxílio do sinal modulante que é amostrado por uma frequência de chaveamento. A frequência de chaveamento de $5 \mathrm{KHz}$ é uma recomendação do fabricante WEG para o controle das chaves eletrônicas dos inversores ( WEG, 2006). Sendo assim, para uma frequência de chaveamento de $5 \mathrm{~K}$, para um período do sinal modulante de $60 \mathrm{~Hz}$ é necessário 83,3333 amostras, na prática, pega-se o inteiro mais próximo, que no caso é 83 . Em resumo, um período de $16,6667 \mathrm{~ms}$ do sinal modulante possui 83 amostras do sinal. Para cada amostra, calcula-se a sua porcentagem em relação a amostra de valor máximo $(m=1)$. A Figura 9 ilustra esse processo. 
Figura 9 - Ilustração do processo de amostragem de uma das fases do sinal trifásico.

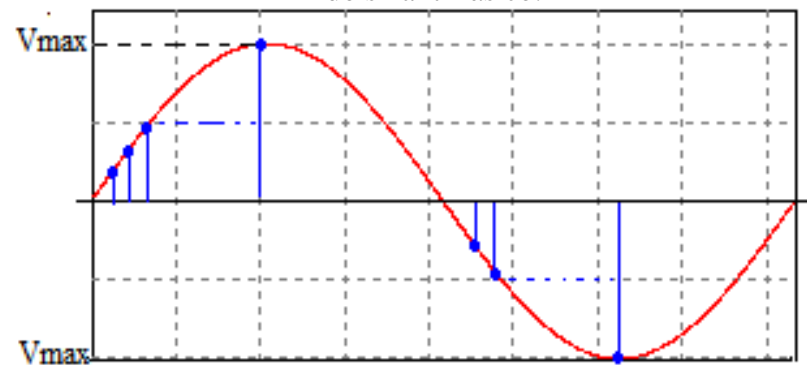

Fonte: Autor.

O EXCEL foi utilizado para calcular a amostragem das três fases do sinal modulante, ou seja, cada uma das $3 * 83$ amostras e o seu porcentual em relação a amostra de valor máximo $(\mathrm{m}=1)$. A tabela 1 apresenta parte do resultado.

Tabela 1 - Tabela com as porcentagem das amostras

\begin{tabular}{cccc}
\hline Amostras & \%Fase1 & \%fase2 & \%fase3 \\
\hline $\mathbf{0}$ & 0,50 & 0,93 & 0,07 \\
$\mathbf{1}$ & 0,54 & 0,91 & 0,05 \\
$\mathbf{2}$ & 0,58 & 0,89 & 0,03 \\
$\mathbf{3}$ & 0,61 & 0,87 & 0,02 \\
$\mathbf{:}$ & $:$ & $:$ & $:$ \\
$\mathbf{2 1}$ & 1,00 & 0,24 & 0,26 \\
$\mathbf{:}$ & $:$ & $:$ & $:$ \\
$\mathbf{8 2}$ & 0,46 & 0,95 & 0,09 \\
\hline \multicolumn{4}{c}{ Fonte: Autor. }
\end{tabular}

Observa-se por meio da tabela 1, que existem três fases e, cada fase contêm 83 valores de porcentuais. Cada um desses valores é convertido para o padrão de informação (período e duty cycle) dos módulos PWM do microcontrolador PIC18F4331. A tabela 2 apresenta parte dos valores convertidos.

Tabela 2 - Resumo da conversão da tabela 1 para PIC18F4331.

\begin{tabular}{ccccccc}
\hline $\begin{array}{c}\text { Amos } \\
\text { tras }\end{array}$ & $\begin{array}{c}\text { \%Fa } \\
\text { se1 }\end{array}$ & $\begin{array}{c}\text { ModP } \\
\text { wm1 }\end{array}$ & $\begin{array}{c}\text { \%Fa } \\
\text { se2 }\end{array}$ & $\begin{array}{c}\text { ModP } \\
\text { wm2 }\end{array}$ & $\begin{array}{c}\text { \%Fa } \\
\text { se3 }\end{array}$ & $\begin{array}{c}\text { ModP } \\
\text { wm3 }\end{array}$ \\
\hline $\mathbf{0}$ & 0,50 & 1000 & 0,93 & 1857 & 0,07 & 143 \\
$\mathbf{1}$ & 0,54 & 1075 & 0,91 & 1817 & 0,05 & 108 \\
$\mathbf{2}$ & 0,57 & 1149 & 0,89 & 1773 & 0,04 & 78 \\
$\mathbf{3}$ & 0,61 & 1223 & 0,86 & 1724 & 0,03 & 53 \\
$:$ & $:$ & $:$ & $:$ & $:$ & $:$ & $\vdots$ \\
$\mathbf{8 2}$ & 0,46 & 925 & 0,95 & 1892 & 0,09 & 183 \\
\hline \multicolumn{7}{c}{ Fonte: Autor. }
\end{tabular}

O PIC18F4331 é um microcontrolador da Microchip de baixo custo, com recursos para aplicações de controle de motores, em especifico, módulos de PWM mais adequados para a aplicação. Dentre eles se destacam:

a) Quatro canais PWM com saídas complementar;

b) Controle da banda morta;

c) Simultânea atualização de período e duty cyle;

d) Dentre outros.

Um programa foi escrito em linguagem $\mathrm{C}$, onde foram inseridas três tabelas pré-programadas com 83 valores de duty cycle, para cada fase. $\mathrm{O}$ microcontrolador envia simultaneamente, três valores de duty cycle, um de cada tabela, a cada $200 \mu \mathrm{s}$, para o modulo de potência. O resultado é a geração de um sinal trifásico de frequência de
$1 /(83 * 200 \mu \mathrm{s})=60,24 \mathrm{~Hz}$ sobre a carga. A simulação foi realizada no PROTEUS e o sinal gerado está apresentado na Figura10.

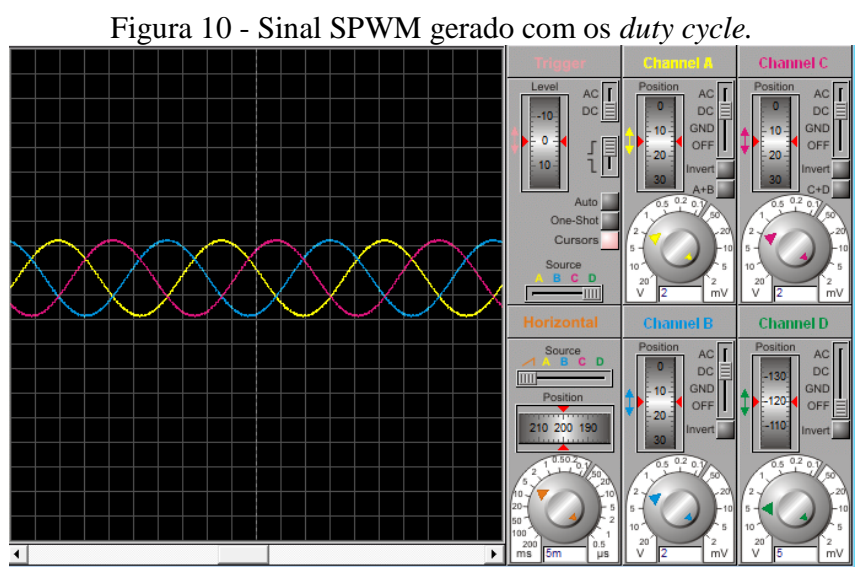

Fonte: Autor.

A análise espectral do sinal da Figura 10 está apresentada na Figura 11.

Figura 11 - Análise espectral da Figura 10.

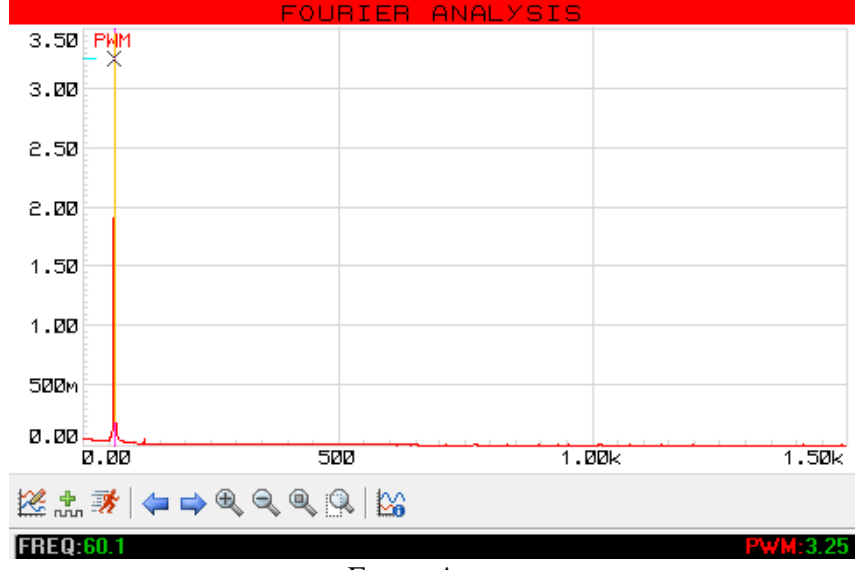

Fonte: Autor.

Observa-se que a componente fundamental está centrada em $60 \mathrm{~Hz}$ e o ruído harmônico visualmente é muito baixo. Igualmente utilizando a equação (6), calculou-se a THD e o valor encontrado foi de aproximadamente $1,4 \%$. Foi simulado a geração de um sinal SPWM em $5 \mathrm{~Hz}$ com $\mathrm{m}=0,2$, para uma avaliação da geração da SPWM com os módulos PWM do microcontrolador em baixas frequências. O resultado esta apresentado na Figura 12.

Figura 12 - Sinal SPWM trifásico em 5Hz.

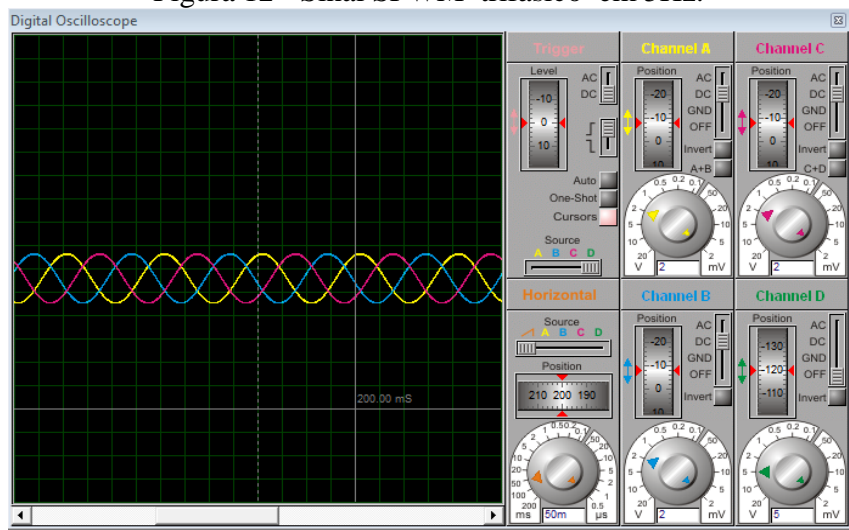

Fonte: Autor. 
O sinal SPWM de $5 \mathrm{~Hz}$ apresentado na Figura 12 , apresentou um ruído harmônico compatível com os de altas frequências.

\section{CONCLUSÃO}

Este trabalho apresentou um estudo, simulações e implementação de dois métodos de geração de um sinal SPWM trifásico, o ponto a ponto e o modulo PWM. O método ponto a ponto gera o sinal SPWM pelo confronto de dois sinais gerados discretamente pelo microcomputador, resultando em um total de 756 vetores para o controle de MIT na frequência de $60 \mathrm{~Hz}$. Cada vetor é enviado em $22 \mu \mathrm{s}$ e, esse tempo é praticamente a capacidade de processamento do microcomputador, sobrando pouco ou nenhum tempo para outras atividades. O sinal SPWM gerado apresentou baixa distorção harmônica com uma THD em torno de 2,39\%. Uma outra abordadem para a geração do SPWM foi através dos modulos PWM do PIC18F4331, que foi estudada com auxilio do EXCEL e diversas simulações, com auxilio do PROTEUS, foram feitas. O resultado foi a geração de um sinal SPWM trifásico de baixo ruído harmônico, com uma THD em torno de $1,4 \%$ e um baixo nível de processamento. Cada conjunto, com três vetores, foi enviado a cada $200 \mu \mathrm{s}$, e usou três tabelas préprogramada com apenas 83 valores cada uma. O uso dos modulos PWM se mostrou mais eficiênte, na geração de harmônicas, apresentou menor processamento, disponibilizando mais tempo para as outras atividades e, por fim, utilizou menos mémoria para as tabelas. Uma outra vantagem e a geraçao de sinais de baixas frequências com THD compativeis, aos de frequencias altas, característica não encontrada na técnica ponto a ponto, devido a enorme tabela pré-programada necessária. Desse modo, o método se mostrou melhor do que o ponto a ponto e assim sendo, mais adequado para novas aplicações.

\section{REFERÊNCIAS BIBLIOGRÁFICAS}

Blooming, T. M.; CARnOVale, D. J. Application of IEEE std 519-1992 Harmonic Limits. IEEE, 2006.

HAIDER, R.; ALAM, R..; YOUSUF, N. B.; SALIM, K. M. Design and Construction of Single Phase Pure Sine Wave Inverter for Photovoltaic Application. Bangladesh: IEEE/OSA/IAPR International Conference on Informatics, Electronics \& Vision, 2012.

MARCELINO, M. A.; FIOROTTO, F. A. Geração para Controle de Velocidade de Motores. Revista da Propriedade Industrial, INPI, PI-9704081-9, v. 1470, p. 19, 1999

NEACĂ, M. I.; NEACĂ, A. M. Simulation of a ThreePhase SPWM Command System with Microcontroller. România: ICATE, 2014.

RAHMAN, A. S. F.; OTHMAN, M.; RAZAK, A. R. A.; HASAN S.; ISMAIL, B.; HASSAN, S. I. S.. Microcontroller Based SPWM Generator: A Conventional Design Perspective Through Graphical Oriented Approach. Volume No. 1, Issue No. 3. Malaysia: IJITR, 2013.
SOUZA, A. R..; BARREIRO M. J., M.; MARCELINO, M. A.; GRANDINETTI, F. J. Otimização de Tabelas Préprogramadas para Geração PWM Discreta. Revista SODEBRAS, V.6, n.70, p. 3-6, out. 2011.

THAKUR, N.; LODHI, R. S. Computer Simulation of SPWM-VSI for Minimizing the starting torque and current in Asynchronous Motor Drive. Índia: International Journal of Research (IJR), 2014.

VIANA, A. N. .; BORTONI, E. C.; NOGUEIRA, F. J. H.; HADDAD. J.; NOGUEIRA, L. A. H.; VENTURINI, O. J.; YAMACHITA, R. A. Eficiência Energética: Fundamentos e Aplicações. Campinas - SP: Elektro; Universidade Federal de Itajubá; Excen e Fupai, 2012.

YING, Z.; QIAN, Y.; QIANG, Z.; LEI Z. The Generating Method of SPWM with Double-Interruption Based on DSP. China: Second International Conference on Intelligent Networks and Intelligent Systems, 2009.

WEG. Motores de Indução Alimentado por Inversores de Frequência PWM-Guia técnico. Disponível em: $<$ http://ecatalog.weg.net/files/wegnet/WEG-motores-deinducao-alimentados-por-inversores-de-frequência-pwm027-artigo-tecnico-portugues-br.pdf $>$. Acessado em: 01/03/2016.

WEG. Motores de indução alimentados por conversores de frequência PWM -Guia técnico - Revisão: Setembro de 2006. Disponível em: < http://www.coe.ufrj.br/ richard/Acionamentos/motores_de_ inducao_alimentados_por_conversores_de_frequencia_PW M.pdf > . Acessado em: 10/08/2016.

\section{COPYRIGHT}

Direitos autorais: Os autores são os únicos responsáveis pelo material incluído no artigo. 


\title{
CONCENTRAÇÃO DE TENSÕES EM PEÇAS E COMPONENTES ESTRUTURAIS ATRAVÉS DO MÉTODO DOS ELEMENTOS FINITOS
}

\author{
CONCENTRATION OF STRESSES IN STRUCUTURAL PARTS AND \\ COMPONENTS THROUGH THE FINITE ELEMENT METHOD
}

\author{
ERICK SIQUEIRA GUIDI ${ }^{1}$; FERNANDO DE AZEVEDO SILVA ${ }^{1}$; CAIO CAVAGIONI ${ }^{1}$; \\ CARLOS ALBERTO CHAVES ${ }^{2}$ \\ 1 - UNIVERSIDADE ESTADUAL PAULISTA/FEG-UNESP; 2 - UNIVERSIDADE DE TAUBATÉ \\ eguidi@uol.com.br;fazevedo@feg.unesp.br;caiocavagioni@yahoo.com.br;chaves@unitau.br
}

\begin{abstract}
Resumo - Qualquer processo de falha que possa ocorrer em uma peça provavelmente está localizado onde a tensão excedeu o nível de resistência. Sempre que uma peça ou componente possui uma variação brusca em sua geometria tais como ranhuras, furos, entalhes, ressaltos ou qualquer outro tipo de irregularidade, ocorre um aumento concentrado de tensão num determinado local da peça. $O$ objetivo deste trabalho é determinar as tensões máximas em peças e componentes estruturais por meio das equações da teoria da elasticidade em conjunto com o fator de concentração de tensão experimental e compará-las com os resultados obtidos pelo método dos elementos finitos.
\end{abstract}

Palavras-chave: Concentração de Tensão. Método dos Elementos Finitos. Componentes Estruturais.

\begin{abstract}
Any failure process that may occur in a part is likely to be located where the stress has exceeded the resistance level. Whenever a part or component has a sudden variation in its geometry such as grooves, holes, notches, rebates or any other type of irregularity, a concentrated stress increase occurs in a certain place of the piece. The objective of this work is to determine the maximum stress in structural part and component by means of the elasticity theory equations together with the experimental stress concentration factor and compare them with the results obtained by the finite element method.
\end{abstract}

Keywords: Stress Concentration. Finite Element Method. Structural Components.

\section{INTRODUÇÃO}

No atual mercado competitivo, as companhias precisam desenvolver produtos de alta qualidade, inclusive com elevada complexidade, performance e durabilidade em um curto espaço de tempo. Para atender a essa demanda de mercado, as companhias passaram a utilizar as ferramentas de análise computacional de engenharia, a fim de otimizar o projeto e ganhar competitividade (MARIM, 2009).

Em trabalho, componentes estruturais, na presença de fatores concentradores de tensão, podem ser submetidos a esforços de flexão, tração, compressão ou torção, que podem atuar isoladamente ou de maneira combinada. Assim é esperado que esses esforços atuem de forma combinada, o que leva o projetista a ter que considerar as cargas estáticas como parâmetro importante no desenvolvimento do projeto, uma vez que o componente estrutural pode estar submetido a tensões estáticas, que podem vir a provocar a falha do mesmo, devido a um fator de concentração de tensão, e podento até mesmo, provocar a falha de todo o sistema (CHAVES et al., 2016).

Muitos trabalhos tem sido desenvolvidos, relacionando fator de concentração de tensão e juntas soldadas (CAO et al., 2013).

Estudos obtendo numericamente o fator de concentração de tensão foram realizados, utilizando o método dos elementos finitos (SZYMCZAK; KOWALEWSKI; BRODECKI, 2016).

O ANSYS é um software de elementos finitos (ALVES FILHO, 2007) que vem sendo utilizado nas mais diversas classes de problemas de engenharia (WARHADPANDE, JALALAHMADI, SLACK e SADEGHI, 2010).

Silva (2012) compara resultados analíticos e numéricos, de fator de concentração de tensão, com o uso do Ansys, um software comercial que utiliza o método dos elementos finitos, em diversas geometrias utilizadas em engenharia mecânica.

Neste contexto, afirma-se a importância de estudar a concentração de tensões, visto serem nestes pontos, onde a tensão atinge valores críticos, formando o que chamamos de pontos de concentração de tensão, na qual a tensão máxima que age no material pode ser várias vezes superior à tensão calculada pela teoria da elasticidade (TJERNBERG, 2002).

Assim, em função do que foi exposto, este trabalho tem como objetivo estudar mais profundamente a concentração de tensões, bem como levantar uma comparação entre os dados obtidos teoricamente pela teoria da elasticidade, com os dados retirados dos softwares Inventor e Ansys, para três modelos de peças com geometrias diferentes (SILVA et al., 2016).

\section{METODOLOGIA}

A metodologia consiste em calcular as tensões máximas (normais e cisalhantes) em peças e componentes estruturais de duas maneiras distintas e comparar os resultados obtidos por ambos os métodos.

O primeiro método se resume em determinar primeiramente a tensão média por meio das equações da teoria da elasticidade. Posteriormente, com o auxílio dos 
gráficos que fornecem o fator de concentração de tensão, se obtém o valor da tensão máxima por meio de uma simples multiplicação entre a tensão média e o fator de concentração de tensão.

O segundo método consiste em utilizar os programas Autodesk Inventor (CRUZ, 2015) e Ansys Workbench (ANSYS, 2016), para simular qual é a tensão máxima e em qual região da peça ela ocorre, utilizando os mesmos exemplos do primeiro método, sob as mesmas condições de carga.

\section{Material utilizado}

O material utilizado em todos os modelos simulados foi o aço estrutural AISI 1020, esse material foi escolhido devido sua ampla utilização na engenharia, alta resistência e baixo custo. A Tabela 1 fornece os dados das características do material selecionado.

\begin{tabular}{|c|c|}
\hline Característica & Valor \\
\hline Módulo de elasticidade E (GPa) & 200 \\
\hline Módulo de cisalhamento G (GPa) & 76,9 \\
\hline Constante de Poisson $\boldsymbol{v}$ & 0,3 \\
\hline Densidade $\boldsymbol{\rho}\left(\mathrm{kg} / \mathrm{m}^{3}\right)$ & 7850 \\
\hline
\end{tabular}

\section{Calculo analítico das tensões no componente 1}

Calculando as tensões normais $(\sigma)$ do componente 1 (Figura 1), sem e com o concentrador geométrico de tensão, que neste caso é o rebaixo arredondado no eixo, tem-se três casos diferentes. Um para o maior diâmetro, outro para o eixo de menor diâmetro e para o caso mais critico, com menor diâmetro e com o coeficiente geométrico de tensão, como mostrado na Figura 1.

Figura 1 - Componente 1, indicação dos trechos que foram calculados as tensões normais.

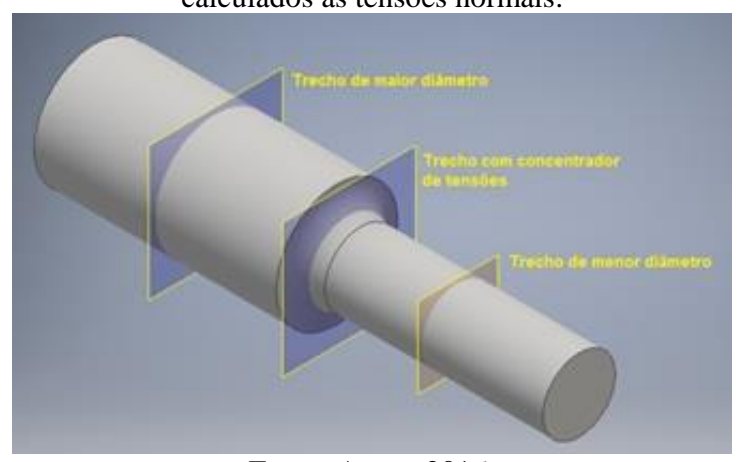

Fonte: Autor, 2016

As tensões são calculadas no primeiro caso, para o maior diâmetro, como uma razão entre carga e área (A) circular do trecho, conforme Equação 1, que estabelece a tensão normal num trecho circular sem concentradores de tensões.

$\sigma=\frac{P}{A}=\frac{4 \cdot P}{\pi \cdot D^{2}}$

Onde D é a dimensão, em mm, do maior diâmetro.

As tensões são calculadas no segundo caso, para o menor diâmetro, como uma razão entre carga e área (A) circular do trecho, conforme Equação 2, que estabelece a tensão normal num trecho circular sem concentradores de tensões.

$\sigma=\frac{P}{A}=\frac{4 \cdot P}{\pi \cdot d^{2}}$

Onde d é a dimensão, em mm, do menor diâmetro.

Para o terceiro caso, para a região mais critica, região com o concentrador geométrico de tensão (rebaixo arredondado), calculou-se novamente a tensão, que neste caso é a tensão máxima, para isto, utilizou-se a Equação 3, da tensão normal numa região retangular com concentradores de tensões, onde o Kt é o fator geométrico de concentração de tensão e $\sigma$ ' é a tensão normal corrigida pelo fator de concentração de tensões. Kt foi calculado utilizando a Equação 4, do coeficiente geométrico de concentração de tensão.

$$
\begin{aligned}
& \sigma^{\prime}=K_{t} \cdot \frac{P}{A}=K_{t} \cdot \frac{4 \cdot P}{\pi \cdot d^{2}} \\
& K_{t} \cong A \cdot\left(\frac{r}{d}\right)^{b}
\end{aligned}
$$

Os índices A e b da Equação 4 referem-se a valores empíricos e podem ser encontrados na Tabela 2, estes valores são uma função do raio e da dimensão do menor diâmetro.

Tabela 2 - Índices A e b referente à equação do calculo do Kt

\begin{tabular}{ccc}
\hline $\mathbf{D} / \mathbf{d}$ & $\mathbf{A}$ & $\mathbf{b}$ \\
\hline 2,00 & 1,01470 & $-0,32035$ \\
1,50 & 0,99957 & $-0,28221$ \\
1,30 & 0,99682 & $-0,25751$ \\
1,20 & 0,96272 & $-0,25527$ \\
1,15 & 0,98084 & $-0,22485$ \\
1,10 & 0,98450 & $-0,20818$ \\
1,07 & 0,98498 & $-0,19548$ \\
1,05 & 1,00480 & $-0,17076$ \\
1,02 & 1,01220 & $-0,12474$ \\
1,01 & 0,98413 & $-0,10474$ \\
\hline \multicolumn{3}{c}{ Fonte: Autor, 2016. }
\end{tabular}

Calculando as tensões normais $(\sigma)$ do componente 2 (Figura 2), sem e com o concentrador geométrico de tensão, que neste caso é o rebaixo arredondado na placa, tem-se três casos diferentes. Um para o maior segmento, outro para a menor área da chapa e para o caso mais critico, menor área e com o coeficiente geométrico de tensão, como mostrado na Figura 2.

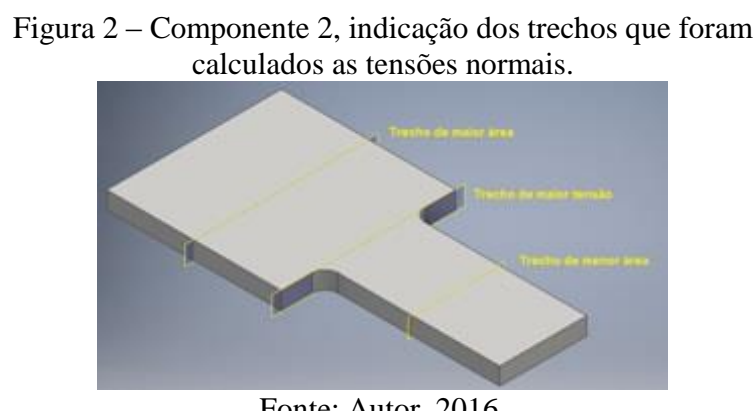

As tensões são calculadas no primeiro caso, como tensão normal num trecho retangular sem concentradores de 
tensões, como uma razão entre carga e área (A) retangular do trecho, conforme Equação 5.

$$
\sigma=\frac{P}{A}=\frac{P}{h \cdot D}
$$

Onde D é a dimensão, em mm, da maior largura da barra plana e h é a dimensão, em mm, da espessura da barra plana.

As tensões são calculadas no segundo caso, como tensão normal num trecho retangular sem concentradores de tensões, como uma razão entre carga e área (A) retangular do trecho, conforme equação 6.

$\sigma=\frac{P}{A}=\frac{P}{h \cdot d}$

Onde d é a dimensão, em mm, da menor largura da barra plana e h é a dimensão, em mm, da espessura da barra plana.

Para a região mais critica, região com o concentrador geométrico de tensão (rebaixo arredondado), calculou-se novamente a tensão, que neste caso é a tensão máxima, para isto, utilizou-se a Equação 7, onde o Kt é o fator geométrico de concentração de tensão e $\sigma$ ' é a tensão normal corrigida pelo fator de concentração de tensões. Kt foi calculado utilizando a Equação 8.

$$
\begin{aligned}
& \sigma^{\prime}=K_{t} \cdot \frac{P}{A}=K_{t} \cdot \frac{P}{h \cdot d} \\
& K_{t} \cong A \cdot\left(\frac{r}{d}\right)^{b}
\end{aligned}
$$

Os índices A e b da Equação 8 referem-se a valores empíricos e podem ser encontrados na Tabela 3, estes valores são uma função do raio e da dimensão do menor segmento.

Tabela 3 - Índices A e b referente à equação do calculo do Kt

\begin{tabular}{ccc}
\hline $\mathbf{D} / \mathbf{d}$ & $\mathbf{A}$ & $\mathbf{b}$ \\
\hline 2,00 & 1,09960 & $-0,32077$ \\
1,50 & 1,07690 & $-0,29558$ \\
1,30 & 1,05440 & $-0,27021$ \\
1,20 & 1,03510 & $-0,25084$ \\
1,15 & 1,01420 & $-0,23935$ \\
1,10 & 1,01300 & $-0,21535$ \\
1,07 & 1,01450 & $-0,19366$ \\
1,05 & 0,98797 & $-0,13848$ \\
1,02 & 1,02590 & $-0,16978$ \\
1,01 & 0,97662 & $-0,10656$ \\
\hline \multicolumn{3}{c}{ Fonte: Autor, 2016.}
\end{tabular}

\section{Malha utilizada}

A malha utilizada será a automática gerada pelo ANSYS. O motivo para tal, foi que ao esboçar-se um teste de convergência, obteve-se uma variação mínima de resultados com grandes variações na quantidade de elementos gerados, dessa forma, chega-se à conclusão de que as malhas geradas automaticamente para as duas situações estudadas estão próximas de suas configurações ótimas, levando a um menor esforço computacional.

\section{Carregamentos e restrições}

Todos os carregamentos utilizados nos modelos foram de $10 \mathrm{kN}$, aplicados de forma axial ao componente. Para todos os casos, restringiu-se o movimento na face oposta ao carregamento, a restrição de deslocamento foi para todas as direções, ou seja, $x=0, y=0$ e $z=0$, para o sistema de coordenadas adotado.

O componente 1, como mostrado na Figura 1, está modelado na Figura 3 e descrito suas dimensões e carregamento na Tabela 4 .

Tomando alguns parâmetros específicos para este modelo, tem-se que o carregamento foi aplicado de forma axial ao componente, tomando o sentido positivo do eixo $\mathrm{x}$, já a restrição foi adotada na face oposta ao do carregamento, como ilustrado na Figura 4.

Figura 3 - Componente 1, eixo com rebaixo arredondado, suas dimensões e carregamento axial.

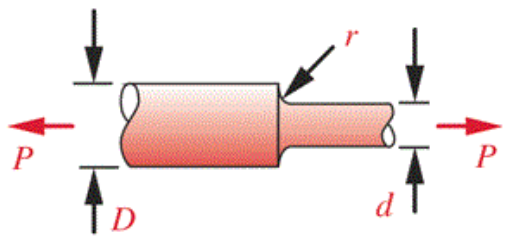

Fonte: Autor, 2016

Tabela 4 - Tabela com as dimensões e cargas do Componente 1

\begin{tabular}{lc}
\hline \multicolumn{1}{c}{ Característica } & Valor \\
\hline Diâmetro maior D & $45 \mathrm{~mm}$ \\
Diâmetro menor d & $30 \mathrm{~mm}$ \\
Raio de arredondamento r & $7,5 \mathrm{~mm}$ \\
Carga axial P & $10 \mathrm{kN}$ \\
\hline
\end{tabular}

Fonte: Autor, 2016

Figura 4 - Componente 1, indicação dos locais de aplicação dos parâmetros carga e restrição de deslocamento.

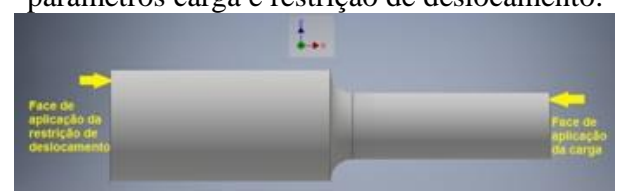

Fonte: Autor, 2016

O componente 2, como mostrado na Figura 2, está modelado na Figura 5 e descrito suas dimensões e carregamento na Tabela 3.

Figura 5 - Componente 2, barra plana com rebaixo arredondado, suas dimensões e carregamento axial.

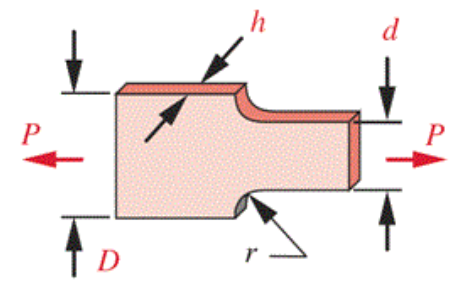

Fonte: Autor, 2016.

Tabela 5 - Tabela com as dimensões e cargas do Componente 2.

\begin{tabular}{cc}
\hline Característica & Valor \\
\hline Dimensão maior D & $100 \mathrm{~mm}$ \\
Dimensão menor d & $50 \mathrm{~mm}$ \\
Raio de arredondamento $\mathrm{r}$ & $7,5 \mathrm{~mm}$ \\
Espessura h & $10 \mathrm{~mm}$ \\
Carga axial P & $10 \mathrm{kN}$ \\
\hline \multicolumn{2}{c}{ Fonte: Autor, 2016.}
\end{tabular}

Tomando alguns parâmetros específicos para este modelo, tem-se que o carregamento foi aplicado de forma axial ao componente, tomando o sentido positivo do eixo $\mathrm{x}$, 
já a restrição foi adotada na face oposta ao do carregamento, como ilustrado na Figura 6.

Figura 6 - Componente 2, indicação dos locais de aplicação dos parâmetros carga e restrição de deslocamento.

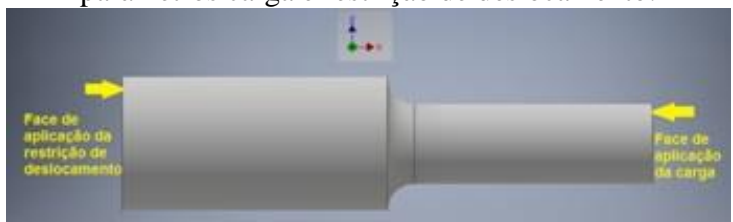

Fonte: Autor, 2016.

\section{RESULTADOS E DISCUSSÕES}

Simulação numérica do componente 1 utilizando o Autodesk Inventor

Os resultados das tensões e deslocamentos do componente 1 utilizando uma simulação numérica com o software Autodesk Inventor estão apresentados na Tabela 6 e Figuras 7 e 8.

As tensões mostradas são as tensões de von Mises e os deslocamentos são direcionais no eixo $\mathrm{x}$.

Figura 7 - Tensões de von Mises no componente 1 em uma simulação numérica com Autodesk Inventor.

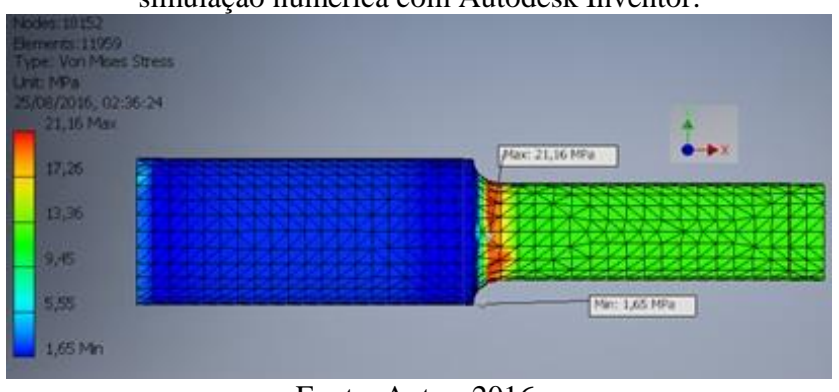

Fonte: Autor, 2016

Figura 8 - Deslocamentos no eixo x no componente 1 em uma simulação numérica com Autodesk Inventor.

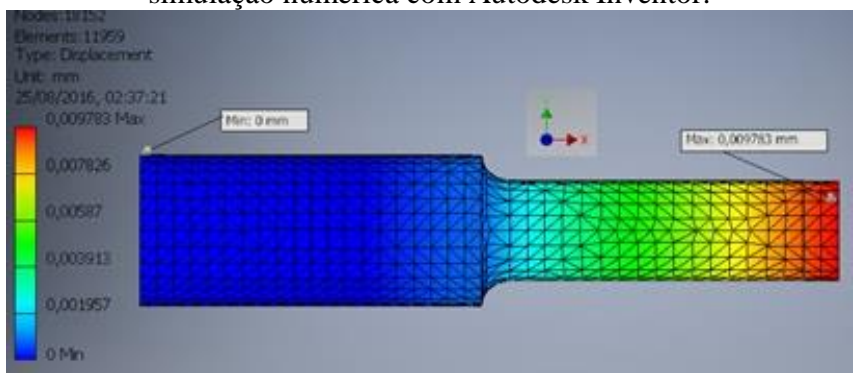

Fonte: Autor, 2016.

Tabela 6 - Resultados obtidos com a simulação numérica do componente 1 no Autodesk Inventor

\begin{tabular}{lc}
\hline \multicolumn{1}{c}{ Característica } & Valor \\
\hline Tensão Máxima & $19,41 \mathrm{MPa}$ \\
Tensão Maior Diâmetro & $6,29 \mathrm{MPa}$ \\
Tensão Menor Diâmetro & $14,15 \mathrm{MPa}$ \\
Tensão Mínima & $1,37 \mathrm{MPa}$ \\
Deslocamento Máximo & $0,01 \mathrm{~mm}$ \\
Deslocamento Mínimo & $0,00 \mathrm{~mm}$ \\
\hline
\end{tabular}

Fonte: Autor, 2016

Simulação numérica do componente 2 utilizando o Autodesk Inventor

Os resultados das tensões e deslocamentos do componente 2 utilizando uma simulação numérica com o software Autodesk Inventor estão apresentados na Tabela 7 e Figuras 9 e 10.

As tensões mostradas são as tensões de von Mises e os deslocamentos são direcionais no eixo $\mathrm{x}$.

Figura 9 - Tensões de von Mises no componente 2 em uma simulação numérica com Autodesk Inventor.

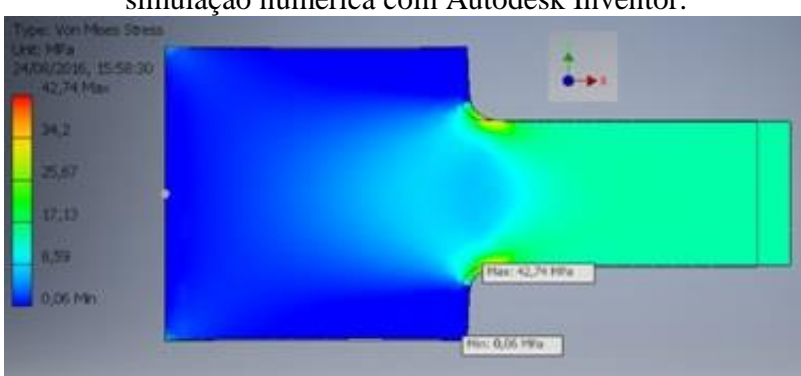

Fonte: Autor, 2016

Figura 10 - Deslocamento no eixo x no componente 2 em uma simulação numérica com Autodesk Inventor.

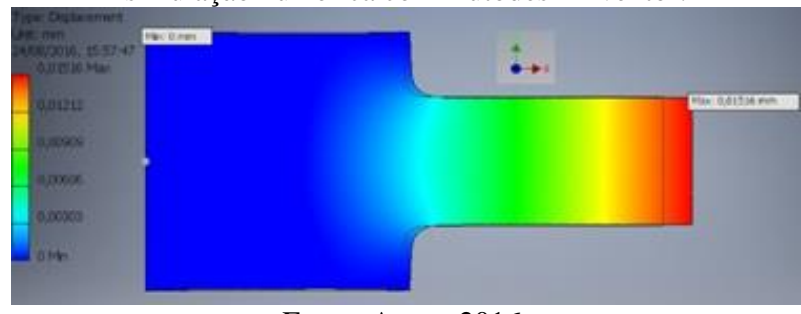

Fonte: Autor, 2016

Tabela 7 - Resultados obtidos com a simulação numérica do componente 2 no Autodesk Inventor

\begin{tabular}{lc}
\hline \multicolumn{1}{c}{ Característica } & Valor \\
\hline Tensão Máxima & $42,74 \mathrm{MPa}$ \\
Tensão Maior Diâmetro & $10,00 \mathrm{MPa}$ \\
Tensão Menor Diâmetro & $20,00 \mathrm{MPa}$ \\
Tensão Mínima & $0,06 \mathrm{MPa}$ \\
Deslocamento Máximo & $0,02 \mathrm{~mm}$ \\
Deslocamento Mínimo & $0,00 \mathrm{~mm}$ \\
\hline
\end{tabular}

Simulação numérica do componente 1 utilizando o Ansys Workbench

Os resultados das tensões e deslocamentos do componente 1 utilizando uma simulação numérica com o software Ansys Workbench estão apresentados na Tabela 8 e Figuras 11 e 12.

As tensões mostradas são as tensões de von Mises e os deslocamentos são direcionais no eixo $\mathrm{x}$.

Figura 11 - Tensões de von Mises no componente 1 em uma simulação numérica com Ansys Workbench.

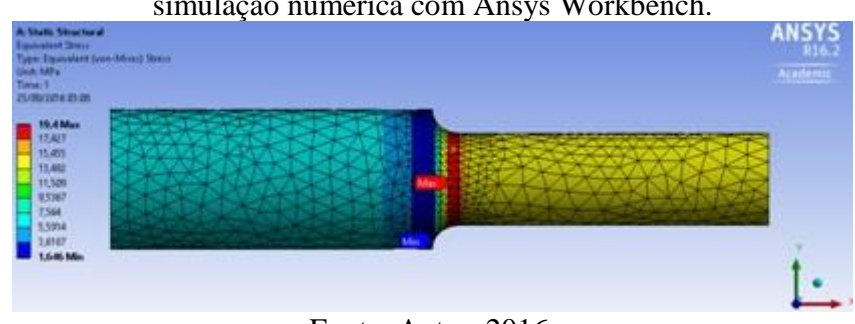

Fonte: Autor, 2016 
Figura 12 - Deslocamento no eixo x no componente 1 em uma simulação numérica com Ansys Workbench.

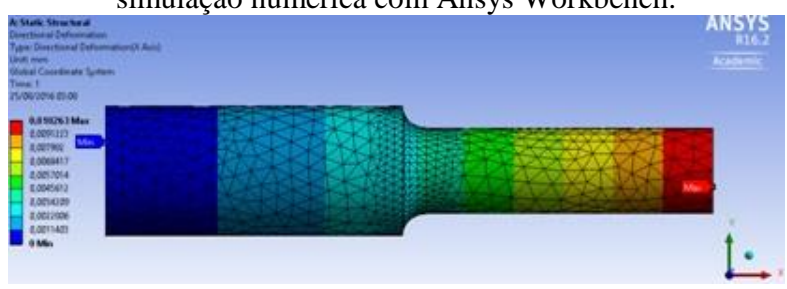

Fonte: Autor, 2016.

Tabela 8 - Resultados obtidos com a simulação numérica do componente 1 no Ansys Workbench

\begin{tabular}{lc}
\hline \multicolumn{1}{c}{ Característica } & Valor \\
\hline Tensão Máxima & $19,44 \mathrm{MPa}$ \\
Tensão Maior Diâmetro & $6,29 \mathrm{MPa}$ \\
Tensão Menor Diâmetro & $14,15 \mathrm{MPa}$ \\
Tensão Mínima & $1,29 \mathrm{MPa}$ \\
Deslocamento Máximo & $0,01 \mathrm{~mm}$ \\
Deslocamento Mínimo & $0,00 \mathrm{~mm}$ \\
\hline
\end{tabular}

Fonte: Autor, 2016.

Simulação numérica do componente 2 utilizando o Ansys Workbench

Os resultados das tensões e deslocamentos do componente 2 utilizando uma simulação numérica com o software Ansys Workbench estão apresentados na Tabela 9 e Figuras 13 e 14.

As tensões mostradas são as tensões de von Mises e os deslocamentos são direcionais no eixo $\mathrm{x}$.

Figura 13 - Tensões de von Mises no componente 2 em uma simulação numérica com Ansys Workbench.

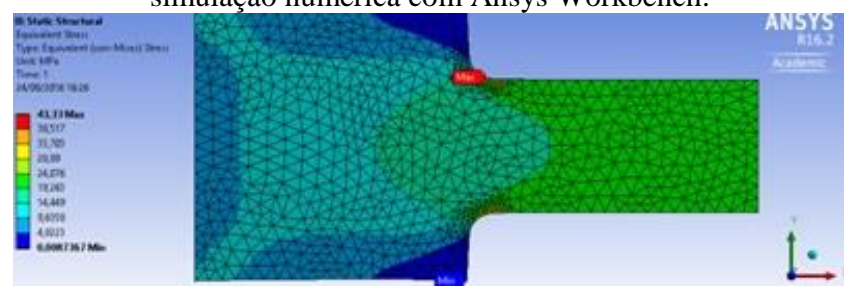

Fonte: Autor, 2016.

Figura 14 - Deslocamento no eixo x no componente 2 em uma simulação numérica com Ansys Workbench.

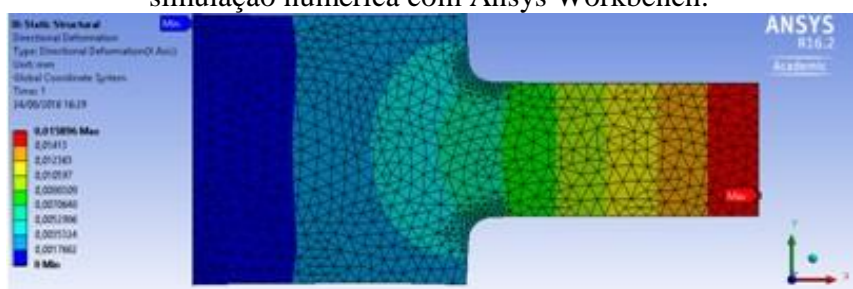

Fonte: Autor, 2016

Tabela 9 - Resultados obtidos com a simulação numérica do componente 2 no Ansys Workbench

\begin{tabular}{lc}
\hline \multicolumn{1}{c}{ Característica } & Valor \\
\hline Tensão Máxima & $43,33 \mathrm{MPa}$ \\
Tensão Maior Diâmetro & $10,00 \mathrm{MPa}$ \\
Tensão Menor Diâmetro & $20,00 \mathrm{MPa}$ \\
Tensão Mínima & $0,01 \mathrm{MPa}$ \\
Deslocamento Máximo & $0,02 \mathrm{~mm}$ \\
\hline Deslocamento Mínimo & $0,00 \mathrm{~mm}$ \\
\hline
\end{tabular}

Fonte: Autor, 2016

\section{Cálculo analítico das tensões no componente 1}

Utilizando a Equação 1 e substituindo as incógnitas da equação pelos valores encontrados na Tabela 4, obtém-se o resultado de 6,29 $\mathrm{MPa}$ para o primeiro trecho, região de maior diâmetro.

Já para o segundo trecho, região de menor diâmetro, tem-se a Equação 2, e seguindo os mesmos procedimentos para o cálculo da tensão normal da região de maior tensão, calculando-se a tensão normal nessa região obteve-se o valor de 14,15 MPa.

Para o terceiro caso, para a região mais critica, região com o concentrador geométrico de tensão (rebaixo arredondado), utilizando os valores encontrados na Tabela 2, têm-se as razões D/d e r/d respectivamente iguais a 1,5 e 0,25, com esses valores e utilizando a Equação 4, obtém-se o valor de $\mathrm{Kt}$ igual a 1,47816. Logo a tensão normal corrigida, utilizando a Equação 3, é igual a $20,91 \mathrm{MPa}$

A Tabela 10 resume os resultados para o cálculo analítico das tensões, máxima, maior diâmetro e menor diâmetro, para o componente 1 .

Tabela 10 - Tabela de Resultados obtidos com o cálculo analítico do componente 1 .

\begin{tabular}{lc}
\hline \multicolumn{1}{c}{ Característica } & Valor \\
\hline Tensão Máxima & $20,91 \mathrm{MPa}$ \\
Tensão Maior Diâmetro & $6,29 \mathrm{MPa}$ \\
Tensão Menor Diâmetro & $14,15 \mathrm{MPa}$ \\
\hline \multicolumn{2}{c}{ Fonte: Autor, 2016 }
\end{tabular}

\section{Cálculo analítico das tensões no componente 2}

Utilizando a Equação 4 e substituindo as incógnitas da equação pelos valores da Tabela 5, obtêm-se o resultado de 20,00 MPa para a região sem o concentrador geométrico de tensão.

Utilizando os valores encontrados na Tabela 3 , têm-se a razão d/W respectivamente igual a 0,2 , com esse valor e utilizando a equação 6, obtém-se o valor de 2,50197. Logo a tensão normal corrigida, utilizando a equação 5 , é igual a $62,55 \mathrm{MPa}$

A Tabela 11 resume os resultados para o cálculo analítico das tensões, máxima, maior diâmetro e menor diâmetro, para o componente 2 .

Tabela 11 - Tabela de Resultados obtidos com o cálculo analítico do componente 2 .

\begin{tabular}{l|c}
\hline \multicolumn{1}{c|}{ Característica } & Valor \\
\hline Tensão Máxima & $40,42 \mathrm{MPa}$ \\
Tensão Maior Diâmetro & $10,00 \mathrm{MPa}$ \\
Tensão Menor Diâmetro & $20,00 \mathrm{MPa}$ \\
\hline
\end{tabular}

Fonte: Autor, 2016.

\section{Análise dos resultados encontrados}

Adotando que os resultados calculados analiticamente sejam os reais, foram comparados os resultados das simulações numéricas com esses resultados. Esses valores podem ser adotados como verdadeiro, pois os cálculos analíticos são cálculos exatos e esses valores são aceitos no meio acadêmico sem nenhum preconceito. A comparação dos resultados e seus respectivos erros estão na Tabela 12 para o Autodesk Inventor e na Tabela 13 para o Ansys Workbench. 
Tabela 12 - Tabela de comparação dos resultados obtidos nas analises dos 2 modelos e os erros percentuais de cada simulação para o software comercial Autodesk Inventor.

\begin{tabular}{lccc}
\hline Modelo & $\begin{array}{c}\text { Cálculo } \\
\text { Analítico } \\
(\mathbf{M P a})\end{array}$ & $\begin{array}{c}\text { Autodesk } \\
\text { Inventor } \\
(\mathbf{M P a})\end{array}$ & $\begin{array}{c}\text { Erro } \\
\text { Inventor } \\
(\boldsymbol{\%})\end{array}$ \\
\hline 1 & 20,91 & 21,16 & 1,19 \\
2 & 40,42 & 42,74 & 5,74 \\
\hline \multicolumn{4}{c}{ Fonte: Autor, 2016 }
\end{tabular}

Tabela 13 - Tabela de comparação dos resultados obtidos nas analises dos 2 modelos e os erros percentuais de cada simulação para o software comercial Ansys Workbench.

\begin{tabular}{|c|c|c|c|}
\hline Modelo & $\begin{array}{c}\text { Cálculo } \\
\text { Analítico } \\
\text { (MPa) }\end{array}$ & $\begin{array}{c}\text { Ansys } \\
\text { Workbench } \\
\text { (MPa) } \\
\end{array}$ & $\begin{array}{c}\text { Erro } \\
\text { Ansys } \\
(\%) \\
\end{array}$ \\
\hline 1 & 20,91 & 19,44 & 7,03 \\
\hline 2 & 40,42 & 43,33 & 7,20 \\
\hline
\end{tabular}

Observa-se das Tabelas 12 e 13 que para os modelos 1 e 2 que o Ansys Workbench apresentou erros relativos maiores do que 7\%, enquanto o Autodesk Inventor apresentou erros menores do que o Ansys, principalmente para o primeiro modelo, o qual a diferença entre erro foi de $5,74 \%$.

Essa diferença entre os resultados deve-se principalmente a malha utilizada em cada simulação, para uma malha mais refinada, os resultados são mais próximos da realidade, para malhas mais grosseiras, resultados mais distantes. E como o software Ansys Workbench apresentava uma limitação em relação ao número de nós e o Autodesk Inventor não, pois o número de nós era ilimitado, acabou-se que o Autodesk Inventor apresentasse resultados melhores.

Outro fator de erro determinante é o calculo dos coeficientes geométricos de concentração de tensões, esses coeficientes foram determinados de forma experimentalmente, ou seja, são equações empíricas e consequentemente apresentam erros e imprecisões nos seus resultados. E apesar dos resultados analíticos serem aceitos no meio acadêmico, eles podem ser, de certa forma, imprecisos, o que geraria um erro entre os resultados da simulação numérica e a analítica.

\section{CONCLUSÕES}

O software Autodesk Inventor apresentou melhores resultados para as simulações feitas nos modelos selecionados do que o Ansys Workbench, mas apesar do Ansys apresentar erros maiores nos cálculos das tensões, os dois softwares podem ser amplamente utilizados nas situações aqui selecionadas, e seus resultados creditados sem grandes problemas, pois todos os erros relatados foram relativamente baixos.

Os erros de ambos os softwares foram menores do que $8 \%$, em todos os casos. Em qualquer projeto mecânico, existe uma margem de erro pré-estabelecida pelo engenheiro responsável do projeto, e que com certeza engloba esses pequenos erros de cálculos softwares. Na grande maioria dos casos essa margem de segurança corresponde a no mínimo, num caso crítico, de $10 \%$, ou seja, em todos os casos estudados, os componentes seriam aprovados e não teriam nenhum problema em sua execução, pelos cálculos aqui estabelecidos.

\section{REFERÊNCIAS BIBLIOGRÁFICAS}

ALVES FILHO, A. Elementos finitos, a base da tecnologia CAE. Ed. Érica, São Paulo, Brasil, 2007, 294p.

ANSYS 16. User`s Manual. 2016.

CAO, Y.; MENG, Z.; ZHANG, S.; TIAN, H. Fem study on the stress concentration factors of $\mathrm{K}$-joints with welding residual stress, Applied Ocean Research, v. 43, pp.195205, 2013.

CHAVES, C.A.; SILVA, F.A.; MONTEIRO, F.L. Análise de tensões estáticas em uma árvore de transmissão de uma laminadora utilizando o método dos elementos finitos, Revista SODEBRAS, v.11, n.126, pp.135-140, 2016.

MARIM, M. Utilização do método dos elementos finitos para cálculo de durabilidade de componentes mecânicos. Dissertação (Mestrado em Engenharia Mecânica) - Escola de Engenharia de São Carlos, Universidade de São Paulo São Paulo, 2009.

MATWEB (2016) AISI 1020 Steel, cold drawn, high temperature stress relieved, 50-75 $\mathrm{mm}$ (2-3 in) round.

NORTON, R. L. Projeto de máquinas: uma abordagem integrada. 2. ed. Porto Alegre: Bookman, 2004. 931 p.

SILVA, F.A.; CHAVES, C.A.; GUIDI, E.S. Análise de falha por fadiga em eixo de transmissão utilizando o método dos elementos finitos, Exacta - EP, v. 14, n. 2, pp. 207-219, 2016.

SILVA, R. G. Concentração de tensões em peças e componentes estruturais, uma abordagem através do método dos elementos finitos, 2012. 43 f. Dissertação (Graduação em Engenharia Mecânica) - Faculdade de Engenharia de Guaratinguetá, Universidade Estadual Paulista, Guaratinguetá, 2012.

SZYMCZAK, T.; KOWALEWSKI, Z.; BRODECKI, A.; Determination of artificial defects in material under monotonic tension by the use of FEM and DIC methods, Materials Today: Proceedings, v.3, issue 4, pp. 1171-1176, 2016.

TJERNBERG, A. Fatigue lives for induction hardened shafts with subsurface crack initiation. Engineering Failure Analysis, v. 9, p.45-61, 2002.

WARHADPANDE, A.; JALALAHMADI, B.; SLACK, T.; SADEGHI, F. A new finite element fatigue modeling approach for life scatter intensile steel specimens. International Journal of Fatigue, v. 32, p.685-697, 2010.

\section{COPYRIGHT}

Direitos autorais: Os autores são os únicos responsáveis pelo material incluído no artigo. 


\title{
GESTÃO DE PROCESSOS INDUSTRIAIS - APLICAÇÃO DO COMISSIONAMENTO INTEGRADO NO PROCESSO DE GA̧SEIFICAÇÃO
}

\author{
INDUSTRIAL PROCESS MANAGEMENT - APLYING THE INTEGRATED \\ COMMISSIONING IN THE GASIFICATION PROCESS
}

\author{
GLORIA MARIA ALVES NEY ${ }^{1}$; MARCIO ZAMBOTI FORTES ${ }^{1}$; GILSON LIMA ALVES BRITO ${ }^{1}$ \\ 1 - UNIVERSIDADE FEDERAL FLUMINENSE \\ $m z f @ v m . u f f . b r$
}

\begin{abstract}
Resumo - Este artigo apresenta um estudo de casso para o comissionamento do sistema de gaseificação. $O$ objetivo deste estudo é apresentar um modelo genérico de atuação para uma planta industrial e a partir deste, realizar uma simulação no software ARENA e propor uma redução de tempo na etapa de comissionamento. Será levado em consideração os principais equipamentos deste processo e será proposto um processo de comissionamento integrado.
\end{abstract}

Palavras-chave: Comissionamento. Processo de Gaseificação. Macroprocesso. Software ARENA.

Abstract - This paper presents a case study for the gasification process commissioning. The main target is to show a general model of a industrial plant and do a simulation at ARENA software to propose a reduction in time of the commissioning stage. It will be considered the main equipment of the process and it will be proposed a integrated commissioning.

Keywords: Commissioning. Gasification Process. Macro Process. ARENA Software.

\section{INTRODUÇÃO}

O comissionamento é um desafio para as empresas, pois deve ser realizado em menos tempo e com a garantia que todos os requisitos de projeto foram atendidos. $\mathrm{O}$ comissionamento de uma unidade industrial é muito importante para verificar a funcionalidade dos equipamentos que são partes dos sistemas da planta. Se o comissionamento for planejado de modo correto, é possível identificar possíveis problemas evitando retrabalho e aumento no custo.

É necessário verificar as atividades de todas as disciplinas envolvidas (mecânica, elétrica, instrumentação e controle, etc.). É comum existir uma dificuldade em definir quais são essas atividades sem retrabalho, duração e custo excessivo e estabelecer boas relações entre disciplinas. Bendiksen e Young (2015) afirmam que é durante a etapa de comissionamento que os problemas de construção surgem e, com isso, será necessário aumentar o custo e o tempo para reparar estes problemas. Logo, mudanças e melhorias serão realizadas nas atividades de comissionamento no mesmo momento em que ocorrem.

O sistema de gaseificação vem recebendo mais atenção nas últimas duas décadas graças à demanda por combustíveis limpos e a redução do uso de combustíveis fósseis (MATERAZZI et al., 2016). A gaseificação é um processo seguro e flexível, além de ser uma tecnologia comerciável que contribui para a redução do uso de petróleo e gás natural, sendo uma alternativa limpa para geração de energia, indústria de fertilizantes e indústria química. Este processo pode converter qualquer material com alto teor de carbono em gás de síntese (GSTC, 2017).

As empresas entenderam o quão complexo e sensível é a relação tempo/custo, e isto se tornou relevante para a medição dos desempenhos em relação ao gerenciamento de projeto das companhias e na identificação de áreas que precisam de melhorias (SPALEK, 2015). Shafiee et al. (2014) afirma que a configuração de sistemas pode dar suporte na tomada de decisão e apresentar possíveis alternativas.

O objetivo deste artigo é apresentar e avaliar um macrofluxo do processo de gaseificação que pode reduzir o tempo da fase de comissionamento.

\section{METODOLOGIA}

$\mathrm{Na}$ seção 3 serão apresentadas informações sobre comissionamento, o processo de gaseificação e os casos estudados (TEXACO, SHELL, LURGI e E-GAS), com base nas informações de Higman e Burgt (2011), SHELL (2014), Liebner e Ulber (2000) e CB\&I (2017), que estão disponíveis ao público (internet, livros e artigos). Na seção 4 é apresentado o macroprocesso criado a partir das literaturas de referência, citadas anteriormente, com as principais etapas do processo. Na $5^{\text {a }}$ seção, serão apresentadas as simulações realizadas no software ARENA com o objetivo de comparar o tempo de comissionamento entre os processos estudados para compreender melhor o comissionamento integrado. E por fim, na seção 6 será apresentada a conclusão sobre esta análise. O método está limitado entre os processos que utilizam gás natural e coque de petróleo como combustível. As figuras deste artigo estão apresentadas em maior resolução no Apêndice I.

\section{REFERENCIAL BIBLIOGRÁFICO}

Brito et al. (2010) afirma que o comissionamento é um processo para certificar que equipamentos da planta foram testados, instalados, projetados e estão sendo operados segundo os requisitos de operação estabelecidos pelo cliente. 
Cada empresa possui procedimentos próprios de comissionamento para cada disciplina, no documento Manual de Gestão da Engenharia (PETROBRAS, 2010) são apresentadas informações a respeito da qualificação dos funcionários que trabalharão na etapa de comissionamento. Neste documento o comissionamento é apresentado como sendo um conjunto de conhecimentos, práticas, procedimentos e habilidades com o objetivo de deixar a unidade pronta para a operação de acordo com o desempenho desejado. A transferência da etapa de projeto para a de operação precisa ser realizada de maneira rápida, organizada e segura, sendo certificada quanto ao desempenho, a confiabilidade e a rastreabilidade de informações.

Oliveira, Alencar e Costa (2015) afirmam que utilizar um sistema para a avaliação de projetos que auxiliem na tomada de decisão é priorizar o uso de recursos, desenvolver habilidades de gerenciamento e avaliar o desempenho de projetos anteriores. O uso do portfolio de projetos tem o objetivo de identificar, priorizar, gerenciar e controlar projetos e seus riscos, seus recursos e outras prioridades associadas (OLIVEIRA, ALENCAR e COSTA, 2015).

Portanto o comissionamento diz respeito a um conjunto de práticas que resultam em uma boa operação dos sistemas e os requisitos de projeto foram atendidos permitindo a partida do projeto. $\mathrm{O}$ gerenciamento da operação tem o objetivo de controlar os processos de maneira que a produção se torne mais rápida, melhor e mais barata, isto se concentra na eficiência e na efetividade dos processos (MODRAK e DIMA, 2013). Project Management Knowledge Base (2015) divide o comissionamento em cinco fases:

- Planejamento e Engenharia: nesta etapa os requisitos de contrato, a engenharia de projeto e os documentos dos fornecedores são analisados;

- Pré-comissionamento: neste momento os equipamentos, os sistemas e os subsistemas estão em conformidade. Eles são avaliados através de inspeções e de testes sem carga;

- Comissionamento: são realizados os testes nos equipamentos e nos sistemas conforme serão operados;

- Partida: é o início da operação da planta, neste momento são realizados a manutenção e os testes de desempenho;

- Operação Assistida: neste estágio a equipe de operação é treinada, as pendências são resolvidas e a unidade é entregue ao cliente.

Compreender o processo para realizar o seu planejamento de forma correta. Corso et al. (2015) afirma que um macrofluxo é composto por diversas etapas com um intervalo de tempo entre elas. Um processo é composto por atividades com um início e um fim determinados.

Identificar o macrofluxo é importante para estabelecer prioridades e ajudar na tomada de decisão, é possível conhecer quais são os processos mais complexos e que causam mais impactos (CARMO, 2016). Gerenciar processos é necessário para garantir que os processos alcancem os seus objetivos e sejam eficientes. Também é importante ter uma visão global do projeto e ter indicadores de desempenho para avaliar o macrofluxo de acordo com os objetivos da companhia. Realizar o mapeamento dos processos dá suporte na identificação de desperdícios e com os processos visíveis é possível tomar decisões, Segundo Gomes e Souza (2010).
Neste artigo será apresentado um macrofluxo do processo de gaseificação. Breault et al. (2010) afirma que a gaseificação é uma tecnologia que transforma qualquer material rico em carbono em gás de síntese. ThyssenKrupp Uhde (2014) apresenta a gaseificação como sendo uma oxidação parcial em alta temperatura de um material com altos teores de carbono em gás de síntese, este é composto, basicamente, por monóxido de carbono e hidrogênio.

Chiu et al. (2015) afirmam que deve ser considerado o ciclo de vida de um produto e como a sua produção afeta o meio ambiente. Estes produtos sustentáveis podem ser categorizados em: redução da quantidade de produto produzida, expansão do seu uso, redução do consumo de energia consumida, aumento de recursos sustentáveis e a redução dos riscos de danos ambientais. Segundo o U. S. Department of Energy (2016) a gaseificação é benéfica para o meio ambiente devido às baixas emissões de óxidos e particulados resultantes da queima de carvão, isto se deve pelo tratamento realizado após a queima do combustível. Também é possível o uso de lixo para a geração de energia através de dois processos, incineração e gaseificação. Transformar materiais não recicláveis em eletricidade reduzir a quantidade de lixo nos aterros sanitários, com isso há uma prevenção da contaminação do ar e da água (KLEIN, 2002).

Com todas as informações apresentadas sobre gaseificação, serão apresentados os processos que foram estudados para a elaboração do macrofluxo.

No processo da TEXACO, as informações foram apresentadas por Higman e Burgt (2011), o petróleo e o vapor são misturados dentro da caldeira. Esta mistura entra no gaseificador junto com o oxigênio. $\mathrm{O}$ gás de síntese junto com suas impurezas atravessa dois purificadores 3 deixam o processo como um gás de síntese limpo (HIGMAN e BURGT, 2011).

Figura 1 - Diagrama simplificado da TEXACO (em anexo). Fonte: Autores, 2017.

O segundo processo estudado foi o da SHELL, informações sobre o processo estão disponíveis em SHELL (2014). O processo de gaseificação da Shell tem a vantagem de converter diferentes materiais em gás de síntese, isto inclui óleos brutos, viscosos e com alto teor de enxofre (SHELL, 2014). Na Figura 2 é apresentado este processo de gaseificação.

Figura 2 - Diagrama de gaseificação da SHELL (em anexo). Fonte: Autores, 2017.

Higman e Burgt (2011) apresenta o gaseificador da SHELL como sendo vertical e com queimadores intermediários. Este processo reaproveita o calor que seria perdido no processo, primeiro é utilizado no resfriamento do gás de síntese e depois na água de alimentação do reator. $\mathrm{O}$ gás que deixa o gaseificador sai com uma pequena quantidade de carbono livre, este carbono é removido nas cinzas em dois estágios de lavagem com água. Após estas etapas o gás de síntese deixa o processo com uma temperatura de $40^{\circ} \mathrm{C}$.

O terceiro processo é da empresa LURGI, informações em Liebner e Ulber (2000). Este processo pode ser realizado com gás natural ou gases reciclados pré-aquecidos antes da entrada no gaseificador. $\mathrm{O}$ oxigênio também é pré-aquecido utilizando uma pequena quantidade de vapor a alta pressão 
que vem da caldeira de reaquecimento. Na torre de purificação de água há a remoção de fuligem, ácido cianídrico e amônia. Neste processo a formação de fuligem é extremamente baixa não necessitando de filtragem extra (LIEBNER e ULBER, 2000).

Nas Figuras 3 e 4 são apresentados os diagramas do processo de gaseificação da LURGI, uma vez que este possui duas formas distintas de acordo com o processo de resfriamento escolhido.

Figura 3 - Processo LURGI com sistema de resfriamento com água (em anexo). Fonte: Autores, 2017.

Figura 4 - Processo LURGI com o sistema de resfriamento de gás de síntese (em anexo). Fonte: Autores, 2017.

O último processo que será apresentado neste artigo é da E-GAS, as informações sobre o processo então contidas em CB\&I (2017). Na primeira etapa é realizado o tratamento do combustível antes de sua entrada no gaseificador, o combustível pode ser coque de petróleo ou carvão, que são esmagados e misturados com água criando uma lama. O gaseificador é de múltiplos estágios, isto aumenta a eficiência do processo e reduz o consumo de oxigênio. Quando o gás de síntese deixa o gaseificador é resfriado, o calor é recuperado e é gerado vapor a alta pressão. O gás de síntese é filtrado para a remoção das cinzas, que são tratadas e retornam ao gaseificador. No fim do processo o gás de síntese é queimado dentro de uma turbina para a geração de energia (CB\&I, 2017). Na Figura 5 é apresentado o diagrama da E-GAS.

Figura 5 - Diagrama do processo de gaseificação da E-GAS.

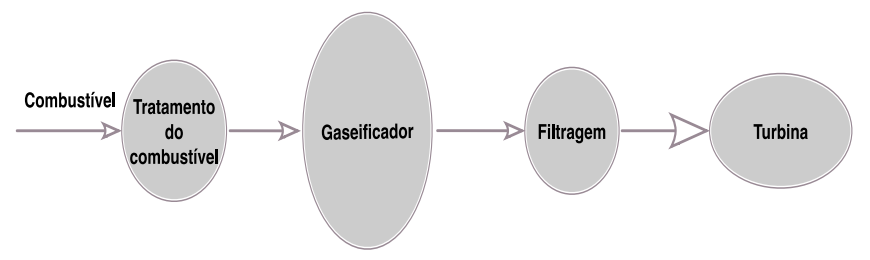

Fonte: Autores, 2017.

O processo da TEXACO foi o pioneiro no uso de petróleo e derivados como combustível no gaseificador e neste momento existia uma caldeira para a queima do combustível. Em sequencia cronológica, a SHELL apresenta anos depois um gaseificador de múltiplos estágios que melhora a eficiência do sistema e permite o uso de diversos materiais.

O gaseificador da LURGI utiliza apenas gás natural, não reaproveita rejeitos do processo e realiza tratamento dos seus rejeitos. No processo é possível reaproveitar a água no sistema de resfriamento.

Outra tecnologia apresentada é da E-GAS em que o coque de petróleo alimenta o gaseificador, gera o gás de síntese que será utilizado para movimentar uma turbina e gerar energia.

O estudo de diferentes sistemas de gaseificação permitiu o entendimento e a visualização de semelhanças entre os processos e quais são os principais equipamentos. Estas informações foram essenciais para a elaboração do macrofluxo.

\section{MACROFLUXO}

A relevância de mapear o processo de gaseificação é a possibilidade de compreender e ter uma visão global do projeto (CARMO, 2016). Mapear atividades é buscar uma excelência operacional e criar melhorias no projeto, Segundo Carmo (2016). Aleu e Aken (2015) afirmam que a melhoria continua é planejada, organizada e uma abordagem sistemática para melhorar o desempenho da organização. Modelar é realizar uma análise detalhada para alcançar o objetivo do projeto, neste artigo, o objetivo é otimizar o comissionamento do processo de gaseificação. Quando o mapeamento é finalizado é possível conhecer os pontos fortes e fracos do projeto. Conhecendo estes pontos é possível reduzir custos e falhas, simplificar e otimizar o processo (CORSO et al., 2015). Segundo Spalek (2015), a indústria possui o objetivo de ter ferramentas eficientes para a otimização do seu desempenho, isto deve ser feito para diferentes disciplinas e incluir boas práticas como referência.

Personalizar a configuração do produto/projeto tem a possibilidade da obtenção dos seguintes benefícios, Segundo Hvam (2013):

- Tempo de espera: é o tempo entre o início de um processo de especificação até ser finalizado;

- Entregas no prazo: é o percentual de quantas especificações foram completadas no tempo acordado;

- Consumo de recursos para as especificações determinadas: são as análises feitas com o intuito de revelar o consumo dos recursos;

- Qualidade das especificações: isto pode ser a avaliação do cliente, que é difícil de ser mensurada, ou pode ser a quantidade de erros no projeto;

- Otimização de produtos e serviços na especificação do processo: quando a configuração do sistema é utilizada há a possibilidade da otimização do produto segundo os requisites do cliente.

Uma outra maneira de auxiliar na tomada de decisão em um processo apresentada por Tsaur (2011) seria através de uma avaliação multicritério, o TOPSIS avalia qual é a melhor alternativa, ou seja, aquela cujo desempenho é o mais próximo a solução ideal. Segundo García-Cascales e Lamata (2012) a tomada de decisão por múlticritério consiste em encontrar a melhor alternativa entre os resultados possíveis.

Após a análise dos processos, foi possível perceber uma semelhança entre os processos. A partir dessas informações, foi feita uma simplificação com os principais sistemas que compõem o processo de gaseificação. $\mathrm{Na}$ Figura 6 é apresentado o macrofluxo elaborado.

Figura 6 - Diagrama do processo de gaseificação.

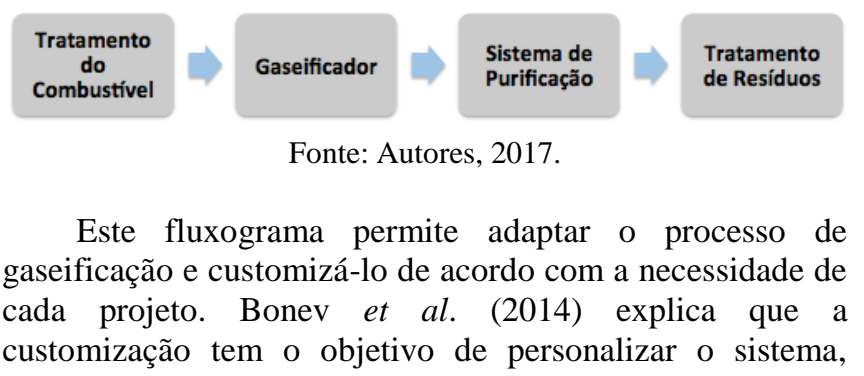


ajustar produtos, ter processos flexíveis e adaptar organizações. Outro ponto levantado por Bonev et al. (2014) é que com plataformas comuns providenciam uma alternativa de estratégia de normalização a construção tradicional.

\section{RESULTADOS}

Foram simulados os processos da LURGI, da SHELL, da TEXACO e o macrofluxo apresentado na seção anterior que será chamado de PROPOSTO. A simulação foi feita considerando 8 horas de trabalho diárias e uma duração total de 240 horas, este tempo total é importante para gerar dos dados estatísticos necessários. Para simular foi necessário conhecer o volume de combustível que entra no gaseificador. Os volumes necessários foram retirados de Higman e Burgt (2011).

Na Figura 7 é apresentado o modelo baseado no processo da LURGI. A alimentação deste gaseificador pode ser realizada com gás natural ou gases reciclados sendo préaquecido antes da entrada no reator. $\mathrm{O}$ oxigênio é também pré-aquecido usando uma pequena quantidade de vapor a alta pressão que vem da caldeira de recuperação de calor. Parte do calor é utilizado para pré-aquecimento dos combustíveis de alimentação, água de alimentação da caldeira e água desmineralizada. Finalmente, uma torre de água de purificação remove vestígios de fuligem, ácido cianídrico e amônia (LIEBNER e ULBER, 2000). O controle de carbono do processo é realizado no Metals Ash Removal System (MARS), de acordo com Higman e Burgt (2011).

Figura 7 - Processo de Gaseificação da LURGI (em anexo). Fonte: Autores, 2017.

O modelo do processo de gaseificação da SHELL é apresentado na Figura 8. Este modelo conta com três entradas de dados (oxigênio, resíduo e vapor) e são misturados dentro do gaseificador. $O$ gás deixa 0 gaseificador e passa por um processo de resfriamento e tratamento de cinzas para sair como gás de síntese.

Figura 8 - Processo de Gaseificação da SHELL (em anexo). Fonte: Autores, 2017.

Na Figura 9 é apresentado o modelo do processo de gaseificação da TEXACO. Neste processo há duas possibilidades de resfriamento do gás de síntese, na primeira o resfriamento é direto com água e na segunda é utilizando um resfriador de gás de síntese para gerar vapor. Após o resfriamento, o gás de síntese sai do reator com uma temperatura de $250^{\circ} \mathrm{C}$ e uma pressão de 80 bar. Durante o resfriamento há a remoção de impurezas que são descartadas sob a forma de uma lama (HIGMAN e BURGT, 2011). Este processo conta com três dados de entrada (vapor, resíduo e oxigênio), sendo que o vapor e o resíduo entram primeiro na caldeira para se misturarem e quando entram no gaseificador se juntam ao oxigênio.

Figura 9 - Processo de Gaseificação da TEXACO (em anexo). Fonte: Autores, 2017

O modelo do processo PROPOSTO é mostrado na Figura 10. Este processo conta com um único dado de entrada por considerar que o combustível já foi tratado previamente. O processo proposto considera apenas as etapas principais do processo podendo ser adaptado segundo a necessidade do projeto.

Figura 10 - Processo de Gaseificação PROPOSTO (em anexo). Fonte: Autores, 2017.

Nas Tabelas 1, 2, 3 e 4 são apresentados os tempos encontrados na simulação do ARENA software. Os tempos estão apresentados em horas e são referentes ao tempo que uma unidade leva para passar pelo equipamento e o tempo acumulado durante os processos, ou seja, é a soma do valor acumulado de todas as unidades que passaram pelo processo.

Tabela 1- Resultado da Simulação para a LURGI (unidade: horas).

\begin{tabular}{lcc}
\hline \multirow{2}{*}{ Equipamento } & \multicolumn{2}{c}{ LURGI } \\
\cline { 2 - 3 } & $\begin{array}{c}\text { Tempo } \\
\text { por } \\
\text { Unidade }\end{array}$ & $\begin{array}{c}\text { Tempo } \\
\text { Acumulado }\end{array}$ \\
\hline Caldeira & 2,00 & 1363,29 \\
Gaseificador & 2,49 & 1708,85 \\
MARS & 1,49 & 3050,32 \\
Purificador & 1,50 & 1028,81 \\
Purificador 2 & & \\
Resfriador & 1,00 & 681,94 \\
Resfriador 2 & & \\
Separador de & & \\
Fuligem & & \\
Tratamento & & \\
de Resíduo & & \\
\hline TOTAL & & 7833,21 \\
\hline
\end{tabular}

Tabela 2 - Resultado da Simulação para a SHELL (unidade: horas).

\begin{tabular}{lcc}
\hline & \multicolumn{2}{c}{ SHELL } \\
\cline { 2 - 3 } Equipamento & $\begin{array}{c}\text { Tempo } \\
\text { por } \\
\text { Unidade }\end{array}$ & $\begin{array}{c}\text { Tempo } \\
\text { Acumulado }\end{array}$ \\
\hline Caldeira & 2,50 & 8333,64 \\
Gaseificador & & \\
MARS & 1,50 & 4874,02 \\
Purificador & & \\
$\begin{array}{l}\text { Purificador } 2 \\
\text { Resfriador }\end{array}$ & 1,00 & 3302,38 \\
$\begin{array}{l}\text { Resfriador 2 } \\
\text { Separador de }\end{array}$ & 1,01 & 3333,92 \\
$\begin{array}{l}\text { Fuligem } \\
\text { Tratamento } \\
\text { de Resíduo }\end{array}$ & 1,51 & 4951,81 \\
\hline TOTAL & & \\
\hline
\end{tabular}


Tabela 3 - Resultado da Simulação para a TEXACO (unidade: horas).

\begin{tabular}{lcc}
\hline & \multicolumn{2}{c}{ TEXACO } \\
\cline { 2 - 3 } Equipamento & $\begin{array}{c}\text { Tempo } \\
\text { por } \\
\text { Unidade }\end{array}$ & $\begin{array}{c}\text { Tempo } \\
\text { Acumulado }\end{array}$ \\
\hline Caldeira & 2,01 & 2053,99 \\
Gaseificador & 2,49 & 3605,47 \\
MARS & & \\
Purificador & 1,50 & 2138,92 \\
Purificador 2 & 1,49 & 2139,95 \\
Resfriador & & \\
Resfriador 2 & & \\
Separador de & & \\
Fuligem & & \\
Tratamento & & \\
de Resíduo & & \\
\hline TotAL & & 9938,33 \\
\hline
\end{tabular}

Tabela 4 - Resultado da Simulação para o PROPOSTO (unidade: horas).

\begin{tabular}{|c|c|c|}
\hline \multirow[b]{2}{*}{ Equipamento } & \multicolumn{2}{|c|}{ PROPOSTO } \\
\hline & $\begin{array}{c}\text { Tempo } \\
\text { por } \\
\text { Unidade }\end{array}$ & $\begin{array}{c}\text { Tempo } \\
\text { Acumulado }\end{array}$ \\
\hline Caldeira & & \\
\hline $\begin{array}{l}\text { Gaseificador } \\
\text { MARS }\end{array}$ & 2,53 & 615,29 \\
\hline Purificador & 1,49 & 359,20 \\
\hline Purificador 2 & & \\
\hline Resfriador & & \\
\hline Resfriador 2 & & \\
\hline $\begin{array}{l}\text { Separador de } \\
\text { Fuligem }\end{array}$ & & \\
\hline $\begin{array}{l}\text { Tratamento } \\
\text { de Resíduo }\end{array}$ & 1,48 & 357,34 \\
\hline TOTAL & & 1331,83 \\
\hline
\end{tabular}

O tempo total acumulado maior foi o apresentado pelo processo da SHELL, isto indica que esta diferença é devido a uma quantidade maior de atividades, mais dados de entrada. Por consequência o custo deste processo deve ser o mais elevado, com uma necessidade maior do uso de recursos. E o menor tempo acumulado foi o do processo PROPOSTO, isto reflete que conhecendo o processo de gaseificação e realizando o comissionamento de forma integrada é possível reduzir a quantidade de horas trabalhadas, a quantidade de atividades e a consequência é a redução do uso de recursos e custos.

Nesta seção foi apresentada uma simulação realizada no software ARENA com o intuito de avaliar o tempo de cada etapa dos processos estudados e compará-los a um macrofluxo integrado. A diferença encontrada nos tempos mostra que quanto mais atividades e dados de entrada há um aumento na quantidade de horas para a realização do comissionamento.

\section{CONCLUSÃO}

O comissionamento integrado é uma excelente opção para a redução do tempo de comissionamento. A prática de ter uma equipe de comissionamento que entra no processo apenas no final do projeto (antes do startup da planta) causa um aumento de custo e de atividades para que esta equipe se familiarize com o projeto.

Este estudo vem sugerir que exista uma consolidação das atividades, ou seja, que deve ser visto quais são os principais equipamentos e realizar o comissionamento de maneira integrada e tendo uma equipe que acompanhe o projeto desde o seu início para que não haja aumento do número de atividades de comissionamento sem necessidade.

A gaseificação é um processo flexível que pode ser utilizado em diversas indústrias e com diferentes combustíveis.

Através do macrofluxo foi possível ter uma visão global do processo e através de sua análise no software ARENA foi visto a importância de se conhecer os principais equipamentos, reduzindo o excesso de atividades para então a quantidade de horas dispendidas no comissionamento ser o menor possível.

\section{REFERÊNCIAS BIBLIOGRÁFICAS}

ALEU, F. G.; AKEN, E. M. V. Systematic Literature Review of Critical Success Factors for Continuous Improvement Projects. International Journal of Lean Six Sigma. v. 7, n. 3, p. 214-232, 2015.

BENDIKSEN, T.; YOUNG, G. Commissioning of Offshore Oil and Gas Projects: The Manager's Handbook. AuthorHouse. p. 177, 2015.

BONEV, M.; WÖRÖSCH, M.; HVAM, L. Utilizing Platforms in Industrialized Construction: A Case Study of a Precast Manufacturer. Construction Innovation. v. 15, n. 1, p. 84-106, 2014.

BREAULT, R.W. Gasification Processes Old and New: A Basic Review of the Major Technologies. Energies, MDPI, v. 3, p. 216-240, 2010.

BRITO, A. S.; RIBEIRO, H.; MATOS, L. M. Comissionamento em Sistemas de Tubulações de Utilidades: Aplicação do Comissionamento a um Sistema de Resfriamento. Instituto SENAI de Educação Superior. p.195, 2010.

CARMO, J. P. Modelagem de Processos. Instituto Federal do Espírito Santo, p. 42, 2016.

CB\&I. E-Gas Technology for Coal \& Petcoke Conversion. Disponível em: hhttp://www.cbi.com/What-WeDo/Technology/Gasification/E-Gas ${ }^{\text {TM}}$-Technology-forCoal-Petcoke-Conversion>. Acesso em 18 jan. 2017.

CHIU, M. C.; CHANG, C. H.; YU-TING, C. JR-YI, C.; YIJIE, C. Redesign for Sustainability and Assemblability Using Particle Swarm Optimization Method. Journal of Industrial and Production Engineering. v. 33, n. 2, p. 103-113, 2015.

CORSO, E.; BERTIN, R.; SEVERO, E. A.; GUIMARÃES, J. C. F.; EL-AOUAR, W. A. Mapeamento do Processo Produtivo em uma Indústria de Móveis. Connexio, Universidade Potiguar, v. 4, n. 2. Disponível em 
https://repositorio.unp.br/index.php/connexio/article/view/7 55. 2015.

GARCÍA-CASCALES, M. S.; LAMATA, M. T. On Rank Reversal and TOPSIS Method. Elsevier. v. 56, p. 123 - 132, 2012. DOI: $10.1016 /$ j.mcm.2011.12.022

GOMES, D. R.; SOUZA, S. D. C. Mapeamento do Processo de Produção Em Uma Fábrica Do Pólo de Cerâmica Vermelha Do Norte Fluminense. In: XXX Encontro Nacional De Engenharia De Produção, Associação Brasileira de Engenharia de Produção, 2010.

GSTC. The Gasification Process. Disponível em <http://www.gasification-syngas.org/technology/thegasification-process/. Acesso em 18 jan. 2017.

HIGMAN, C.; BURGT, M. v. d. Gasification. Gulf Professional Publishing, p. 456, 2011.

HVAM, L.; HAUG, A.; MORTENSEN, N. H.; THUESEN, C. Observed Benefits from Product Configuration Systems. The International Journal of Industrial Engineering: Theory, Applications and Practice, 2013.

KLEIN, A. Gasification: An Alternative Process for Energy Recovery and Disposal of Municipal Solid Wastes. Columbia University, p. 50, 2002.

LIEBNER, W.; ULBER, D. MPG - Lurgi Multi Purpose Gasification: Application in "Gas-Gasification". In: 2000 Gasification Technologies Conference, Gasification \& Syngas Technologies Council, p. 1-10, 2000.

MATERAZZI, M.; LETTIERI, P.; TAYLOR, R.; CHAPMAN, C. Waste Management. Elsevier, Vol. 47, p. 256-266, 2016.

MODRAK, V.; DIMA, I. C. Recent Directions In Production And Operation Management: A Survey. International Journal of Industrial Engineering, v. 20, p. 526-533, 2013.

OLIVEIRA, E. C. B.; ALENCAR, L. H.; COSTA, A. P. C. S. An Integrated Model For Classifying Projects And Project Managers And Project Allocation: A Portfolio Management Approach. International Journal of Industrial Engineering, v. 22, p. 330-342, 2015.

PETROBRAS. Manual de Gestão da Engenharia: Volume 2: Implementação de Empreendimentos. Disponível em http://docslide.com.br/documents/01magescapitulo15-comissionamentoh.html. 2010. Acesso em 18 jan. 2017.

PROJECT MANAGEMENT KNOWLEDGE BASE. Requisitos básicos de Comissionamento. Disponível em http://pmkb.com.br/download/requisitos-basicos-decomissionamento/. 2015. Acesso em 18 jan. 2017.

SHAFIEE, S.; HVAM, L.; BONEV, M. How to Scope a Product Configuration Project in an Engineering Company. In: $6^{\text {th }}$ International Conference on Mass Customization and Personalization in Central Europe, 2014.

SHELL GLOBAL SOLUTIONS. Residue Gasification: Converting the Bottom of the Barrel into Valuable Products. Disponível em http://www.shell.com/businesscustomers/global-solutions/gasification-licensing/residuegasification/_jcr_content/par/textimage_330759342.stream/ $1444052720177 / \mathrm{a} 5 \mathrm{e} 92982$ dafaa7c1aca6dea89fc596d705c8c 08a32cae05a531e3a7ab368021e/residue-gasificationfactsheet-v2-screen.pdf. 2014. Acesso em 18 jan. 2017.

SPALEK, S. Establishing A Conceptual Model For Assessing Project Management Maturity In Industrial Companies. International Journal of Industrial Engineering. v. 22, p. 301-313, 2015.

THYSSENKRUPP UHDE. Gasification Technologies. Disponível em https://www.thyssenkrupp-industrialsolutions.com/en/suche.html?query=gasification. 2014. Acesso em 18 jan. 2017.

TSAUR, R. C. Decision Risk Analysis for Interval TOPSIS Method. Elsevier. v. 218, p. 4295 - 4304, 2011. DOI: 10.1016/j.amc.2011.10.001

U. S. DEPARTMENT OF ENERGY. Gasification. Disponível em http://energy.gov/fe/scienceinnovation/clean-coal-research/gasification. 2016. Acesso em 18 jan. 2017.

\section{COPYRIGHT}

Direitos autorais: Os autores são os únicos responsáveis pelo material incluído no artigo. 
Figura 1 - Diagrama simplificado da TEXACO (adaptado Higman e Burgt, 2011).

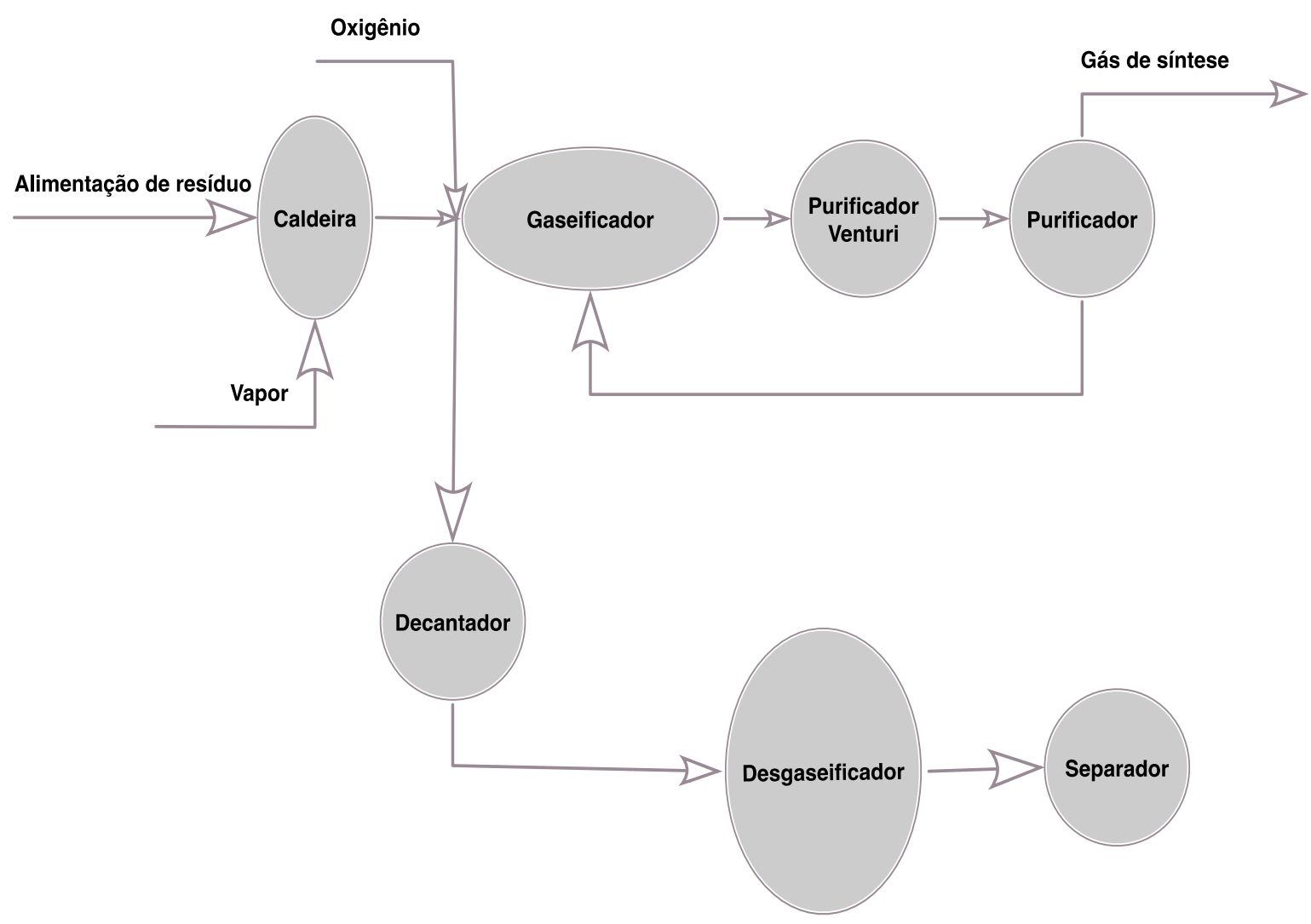

Figura 2 - Diagrama de gaseificação da SHELL (adaptado de SHELL, 2014).

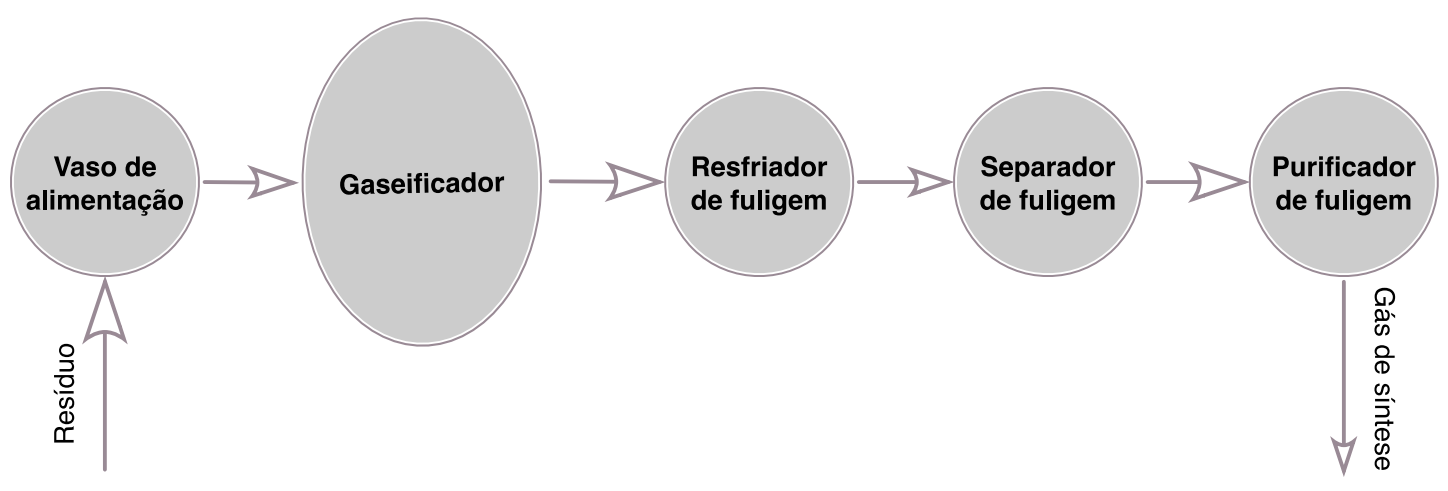


Figura 3 - Processo LURGI com sistema de resfriamento com água (adaptado de Higman e Burgt, 2011).

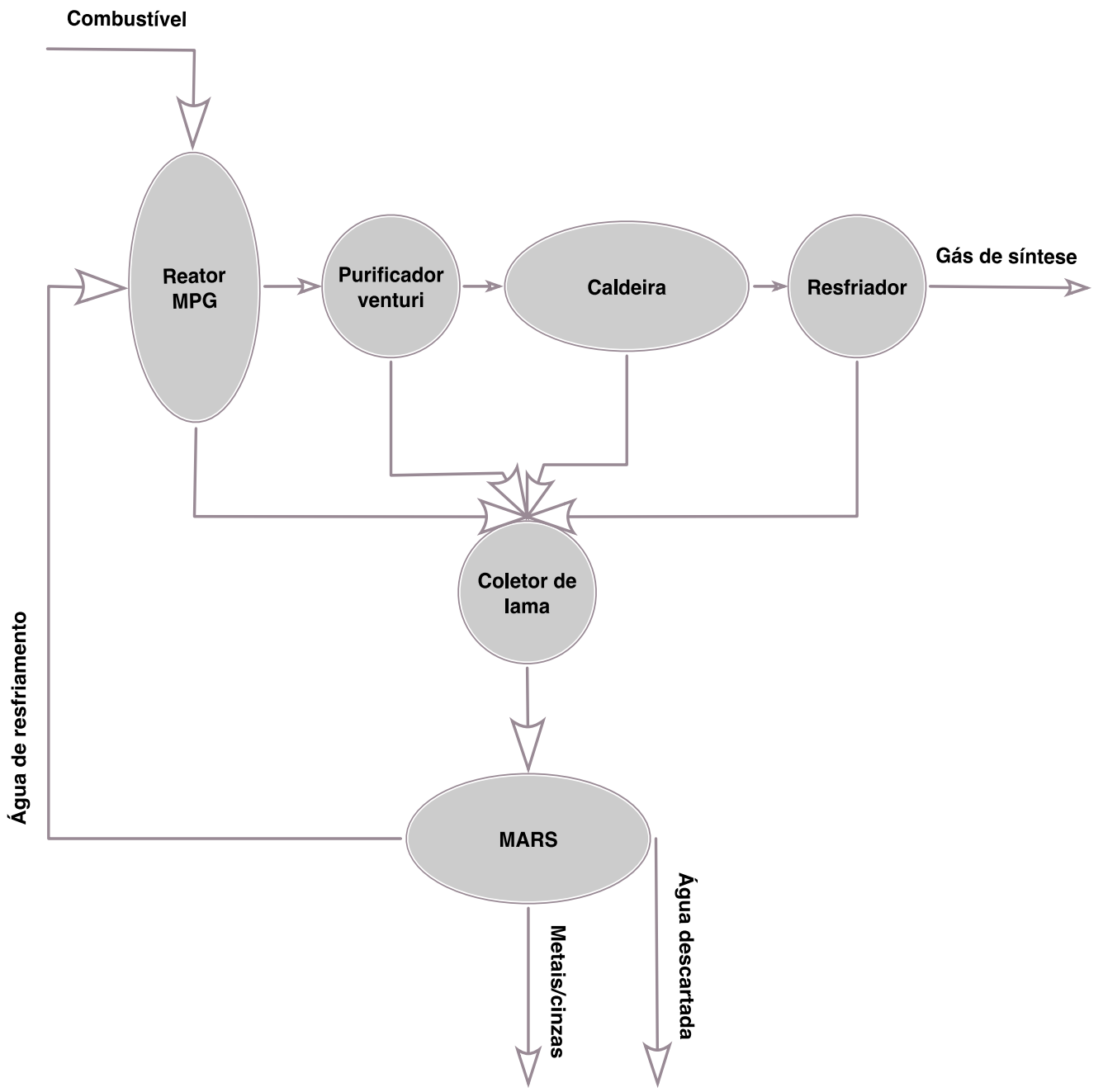

Figura 4 - Processo LURGI com o sistema de resfriamento de gás de síntese (adaptado de Higman e Burgt, 2011).

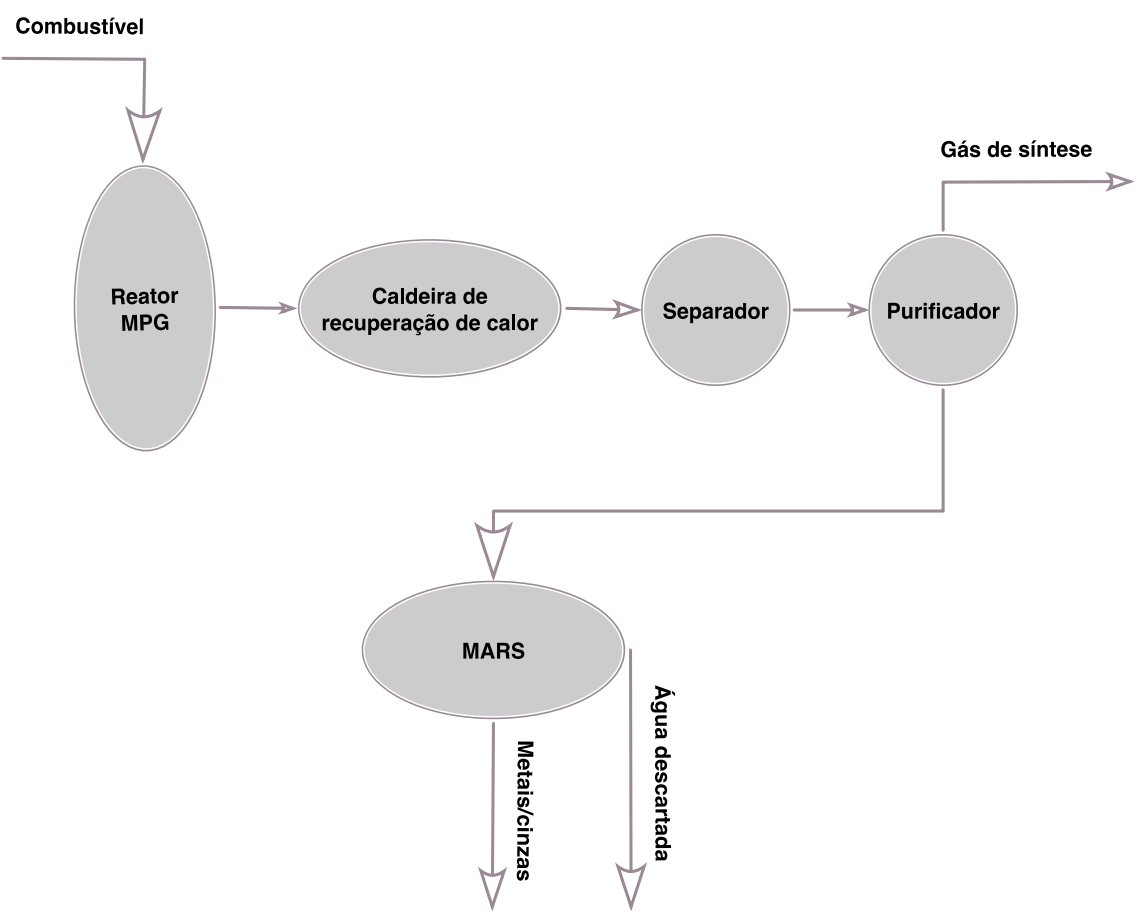


Figura 7 - Processo de Gaseificação da LURGI.

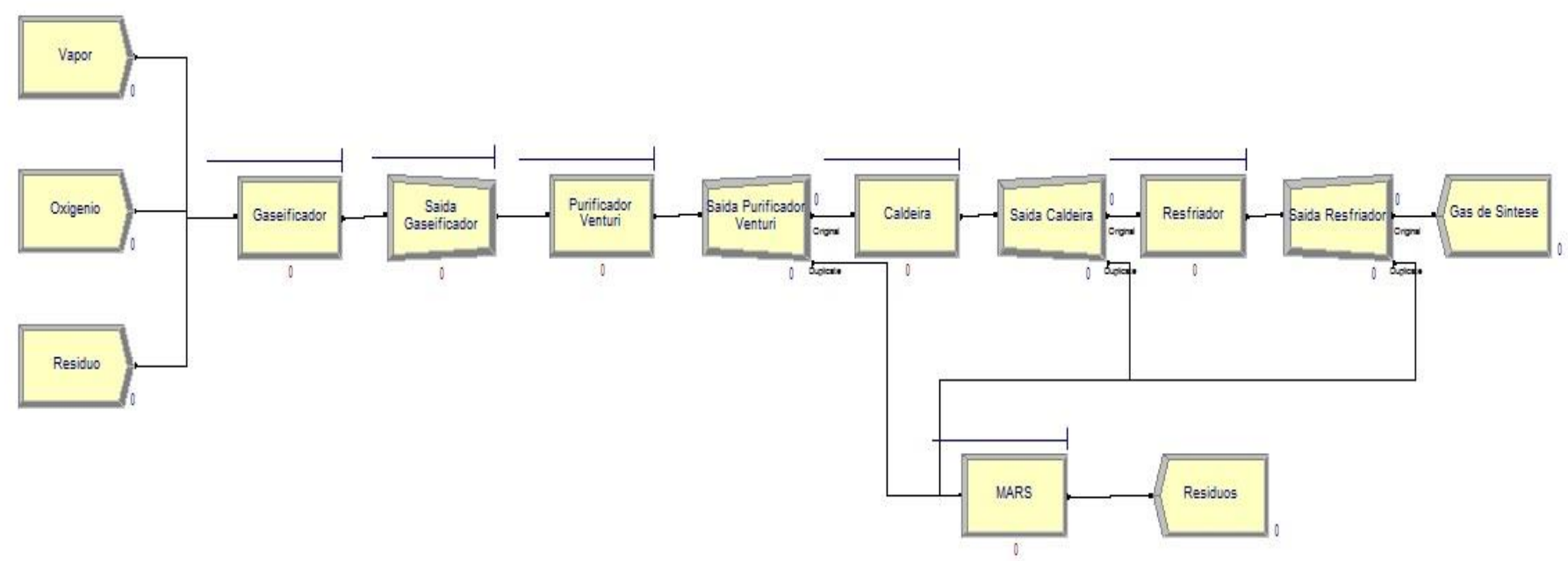

Figura 8 - Processo de Gaseificação da SHELL.

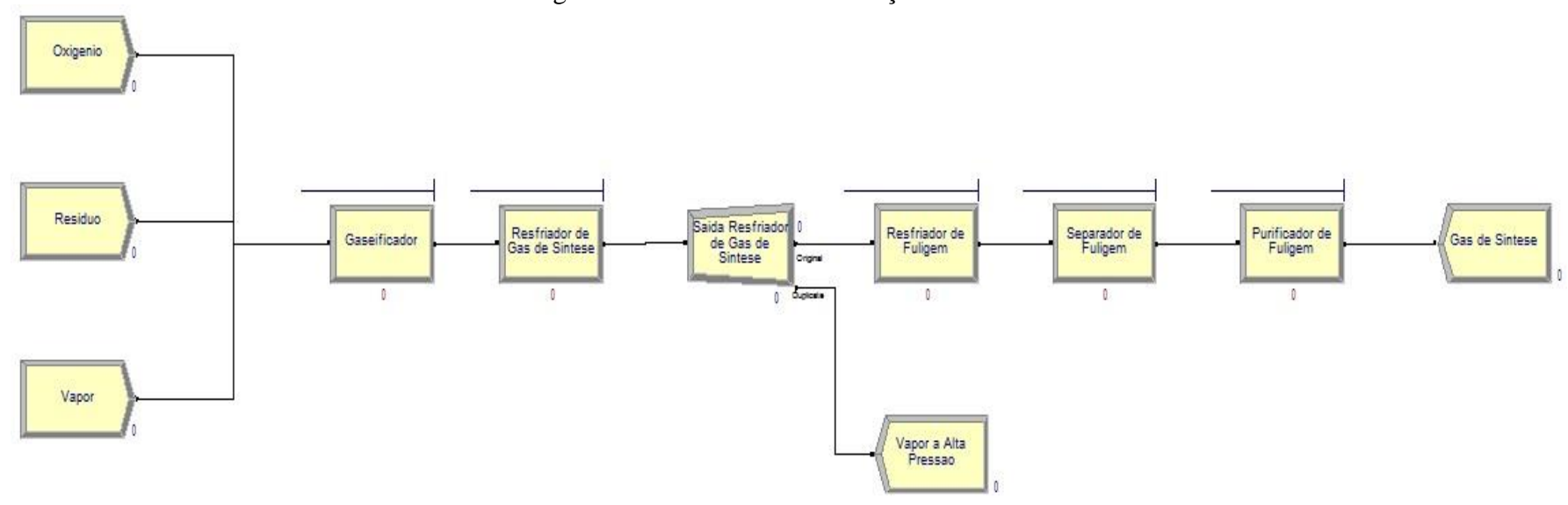

Figura 9 - Processo de Gaseificação da TEXACO.

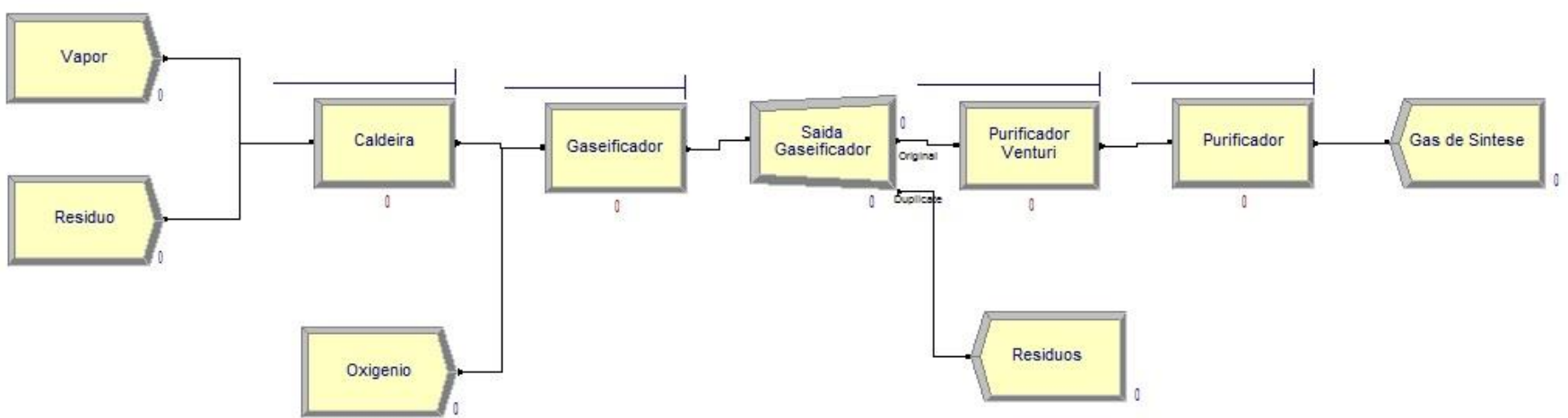

Figura 10 - Processo de Gaseificação PROPOSTO.

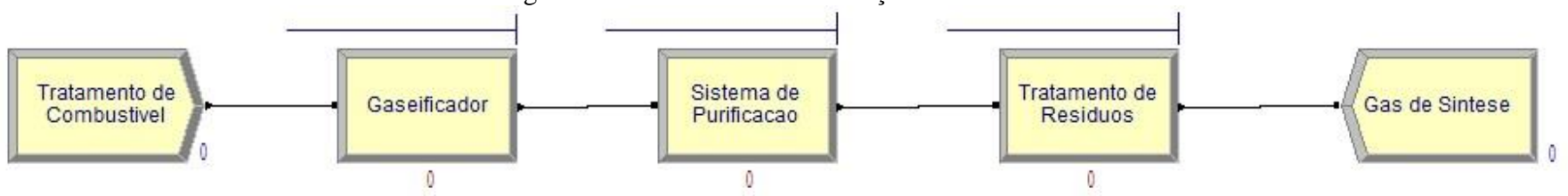

Submetido em: 22/12/2016

Aprovado em: 20/01/2017 


\title{
ALTERNATIVAS PARA REDUÇÃO DOS RESÍDUOS FINAIS DA UNIDADE DE VALORIZAÇÃO DE RECICLÁVEIS DE CURITIBA/PR
}

\author{
ALTERNATIVES FOR THE REDUCTION OF FINAL WASTE OF THE \\ CURITIBA / PR RECYCLABLE RECOVERY UNIT
}

\author{
DR. ROBSON SELEME ${ }^{1}$; DRA. ADRIANA DE PAULA LACERDA SANTOS ${ }^{1}$; EDUARDO PALMEIRA ${ }^{1}$; \\ WILIAM DE ASSIS SILVA ${ }^{1}$; DRA. IZABEL CRISTINA ZATTAR ${ }^{1}$; DRA. ALESSANDRA DE PAULA ${ }^{2}$ \\ 1 - PROGRAMA DE PÓS-GRADUAÇÃO EM ENGENHARIA DE PRODUÇÃO (UFPR); 2 - CENTRO \\ UNIVERSITÁRIO INTERNACIONAL (UNINTER) \\ robsonseleme@hotmail.com;adrianapls@ufpr.br;eduardopalmeira@ufpr.br;wiliamdeassis@gmail.com; \\ izabel.zattar@gmail.com;alessandra_rs1@hotmail.com
}

\begin{abstract}
Resumo - A destinação dos resíduos gerados pelo ser humano em virtude do desenvolvimento das cidades é um dos grandes desafios ambientais encontrados. Uma das alternativas mais conhecidas é a reciclagem, a qual somente possível devido à coleta e separação do lixo. Para este fim, a cidade de Curitiba conta com a Unidade de Valorização de Recicláveis (UVR). Este trabalho tem como objetivo, através da revisão da literatura e do estudo de caso do local, encontrar alternativas de como minimizar o material que chega até a unidade, mas não é utilizado para a reciclagem, sendo destinado a aterros sanitários. A mecanização dos processos da unidade e a conscientização da população para a facilitação da separação de materiais foram as principais soluções para o problema, conceitos já empregados anteriormente em outras cidades.
\end{abstract}

Palavras-chave: Gerenciamento de Resíduos Sólidos Urbanos. Centros de Triagem. Reciclagem. Valorização de Recicláveis.

Abstract - The disposal of waste generated by humans due to the development of cities is one of the major environmental challenges encountered. One of the most well-known alternatives is recycling, which is only possible due to the collection and separation of waste. For this purpose, the city of Curitiba has the Recycling Valuation Unit (UVR). The objective of this work is to review the literature and the case study of the site, to find alternatives to minimize material that is sent to the unit, but is not used for recycling and is destined to landfills. The mechanization of the unit processes and the awareness of the population to facilitate the separation of materials are the main solutions to the problem, concepts previously used in other cities.

Keywords: Urban Solid Waste Management. Sorting Centers. Recycling. Recyclable Valuation.

\section{INTRODUÇÃO}

A atividade humana de forma geral gera resíduo. Locais de alta atividade humana, como as grandes cidades, naturalmente, produzem uma maior quantidade destes. A forma que a sociedade foi moldada até os formatos atuais, potencializou essa geração de uma forma em que o modo de tratar esse resíduo passou a ser um tema de alta relevância.

Conforme pesquisa bibliométrica que compreendeu o período de 2011 até setembro de 2016 e realizada na base de dados Scopus com as palavras-chave "resíduos sólidos" e "solid waste", verifica-se que nos últimos cinco anos foram publicados cerca de 11.853 trabalhos de 28.616 autores e coautores diferentes, publicados em 1.558 periódicos. Refinando a pesquisa destacam-se os termos "Municipal solid waste", "Waste management", "Waste treatment" e "Recycling", com $3.945,2.270,1.688$ e 1.341 trabalhos respectivamente. Isto demonstra a preocupação gerada pelos resíduos sólidos nas grandes cidades e a busca por alternativas para este problema.

Neste contexto tem-se a cidade de Curitiba/PR que de acordo com reportagem publicada em outubro de 2013 pelo portal de notícias G1, gera 1.800 toneladas de lixo por dia, o que totaliza em média 54 mil toneladas por mês ou cerca de 650 mil toneladas por ano. Diante dessa elevada quantidade de resíduos é latente a preocupação acerca de questões ambientais, como destinação de resíduos, minimização de impactos e também questões da sustentabilidade ambiental considerandose que os recursos naturais são limitados.

Segundo Silva, Fugii e Marini (2015), a gestão dos resíduos sólidos trata-se de um problema crescente e de grande impacto na sociedade atual. Os autores apontam ainda que há crescimento na quantidade de materiais sólidos cuja degradação pelo meio ambiente é demorada. Assim, a reciclagem é uma oportunidade que não deve ser omitida. Sendo esta definida como um processo que envolve coleta, processamento, comercialização e uso de materiais que seriam considerados lixo (MEDEIROS, 2016).

A cidade de Curitiba/PR, por meio de sua prefeitura, apoia a iniciativa da Unidade de Valorização de Recicláveis (UVR), que através do Instituto Pró Cidadania de Curitiba (IPCC), recebe parte dos resíduos gerados (cerca de 35\%), com potencial de reciclagem de toda a capital paranaense. Essa coleta de resíduos é popularmente conhecida como "lixo que não é lixo" e trata-se de uma campanha que existe desde a década de 90 (IPCC, 2016).

Em visita realizada em 06 de outubro de 2016 constatouse através de observação direta e conversa com os gestores da UVR a existência de materiais que mesmo após o processo de separação dos resíduos ainda são descartados em aterros sanitários. 
Desta forma, o objetivo deste artigo busca por alternativas para minimizar a quantidade de rejeitos da UVR que serão destinados a aterro sanitário.

\section{REVISÃO DA LITERATURA}

A gestão de resíduos sólidos urbanos é um dos maiores problemas ambientais que a raça humana se depara atualmente. A expansão urbana, mesmo com várias pesquisas e avanços neste assunto, implica em problemas cada vez maiores de como tratar este tipo de resíduo sólido, com custos de coleta, transporte e armazenamento cada vez mais elevados. Estudos revelam que, em países subdesenvolvidos, o resíduo sólido gerado pelas cidades descartado de maneira imprópria, como terrenos abandonados (chamados lixões), rios, rodovias e outros, pode chegar a $90 \%$. Desta forma sendo um problema ambiental e também sendo uma ameaça à saúde pública (SHARHOLY et al., 2008).

Aterros sanitários, preparados com o intuito de receber resíduos e desta forma diminuir o impacto ambiental causado, possuem a limitação de espaço físico. As quantidades de lixo produzidas pelas grandes cidades, provocam a saturação destes locais de forma cada vez mais rápida, sem haver tempo hábil para a degradação dos dejetos. (LING, LESHCHINSKY, MOHRI, KAWABATA, 1998).

Zikmund e Stanton (1971) classificam a reciclagem de resíduos sólidos como um objetivo principal de ecologia. Por diversos benefícios associados a esse processo, como a diminuição de material descartado (freando a utilização dos aterros), a economia de energia (se comparado com a fabricação de um produto novo), redução da poluição, geração de novos empregos e a diminuição de emissões de gases. Mas para a reciclagem ser viável, fatores como políticas e incentivos governamentais, educação populacional, área disponível, administração de resíduos sólidos e mercado de materiais reciclados são necessários (TROSCHINETZ, 2009).

A primeira etapa do processo de reciclagem é a coleta e separação do material a ser processado. Num grande centro urbano, com a grande geração de lixo, isto só é viável devido a centros de triagem que ficam encarregados de separar os materiais que podem ser utilizados para reciclagem. Mas antes da coleta efetiva é necessário entender de que maneira esta acontece, a seguir comenta-se sobre a situação da coleta e potenciais métodos para a separação dos resíduos em centros de triagem.

\section{1 - Métodos de coleta dos resíduos}

A coleta trata-se do momento em que caminhões recolhem os materiais residuais e fazem o devido transporte sejam para lixões, aterros sanitários ou centros de triagem (PEIXOTO et. $a l, 2005)$. A questão aqui tratada se refere a como este lixo fica disposto para os caminhões. Conforme Maccari e Reis (2015) não há consenso definitivo de qual a maneira de dispor tais materiais para a coleta dos caminhões, dentre as duas opções mais citadas tem-se a ABNT 10.004/2004 e a CONAMA 275/2001 descritas a seguir.

A separação na fonte por meio da classificação de resíduos sólidos, conforme a Norma ABNT 10.004 de 2004 que define três classificações: Resíduo Perigoso Classe I, Resíduo não-Inerte Classe II A e Resíduo Inerte Classe II B. Os resíduos Classe I, são os considerados perigosos, pois, tem características de inflamabilidade, corrosividade, reatividade, toxidade ou patogenicidade e podem apresentar risco de periculosidade a saúde pública ou o meio ambiente. Os de
Classe II A são os materiais não-inertes que podem ter propriedades de combustibilidade, biodegrabilidade ou solubilidade em água. Já os que são recicláveis e foco deste estudo são os materiais de Classe II B, os inertes não solúveis, que não sofrem reação física, ou química (ABETRE, 2006).

Outra opção, usualmente observada em locais públicos da cidade de Curitiba é a separação através da coleta por cores padronizadas conforme a resolução CONAMA 275 de 2001. Quando a pessoa ao fazer o descarte tem à disposição diversas latas para depositar o lixo como: azul para papel, vermelho para plástico, verde para vidro, amarelo para metal, preto para madeira, laranja para resíduos perigosos, branco para resíduos relacionados a serviços de saúde, roxo para resíduos radioativos, marrom para resíduos orgânicos e cinza para material não reciclável ou contaminado que não seja possível a reutilização (MINISTÉRIO DO MEIO AMBIENTE, 2001).

Após a coleta os resíduos devem ser enviados para os centros de triagem visando a efetiva separação.

\section{2 - Métodos de separação de resíduos em centros de triagem}

A separação dos resíduos pode ser feita de forma automática, semi-automática ou manual. De acordo com Machado (2013), não é recomendado utilizar a triagem automática em cidades pequenas, onde o volume de produção não justifica o investimento necessário para a triagem automatizada. Por outro lado, utilizar o modo automatizado, possibilita uma mais alta qualidade dos produtos separados, sendo mais fáceis de vender. A capacidade do centro de triagem mecanizado é elevada se comparado com um centro de trabalho manual, sendo recomendado para cidades de grande porte. Além de viabilizar a reciclagem, a geração de empregos e a valorização dos materiais que seriam descartados, são pontos positivos destes centros.

Assim, conforme quadro 1, adaptado de Rojas (2014) pode-se observar os potenciais equipamentos para a mecanização de uma indústria de separação de resíduos, que podem eliminar o processo manual nas etapas de pré-triagem e triagem dos materiais.

Quadro 1 - Potenciais equipamentos para mecanização da UVR

\begin{tabular}{|c|c|c|}
\hline Etapa & Equipamento & Função \\
\hline Pré-Triagem & $\begin{array}{l}\text { Abre-sacos } \\
\text { Aspirador de } \\
\text { plástico filme } \\
\text { Crivo Plano } \\
\text { Crivo Rotativo } \\
\text { ou Trommel } \\
\text { Classificador de } \\
\text { ar }\end{array}$ & $\begin{array}{l}\text { Abrir sacos plásticos. } \\
\text { Aspirar os sacos plásticos. } \\
\text { Faz a separação de materiais } \\
\text { através de peneiramento. } \\
\text { Também separa materiais pelo } \\
\text { peneiramento. } \\
\text { Permite a remoção de } \\
\text { materiais finos com precisão. }\end{array}$ \\
\hline Triagem & $\begin{array}{l}\text { Mesa de triagem } \\
\text { Separadores } \\
\text { magnéticos } \\
\text { Separador por } \\
\text { corrente de } \\
\text { Foucault } \\
\text { Separador } \\
\text { balístico } \\
\text { Separador ótico }\end{array}$ & $\begin{array}{l}\text { Consiste numa esteira } \\
\text { transportadora. } \\
\text { O separador magnético para } \\
\text { captura de materiais ferrosos. } \\
\text { Permite separar os metais não } \\
\text { férricos tais como o alumínio. } \\
\text { Separa materiais rolantes. } \\
\text { Classifica e separa os } \\
\text { materiais em diversas } \\
\text { categorias, como por diferente } \\
\text { tipos de plástico. }\end{array}$ \\
\hline
\end{tabular}




\section{MÉTODO DE PESQUISA}

O método proposto foi a revisão da literatura bem como a análise dos dados obtidos em visita realizada à UVR em outubro de 2016. Assim, este artigo trata-se de um estudo de caso definido conforme Yin (2010) como "a investigação empírica que permite a análise de um fenômeno contemporâneo dentro de seu contexto da vida real, especialmente quando os limites entre o fenômeno e o contexto não estão claramente definidos".

A figura 1 ilustra as técnicas utilizadas em cada fase da pesquisa conforme a estrutura adaptada de Miguel (2010)

Figura 1 - Metodologia adotada na pesquisa.

\begin{tabular}{|c|c|c|}
\hline Etapa & & Técnica utilizada \\
\hline $\begin{array}{c}\text { Definir uma estrutura conceitual- } \\
\text { teórica }\end{array}$ & $\rightarrow$ & $\begin{array}{l}\text { Definição de objefivos } \\
\text { Revisẫo da literatura }\end{array}$ \\
\hline Planejar o caso & $\rightarrow$ & $\begin{array}{c}\text { Revisão da literatura } \\
\text { Escolha da unidade de análise }\end{array}$ \\
\hline Coletar os dados & $\rightarrow$ & $\begin{array}{c}\text { Visita a UVR } \\
\text { Registro dos dados }\end{array}$ \\
\hline Analisar os dados & $\rightarrow$ & $\begin{array}{l}\text { Identificaçãa causalidade } \\
\text { Construção de painel }\end{array}$ \\
\hline Gerar relatório & $\rightarrow$ & Produção da narrativa \\
\hline
\end{tabular}

Fonte: Adaptado de Miguel, 2010.

Conforme figura 1, após definida a estrutura teórica almejada pelo trabalho, buscou-se a definição de objetivos e o mapeamento da literatura. Após isso, paralelamente ao planejamento do caso foi feita a revisão da literatura e a escolha da Unidade de Valorização de Recicláveis (UVR) como objeto da análise. Depois, durante a coleta de dados realizou-se o registro das informações por meio de observação direta dos fenômenos in loco e dados apresentados pelos gestores da UVR. Na análise de dados buscou-se fazer as devidas correlações entre a bibliografia pesquisada e o caso visitado de modo a propor alternativas para solução do problema que é a minimização da quantidade de resíduos finais que a UVR ainda envia para o aterro sanitário. Por fim foi gerado o presente relatório da pesquisa.

\section{VISITA À UVR}

A coleta dos dados deste estudo de caso aconteceu em 06 de outubro de 2016 em visita à Unidade de Valorização de Recicláveis (UVR). A localização desta unidade fica no município de Campo Magro na região metropolitana de Curitiba estado do Paraná, distante em linha reta aproximadamente $22 \mathrm{~km}$ do centro da cidade de Curitiba.

Durante esta visita foram apresentadas informações referentes à gestão da mesma, como a quantidade média de resíduos recebidos pela unidade que é de 200 toneladas por semana ou 800 toneladas/mês. O conhecimento de que a UVR não faz a gestão total dos resíduos recicláveis de Curitiba, mas sim de cerca de $35 \%$, sendo que o restante dos resíduos é coletado pelas pessoas conhecidas como "carrinheiros" e destinada a atravessadores.
Com relação à demanda de material na usina, esta apresenta certa sazonalidade na chegada dos resíduos, sendo que durante a semana a taxa de caminhões carregados de lixo é de 10 por dia e nos finais de semana esta taxa chega a 36 caminhões. Outro elemento de sazonalidade é o mês de dezembro, quando este sozinho chega a totalizar 1600 toneladas de resíduos.

Sobre o processo de produção aplicado a usina, segundo o gestor da mesma, é uma produção em massa, com linhas para a coleta. Basicamente, quando um caminhão carregado de resíduos chega à usina o lixo está armazenado em sacolas plásticas, que são abertas manualmente e esvaziadas numa esteira que sobe até um elemento parecido com um funil, etapa que pode ser considera como a pré-triagem dos resíduos. Deste funil o lixo desce por gravidade até outra esteira disposta em linha na qual diversos operários estão ao lado da mesma, estes operários farão a seleção manual dos materiais que serão reciclados. Basicamente os critérios de escolha dos materiais são a separação de metais, plásticos, vidros e papéis, sendo que segundo informado a quantidade de itens diferentes que podem ser separados chega até ao número de 70.

Após a coleta dos respetivos materiais estes são armazenados em tambores como ilustrado na figura 2 .

Figura 2 - Tambores de armazenamento.

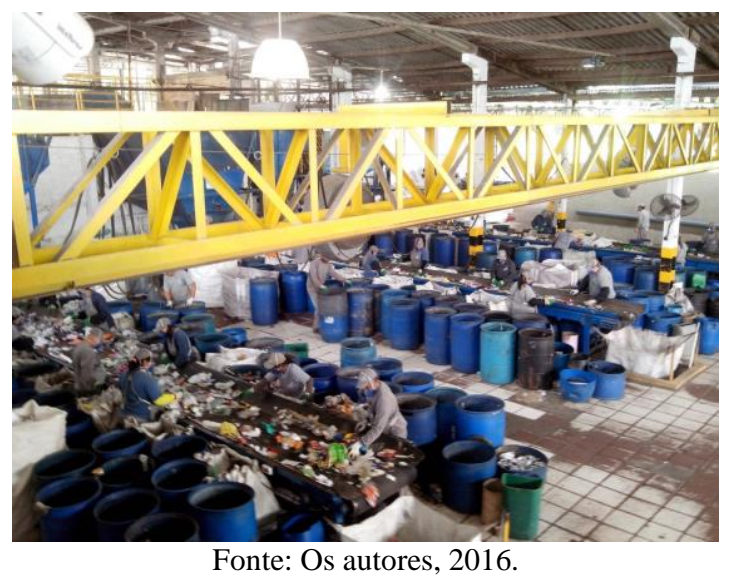

Salienta-se que durante este processo é visível a quantidade de material que não é selecionado manualmente e que será posteriormente descartado em aterro sanitário como mostrado na figura 3 .

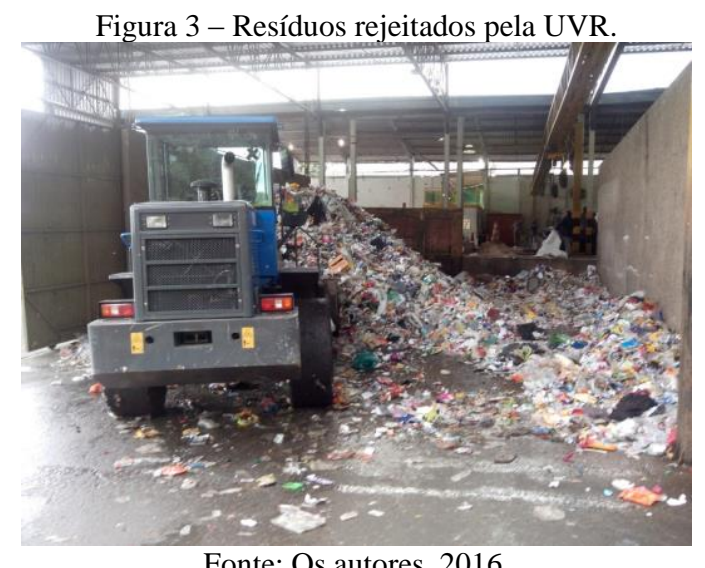

Conforme informado pela usina do total recebido cerca de $70 \%$ é separada e $30 \%$ acabará indo para aterro sanitário. 
Com relação ao destino para o aterro sanitário, este se localiza em outra localidade da região metropolitana de Curitiba, no caso o município de Fazenda Rio Grande, que está localizado a mais de $40 \mathrm{~km}$ em linha reta da UVR.

Assim, a etapa de triagem dos materiais está concluída e continuando o processo os materiais que foram separados em tambores serão posteriormente prensados e pesados em forma de cubos (figura 4) para facilitar o transporte por paleteiras e armazenados em barracão, que são as fases de compactação e armazenamento. Após o acúmulo de certa quantidade de material, empresas interessadas na compra destes materiais farão a coleta para posterior processamento para reuso, como a reciclagem por exemplo.

Figura 4 - Materiais separados aguardando transporte.

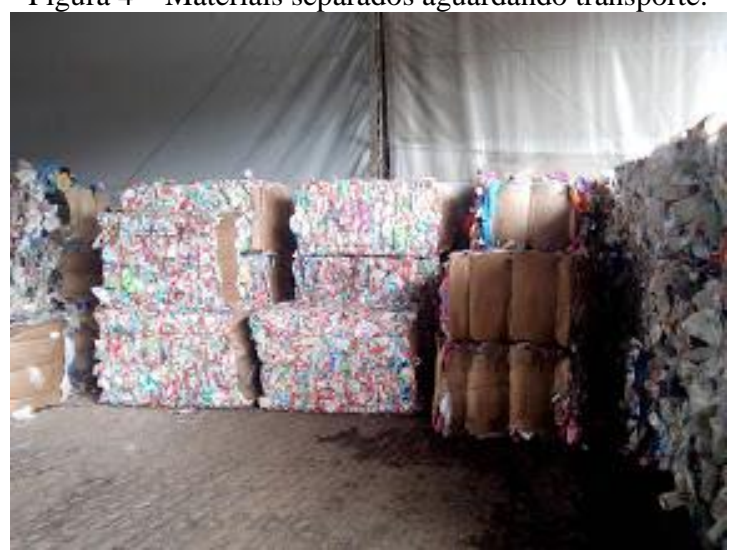

Fonte: Os autores, 2016.

Desta forma, o processo pode ser resumido conforme a figura 5, nas etapas básicas de descarregamento (prétriagem) dos materiais que chegam de caminhões, a triagem dos materiais que no processo atual ainda é, em partes, manual, a compactação e pesagem e o armazenamento até a coleta pelas empresas interessadas.

Figura 5 - Fluxo de funcionamento atual da UVR.

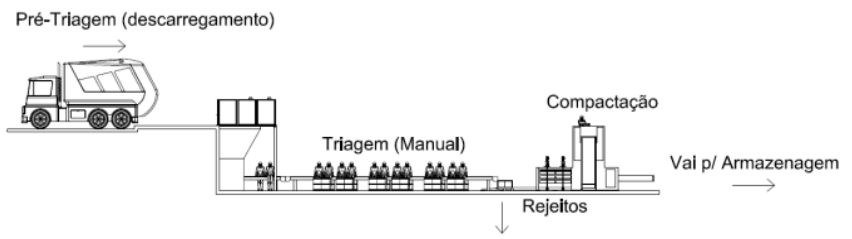

Fonte: Os autores, 2016.

Outras observações sobre o processo são o elevado grau de absenteísmo dos funcionários talvez em função da insalubridade do local. A usina informou que lá trabalham cerca de 80 funcionários divididos em 2 turnos e que certa quantidade costuma faltar desfalcando as equipes de trabalho.

Deste contexto, ficou latente a preocupação com a quantidade que mesmo em face da separação é perdida e destinada a aterros. Destes rejeitos verifica-se que estes têm em sua composição pequeno tamanho, estão úmidos e geralmente são materiais sujos como embalagens de iogurte ou também plásticos metalizados utilizados como embalagem de salgadinho por exemplo. Com relação ao tamanho pequeno é justificada a transformação em rejeito, pois como o processo é manual não faria sentido a mão de obra gastar energia selecionando pequenas unidades em detrimento de outros resíduos maiores, com mais volume e peso para valorização.
Obviamente materiais que não podem ser valorizados devem ser descartados, mas ainda se constatou que mesmo sendo uma usina para destinação de reciclados, esta recebe materiais incorretamente como resíduos sanitários, remédios, lâmpadas fluorescentes entre outros, que são materiais não passíveis de valorização. Para estes materiais existem políticas específicas como, por exemplo, na cidade de Curitiba que é o caso da coleta de lixo tóxico que é realizada de forma itinerante, a cada dia um caminhão que faz esta coleta específica fica em um ponto estratégico da cidade, e é nesses lugares que a população deve destinar estes materiais (CURITIBA, 2013).

Além desta preocupação, podem-se questionar os impactos e custos inerentes as distâncias que estes resíduos percorrem, seja até a UVR, ou até o aterro sanitário na Fazenda Rio Grande. Este transporte é feito por caminhões movidos a combustíveis fósseis e que por sua vez são também poluidores

\section{ANÁLISE E RESULTADOS}

Em seu trabalho Rojas (2014) apresenta uma hierarquia estratégica adotada pela União Europeia para gerenciamento de resíduos. Esta hierarquia começa, sobretudo com a prevenção, que deve ser a conscientização da população para se evitar descartes e consumos inadequados, em seguida a reutilização que pede aos consumidores que reutilizam ainda em suas residências o máximo possível todo e qualquer material. Não sendo isso possível vem o conceito de reciclagem, quando neste contexto se pode encaixar a UVR, seguido de outros tipos de valorização como, por exemplo, a compostagem e a utilização como fonte de energia, para, por fim, a eliminação quando nada mais se pode fazer com determinado material.

Assim, possíveis soluções para redução da quantidade de resíduos da UVR começam primeiramente com a consciência da população e por técnicas na própria UVR. Conforme detalhado a seguir.

\section{1 - Participação da população no processo}

Da observação do processo produtivo da UVR percebe-se que um dos problemas que impede a total separação é o envio inadequado dos resíduos pela população, como, por exemplo, devido à separação inadequada. Conforme Galbiati (2001) a separação dos resíduos direto na fonte geradora é a chave para a coleta seletiva, pois evita a perda da qualidade dos recicláveis e melhora as condições de trabalho dos profissionais desta cadeia.

Para o presente estudo de caso fica a questão sobre qual seria a melhor forma de separação dos resíduos por parte da população, se o sistema por cores do CONAMA, ou a proposta pela ABNT. Certamente a separação extrema por cores seria a maneira mais eficiente, no entanto, esta depende de investimento em educação e mobilização cultural para que toda a população fique consciente e também da disposição de todas as cores de latas de lixo. Assim para o presente caso da UVR, nas residências talvez apenas a separação entre inertes e não inertes, seja a melhor opção para o momento, sendo que é fundamental que haja a separação entre resíduos orgânicos úmidos, secos e sanitários. Desta forma, os resíduos orgânicos podem ser destinados a compostagem, os secos devidamente reciclados 
e os sanitários enviados a destinação correta para os aterros (GALBIALTI, 2001).

\section{2 - Alternativas para a UVR}

Já, nos centros de triagem (UVR), conforme observado em outros países que vem apresentando elevada taxa de separação e reutilização de recicláveis como, Espanha, Alemanha e Suécia (SPERANDIO, 2011; LAZARETTI, 2012; MACHADO, 2013), a solução para melhoria dos índices de separação está possivelmente na mecanização.

A experiência desses países mostra que aliada à conscientização educacional da população e a mecanização, o lixo pode deixar de ser um problema para ser uma solução. A solução no que tange ao melhor aproveitamento dos recursos e também como solução para geração de energia, ou fertilizantes para hortas.

Dentre as alternativas de mecanização tem-se de casos como o da cidade de Barcelona na Espanha que utiliza de sistemas de coleta por meio de dutos subterrâneos, no qual o lixo é coletado em pontos estratégicos da cidade e por um sistema de tubulação a vácuo ele é transportado, já parcialmente separado até estações de tratamento onde a mecanização fará a separação completa do material a ser reciclado (LAZARETTI, 2012). Neste sistema se observa a vantagem da eliminação dos caminhões para transporte do lixo e consequentemente eliminação de emissões de gases tóxicos dos combustíveis fósseis.

Nos casos da Alemanha e Suécia, a mecanização junto à cultura local de separação traz bons resultados no que tange o reaproveitamento dos materiais reciclados, nestes países o cidadão pode ser remunerado pela separação, como ocorre nos terminais de coleta de garrafas de vidro, quando o próprio consumidor separa as garrafas e as deposita em máquinas que contabilizam a quantidade e mensuram um valor a ser pago para o consumidor. Tal iniciativa incentiva a separação do lixo (MACHADO, 2013).

Para segregação destes materiais sugere-se a mecanização proposta por Gomes (2014) e Rojas (2014).

A figura 6 é uma proposta de como poderia ser a integração entre as ferramentas para esta mecanização.

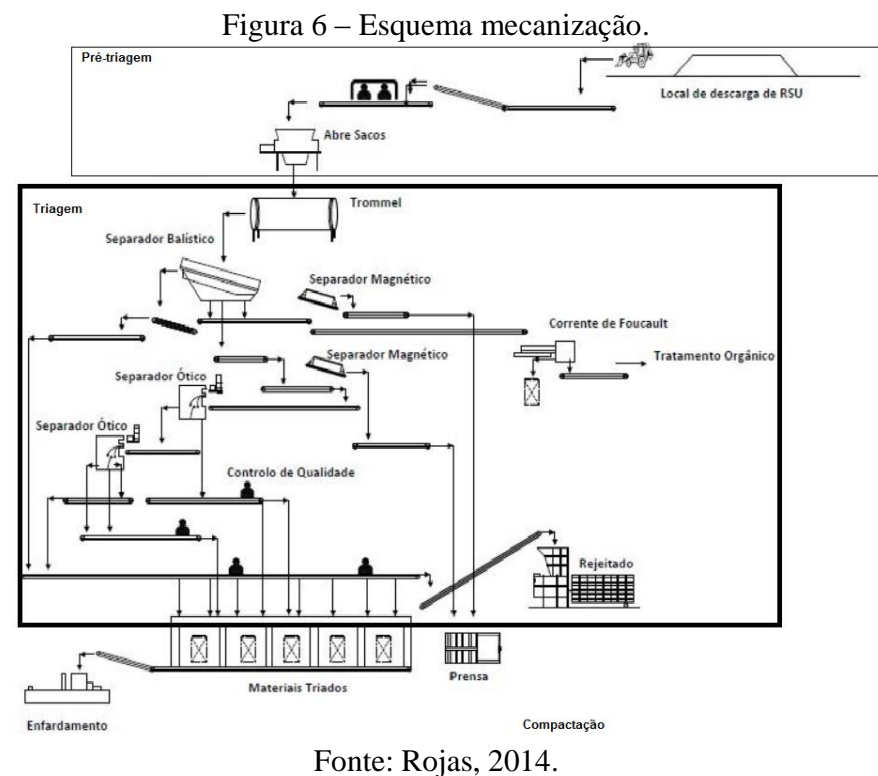

Primeiramente os sacos de lixo coletados, através de uma esteira passariam por uma inspeção geral manual, para a remoção de materiais que possam prejudicar os equipamentos de triagem, como materiais de grandes dimensões. A seguir, os sacos plásticos passariam pelo abresacos, deixando todo o material de dentro disponível para a separação. Um aspirador de sacos poderia estar trabalhando em conjunto com o abre-sacos. Os resíduos seguiriam para um trommel, que faria a separação por peneiramento dos materiais menores.

Um separador balístico seria responsável por separar latas, garrafas e outros materiais rolantes. Estes passariam por separadores magnéticos e separadores por corrente de Foucault assim separando os materiais férricos e não férricos.

O restante dos objetos que não foi separado pelo separador balístico ("materiais não-rolantes") passaria por separadores ópticos que fariam a separação de materiais específicos. De acordo de como cada um desses instrumentos é programado, um tipo de material seria separado por ele.

A etapa final seria um controle de qualidade manual, onde colaboradores da unidade fariam um controle visual dos objetos separados. Como todos os resíduos já passaram por diversas separações, o trabalho destes funcionários seria muito mais simples do que é atualmente. Por fim os materiais triados seriam compactados e separados para serem enviados às indústrias de reciclagem ou enviados à aterros sanitários.

A mecanização do processo tende a eliminar o contato direto dos trabalhadores com os resíduos e consequentemente evitar acidentes de trabalho ou contaminação, por outro lado exigirá desses trabalhadores mais preparo e treinamento para operação das máquinas, o que certamente exigirá investimentos em educação para a mão-de-obra. Outro percalço da mecanização é que eventualmente este pode acarretar na redução dos postos de trabalho o que pode gerar desemprego a uma mão de obra frágil.

Mas é a mecanização que pode proporcionar melhores níveis de separação dos materiais conforme apresentou em seu trabalho Gomes (2014) tinha incialmente uma taxa de refugo de $21,3 \%$ e com a mecanização esta taxa reduziu para $13,2 \%$. Outro exemplo que ilustra o potencial da mecanização está na cidade de São Paulo que inaugurou a primeira usina de reciclagem mecanizada da América Latina em 2014 e que sozinha tem capacidade para processar 250 toneladas de resíduos por dia (BRASIL, 2014), praticamente a demanda semanal da UVR Curitiba.

\section{CONCLUSÕES}

A gestão dos resíduos sólidos urbanos é um problema latente, seja pela quantidade de publicações acerca do tema, seja, pela quantidade de resíduos gerados diariamente pelas populações. Diante deste problema fica clara a importância da conscientização e tomada de decisões no sentido de se minimizar o problema.

Como observado neste trabalho, existem iniciativas como a de Curitiba/PR que por meio de um programa ambiental o "lixo que não é lixo" faz a coleta seletiva, e apoia a estrutura da Unidade de Valorização de Resíduos (UVR), que se trata de um centro de triagem, onde são separados materiais com potencial para reciclagem.

No entanto, mesmo que a UVR receba somente materiais oriundos de uma coleta seletiva, a mesma não é capaz de separar todo o material e ainda envia para o aterro 
sanitário, como rejeitos, cerca de $30 \%$ de todo material por ela processado.

O que se observou durante a visita à UVR é que mesmo com alguma mecanização (esteiras, máquina de prensa, empilhadeira) a separação efetiva dos materiais ainda é manual. Basicamente é a mão de obra que separa visualmente os materiais entre os seus diferentes tipos (metal, vidro, plástico, papel). Outro obstáculo verificado foi a quantidade de material que passa pela unidade e é descartado por não haver mercado para a comercialização do mesmo.

Diante deste elevado número de rejeitos, este trabalho buscou entender o processo e buscar alternativas para minimizar tal taxa. Verificou-se que será necessário para redução desse descarte envolver a população e investimentos em mecanização na UVR.

Com relação à população deve-se trabalhar com a conscientização ambiental, de modo ampliar a quantidade separada e também, a separação correta, pois se constatou que mesmo resíduos separados, chegam erroneamente ao centro de triagem (contaminados, úmidos, sujos, tóxicos). Já os investimentos para mecanização devem ser mais bem analisados, pois são caros, e vão demandar interesse dos gestores públicos, ou parcerias público-privadas.

Por fim, observou-se no processo produtivo da UVR que o material depois de separado é vendido para ser efetivamente valorizado por outras empresas. Talvez o grande desafio da UVR, além da redução do desperdício seja de fato agregar valor ao seu produto. Pode-se investir em artesanato ou pequenas fábricas para fabricação de outros materiais e somente vender produtos com maior valor agregado, trazendo lucratividade.

Como sugestões para trabalhos futuros indica-se escolher itens de mecanização (equipamento) e desdobrar alternativas para barateamento e, finalmente escolher algum item de rejeito e verificar hipóteses para sua maior valorização.

\section{REFERÊNCIAS}

ABETRE - Associação Brasileira de Empresas de Tratamento de Resíduos. Classificação de Resíduos Sólidos Norma ABNT NBR 10.004:2004. Disponível em: <http://www.abetre.org.br/biblioteca/publicacoes/publicacoe s-abetre/classificacao-de-residuos $>$. Acesso em: 15/11/2016.

BRASIL. São Paulo inaugura primeira usina de reciclagem mecanizada da América Latina, 2014. Disponível em: <http://www.brasil.gov.br/meioambiente/2014/06/sao-paulo-inaugura-primeira-usina-dereciclagem-mecanizada-da-america-latina>. Acesso em: 25/11/2016.

CURITIBA. População pode entregar lixo tóxico em terminais de transporte, 2013. Disponível em: $<$ http://www.curitiba.pr.gov.br/noticias/populacao-podeentregar-lixo-toxico-em-terminais-de-transporte/28562>. Acesso em: 14/11/2016.

G1. Curitiba produz 1,8 mil toneladas de lixo por dia, segundo a prefeitura, 2013. Disponível em: < http://g1.globo.com/pr/parana/noticia/2013/10/curitibaproduz-18-mil-toneladas-de-lixo-por-dia-segundoprefeitura.html>. Acesso em: 10/10/2016.

GALBIATI, A. F. O Gerenciamento Integrado de Resíduos Sólidos e a Reciclagem, 2001 . Disponível em:
<http://www.amda.org.br/imgs/up/Artigo_15.pdf>. Acesso em: $11 / 11 / 2016$.

GOMES, J. P. M. Aplicação da filosofia lean manufacturing numa central de triagem de resíduos sólidos urbanos. Dissertação de mestrado. Universidade do Minho. Braga, 2014. Disponível em: < http://hdl.handle.net/1822/28601>. Acesso em: 21/11/2016.

IPCC - Instituto Pró- Cidadania de Curitiba. UVR Unidade de Valorização de Resíduos, 2016. Disponível em: < http://www.ipcc.org.br/comercial/uvr>. Acesso em: $10 / 10 / 2016$.

LAZARETTI, Bruno. Veja como funciona a coleta de lixo em Barcelona, 2012. Disponível em: <http://planetasustentavel.abril.com.br/noticia/lixo/moderno -sistema-tubulacoes-subterraneas-coleta-lixo-barcelona703611.shtml>. Acesso em: 05/11/2016.

LING, H., LESHCHINSKY, D.; MOHRI, Y.; KAWABATA, T. Estimation of Municipal Solid Waste Landfill Settlement. Journal of Geotechnical and Geoenvironmental Engineering v.124, n. 1, 1998.

MACCARI, A. C. REIS, M. R. Configurações das lixeiras nos campi das instituições de ensino superior de Chapecó - Uma análise comparativa. In: V SEPE Seminários de ensino, pesquisa e extensão. Vol. V (2015) Anais do V SEPE e V Jornada de iniciação Científica, 2015. Disponível em:

https://periodicos.uffs.edu.br/index.php/SEPE-

UFFS/article/viewFile/2586/2022 >. Acesso em: 05/11/2016.

MACHADO, G. B. Coleta Seletiva na Alemanha, 2013.

Disponível

em:

<http://www.portalresiduossolidos.com/coleta-seletiva-naalemanha/>. Acesso em: 05/11/2016.

MACHADO, G. B. Central de Triagem. 2013. Disponível em: <http://www.portalresiduossolidos.com/central-detriagem/>. Acesso em: 25/11/2016.

MEDEIROS, M. A. de O. Aproveitamento da glicerina, co-produto do processo de produção de biodiesel, com a reciclagem do PET (pós-uso) para fabricação de blendas poliésteres/PET. Dissertação de mestrado. Universidade Federal da Bahia. Salvador, 2016. Disponível em:< https://repositorio.ufba.br/ri/handle/ri/19548>. Acesso em: 10/10/2016.

MIGUEL, Paulo Augusto C. (Coord.). Metodologia de Pesquisa em Engenharia de Produção e Gestão de Operações. Rio de Janeiro: Elsevier, 2010.

MINISTÉRIO DO MEIO AMBIENTE. Resolução Conama $\mathrm{n}^{\circ} 275$, de 25 de abril de 2001 Publicada no DOU no 117-E, de 19 de junho de 2001, Seção 1, página 80. Disponível em:

http://www.mma.gov.br/port/conama/legiabre.cfm?codlegi= 273>. Acesso em: 25/11/2016.

PEIXOTO, K. CAMPUS. V. B. G. DAGOSTO, M. A. A coleta seletiva e a redução dos resíduos sólidos, 2005. Disponível em: <http://aquarius.ime.eb.br/ webde2/prof/vania/pubs/(7)colet aresiduossolidos.pdf>. Acesso em: 05/11/2016.

ROJAS, M. G. R. Otimização da Operação e Manutenção de um Sistema de Separação de Resíduos - Centro de 
Tratamento de Resíduos Sólidos Urbanos da AMRPB. Dissertação de mestrado. Escola Superior de Tecnologia e Gestão de Viseu. Viseu, 2014. Disponível em: < http://hdl.handle.net/10400.19/2543>. Acesso em: 25/11/2016.

SHARHOLY, M.; AHMAD, K.; MAHMOOD, G.; TRIVEDI, R. C. Municipal solid waste management challenges in developing countries - Kenyan case study. Waste Management, v. 28, n. 2, p. 459-467, 2008.

SILVA, C. L; FUGII, G. M; MARINI, M. J. Gestão da cadeia de reciclagem em rede: um estudo do projeto Ecocidadão no Município de Curitiba. Fundación Dialnet. v. 5, n. 1, p. 20-37, 2015.

SPERANDIO, Marcelo. Boras, Suécia: a cidade campeã da limpeza, 2011. Disponível em: <http://planetasustentavel.abril.com.br/noticia/lixo/borassuecia-cidade-campea-limpeza-682410.shtml>. Acesso em: 05/11/2016.

SUDHIR, V.; SRINIVASAN, G.; MURALEEDHARAN, V. R. Planning for sustainable solid waste management in urban India. System Dynamics Review, v. 13, n. 3, p. 223-246, 1997.

TROSCHINETZ, A. M.; MIHELCIC J. R. Sustainable recycling of municipal solid waste in developing countries. Waste Management v. 29, n 2, p. 915-923, 2009.

YIN, R. K. Estudo de caso: planejamento e métodos. 4. ed. Porto Alegre: Bookman, 2010

ZIKMUND, W. G.; STANTON, W. J. Recycling Solid Wastes: A Channels-of-Distribution Problem. Journal of Marketing v. 35, n. 3, p. 34-39, 1971.

\section{COPYRIGHT}

Direitos autorais: Os autores são os únicos responsáveis pelo material incluído no artigo. 


\title{
CONCEPÇÕES DOS DISCENTES EM RELAÇÃO À FORMAÇÃO DE PROFESSORES DE BIOLOGIA NA MODALIDADE A DISTANCIA NO PERÍODO DE 2013-2016 EM PARAUAPEBAS - PA
}

\section{THE STUDENTS' CONCEPTIONS REGARDING THE TRAINING OF BIOLOGY TEACHERS IN THE DISTANCE MODALITY IN THE PERIOD OF 2013-2016 IN PARAUAPEBAS - PA}

\author{
MAIELY GLENDA GUIMARAES DA SILVA ${ }^{1}$ NILSON SANTOS TRINDADE ${ }^{1}$ \\ 1-UNIVERSIDADE FEDERAL DO PARÁ \\ glendaguimaraes@hotmail.com; nilsonufpa17@gmail.com
}

\begin{abstract}
Resumo - Este trabalho objetivou investigar as concepções dos discentes em relação à formação de professores de biologia na modalidade a distância no período de 2013-2016 em Parauapebas - Pa. A presente pesquisa foi realizada na turma de ciências biológicas da Universidade Federal do Pará no município de Parauapebas- PA. A metodologia aplicada é caracterizada como descritiva e abordagem mista. A amostra compreendeu vinte e cinco discentes de uma população de trinta e quatro. Foi utilizado como instrumento de coleta de dados um questionário com questões abertas e fechadas dirigidas aos discentes abordando temas como suas concepções acerca do ensino superior a distância, formação de professores na modalidade á distancia, metodologia de ensino e práticas pedagógicas. Pela análise dos dados foi possivel perceber que a formação de professores de biologia na modalidade a distância depende de um bom gerenciamento do aluno, além de uma boa estrutura e metodologia adequada ao ensino.
\end{abstract}

Palavras-chave: Distância. Formação. Professores.

Abstract - This work aimed to investigate the students' conceptions regarding the training of biology teachers in the distance modality in the period of 2013-2016 in Parauapebas Pa. The present research was carried out in the biological sciences class of the Federal University of Pará in the city of Parauapebas-PA. The applied methodology is characterized as descriptive and mixed approach. The sample comprised twentyfive students from a population of thirty-four. A questionnaire with open and closed questions addressed to the students was used as a data collection instrument, addressing topics such as their conceptions about distance higher education, teacher training in the distance modality, teaching methodology and pedagogical practices. Through the analysis of the data it was possible to perceive that the training of biology teachers in the distance modality depends on a good management of the student, besides a good structure and methodology appropriate to the teaching.

Keywords: Distance. Training. Teachers.

\section{INTRODUÇÃO}

Nas últimas décadas, a educação a distância tem se apresentado como uma das novas possibilidades para a formação de professores. A EAD é uma modalidade de ensino que se constitui pelos mesmos elementos fundamentais da modalidade presencial: concepção pedagógica, conteúdo específico, metodologia e avaliação; contudo, diferencia-se pelo modo como se estabelece a mediação pedagógica (CATAPAN, 2010 apud LAURINO; NOVELLO, 2012).

Observa-se que a formação de professores na modalidade a distância os alunos têm melhores condições de atuar na sala de aula no que se refere ao uso das tecnologias na educação, uma vez que estas fazem parte do seu cotidiano de formação. Isso se deve, principalmente, ao fato de que os alunos dos cursos EAD têm acesso às tecnologias de comunicação e informação mais facilmente e constantemente, o que os torna capazes de adquirir autonomia no que diz respeito à utilização desses meios.

A Educação a Distância é uma excelente estratégia de construir conhecimento, dominar tecnologias e desenvolver competências e habilidades, favorecendo os discentes não somente a autonomia para aprender sempre, mais também os tornando, profissionais preparados para trabalhar com seus alunos de forma moderna, criativa, inovadora $\mathrm{e}$ dinâmica.

As tecnologias da informação aplicadas à EAD proporcionam maior flexibilidade e acessibilidade à oferta educativa, fazendo-as avançar na direção de redes de distribuição de conhecimentos e de métodos de aprendizagem inovadores, revolucionando conceitos tradicionais e contribuindo para a criação de novos sistemas educacionais.

A formação de professores na modalidade a distância favorece ao profissional docente conhecimento, complexidade, além de competências e habilidades para enfrentar os desafios da profissão. Capacita o professor a entender as transformações que ocorrem na sociedade a fim de que possa atuar com responsabilidade e com compromisso com a educação dos seus alunos. A formação EAD desenvolve também grande maturidade em seus discentes, pois potencializam competências de disciplina, dedicação, autonomia, compromisso e organização.

Diante deste cenário, este trabalho apresenta a seguinte problemática: Quais as concepções dos discentes em relação à formação de professores de biologia na modalidade a distância no período de 2013-2016 em Parauapebas - PA? 
As questões que nortearam esta pesquisa foram: Quais os recursos utilizados para o ensino aprendizagem dos discentes do curso de ciências biológicas na modalidade à distância? Quais as práticas pedagógicas dos docentes do curso de ciências biológicas na modalidade à distância? Qual o perfil dos discentes do curso de ciências biológicas na modalidade à distância?

$\mathrm{O}$ interesse pela proposta de pesquisa surgiu devido dificuldades sentidas e observadas ao decorrer do curso, dificuldades estas, propostas nas perguntas da pesquisa. $\mathrm{O}$ ensino a distância depende de programas bem definidos, recursos metodológicos adequados, professores e tutores capacitados além de um aluno preparado para essa modalidade de ensino.

Um bom planejamento é o meio para facilitar a interatividade entre aluno e aprendizagem, respeitando a realidade dos alunos a serem atendidos. Os processos do projeto de um curso EAD precisam interagir em perfeita harmonia para que se atinja os objetivos do ensino EAD.

Sendo assim, o objetivo geral desta pesquisa foi investigar as concepções dos discentes em relação à formação de professores de biologia na modalidade a distância no período de 2013-2016 em Parauapebas - PA e os objetivos específicos foram: identificar os recursos utilizados para o ensino aprendizagem dos discentes do curso de ciências biológicas na modalidade à distância; avaliar as práticas pedagógicas dos docentes do curso de ciências biológicas na modalidade à distância e verificar o perfil dos discentes do curso de ciências biológicas na modalidade à distância.

\section{CONSIDERAÇÕES METODOLÓGICAS}

Trata-se de uma pesquisa descritiva com abordagem mista. A turma em estudo possui 34 alunos que constituiu contribui a nossa população, entretanto, a amostra da pesquisa foi de 25 discentes, representando $73 \%$ da mesma. Foi aplicado um questionário com catorze perguntas abertas e fechadas aos participantes, a fim de colher as informações necessárias para o diagnóstico da problemática, os questionários foram preenchidos e entregues em um único momento e presencialmente. Os participantes apresentaram dificuldades quando necessitavam justificar as suas respostas.

Aos participantes da pesquisa foi aplicado um termo de consentimento livre e esclarecido. O TCLE é um documento que informa e esclarece o sujeito da pesquisa de maneira que ele possa tomar sua decisão de forma justa e sem constrangimento sobre a sua participação em um projeto de pesquisa. Lembrando que este trabalho foi aprovado por uma comissão de ética.

\section{RESULTADOS E DISCUSSÃO}

A análise dos dados se deu a partir de uma análise descritiva para mensuração e classificação de variáveis disponíveis: qualitativas e quantitativas, expondo algumas falas dos informantes e, ao mesmo tempo, expondo ideias de autores que versam sobre o assunto.

A fim de garantir o anonimato dos participantes, utilizamos a codificação $\mathrm{PX}$, onde $\mathrm{P}$ significa participante $\mathrm{e}$ $\mathrm{X}$ representa um número qualquer; então, P01 quer dizer participante 01. Esta numeração se deu de forma aleatória.

Inicialmente, tratou-se e verificar o perfil do aluno a partir da sua idade cronológica. A análise dos dados aponta;
$28 \%$ apresentam idade de 18 a 25 anos, $32 \%$ idade entre 30 a 40 anos e $40 \%$ apresentam idade de 25 a 30 anos. Concluindo então que $72 \%$ são alunos apresentam idade acima de 25 anos no geral.

Quem são os alunos que abrem mão de uma graduação presencial por uma à distância? As pessoas que fazem uma graduação na modalidade a distância têm em média 30 anos, confirmado com esta pesquisa, são casadas e trabalham. Mas não é apenas a idade que determina o perfil desse estudante. É preciso ter maturidade para encarar uma rotina mais solitária de estudo.

Para um curso a distância o aluno precisa ter algumas características especificas como: organização, disciplina, automotivação, autogerenciamento, além de uma internet de boa qualidade a disposição e manuseio de ambientes virtuais. No Brasil, nem sempre os estudantes optam por um curso a distância por apresentarem o perfil para essa modalidade e sim pela dificuldade de chegar aos grandes centros.

Quando questionados sobre suas experiências em outros cursos EAD, 56\% afirmam não apresentar nenhuma outra experiência na modalidade a distância.

Com relação à concepção sobre a modalidade de ensino EAD, $72 \%$ dos pesquisados responderam que a modalidade de ensino EAD é eficaz, isto indica que os discentes reconhecem a qualidade da sua modalidade de formação, além de favorecer aos discentes outras vantagens relatadas a seguir:

A AED oferece ao discente uma maior flexibilidade de horários e planejamento de estudo. (P07).

A EAD imprime uma busca ativa maior em relação aos conteúdos por parte do discente. (P08).

A EAD oferece aos alunos uma maior flexibilidade de horários de estudos como foi mencionado pelo participante P07, porem o aluno precisa gerenciar seu planejamento de estudo com dedicação, disciplina e organização, pois a EAD exige prazo a serem cumpridos. Engana-se quem pensa que ao escolher essa modalidade de ensino poderá dedicar menos tempo ao estudo. Optar por essa modalidade de ensino, sim oferece uma flexibilidade maior de horário, mais isso não significa que se exige menos dele. É importante que o estudante que faz ou queira fazer um curso a distância se conscientize que não se trata de uma opção mais fácil.

Segundo Hack (2011) A EAD, é uma modalidade que possibilita a eliminação de distâncias geográficas e temporais ao proporcionar ao aluno a organização do seu tempo e local de estudos.

Deste modo, a EAD oferece ao aluno uma comodidade, flexibilidade e autonomia a seus estudos, além de uma excelente estratégia de construir conhecimento, dominar tecnologias e desenvolver competências e habilidades ao aluno.

Quando indagamos sobre sua concepção quanto ao projeto do curso, $60 \%$ dos pesquisados responderam que não houve mudança da cultura docente do sistema presencial para o EAD. Algumas justificativas a seguir:

Não, o ensino EAD tem se mantido tradicional, os professores não se preocupam no desenvolvimento do assunto. (P02)

Não, nesse aspecto tivemos que aprender a sermos autossuficientes. (P10) 
A EAD exige que o aluno esteja em busca constante da construção de seu próprio conhecimento, o aluno é o fator central da aprendizagem, na EAD o aluno nem sempre tem a presença física do professor, não significando que mediações possam ser solicitadas a qualquer momento, deixando o aluno livre para intervenções assim que necessárias.

Os demais pesquisados, o restante $40 \%$ apontam que a cultura trabalhada foi diferenciada do sistema presencial, expondo suas opiniões e justificativas.

Sim. Mas o sistema EAD com os tutores foi fundamental para nos alunos. (P11).

Sim, pois o aluno não fica preso ao professor presencial, ele não tem esse elo físico, deixando o aluno mais livre. (P18).

Nesse processo em EAD, o professor tutor é o profissional que atua como um mediador da aprendizagem. Ele assume um papel de extrema relevância e importância de variadas formas possíveis, estimulando, engajando, motivando os alunos.

Quando nos referimos a cultura dos discentes de EAD se foi trabalhada durante o desenvolvimento do curso, $64 \%$ dos pesquisados afirmam que sim e os demais $36 \%$ que não. Justificativas a seguir:

Sim, pois os professores foram bem flexíveis, quanto ao tempo e as orientações das disciplinas. (P18).

Sim, focado em um curso de licenciatura para melhor aprimorar estratégias metodológicas. (P24).

A eficiente metodologia EAD, engrandece o processo de aprendizagem, os alunos se demostram motivados e satisfeitos quando se deparam com profissionais dispostos a contribuir com o seu conhecimento, compartilhando suas experiências com criatividade e inovação, assim favorecendo a interação entre os indivíduos desse processo.

Ao abordar sobre o domínio conceitual dos docentes, $56 \%$ dos pesquisados afirmam que os docentes do curso, de forma geral, demostraram apresentar um domínio conceitual de suas respectivas disciplinas, o restante $44 \%$ responderam que não apresentam domínios conceituais das disciplinas.

Ao se referir sobre os exercícios propostos e as unidades didáticas, foram claros e relacionados a teoria $\mathrm{EAD}, 68 \%$ dos pesquisados afirmaram que não e o restante $32 \%$ afirmam que sim.

Ao se tratar da questão que propõem analisar se o sistema EAD oferece aproveitamento melhor do que em cursos presenciais, 92\% dos pesquisados afirmam que o sistema EAD não oferece o mesmo aproveitamento.

$\mathrm{O}$ ensino de biologia demanda alguns recursos que o ensino a distância não proporciona, aulas teóricas-práticas, aulas de laboratório e de campo. Apesar de reconhecer a complexidade da demanda de um curso de biologia, pensar neste curso na modalidade EAD é preciso considerar questões como uma boa estrutura organizacional e curricular, de maneira que se leve em consideração a realização das aulas teórico-prática.

$\mathrm{Na}$ EAD o comprometimento da aprendizagem deve partir do aluno ao professor e do professor ao aluno. Justificativas a seguir:

Não, acredito que o sistema EAD tem peso, mas não tanto como o presencial. (P11)
Não, o comprometimento professor-aluno é muito menor. (P15)

Não, o aprendizado é inferior. (P25)

A educação presencial se diferencia da educação distância, na EAD o aluno tem flexibilidade para gerenciar seus estudos construindo seu próprio conhecimento, aprendendo assim a desenvolver suas competências, habilidades, além de favorecer a disponibilidade de escolha do seu tempo e local adequado ao seu estudo, contando com a mediação de professores por diversos meios de comunicação, e com materiais de didáticos organizados e adequados a modalidade de ensino.

Quando perguntados se o sistema de tutoria, apresenta vantagens em relação as atividades de atendimento aos alunos no sistema presencial, $56 \%$ responderam que sim e $44 \%$ responderam que não. A seguir alguns relatos sobre suas concepções:

\begin{abstract}
Sim, muito. Eles são os porta vozes interligados entre a turma e o professor e entre o professor e a turma, inclusive quanto aos esclarecimentos do
\end{abstract} conteúdo. (P03)

Sim, acredito que os discentes apresentam maior contato e interação com tutores, talvez por ser o único meio de nossa de informação. (P08)

Sim, a tutoria é essencial para o melhor entendimento dos conteúdos, tiram dúvidas quanto ao assunto. (P18)

O profissional docente tutor desempenha um papel fundamental no ensino-aprendizagem na EAD, ele observa e organiza todo o fluxo de conhecimento além de tirar as dúvidas dos alunos. Os tutores desenvolvem um conjunto de ações educativas que tem como objetivo desenvolver e potencializar capacidades e habilidades dos alunos.

O tutor EAD é de suma importância para os alunos e influencia diretamente em seu processo de aprendizagem. Sendo interessante que o tutor busque sempre refletir sobre suas práticas pedagógicas para que se torne cada vez mais eficiente e benéfica ao aluno.

A questão seguinte refere-se à qualidade dos materiais didáticos, $72 \%$ dos respondentes afirmam que os materiais didáticos não atendem a necessidade do curso.

A EAD é totalmente dependente da disponibilidade de material instrucional adequado ao modelo pedagógico e às mídias utilizadas. As situações de aprendizagem, na educação a distância, precisam estar expressas nos materiais didáticos de modo acessível, claro, interessante e passível de apropriação e execução (LAURINO; NOVELLO, 2012 p. 03).

O material didático é o instrumento para o diálogo permanente entre alunos, professores e o conhecimento. Esse material precisa estar bem produzido e organizado mantendo coerência entre os conteúdos e metodologias aplicadas.

A elaboração do material didático deve passar por tratamento pedagógico cauteloso, com esse cuidado é possível tornar as aulas interativas e motivantes e assim alcançando os objetivos educacionais.

Quando nos referimos sobre a comunicação pelo portal Moodle, $72 \%$ respondentes afirmam que a comunicação Moodle não é satisfatória. A seguir alguns relatos sobre suas concepções: 
Não, ainda precisa melhorar, isso se dá pela falta de cultura no acesso ao Moodle. (P03)

Não, maioria das situações não há retorno por parte dos docentes. (P05)

Não, falta comunicação, falta retorno em curto prazo. (P16)

Os depoimentos acima sinalizam um dos problemas mais comuns em programas de educação a distância: a escassa comunicação promovida entre alunos, tutores e professores, que gera isolamento e empobrecimento no tratamento da informação, falta de motivação e limita o potencial de transferência dos conhecimentos à prática, a outras realidades ou problemas. Logo, é necessário repensar uma oferta educativa que se constitua a partir do diagnóstico das necessidades de formação da população-alvo e de suas características culturais, elemento central do planejamento educativo e das estratégias de comunicação.

A próxima questão se propôs analisar o objetivo dos planejamentos ofertados. A maioria dos respondentes, ou seja, $72 \%$ afirmaram que os objetivos das disciplinas foram alcançados.

O planejamento deve ser entendido como estratégias que podem ser construídas para se obter um desempenho superior à média, criando e desenvolvendo uma posição exclusiva e sustentável nos processos de gestão da EAD.

O planejamento do curso a distância deve ser feito de acordo com as características do público-alvo, de modo a atender às suas necessidades e expectativas e, assim evitar, a evasão e a desmotivação (BARBOSA; CARVALHO, 2014, p. 12).

Neste sentido, quando se define os objetivos educacionais, as competências a serem atingidas, o desenho pedagógico, etapas e atividades, os sistemas de apoio à aprendizagem, as mídias a serem utilizadas, a avaliação, os procedimentos acadêmicos e o sistema de funcionamento como um todo, é importante estabelecer as estratégias metodológicas para que se possa assegurar um sistema em pleno funcionamento.

Os objetivos de aprendizagem devem estar claramente definidos, de modo a facilitar a construção de conteúdos disciplinares organizados em blocos temáticos, quer sejam módulos, aulas ou unidades de ensino, conforme o planejamento adotado.

Com o objetivo de analisar sobre a metodologia de avaliação da aprendizagem, $60 \%$ dos respondentes afirmam que o método de avaliação foi a adequada a modalidade a distância.

Reflexões acerca das questões metodológicas do ensino de Ciências e Biologia são importantes porque sinalizam o caminho que deve ser trilhado para a construção plena do ensino-aprendizagem. É inadmissível pensar em cursos de Ciências e Biologia que não primem pela capacitação dos seus discentes para a compreensão do mundo à sua volta através de um posicionamento críticoreflexivo, indagador e instigador. Entretanto, é essencial construir projetos pedagógicos bem fundamentados e que atendam às exigências das metodologias do ensino, não somente de Ciências e Biologia, mas nas diferentes áreas do saber (GOMES; MOTA; LEONARDO, 2016).

A avaliação pode ser definida como a aplicação sistemática de procedimentos metodológicos para determinar, a partir dos objetivos propostos e com base em critérios internos e/ou externos, a relevância, a efetividade e o impacto de determinadas atividades com a finalidade de tomada de decisão.

Para finalizar a análise dos dados, foi proposto aos participantes que registrasse quaisquer informações importante e necessária para completar essa pesquisa. Dois dos demais depoimentos me chamou muita atenção. Depoimento a seguir:

A modalidade a distância trouxe acessibilidade para os discentes que tinham vontade de ter um curso superior, porem seu tempo não cabia dentro de um curso presencial. A EAD veio para revolucionar o ensino e alcançar pontos antes não alcançados. (P07)

O aluno da EAD tem o acesso à educação mais flexível, com a opção de gerenciar com autonomia o seu horário e o seu local de estudo, conforme suas necessidades. Isso permite que muitas pessoas, por questões de distância geográfica, horários de trabalho ou por outras razões não puderam ou não podem cursar o ensino presencial, possam realizar o sonho de um ensino superior de qualidade.

\section{CONSIDERAÇÕES FINAIS}

Com a analises dos dados notou-se que a maioria dos discentes pesquisados afirma que os recursos metodológicos (materiais didáticos, comunicação Moodle, exercícios e unidades didáticas propostas) disponibilizados não foram adequados para se trabalhar em um curso na modalidade a distância.

Sobre as práticas pedagógicas, observou-se que a mediação pedagógica foi efetiva (cultura docente e discente, planejamentos e metodologia de avaliação da aprendizagem), constituem-se em uma postura facilitadora, estimuladora do desenvolvimento e da aprendizagem do aluno, as vivências compartilhadas pelos docentes e discentes favoreceu o aluno a refletir, discutir, compartilhar, questionar, analisar, comparar, enfim, construir seu próprio conhecimento, tendo como gênese suas vivências e experiências.

Percebeu-se que a maioria dos pesquisados, ou seja, $72 \%$ são alunos com idade entre 25 a 45 anos. O perfil do aluno virtual de sucesso é composto geralmente por pessoas com mais idade e maturidade. Esses alunos têm condições de avaliar melhor a real necessidade de fazer um curso a distância sabendo que terão que estudar na maior parte do tempo sem o acompanhamento de um professor. O aluno EAD precisa ser organizado, ter disciplina, automotivação e autogerenciamento, assim, possivelmente o aluno terá um bom desempenho no seu curso a distância com a qualidade desejada.

A formação de professores de biologia na modalidade a distância está ocorrendo de forma produtiva, porém os recursos metodológicos precisam ser trabalhados, exigindo tratamento pedagógico cuidadoso para que possa alcançar seus objetivos educacionais. $\mathrm{O}$ uso de recursos adequados EAD cria-se um vínculo mais estreito com o aluno, dependendo de um planejamento metodológico centralizado no processo de ensino-aprendizagem. Notou-se que os discentes concordam que a educação a distância possui as suas peculiaridades, portanto diferente do ensino presencial.

Recomenda-se mais estudos aprofundados na área de formação de professores de Biologia pela modalidade a distância de aprendizagem para um bom desenvolvimento 
profissional docente, pois ainda há uma carência de pesquisas neste sentido.

\section{REFERÊNCIAS BIBLIOGRÁFICAS}

BARbOSA, T. R. C. G.; CARVALHO, M. L. Planejamento e desenvolvimento em cursos EAD. Viçosa, MG: Ed. UFV, 2014.

CATAPAN, A. H. Mediação pedagógica diferenciada, 2010. In: NOVELLO, T. P.; LAURINO, D. P. Educação a distância: seus cenário e autores. Rio Grande: Revista Ibero-americana de Educação, 2012.

GOMES, S. G. S.; MOTA, J. B.; LEONARDO, E. S. CEAD 15 ANOS: Reflexões sobre experiências didáticas em EAD. Viçosa (MG): CEAD, 2016.

HACK, J. R, Introdução à Educação a Distância. Florianópolis: LLV/CCE/UFSC, 2011.

LAURINO, D. P.; NOVELLO, T. P. Educação a distância: seus cenário e autores. Rio Grande: Revista Iberoamericana de Educação, 2012.

\section{COPYRIGHT}

Direitos autorais: Os autores são os únicos responsáveis pelo material incluído no artigo 